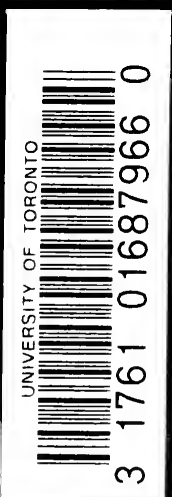




Digitized by the Internet Archive in 2007 with funding from Microsoft Corporation 


\section{T A L Y}

MEDIAEVAL AND MODERN

A HISTORY 


\section{Oxford University Press}

London Edinburgb Glasgow New rork

Toronto Melbourne Cape Town Bombay

Humphrey Milford Publisher to the University 


\section{$J$}

\section{T A L Y}

MEDIAEVAL AND MODERN

A HISTORT

BY

E. M. JAMISON, C. M. ADY, K. D. VERNON

AND C. SANFORD TERRY

O XFORD

AT THE CLARENDON PRESS

I 9 I 7

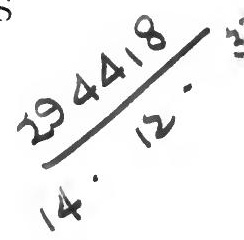


PRINTED IN ENGLAND

AT THE OXFORD UNIVERSITY PRESS

$$
\begin{aligned}
& \text { DG } \\
& 468 \\
& 53
\end{aligned}
$$




\section{PREFACE}

IT is no wonder that Italian history should be invested, in the eyes of Englishmen, with a perennial fascination, considering how profoundly we have been influenced at critical stages of our national development by the Italian genius. The catalogue of our obligations is too lengthy to be recited in a preface. A few examples must suffice. It is to an Italian, Gregory the Great, that we owe our Christian faith; to Benedict of Nursia and to Francis of Assisi we are indebted for interpretations of that faith which have survived the Middle Ages and our own Reformation. It was on Italian soil that English humanists made their first acquaintance with the wisdom of antiquity and the spirit of free thought. Machiavelli first inspired us to reason about the nature and the purpose of the modern State; Mazzini taught us to respect the idea of nationality. Dante and Petrarch, Ariosto and Tasso, have been accepted models in more than one great age of English poetry. Nowhere have the great Italian artists, from Giotto to Raphael, been better loved or more closely studied than in England.

Our sense of these obligations is reflected in our historical literature, which is full of admirable monographs on particular epochs of Italian history, and on the leaders of Italian religious and political movements. Yet it is strangely difficult to find any general sketch of Italian 
history, from the barbarian invasions to the present day, which can be recommended as an introduction to more detailed studies. It was to supply this need that the present volume was planned and written. The authors

' have taken a broad view of their subject. They have devoted considerable space to political and ecclesiastical history because Italy, long before she attained to national unity, was the scene of many fruitful experiments in political and-ecclesiastical organization. But they have also called attention to the more remarkable achievements of the Italian spirit in the fields of art and philosophy and science, and the historical conditions which made these achievements possible. Finally, they have traced, so far as it is possible to do so in a textbook, the working of those instincts, deeply rooted in the national history and national character, which from age to age promoted or retarded the cause of national unity.

It is the hope of the writers and the editor that this book may do something to encourage and direct its readers in studying the life-history of the Italian people, with whom our ancestors have been linked for centuries by ties of intellectual and spiritual sympathy, and with whom we are to-day united in defending the liberties of Europe.

$$
\text { H. W. C. DAVIS. }
$$

Balliol College, Oxford,

March I2, I9I7. 


\section{CONTENTS}

PAGE

PREFACE

ITALY BEFORE $125^{\circ}$

I. Political Development . . . . . . I

2. The Papacy . . . . . . . . $\quad . \quad 5^{8}$

3. The Normans in the South $\therefore \quad . \quad . \quad 95$

4. Religion and the Civil Tradition . . . . II6

ITALY, $1250-1527$

1. The Years of Transition, 1250-1313. . . 141

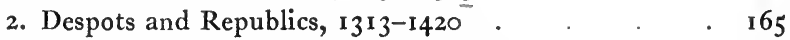

3. The Age of the Renaissance, 1420-1494 . . . 189

4. Italy and her Invaders, 1494-1527 . . . . 218

ITALY, I 528-1789

I. External Politics . . . . . . . 236

2. Internal Politics and Administration . . . . 274

3. Social and Intellectual History . . . . . 312

\section{THE EVOLUTION OF UNITY}

I. France and Italy, 1789-1815 • • . . . 353

2. The Carbonari and the Revolutions of 1820-I . . 363

3. Italy and the French Revolution of 1830 . . . 372

4. La Giovine Italia . $\quad . \quad$. $\quad$. . . 378

5. The Moderates of $1843-6 \quad$. $\quad . \quad . \quad . \quad 389$

6. Pius IX $\quad . \quad$. $\quad . \quad . \quad . \quad . \quad . \quad .395$

7. The Reaction, $1849-59$. . . . . . . 414

8. Cavour . . . . . . . . . 418

9. Napoleon III and Cavour . . . . . . 432

10. The Union of Central Italy, 1860 . . . . 448

II. Garibaldi and The Thousand, I860 . . . . 456

12. Cavour and Rome, I86I . . . . . . . 466 
The Evolution of Unity (continued) Page

13. Sarnico and Aspromonte, $1862 \quad$. $\quad . \quad$. 472

14. The September Convention and the Syllabus, 1864 • 477

15. The Third War of Independence, I866 . . . 486

I6. Mentana, I867 .

17. Roma Capitale, I870 . . . . . . . . 495

18. The Triple Alliance, I882-1915 . . . . $50 \mathrm{I}$

BIBLIOGRAPHY • . . . $\quad$. $\quad$. $5^{12}$

LISTS OF KINGS, Etc.

Italian Kings and Roman Emperors . . . . 520

Genealogical Tables . . . . . . . $\quad 525$

List of the Popes . . . . . . . . 535

INDEX $. \quad . \quad . \quad . \quad . \quad . \quad . \quad . \quad . \quad 54 \mathrm{I}$

\section{MAPS}

Italy at the Beginning of the Eighth Century a , . 16

Italy at the Peace of Venice, II 1 . . . . . 44

Papal States . . . . . . . . . . 94

Italy after the Peace of Lodi, 1454 . . . . . 209

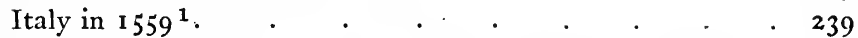

The Territorial Progress of the House of Savoy in Italy ${ }^{1}$. 245

The Union of Italy, 1859-70 . . . . . . . $\quad .467$

Map showing Colonial Possessions of Italy, 1914 . . . 506

1 Based on the map in Italy from $1494-1790$ by $K$. D. Vernon (Cambridge Historical Series, edited by G. W. Prothero), by the kind permission of the Syndics of the Cambridge University Press.

\section{CORRIGENDA}

Pp. 22, 1. 24, 24, 1. 13, 29, 1. 2, 70, 1. 20, for revival read institution. P. 7 I, 1. 22, for restoration read institution. 


\section{ITALY BEFORE I $25^{\circ}$}

\section{I \\ Political Development}

ITALY was at once greater and less than Rome : greater Italy and than the city on the Tiber and less than the empire of the Roman the world which sprang from the city and received its name. The primitive Roman community extended its dominion in ever-widening circles. First the Latin League, next the Samnites and Etruscans and the Greek cities of the south were brought in, and then the Celts of the Po valley and the mountain were absorbed. The new unity of Italy was expressed in the extension of Roman citizenship to all the conquered cities, and from this basis the Roman state spread its authority over Asia and Africa and Europe. In this expansion Italy lost its individuality and became merged in the vast unity of the Roman Empire. Just as the unity of Italy was recognized in the grant of Roman citizenship, so the gift of the same citizenship to all the free inhabitants of the Empire signified the recognition of a single state conterminous with the civilization of the Graeco-Roman world. Outside the circle of the Empire, beyond the frontier of the Rhine and Danube, barbarian tribes were pressing forward, and for 500 years the Empire struggled for existence, endeavouring to absorb the barbarian elements when it could no longer force them back. 1832.3 
Within the Empire local differences in custom and the local autonomy of the city communities survived, but the sovereignty of the respublica was expressed in the universal acceptance of Roman law and in the increasing autocracy of the Emperor, who became the unique depository of civil and military authority. The advance towards absolutism was hastened by the anarchy of the third century, when the legionaries made and unmade emperors at will. Diocletian saw the need for a reorganization of the State; he fixed on despotism and centralization as the pivot of the new system of government and defence against the barbarian. The Emperor became an absolute monarch, whose authority rested on an elaborate civil service and a new model army. His majesty was enhanced by the attribution of divinity and by every device of ceremonial. The efficiency of the supreme power was increased by the partition of the imperial burden between two co-emperors, while the imperium remained undivided. Each emperor moreover was given a subordinate colleague and presumptive successor with the title of Caesar. The provincial administration of the whole Empire was unified, and privilege and anomaly were as far as possible removed. Four prefectures were set up, of which Illyricum and the East tended to become the sphere of one emperor, while his colleague devoted his attention to Italy and the Gauls. Thus the fundamental cleavage in history and civilization between the east and the west began to make itself felt in the scheme of administration.

The indi- Rome ceased to be the capital of the Empire even in viduality the west, and Italy was reduced from its position of 
honour and privilege. The traditional immunity from of Italy taxation and from supporting military garrisons was merged in withdrawn, and in one peculiarity alone did the adminis- of the tration recall the former predominance: within the Empire. peninsula the authority over the city of Rome and the suburbicarian region of one hundred miles round it was still entrusted to the praefectus urbi, and the authority of the pretorian prefect was restricted to the more northern provinces. With the transference of the capital from Rome to Constantine's new city on the Bosphorus, the conception of empire was detached from its local origin and the theory of a universal state embracing the whole civilized world asserted its validity. The universal ideal embodied in the Empire was reinforced at the crisis of its fate by the ideal of the Catholic Church. Unity and universality were of the essence of the Christian society with its world-wide mission to all mankind. The Church had developed alongside the Empire, but outside it, and in the first centuries there was a sharp distinction between the Christian society and the world, although the Church taught the duty of obedience to the civil power. Ecclesiastical organization followed the lines of the Roman municipal and provincial administration, and a unified system gradually took the place of the loose federation of local churches of the first age. With the 'peace of the Church' and the adoption of Christianity under Constantine as the religion of the Empire, the ecclesiastical organization became the recognized counterpart of the civil, and the two systems met in the Emperor, who began to exercise a directive control over the Church. Nevertheless the 
ancient conception of its separateness from the world, and the growth of external unity through the primacy of the see of Rome, produced a persistent stream of opposition to the claim of the civil power to interfere in Church matters. Theorists were, however, held up by the fact that ecclesia and respublica were conterminous, Christian and Roman interchangeable names, and in the fifth century Pope Gelasius I reconciled the divergent views in his theory of a single society embracing the whole world, of which the spiritual government was given to the Church and the civil to the Empire.

The effort

At the moment when complete unity seemed attained, of Italian individuality to detach itself from the Roman unity in the Niddle the forces of disintegration began to assert themselves; and mediaeval history is the record of the conflict between the unity of the Roman world and the differences that were contained within it. Already the effort of Diocletian to strengthen the unity had taken account of the differences; the partition of the Empire was based on the divergence between the eastern and the western regions, and the provincial reorganization regarded geography and race, the main elements which enter into the formation of nations. In Italy, in a supreme degree, historical interest is centred on the effort of Italian individuality to detach itself once more from the Roman unity. The process began when Italy ceased to be the ruling state at the end of the third century: it developed rapidly during the isolation of the peninsula throughout the fifth century and the establishment of a barbarian monarchy at its close. The Empire was shared for sixty years by members of the Theodosian house, but in spite of the theoretic unity, the different 
needs of the pars occidentalis and the pars orientalis, in face of the barbarian onslaught, led to different policies and the virtual independence of Italy as the other provinces fell before the attack.

The development of the Church throughout this period worked in the same direction. The Pope became the representative of the ancient Roman headship and maintained the association of the imperial idea with the former local habitation of the Empire. To the practical Italian mind, concrete tradition was more potent than the finest of abstract ideas. The Pope, moreover, as the unique patriarch in the west, was ready to battle for its rights against the east, and in the absence of the Emperor was able to assert claims to spiritual independence that were denied his brother at Constantinople.

The barbarian element within the peninsula was far Italy the less decisive in the formation of the new Italy of the of Roman Middle Ages than in the kingdoms north of the Alps. civilization The Gothic peoples who eventually conquered Italy at aeval the end of the fifth century had long been in contact Europe. with the Empire ; they maintained the Roman tradition of government and founded no new race kingdom. But one element the more was added to the constant stream of immigration of the last thousand years. The decisive factor in the formation of the Italian people was the strong geographical unity, which acted without intermission on the shifting racial types, and transformed them into a single people with constant characteristics. Italian individuality gradually emerged, but because there had been no profound breach with the Roman past, and the predominant elements of life and 
culture were Roman, the process was checked by the fulfilment of the great office of civilizer and transmitter of Roman government and literature and art. Italy was held in bondage to Western Europe, because though she might have worked out her own destiny in isolation, she could not so hand down the Roman tradition. Italy did her work for Europe well. The mediaeval ideal was summed up in philosophy in the assertion of the oneness of being, unity, and good, and in institutions in the Roman Empire and the Roman Church. Church and Empire went behind the outward appearance of European political life, and represented the underlying unity of western civilization in language and religion and society, which was formed by the coalescence of Roman tradition, Roman Christianity, and barbarian vigour. The price of the share contributed by Italy was political disunion. This disunion was not, in the earlier Middle Ages, greater than in the rest of Western Europe, but it rested on deeper foundations. Not only was the struggle between the universal and local principles fought out on Italian soil from the time of the Emperor Justinian onwards, but the dualism within the universal expressed in the Empire and Papacy, each with its local anchorage in Italy, enforced disunion at the moment when the rest of Europe was forming national states based on the coincidence of race, geography, and polity. In the end, but not till the nineteenth century, the fundamental unity of the Italian people and the Italian genius triumphed, and, shaking off classical and mediaeval traditions, received its expression as a national state in the conditions of the modern world. 
The barbarian invaders of the Roman Empire fall The barinto two great groups : the Teutonic peoples, Franks, barian inBurgundians, Alemans, and Saxons, eventually occupied Gaul and Britain; the Scandinavian group, Goths, Vandals, and Gepids, entered Aquitaine, Spain, Africa, and finally Italy. They had long penetrated the society of the Empire as traders, slaves, settlers, and above all in ever-increasing numbers as soldiers. From the fourth century men of barbarian origin began to hold the highest military commands; generals such as Arbogast the Frank or Stilicho the Vandal directed the policy of the Empire and organized its defence, as masters of the troops under the emperors of the Theodosian house (379-455). The great mass movement, which lasted from the third to the sixth century, was due partly to the need for wider territory, partly to the pressure from the east of the savage Huns. It was no longer the passage of small bodies of troops and colonists into the Empire, but the entry of whole peoples under their kings, who offered their services to the Emperor in return for land and formal recognition.

The advance began with the Goths. One tribe, the The Goths. Visigoths, moved westwards from the northern shore of the Black Sea, and after a century spent in Dacia they defeated the Emperor Valens at Hadrianople in 378, and obtained in Thrace a new settlement safe from the Huns. The conversion of the Goths to Christianity began in the fourth century through the efforts of Ulfilas, their first bishop and translator of the Bible, but it was Arian Christianity which they received, because this heresy happened to be dominant in the east at the 
time of their contact with the Empire. At the end of the fourth century the Visigothic people began to move again under Alaric. From 400 to 403 he invaded Italy, only to withdraw before Stilicho, Honorius' master of the troops, and in 405 the similar advance of Radagaisus at the head of the Vandals and Ostrogoths ended in defeat and capture. Stilicho, who relied on barbarian troops, and regarded fusion as the only means of saving Italy from conquest, was destroyed by the intrigues of a party hostile to Germanic influence, and the way was open once more to Alaric. Twice over, in 408 and 409 , he marched on Rome, and failing to obtain from Honorius the legitimation of his position with the title of magister militum, he again attacked the city in $4 \mathrm{IO}$. For three days Rome was given over to plunder; the news sent a thrill of horror through the civilized world. Alaric moved south to the conquest of Sicily, but he died on the march and was buried with his treasure in the bed of the Busento. His brother-in-law Athaulf succeeded him as King of the Goths, and married Galla Placidia, the sister of Honorius. Nevertheless he left Italy for Gaul to found the Visigothic kingdom in Aquitaine and Spain; for forty years Italy was free from barbarian attack.

The Huns and the Vandals.
Then the Huns came. After the great battle at Troyes, Attila entered Italy in $45^{2}$; he plundered Aquileia, Milan, and Pavia, but for some reason retreated from Rome without sacking the city. Tradition ascribes his forbearance to the ardent prayers of Pope Leo. In 455 the house of Theodosius in the west came to an end with the murder of Valentinian III, and Gaiseric the Vandal plundered Rome. 


\section{Political Development}

The attitude of the Italians in face of the disaster of The condithe Empire was one of apathy and resignation. Initiative tion of the and hope had been crushed by a rigid social system intended to secure the fulfilment of public burdens. All occupations and offices had been made hereditary, and it was impossible for a man to leave the class in which he was born. Taxation was heavy and ill-adjusted; it fell ultimately on the cultivators, on the trade guilds, and on the members of the curiae or senates of provincial municipalities, who were responsible for collecting the taxes in their towns. Universal military service had been abandoned because the withdrawal of men from agriculture and industry diminished the number of taxpayers, and all but a small section of the population was untrained in arms. Another effect of the pernicious fiscal system was the decay of local town life: the curiales abandoned their land and commended themselves to great proprietors as the only means of escape from their burdens. Municipal self-government, the original basis of Roman expansion, practically disappeared in Italy until its revival in far other conditions in the eleventh century.

Between 455 and 476 eight emperors rose and fell, Odovacar and the substance of power rested with the patricius, and the Ricimer the Sueve, a veritable kingmaker. His authority Western was based on a new group of tribes, Heruli, Sciri, Rugians, who received lands in Italy and supplied soldiers for the legions. In 475 Orestes, a Roman from Pannonia, became patricius and raised his young son Romulus Augustulus to the western throne. The new settlers demanded a third of the soil of Italy, and when Orestes 
refused they made Odovacar the Scirian their king. The boy. emperor was banished to a Campanian villa, and the imperial insignia were sent to the Emperor Zeno in the east. The scheme of co-emperors came to an end, and the ruler of Constantinople gathered all imperial authority into his hands. In Italy, Odovacar was king of the barbarian settlers; he was also patricius, and as such the accredited representative of the Emperor.

Theodoric the Ostrogoth.
The government of Odovacar was overthrown by Theodoric, the King of the Ostrogoths, who entered Italy with a commission from Zeno in 489. The Emperor distrusted the Scirian, and welcomed the chance of freeing Thrace from the aggressions of the Ostrogoths. Theodoric, an Arian like the rest of his people, had spent ten years as a hostage at the Byzantine court. There he had learnt to reverence Roman government and civilization, and he was ready at the bidding of the Emperor to lead his people to a fresh home in Italy. The Goths received a third part of the Italian lands in the northern and central districts-they did not penetrate into the south-and lived a country life under their own laws and counts appointed by the King. In the towns the Catholic Italians predominated, and side by side with the Gothic system, Roman law and administration was maintained. In race and institutions there was a dualism in the state, which was only reconciled in the person of Theodoric, patrician and Ostrogothic King. His court on its Gothic side was served by the usual household officers of a Germanic king, the chamberlain, the steward, and the rest; but it had another aspect in the trained administrators of the Roman civil 
service. Cassiodorus was the secretary of state who drew up documents in the Roman style, and Boethius, 'last of the Romans', served Theodoric all his life. The senate continued its functions in Rome; the King took part in its debates, and he showed his care for the city by reviving the games and the corn doles and repairing the aqueducts. Theodoric was a great builder in Verona and Ravenna, where his mausoleum remains the only perfect monument of his reign. Beyond the Alps he made family alliances with the Kings of the Franks, the Burgundians, and the Visigoths. For a time he governed the Visigothic lands in Spain and Gaul on behalf of the young King Amalric, his own grandson. To Italy he gave peace, civil and religious. He granted toleration to all, even Jews, for he declared that no man could be compelled to believe against his will. At the end of his reign, the imperial persecution of the Arians awakened his hostility, but even then it was rather political than religious. He became gloomy and suspicious, and believed that the Italians were plotting against him at Constantinople. Boethius was almost certainly guiltless, and yet he was executed after a long imprisonment, during which he wrote the Consolation of Pbilosopby. Perhaps the last piece of literature which represented the true spirit of ancient Rome, the book exercised an immense influence in its strong appeal to the mediaeval mind.

The year after the death of Theodoric, Justinian The (527-65), the codifier of Roman law, the builder of restoraSt. Sophia, and the conqueror of Italy, ascended the imperial imperial throne. All the western provinces of the govern- 
mentby Empire were in the hands of barbarian kings; some Justinian. indeed, like the Ostrogoths in Italy, admitted a formal dependence on the Empire, but the goal of complete freedom could not be far distant. Across this settlement of the long struggle there struck the ambition of Justinian, with its fanatical purpose of reconquering 'the countries possessed by the ancient Romans to the limits of the two oceans'. 'The outlying provinces were gone beyond recall, but in Africa the Vandal monarchy fell at once and Italy was won after twenty years of warfare. The feuds that broke out after the death of 'Iheodoric gave Justinian his opportunity, and in 535 Belisarius was sent to Italy at the head of an army. At the end of the next year Sicily, Naples, and Rome had fallen, but the Goths forthwith besieged Belisarius in Rome, and the great general successfully defended the city for over a year. In $54^{\circ}$ Ravenna fell and a few towns in the north alone held out. From this nucleus a great Gothic reaction set in. The chivalrous highhearted Baduila was chosen King, and his justice and restraint no less than his courage in attack recovered all Italy. Nevertheless the days of Gothic rule were numbered. Narses, the imperial chamberlain, met and defeated Baduila at Taginae, where the gallant Gothic horsemen dashed themselves to pieces against the solid wall of Narses' dismounted troops. Baduila was slain, and the remnant of the Goths disappeared over the Alps to an unknown fate.

The gradual separation of Italy

Justinian had conquered, and Italy was brought once more within the imperial bond, but the population, which had welcomed deliverance from its Arian rulers, 
found only economic ruin and administrative oppression. from the

Moreover the divergence between the east and west had steadily increased during the period of barbarian invasion, and Italy was now an outpost of the west, forcibly portion of united with the Graeco-Oriental empire. For the next five hundred years the history of Italy is the history of its separation from the east and fresh incorporation with the west. The liberation was accomplished piecemeal, but the first step followed hard on the victory of Justinian.

In 568 Alboin led his fair-haired Lombards, half- The first pagan and half-Arian, with their wives and children stage in and household effects, through the gap of Laibach into tion: the
foundathe valley of the Po, which was henceforth to bear their tion of the name. The desolation and depopulation that followed Lombard the Gothic war left a clear field for fresh settlers, and kingdom. only the walled towns made any resistance. By 572 most of Venetia, Liguria, and Tuscany were occupied, and Pavia, after a three years' siege, became the capital of the new kingdom. Alboin was murdered in 573, and after the brief reign of Cleph the Lombards lived for eleven years without a king. During this period independent war-bands crossed the Apennines and carved out duchies for themselves round about Spoleto and Benevento. The country defended by the great towns of Ravenna, Perugia, Rome, and Naples remained in imperial possession, and a very mosaic of political divisions was built up. In this hour of disruption Pope Pelagius sent the first summons of the Papacy to the Catholic Franks. They answered the appeal to their orthodoxy and helped for a time to check the Lom- 
bards. The alliance was short-lived, but it led the Lombard dukes to revive the royal power. The monarchy was inherently weak because its elective character prevented the establishment of a strong dynasty. In two hundred years nine families occupied the throne, and dynastic quarrels were intensified by the religious differences between Arians and Catholics. Every vigorous Lombard king had two political objects : the attack on the imperial districts, and the subjection of the dukes, especially in the north-east and the extreme south. In 590, after the short reign of Authari, Agilulf, the true founder of the Lombard state, was chosen King. He married Theodelinda, the widow of Authari and a daughter of the Catholic duke of Bavaria, thus maintaining a useful alliance and at the same time unconsciously keeping a way open for the entrance of Catholicism into the Arian kingdom. Agilulf's advance against the Empire was opposed by the Exarch Romanus, who had the marsh fortress of Ravenna for his capital, but his limited resources compelled him to leave the protection of the more distant region of Rome to its $d u x$ and the Pope who overshadowed him. In Gregory the Great Agilulf found a worthy foe. Consumed by a passionate love for Italy and by a sense of responsibility for his flock, Gregory was impelled to enter the political world and in so doing to lay the foundation of the future greatness of the Papacy. Twice over Rome was threatened, and the Pope took upon himself the task of organizing the defence and negotiating the withdrawal of the Lombards. In the north Agilulf conquered the remnants of territory on the Po, which were still in Roman 
hands, and this gain was followed up by Rothari, who took Oderzo and the Ligurian coast-strip with Genoa. Rothari $\left(6_{3} 6-52\right)$ began the consolidation of the royal power. He published his celebrated edict, the first written law of the Lombards, with the object of enforcing a uniform code instead of local custom; he laid the foundation of the royal demesne in the newly-won region of Genoa and established his control over the duchies of Piedmont. The influence of the kings in the south was greatly strengthened by Grimoald the Beneventan duke, who ascended the throne in 662 . For a time all the Lombard lands were united in the hands of his family, and Taranto and Brindisi were conquered from the Empire. After Grimoald's death the crown passed again to the descendants of Theodelinda. They abandoned the policy of conquering Roman Italy, and the year 68I saw the final victory of the Catholic Church in Lombardy and the conclusion of a definite peace with the Empire. Henceforward the sharp division between Lombard Italy and Roman Italy was admitted, and the cleavage of the seventh century left its impress on the land till the union of Italy in the nineteenth century. To the kingdom belonged the whole country from the Alps to the mouth of the Adige and the Apennines, with Tuscany and the southern duchies of Spoleto and Benevento. Between these regions lay the partes Ravennates and the partes Romanae with Campania, which belonged to the Empire, as did the Venetian islands in the north, Calabria in the extreme south, and the islands of Sicily, Sardinia, and Corsica.

The history of Roman Italy during the seventh cen- 


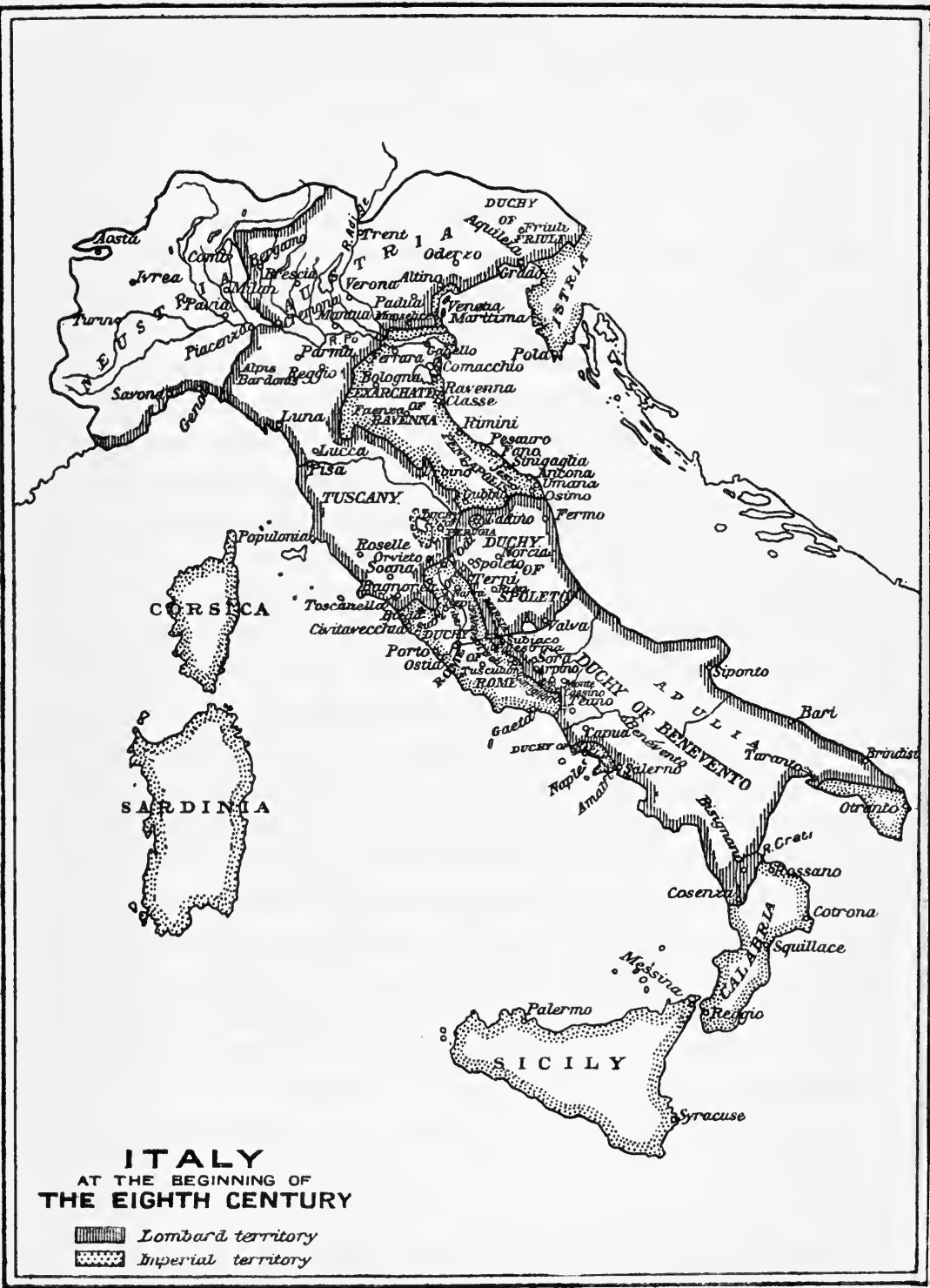


tury illustrates the growing divergence from Byzantium, The both in religious and secular aims. The emperors were imperial well aware of this antagonism; and twice over a deter- during the mined effort was made to bring Italy into closer adminis- century. trative and ecclesiastical subjection. The Asiatic and African provinces of the Empire were bearing the brunt of the first Mohammedan attacks, and Constans II (Constantine, 64I-68) aimed at making Italy the basis of fresh resistance to the barbarian menace, both Arab and Lombard. He took up his residence first in Rome and then in Sicily; but his policy aroused the discontent of the Italians, who were expected to bear the burden of commissariat and transport for the army. The opposition was increased by the Emperor's dictatorial attitude in the Monothelite controversy, and his policy succeeded only in driving the Exarch to revolt and in arousing the heroic resistance of Pope Martin I. The immediate successors of Constans abandoned his schemes, but Leo the Isaurian (7I7-40) again took up the task of crushing the independence of Italy. Within the country, during the intervening years, the stirrings of self-conscious individuality were plainly felt, but the two great movements of the period were mutually opposed and prevented a single aim. On the one hand the Lombard kings were determined to unite the whole of Italy under their rule; on the other the Italians strove to free themselves from the Exarch and win their autonomy under the Empire.

In the Lombard kingdom a gradual assimilation of The Italian Roman elements in race and civilization had taken Revolution Roman elements in race and civilization had taken and the place; and, while much that was distinctively Lombard Lombard 
dream of remained, the Roman heritage became the basis of a united Italy. development in architecture, in trade and industry, and in the conception of the State. In order to realize the dream of a united Italy, King Luitprand (7 1 2-44) saw that he must absorb the southern duchies as well as the Roman districts. He strengthened his position abroad by an alliance with the Frank, Charles Martel, while in Italy he pursued an opportunist policy. At first he made war on the Exarch and occupied Bologna and the Pentapolis; then, taking advantage of the revolt of Roman Italy, he supported his former enemy. The immediate occasion of the Italian Revolution was the order of the Emperor Leo to enforce a new system of direct taxation, which threatened the fiscal privileges of the great landowners, lay and ecclesiastical alike. These privileges had created a strong sense of local independence and opposition to the higher officials, who were sent straight from Constantinople. The revolution found its leader in Gregory II, whose rights as the greatest of ecclesiastical landowners were threatened. The Pope boldly opposed the tax, and the Romans of the duchy and the Lombards of Spoleto rallied to defend him against the Exarch. Into this combustible situation Leo flung the Iconoclastic Decree of 726 , and all Italy flamed into revolt; each region threw off the authority of the imperial officials and elected its own $d u x$. The victory of the Empire was secured by a sudden and unnatural alliance between the Exarch and the Lombard king, who encamped before the walls of Rome. Gregory II was compelled to submit to a humiliating peace.

Outwardly the Empire had triumphed, but in truth 
the mistake of Justinian had been repeated and a clear The Lomfield was left to the Lombards. The way was open, bard but Luitprand's piety neutralized his ambition and his Ravenna conquests were given back in obedience to Pope and the Zacharias. Aistulf, who became king in 749, was a man Pope stop the capture of Ravenna, though it may account for the curious hesitation in attacking Rome. The Exarch was powerless, and at the express desire of the Emperor Pope Stephen went in 753 to plead with Aistulf at Pavia. $\mathrm{He}$ foresaw the uselessness of the effort, and already he had begun negotiations with the Franks, the earliest supporters of the Papacy against the Lombard invaders. With masterly decision Stephen crossed the Alps and, in a meeting with King Pippin at Ponthion, won his help. Pippin, taking upon himself 'the cause of St. Peter and the republic of the Romans', promised to restore 'the exarchate of Ravenna and the rights and territories of the republic'. The Pope for his part anointed Pippin as King of the Franks and patricius of the Romans at St. Denis.

In two expeditions, in 754 and 756 , Pippin forced Aistulf to abandon his conquests and made them over not to the Exarch, but to the Pope, who tacitly claimed to represent the Roman Empire. The Papacy had state. taken the decisive turning in its history and the history of Italy. At first little difference was apparent in Italian affairs. The Lombard kingdom was thrust back within the boundaries of 68I ; Roman Italy still formed part of the Empire in theory, although the Exarch and the $d u x$ in Rome had disappeared and the Pope appointed 
the officials. Pippin returned over the Alps; and until the expedition of his son, Charles the Great, the Frankish King exercised no more authority in Italy than an honorary protectorate over the Papacy. Twenty years later the situation of 753 was repeated. The Lombard King Desiderius attacked the exarchate and threatened Rome, and Charles crossed the Alps to take up the quarrel. Pavia fell after six months; during the siege Charles came to Rome and offered Pope Hadrian a donation that gave him all Italy south of a line from Luna to the mouth of the Adige, while it purported merely to confirm the grant of Pippin. Desiderius was captured and carried off with his queen to a German prison; Charles in 774 received the Lombard crown, and the Frank entered into a fresh relation with Italy. To the Pope and the Romans he was still the new-fangled patricius, but to the Lombards he acquired the rights and duties of Rothari or Luitprand.

Charles the Not till 78I was Charles at leisure to take stock of Great and the kingdom of the Lombards, or Regnum Italicum as it
the king. dom of came to be called in opposition to Romania, the land Italy. subject to the Pope. Except for brief periods at the beginning of the tenth and the beginning of the eleventh century, the kingdom was henceforth held by sovereigns with ties beyond the Alps, but it was never merged in the kingdom of the Franks or the Saxons. The political individuality of Italy was secured in the coronation of Pippin, Charles's second son, who began a succession of separate kings under the sovereignty of the head of the family. Special edicts were issued and added to the ancient Lombard Code, although the general capitularies 
of the Frankish realm were also extended to Italy. Considerable changes were made in the administration; the Lombard dukes were replaced by Frankish counts, but the essential basis of Italian institutions was preserved. An old Roman city-the civitas, consisting of the town itself with the surrounding district-had been the centre of the duke's authority, and the same principle was observed in the formation of the counties. The counts were appointed directly by the King to exercise the military, judicial, and financial power of the crown in their counties. They were strictly officials, under the supervision of the missi dominici, who travelled in definite circuits throughout the country. The tendency to found comital families was checked by the rapid change of sovereigns after 888 , each of whom established fresh counts. The general Carolingian aim was to prevent the growth of territorial units larger than the ordinary county, but in the ancient duchies of Friuli and Spoleto, as well as in Tuscany, states intermediate in power between the kingdom and the county were formed by powerful marquesses of Frankish or Bavarian race. The traditional Frankish policy of strengthening the Church was extended to Italy, and the bishops received grants of immunity for the lands of their sees. This meant not only that the entry of royal officials within the episcopal territory was forbidden for fiscal or judicial business, but that their functions in regard to the tenants of the bishop were entrusted to an advocate appointed by him. In this way was laid the basis of the future territorial and administrative power of the bishops. 
Besides his care for local government, Charles did not neglect the territorial rights of the kingdom. As King he was bound to withdraw from the rash grant made to Pope Hadrian before his coronation at Pavia, and in $78 \mathrm{I}$ an arrangement was concluded by which the Papacy was substantially restricted to its former possessions of the exarchate and the Roman duchy. Spoleto was definitely incorporated in the kingdom, but Charles was dilatory in making good his claims to Benevento, and he never succeeded in getting any real hold on the duchy. As early as 774 Duke Arichis consciously adopted the rôle of representative of Lombard nationality: he took the title of prince, and aimed, in alliance with Byzantium, at restoring Desiderius' son to the throne of Pavia. In 787 he was forced to give one of his sons as a hostage for the fidelity of the duchy; nevertheless the attitude of the Beneventans remained disloyal, and Pippin of Italy had hard work to enforce his authority.

The second On Christmas Day in the year 800, nearly twenty-seven stage in the separa. tion of Italy from the East: the revival the traditional greeting of an Emperor: Karolo Augusto of the Western Empire. a Deo coronato magno et pacifico imperatori vita et victoria. This dramatic act had many interpretations, and the chief actors regarded it from different points of view. For the Pope there could be no idea of any breach of historical continuity. Rome had never ceased to belong to the Empire, and the Romans were but recalling the imperium, which had had its seat at Constantinople since 
476. Leo's chief motive was a very practical one. The successor of St. Peter had waged an endless struggle with his new subjects in the patrimony; they refused to admit his temporal authority or the right of the Frankish patricius to compel their obedience. Once the Romans had conveyed the Empire to Charles, the difficulties of the position, so the Pope argued, would be solved. The theory of the direct choice of the Emperor by the people of Rome long survived in the ceremony of election in the atrium of St. Peter's before a coronation. Leo acted, however, not only as a Roman, but also as the Vicar of St. Peter; he must have had plainly in mind the false Donation of Constantine, which conferred on the successor of the Apostle Rome and Italy, and all the west. To Charles this aspect of the Pope's action was unwelcome, and he desired to call attention to the view expressed in the chant of the Romans-a Deo coronato. He conceived of the Empire from an ideal standpoint. The City of God was his best-loved book, and from it he absorbed the truth of the essential oneness of Christian society. The Western Empire could not claim to include all Christendom, but it represented the real unity of Western Europe at the beginning of the ninth century. This unity was seen in the general likeness of institutions and laws among the barbarian peoples: it was expressed too in the common Roman Christianity and in the use of Latin in liturgy and legal code, in chronicle and theological treatise. Charles's wide dominions, moreover, corresponded broadly to the ancient provinces of the west, and men loved to call him pater Europae. To 
the. Emperor at Byzantium the innovation was not acceptable, and the problem of adjusting the relation of the two empires was not solved as long as the Greeks remained in Italy. For a time Charles conceived the fantastic plan of uniting east and west by marrying the Empress Irene; but in 812 he accepted the compromise of a partition not only of the Empire but also of Italy. His right to the imperial title was recognized, and in return he ceded to the east Venice and the Dalmatian coast, though Istria with Pola was retained by the west. Dreams of Frankish conquest in the old Roman districts of the south were perforce abandoned.

The revival of the Western Empire solved the problem of Italian development which had vexed the statesmen of the seventh and eighth centuries. The dream of a Lombard Italy was destroyed, and the Pope succeeded in shaking off Byzantine tyranny without leaving the imperial bond. The central 'Roman' districts, as well as the Lombard kingdom, were brought within the new Empire, but the territorial possessions of the Papacy preserved the outline of the former cleavage. For the present the Frankish emperors enforced their sovereignty over Rome and insisted on their right of confirming papal elections; nevertheless the seeds were sown of the future claims of the Papacy to temporal predominance in Italy. In the south the compromise with Byzantium delayed the incorporation of this last 'Roman' region with the Western Empire, and when its separation from the east was at length brought about by the Normans, the Empire was too weak to assert its suzerainty. Frankish intervention reclaimed Italy from isolation and bound 
the country once more to the task. of handing on the Roman heritage to Eùrope.

The unity of the Empire was destroyed in practice, The later if not in theory, after the treaty of Verdun (843), barbasions when the grandsons of Charles the Great divided the and the Carolingian inheritance into the kingdoms of France, of feudal Italy, and Germany. New problems appeared north and throughout south of the Alps alike. Italy, left to manage its own Italy. affairs, was faced by the fresh barbarian attacks of Saracens and Hungarians, and by the formation of small feudal states within the kingdom. Louis II, first as King (844-50), and then, for a quarter of a century, as Emperor (850-75), devoted all his energy and ability to the cause of Italy. To maintain peace in the northern and central regions; to preserve his sovereignty over the papal state; above all, to battle unceasingly with the disruptive elements that appeared in the south forty years before they became acute in the north, this was the task of Louis.

The new power of Islam was firmly established in Louis II, Spain and Africa, and in 827 Ziyadet-Allah, the Aghlabid the Saraemir of Kirwan, began the systematic conquest of Sicily. the Palermo fell in 831 and a strong base was established for $\begin{aligned} & \text { southern } \\ & \text { duchies. }\end{aligned}$ raids on the Italian coasts. In 846 the basilicas of St. Peter and St. Paul at Rome were sacked; a second attack the next year roused Pope Leo IV to form a league of the republics of Naples, Gaeta, and Amalfi, and a brilliant naval victory was won off Ostia. The internal disunion of the south played into the hands of the invaders; rival factions in Benevento helped to establish Saracen settlements at Bari and 'Taranto, and 
the commercial republics found greater safety in alliance than in battle with the infidel. The emperors of the east and the west alike undertook the task of driving out the Saracens, but common action and co-operation between the Frankish army and the Greek fleet was prevented by conflicting theories of empire. Basil I regarded Louis as an emperor of the Franks, who stretched out his hands over Byzantine dominions in the south, while Louis called himself Roman Emperor and based his rights to Italy on his election by the Romans.

As early as 847 Louis came south, and continued to spend his energies on settling the eternal feuds of the Lombards and capturing Saracen strongholds. He was preparing to attack Taranto when he was treacherously seized and imprisoned by the graceless Beneventans. Fear of a fresh Saracen inroad secured the release of the Emperor, but in 875 he died, while he was collecting a new army. There is no more fitting commentary on his reign than the I 2oth Psalm, which he charged the monks of Casauria to chant daily on his behalf : 'Deliver my soul, O Lord, from lying lips : and from a deceitful tongue. . . . I labour for peace, but when I speak unto them thereof : they make them ready to battle.' Louis left no son to carry on his work, and for another century and a half South Italy was to belong to the east and not the west. The Eastern Emperors took up the task dropped by the Frank and succeeded in ridding Calabria and Apulia of the Saracens.

The con- After the death of Louis II internal disunion and

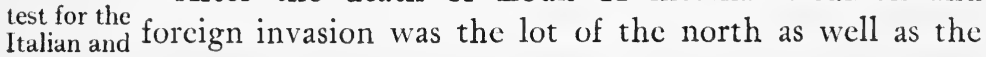


south of Italy. The immediate need was to find a king. imperial

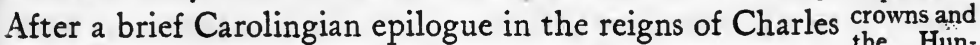
the Hunthe Bald and Charles the Fat, princes from beyond the garian Alps and marquesses of Italian birth, but Frankish descent, held the crown in rapid succession with the support of some party within the kingdom. The initiative always came from the Italians, and when a foreigner took the crown it was invariably at their bidding. Berengar, Marquess of Friuli, held the kingdom from 888 to 924, against the Emperors Guy and Lambert of Spoleto, Arnulf of Germany, and Louis of Provence, and against King Rudolf of Burgundy. He received the imperial crown in 9I 5 , but his reign was filled with disaster. Civil war was chronic; the Hungarians, who first arrived in Lombardy in 899 at Berengar's own summons, continued to ravage the country up to the walls of Rome; the Papacy fell under the sinister influence of the Roman dynasty of Theophylact. The only relief is found in the defeat of the Saracens at the Garigliano by a great league of Italian powers, and in this Berengar alone had no part. After his death, Hugh, Marquess of Provence, was made King, and he held all Northern and Central Italy in a firm or rather a tyrannical grip for twenty years. After the short reign of his son Lothar, Berengar II, Marquess of Ivrea, seized the crown and imprisoned Lothar's young widow, Adelaide of Burgundy. She escaped and appealed for protection to Otto the Great, the Saxon King of Germany. In September 95 I he was in Pavia, and the same year he married Adelaide and took the title of Italian King, with the support of his new subjects. Berengar received the kingdom again 
as Otto's vassal, but his attack on Pope John XII led to his final deposition in $96 \mathrm{r}$. In the next year Otto received the imperial crown and a new epoch opened in the political history of Italy.

The rise of The true interest of the period between 888 and 962 the mar- lies in the break-up of the uniform comital system, and
quesses and the the rise of new local powers, the marquesses and the bishops in bishops. By the side of the older states of Friuli, Spoleto,
Northern and Cen- and Tuscany, the 'younger' marchional families were tral Italy. established as supporters of the successive kings; they added county to county, establishing new territorial groups and preparing to play a great part in the politics of the future. A notable impetus to the power of the bishops had been given by the Carolingian grants of immunity, and now in the dissolution of the old administrative system their importance increased still more. The burden of defence against the Hungarians in the tenth century seems to have fallen on the cities and on the bishops, who acted as the representatives of the citizens. Constantly they seek royal permission to build walls or dig ditches, and nowhere do we hear of the action of the counts. The bishops throughout the period received grants of public authority over all the inhabitants of their immunity and not merely over their own dependents. A further step was made when the process began of vesting the public powers in a city and a mile or more round it in the bishop as the only effective authority. This separation of the cities from the surrounding country intensified their individual consciousness, and unattractive as the period is externally it contained the germs of the constitutional revolution of the future. 


\section{Political Development}

The revival of the Western Empire by Otto the Saxon Otto the recalls forcibly its revival by Charlemagne more than the Holy a century and a half before. Both emperors emphasized Roman the universal aspect of society and both were conscious of the sacred character of their office. There were nevertheless several points of divergence. The Carolingian Empire rested on the supremacy of the Frankish race in Europe and its alliance with the Roman pontiff: the Holy Roman Empire founded by Otto was based on the permanent union of the Italian and German crowns. From 962 onwards, the king elected by the German magnates-he bore the title of King of the Romans from the eleventh century-became as of right King of Italy and candidate for the formal suffrages of the Romans and coronation by the Pope as Emperor. Until the end of the twelfth century the balance of material power lay with Germany; but the moral weight which came from Italy and Rome can hardly be overestimated. With Otto, as with Charles, German interests occupied the foremost place, although, once established south of the Alps, he accepted loyally the duties of Roman Emperor and Italian King, and his dynasty brought with it the untold blessings of unity and peace. As Emperor, Otto determined to relinquish no jot of his sovereignty over Rome, and when John XII rebelled in 963 he had him condemned and deposed by a synod of Italian bishops. Otto went farther than the Carolingians in his control over the Papacy and transformed the right of confirming the election of the Pope into a right of practical nomination. In Rome he and his successors had to contend with the Crescentii, who were resolved 
to maintain the temporal sovereignty over the city, founded by their ancestors during the abeyance of the Empire. Revolt after revolt, in which the Pope of imperial nomination was driven out, was put down with ruthless severity, and it was clear that the authority of the Empire in the city rested on mere force.

Otto the Great was not slow to formulate the imperial claims of sovereignty over Southern Italy, but there was something of the same confusion of thought in dealing with the problem that marked Charles the Great's policy. Otto aimed at establishing his authority over the Lombard states and maritime republics and perhaps over the Greek districts of Apulia and Calabria. At the same time he hankered after an incompatible alliance with the basileus Nicephorus Phocas and the marriage of his son Otto with a Greek princess. In order to hasten the negotiations he undertook a raid against Bari, which developed into a regular campaign all over the south. John Zimisces, the successor of Nicephorus, wanted to be free from Italian troubles. He agreed suddenly to the alliance and sent the Princess Theophano to Italy. The marriage took place in 972 and Otto gave up his schemes in the south.

Otto II. Otto II succeeded his father in 973. He stands in his political conceptions midway between his pioneer father and his visionary son. An empire was not thrust upon him towards the end of a strenuous reign, and from the first he took an equal view of the claims of Italy and Germany, realizing perhaps the duties of a complete emperor in an unparalleled degree. His southern policy was statesmanlike and free from the contradiction that 
marred the work of his father. In 981 Otto revived the claims of the west over all Italy and Sicily. He spent many months in besieging Byzantine cities in Apulia; and then, abandoning his hostility towards the Greeks, he advanced through Calabria to oppose a fresh Saracen occupation. In a great battle near Cotrone he was at first victorious, but the Saracens rallied and inflicted a severe defeat on the exhausted Germans. By 983 the Emperor had got together a fresh expedition to avenge 'the honour of fair-haired Germany', but death met him in Rome, where he had turned aside on his way south.

The boy Otto III did not come to Italy till 996, Otto III. when he was crowned Emperor by his cousin Bruno, whom he had made Pope under the name of Gregory V. The interest of the reign lies in the development of his political ideals. From his mother Theophano, Otto absorbed the current Greek view of life, with its absolutist ideal of empire, its contempt for Saxon barbarism, and its love of elegance and ordered splendour. Nevertheless the young Emperor's gaze was in truth rather turned backward through the ages to ancient Rome than across the sea to Byzantium. Genere Graecus imperio Romanus, Gerbert wrote of him, and it was from Gerbert, the founder of the new French school of classical learning, that Otto drew his ideal of empire. After a many-sided career as mathematician, schoolmaster, and politician, Gerbert became Archbishop of Ravenna, and in 999 he succeeded Gregory as Pope with the significant name of Silvester II. His letters are full of references to the respublica Romana, and under his guidance Otto conceived 
of a renewed Roman Empire with its seat at Rome, whence a new Constantine and a new Silvester should rule the whole world. He strove hard to realize his ideal, but his pictorial mind loved to create symbols of empire rather than its substance. He built a palace on the Aventine, and there he gathered round him old Roman officials or newer dignitaries in Byzantine guise : the praefectus urbi, the patricius, and the palatine judges, who were charged to judge Rome and the world in accordance with the code of Roman law. In grasping the ideal, he let slip the reality of power, but Otto III died before complete disillusionment overtook him : Southern Italy was already lost; in the north, Arduin, Marquess of Ivrea, was seeking the Italian crown; Rome sent the Emperor on his last journey north, with the echoes of revolt in his ears. And yet something permanent was saved from the wreck of his schemes. He had restored Roman law to Rome and he had left an ideal of an empire centred in Italy, which was one day to appear again in more practical form in the schemes of Henry VI, Frederick II, and Innocent III.

The Ottos As kings of Italy the Ottos had given a fresh unity of kingdom direction to the State. Great assemblies were held from of Italy. time to time at which general laws were published and pleas were held; imperial missi once more made their rounds to redress injustice and official oppression. Nothing revolutionary was attempted in the administration. Otto the Great was content to strengthen the new forms of organization that had struck root since the end of the ninth century. He confirmed both the marquesses and the bishops in their exercise of public 
authority; but in accordance with the policy which he had followed in Germany he was inclined to favour the bishops. The second half of the tenth century saw a great revival of economic prosperity. The defeat of the Hungarians at the Lechfeld in 955 freed Lombardy as well as Germany from their incursions. Wasted valleys were again populated and brought under cultivation; in the renewed security, commerce and industry awoke and began to give a fresh importance to the cities on the Po and the sea-coast.

With the opening of the eleventh century the last The period is reached in the separation of Italy from the east. century. For a century and a half the Normans were engaged in subduing the Saracens and the Lombards and in driving the Eastern Empire from its last foothold in the west. During the same period a great religious revival led, on the one hand to a progressive campaign to free the Church from clerical marriage, simony, and lay investiture, and on the other to the formulation of the claims of the Roman see to spiritual supremacy over kings and local churches alike. A social revolution throughout Italy, influenced in the north by the religious movement, in the south by the anarchy of the Norman advance, brought the cities once more to the surface as selfgoverning communities. The bishops were the stormcentre; their authority was snatched from them by the citizens, and the imperial right of nominating and investing them was contested by the Papacy.

The first three emperors of the period, the Bavarian The third Henry II and the Salians Conrad II and Henry III (IOO2- stage in 56), made intermittent efforts to recover their authority ration of 
Italy from in the south. The great feature in South Italian politics the east: since the defeat of Otto II at Cotrone had been the man con- steady rise of the power of Byzantium, until Greek the south. territory in the Abruzzi marched with the papal lands. The duchy of Benevento had broken up into the states of Benevento, Salerno, and Capua, and the dependence of the two last on the east enabled Greek influence to penetrate as far as the great abbey of Monte Cassino. The attack of Henry II on the Byzantine power is chiefly memorable for the support given to the petty revolt of Meles of Bari, in which Norman adventurers appeared for the first time in South Italian quarrels. The Emperor's measures to detach Capua from the Greek alliance failed, but Conrad II was more successful in 1038, when he gave the principality to Guaimar V of Salerno and established the Normans at Aversa to secure the obedience of Capua. When Henry III arrived eight years later, the situation had undergone a radical change. The Normans, reinforced by fresh bands under the sons of Tancred of Hauteville, had conquered the Greek cities of Central Apulia from Melfi southwards and held their conquests in feudal dependence on Salerno. The Greek power was in rapid decline and Guaimar, who conceived the idea of driving the Byzantines from Italy with the help of Norman arms, was now predominant. In Henry's eyes Guaimar was therefore dangerous. He was deprived of Capua and the Norman conquests were brought under the direct suzerainty of the Empire by the investiture of Drogo with Apulia. Henry's policy of binding the Normans to the Empire might have been successful had he been 
able to occupy himself with southern affairs, but after his departure no emperor crossed the Garigliano for nearly ninety years. When Lothar arrived, in II37, the Greeks and Lombards had been overthrown and the Saracens had been driven from Sicily, while the suzerainty over the Norman conquerors was contested by the Papacy.

In the kingdom of Italy, Henry II and Conrad vindi- Henry II cated the claim of the German King to succeed ipso and Confacto to the Italian crown. They triumphed over Arduin Northern of Ivrea and William of Aquitaine, the candidates of the Italy. Italian nobles, with the help of the bishops; but in order still further to strengthen his position in Italy, Conrad developed a new policy of conciliating the great marquesses. He united them by ties of marriage with the chief families north of the Alps, not only in Germany, but also in the newly-acquired third kingdom of Burgundy. The marriage of Count Oddo of Savoy with Adelaide, the Marchioness of Turin, illustrates this policy, and it has a further interest because from it the present King of Italy is descended. The union of the great families, who controlled the Alpine passes, did not always turn out to the advantage of the emperors, and in the Investiture Contest the friendship of Savoy was balanced by the hostility of the Welfs and Canossans.

In Lombardy a social revolution was beginning in The social the hostility between the bishops and their immediate in Lomvassals, the capitanei, on the one hand, and the secundi bardy. milites, or vassals of the captains, on the other. The knights had no legal guarantee for the heritability of their fiefs, and in Milan Archbishop Heribert drove 
them to revolt by exercising to the full his arbitrary rights. Conrad protected the knights. He issued an edict in 1035 granting them the right of inheritance, and he besieged the Archbishop and then deposed him without reference to Pope or synod. The greater security of the knights gave a notable stimulus to the growing independence of the cities and their advance to self-government.

The re- Conrad's high-handed action in deposing Heribert form of the was in accord with his general ecclesiastical policy. He
Papacy: policy of Henry II and was a strong secular-minded person and maintained his authority over the Pope and the bishops on the Henry III. temporal side with the aid of simony and direct nomination. For the spiritual welfare of the Church he seems to have cared nothing. In marked contrast to this attitude was the part played by Henry II and Henry III in forwarding ecclesiastical reform. Henry II determined to stamp out simony in nomination to benefices, and he furthered the work of Benedict VIII in holding councils for reform in Italy and Germany. After the death of this Pope the situation of the Papacy rapidly deteriorated, and the worst scandals perhaps of any age disgraced the see of Rome, under John XIX and Benedict IX. In 1046, when Henry III came to Italy to receive the imperial crown, three popes claimed the chair of St. Peter. A synod was assembled at Sutri to cleanse the Papacy, and all three popes were deposed. Henry nominated in their stead Bishop Suidger of Bamberg, who took the name of Clement II. His successors, Damasus II, Leo IX, and Victor II, were all chosen by the Emperor from the German episcopate, and the. 
attack on simony and clerical marriage was pursued with untiring zeal. The friendship of the popes with the Emperor and the obvious sincerity of his action kept out of sight the fundamental contradiction between his policy and the aim of the extreme ecclesiastical party. The earlier reformers had welcomed lay help in cleansing the Church from abuses, but the new school regarded the interference of the laity as the gravest abuse of all. The freedom of the Church from secular control was the real object of these reformers, and the history of Italy becomes merged in the great campaign of the Papacy to root out lay nomination and lay investiture of benefices.

Henry III was succeeded by the child Henry IV in The begin1056; and the weak administration of the minority ning of pa. allowed all the forces in Church and State opposed to pendence. the monarchy to make headway. The first papal election was held without waiting for the royal nomination, and during the pontificate of Nicholas II (I058-60) a Roman synod, under the influence of the Archdeacon Hildebrand, vested the choice of the Pope in the cardinals of the Roman Church, thus depriving the Emperor and the people of Rome of their traditional rights. 'The Papacy found external support for its policy of independence in an alliance with the Norman princes, Richard of Capua and Robert Guiscard of Apulia, while the representatives of the house of Canossa, the great Countess Matilda and her mother Beatrice, placed all the resources of their wide lands at the disposal of the reformers. In Lombardy, and especially in Milan, the hatred of the populace for the wealth and arrogance 
of the higher clergy, drawn as they were from the ranks of the upper military class, was skilfully captured by the Papacy. The movement of the rag-market-the Pataria as it was called-soon lost its class origin and developed into a civil war in which the parties were divided by religious rather than social sympathies. Henry IV In 1072 Henry IV took the government into his own gory VII. hands with a firm determination to recover the power of the crown. His policy awakened the antagonism of the two forces that had profited by the minority-the Papacy and the German princes, who played into each other's hands. Hildebrand, who became Pope as Gregory VII, attacked Henry for his nominations to Milan and other Italian sees, and threatened excommunication. At the same time the Pope made a supreme effort to free the Church by forbidding lay investiture of ecclesiastical benefices, thus striking at the control of the crown over the vast temporal possessions of bishops and abbots. The King replied by summoning the German bishops to a synod at Worms; the Pope was accused of unspeakable crimes, excommunicated, and deposed. Gregory at once pronounced solemn excommunication against the King, deprived him of his royal office, and freed his subjects from their allegiance. 'The hostility of the princes forced Henry to seek absolution. He crossed the Alps as a fugitive and found Gregory at Matilda's hill-fortress of Canossa in January 1077. For three days Henry waited in the outer ward of the castle, clothed in the woollen frock of a penitent. The Pope hesitated, divided between his duty as a priest and his interest as a politician. The priest triumphed 
and Henry received absolution. He promised amendment of his ecclesiastical offences and agreed to Gregory's arbitration in his quarrel with the princes. At Canossa the King suffered an unheard-of humiliation: he acknowledged tacitly the Pope's claim to excommunicate and depose; he acknowledged expressly the claim to arbitrate in the internal affairs of Germany. On the other hand, he recovered his freedom of action and no longer faced the princes as an excommunicate.

Nevertheless the relations of King and Pope were The War of always strained: the mutual ban was again proclaimed Investiand both sides seized the weapon of schism. Gregory recognized Rudolf of Swabia as King, and Henry, at a synod of Italian bishops, raised Archbishop Guibert of Ravenna to the papal throne as Clement III. In Italy Henry had the support of Lombardy and the Tuscan towns, but he did not succeed in fighting his way into Rome for the consecration of Guibert and his own imperial coronation until 1084. The rapid approach of Robert Guiscard forced Henry to retreat; for threc days Rome was given up to fire and plunder, and so great was the rage of the citizens against Gregory for the work of his allies, that he was forced to withdraw to the Norman capital of Salerno, where he died in 1085. Gregory's death brought no peace to Church or kingdom; Rome adhered to the Emperor and the antiPope, but Urban II galvanized the rest of Italy into fresh resistance and Henry lost any real hold on the kingdom. In Germany he recovered much of his authority, but he was forced to abdicate at the last in favour of his son Henry. 
The settle- Once he had become King, Henry $\mathrm{V}$ strenuously ment of the upheld his rights over the Church. Twice over he Contest. forced Paschal II to agree to logical but wholly impracticable settlements of the investiture dispute, and the result was a fresh outbreak of war in Italy and Germany. Nevertheless matters gradually worked to a settlement. In I 22 Calixtus II, an ardent reformer, but a man of statesmanlike breadth of mind, agreed to a reasonable compromise in the Concordat of Worms. Henry abandoned the right of nomination and confirmed the freedom of election of bishops and abbots; he abandoned the use of the ring and the staff, ecclesiastical symbols that caused grave offence, but investiture of the bishop-elect was to take place by touch of sceptre, before consecration in Germany, and within six months after consecration in Italy and Burgundy. The Empire preserved the substance of its authority over the bishops, while the Church obtained the ostensible object for which it fought. It is time to take stock of the results of the long struggle in Italy.

Effects of During the investiture war the Papacy became an the War of international power exercising spiritual superiority over
Investitures : the Empire, the temporal rulers, even over an emperor himself, and vindicating monarchical control over the episcopate of Papacy, and the Europe. In Italy the hold of the popes on Rome and the Patrimony was precarious, but they had extended their temporal dominion over the Norman princes in the south and claimed the ample lands in Emilia and Tuscany, which Matilda had left to Gregory VII. Urban II, moreover, roused Europe in the preaching of the First Crusade, and its startling success in the capture 
of Jerusalem in 1099 added a fresh glory to the Papacy. The Empire had saved the substance of its power in the actual matter of investitures, but its sacred character had suffered severe damage in the humiliations inflicted by the popes and in its failure to head the great Christian expedition to recover the Holy Places from the infidel. The executive of a movement that expressed on one side the unity of Europe passed to princes of the second rank, Godfrey of Bouillon, a subject of the Emperor's own, Robert of Normandy, and above all Boamund of Taranto, the representative of one of the new powers that were excluding the Empire from the possession of Italy. While the Normans were on the verge of con- The rise of solidating their power in a strong monarchy, and over- municipal coming municipal and feudal anarchy in the south, the ernment. cities of Northern and Central Italy were winning selfgovernment. The Augsburg annalist summed up the effect of the investiture war with equal wit and truth when he wrote: 'We are all double: the popes are double, the bishops double, the kings double, and the dukes double.' It was undoubtedly in this period of ambiguous authority that the last stage was made in the journey towards complete self-government. In Milan no less than three archbishops contested the chair of St. Ambrose after 107I. None of them was able to reside in the city, and all legitimate authority seems to have been overthrown. Herlembald, the knightly leader of the Pataria, ruled the city in 1075, acting, in the words of a contemporary, as pope towards the priests and king towards the people. Again, in I 103, the private quarrels of rival archbishops left Milan 
without its traditional head till 1116. During this period the first war with Lodi took place, and the earliest mention of the consuls as the leaders of Milan is found in 1107. A great earthquake terrified the population of Lombardy in III7, and the Archbishop issued a general call to penitence. Two great stands were erected for the occasion, and on one stood the Archbishop and clergy, on the other the consuls of Milan with men learned in the law. After the description of this characteristic scene, the consuls are frequently mentioned as the typical officers of the new city commune independent of the Archbishop. One effect of the long civil war had been to check the opposition of classes, and the unity of the city appeared plainly in the constitution of the consuls. They were chosen from the three classes of captains, vavassors, and merchants, although the consuls belonging to the military classes were in the majority. From the beginning of the twelfth century the consular government seems to have become universal in the cities of Lombardy, Romagna, and Tuscany. The consuls acted as the military and civil heads of the State and exercised the regalia, as the public rights of the State in justice and finance were called. These rights and duties had been granted by the crown to bishops and marquesses, and they now passed, generally without the imperial sanction, to the cities. The consuls were assisted by a small council of notables known as the credenza, and the ultimate authority was exercised by a general assembly of the citizens. The external activity of the communes began simultaneously with their internal autonomy, and throughout the first half 
of the twelfth century they waged savage war on their neighbours. The great seaports had wider scope for their activities: Pisa and Genoa drove the Saracens from Corsica and Majorca, but the jealousy of Pisa deprived Genoa of a permanent share in the conquest. Both cities took part in the First Crusade, and soon they had established trading quarters with special privileges in the Syrian cities. Venice and Amalfi, too, held a position of even greater independence and enterprise, but the internal history of these sea-states, which had remained formally at any rate members of the Eastern Empire, had followed a different course. Amalfi was destroyed by Pisa, but the Fourth Crusade and the fall of the Greek Empire provided Venice with the opportunity to found a great colonial power in the Aegean.

In the early years of the twelfth century the three The attraditional authorities in Italy, the Eastern and Western the EmEmpires and the Papacy, found themselves practical pires of exiles; and Italian history in its broad political outline West and is concerned with the attempt of these powers to take root once more. The Papacy in becoming international their had lost its hold on Rome and the Patrimony; the in Italy. Western Empire had become a German power ousted from the Italian kingdom; the claims of Empire and Papacy as well as of Byzantium in Southern Italy were menaced by the union of the Norman dominions in a single strong monarchy.

The most determined and successful attempt of the The EmWestern Empire to recover its authority throughout Italy pires and in the twelfth century was made by Frederick Barbarossa in alliance (I $5_{2-90}$; but his effort was not the first. At his acces- Normans. 


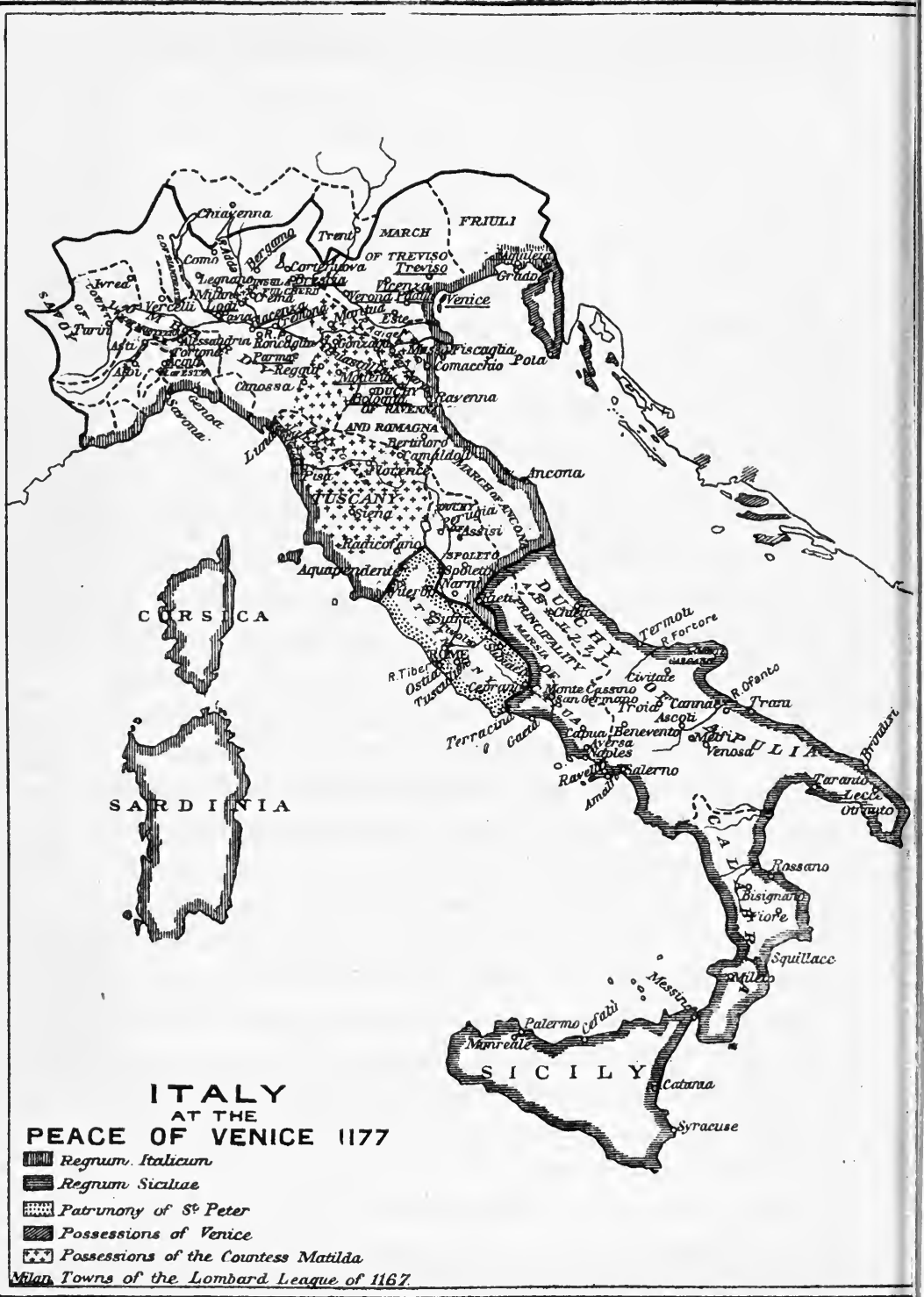


sion he inherited the policy inspired by St. Bernard of a coalition of Pope and Emperor against Sicily. The policy was plausible, but it failed because it did not take into account the essential opposition between the Papacy and Empire in Italy, nor the instability of the Empire owing to its dependence on the caprice of the German electors. The great monastic revival had given the direction of Europe to St. Bernard, the Abbot of Clairvaux, a mystic and ascetic, but a very practical politician withal. The power of Roger II of Sicily was a tacit attack on the Papacy, and he had even dared to support Anaclete II when St. Bernard declared that Innocent II was the rightful successor of St. Peter. In I 136 an expedition led by the Emperor Lothar and Pope Innocent, supported by Greek gold and the Pisan fleet, and helped within the Sicilian kingdom by rebel towns and barons, had hurled itself against the Norman power and failed to break it. Lothar went home, and Roger defeated Innocent and forced him to grant investiture of Sicily, Apulia, and Capua with the royal title. Then civil war began in Germany and the Pope was deprived of imperial help. Lothar had aimed at establishing a strong monarchy, and he had massed all the lands at his disposal in Saxony, Franconia, and Tuscany in the hands of his Welf son-in-law, Henry the Proud, Duke of Bavaria, with the expectation of his succession to the Empire. The electors chose not Henry, but Conrad of Hohenstaufen, and the strength of the Empire was wasted in the feud of Welf and Waiblingen, Guelf and Ghibelline, names that were identified later on in Italy with the papal and imperial parties, though 
they were often mere labels of the city factions in the thirteenth and fourteenth centuries. Italy was left to itself for fifteen years and the Empire lost ground all along the line. In Sicily the Norman kings organized their power on a sure basis; the Lombard cities shook off all control; the spirit of municipal independence reached Rome and the new commune proclaimed on the Capitol drove the Pope from the city. With the accession of Barbarossa, Hadrian IV revived the coalition against Sicily: Frederick arrived in Rome in 1155 and forced the commune to receive the Pope, but he failed, owing to the opposition of the German princes, to undertake the campaign against William I, in alliance with the Emperor Manuel Comnenus. A Greek army indeed landed at Ancona and overran the Adriatic coast, but William was victorious, and Hadrian saw himself compelled, like Innocent II, to grant investiture to the Sicilian, to the detriment of the Papacy, but far more of the Empire. The coalition policy had failed. Barbarossa's Italian journey was the turning-point in his reign, and the first-hand knowledge that he gained determined his future policy.

The Pa- Frederick was the representative of the new Europe pacy, the Normans, and the Lombard cities against the Emperor that succeeded the Europe of St. Bernard. The ruling religious and monastic motive gave place to the ideal of chivalry on the one hand, and, on the other, to the principles of the civil and the canon law. The Empire adopted the theories of the State founded on the maxims of Justinian, and the Church passed from the direction of the great masters of the spiritual life to the control of jurists and financiers. Frederick, moreover, shared 
to the full the passion for justice and legality which was characteristic of the great kings of the twelfth century. His conception of his rights brought him into conflict with the Papacy and the Lombard cities, and the conquest of Sicily was postponed, while the Emperor strove to recover his authority in these two directions.

Relations with Hadrian had been strained ever since the failure to attack Sicily, and Frederick resented keenly the suggestion of the Pope and his legate the Cardinal Roland that the imperial crown was conferred by the Papacy, while he himself awakened hostility by claiming sovereign rights in Rome and the territory of St. Peter. Matters came to an open breach when the election of Roland as Alexander III brought about the counter-election of the imperialist Octavian, and Alexander was thrown into close alliance with Lombardy and Sicily.

Frederick's sense of order and justice was outraged by The war the Lombard ideal of liberty. The greater cities were with the trying to absorb their smaller neighbours and overcome the feudal marquesses. Milan had fought Como for ten years and Lodi for four, and a long war had been waged by Cremona and Parma against Milan, Piacenza, and Crema. Frederick's first object was to restore order : the Milanese, who refused to give up Como and Lodi, were put to the ban of the Empire and deprived of the regalia. In II 59 they were besieged by the Emperor and capitulated on terms which guaranteed the freedom of the oppressed cities and the full recognition of imperial authority. Having thus cleared the way, Frederick sought a legal basis for the re-establishment of 
imperial government in Italy. At Roncaglia a great land-peace was proclaimed and an inquest into the royal rights was entrusted to representative judges from all the Lombard cities and doctors of the law from Bologna. The regalia-mints, tolls, judicial fines, fodrum, royal palaces, appointment of judges, treasure trove, and the rest-were resumed by the Emperor unless the possessors could show documentary evidence for their right, and a vast revenue accrued to the crown. Podestà were nominated to govern the cities in place of the elective consuls, and Milan stood a second and more terrible siege in 1162 , because the citizens refused to accept the new imperial officials. Frederick realized his aim of governing directly all Northern and Central Italy and his generals vigorously attacked the papal lands. His legal position was unassailable, but he had taken no account of the long prescriptive independence of the cities.

The Peace

A reaction set in and in 1167 the steady pressure of of Venice and the the Imperial Government induced the towns to lay aside Peace of Constance. their mutual jealousy. All the cities from Milan to Venice and from Bergamo to Bologna joined in the Lombard League, and the triple alliance between the Lombards, Alexander III, and Sicily was confirmed. Frederick was worsted in the fresh war; in 1175 he was forced to raise the siege of Alessandria, and in 1176 he failed to improve his fortunes on the field of Legnano. The Emperor decided to come to terms. At Venice he made his submission to Alexander, thus ending the schism, and concluded separate truces with the Lombards and William II of Sicily. In I 83 the Peace of Constance 
recognized the legality of the League and the right of the cities to govern themselves, with possession of the regalia within the walls. Imperial suzerainty was secured by a general oath of fidelity and the investiture of the elective consuls. The position of the Emperor was immensely strengthened by abandoning the decrees of Roncaglia; the cities were transformed from rebel subjects to friendly vassals, and the League fell apart as soon as the common danger was over. In Central Italy the imperial administration was organized under the official dukes of Tuscany, Spoleto, and Romagna and the March, and Frederick was able by peaceful means to carry out his plans of recovering Sicily. The marriage of the young King Henry with Constance, the heiress of William II, prepared the way for the union of Sicily and the Empire.

With the accession of Henry VI (I I90-97) everything Henry VI was subordinated to the conquest of his new kingdom. and the William had died, and a party within the kingdom sup- of Sicily. ported Tancred, a grandson of Roger II, of illegitimate birth, against Constance and her imperial husband. By the end of II94 Henry made his triumphal entry into Palermo; and the birth of Frederick stupor mundi, the only son of Henry and Constance, seemed a pledge for the continued union of all Italy under the descendants of Hauteville and Hohenstaufen. The centre of power was shifted from Germany to Italy; Henry aimed at freeing the Empire from the control of the German electors and making it hereditary, like the Sicilian monarchy. With Italy as the basis of his power, he formed a new conception of imperial dominion. The 1832.3 
Pope was to content himself with spiritual functions; the Emperor was to reunite east and west in a single empire. Henry worked with feverish rapidity. A rebellion in Sicily was suppressed, Lombardy was cleverly divided, and the papal Patrimony was secularized; but there were too many hostile interests to conciliate in a short time. Death, which carried off Henry, as it carried off his son and grandson at the crisis of their fate, destroyed his imperial schemes. The hegemony of Italy passed to the great Pope, who ascended the throne of St. Peter in 1198.

Innocent Innocent III made the recovery of the papal possesIII and the sions and the separation of Sicily from North Italy and schism. Germany the foundation of his Italian policy. When the German electors passed over the child Frederick and divided their votes between his uncle Philip of Hohenstaufen and Otto the son of the Welf Henry the Lion, Innocent claimed to decide between the rival candidates. He gave his support to Otto on the basis of an acknowledgement of the papal right to all the territory ever granted by the Frankish emperors and the suzerainty of Sicily. Frederick was secured in the possession of his mother's kingdom, and Innocent assumed direct executive functions during the minority. In Central Italy the German governors of Henry VI were driven out and replaced by papal rectors. Rome returned to its obedience, and the league of Tuscan cities consented to make alliance with the new ruler of Italy. In Lombardy alone he had no legal claims. Innocent aimed at uniting in his own hands the plenitude of temporal as well as spiritual dominion. 
The murder of Philip by a private enemy left Otto Frederick without a rival. In 1209 he received the imperial crown, II in Italy, and with staggering rapidity his attitude changed. Germany. Regardless of repeated guarantees, he refused to give up the papal lands and invaded Apulia. Innocent, in the overthrow of his schemes, was driven to a negation of his whole policy. In alliance with France, he obtained the election of Frederick as King of the Romans, and in 1212 he sent the 'boy of Apulia' across the Alps to take up his father's inheritance. Innocent still clung to his great Italian aims. Frederick swore again and again to respect the State of the Church and acknowledge the dependence of Sicily; in 1216 he even promised to abandon Sicily to his infant son Henry, to prevent its union with the Empire. Nevertheless, Innocent's successor, Honorius III, was forced to content himself with the guarantee of administrative separation, when the election of Henry as King of the Romans secured the union of the crowns. The separation of Sicily and Germany was accomplished in far other ways than Innocent had planned; the southward trend of the Empire had already made itself felt, and under an emperor of Italian birth and upbringing the intellectual and constitutional divergence was complete.

The partition of Italy between the Pope and the The relaEmperor was the legacy of Innocent III, and for twenty tions of the Emperor was the legacy of Innocent 1II, and for twenty Empire years it determined the relations of the two powers. and PaUntil the breach with Gregory IX Frederick acknow- Italy. ledged his indebtedness to the Papacy for the imperial crown, he admitted the papal suzerainty in Sicily and respected the territory of the Church in Central Italy; 
but within these limits he set himself to recover the diminished authority of the crown in the Italian and Sicilian kingdoms. Gregory never accepted the partition in principle and meant to reduce Frederick to the position of a mere papal agent. He claimed ultimate temporal authority over all Italy, but as long as Frederick was careful to preserve a technically correct attitude, he was forced to content himself with thwarting his schemes at every turn and seizing any pretext for attack.

Causes of Frederick had taken the cross as early as I2I5; he

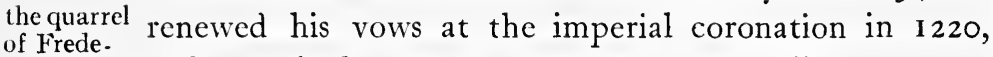
rick II with and promised to start on crusade the following year. Gregory Revolts in Sicily and Lombardy compelled Honorius twice over to allow the postponement of the expedition. In 1227 Frederick at length sailed from Brindisi, only to return immediately to port, a victim of the pestilence that raged in the crusading army. Gregory IX, refusing to believe the facts, excommunicated the Emperor and forbade the Crusade. Frederick, who had married Yolande of Brienne, the heiress of King John of Jerusalem, had reasons enough for continuing the enterprise in the imperial interest. In $\mathbf{1} 228$ he landed in Syria in defiance of the Pope's prohibition. By negotiation with the Mohammedan powers instead of by fighting - further cause of papal hostility-he obtained the restitution of the Holy Cities with the ports of Sidon and Acre; in spite of the interdict he took the crown of Jerusalem from the altar of the Holy Sepulchre and placed it on his head. News that the occupation of the march of Ancona by the Sicilian regent had been met by a regular 
papal invasion of Apulia brought Frederick quickly home. The kingdom was rapidly cleared of Gregory's troops and the Emperor opened negotiations. Peace was made at San Germano in $\mathbf{1 2 3 0}$ on the basis of a mutual restoration of territory; Frederick agreed, moreover, that the Sicilian clergy should be exempt from secular jurisdiction and taxation, and guaranteed the freedom of elections. The reorganization of Sicily begun in $\mathbf{1 2 2 0}$ was carried out in I23I on the lines laid down by the Normans. A great code of law was issued at Melfi, and the administration was developed on the lines of greater centralization and technical efficiency, while the privileges of the towns and barons were destroyed. The whole system intensified papal distrust and led to constant friction in regard to the independence of the Sicilian clergy. In $\mathbf{I} 226$ Frederick turned to Lombardy, where the royal authority had been seriously impaired since the death of Henry VI. The summons for a great diet to assemble at Cremona was the signal for the renewal of the Lombard League, and the attempt of the towns to impose the most humiliating restrictions on Frederick's freedom of action. The Emperor voluntarily accepted papal arbitration. For ten years long and tortuous negotiations continued, and Frederick became the victim of the slippery and disingenuous Lombards and the temporizing Papacy, which made a show of impartiality and always favoured the towns. The adhesion of Eccelino da Romano, who controlled Eastern Lombardy, and the arrival of German forces after the suppression of the revolt of the young King Henry, gave Frederick the military advantage. In 1237 he defeated the Lombards at Cortenuova and 
felt so secure that he threw away the chance of coming to an honourable reconciliation. Matters worked rapidly towards an open breach with the Papacy. Already in 1236 Frederick, in a general letter, formulated his aim of ruling all Italy. He explained that since he was King of Jerusalem, Sicily, and Germany, it was plainly the divine purpose that the intermediate part, Italy, should return to the imperial bond. By Italy he meant not only Lombardy and Tuscany but also the papal lands. He sent the Milanese Caroccio to the Romans in token of his intention to make Rome the capital city; he oppressed the Sicilian clergy and directly attacked the papal territorial claims in making his son Enzio King of Sardinia. In 1239 Gregory IX pronounced sentence of excommunication.

Character The long delay in throwing down the challenge to Frederick the Papacy is explained by Frederick's instinctive perII. ception of the relative weakness of the Empire: it accounts for the moderate Peace of San Germano; it accounts for the Emperor's patience in the Lombard arbitration; later on, it gives the clue to the protracted negotiations in $1243-4$ with Innocent IV, when Frederick once more reverted to the basis of a partition. The Empire had ceased in any sense to represent the universal aspect of European society. Politically the unity of Europe had never been realized in the Empire since the days of Charles the Great; and Frederick, though he still used traditional phrases, never thought of putting the clock back. $\mathrm{He}$ aimed rather at establishing national states in Germany and Italy on the model of the kingdoms of France or England. In the 
moral sphere the direction of the world had passed to the Papacy; spiritual organization extended into the farthest corners of the west and enabled it to draw on inexhaustible political and financial reserves. Behind the Papacy was the strength of Europe. Frederick recognized the fact, and he set himself to recover the spiritual influence of the Empire over the Church and over society. This is plain in his appeal from the Pope to a general council of the Church and in the exposition of his cause at the bar of public opinion in Europe.

Between Frederick and Gregory there was the clash of aim-the common desire to rule Italy : there was also the clash of mental outlook. Frederick's upbringing in the Graeco-Oriental society of Palermo had intensified the streaks of cruelty and sensuality in his character and fostered the curiosity of mind that led him to investigate Arab doctrines in theology and philosophy with the same intellectual aloofness that he gave to the problems of physiology. Gregory had the hatred of a high and narrow idealist for a character which he failed to understand. He seized on Frederick's intellectual scepticism and filled his manifestos with fairy stories of the Emperor's blasphemies against the Christian religion. The Cardinal, Ugolino, who had been the protector of St. Francis and St. Clare, with a mind open to new ideals of living, in his old age launched the Friars Minor on an organized defamation of the Emperor throughout Europe.

By I24I Frederick had occupied all Central Italy as The federa. well as the Patrimony and Benevento, and completed Italy. $_{\text {Iton }}$ the organization of the whole country. His ideal state was a federation, which should take account of differences 
and yet should ensure unity in geography and civilization by the union of the northern and southern crowns. Italy was administered by an imperial legate with five or six subordinate vicars, between whom the whole north and centre was divided. There was a fair hope of the success of the federal scheme. At first sight the centralized official system seems alien to the feudal and municipal traditions of Lombardy and Romagna and Spoleto, but the population was weary of disorder and civil war, and ready to submit to absolute rule. The tendency was already visible which led later on to civic despotism. Some at any rate of the signories of a century later developed out of Frederick's vicariates, and traces of his system persisted. The failure of his schemes was due, not to the opposition of Italy, but to the unremitting hostility of the political Papacy.

Innocent IV.

In 1243 the Genoese Sinibaldo Fieschi became Pope. Innocent IV, the creator of the international system of papal finance, carried the territorial ambitions of the Holy See a step farther. Cold, self-contained, and calculating, he was obsessed with the idea of incorporating Sicily directly into the papal state. His object was not merely to separate the Empire and Sicily, or to destroy Frederick, but he meant to root out the whole Staufer brood. Every means at his disposal was pressed into use — spiritual censures, ecclesiastical revenues, unscrupulous diplomacy, assassination. At the Council of Lyon, in I 245, Frederick was excommunicated afresh and deposed, and a crusade was preached against him. Anti-kings followed one another in rapid succession in Germany; papal delegates went to govern Lombardy in their 


\section{Political Development}

name; an army was sent to conquer Sicily for the Pope. In spite of severe checks in the defeat before Parma and the capture of Enzio by Bologna, Frederick maintained his superiority in Germany and Italy. Public opinion was on his side : Henry III of England and St. Louis urged the Pope to make peace. Innocent was reduced to plots to murder the Emperor and stir up disloyalty among his trusted ministers. To his contemporaries it The death seemed that Frederick had gained the victory, when of Frededeath overtook him at Fiorentino in I250. His descendants were pursued by the implacable Papacy, and the hope of an Italian federation died with them. Guelf Italy could, develop only on local lines, since the one power which had a legal claim to the whole country was broken by the territorial ambition of the Vicar of St. Peter. 


\section{The Papacy}

The rise of THE temporal power of the Papacy was born in conflict, the Papacy the conflict between east and west, between barbarian cal power, Italy and Roman Italy, between the universal and the 554-754. local organization of society, and in its birth it represented the inevitable compromise in a struggle where victory hesitated long and delayed to award the crown. In the sixth century the see of Rome took its place beside the Roman Empire and the Lombard kingdom as a third political factor, and the first period in the history of the mediaeval Papacy was inaugurated $\rightarrow$ a period which extended from the Pragmatic of Justinian in 554 to the Promissio of Pippin in 754. During these two centuries the Papacy was the unswerving protagonist of the sancta respublica against the Lombard dream of a united Italian kingdom, but at the same time the respublica in Italy was to be Roman and not Byzantine. Roman Italy, under the leadership of St. Peter, was determined by its own unaided efforts to prevent its absorption in the Lombard power and also to accomplish its liberation from the east. By the middle of the eighth century the failure of the policy of fare da se was manifest : the popes sought external aid, and under Frankish protection carried through their aims.

The nature The Papacy was an institution of many aspects, and
of papal authority. it was this manifold character which gave it a special 
aptitude for entering the political world. It brought to bear on the distracted politics of the day the weight of unmatched moral and spiritual authority and of no mean material power derived from the wide estates of the Roman Church. As the successors of St. Peter, the popes claimed that pastoral care and spiritual authority over the whole Church which the divine commission to feed the sheep and bind and loose the sinner seemed to confer on the Apostle. Moreover, since Rome urbs urbium et totius mundi caput was the see of Peter, the whole force of secular tradition came to support the apostolic claim to the primacy of honour. But it is essential to remember that the authority of the popes was local as well as universal. The possession of Rome as the episcopal see, while it strengthened the claim of the successor of the Apostle to primacy over the whole Church, also limited his authority, because from Rome he drew in ever narrowing circles his position as patriarch of the west, as metropolitan of the suburbicarian provinces, and as bishop of the Eternal City.

The power of the popes was first of all and essentially a spiritual power resting on spiritual sanction, but the exercise of this authority depended to a considerable extent on secular authorization. In Rome and the suburbicarian provinces indeed, except that the Emperor held the unquestioned right of confirming the election of the Pope before consecration, papal authority was exercised in virtue of canonical sanctions. The wider jurisdiction, however, over the western provinces of the Empire was drawn in origin from imperial legislation, and rested in consequence on secular authority. The emperors 
claimed, indeed, that they too exercised a priestly office, and insisted on their right of preserving the Church from error and deciding questions of doctrine. The popes strenuously opposed this claim and made the Gelasian theory of the relationship of the temporal and spiritual powers the basis of their opposition. Within the respublica or the ecclesia-for the two are identicalthere are two authorities, the spiritual and the temporal, or, more precisely, the sacerdotium and the imperium. To the spiritual, indeed, a slightly greater weight must be given, but the functions of the two must be kept separate. The Emperor as well as the Pope is divinely appointed; obedience to his commands is a sacred duty; but his orders should be restricted to the temporal sphere. It is, moreover, his duty to preserve the pax fidei and maintain the discipline of the Church. The spiritual authority, on the other hand, should equally avoid encroachment in temporal matters, for secular service leads to distraction from the work of God. Nevertheless the bishop must be ready to relieve the temporal needs of his flock and to protect the oppressed to the extent of remonstrating with unjust officials and appealing even to the Emperor himself in cases of tyranny and wrong. In a supreme degree this task was laid upon the Bishop of Rome, and its fulfilment necessarily led the Papacy into the sphere of temporal action. Other influences were likewise working in the same direction. The limited governmental functions conferred by the Pragmatic of Justinian were eloquent for the future; but immediately the great landed estates of the Roman Church were of first importance in the firm basis of 
material power which they gave to the Papacy. These estates, the patrimonium pauperum, were found in every district of Italy, more particularly in Sicily and Campania and in the patrimonies round the city of Rome. Economically its bishop was the most important personage in Italy.

Into this framework of rights and duties there stepped Gregory in 590 the figure of Gregory the Great. A Roman of the Great. the Romans, with rank, wealth, and education, he had won a wide experience of men and affairs as urban prefect, as monk at St. Andrew's, and as papal ambassador at Constantinople. He realized to the full the disaster and disillusionment in the world around him, and his greatness lies in the fact that his qualities were precisely those demanded by his age. Christian patience and Roman fortitude, joined to a tenacity of purpose, a grasp of detail, and an unflinching acceptance of responsibilities thrust upon him by circumstance, enabled him to win for the Papacy a new position in the shifting world of his day. Everywhere in Italy the administration of the Exarch of Ravenna was unequal to the task laid upon it, and in Rome the native authority of the Pope was left in practical control. He was the one power who had come over with undiminished effectiveness from the past, and his official system was ready to fill the gaps in the imperial administration. The regular State distribution of corn had already been replaced by the vast system of poor relief organized by the Papacy from the revenues of the patrimonies. During the pontificate of Gregory the Imperial Government sent the corn destined for the provisioning of Rome and its garrison to the safe 
keeping of the Church; and the Pope, for a time at least, received and paid over the wages of the soldiers. By the seventh century the Church had even undertaken the care of the aqueducts and the repair of the city walls. Besides this gradual absorption of the administrative services, Gregory saw himself forced from time to time to take over direct executive functions. In 59I, when Ariulf of Spoleto was threatening the northern frontier of the Roman duchy, the Pope went so far as to appoint a military governor of Nepi ; in the next year he gave advice on tactics to the imperial generals, and on his own initiative appointed a tribune to take over the command of Naples. He even wanted to make a separate peace for the duchy of Rome, and in consequence brought down on himself the violent abuse of the Emperor Maurice, who stigmatized his independent action as fatuous. The circumstances were exceptional, but they had the effect of colouring his whole attitude to the Imperial Government. Gregory maintained firmly the duty of obedience to the sacred Emperor, and his hatred of the Lombards was due as much to his devotion to the name of Rome as to the Catholic faith. 'For my sins', he writes, 'I find myself bishop, not of the Romans but of the Lombards, whose promises stab like swords, and whose kindness is bitter punishment.' Nevertheless he knew that Italian interests did not receive full consideration at Constantinople; within his patriotism as a subject of the Empire there appeared a subordinate patriotism for Italy, and an even narrower local patriotism for the Roman duchy. During the pontificate of the great Pope the political independence of the Roman see was not as yet envisaged, 
and a true instinct suggested that it would never reach its full capacity for universal dominion unless the integrity of the respublica was preserved against a further Lombard advance.

Gregory the Great died in 604, and during the next The Pahundred and fifty years the Papacy was the representative pacy and of the growing antagonism between Italy and the Empire during the in secular no less than in ecclesiastical matters. The Monophyecclesiastical divergence showed itself in doctrinal opposi- Monothetion and in rival theories of Church government; the lite conpopes attacked the interference of the Emperor in spiritual matters and asserted their own primacy over the Patriarch of Constantinople. The metaphysical temperament of the eastern provinces of the Empire was engaged in subtle theological speculation, while the practical Roman mind was determined to adhere to traditional statements of the faith. The great Monophysite and Monothelite controversies as to the nature and the will of Christ were raised in the east; and the Roman bishops chose martyrdom in all but the fact, rather than accept innovations which attacked alike the faith and authority of the see of Rome. The Emperor Constans tried to check the Monothelite dispute by forbidding further discussion, but Pope Martin I refused to be silenced. Backed by a Roman synod he condemned both the Monothelite heresy and the imperial interference, and the Exarch Olympios at the head of the Italian army openly took his side. The revolt was at length crushed, and Martin was carried off to Constantinople. He was tried and deposed for treason and banished to the Crimea. His immediate successors, elected under imperial influence, temporized 
on the doctrinal question, but in 68I a dogmatic reaction set in at Constantinople and the Sixth General Council accepted the papal position.

The Icono- During the eighth century the dispute turned on the clastic con- veneration of images. In the east the practice had
troversy. given occasion for reproach from the new followers of Mohammed, and Leo the Iconoclast determined to root out a practice of doubtful antiquity and more doubtful authority. The pictorial mind of Italy was roused to fury at the attempt to destroy the images and the theological controversy gave added strength to the revolt against the new taxes imposed by the Emperor. The natural leader was Gregory II, who saw that the fiscal privileges of the estates of the Church were threatened, as well as the Roman practice of venerating images. 'The revolt was crushed owing to the alliance of the Exarch and Luitprand, and the Papacy was shorn of the Southern Italian dioceses, which were transferred to Constantinople, while the patrimonies in this region were confiscated. Nevertheless the Papacy remained the only effective force in Roman Italy, and its temporal influence was increased by the separation of the duchy of Rome from the exarchate and its consequent isolation from the main current of Byzantine affairs. When it became evident that the Exarch lacked the military force to check the advance of the Lombards, and that the Emperor was powerless to intervene, the Papacy once more placed itself at the head of the Roman districts. The action of Stephen II in appealing to Pippin in 753 was but the corollary of the action of his predecessors throughout the century. He saved Rome from the aggressions of 
Aistulf and destroyed the Lombard scheme of uniting Italy, but at the same time he prepared the way for the exclusion of the Greek administration from Central Italy. When he returned from beyond the Alps, he The probrought with him Pippin's promise to restore the imperial mise of districts, which had been seized by Aistulf. The restoration was made to the Roman Church, not to the Roman Empire, and the essential turn was reached in the evolution of the temporal authority of the Papacy.

With the establishment of the papal state under Frank- The Paish protection a fresh period opens in papal history. pacy, the For the next three centuries the popes were engaged in tants of a ceaseless struggle to maintain their new authority in state, and face of the opposition of the local nobility to the clerical the Wesadministration, and the fundamental difficulty of the tern Emposition conditioned their relation to the rulers of Italy ${ }^{1048 .}$ before and after the revival of the Empire of the West. The influence of the events of 754 was so far-reaching that some examination of their import is needed.

At the time of his death in 757 , Stephen II ruled two The terridistinct regions, the duchy of Rome with the duchy of torial posPerugia and the exarchate of Ravenna with the Pentapolis, of the and his authority rested on two distinct bases. In the Papacy. duchy no express transfer of the dicio took place, but ever since the Italian Revolution the Pope had exercised a practically independent authority and the patrician $d u x$ had governed as his viceroy. At the same time the notion was developing of a respublica limited in area and identical in terminology with the sancta Dei ecclesia or the causa Sancti Petri. This was the view of Stephen II, and Pippin accepted the coincidence of the Roman 1832.3 
duchy with the territory of St. Peter and its quasisacred character. But he never made the duchy the subject of a donation; it was not his to give, because since it was not in Aistulf's hands, there was no occasion to conquer it. Stephen extended his tacit claim to rule the duchy to the exarchate at the time of his journey beyond the Alps, and Pippin, without investigating the anomalies and subtilties of the position, took him at his word and promised to 'restore' Ravenna. Conquest gave to the Frank the right of donation, and in 756 he handed over to St. Peter the keys of the two-and-twenty places that had been taken from Aistulf. The territory thus acquired did not cover the whole of the exarchate; and the Papacy in 757 obtained the promise, though not the actual possession, of Faenza, Gabello, and Ferrara as the price of supporting the claim of Desiderius to the Lombard throne.

The Pa- The relations of Pippin to the Papacy are refreshingly pacy and the patricius Roma-Pope Zacharias had done him good service in confirming norum. the abolition of Merovingian royalty in $75^{2}$, and Pippin was filled with gratitude and the desire to save his own soul. Consequently he hastened to obey Stephen's summons without attempting to exercise any jurisdiction in Italy. His purely personal relation as protector of the Pope was expressed fairly accurately in the title of patricius Romanorum. The dignity of patricius had been frequently given in the past by the emperors to barbarian allies, but its restriction to a particular region by the qualification Romanorum represented the local idea of the republic which Stephen seems to have conceived. 
The eternal paradox of the papal position has already appeared. In order to rule spiritually the whole Roman world, the Pope must assert a local supremacy over the Roman duchy.

In considering the Pope's action in relation to the The PaEastern Empire some historians have maintained that pacy and he was negotiating on behalf of the Imperial Government pire. the restoration of a province to the Empire. This is putting the matter in far too correct a light, and it was not the view taken at Constantinople. Still the formal supremacy of the Emperor was acknowledged in documents and on coins, although the dicio had at length passed into the hands of the greatest of the Italian landowners, who for a century or more had gradually been acquiring administrative functions. The Pope stepped into the place of the higher imperial officials, but he was not appointed by the Emperor, and for the last two elections the imperial confirmation had not even been asked.

There was therefore a fundamental flaw in the papal The Paposition as regards the Empire; and it reacted on the pacy and relations of the popes to the other local powers, who tants of refused to acknowledge their right to rule. In Rome of Rome itself the patrician $d u x$ disappeared and the officials and the exof the papal curia were employed in the administration. Ravenna. The Pope appointed the prefect of the city and took command of the militia. Outside Rome he endeavoured to control the local dukes and tribunes, but his action was strenuously opposed on the ground that these hereditary officials had a better right to carry on the government, since they at least had once received imperial 
authorization. The opposition between the old official nobility and the papal bureaucracy, with its disastrous effect on the internal conditions of the city and the duchy, appears as early as the reign of $\mathrm{Paul} I(757-67)$. In 769 an attempt was made to restrain the power of the nobles by excluding them from their traditional share in the papal election ; but the futility of the effort was seen in the intrigues and violence which continued to disgrace the city. In Ravenna the papal position was equally precarious, for the Archbishop aimed at supplanting the Pope as the successor of the Exarch. Attempts It was therefore needful to provide some legal basis a legal for the new position of the Papacy, and the first attempt the temporal authoof the kind was made in the Constitutum or Donation of Constantine. This famous document, composed between rity of the 755 and 766 , is first mentioned, as it would seem, by
Papacy: the Dona- Pope Hadrian in 778. After reciting the history of the tion of Constantine. conversion of Constantine by Silvester I, the Constitutum sets out the Emperor's colossal act of gratitude. Constantine by an imperial decree raises yet higher the office of Christ's Vicar and grants to the glorious see of St. Peter authority over the four patriarchal sees and the churches of the whole world. Next he sanctions expressly, in anticipation, the recent acts of papal authority, in transferring the government to the ecclesiastical officials and raising the clergy to senatorial rank. Finally, Constantine grants the crown and phrygium and all the imperial insignia, and gives his Lateran palace, the city of Rome and all the provinces of Italy, and the western regions into the power and dicio of the pontiff and his successors, while he removes the empire to Byzantium 
and the east. By the donation the door is opened for a claim to territorial dominion far beyond the confines of the duchy and the exarchate. At the same time the spiritual sphere of the Papacy is enlarged and Silvester receives the title of 'universal bishop', abhorred by Gregory the Great. Constantine, moreover, acts as Charles the Great did at Ponthion as the stirrupbearer of the Pope, and yet all the rights conferred by this astonishing document are made to rest expressly on the grant of the Emperor. There is not the smallest hint of inherent temporal authority on the part of the Papacy. Meanwhile events were moving rapidly in Italy. With the fall of Pavia and the assumption of the Lombard The Dona. crown by Charles the Great, the political situation ${ }_{\text {Charles the }}$ underwent a radical change. The distant protector of the Great. Pope became a near neighbour with rights of his own in Italy, and this transformation brought about a readjustment of the territorial possessions of the Papacy and of the conflicting claims to sovereignty. During the siege of the Lombard capital in 774 Charles had visited Rome and honoured the Apostle with a new and wider donation than Pippin's. This gift included all Lombard Italy south of a line which started at Luna and passed north of Parma, Reggio, and Mantua to Monselice, thus adding Corsica, Tuscany, part of Venetia and Istria, as well as Spoleto and Benevento, to the existing papal dominions of the exarchate and the duchy. For a brief period Hadrian I dreamed of reconciling his actual position with the visions of the Donation of Constantine, but Charles, after he received the Lombard crown, was bound to secure the modification of his reckless gift. As early as $78 \mathrm{I}$ the Pope 
renounced all right to the duchies of Spoleto and 'Tuscany, and received in exchange the public tribute from these provinces and the territory of the Sabina. Corsica, Parma, and Reggio henceforth belonged to the Italian kingdom, and Venice and Istria remained in formal dependence on Constantinople. The question of Benevento was regulated in 787 , when the independent Prince Arichis was forced to acknowledge Charles. The papal claims were satisfied by the restoration of the ancient patrimonies of the Church in Benevento, Salerno, Calabria, and Naples, and by the grant of certain rights over the cities of Arce, Aquino, Arpino, Sora, Teano, and Capua. At the same time the southern portion of Lombard Tuscany was joined for all time to Roman Tuscany. With the exception of these fresh concessions, the actual territory of St. Peter was now definitely fixed in accordance with the donations of Pippin. The pactum of Louis the Pious in 8I 7 enumerated all these possessions and formed the chief title-deed of the Holy See.

The revival of the Western Empire.

The adjustment of the claims to sovereignty was a longer and more difficult matter. The emperors at Constantinople had indeed renounced all claim to papal Italy and had acknowledged Charles as King of the Lombards, but this did not alter his legal relations to the Romans, which were still based on the ill-defined office of patricius. In practice Charles's actual power had increased in the papal territory, and he claimed a share in ecclesiastical affairs and interfered to redress administrative abuses. The Papal Government was still at the mercy of the quarrels of the clerical and military parties, and Leo III determined to place the authority 
of the patricius on a more definite basis and use his growing power to support the Papacy against its rebellious subjects. Already at the moment of his accessionthe first since the establishment of Frankish rule in Lombardy-he had sent to Charles a formal notification of his election, and accompanied it, not only by the customary ceremonial gift of the keys of the tomb of the Apostle, but also by the banner of the city. In this way he intended to imply the transfer of the temporal authority to the patricius. This new aspect of affairs was emphasized in the mosaic set up by Leo in the Lateran, in which on the one hand Christ is seen giving the keys to St. Peter and the banner to Constantine, and on the other St. Peter in his turn grants the pallium to Leo and the banner to Charles.

The gift of the banner in 795 was followed by the gift of the imperial crown five years later, and it is plain that the motive was the same. The Pope had been driven across the Alps by the accusations of his subjects, and Charles had come in person to Rome to prescribe an oath of purgation as the only legal means of reinstating Leo. By the restoration of an Emperor of the West and the subordination of all Roman Italy to his authority, the Pope hoped to obtain the support he so sorely needed, since in Rome the Empire was coming to be regarded more and more from a local point of view. Leo and the Romans took an oath of fidelity to the Emperor they had made, and performed a solemn act of adoration. Charles at once sat in judgement in the city in virtue of his imperial sovereignty, but he never again visited Rome. He was dissatisfied with the manner of his 
inauguration and would have preferred to emphasize his wider claims to empire. In the provision for the continuance of imperial authority he was careful to ignore the original intervention of the Pope, and his son and grandson took the crown in the first instance direct from the altar of God. Charles avoided, moreover, any precise regulation of his relation to the Papacy in Rome and the duchy, and it was left to his immediate successors to devise some settlement of the ambiguous situation.

The Pac- The death of Leo III in 816 provided the opportunity. tum of 817 . The next Pope, Stephen IV, succeeded in making good the omission of papal intervention in the inauguration of the Emperor Louis by placing an imperial crown on his head at Rheims. This action, followed in 823 by the coronation of the co-Emperor Lothar by Paschal I, definitely established the papal right of crowning the Emperor, but the regulation of other relations between Pope and Emperor had a more chequered history. The first extant agreement is the pactum concluded in 817 between Louis and Paschal. This document contains in the first place the confirmation of the dicio of the popes in their territories, which are set out in great detail; next Louis promises not to exercise jurisdiction in Rome except at the request of the Pope himself, save when complaint was brought to him of oppressions on the part of the potentiores, in other words the papal bureaucracy; finally, provision is made for the continuance of the practice followed since Leo III in papal elections, and the Pope is bound to announce his accession and beg the renewal of the pactum only after his consecration, pro- 
vided indeed that his election has been made with unanimity and due observance of canonical form. The general tenor of the pactum is to confirm existing relations both in the territorial and jurisdictional sphere; the theoretic sovereignty of the Emperor is maintained now as always, but he makes no greater claims in practice than the patricius had done.

The perpetual disorders in Rome caused by the papal The Consti. militia and the suspected complicity of the Pope showed, mana of however, once more that the situation was an impossible ${ }^{824}$. one. Louis was not slow to seize the opportunity of establishing a fresh basis of relations, which was offered in 824 by the accession of Eugenius II, accompanied as it was by the violent quarrels of clergy and nobles. He commissioned his son Lothar, who was both co-Emperor and King of Italy, to arrange matters in his stead with the new pontiff and the Roman people as the necessity of the case demanded. Lothar, in his Constitutio Romana, aimed at avoiding the recurrence of arbitrary acts on the part of the papal officials by strengthening the imperial control over the city and by increasing the power of the lay nobility. The magistrates, although they were not appointed by the Emperor, were charged to appear before him to receive an admonition on the duties of their office, and two permanent missi, nominated the one by the Emperor and the other by the Pope, were established in Rome with the duty of making an annual report to the Emperor on the administration of the city; they were, moreover, to bring any complaints of official injustice to the ears of the Pope, and if he failed to yield redress recourse must be had to the Emperor. The 
position of the nobles was improved by a provision which made their persons inviolable, and that under penalty of death. The constitution of Lothar tightened the imperial control over the papal election : the rights of the laity, abrogated formally at least by the decree of 769, were tacitly restored, and the pontiff-elect, before proceeding to his consecration, was bound to announce his accession to the Emperor and beg the renewal of the pactum. Further, equally before consecration, the imperial missus in the presence of the whole people was charged to receive the solemn promise of the Pope, after the manner of the promise freely made by Pope Eugenius, to maintain the imperial authority as laid down in the constitution. As a guarantee for the continuance of this system, an oath of fidelity to the emperors was imposed on the whole Roman population, saving the fidelity owed to the Pope.

The Gela- The interest of papal history from the constituin practice. tion of Lothar until the accession of Leo IX centres in the fact that the two forces, the universal Empire and the local nobility, alike sought to control the action of the popes. Both traditions showed amazing vitality and reappeared again and again, acting sometimes in violent opposition and sometimes in a kind of tacit alliance in order to gain the common end. When the influence of the Germanic emperors was dominant it succeeded in raising the Papacy to some sense of a universal mission, and that because it contributed the necessary element of externality; when the local powers gained the upper hand they made of the Papacy a local power like themselves, and controlled both the temporal dominion of 
the popes and the spiritual authority which was its justification. The reign of Louis II in Italy is in many respects the most interesting episode of the period, for it shows a practical attempt, under the most favourable conditions ever attained, to work out the Gelasian theory of the twin powers. The Emperor had become completely Italian in his interests; the government of Italy was his first care. On the whole, the spiritual and temporal powers acted in a sufficiently correct harmony. The Emperor, nevertheless, on his side, by supporting the Roman nobles in their constant opposition to Leo IV and Nicholas I, and by making feudal grants of land in the Patrimony, laid the foundations of the tyranny of the Roman nobility in the tenth century. At the same time there was a marked tendency on the part of the Papacy to assert its authority in spiritual matters even over the Emperor and his family, while the Emperor exerted a steady, if passive, resistance. Nicholas I (858-67), whose pontificate foreshadowed the rule of Gregory VII, firmly, even tyrannically, upheld the validity of the canon law against the action of King Lothar II, the Emperor's brother, in repudiating his wife for the sake of Waldrada. A useful precedent was thus provided for future papal claims to enforce spiritual laws against even kings. Nicholas moreover vindicated, with equal firmness, the monarchical claims of Rome over the Frankish and Italian episcopate. His action found confirmation in the Pseudo-Isidorian Decretals, which were composed in the Frankish Empire, most probably in the province of Tours, about the year 850 . This compilation amplified, by means of spurious decretals attributed to early popes, 
the genuine collection of canons and decretals in use in the Spanish Church in the eighth century. The forged decretals were taken to Rome in $86_{4}$; but though their tendency was to give greater cohesion to the Church by increasing papal centralization, Nicholas does not appear to have derived his ideas from this source. He acted before 864 precisely as he did later, but the decretals no doubt provided him with fresh support for his arguments and prepared the Frankish Church for the reception of Roman claims.

The dy- With the death of Louis II the Gelasian experinasty of Theophylact in Rome. ment, such as it was, broke down completely, in spite of the gallant effort of John VIII to free himself from the aggressions of the Roman nobles by consecrating the emperors Charles the Bald and Charles the Fat. The conception of a unified political system fell into abeyance, and the period of local independence, which succeeded throughout Italy to the period of Carolingian rule, left a permanent impress on the Papacy and the Patrimony of St. Peter. For almost a century and a half a series of strong local dynasties related by blood or marriage arose in the city of Rome from among the lay nobility, and succeeded in obtaining control of the secular and ecclesiastical government alike. The line of city tyrants began in 900 with Theophylact, who united in his person the chief financial and military offices, and combined with them the presidency of the Senate, now a close body of hereditary civic nobles. In virtue of this position of dominus urbis, Theophylact was able to exercise a decisive influence on papal elections, and his nominees filled the chair of St. Peter. On his death the dynasty 
was continued by his too celebrated daughter Marozia, who married in turn Alberic of Spoleto, Guy of Tuscany, and King Hugh of Italy, after a well-attested connexion with Pope Sergius III. She maintained her control over the Papacy by obtaining the election of three successive popes, the last of them her own son, John XI ; but her power was overthrown in 932 by another son, Alberic, the son of Alberic of Spoleto. He exercised the temporal sovereignty in Rome with the title of Princeps et omnium Romanorum Senator, while the Papacy became a purely ecclesiastical office. Alberic, as the chief elector among the Romans, made respectable appointments and encouraged monastic reform under the auspices of Cluny. He was succeeded in 954 by his son Octavian in the monarchy of Rome, but the situation was changed in the next year by the election of Octavian as Pope John XII. The spiritual and temporal authority was once again united in the same hands, with this difference, that John depended exclusively on the prestige of his family and not on his position as the successor of St. Peter. He was attacked by Berengar of Ivrea, who held the Italian kingdom as the vassal of Otto of Germany. Berengar aimed at extending his kingdom at the expense of the territory of St. Peter, and John found himself face to face with much the same situation that had confronted Stephen II in the aggressions of Aistulf. The same remedy occurred to John: he summoned Otto to his aid, and in 962 crowned him Emperor in St. Peter's.

The revival of the Empire emphasized afresh imperial The emsovereignty over the Pope and over the papal state, and the OttoOtto and his successors entered into the obligations and nian house 
and the rights of the Carolingian emperors. His great conPapacy. firmation of papal lands, shorn of later interpolations, represented the substance of the pactum of Louis the Pious, with the further gift of certain scattered places in the duchy of Spoleto, notably Marsia, Valva, Rieti, and Norcia. This new donation does not seem to have taken effect, but on it the Papacy based the claim to Marsia, which it vindicated later against the Norman kings. Before entering Rome, Otto took an oath to restore whatever papal lands should fall into his possession, and he followed this up in 967 by a diploma to give back Ravenna and other lands which had been withdrawn from the Roman pontiffs. Otto III, in IOOI, granted to Silvester II the cities of the Pentapolis, which belonged of right to the Empire, as the diploma declared. But no donations could make good the actual losses suffered by the Papacy: much of the Roman territory had been granted out to the nobles whose fortresses looked down from each hill city, while the archbishops of Ravenna continued to exercise that effective control over the exarchate which dated from the beginning of the tenth century. In the sphere of jurisdiction Otto expressly took up the position of the Constitution of 824, and there is abundant evidence of placita held by him and his successors in the city: in the matter of electoral control Otto went farther than the emperors of the ninth century, for after the conspiracy of John XII, in 967 , he made the Romans swear not to proceed to an election until they had received imperial nomination of the candidate. Nevertheless there was a profound difference between the Empire of the Ottos and the 
Salians and the Empire of the later Carolingians. For nearly fifty years in the ninth century an emperor had resided in Italy, controlling the Papacy and moulding the affairs of the whole country. These conditions were not repeated: from time to time an emperor might spend a few years in the peninsula; Otto II strove to fulfil the imperial task of conquering the south; Otto III sought to re-establish the universal Empire in its local habitation, but the schemes of the boy-Emperor, half dreamer and half play-actor, had no permanent effect on Roman politics. Branches of the house of Theophylact, the Crescentii and the Tusculans, in turn made good their claim to the presidency of the Roman State. With the title now of patricius, now of Senator of all the Romans, they carried on the government and managed to thrust first one and then another member of the family into the Papal Chair. The aims The early of Henry II and Conrad II were hard-headed and Salians and practical : they forced the Tusculans to admit theirlans. sovereignty and receive from them a formal grant of power, but it was at the price of supporting this branch of the family against their rivals. When the emperors were in Rome they resumed the exercise of sovereign power; in their absence the Tusculans, on whom they conferred the office of patricius and city prefect, carried on the administration. The Papacy, in consequence of this dynastic system, became more and more profoundly Roman in the narrowest sense of the word; it was but at rare intervals, under a Silvester II or a Benedict VIII, that the successors of St. Peter seemed aware of their duties to Western Christendom. The degradation 
of the Holy See under the Tusculan Benedict IX (IO321046) recalled the days of John XII. All the Roman efforts to shake off the Tusculan yoke, officially supported as it was by the Empire, succeeded in producing only civil war, simony, and triple schism. The direct interposition of Henry III was needed to restore unity: at the Synod of Sutri (1046) he deposed all three claimants and instituted a series of German popes. Outwardly there was nothing to distinguish the swift action of Henry from high-handed proceedings of a like nature in the past, and the Romans expressly repeated their oath renouncing their electoral right, although they had in fact generally exercised their choice under the German supremacy. Nevertheless the Synod of Sutri marks the end of the period inaugurated by the promise of Ponthion, and the beginning of a transformation of equal moment in the history of the mediaeval Papacy.

The re- The remaining period of papal history (I048-I254), formed Papacy, which comes under the present survey, opens with the 1048-1254. wonderful uplift of the Papacy in the middle of the eleventh century. The inherent spiritual force of the Church captured the Holy See and raised it in a brief quarter century from a Roman bishopric controlled by local faction to a universal patriarchate itself controlling the western world. The first century of the reformed Papacy, from the accession of Leo IX (IO48) to the death of Innocent II (I I43), was a period of renewed spiritual claims involving supremacy not only over all the churches of the west, but also, as the corollary of spiritual authority, over the temporal power. At the same time, a fresh set of pretensions to territorial dominion was put forward. 
The reformation of the Papacy is inevitably connected Gregory with the name of Hildebrand, Pope Gregory VII. All VII. the varied ecclesiastical currents of the day touched him, and from each school of reform he adopted its most characteristic doctrine. The Cluniacs of St. Mary on the Aventine, where he was educated, taught him to look to Rome as the protector of their order, and the conception of papal supremacy received fresh emphasis from the traditions of the Roman curia, when he entered the service of the popes. He accompanied Gregory VI to his exile in Lorraine, and there he came in contact with the canonists, who expounded the fundamental principles of spiritual authority. Gregory's claim to originality lies rather in the ordered synthesis, which he evolved, than in the novelty of his ideas. The freedom of the Church from temporal control; Rome its head and centre; the superiority of everything spiritual to everything temporal-such was the programme which Gregory sought to realize with white-hot intensity of idealism. $\mathrm{He}$ admitted neither obstacles nor defeat, and his singleminded courage carried the Papacy to a position from which it could never again withdraw.

The first step was made when Leo IX (Bruno of The Toul) began the great crusade to purify the Church decree of from simony and clerical marriage. The purity of the ro59. Church was seen to involve freedom from all secular control, for so only could the contamination of the world be avoided. Soon the freedom of the Church was the watchword cried aloud by the reformers, and the first act of the pontificate of Nicholas II was to make good the claim in regard to the Papacy itself. 1832.3 
The Synod of Rome, in 1059, boldly removed all lay interference in the papal election, whether exercised by the Roman nobles or the German emperors. To a certain extent the influence of the two had been merged when the Romans resigned the patriciate of the city, with its first voice in the election, to Henry III ; and since his death the golden circlet had been sent to the boy-King Henry IV. The election was now placed in the hands of the cardinals, especially the cardinal bishops, while the rest of the clergy were granted merely the right of acclaiming the candidate chosen. Of the powers exercised by the Ottos or the Salians nothing remained but an honorific right of confirmation. The synod proceeded to forbid lay nomination to any ecclesiastical benefice; and this was followed up in 1075 by the prohibition of lay investiture of bishops and abbots with the ring and the staff. Urban II even went so far as to forbid the bishops to do homage, and Hadrian IV took up this position against Frederick I.

Theories of The Gregorian philosophy of the relation of the spirithe relation of the tual and temporal was based originally on the Gelasian spiritual theory of the independence of each in its own sphere, and temporal but the admission that greater weight must be given to powers. the spiritual was pressed in the eleventh century to its utmost extension. The superiority of the spiritual was supported by scriptural warrant and historic precedent, and the temporal, which in his more exasperated moments Gregory likened to the work of the devil, was held to owe obedience in all spiritual matters. From this position sprang the claim to excommunicate even the Emperorelect for his disregard of the ecclesiastical and moral law. 
Henry IV was guilty of simoniacal appointments and sins of private life; he had even dared to lift his voice against the Pope and procure his deposition. The scene at Canossa, when the King was forced to wait as a suppliant for papal absolution, was a signal acknowledgement of the supremacy of the spiritual power in its own sphere. But the logical sequence of ideas went even farther : civil obligations were ipso facto dissolved when a man was put outside the Church, and from the spiritual claim to excommunicate there followed the temporal claim to depose kings and absolve their subjects from allegiance. This claim Gregory made good in the deposition of Henry IV in 1076 and again in 1080; and he made his action the subject of a considered defence in his letters to Bishop Hermann of Metz.

In all this, Gregory based his interference in temporal New terrimatters on his spiritual power, but he regarded his $\begin{gathered}\text { torial } \\ \text { claims. }\end{gathered}$ exercise of territorial dominion as the result of the donations of the emperors from Constantine downwards. The breach with the Roman and Germanic powers left the Holy See without a protector, and the power of the popes over the Patrimony, and even over the city of Rome, was intermittent up till the time of Innocent III. But while the control over the ancient states of the Church was more than precarious, a new set of claims was put forward. As early as 1052 Leo IX won the first foothold Southern for the Papacy in the south, when he obtained from the Italy. Emperor the grant of Benevento, presumably the city only, in exchange for the rights over the bishopric of Bamberg granted by Henry II to the Roman see. Leo looked askance at the Normans as breakers of the peace, 
who cut across his aim of reforming the churches of the southern regions and bringing them back to the Roman obedience after a separation of over three centuries. In I053 he organized an expedition against them, only to suffer a severe defeat at Civitate. Nicholas II took a more statesmanlike view, and saw in these adventurers a counterpoise to the attacks of the Roman baronage. In I059, at Melfi, the Norman princes, Richard of Capua and Robert of Apulia, swore to protect the Pope and his successors and hold their lands, present and future, from St. Peter. The Norman principalities were by degrees united in a single kingdom, and, much as he disliked this strong power in the south, Innocent II granted investiture to Roger II for Sicily, Apulia, and Capua in I 39 . Thus the Papacy extended its dominion, indirectly indeed, but effectively, over the whole of Southern Italy, finding a legal basis for its position in the Carolingian donations. A good deal of support could be obtained from the grants of patrimonial rights and the tribute from certain cities in the Capuan territory in the pactum of $8 \mathrm{I} 7$, and whatever was wanting could be made good by discreet additions. The clause concerning Sardinia, Corsica, and Sicily apparently found its way into the pactum at this time, and the account of Charles the Great's donation of 774, with its grant of Spoleto and Benevento, seems to have been inserted in the diplomas of later emperors. Moreover, the Donation of Constantine, mentioned by Gregory VII as validating other claims of St. Peter, was probably held to apply here as well.

The Matil- In Central Italy the Papacy made the second great dine lands. addition to its territory. The family of Canossa had 
succeeded to the dukedom of Tuscany and in the first half of the eleventh century built up a solid dominion, consisting on the one hand of the official fief of Tuscany, and on the other of the allodial possessions of the family in Emilia, Lombardy, and Tuscany. The allods occupied a solid block of territory in the neighbourhood of Mantua and Gonzaga and the mountainous regions of the counties of Reggio and Modena, and included the outlying districts of Insula Fulcherii on the Adda, and the Garfagnana and Versiglia in Tuscany. The county of Ferrara was held of the Pope, but the city, as well as all the other chief towns, had acquired during the eleventh century rights of self-government. The great Countess Matilda twice over, in 1086 and again in I102, granted her possessions to the Holy See, that is to say, her allods, for her fiefs escheated on her death in III 5 to the Emperor Henry V. The Emperor claimed, however, that Matilda left him the allods and took them into his possession together with the Tuscan duchy.

For a century the domus or terra comitissae Matbildis was a very apple of discord between Pope and Emperor. The well-disposed Lothar III recognized the right of the Papacy to the allods in order to prevent them falling into the hands of the Hohenstaufen, who were the legal heirs of Henry V. In I 33 Lothar received investiture from Pope Innocent II, with the ecclesiastical symbol of a ring, and promised an annual rent: then Pope and Emperor together granted the lands, with the duchy of Tuscany, to Lothar's son-in-law Henry of Bavaria, who, unlike the Emperor, took the oath of fidelity to the Pope and entered into a feudal relation. 
The papal The last phase in the development of papal power

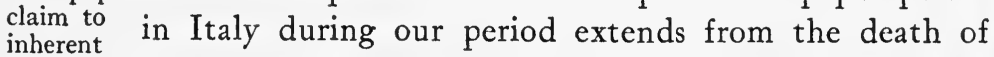
temporal Innocent II (II43) to the death of Innocent IV (1254). power, ${ }_{\text {I } 43-1254}$. It is marked by a claim to inherent temporal authority; and the Papacy, as the result of its recovery of territorial dominion, became a specifically Italian as well as a universal power. The popes no less than the emperors continued to set out the Gelasian theory of the necessity of the two powers for the well-being of the world, but the claims of each received a definition and extension, which brought them into sharper antagonism. Frederick Barbarossa urged afresh the divine sanction, by which alone he was dominus urbis et orbis, and he claimed in virtue of his office the right of deciding the disputed election between Alexander III and Victor IV. The popes, on their side, were no longer content to define their position in terms of spiritual superiority. The Vicar of Christ adopted the language of the world, and phrases were used which seemed to imply the feudal dependence of the Empire and an inherent right of the Papacy to the territory of St. Peter. To Barbarossa, as it seemed, the matter began with a picture, went on with an inscription, and ended with the establishment of a presumptive claim. The picture in question was set up to commemorate the coronation of Lothar III and his investiture with the Matildine lands. The inscription boldly confused the two events and represented the Emperor as becoming the man of the Pope when he received the imperial crown. The idea of feudal dependence was emphasized by the use of the word beneficia by Hadrian IV in a letter to Frederick where he speaks of 'conferring the imperial crown'. 
The Pope explained later that beneficia could and did mean ' benefits' and not ' fiefs', and removed the picture that had given colour to the interpretation. Innocent III never asserted in so many words that the Empire was held as a fief of the Papacy, but he insisted again and again that the Empire appertained to the apostolic see originally and finally-originally because the Papacy translated the Empire from the Greeks to the Germans, and finally because every Emperor received his position from the Pope, since he was blessed, crowned, and invested with the Empire by him. From this basis Innocent developed, in view of the disputed imperial election of 1198 , the ius examinandi personarum, or right of pronouncing on the merits of the respective candidates for the Empire. He admitted that the right of election belonged undoubtedly to the German princes, but he asserted that it came to them from the apostolic see. The Pope was, moreover, bound to insist that a suitable candidate was presented for coronation: surely, he asked, he was not bound to consecrate a heretic. Finally, Innocent took the last step. He preached the doctrine that Peter alone had assumed the fullness of power, and to his successor was given the mitre as a symbol of the spiritual, and the crown as a symbol of the temporal, government. It should be noticed, however, that Innocent did not claim for himself the direct exercise of the imperium except in Italy. Elsewhere the Pope seems to be endowed with no more than ultimate temporal authority.

The claim to the dominium temporale in Italy was con-Opposition tested, as of old, for half a century before the accession of the city of Innocent III, by the city of Rome and the Hohen- 
staufen emperors. The universal Pope was for the most part an exile from the Patrimony-Ab urbe pulsus in orbem accipitur ran the contemporary epigram. In II 43 the citizens of Rome overthrew the traditional authority of the nobles in the government and established on the Capitol an independent municipality. A new era was held to begin with this renovatio senatus, as the revolution was named, and an attempt was made to vindicate the ancient right to confer the imperium. The temporal authority of the Pope was repudiated, and the German kings, Conrad III and Frederick I, were invited to receive the Empire from the senate without any priestly interference. The hostility to the temporal power received a fresh impulse from the fiery preaching of Arnold of Brescia, who denounced the wealth and secular interests of the clergy and urged a return to apostolic poverty. From the first revolt of the commune against Innocent II, the popes carried on an intermittent struggle until at length a basis of agreement was found, and in II 88 the fundamental charter of the commune was granted by Clement III. The senate and people recognized the papal sovereignty; the senators every year were to take an oath of fidelity, they were to guarantee the personal safety of the Pope, cardinals, and curia, and to defend the Patrimony. The Pope on his side admitted the legal existence of the commune and undertook to finance the administration, as well as to help the Romans against their special enemies the people of Tusculum. The Papacy was forced to make a bargain, but it succeeded in preserving its theoretical rights over the city.

The temporal dominion was attacked at the same time 
from another quarter; for the Empire was making a Opposition determined effort to vindicate its sovereignty throughout ${ }_{\text {Empire. }}^{\text {of the }}$ the territory of St. Peter. This was part of the larger scheme of Frederick Barbarossa to recover the regalian rights in Northern and Central Italy. It led to the long war with the Lombard towns and gave Alexander III the powerful friendship of their League. As early as I 59 Frederick tried to make good his fiscal claims in Roman Tuscany and the Campagna as well as in the Matildine lands. Hadrian IV at once formulated the papal position: he denied the right of the Emperor to send ambassadors to Rome without the knowledge of the Pope, to whom belonged the entire magistrature and the regalia of St. Peter; he denied further the right to take fodrum from the papal demesne except on the occasion of the coronation; and he demanded the restitution to the Roman Church of all the territory from Aquapendente to Rome, the lands of the Countess Matilda with Ferrara and Massa, the duchy of Spoleto, and the islands of Corsica and Sardinia. Nothing is said about the exarchate of Ravenna, which had been for some centuries an imperial district, and no claim seems to have been raised to this ancient possession till the time of Innocent III. Frederick replied that, since he was Roman Emperor by divine consecration, he would but present a semblance of dominion and bear an empty name, were the city of Rome excluded from his power. During the schism between Alexander III and the imperialist anti-popes, the Emperor occupied Rome, the Patrimony, the Matildine lands, and all Central Italy, but in the final reconciliation with Alexander at Venice in II77, 
he was compelled to abandon some part of his pretensions : he restored the sovereignty over the Patrimony, together with the prefecture and other regalia, to the Pope and admitted the papal right to the lands of Matilda, although the actual restitution was delayed. The Pope tacitly recognized Spoleto, Ancona, and Romagna as undoubtedly pertaining to the Empire, thus abandoning earlier papal claims. Alexander was preoccupied with the ecclesiastical rights of the Papacy, and determined to prevent so far as he might the recurrence of schism. In I I79, at the Lateran Council, it was enacted that a two-thirds majority of the cardinals present at an election should secure its validity. For a long period the Papacy was free from schism, but Henry VI, regardless of the peace of Venice, occupied all the lands of the Pope and won over the city of Rome ; he held besides Northern Italy and Sicily, which he governed in right of his wife.

Recovery Innocent III is often regarded, and with a good deal of the pa- of truth, as the real founder of the papal state. He by Inno- started from the standpoint that he was charged with cent III. the supervision of the whole world, and therefore it behoved him to see that Italy, the foundation of the Christian faith, was raised through the primacy of the apostolic see to supremacy over the sacerdotal and royal power. It was, then, the supreme aim of Innocent III to make Italy the head of a papal monarchy over the whole world, just as Henry VI had made it the head of a temporal monarchy. The great Pope could not, however, free himself from the tradition that the territorial rights of the popes were based on the donations of 
emperors. He saw nevertheless that he must sweep away the tangled obligations of the last four centuries, and he boldly took his stand on the donation of Louis the Pious. During the abeyance of imperial authority, which followed the death of Henry VI, Innocent established his actual dominion over all Central Italy. He began by inducing the Roman commune to admit his sovereignty, and renewed the treaty of Clement III. Next he recovered the Patrimony from the feudal nobles or heretic communes such as Narni or Viterbo. Then he turned against the German officials of the Empire and established papal government in Spoleto, Romagna, and the Marches.

The imperial schism provided the opportunity of The prividividing Sicily from the Italian and German kingdoms Otto IV and winning imperial confirmation of the Pope's position and Fredein Italy. Sicily went to the child Frederick of Hohenstaufen; the Welf candidate for the Empire, Otto of Brunswick, in return for Innocent's promise of the imperial crown, guaranteed twice over the papal dominion. At Neuss, in I20I, and again at Spires, in I 209, he promised to abandon to the Roman Church the possessions recovered by his ancestors and to assist in the recovery of those which were not yet in the Pope's hands; he enumerated without ambiguity the papal territories-the whole land from Radicofano to Ceprano, the march of Ancona, the duchy of Spoleto, the lands of the Countess Matilda, the county of Bertinoro, and the exarchate of Ravenna and the Pentapolis, as set out in the privileges of the emperors since Louis; Otto promised, moreover, to preserve Sicily in the Roman dependence and guaran- 
teed the good customs of the Roman people. Promises could go no farther; Innocent had obtained imperial confirmation of the ideal claims of the Papacy contained in Charles the Great's donation of 774. When Otto IV reverted to the essential imperial policy and began to recover Central Italy and the Sicilian kingdom, Innocent turned to Frederick of Sicily and sent him to Germany to win the imperial crown, bound by the same promises which Otto had given. In addition, the Pope exacted the further concession that Frederick should hand over Sicily to his son and maintain the separation of North and South Italy. The confirmation of papal territory was in effect a partition of Italy; and with the accession of Gregory IX the impossibility of this solution of the long conflict was evident. Gregory developed to its fullest extent the theory of papal power laid down by Innocent III. He explained his position by a direct quotation from the Donation of Constantine : 'Abandoning Italy to the apostolic see, he chose a fresh abode in Greece.' When the Church transferred the seat of empire to Germany and granted to Frederick and his predecessors the power of the sword, she did not thereby diminish in any way the substance of her authority. The Patrimony of St. Peter remained under the direct rule of the Pope as a token of his universal dominion, while the other rights of the Empire were committed to the secular prince as the defender of the Church. The theory of the subordination of the Emperor could hardly go farther.

The claim Innocent IV was not content with the Patrimony as of the a token of universal authority, and he determined to 
carry out the incorporation of the Sicilian kingdom into Papacy the papal state. To this end he pursued Frederick and to Sicily. the whole house of Hohenstaufen with merciless persistence. In 1247, and again in 125 I, he appointed Cardinal Peter Capocci as governor of Sicily and gave away fiefs and privileges within the kingdom. Nevertheless Innocent was forced by the opposition of Manfred and Conrad to abandon the scheme, and in order to get foreign help he hawked the crown round Europe. Richard of Cornwall, Charles of Anjou, Edmund of England, all had the refusal of it. The Sicilian kingdom was at any rate definitely separated from Italy and Germany, and the papal state was secured to the successors of the Apostle.

Seven centuries exactly had passed between the promise of Pippin and the death of Innocent IV, and some general judgement of the influence of the Papacy in Italy may perhaps be attempted. The lasting glory of the Holy See is the maintenance of the ancient Roman tradition of empire and civilization in the west. But for the action of Stephen II and his successors, Italy, in passing from the dominion of Byzantium, would have entered, not the revived unity of the west, but the kingdom of the Lombards, and the great task of civilizer and transmitter would have been obscured. At the same time, the means by which Italy was saved for its universal mission destroyed its own unity. The preservation of the boundaries of 'Roman' Italy as the territory of St. Peter laid the foundation of the papal claim to territorial sovereignty and brought it into conflict with the right of the Empire. Both powers aimed 
at making their head-quarters in the peninsula, and Italy fell a victim, not to the mediaeval ideal of a universal society, but to the fundamental dualism of that society. The Papacy had destroyed the Empire in Italy and sat crowned upon the grave thereof. Nevertheless it was but a temporal crown for which the greatest spiritual heritage on earth was bartered.

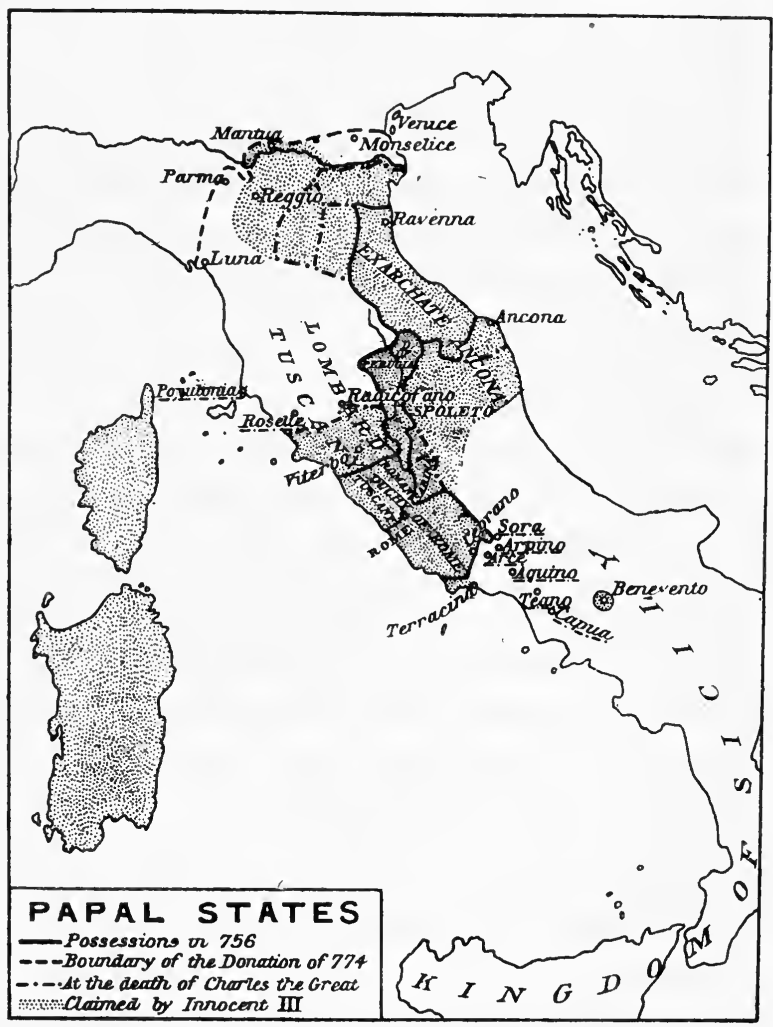




\section{3 \\ The Normans in the South}

THE second flood of barbarian invasion was stayed by The exthe middle of the tenth century, and with the ebb pansion of the knighthood of Europe streamed out over the infidel the lands to east and west and south. For a hundred years century. and more Europe had lived on a war footing, and from the need of defence had sprung a class pledged to military service. With the slackening of the attack, the main occupation of the most active element in society was gone, just at the moment that it was reinforced in numbers and daring by the Northmen, who obtained a footing in Northern France. Population increased with comparative peace, and the pressure of economic need set up a new land hunger. The expansion of Europe took many forms. Saxon ethelings strove to win a footing in the Slavonic lands beyond the Elbe; restlessness and sheer love of adventure drove many a landless knight to the sea, to sail like Robert the Frisian to Spain and Greece; pilgrimage to Rome or Jerusalem was a penance that appealed to every instinct of the knightly sinner, and rid his neighbours of his presence for months or years. As the eleventh century wore on, the Norman William led his barons to the conquest of England; at its close Pope Urban directed the piety and lawlessness of Northern and Western Europe against the Turkish conquerors of the Holy Places. 
Norman adventurers and Lombard rebels.

The greatest adventure of the age was the foundation of the Norman kingdom of Sicily. In its beginning it was the private enterprise of a few rovers, and the story of this state in the making reads like a gest of chivalry in the pages of Aimé's prose epic or William of Apulia's rhyming chronicle. Pilgrimage took the first Normans to Italy; one story tells of a meeting at the shrine of St. Michael on Monte Gargano with Meles, a Lombard citizen of Bari, who implored the help of the northern knights against Greek oppressors; another account speaks of a band of pilgrims on their way from Palestine to Rome, who passed by Salerno and helped to beat off a Saracen assault. They went home rewarded with solid gold and strange fruits to tell stories of a land of noble horses and pale lemons and stiff cactus tipped with flame. More Normans came, landless sons crowded out by growing brothers, or broken men fleeing from ducal justice. The distracted political condition of the south was the opportunity of the Normans. The Greeks were in process of recovering their dominion: at the end of the tenth century they had cleared Calabria and Southern Apulia of the Saracens, and now, at the beginning of the eleventh, the catapans began to force back the Lombard frontier till all the country south of Termoli on the east and the bay of Salerno on the west was directly under Byzantine rule. The basileus was undoubtedly the greatest power in Southern Italy when the Normans arrived, but Sicily remained in Moslem hands, and the Lombard principalities were still to be reckoned with. In the cities, the impulse towards independence, which revolutionized town life in the 
valley of the Po, was already stirring, and sporadic revolt appeared up and down the Lombard regions of Apulia subject to Greek rule.

The Normans were out to make their fortunes. For twenty years they lent their swords in exchange for the 'grandissimes domps', the gold, the horses, and the precious stuffs that their barbarian souls so ardently desired. They fought for the Lombards of Bari or Trani against their Greek governors and beat them at the Fortore and Civitate in ror 7 , only to suffer a severe defeat at Cannae; they fought for the Greeks against the Saracens, and helped to take Messina in 1038 and Syracuse in 1040; they fought for Naples against Capua and at length settled down in the service of Salerno. Already they had demanded land, 'because every man who leaves his own country is bound to increase his honour and power', and Conrad II when he came south in 1038 confirmed them in the possession of Aversa. Salerno began to take the leading position among the southern states, and with Salerno the Normans rose too, extending their dominion over the Greek regions.

About ro40 there came to Italy the elder sons of The family Tancred of Hauteville, a knight of the Cotentin, whose of Tancred family was to mould the destinies of Italy and Sicily. ville. The Norman freebooters in general added but another element of disruption to the heterogeneous politics of the south, as they began to carve out counties and lordships for themselves; the house of Hauteville alone supplied the unifying force and political insight capable of asserting its supremacy over fellow adventurers and building a single state out of the broken provinces of 1832.3 
the Greeks, the Saracens, and the Lombards. Success was rapid and brilliant. Within a century of the arrival of the Hauteville brothers, Roger II was crowned King of Sicily, Calabria, and Apulia, and he handed on a marvellously organized state to his son and grandson, William I and William II. Two centuries only elapsed between the days of Tancred the knight, whose sons, William Fer-a-bras and the rest, came to seek their fortunes in Italy, and Tancred the King, whose son William III was carried a prisoner to Germany in II95. The Norman kingdom survived this German conquest by the Emperor Henry VI, who had married Constance, Roger's daughter; and in the reign of their son Frederick II, grandson indeed of Frederick Barbarossa, but also grandson of Roger, the Sicilian monarchy had its St. Martin's summer of unsurpassed brilliance. The true tragedy of the Norman state was played out on the piazza del Mercato in Naples, when the boy Conradin, Frederick's grandson, fell beneath the headsman's axe at the command of Charles of Anjou in the year 1268 .

The story of the exploits of William Fer-a-bras belongs to the period of romance. A body of knights from Aversa was lent by Guaimar of Salerno to Ardoin, the Byzantine governor of Melfi, who was planning a revolt. By night the Normans entered Melfi, 'a strong gate as it were into Apulia'; the citizens submitted, and in the morning the Normans ' went away rejoicing by the fields and gardens to Venosa. They were gay and joyful on their horses and rode up and down; . . . and the next day they went to Ascoli and thence into fair 
Apulia, and what pleased them they took, and what they liked not, that they left.' The condottiere period was over; the knights settled in the cities taken from the Greeks, and William was chosen as the head of the primitive federation round Melfi, with the title of Count of Apulia. His political insight carried the enterprise a step farther. He broke the bond of dependence on Aversa, and entered into direct feudal relations with Guaimar, whose daughter he married. Like so many of his family, William founded his fortunes by a prudent marriage and sought a legal basis for his authority. Henceforward the Norman conquest proceeded from two centres. The counts of Aversa turned northwards and took Capua and Gaeta; eventually they conquered the whole principality of Capua and stepped into the place of the old Lombard princes. From Melfi, the sons of Tancred extended their dominion on every side, until all the regions of Southern Italy except Capua were included in the new duchy of Apulia. Drogo, the next brother, succeeded William. He too made alliance with Guaimar and received the authorization of the Emperor Henry III for the new state, which the Normans were building upon the ruins of Greek and Beneventan power. In I05I he was murdered and the succession passed to his brother Humphrey.

Robert Guiscard, the most famous of the sons of Robert Tancred, joined his brothers in 1047, and Roger, the Guiscard. youngest of the family, followed ten years later. Neither of the new comers met with a warm welcome, and they were sent off in turn with a handful of knights to begin the conquest of the narrow valleys of Calabria and 
support themselves by cattle-lifting and extortion. Poverty in the eyes of Guiscard excused any shift to which he was driven, but he was careful, when wealth and honour came to him, to make amends for what he had done when he was poor. To the free-booting days belongs a story which illustrates the character of the Guiscard. Peter of Bisignano was a rich man with whom Robert was on friendly terms. One day, under pretext of a warm embrace, Robert dragged him from his horse, carried him off captive, and fell at his feet demanding a great ransom: 'You are my father, indeed you are my father, and a father always has compassion on his poor son.' When Robert came to his own, Peter's cattle always went in safety, and dowries were provided for his daughters.

The Pa- It was at this stage of the adventure that the Normans pacy and Robert Guiscard in Apulia. came in contact with the Papacy. Leo IX had received the city of Benevento from Henry III, and he took seriously to heart the cruelty and havoc wrought by the Normans. He aimed, like his successors Paschal II and Calixtus II, at reforming the Church and establishing peace in the south. He got together an army of Lombards, stiffened by a body of Lorrainers, but he was beaten and captured at Civitate in 1053. The Normans treated him with exaggerated respect, sent him to his own city, and continued their aggressions. In I059 Nicholas II, no doubt inspired by Desiderius of Monte Cassino, the friend of Richard of Capua, took a different line, and the formal alliance between the Papacy and the Normans was concluded at Melfi. Robert, Duke of Apulia, and Richard, Prince of Capua, 
agreed to protect the Holy See and to hold from it the lands which they now had or should conquer in the future. The immediate advantage to both parties was obvious; the Pope obtained a protector and the prospect of influence in the south; the Normans obtained a fresh title to their lands when the imperial guarantee had declined in value owing to the minority of Henry IV. The Papacy never relinquished its overlordship, but the alliance was chequered to a degree. Hildebrand for the most part played off Capua against Apulia; and Robert was excommunicated for his aggressions in regions of the Abruzzi claimed by the Papacy, until in I080 he once more consented to do homage. In 1084 he came to the assistance of Gregory against the Emperor, and showed his devotion by sacking Rome. Throughout the reigns of his son and grandson in Apulia, friendly relations prevailed, but with the advent of the Sicilian monarchy a fresh situation arose. Between 1060 and 1077, Robert had extended the duchy of Apulia over all Southern Italy and Sicily except the principality of Capua and the duchy of Naples. The power of the Greeks ended with the fall of Bari in I07I, and the capture of Salerno, the old protector of the Normans, in 1077, gave Robert a new capital and left him without a serious rival. The conquest of Calabria had been completed by his brother Roger in 1060 ; and in conjunction Robert and Roger began the recovery of Sicily from the Saracens. Palermo fell in 1072, but the Arab power was not completely destroyed for another twenty years. Owing to the circumstance of the joint conquest, Robert maintained his feudal superiority with 
the title of Duke of Apulia, Calabria, and Sicily, while Roger was made Count of Sicily and Calabria with the direct administration of the greater part of the two provinces. Rebellions among the Norman baronage of Apulia were sternly repressed, and Robert in his old age dreamed of fulfilling the Viking ambition of conquering Constantinople. He died at Durazzo in the attempt in the year 1085. Robert had his full share of the physical beauty of his family; the chroniclers delight in dwelling on his persuasive eloquence, and the irresistible attraction that he had for all with whom he came in contact, whether they were great princes or 'poor widows and little boys who told him all their troubles'. Robert was still the Viking, brave and cunning, with a great lust of wealth and power, and a keen delight in his conquests and the terror which he inspired. His barbarian energy allowed his body no rest; his love of arms and horses and luxurious dress was still natural and unaffected, and had not become the measured satisfaction of the art patron. Nevertheless, contact with political life and an old civilization modified the primitive Norman character: guile was becoming diplomacy and the power of using men and circumstances for his advantage. Robert's genius was above all military and political, and he held his conquests together by the force of his personality. He had, however, little of the organizing ability which Roger and the Sicilian branch of the Hautevilles possessed in a supreme degree; he made no attempt to provide a stable government for the heterogeneous peoples of his duchy, and on his death his dominions fell apart into the regions from which 
they had been formed. His sons frankly divided their inheritance, Boamund taking the original Norman conquests as Prince of Taranto, and Roger as Duke of Apulia keeping the principalities of Benevento and Salerno. Even here the duke's hold was very precarious, and he only maintained himself with the assistance of the Papacy and his uncle Roger of Sicily.

The great count still acknowledged the suzerainty The great of Apulia, but his power increased steadily and the ducal ${ }_{\text {Roger in }}^{\text {Coun }}$ rights in Calabria and Sicily were bartered bit by bit Sicily. for aid in troops and money. Roger had a clear field in organizing the government of the island. It had passed from Greek to Roman and from Byzantine to Saracen, and the Normans were the first conquerors from the north who came in contact with its ancient civilization. There was no nascent Lombard feudalism and no strong Church, as there was on the mainland, to complicate the situation. The new fiefs granted to Normans and Italians from Piedmont, who had carried out the conquest, were limited in extent and in rights of jurisdiction ; the new Latin bishoprics were marked out by Roger himself, and the Sicilian clergy were always in close dependence on the monarchy. Roger had won Sicily from the infidel, and Urban II rewarded him as a crusader with the crowning grant of legatine authority in his dominions. This was interpreted by the count to include the right to appoint the bishops, and the privilege became a source of disagreement between the popes and Roger's descendants. The first kings extended their extraordinary authority to Apulia, but in 1156 Pope Hadrian IV succeeded in restricting it to Sicily and 
reducing the right of nomination to a simple veto on elections; Tancred and Frederick II submitted to further concordats which diminished their independence in church matters, even in the island. But while new institutions were established, the old were preserved. Roger's curia, composed of Norman barons and clerks of the chapel, became the chief organ of the administration, but the Diwan, the fiscal bureau of the Arabs, was maintained with its personnel of Greek or Saracen officials. In the west of the island Arab peasants still cultivated the land and Arab lords held their estates of the new count ; in the east, the bulk of the people were GraecoRomans engaged in trade and commerce over sea. Greeks and Saracens alike lived under their own laws and practised publicly their own religion. The Normans had a profound respect for personal law, and with the Mohammedans, no less than the Jews, law and religion were one. Self-interest, moreover, led the counts and kings to protect the faith of Saracen soldiers and notaries, who formed a constant counterpoise to feudal independence. From time to time outbursts of persecution against individuals or classes were countenanced, but in general the Norman kings were animated by a real spirit of toleration engendered by the complex civilization which they had fostered. Even William II, the pious church-builder and crusader, could reassure the servants of the royal palace, who were filled with alarm, when he overheard them, in the midst of an earthquake, calling upon Allah and his prophet. 'Let every one', he said, 'call upon the Being whom he worships and in whom he believes.' Administrative assimilation and 
religious toleration were the foundation of the Norman state. Under the great count's rule Sicily took a prominent part in European affairs. He supported Urban II against Henry IV and married one of his daughters to the anti-king Conrad. Another daughter found a husband in Hungary, and yet another in Toulouse, while Roger himself married as his third wife Adelaide, a niece of the Aleramid marquess, Boniface of Savona. On Roger's death, in I IOI, Sicily passed for a quarter of a century out of the circle of European politics.

The regent Adelaide met with rebellion and opposition Roger II from the Norman barons, and in order to defend the and the heritage of her young son Roger II, she relied on the of Sicily. Greek elements in her dominions. Her policy was more definitely oriental in its outlook than the great count's had been, and the court moved from Mileto in Calabria to Messina or Palermo in Sicily. The piety of the countess and her son was exercised on behalf of Basilian rather than Benedictine monasteries, and her chief advisers outside the members of her own family were the emirs or admirals, Eugenius and Christodulus. The circumstances of his minority coloured the young Roger's outlook and determined the general direction of his policy. Dominating the fairway between east and west, he set himself to build up a great Mediterranean power, which should control the trade and politics of Africa and Byzantium, as well as the maritime cities of Italy. The conquest of the Norman dominions on the mainland with the possession of Bari and Naples and Amalfi was a necessary part of this policy. The death of his cousin, the childless William, Duke 
of Apulia, opened the way to Roger's succession to all the dominions of Robert Guiscard, and in I I 30 he took the title of King. His ambition awakened the hostility of the Emperor Lothar, Pope Innocent II, the Prince of Capua, and the Apulian baronage and towns. Commercial jealousy led the Pisans to join this formidable coalition, which received financial support from Constantinople. In II40 Roger was at length victorious, and he united in a single monarchy all the Norman territories, Sicily, Apulia, and Capua, under the formal suzerainty of the Papacy. He had taken his place in the front rank of European politicians and was free to carry out wider schemes. As early as III 7 and I 23 efforts had been made to obtain a footing on the African coast, and this was now followed up by the conquest of El-medeah and Sfax, and the establishment of a Norman dominion in the Tripolitana, which anticipated the modern developments of Italian policy. In his later years Roger tried to realize Guiscard's dream of conquering Constantinople and handed the tradition on to his grandson William II. A great expedition was organized by sea and land against Corinth and Thebes in I I 47, the year of the Second Crusade. In this Roger took no part, for his conception of its conduct differed profoundly from the scheme of St. Bernard, who inspired the effort of Christendom. He conceived of an expedition carried by sea in Sicilian ships, with an attack on the Eastern Empire by the way. St. Bernard insisted on the land route and on close co-operation with Constantinople. William I gave up the Greek and African schemes, but William II once more pursued a policy of 
expansion and aimed at becoming Emperor of the East and protector of the Christians in Syria and Spain. He attacked Saladin in Egypt and the Almohades in Majorca. In 1185, in preparation for the conquest of Constantinople, a combined fleet and army captured Salonika, but the Normans were unable permanently to maintain their position and soon retreated. Henry VI took up William's plans; had he lived there would have been a chance of establishing a Latin Empire at Constantinople on a statesmanlike basis, instead of under the disordered conditions of the Fourth Crusade.

Roger II never sat on the throne of the basileus, but none the less he entered intellectually into the Byzantine heritage. His education would seem to have been in the hands of Greek rather than Latin clerks, and though the language of the court was French, his autograph is

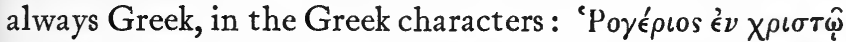

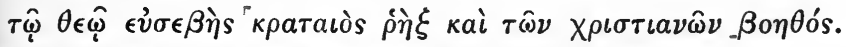
With his Greek signature and his Greek coronation garments, he set himself to realize the Byzantine conception of monarchy. He was the fount of justice, the source of legislation and office, the governor of the people committed to him by God, from whom kings and emperors alone hold their power. The Code of Justinian supplied many titles of the Assizes of II4O, which became the kernel of the later Norman legislation and of the great Constitutions of Frederick II, drawn up at Melfi in Greek as well as Latin. The remarkable treason law of Roger, which made it a penal offence so much as to question the acts of the King or his ministers, comes straight from Constantinople and forms the strangest contrast 
with the contemporary law of the kingdom of Jerusalem which legalized rebellion.

The ad- Roger kept all the threads of the administration in his ministra-
tion of the kingdom. of government; barons and bishops still took part in its deliberations; a Latin chancellor was introduced to deal with the increasing business of the mainland, and professional justiciars assisted at the judicial sessions: nevertheless the chief influence was exercised by the great admiral. Roger saw that the basis of the Sicilian monarchy was a powerful fleet and army and an efficient fiscal system. He declared that a man was lost who did not keep accounts, and he spent all his spare time in the treasury. His prime minister was George of Antioch, the great admiral, whose functions included command of the navy and control of the finance office. The Normans had taken over the Arabic Diwan, itself a legacy from the Byzantine Empire, as its usual title of $\sigma \epsilon \in \boldsymbol{\epsilon} \in \tau o \nu$ suggests. Under Roger, the Saracen and Greek names were general, but under the later kings the hybrid Dobana de secretis appeared with greater frequency. The chief fiscal officials, $\sigma \in \kappa \rho \in \tau \iota \kappa o$ i or magistri dobanae, drew up the lists of villeins on the royal demesne ; they kept the land books and the record of customs dues; and they prepared the registers of fiefs and naval and military services. The masters of the Dohana also travelled through the country to hear fiscal appeals and audit the accounts of the local officials, thus providing the model for the scholae rationum of Frederick II. A staff of notaries drew up documents in Greek, Arabic, or Latin, according to the district of the kingdom concerned. The revenue was derived in great measure from 
the customs and shipping dues collected from the merchants, native and foreign, who crowded the ports of the regnum: the corn trade was controlled by the monarchy in its own interests, and salt-works and the tunny fishery, as well as the finer kinds of dying and silk-weaving, were royal monopolies.

After the fall of the great admiral Maio in II6I, his many duties were separated; the naval command was still given to an admiral, but the control of the Dohana passed to the great chamberlain, and the functions of royal minister were shared by a committee of familiares. The life of the court under the two Williams was frankly oriental in its luxury and elegance and in the palace intrigues and dubious morals, which form the darker side of the picture. Jealousy between the bishops and barons of Norman and French origin, the Lombard officials from Salerno, and the Graeco-Saracen servants of the palace and the Dohana produced a hot-house atmosphere of plot and counterplot.

The most creative work of the Norman monarchy was The addone on the mainland. Peace was established, and royal ministrajustice and royal authority were made a reality in a country Apulia, where oppression and private war had become chronic. Calabria. No attempt was made to transfer Sicilian institutions wholesale to Apulia and Capua with their divergent political and racial history, but the framework of the existing system was retained and, with the help of fresh material, built into a consistent scheme of local government. The old political divisions became the basis of the new provincial organization. At first the government of the provinces was entrusted to the king's sons, but 
later on master captains or constables of Calabria and of Apulia and Capua were set up. The whole country was mapped out into a number of districts within which new officials, the royal justiciars and royal constables, judged criminal cases and supervised the military tenants. Chamberlains were established to administer higher civil justice, to manage the royal demesne and vindicate the fiscal rights of the crown. The feudal classes were made to acknowledge the royal authority, but it was no part of Roger's scheme to destroy them. The counts retained their fiscal privileges and continued to exercise their rights of criminal jurisdiction as the authorized public authority within their counties, while from the knights and lesser baronage in Apulia and Capua the King drew the most faithful of the new justiciars and constables. The ultimate unit of the administration was the city or town, and the Norman kings showed themselves no friends of city independence. The magistrates -strategoti or catepani-were appointed directly by the King, and except in Salerno, which enjoyed the same privilege as Messina and Palermo, they were deprived of criminal jurisdiction. The kingdom checked the movement towards independence in the towns and decided that there were to be no communes and no city states in the south. The Norman kings did their work well, and the reforms of Frederick II in administration and legislation were but the natural development of their system. He modified and added, theirs was the conception.

Art and Such peace as Roger and William and Frederick architecture. gave had not been known in the south since the days 
of Theodoric. The kings held the balance between the discordant peoples, who under this guidance yielded up the varied contribution of Sicily and the south to the great renaissance of the twelfth and thirteenth centuries. The artistic expression of the age was found in architecture and the subsidiary arts. In Campania Monte Cassino was the centre of a great school of architecture and marble mosaic, but important as was its influence both in the regnum and northwards in Rome, it arose independently of the Norman conquest. In Apulia the Norman influence was plainly felt; the Roman basilica was still used as a model as it was in Campania, while a series of churches with cupolas betrayed the influence of a local style, but many buildings, such as St. Nicholas at Bari, reproduced the general scheme of the churches of Normandy. Others again showed the typical features of the Burgundian architecture of Cluny, or recalled the manner of the Pisan builders. Rarely, however, was a church carried out in one consistent style; details were borrowed from widely different sources and worked into the general plan.

In Sicily, under the guidance of the kings, architecture was frankly eclectic, and the most varied elements, Roman, Norman, Greek, and Arabic, were combined in a new harmony of colour and form. Secular architecture, apart from military fortification, received attention unknown in the rest of Europe. Roger built a great palace in the Saracen style, with cool rooms lined with marble faintly cream, and adorned with mosaics of green trees and blue peacocks touched with gold. Summer retreats with pools and gardens, and hunting lodges round 
Palermo, the Cuba, the Ziza, the Favara, show the external characteristics of Arab building with its domes, and pointed arches and flat mouldings. In Roger's churches, the Cappella Palatina and the cathedral of Cefalù, and in William's great foundation of Monreale, the general plan comes indeed from the Roman basilica, but the height of the choir, the pointed arches carried on slender columns, the glowing marble and mosaic of pavement and walls convey the sense of a new and strange creation. In the chapel Arabic influences appear in the pendants of the honeycomb roof, in the design of the marble inlay and the Cufic inscriptions on the walls. At Cefalù and Monreale Norman architects have left their mark in the interlaced arcading and the towers which flank the gabled western front. Byzantium made its contribution in the external domes and the brilliant mosaics within. The great figure of Christ in majesty, clothed in robes of blue and white, looks down from the high apse in all three churches. In the chapel and at Monreale no space is left uncovered by mosaic in gold and colour, but the stiff traditional figures of saints and apostles of the first period give place at Monreale to the whole history of the Old and New Testament treated in an unbroken series of dramatic pictures. The influence of the antique is predominant in sculpture. Acanthus capitals, and here and there the skill shown in the treatment of the nude, recall Graeco-Roman art ; while the technique of the porphyry sarcophagi in which the kings lie buried at Palermo far surpasses any contemporary western effort. Nevertheless Byzantine, Lombard, and Transalpine motives constantly appear in the detail. From 
Byzantium too came the inspiration of the artists in bronze relief, natives of Apulia, who made the great doors at Trani and Troia and Ravello.

The intellectual contribution of the kingdom was Intellecperhaps more far-reaching than its artistic offering. activity. The Norman court became a centre where Jewish, Greek, and Mohammedan scholars and travellers congregated and passed on their learning to students from beyond the Alps. The primitive love of the Normans for travel and adventure reappeared in Roger's keen interest in geography, and it was at his suggestion that Edrisi wrote his famous Arabic treatise. This important work was little known outside the kingdom, but in the sphere of pure scholarship Sicily acted as one intermediary in the passage of Greek philosophy and science into Western Europe. High officials of the court were famous for their learning, and William I took his part in Greek studies. The admiral Eugenius worked at mathematics and astronomy, and Henry Aristippus, archdeacon of Catania, investigated the eruptions of Vesuvius. Yet it was as translators that these men rendered their greatest service to knowledge. Eugenius made a Latin translation of Ptolemy's Optics direct from the Greek, and the versions of the Dialogues of Plato and certain of the works of Aristotle and Euclid in general use in the west can be traced straight to Sicily. For a few years after II60, Palermo was the centre of translation from the Greek; but the Greek element in the population declined, and when the second period of Sicilian translation began under Frederick II and Manfred the translations were made by scholars such as Michael Scot and Hermann the German, not themselves 1832.3 
Sicilians, who worked on the Arabic versions of Aristotle made by the Moslem philosophers of Spain. With Aristotle, the commentaries of Averroes and other Arabs were eagerly studied at the Hohenstaufen court, and the doctrines of the mortality of the soul and the eternity of matter entered into contemporary speculation. Frederick's interest was in a large measure scientific as well as philosophic; the wide extent of his own knowledge is seen in his celebrated treatise on Falconry; and under his care the medical school of Salerno continued to exercise the influence that had been a marked feature of the Norman reigns.

The work of the Normans and Hohenstaufen was broken off, still unfinished, by the ambition of Innocent IV and Charles of Anjou. What they accomplished for the south and for Italy at large is plain, and there is a strong temptation to speculate on the future influence of the kingdom had its development continued on the lines laid down by Roger and Frederick. Because of the circumstances of its recovery from the east, Southern Italy was separated politically and in its institutional life from the rest of the peninsula, but Frederick's scheme of a federal Italy offered a fair chance for a closer union with the northern and central regions. The peculiar brilliance and diversity of the intellectual and artistic culture of Sicily was the result of its late incorporation with the west. The Normans saved the intenser Roman and Greek civilization of the south for mediaeval Europe. In religion, in learning, and in politics, Sicily made its characteristic contribution. Nevertheless, before the fall of the Hohenstaufen, the Greek and Saracen elements 
were rapidly declining and Sicily was on the road to full assimilation with Italy. To the practice and encouragement of Frederick and his sons, the first flowering of Italian poetry was due; the early songs and lyrics were produced in the dialect of Sicily, and, in Dante's day, poetry in the Italian vernacular was still described as Sicilian. The language of si was spoken from the borders of Genoa 'to that Italian cape that marks the entrance of the Adriatic Sea and Sicily'. 


\section{Religion and the Civil Tradition}

The genius THE conception of the personality of Italy must always of Italy. be kept in view as the starting-point for the understanding of Italy in its relation to Europe, and in particular to the Western Empire and the Western Church. ' These two institutions, the crowning monuments of Italian creative genius', it has been truly said, 'dominate the Middle Ages, powerful as facts, but still more powerful as ideas.' We have then to consider the nature of the Italian genius in the earlier Middle Ages, and the legacy of that genius to the world at large. The essential characteristics are the genius for living and the close consciousness of the realities of life. It has been asserted that religion was the supreme achievement of the Italian genius in the Middle Ages, when it was rather the expression, in terms of the Christian life, of a genius that found a parallel outlet in formulating rules for the civil and physical life. The practical Italian mind concerned itself more with the conduct of the individual or the community in the relations, human or divine, of everyday life, than with the speculations of abstract thought. For this reason the great contribution of Italy to religion was in the development of the institutional aspect of the Church and the principles of the monastic life, and not in the evolution of a theological system. In the sphere of civil life, the Italian genius 
manifested itself pre-eminently in law and science, political and physical. The whole ideal of life found its concrete expression in the achievement of a great architecture. In the fourth century, with the appearance of the Christian basilica, the fundamental lines were laid down which the future development of ecclesiastical building was to follow.

Both in religion and in secular relations, the passion for equality and liberty conditioned Italian development. A supreme common sense which is the highest sanity, and a great simplicity of soul which fails to perceive differences, produced a universal levelling of values. In religion this bridged the gulf between the seen and the unseen, and both were equally near and familiar. There is none of the constrained awe of northern religion based on the perception of the mystery of existence, but a natural outrush of the soul towards the divine in consuming love, and an asceticism which had no use for the things of this world, and at the same time passionately accepted the gift of revealing beauty. In secular life the sense of equality was fundamental; there was no sharp cleavage between the ranks of society; trade and fighting were equally honourable employments, to the frank amazement of a northern observer like Otto of Freising. Equality has its necessary corollary in liberty, and a marvellous absence of system marked Italian society, politics, and religion. Organization, except in the papal curia, was everywhere subordinated to the liberty of living or fighting or praying, and this led to endless variety. Nowhere was individuality so intense in the individualist Middle Ages as in Italy. Experiment 
followed experiment in government and religion; the great leaders in law and politics and in the monastic life effected a constant renewal of the vital principle, adapting and applying it to changing circumstances. The Benedictine rule is a rule of life, flexible and instinct with possibilities of development, not the charter of a monastic order; only outside Italy did it become the basis, in the hands of Cluniacs and Cistercians, of a stereotyped code. The rule of St. Francis, again, is a way of life : freedom to follow the Gospel precept, freedom of divine intercourse for each individual was the message which his followers fought so hard for permission to obey.

Alongside the passion for liberty, there was a simultaneous feeling for the claims of social duty. In Italian religion, the vita contemplativa was very close to the vita activa, and that long before the friars gave their sublime exposition of the gospel of mercy. The moral responsibility of the individual for the ills of the community was preached by all the social reformers of Italy. Between the individual and society, as a whole, the claims of the group gradually interposed. The monk was bound by the authority of his order as it became a corporate society instead of a Christian household; the citizen was deprived of freedom of action by the growth of his city to political consciousness; the merchant or the artisan was controlled in the smallest details of life by his guild. The victory of the group over the individual was hastened by the final loss of political unity in the middle of the thirteenth century, and the common genius of Italy broke up into ' a whole family of cognate geniuses, grouped together, conscious of affinity, obeying 
the same general conditions, but issuing in markedly divergent characteristics'.

In the period of beginnings and endings in which the The forbarbarian kingdom established itself by the side of the mative Roman Empire, the Italian mind began to adapt itself to the sixth new conditions of life. The century between the accescentury. sion of Gelasius I' in 492 and the death of Gregory I in 604 laid the foundation of the specifically Italian development in religion. Monasticism in a new form, the Papacy as a political force and the head and centre of Western Christendom, the theory of the joint authority of the sacerdotium and imperium to explain the actual relations of Church and State-all these factors appeared within these brief limits. Even the typically Italian theology of Gregory, the fourth Doctor of the Latin Church, belongs to the same period. Profoundly distrustful of intellectual speculation, endowed with the practical and expository mind of the organizer and teacher, he handed down the substance of western theology in a form suited to an uncritical age. He had to provide not only for the despairing Romans, but also for the barbarian peoples, to whom the institutional and moral teaching of the Church was of chief importance. Not deeply learned-Gregory was ignorant of Greek and Hebrewhe based his teaching on the Creeds and on the conclusions rather than the reasoning of Augustine; to this he added the popular ideas of his age on angels and demons, heaven and hell; and Christian doctrine received at his hands the material and intensely juristic setting that prevailed till the eleventh century. The soil of Italy was never congenial to the growth of a theological school, and the 
great Italian theologians, Anselm, Peter Lombard, Bonaventura, and Aquinas, sought their training beyond the Alps. Anselm marks the awakening of the new speculative theology of the Middle Ages, Aquinas marks the full development of the scholastic theory of existence, human and divine; but, although they preserved a characteristically Italian outlook, their history belongs rather to the general history of European thought than to Italy.

St. Benedict.

The growth of the Roman Church has already been sufficiently considered, but western monasticism, which rose alongside the Papacy and became one source of its strength, was left out of the picture. Until the tradition of service to the State was broken by the barbarian attack, monasticism, with its eastern origin, made little appeal to the men of Italy; it was the work of Benedict of Nursia to lay down principles of the monastic life suited to the western temperament. As a boy of fifteen, Benedict was driven from his studies in Rome by an overmastering desire for solitude, and he sought a refuge from himself in the bare hills beyond Subiaco, high above the valley of the Aniene. The call of the mountain and forest to the city dwellers of Italy was not always recognized, obscured as it was by the insistent desire to flee the distractions of this life, but it was in the compelling beauty of the natural world that they found the peace of the divine. Nowhere is the achievement of men so closely knit with their external habitation as in the solitudes of Italy; Subiaco, Monte Cassino, Le Carceri, La Verna, are instinct with the spirit of their saints. In the privations of the Sagro Speco, Benedict passed through the inevitable temptations of an imagina- 
tive nature deprived of the relief of action, but he trained himself in the practice of divine communion and learnt the wisdom in dealing with men that marks his rule. Disciples came and a group of monasteries was founded round the master's cave: the solitary life in Italy was very close to the social life of the monastery, and the great founders passed from the one to the other. Nevertheless the wisdom of St. Benedict recognized that the hermit life was not for the majority of men, who needed guidance and companionship in the imitation of Christ. He conceived of the monastic life as the life of a Christian household under the absolute authority of the abbotthe paterfamilias of the Roman world. Work and prayer in the bond of the threefold vow of poverty, chastity, and obedience was the foundation of the great endeavour. The variety of employment was meant to secure a true balance between the different faculties, and to guard against the emotional excesses of the eastern monks or the western hermits of a later age. Benedict laid down principles of living, not a rigid rule, and he himself made provision for the necessary modification in food and dress according to individual or local needs.

The ultimate placida quies of the saint was found at Cassio-

Monte Cassino, the true home of the monastic order, dorus.

whence the rule spread to all the monasteries of Western Europe. Of Monte Cassino as the guardian of books and the centre of artistic creation Benedict had no thought; but the ideal of a monastery as a pleasant home of learning in the tranquillity of the religious life was realized by a contemporary of Benedict, Cassiodorus the secretary of Theodoric. His foundation of Vivaria with its library, 
sacred and profane, its students and transcribers, found few imitators in Italy, until the Benedictine houses of a later age realized the precept of labour in a life of study. The her- In the tenth and eleventh centuries the hermits came mits : Nilus of to their own and captured the religious enthusiasm of Rossano. Italy. On its negative side the hermit ideal was touched by the dualistic conception of the universe, which insisted on the inherent evil of everything material and human, and the goodness of the spiritual alone; on its positive side it sought peace of soul in divine contemplation, and aloof as it was from human interests, it yet admitted the social duty of works of mercy, or of preaching the moral regeneration of the Church. The life of solitude and mortification found its most attractive exponent in the Calabrian Nilus of Rossano, in the second half of the tenth century. The disciple who wrote his life says that ' nature had endowed him with a happy disposition, an acute mind and charming manners'. He made his profession as a monk of the Greek order of St. Basil, but he was soon drawn to a literal imitation of the life of the Apostles, going uncovered, with a single coat, and barefoot. After a time he embraced the solitary life in a cave hollowed in the rock, furnished with an altar. 'Here he was quite alone, admitting no one but God, conscious perpetually of His invisible presence.' He lived a life of incredible austerity, spending the day in copying manuscripts in a small neat cursive hand, in meditation, and in the study of the Scriptures and Fathers. 'After nones and vespers he went out to walk to refresh his senses ... remembering that the Creator may be comprehended in the 
visible loveliness of things created; at sunset ... he took his simple meal.' The night, after a single hour of sleep, was spent in reciting the Psalter.

Nilus was no founder of a new rule like St. Benedict or St. Francis, but he stood in temperament as in time between these masters of the spiritual life. The insistence on the study of the Scriptures and the regular round of work and prayer recalls the Father of Monasticism, but he is like the 'Poor Man of Assisi' in the literal following of the Gospel precepts, in the delight in the refreshment of nature and above all in the recognition of the social duty of the monk. His miracles were miracles of healing of body or mind; there was no danger or suffering, we are told, that he would not undergo to protect and succour the poor who were unjustly, or even justly, oppressed. The work of the monk, he said, 'is mercy, peace, and thanksgiving'. His compelling saintliness had a great power of attraction, and men of all classes, learned abbots, poor monks, high officials of the State, sought his advice. He was withal no respecter of persons. In his old age Nilus was driven north by the Saracens, and he carried the Basilian rule to Grottaferrata.

Romuald of Ravenna, a contemporary of Nilus, is Romuald a type of the hermit intensely repellent to the modern of $\mathrm{Ra}$ mind; he practised horrible self-torture, suffering the inevitable demoniac nightmares of a disordered mind and body, although he was consoled by the gift of torrential tears, which was regarded as the surest pledge of sainthood. In spite of his unhappy temperament, restless, intolerant of human companionship, absorbed in working out his own salvation, Romuald had a wonderful power 
of drawing the men of his age to the solitary life. His passion for winning souls to salvation drove him to preach the hermit ideal far and wide. Crowds of young men gathered round him and built their cells in the pleasant places of Tuscany and the Marches that he chose for the life of contemplation. No sooner had he gathered companions together, than he conceived a great hatred of their presence and wandered off on a fresh tour of preaching. The most famous of his hermitages was Camaldoli, where the hermits lived, under the direction of a prior, a life of solitude, silence, and perpetual fast, although the necessarily limited intercourse between the brethren made it impossible to lay down minute regulations. Later on, many of the Camaldolesi, like the canonist Gratian, gave themselves to a life of study.

Peter Da- Of Romuald's followers, the most celebrated was his miani. biographer, Peter Damiani. At Fonte Avellana he performed his full share of fastings, watchings, prayer and scourging, and it was sorely against his will that he was summoned from the hermitage to champion the movement of ecclesiastical reform, as Cardinal-Bishop of Ostia. With fierce denunciation he lashed the moral evil among the clergy and the monks, laying bare their avarice and simony, their unchastity and intemperance, in his terrible Book of Gomorrba. Nowhere did the Papacy find a more effective agent in dealing with clerical scandals or the irregularities of a German king. Nevertheless Peter resented his bondage to Hildebrand, 'his Holy Satan', and feared for his own soul when he was dragged from the solitude of Fonte Avellana. With 
all his passionate admiration for Romuald, Damiani is far removed from his master's ignorant, self-righteous austerity : his faculty of criticism of himself as well as of others is well developed, and he is not blind to the wider needs of society. On one occasion he warned a noble lady against the enjoyment of revenues wrung from the poor, and he composed a model treatise on almsgiving.

Throughout the eleventh and twelfth centuries there Revoluis a growing sense of the wretchedness of the poor, the evils of feud and bloodshed, and the failure of the Church An to bring any redress. Indeed the wealth and secularity tionary reformers : Arnold of Brescia. of the clergy was the worst evil. The denunciation of a Peter Damiani or a Bernard of Clairvaux and the fanatical outbreak of the Milanese Pataria were followed up by the more radical attack of Arnold of Brescia. He was no longer content with a moral reform of the Church, the abandonment of secular preoccupations and the worldly spirit, but he preached a literal return to the povierty of the Gospel, not as a counsel of perfection for individuals, but as the necessary condition of the Church. By denying to the clergy the right to hold property and advocating the forcible resumption of ecclesiastical possessions by the secular power, he contemplated nothing less than revolution; the Church as it existed in the twelfth century would necessarily be overthrown. Even the temporal power of the Papacy was to be destroyed and the sovereignty of Rome vested in the new commune, which was already threatening the independence of the vicars of St. Peter.

Arnold's immediate plan of reconstituting the Church 
The Hu- without a material basis failed, but the idea of a return miliati. to apostolic poverty was deeply rooted in the mind of the twelfth century. At Lyon Peter Waldes had founded his Society of Poor Men pledged to preach and expound the Scriptures ; in Italy the communities of the Humiliati had arisen. One group of the Humiliati threw in their lot with the Waldenses and adopted heretical opinions. These Pauperes Lombardi maintained that the validity of the sacraments depended not on the ordination but on the merit of the celebrant, and they carried the principle, that it was better to obey God rather than men, to the extent of denying any function to the priesthood which might not equally be performed by the laity. Another section of the Humiliati obtained the recognition of Innocent III, and appear as an orthodox society divided into three orders : priests, and women, alike bound by monastic vows, and lay persons who remained in the world. The statutes of the third order reproduced many of the less radical tenets of the Pauperes Lombardi. The members were bound to live by their labours in great simplicity, giving themselves to active works of mercy in tending the poor and sick, and preaching repentance. They were, moreover, forbidden to take unnecessary oaths or join in war and feud. In this way they became a strong force enlisted on the side of social order. Their economic influence was powerful; they were specially strong in Florence and controlled the Tuscan wool-trade.

The Ca- The conception of the inherent evil of material tharists. things, and organized human society, lay or ecclesiastical, which led directly to the distinction between the spiritual church and its members, and the general body of 
Christians, struck at the foundation of the Church. The distinction appeared in different forms during the twelfth and thirteenth centuries. The Catharists, whose frankly heretical doctrine was based originally on Oriental Manichaeism, were numerous in Northern and Central Italy as well as in Provence. The 'perfect' among them lived apart a life of ferocious asceticism, which was intended directly to hasten their release from this evil world, while the ordinary members of the community, accused of an antinomian morality, frequently belonged to the wealthy classes of society, and occupied often enough the magistracies of their cities. The Catharists aimed at maintaining the tradition of the early Church as they had received it. Above all, they emphasized the doctrine of the Holy Spirit working in the soul.

The doctrine of the Spirit reappears in a different Joachim of form in the teaching of the Catholic Joachim, Abbot of the Cistercian house of Corazzo in Calabria, and founder of the monastery of Fiore. $\mathrm{He}$ embraced the solitary life during a pilgrimage to the Holy Land, and on his return he lived as a hermit in Sicily and Calabria before he entered the Cistercian Order, about II68. Obtaining permission to withdraw once more into solitude, he wrote his books, the Concordia Novi ac $V$ eteris Testamenti, the Expositio in Apocalypsim, the Psalterium decem Chordarum, and then in the forests of the Sila he built the house of Fiore for his disciples. Joachim shared the sympathy of the reformers of his age for the wretched and downtrodden, and he seems to have looked forward to a social rising of the poor against 
their oppressors. His interpretation of the Scriptures led him to expect the coming of Antichrist and the beginning of a new epoch in the history of the world. As the revelation of the Old Testament under the guidance of the Father gave place to the New Testament in the gospel of the Son, so now the eternal gospel of the Holy Spirit was to present the final and culminating revelation, ' since the letter killeth, but the spirit giveth life'. In each era an order of men was charged with the duty of presenting the highest expression of the religious life, and as the first and second eras had been marked by the patriarchs and the priests, so the third era was to be the era of the monks and above all the hermits. Each age overlapped the succeeding age; consequently Joachim saw the beginning of the era of the monks in St. Benedict, though its fullness would appear only when the Holy Spirit should have shown all His power. The ideal of Joachim was a spiritual Church, delivered from secular avocations, occupied solely with prayer and psalmody and ruled by a supreme order of monks. For a time the prophecies of Joachim were not seen in their logical bearing, but they were seized on by the 'spiritual' party among the Franciscans, distorted and expanded, until the writings of the Calabrian dreamer were represented as constituting the book of the Eternal Gospel; the Franciscans were the new order of monks, and the secular Church and its corner-stone, the political Papacy, were doomed to destruction.

St. Francis Joachim, like all the reformers who had preceded of Assisi. him, had wide ideas of transforming the Church at large : St. Francis of Assisi adopted many of the elements that 
had been found in these earlier religious movements, but he began with the individual soul. He carried his perception of the true relation of the human and divine into his own life and then preached the new truth throughout Italy. He built his way of life, as others had done, on the literal following of the Gospel, with holy poverty as the corner-stone, for so only could the spirit of man win freedom to follow Christ and serve men. "This is the celestial virtue by which all earthly and transitory things are trodden under foot, and all impediments are lifted away from the soul, so that she can freely unite herself with the Eternal God;' and again, 'if we keep property ... we shall be continually involved in litigation and feuds, and this will oftentimes prevent us from loving God and loving our neighbour'. Nevertheless there is not in Francis a trace of the dualistic view of the universe that darkened the lives of hermits and heretics alike. Not by contempt of the physical world, but by rooting out the lusts of possession, did he reconcile the material and spiritual and accept both as the gift of God. Having won all things through holy poverty, he refused to bind his followers in the fresh bondage of a rigid asceticism, since ' each man ought to consider his strength and take the food he needs, so that the body may render good and loyal service to the spirit'. Gloom and depression must be banished from the religious life, and the joyous spirit of the troubadour converted to Christ must be the mark of the soul set free.

Labour was insisted on as a duty, but there was not necessarily an immediate connexion between labour per- 
formed and the means of livelihood. Work done might or might not produce food and clothes, but it gave a claim to receive subsistance from God through the bounty of the community. It was no longer shameful to beg, for man was in truth as dependent on God as the birds and beasts of the forest. From this position St. Francis reached that essential brotherhood of all created things which issued in the great canticle of Brother Sun and our Sister, Mother Earth-'Praised be thou O my Lord, with all thy creatures'-and in the service of hideous lepers, whom it was far harder to accept as brothers than the birds of Bevagna.. The sense of the injustice of the world and the wrong of wretchedness and suffering had lain very close beneath the impulse that had first turned Francis to a new life. Besides caring for the sick, the new Franciscan brotherhood, the Friars Minor, carried the gospel of penance throughout Italy and Europe, and the son of Pietro Bernardone did not shrink from preaching his message in the tent of the Sultan of Egypt. It was the first attempt to win the infidel except at the sword's point.

The secret of the love of man was the love of God; Francis' self-identification in burning love with the life of the incarnate Christ led him to retire to the quiet places of the hills like the hermits of old. At Greccio in the forest, he made the 'memorial of that Child who was born in Bethlehem', preparing the crib at the side of the altar for the Christmas Mass, and seeming in the intensity of his devotion to see the Babe lying before him. At La Verna, on the rocky height, the vision of the crucified Seraph came in response to 
his ardent prayer to share in the passion of the Saviour and in the immense love, which led to such suffering for the sake of sinners. He bore the marks of the Lord to the day of his death. The hermitages of Umbria and Tuscany are the true homes of the Franciscan spirit.

Besides the order of Friars Minor, the gospel of poverty inspired the second order for women and the third order for the laity, both men and women. Ten years after his conversion St. Francis received the profession of Clare, a noble lady of Assisi, and established her with her companions in the convent of San Damiano. Her loyal devotion was no small strength and comfort to St. Francis, as troubles grew and the expediency of absolute poverty was called in question. At first the 'Poor Ladies' were bound only by the simple rule of the Friars, but the rigid Ugoline Constitutions prescribed enclosure, perpetual fast, and perpetual silence for the houses of women, while the principle of poverty was abrogated. It was only after years of persistent struggle that Clare received on her death-bed the papal privilege to observe poverty as the foundation of the order. The third order was, in the first instance, composed of the devoted but informal disciples such as Orlando of Chiusi or the lady Giacoma. Later it became a regular lay fraternity modelled on the statutes of the Humiliati. The Tertiaries were vowed to observe great simplicity in food and dress, and to give alms and perform active works of mercy. They were to observe the canonical hours, and listen every Sunday to the discourse of an approved brother calling them to penance.

There was no intention in the message of St. Francis 
of subverting the external constitution of the Church or society. Obedience to the Pope and the bishops, reverence for the priesthood and the sacraments, were fundamental parts of the Franciscan position. The saint went so far as to lay a curse on any follower of his who should abandon the Catholic Faith and the Communion of the Church. It is, no doubt, true that had the gospel of absolute poverty and mendicancy been adopted by all the world, the whole economic structure would have collapsed, but St. Francis never looked at the logical results of his teaching; and because he began with the individual, and not with the reform of the community, the subversive element was obscured. Nevertheless, it was the perception of this inevitable conclusion that helped to influence the Papacy against the doctrine of absolute poverty, and throw its weight in the scale of compromise. The popes saw what an incalculable instrument for good had been raised up in the Franciscan brotherhood; and as it grew to a great world-wide community the risk was strong that, without a reasonable economic basis, the force of the society would be dissipated in an uncontrolled struggle for existence. Other considerations too were at work. Men were drawn by the spirit of the order, for whom the letter was an obstacle, and in truth as the work expanded it was plain that the preaching would suffer were no arrangements made for a life of preparatory study. Reason was on the side of the party of compromise, and it triumphed over the party of the strict observance, who in the tenacity with which they held to the letter of the rule fell into the heresies and extravagances of the new Joachim. Much of the true spirit of St. Francis 
remained after the rancour of the conflict was over; but the history of religion in mediaeval Italy seems to end on a note of bondage and betrayed ideals. The passionate love of liberty and the piercing vision gave place to a conventional rule, and the triumph of the political Papacy, in the Church as in the Empire, closes the period.

In the sphere of secular life and interests Italy made The civil no less remarkable a contribution than in the sphere of religion, and here the continuity with the Roman past can be traced even across the darkest age. In the mediaeval Empire, the highest political ideal of Rome was localized in Italy, and the one contribution in the sphere of speculation was contained in the political theory of the Church and Empire. The study of the humanities, the classical contribution to the criticism of life in poetry, history, and science, was naturally appropriated by the Italian mind, and education in the liberal arts was more general than it was north of the Alps.

Efforts to revive education were continuous, and lay Education schools always seem to have existed by the side of the and clerical schools. Theodoric tried to place the municipal schools on a sounder footing; and Lothar I, in 825, divided Northern and Central Italy into nine districts grouped round important towns for education. Notices of scholars wandering from school to school are not uncommon in the tenth and eleventh centuries, and it does not appear that these were connected with a cathedral. There is definite evidence, too, of private teachers who set up schools. The Church, however, did not neglect education. Eugenius II in 826 ordered the establishment 
of an episcopal school in each city and also in the subordinate archipresbyteral churches, while Lombard bishops in the tenth century commanded the parish priests to set up village schools. But whether the schools were clerical or lay, there was not any necessary connexion between education and an ecclesiastical career; the sons of the nobility frequently received a training in the liberal arts ; when every town, large or small, had its judges and notaries, a knowledge of Latin grammar and composition had a very practical bearing.

The 'schools of the liberal arts' seem to have given greater prominence to the teaching of Grammar and Rhetoric than to the third branch of the trivium, Dialectic. These studies were not considered as a mere preliminary to the study of the Scriptures, and some, at any rate, of the scholars were deeply imbued with the spirit of antiquity. Vilgard of Ravenna about the year I000, ' who, according to the Italian habit, neglected the other arts for Grammar, had visions of Virgil and Horace and Juvenal, and received a promise of a share of their glory'; Benedict, Prior of Chiusa, somewhat later, boasted: 'there is no book on the earth which I do not possess : I study them every day. . . . Lombardy, where I learned most, is the cradle of knowledge.' The Italian language was in truth the eldest daughter of Latin, and the scholar of Italy, who wrote and studied in Latin, was not using an alien medium. Familiarity with the vernacular might lead to occasional slips in grammar, but the Latin of Italy was flexible, idiomatic, and natural, even if it was not the language of Cicero ; mediaeval poetry and history are full of classical allusion and the ancient myths clung 
to the soil, offering abundant material for illustration and analogy.

Law was always taught in the schools as a branch Law. of Rhetoric, and Dictamen, the art of composition, included the drawing of legal documents, but from the beginning of the eleventh century law became the predominant study in Italy. In the great revival of learning, with its improved instrument of dialectic, the transalpine peoples applied the analytical method to the substance of theology and metaphysic and debated the problem of the universals or the nature of the Trinity. The Italians with their keen practical instinct seized on law, especially Roman law, as the material for the logical method, and elucidated the principles of jurisprudence as well as the concrete rules for conducting the business of life in a developed society. Italy and Southern Gaul were the two regions in Europe where civil relations were continuously regulated by Roman law, but with this difference. In Italy, reconquered by Justinian, the new Corpus Iuris Civilis that bears his name was introduced, whereas in Burgundy and Aquitaine the Theodosian Code and the derivative Breviary of Alaric II formed the basis of the common law. In Southern Italy, indeed, remaining as it did under the Greek Empire till the second half of the eleventh century, the later Byzantine novellae and the epitomes of the emperors were in force; but this Eastern Roman law, deeply as it affected the customs of the south, seems to have had little influence on the revival of jurisprudence. The coming of the Lombards established Germanic law in the occupied regions, and 
Roman law was confined to voluntary transactions on the part of the conquered population. Nevertheless the growth of trade, with its complicated relationships and intercourse with 'Roman' Italy, brought the influence of the civil law to bear on Lombard custom and edict. The Frankish conquest by introducing the principle of personal law gave an equal validity to Roman as to Teutonic law, and the clergy as a body were judged by Roman law.

Schools of The earliest of the great law-schools of Italy was law :

Pavia, established at Pavia, where Lombard law was preRome, eminently interpreted and studied. Chief among the Ravenna, jurists of the first half of the eleventh century were Bonifilius and Lanfranc, the Archbishop of Canterbury; they were followed by a whole school of later writers. At Ravenna, the ancient imperial capital, a school of purely Roman law was vigorous in the eleventh century, while there are indications that Rome was an earlier centre of teaching. The interests of the Ravennese jurists were coloured by political events, and they intervened in the contest between Henry IV and Gregory VII on the imperial side, calling forth the contempt of Peter Damiani 'for the wise men of Ravenna . . . their books and their Justinian'.

Bologna. The most famous school of all was at Bologna, "the city at the cross-roads of four provinces, Lombardy, the March of Verona, Romagna, and Tuscany', and consequently open to Lombard as well as Roman influences. Tradition ascribed the encouragement of legal studies in the school of the liberal arts at Bologna to the great Countess Matilda, who desired to establish a counter- 
poise to the imperially-minded jurists of Ravenna. 'The first known teacher was Pepo, but the school will always be connected with his more famous successor Irnerius. After the death of Matilda, however, Irnerius went over to Henry $\mathrm{V}$ and acted as a judge of the imperial court in Italy. In political controversy the Bolognese doctors generally preserved an independent attitude, but they naturally tended to favour the monarchical cause; Bulgarus, Martin, James, and Hugh supported the Roncaglia decrees, by which Frederick recovered the royal rights over the Lombard cities. Bulgarus, however, denied to the Emperor's face that he had the rights of an owner over everything held by his subjects; he was merely lord in a political sense.

The work of the Bolognese jurists restored the complete text of the Corpus to the students of the west, with the help of the celebrated Pisan manuscript of the Digest. The literal interpretation of the text was supplied at first by the addition of interlinear or marginal glosses. By degrees the growing material expanded into continuous commentaries. Finally, the texts were subjected to dialectical analysis, with all the ingenuity of the scholastic method, in order 'to present as pure, clear, and complete a statement of Roman legal doctrine as possible'. Discrepancies were noted and the best opinion established after all had been passed under review. The academic standpoint was maintained by Irnerius, Placentinus, Accursius, and the rest; and the method gave an unrivalled knowledge of the matter of the Corpus Iuris, when the age of the glossators ended about 1250 .

Bologna was no less famous as a school of Canon law. 
The great impulse was given by the text-book of Gratian in the middle of the twelfth century. The Concordantia discordantium Canonum or Decretum, as it was commonly called, was by no means the first compilation of decretals and canons, but its juridical arrangement and scholastic method gave it immediate pre-eminence. Canon law was definitely separated from the study of theology, and Bologna ceased to have a theological faculty until I 352 .

The 'Uni. The prominence of legal studies had an important versities' influence on the rise of the 'Universities' of Bologna
ofBologna. towards the end of the thirteenth century. The nonBolognese students, whether Italians or Transalpines, formed guilds, at first four, later two in number, for mutual protection and assistance in a foreign city in which they had no civic rights. The movement towards the foundation of guilds or clubs of merchants or artisans was becoming powerful throughout Europe, and nowhere was it so strong as in Italy, where every kind of union for social or professional purposes sprang up within the civic union during the thirteenth century. Such was the strength of the student associations or universities that they obtained control of the whole organization of legal studies, even the doctors of the law, who did not form part of the universities, submitting to the statutes issued by the Rector of the Students. The doctors, indeed, were organized in the two colleges of civil and canon law, and from 1227 the licence of the archdeacon of Bologna was needed for admission to the degree of doctor; but nowhere out of Italy could such democratic non-ecclesiastical bodies as the student universities have arisen. It is in marked contrast with the organization of Paris, where the 
university of masters or doctors controlled the studium, and struggled for independence of the bishop and chapter of the cathedral.

But although the faculty of law and the jurist univer- Medicine. sities were predominant in Bologna, the old school of the liberal arts persisted and developed into the faculty of medicine and arts, with a medical university and college of medical doctors wholly distinct from the legal organizations. A thorough training in the metaphysical and dialectical works of Aristotle was considered the necessary preliminary to the study of the scientific works of the philosopher, which formed the basis of medical knowledge. Consequently the school of medicine developed out of the arts course. Medicine appealed to the practical Italian interest in life : its study until the middle of the thirteenth century was carried on chiefly in the school of Salerno, which handed on the tradition of the NeoRoman physicians and carried on a practical cure in the mild climate of the city. The school received a great impulse in the middle of the eleventh century, when the writings of Hippocrates and Galen were studied with fresh zeal; something like an organized college of doctors existed, which included women teachers and practitioners. Frederick II forbade practice without a licence, issued after examination by the masters of Salerno and other royal officials in the King's court, and a definite course of study in arts and medicine was prescribed. The school declined after the middle of the thirteenth century, and Montpellier, north of the Alps, and Bologna, in Italy, became the chief centres of medical knowledge. Bologna in especial was noted for surgery 
and anatomy based on actual dissection, which elsewhere was condemned by the Church. Here the medical tradition of the ancients was received through the intermediary of Arabic translations, with the additional commentaries of Jewish or Mohammedan scientists. It was through the popularity of Arabic medicine that the schools of Northern Italy in the fourteenth century became deeply tinctured with Averroistic materialism. The philosophy of Averroes was confuted and rooted out from the universities of Northern Europe, but in Bologna and Padua and Venice the material view of life, which the philosophic position of the 'Commentator' could, without much difficulty, be made to yield, entered into the lay thought of Italy and prepared the way for the philosophic scepticism of the fifteenth-century Renaissance.

The culture of mediaeval Italy mirrored the culture of ancient Rome and handed on the tradition of literary and linguistic studies, as well as the great heritage of Roman law and antique medicine, to form the basis of modern views of life in letters, politics, and science. 


\section{ITALY, I $250-1527$}

The Years of Transition

$$
\text { I 250-I3I3 }
$$

The sixty-three years which passed between the Frederick death of Frederick II and that of Henry VII form at II's legacy once the epilogue of mediaeval Italy and the prelude of future. the new age. Frederick II was the last great representative of the ancient imperial principle, but he was also the founder of a new Italian monarchy. If in a certain sense he strengthened the bonds which tied Italy to the past, he also indicated the lines of her future development. The generation which succeeded Frederick regarded the Empire as an institution which had its roots in Italy rather than in Germany; and from henceforth no one who aspired to supremacy in Italy could altogether free himself from the dream of worldwide domination. On the other hand, Frederick left behind him a new theory of sovereignty. Law as the will of the sovereign, the immediate authority of the monarch over all classes in the state, the person of the despot as the source of national unity-such conceptions helped to shape the policy of future kings of the Two Sicilies, and aided them in their battle with feudal anarchy. From the point of view of Italy as a whole, 
the peculiar importance of Frederick's work lay in the fact that he made the Sicilian kingdom a starting-point for the sovereignty of Italy. The Two Sicilies formed the centre of a federation of princes and republics bound to Frederick by ties of commendation and alliance. Despots rose to power under the shadow of their great prototype, and citics strengthened themselves through political and commercial union with Frederick and his allies. This movement towards federation was prompted mainly by individual interests. A city commended itself to the Emperor for the sake of the advantages which his protection brought, and broke with him when those advantages ceased. Yet it was a step in advance for the separate units to realize that their interests were best served by co-operation. Owing to the incurable individualism of the Italian cities, which showed itself afresh whenever their independence seemed threatened, it was only by some such system as this that Italy could hope to attain national unity. Unity was sought after by the wisest and sanest minds of the age, but the unity of Italian aspiration must always be unity in variety.

Frederick II also bequeathed to Italy the pattern of a Renaissance court. The thirteenth-century scholars who gathered at Palermo were like their brethren of the fifteenth century in the new interest which they found in the world and in humanity, in their enthusiasm for the classics and their scientific spirit. Here Italian as a literary language came into being, while the personal share which Frederick and his sons took in the revival forestalls the influence of the Medici or the Sforza on the intellectual and artistic movements of their day. 
During the fourteenth and fifteenth centuries the ideals of the Renaissance were developed, and at the same time Italy endeavoured to work out a system of government adapted to her peculiar needs. Thus the Italian Renaissance and the Italian city-state give character to the history of the period, and the origins of both are closely associated with the last Hohenstaufen Emperor.

Frederick II died on December I3, I250, and his Manfred of illegitimate son Manfred, Prince of Taranto, became at Taranto, once the central figure in Italian history. Pope Innocent IV, the implacable enemy of the Hohenstaufen, was still at Lyons, and did not come to Rome until October 1253, after nine years' absence. Conrad, the legitimate heir to Frederick's dominions, had more than enough to do in Germany, and Manfred, by the terms of his father's will, was to govern the Two Sicilies as Conrad's representative. This brilliant prince, warrior, poet, and musician, the heir to his father's talents, yet adding to them a beauty and a charm that were essentially his own, seemed the ideal sovereign for the Italians. Some idea of the attraction which he exercised, even over his political opponents, can be gathered from the way in which Fra Salimbene speaks of him, and still more from the place which Dante assigns to him in the Purgatorio. Manfred had sinned deeply, he had usurped authority which belonged to Frederick's lawful heirs, and he had died excommunicate. Yet he is among the late-repentant, because his hold upon the imagination of Italy made it impossible to conceive of him among the lost.

Manfred's position in the Two Sicilies was fraught with difficulty. The friction between the German and 
the Italian element among the Sicilian baronage, and the tendency of feudatories to take advantage of a change to a weaker ruler, made it impossible for him to rely upon the loyalty of his own subjects. At the same time he had to deal with the ceaseless intrigues of the Papacy, and with the jealousy of Conrad, who came to Italy a year after Frederick's death. The friction between the half-brothers continued throughout Conrad's sojourn in Italy, and at his death in May 1254 he showed his distrust of Manfred by appointing the Margrave Berthold of Hohenburg as regent for the infant Conradin. This rejection of Manfred by the imperialists had an important effect on his position. It enabled him to come forward as an Italian national leader, and it is responsible for the efforts which he made to co-operate with the Pope. Innocent IV also had his difficulties. The city of Rome, under the wisest and most single-minded of her senators, the Bolognese lawyer Brancaleone, was advancing rapidly towards republican independence. Brancaleone's name, and not that of Innocent, figured'on the Roman coinage ; and when the Pope visited his capital, in the autumn of I253, he did so at the orders of the powerful senator. The Pope stood in need of external aid in order to reestablish his authority in his own capital, and this fact alone drew him towards Manfred. In September 1254 a treaty was signed between Innocent IV and the ruler of the Two Sicilies, and the Pope entered Neapolitan territory with Manfred holding his horse's bridle. But the alliance between Innocent and the son of Frederick II was too unnatural to last. While professing friendship with the Prince of Taranto, the Pope confirmed his 
offer of the Sicilian crown to Edmund of Lancaster, the son of Henry III. Manfred was aware of the Pope's duplicity, and before the year was out he broke his chains. His defeat of the papal troops at Foggia in December I 254 ushered in the final struggle between the popes and the Hohenstaufen.

The years between I254 and I26I are the years of Manfred's Manfred's ascendancy. Viewed in the light of the ascendfuture they are chiefly interesting as illustrating the kind Italy. of dominion which it was possible for him to establish. In the first place, his was a native Italian rule, based on the consent of his subjects in the Two Sicilies, and on his ability to defend the kingdom against external enemies. His coronation at Palermo on August 10, I258, in defiance of the rights of Conradin, marked him out as an Italian and not as a German prince. Secondly, his power was extended from his own territory over the rest of Italy by a widespread system of alliances and commendations. He made a treaty with Brancaleone, and so ranged himself on the side of law and order in the struggle against the anarchical Roman nobility. $\mathrm{He}$ received the city of Siena under his protection, and helped to win the great victory of Montaperto over the Florentines in 1260. After this, Ghibellinism was triumphant in Tuscany, and Siena stood at the head of a league which included Florence, Pisa, and half a dozen lesser cities, all pledged to Manfred's cause. In Lombardy, Ezzelino da Romano waged war on the Guelfs and the papal legate, although his death in 1259 freed Manfred from a supporter who was dangerously near to being a rival. In his place, the Marquis Oberto Pela1832.3 
vicino became the recognized leader of the North Italian Ghibellines. Pelavicino was in many respects the forerunner of the later Italian despot. $\mathrm{He}$ was elected Podestà of Cremona in order to make peace between the parties, and various other cities who were troubled by faction or exiles received him as their lord. Ghibellinism formed a bond between Pelavicino and the cities subject to him, helping him to consolidate his own power, while his loyalty to Manfred, as the head of the Ghibelline party throughout Italy, strengthened the ties between Lombardy and the Sicilian kingdom. Manfred also made a treaty of alliance with Venice, and through Venice he was brought into touch with Baldwin, the exiled Latin Emperor of Constantinople. Like Robert Guiscard before him, Manfred let his ambitions range across the Straits of Otranto, and he told Baldwin that, if the Pope would grant him even a temporary truce, he would set sail for the east and restore the Latin Empire as a prelude to the reconquest of Jerusalem. When in I26I Manfred was elected Senator of Rome, the climax of his greatness was reached. All the most vital forces in Italy seemed bound up with his cause. He was the representative of Sicilian independence and of Roman Republicanism. In him the political ambitions of the despots and the commercial interests of the cities found their best hope of realization. The possibility of reviving the Latin Empire provided him with that dream of imperial domination which was necessary to make his supremacy in Italy complete. Five years later his dishonoured body lay on the banks of the river Verde, and Italy was at the feet of Charles of Anjou. 
Manfred's downfall was due primarily to the Pope, Causes of but perhaps more fundamentally to the inherent defects of the supremacy which he was able to establish. The Papacy worked persistently for his destruction, and in the hour of crisis his allies melted away. The turn of the tide came in 1262, when Urban IV, alarmed by Manfred's successes, transferred the offer of the Sicilian crown from the weak English candidate to the powerful and ambitious French prince, Charles of Anjou. Even more dangerous to Manfred was Charles's election as Senator of Rome by the Guelf party in 1263 . The election was made without consulting the Pope, who complained bitterly that he was falling from Scylla into Charybdis. Although Urban announced that he wished no prince to rule in Rome save himself, the Guelfs persisted in their support of Charles. The reason for their action lay in the fact that Manfred's senatorship involved the predominance of the Ghibellines. Now the rival party were determined to have a senator who would turn the balance in favour of the Guelfs. Thus Manfred, while striving to found a national monarchy, had only succeeded in establishing a party supremacy. His position in Rome depended upon keeping the city Ghibelline, and when he failed to do this all was lost.

Charles of Anjou's Italian expedition succeeded as Charles of only the great adventures beloved of fortune can suc- Anjou in ceed. On the death of Urban IV a patriotic party $1265-85$. among the cardinals pressed for the election of a Pope who would be reconciled with Manfred, and would combine with him to keep the French out of Italy. But the Conclave hesitated, and the French party 
triumphed in the election of a Provençal as Pope Clement IV in February 1265. When a storm cast Charles on the Pisan shore, in the course of his voyage from Marseilles to Ostia, Manfred's captain arrived just too late to take him prisoner. At every point fortune played into his hands, and Benevento itself was only an accidental victory. Yet from the moment when fortune deserted Manfred the hollowness of his position was revealed. The cities and despots who commended themselves to him did so, not from motives of loyalty or patriotism, but in order to serve their own clearly defined interests. 'Do not ruin yourself for the cause of the Emperor,' Provenzano Salvani had once said to the citizens of Siena, 'but endeavour to gain some advantage from your alliance with him.' This advice is typical of the attitude of Ghibelline Italy towards the Emperor's son. Siena was the champion of Tuscan Ghibellinism, because Manfred's protection gave her greater commercial opportunities and the means of triumphing over Florence, just as to Venice it brought freedom to purchase South Italian corn and the exclusion of Genoese vessels from Sicilian ports. But the Sienese merchants were already realizing that alliance with Manfred was not sufficient to put them on equal terms with Florence. Their rivals were gradually outstripping them in trade, and they were also suffering from the excommunication which they had incurred as Manfred's allies. The papal anathemas were made an excuse for repudiating debts, and papal agents were doing their utmost to paralyse the commerce with France and England, upon which much of the prosperity of Siena 
depended. So Siena wavered in her allegiance, and similar causes explain the numerous defections to the Guelf party which both preceded and followed the battle of Benevento. Pelavicino did his best to oppose Charles's passage through Lombardy, but the treachery of another Ghibelline leader was held responsible for his failure, and very soon he was driven from all the cities which had welcomed his rule. 'Where are my Ghibellines ?' was Manfred's despairing cry, when he reviewed his shrunken forces on the eve of the final struggle. The Manfred weakness of his position was seen even in the battle killed at itself, when the Saracens and the Swabians were overwhelmed by the French onslaught, and thereupon the Italian reserves took refuge in flight. So, on February 26, I266, the hope of Italian nationalism went down before a ruthless foreign conqueror. Manfred fell because his power rested on no more solid basis than a fortuitous combination of separate interests. At the first test, unity had been worsted by variety.

The events of the next two years are a repetition of Conradin's Manfred's career on a smaller and still more tragic scale. TagliaThe reaction against Charles of Anjou, the revival of cozzo, Ghibellinism, and the passionate invitation to Conradin to come and deliver his kingdom from the oppressor, showed that Italy had repented of her selfishness and her treachery. Conradin's defeat at Tagliacozzo, and his betrayal into the hands of his murderer by Giovanni Frangipane, Lord of Astura, showed that the repentance was half-hearted even had it not come too late.

The execution of Conradin in 1268 left two candidates Policy of for supremacy in Italy, Charles of Anjou and the Pope. Anjou. 
Charles's aim was to make the Sicilian kingdom once more the centre of a dominion which extended over all Italy. Manfred at the height of his power had made Italy predominatingly Ghibelline, and now Charles strove to make her Guelf. The Angevin party naturally looked for support to the Papacy, as the leader of the Guelfs and the power which had summoned Charles to Italy. But the popes distrusted and feared their chosen instrument. An Angevin king in the Two Sicilies was certainly preferable to a Hohenstaufen, but it was soon recognized that he might be a dangerous rival to the papal power in Italy as a whole. So the policy of the popes wavered throughout Charles's life. Weak popes turned to Charles for protection, but at any moment he might find his position undermined and his plans shattered by a more independent occupant of the Papal Chair.

For ten years Charles of Anjou held the office of Senator in Rome, where he created an unprecedented reign of order by his stern rule. Clement IV appointed him Imperial Vicar in Tuscany, making the vacancy in the Empire an excuse for his usurpation of imperial rights. On the coming of Conradin, the traditionally Guelf cities of Tuscany rallied round Charles, and Florence, Prato, Pistoia, and Lucca all commended themselves to him. After Tagliacozzo, the Guelf party grew and flourished throughout Italy. Charles became the head of a Guelf Lombard League and lord of many strong places in Piedmont, while Siena made her final renunciation of Ghibellinism and confined the chief magistracy of the republic to 'good merchants of the Guelf party'. 
Angevin ambition, moreover, was not limited to Italy. Charles betrothed his daughter to Philip, son of the ex-Emperor of Constantinople, and made preparations for a great expedition to the East in order to revive the Latin Empire in the person of his son-in-law. The resemblances in the position of Manfred and that of Charles are stronger by far than the differences. The ruler of the Two Sicilies, were he Frenchman or German, regarded the world from an Italian standpoint as soon as he set foot in the kingdom. He might hold down his dominions with foreign soldiery, but his policy, his aims, and the nature of his rule were always those of an Italian prince.

It was during the reign of two popes, Gregory $\mathrm{X}$ and The attiNicholas III, that the first serious attempt was made tude of the to weaken the Angevin power and to lay the foundations of a rival papal supremacy in Italy. Gregory $\mathrm{X}$ was a member of the Milanese house of Visconti, and he was raised to the Papacy in I27I after a three years' interregnum. During those three years the Angevin and antiAngevin parties in the Conclave fought over the election until the citizens of Viterbo forced the situation by taking off the roof from the Archbishop's palace in which the Conclave was sitting. The new Pope was not a particularly learned or distinguished man, but he was remarkably clear-sighted. When he reviewed the European situation three points drew his attention, and upon them his whole policy was based. He saw the Empire restored under Rudolf of Hapsburg, and decided that Italy had nothing to fear from this shadow of former greatness. So he hastened to confirm Rudolf's election, and entered 
into friendly relations with him which tended to their mutual advantage. He also saw the danger of the growing power of France; and, realizing that through Charles of Anjou France had already set one foot in Italy, he determined to assert his independence of his over-mighty protector. Lastly, he saw that Italy was rapidly compassing her own ruin by the violence of her party factions. Charles of Anjou's power in Italy depended upon keeping faction alive. It was therefore with a double object that Gregory endeavoured to reconcile factions, and in so doing he sowed the seeds of a truly national predominance. Unfortunately for his country he died in 1276 , before his wise policy could bear fruit. Nicholas III won two substantial victories for the papal cause. $\mathrm{He}$ obtained from Rudolf a definition of the rights of the Church in Romagna, recognizing in return Rudolf's claims to appoint a Vicar in Tuscany. Thus the territorial power of the Church was strengthened and Charles of Anjou was deprived of his Tuscan vicariate. In the second place, he forced Charles to resign the senatorial office, and issued a constitution which laid down that no foreign prince should ever again be Senator of Rome. Once more the chief power in Rome fell into the hands of the great nobles, and as Nicholas III was himself an Orsini, he was able to control the city through his own family.

The

Sicilian Vespers, 1282.

Nicholas III's successor was a creature of the Angevins, but by this time (1280) other forces were already in motion which were to bring ruin upon the Angevin cause. Charles's rule in the Two Sicilies was far more foreign 
than Manfred's had ever been. Frenchmen filled all the chief offices of State and his subjects were made to feel themselves a conquered people. Above all, Naples and not Palermo became the capital of the kingdom, and the island Sicilians saw their glory passing to the mainland. Ghibellinism, moreover, was not dead in Italy. Conrad of Antioch, almost the solitary survivor of Tagliacozzo, awaited the day of vengeance in a secret hiding place. John of Procida was already in Spain, working with Queen Constance, Manfred's daughter, for the hour when her husband, Peter of Aragon, should be summoned to Sicily as the heir of the Hohenstaufen. Michael Palaeologus, the Greek Emperor of Constantinople, contributed men and money to an enterprise which would keep Charles of Anjou employed in his own dominions and thwart his designs in the East. So the spirit of nationality flamed up in the Sicilian Vespers, and combined with other elements of opposition to Charles to drive him from half his kingdom. On the death of Charles of Anjou in I285, his son and heir was a prisoner in Aragon, and King Peter was firmly established in Sicily. Not until I 288 did Charles II return to Naples to take up his rule in the mainland portion of the kingdom.

A few years of unsurpassed confusion followed. The Pope sons of Peter and Charles fought over Sicily. Popes Ve. followed one another in rapid succession. It was the hey-day of the Roman nobles, and of the rich burgher families of Florence. In no period was the abundant vitality of Italy more conspicuous or more disastrous. When, in I 294, Pietro Murrone, the hermit of the Abruzzi, 
was elected Pope, the choice of a man whose sole qualification was his saintliness seemed to express the longing of Italy for a reign of peace and holiness which would save her from herself. What followed was quite inevitable. Pope Celestine $\mathrm{V}$ learned by bitter experience that a hermitage in the Abruzzi was not the best training school for the government of the Church. He resigned the Papacy five months after his election and Cardinal Benedetto Gaetani became Pope in his stead.

Character The pontificate of Boniface VIII (I294-I303) repreand policy sents the most important attempt to solve the problem face VIII. of Italian unity by means of a papal predominance. During his reign the Papacy was by far the strongest power in Italy. His personality towers above that of his contemporaries; ' a man of great daring and consummate ability,' 'says Dino Compagni, 'he guided the Church as he pleased, and humbled those who did not submit to him.' The aim of his life was the subordination of all temporal authority to that of the spiritual head of Christendom. He persecuted the Colonna, who threatened his supremacy in the States of the Church, not resting until the two Colonna cardinals were deposed and excommunicated and the Colonna fortress of Palestrina was razed to the ground. He waged war on the Sicilians, who dared to elect Frederick of Aragon as their king, in spite of the treaty, framed by Boniface, by which Frederick's elder brother had yielded Sicily to the House of Anjou. He overthrew the White party in Florence, because that party refused him military aid for his Sicilian 'Crusade'. Both in England and in France he acted upon his theory of papal supremacy, in defiance of national 
sentiment. To his lofty imagination it seemed that the fall of the Hohenstaufen had left the Papacy without a rival, and that vigorous action on his part would suffice to make him in very truth the sovereign power of Christendom.

As a Gaetani, Boniface VIII belonged to an ancient Foundanoble family of the Campagna, and he used his relations tions of his to strengthen his authority in the States of the Church. His brother Loffredo was made Count of Caserta by Charles of Anjou. His nephew held the important fortress known as the Torre delle Milizie in Rome, and numerous fiefs in the Campagna. A grand-nephew became Rector of the Tuscan Patrimony. Thus the territorial power of the Papacy was consolidated on a family basis, in a way that foreshadows the policy of the Borgia and della Rovere popes in the fifteenth century. Boniface was a brilliant canonist, trained at the University of Paris, and he was also an intelligent patron of the arts. Giotto was at work in Rome during the greater part of his pontificate. The famous mosaic of the Navicella or ship of the Church, which hangs in the vestibule of St.Peter's, and the fresco in St. John Lateran, representing the proclamation of the Jubilee, are permanent witnesses to Boniface's association with the first of modern painters. This interest in art and architecture sprang partly from the determination to make the glories of Rome contribute to the prestige of the Papacy. In the Jubilee of 1300 Boniface found a unique opportunity for the accomplishment of his purpose. During that year some two million pilgrims entered Rome to visit the holy places; and no thoughtful Italian could fail to be stirred to the very 
depths of his being by the sights which he witnessed. The majesty and universality of the Catholic Faith, Rome the mistress of the world, Italy the Queen of European nations reigning with the Holy Father over the rest of Christendom-such conceptions seemed no longer visions but realities at this crowning moment of Boniface VIII's pontificate.

Invitation

Nevertheless Boniface VIII failed, and the causes of to Charles of Valois.

his failure are summed up in the invitation to Charles of Valois to champion the papal cause in Italy. Charles of Valois was the brother of King Philip IV of France, and the primary object of his intervention was to drive Frederick of Aragon from Sicily. In this he was singularly unsuccessful. Fiederick was more than a match for his enemies, and the war terminated in the Peace of Caltabellota in August I302, leaving Frederick in possession of his kingdom. Before this Charles had been sent to Florence to mediate between the Blacks and Whites. The White party was in power, and although its members were loyal Guelfs they did not wish to embroil Florence in a war which did not concern her. The Blacks, on the other hand, were ready to fight Boniface's battles; and they persuaded the Pope that their rivals were not merely non-interventionists but secret Ghibellines who would strengthen the hands of Aragon and make Florence a refuge for the Colonna. Boniface therefore regarded the situation in Florence as a partisan and not as an arbiter. The result of Charles's mediation was that the Whites went into exile, and there joined hands with their former enemies the exiled Florentine Ghibellines. Boniface VIII, with all his ability, was not so clear-sighted 
as Gregory X. He intensified party feuds when he should have tried to heal them, and the relentless violence with which he pursued his opponents created many Ghibellines who were Ghibellines only because of their personal enmity to the Pope. He increased the French power in Italy, and, when he had given proof of his dependence upon French forces in his own country, he proceeded to threaten the national liberties of France in matters ecclesiastical. Hence the tragedy of Anagni followed all too rapidly upon the triumphs of the Jubilee.

In September I 303 Boniface VIII was a prisoner in Boniface a the hands of his two principal enemies, the French jurist prisoner at Nogaret and Sciarra Colonna. A month afterwards he died of grief and rage in Rome. France had grasped the power which the Pope, in his blindness to all but party interests, had put into her hands. The transference of the Papacy to Avignon in 1305 was the nemesis of Boniface VIII's career.

Among those whose imagination was stirred by the Dante and Jubilee, and who were horror-struck at the indignity Boniface suffered by the Vicar of Christ at Anagni, was Dante. The lofty ambitions of Boniface VIII were not wholly foreign to his own ideals. Both strove to re-create the great Christian Commonwealth of the Middle Ages, and both saw the world mainly through Italian eyes, with Rome as its centre and as the source of spiritual and temporal rule. Yet Dante hated Boniface, not only as the cause of his exile from Florence, but, more impersonally, as one who had misinterpreted and distorted the mediaeval theory of universal sovereignty. In Dante's eyes Boniface had usurped authority which did not belong 
to the spiritual sphere. He had rejected the theory of the twin powers, and had made himself both Pope and Emperor. During the years which followed Anagni, when Italy was like 'a riderless horse', bereft of either temporal or spiritual sovereign, it seemed to Dante that the sole hope for the future lay in the revival of the mediaeval system in its entirety. He looked forward to a day when man should be guided 'by the supreme Pontiff in accordance with the theological virtues to eternal felicity, and by the Emperor according to the moral virtues to temporal felicity'.

Dante and Throughout this period Dante was an exile from Italy.

Florence, and as he wandered through Italy he saw on all sides signs of vigorous, superabundant life. In Florence, the political turmoil which led to his exile, as a member of the White party, coincided with an outburst of intellectual and artistic activity. The Cathedral, the Palazzo Vecchio, and the great Franciscan Church of Santa Croce were all begun between the years I 294 and I298. In the sphere of letters, the cult of the dolce stil nuovo gave fresh inspiration to the poets, among whom Dante himself was chief. When Dante visited Padua in I 306, he found Giotto at work on the frescoes of the Arena Chapel. At Verona he saw Bartolommeo and Can Grande della Scala grasping and consolidating their. power, and welding rival cities into a strong state. He could not be insensible to the immense power for good which existed in Italy, to her capacity for producing the noble, the beautiful, and the permanent. But the crying need of the age was for political stability, for a reign of peace under which all this creative power could be 


\section{The Years of Transition}

developed in its fullness. Italy needed a saviour, and Dante looked to a restored Empire, acting in co-operation with a purified Papacy, to supply her needs.

It is clear that the condition of Italy at the opening of Dante's the fourteenth century throws considerable light on the De Monpolitical theories put forward in Dante's De Monarcbia. Here we are told that the Emperor exists for the good of the people, and that he is the guardian of the world, having as his chief function the maintenance of universal peace, without which the intellectual faculties of humanity cannot be brought to perfection. Moreover, the Empire, as Dante sees it, is an adaptation of mediaeval theory to the conditions of his own age. He recognizes national and local divisions, the necessary existence of different forms of government, and the inevitable rivalries between princes. His Emperor is to act as a universal arbiter, and to do the work which international law has not yet succeeded in doing to-day. "Now between any two princes, one of whom is in no way subject to the other, contention may arise, wherefore there must needs be judgement between such. And one not being subject to the other, there must needs be a third of wider jurisdiction, who, within the compass of his right, has authority over both.' So for his own age and nation Dante tries to reconcile the conflicting claims of a universal reign of law, and the independence of individual states. He recognizes that Italy is a collection of separate principalities and republics, and he looks to the suzerainty of an allpowerful Emperor to weld the many into the one.

The most practical commentary on the political The theories of the De Monarcbia is the career of Henry VII Henry VII. 
in Italy. Henry, Count of Luxemburg, was elected King of the Romans in November I308. His thoughts were at once turned towards Italy, and towards the imperial crown which he hoped to receive in Rome. He had few dominions of his own, and as lord of French-speaking provinces of the Empire he was bound by no rigid national traditions. His dream was the revival of the imperial power and the initiation of a reign of universal peace, unmarred by national rivalries or party factions. At first all went well with him. The French Pope at Avignon favoured his expedition, and the title of ' Rex Pacificus' which he adopted brought hope to the factiontorn cities of Italy. When he crossed the Alps in the autumn of I3IO, the Italian nobility of both parties flocked to his side. The Ghibellines looked forward to a revival in their fortunes and to an end of their exile. The Guelfs came with some suspicion in their hearts, but they were ready to make the best of the situation and to glean what advantages they could from the imperial favour. All Italy was dazzled by the prospect held up before her by the imperial envoys who prepared the way for Henry's coming. When the Emperor was crowned in Rome, they said, the Italians as members of the imperial household would rule the world with him. Yet the enterprise which began so brilliantly proved one more record of failure, a failure which was already assured before Henry VII's death at Buonconvento in August I3I3.

Causes The Emperor's difficulties began in Milan, where a of his failure. scrious tumult broke out in February $\mathbf{I} \mathbf{3} \mathbf{I}$, owing to the pressure of imperial exactions and the arbitrary 
behaviour of imperial officials. In the words of the Milanese lawyer, Cermenate, Henry was 'as richly endowed with virtues as he was destitute of money'. He was hampered throughout by his poverty, which necessitated heavy taxation, and rendered him dependent upon his Italian allies. He also suffered from the inability of the foreigner to understand Italian conditions. The chronicles are full of complaints over the 'stupid fury' of the German soldiers, and of regrets at the injustices committed by Henry through ignorance. The Emperor's brother, Waleran, noticed a picture of the imperial eagle in an hotel at Lodi to which some one had appended a halter and gallows, roughly drawn in charcoal. He chose to regard this harmless jest as a deadly insult, and the host was imprisoned and fined, with the inevitable result that the Italians despised the Germans as much as they hated them. When Henry prepared to put down the rebellion of Cremona, the Guelf leader Cavalcabò, who had instigated the revolt, fled on his approach. Thereupon the moderate Guelfs, who had from the first disapproved of the rebellion, came out of the city with halters round their necks and begged for mercy. But Henry was goaded to fury by the treachery of Cremona, which had welcomed him on his coming and then risen against him. So Supramonte Amati and his friends of the moderate party were executed, and all Italy knew that the wrong people had been punished.

Another cause of Henry's failure was his identification His identiwith the Ghibellines. He came to Italy determined to fication know neither Guelf nor Ghibelline; everywhere he Ghibelfound that the Guelfs were inevitably his enemies and lines.

1832.3 
the Ghibellines his friends. Formal reconciliation between factions and the return of the exiles to the city followed Henry VII's appearance in many an Italian town. Yet the reign of peace lasted a very short time, and when the old quarrels broke out again, Henry was forced on to the side of his traditional allies. In Milan, Matteo Visconti and Guido della 'Torre made peace at Henry's instigation, and at first they seemed to share equally in the imperial favour. Yet before Henry's death Visconti obtained official sanction for his power in Milan, through being made Imperial Vicar, while Della Torre went into exile, and became the centre of Guelf resistance to Henry VII. A Pisan chronicler once said of the Emperor that he was a good man, but a man of little intelligence. He was one of those obstinate idealists who persisted in believing in the good intentions of his bitterest enemies until evidence of bare-faced treachery was brought plainly before his. eyes. When he was thus convinced against his will he gave way to anger, and his vengeance was needlessly severe. Nothing can excuse his blindness to the situation in Rome, where John of Anjou, the brother of King Robert of Naples, was doing his utmost to make it impossible for Henry to enter the city. In succeeding his father, Charles II, in Naples, Robert had also inherited the aspirations of the house of Anjou to ascendancy in Italy. Thus he had the most to lose from a successful assertion of imperial power in Italy; yet because he had accepted Henry's invitation to the coronation ceremonies, and had consented to negotiate a marriage alliance, Henry refused to believe that he his enemy. His eyes were not opened until he had crossed the Ponte Molle under the 
fire of Angevin archers, and had been crowned in St. John Lateran because John of Anjou denied him access to St. Peter's

When at last Henry prepared to avenge himself on France King Robert, he discovered that the power of France was enemy. behind the house of Anjou. Clement V was threatened with the fate of Boniface VIII at Anagni if he acted contrary to the wishes of Philip VI; and from the papal palace of Avignon came a warning to Henry not to interfere in Naples. Negotiations between Pope and Emperor were still pending when Henry VII was struck down by fever at Buonconvento.

In the course of sixty-three years there had been four Insuffibids for supremacy in Italy, and all alike had ended ciency of in failure. Manfred, Charles of Anjou, Boniface VIII, theories. and Henry VII had each striven to unite Italy under their suzerainty, and each had suffered in varying degrees from the fact that the dominion which they tried to establish neither confined itself to Italy, nor was able to embrace Italy as a whole. All were hampered by European complications. Manfred was half a German, Charles of Anjou was a Frenchman, Boniface VIII's difficulties were increased by the interaction of Italian and European quarrels, Henry VII was bound by the traditions of the Empire. Not one of them succeeded in establishing more than a party supremacy in Italy. The domination of Manfred was as avowedly Ghibelline as that of Charles or of Boniface was Guelf. Henry VII alone strove after a higher ideal, and he was vanquished by the spirit of faction which was the bane of Italy. Throughout the period, mediaeval traditions of the unity of Christendom 
and of the rivalry between Pope and Emperor still held the field. Yet new aspirations after national unity and strong government were struggling to find expression, while the civilization and creative genius of Italy already gave her a unique place among European nations. The old theories had failed to adapt themselves to the new conditions. It was time for new theories to arise in their place. 


\section{Despots and Republics}

\section{$1313-1420$}

DURING the fourteenth century Pope and Emperor Italy exercised only a secondary influence over Italian affairs. in the The destinies of Italy lay for the most part in the hands century. of the Italians themselves. It is the first great age of the despots. Della Scala in Verona, Visconti in Milan, Este in Ferrara, Gonzaga in Mantua, Carrara in Padua-all rose to greatness in the fourteenth century. It is also the age of the republics. Marsiglio of Padua preached the sovereignty of the people; and Rienzi tried to translate his doctrines into action. In Florence, Perugia, and Siena the nobility were excluded from political power, and the merchant classes reigned supreme. Florence began to extend her rule over neighbouring cities, while Perugia, as the champion of the Guelf cause in Umbria, 'conquered in the Church's name, and took what she had conquered to herself'. In the course of the fourteenth century Venice developed the most characteristic features of her constitution and emerged with undiminished forces from her long struggle with Genoa. The condottiere system was organized, and the disenfranchised nobility found fresh scope for their activity in the profession of arms. It is the age of Petrarch and Boccaccio, the prophets of humanism, of Arnolfo di Cambio, the Pisani and the Giotteschi who completed what has been called the heroic 
period of Italian art. It is a time when Italy cannot be treated as a whole. The true Italian history of the fourteenth century is written in a dozen varying forms in the records of each separate city-state.

Florenceher chief characteristics.

Of all the Italian states none is at once so fascinating and so disappointing, so unique and so typical as Florence. Nowhere perhaps was there a truer or more abiding love of liberty than among the Florentines. Nowhere were there such men of genius or such possibilities of greatness. Yet with love of liberty and hatred of tyranny went an utter lack of discipline which rendered some form of tyranny inevitable. Guicciardini put his finger on the cause of at least half the ills of Florence when he said that she suffered from her passion for equality joined with the ambition of every family to be first. The thirteenth century had been marked by the rise to power of a wealthy middle class, organized in their trade guilds or arts, and popularly known as the Popolo Grasso. In their wake came the Popolo Minuto, or members of the lesser arts, who were allowed a modicum of constitutional authority. The rise of the Popolo brought with it the ousting of the nobility from political life. From the promulgation of the Ordinances of Justice in $\mathbf{I} 293$ the supreme magistracy in Florence consisted of the Gonfaloniere di Fustizia and the six Priori, who held office for two months at a time and were drawn exclusively from members of the arts. No one who did not actually practise a trade was permitted to enrol himself in an art, and all families which numbered a knight among their members suffered under the political and civil disabilities of Grandi. 'The Florentine constitution showed the characteristic weak- 
nesses of a democracy; it had a weak executive, a cumbersome system of representation, and a prejudice against great men. On the other hand, it suffered from many of the defects of an oligarchy. Florence was governed by a few wealthy families, acting in their own interests; and when the members of the Popolo Grasso quarrelled among themselves, there were at least three classes in the city ready to take advantage of the split in the government. The semi-enfranchised lesser arts, the disenfranchised nobility, and the unenfranchised artisans, all contributed to the political upheavals of fourteenthcentury Florence.

Meanwhile the city was rapidly acquiring territory Growth of and rising to a foremost place among Italian states. territory.

San Miniato, Pistoia, Prato, Arezzo, Volterra, and San Gimignano, all bowed to the Florentine yoke in the course of the century; and during the supremacy of the Albizzi the boundaries of the Florentine state included Cortona and Montepulciano on the south, and Pisa and Leghorn on the west. The subjugation of Pisa, the ancient rival of Florence, in 1406 was the crowning triumph of a long period of expansion. Florence, moreover, had constantly to defend herself against aspirants to supreme power in Italy. She bore the brunt of the resistance to Henry VII, and after his death her liberties were seriously threatened by Castruccio Castracani, Lord of Lucca, the leading Ghibelline in Tuscany. In I340 Mastino della Scala, then at the height of his power in Verona, took possession of Lucca, and began to make his influence felt in Pisa and Arezzo. The time of Florence's gravest peril was. however, during the ascendancy of Gian 
Galeazzo Visconti. At the moment of his death in $\mathbf{1} 402$ his armies were closing round the city, and Florence was saved by what seemed like a miracle.

Attempts to supplement the constitution.

Florentine On the expulsion of the Whites in I 301 , Corso Donati, despots.

These new acquisitions of territory and the menace to Florentine liberties from ambitious neighbours called for a strong and efficient government, capable of dealing effectively both with home and foreign politics. For this task the municipal constitution was wholly inadequate, and attempts were made to supplement its weakness by various forms of unofficial rule. Florence fell beneath the sway of would-be despots, both internal and external, of a political club and of a powerful family. All alike exercised an authority that was purely transitory, and all owed their fall partly to their own unbridled ambitions, partly to the Florentine passion for liberty which grew restive at the first suggestion of despotism.

the leader of the Black party, was unquestionably the first man in Florence. For four years his supremacy was unchallenged, and he began to intrigue with the enemies of Florence in order to overthrow the Signoria and make himself lord of the city. But the Florentines got wind of the conspiracy and Corso Donati perished ignominiously in a street fight. As a means of defence against Castruccio Castracani, Florence commended herself to Charles of Calabria, the son of King Robert of Naples. Machiavelli's History of Florence records the death of Castruccio in 1328 with the following significant comment : 'Fortune seldom fails to link one good with another: it happened at this time that Charles, Duke of Calabria and Lord of Florence, died at Naples; so that within a brief period 
the Florentines were freed from their fears of the one, and from the oppressions of the other.' In September 1342, Walter de Brienne, the titular Duke of Athens, was appointed Lord of Florence for life amid the acclamations of the citizens. In July I343, ' the cry of Liberty being raised, the whole city ran to arms. . . . All the heads of the families, whether Grandi or Popolani, swore fidelity to one another and death to the Duke.' The ten months' tyrant took refuge in flight, after being forced to sign his abdication.

During the greater part of the fourteenth century the Rising chief power lay with the Parte Guelfa, a political club, ${ }_{\text {Ciompi, }}$, with its own officers and organization, existing for the 1378 . purpose of carrying out the proscription of Ghibellinism within Florence, and of keeping in touch with the Guelf faction throughout Italy. But in course of time the captains of the Parte Guelfa began to abuse their authority. They proscribed their personal enemies as Ghibellines, and acted in public matters as if they, and not the Signoria, were the heads of the Florentine state. In 1378 a new Signoria came into office bent on the downfall of the Parte Guelfa. This quarrel between the official and the unofficial government gave occasion to the rising of the Ciompi, the unenfranchised artisans of Florence. The city found itself in the throes of a social revolution, and when order was restored the predominance of the Parte Guelfa gave place to that of the Albizzi. From 1382 to 1434 Maso degli Albizzi and his son PredomiRinaldo controlled Florentine politics. They supplied of the the element of strength and permanency which was Albizzi. lacking in the Signoria, while their trade connexions 
outside Florence gave them a special importance in foreign affairs. They took their full share in the literary and artistic activities of the Florentines, and made themselves even more popular outside the city than they were within its walls. Subject cities, such as Pisa, regarded the suzerainty of the Albizzi as infinitely preferable to that of the rival republic which had conquered them. Thus the Albizzi were despots in all that concerned the practical work of government, although in outward form they remained simple Florentine citizens. Florence had at last found a form of government which supplemented the defects of her constitution while respecting her democratic prejudices. When in I434 the Albizzi were overthrown by the Medici, it was the family and not the system which was changed. Cosimo dei Medici and his descendants fulfilled all the functions of the Albizzi; their distinction lay in fulfilling them even more effectively.

Siena. The problems which beset other Italian cities did not differ materially from those of Florence. Civil strife, external enemies, and inadequate municipal constitutions were the main causes of the decline of Siena and Perugia in the fourteenth century. Philippe de Commines summed up the history of Siena when he said that 'the city is always divided against herself and is governed more foolishly than any other city in Italy'. Yet in the thirteenth century Siena was at the height of her prosperity. Her great noble families, such as the Salimbeni, the Tolomei, the Piccolomini, and the Malavolti, were both soldiers and merchants, who enriched the city by their commerce and defended her against her enemies. The 
strength of the civic spirit was manifested in Siena's clean, well-paved streets, in the beauty of her public buildings, and in her university with its professors chosen and paid by the republic. It was the rise to power of the burgherclass, and subsequently of the artisans, which plunged the city into unending civil strife. She underwent at least three revolutions in the fourteenth century, and the quarrels between her five Monti or factions made Siena an easy prey to Gian Galeazzo Visconti in 1388. Finally, the recurrence of internal troubles, and the threat to her independence from the King of Naples in the fifteenth century, led to the despotism of Pandolfo Petrucci.

The golden age of Perugia lay like that of Siena in Perugia. the latter half of the thirteenth and the beginning of the fourteenth centuries. This was the time of material progress, of the foundation of the university, of the growth of territory, and of great building activity. With the removal of the Papacy to Avignon, Perugia became the leader of the Guelf party in Umbria, and her power and independence were consequently increased. But after the peace which followed the departure of the Emperor Louis from Italy, a rupture between the classes took place. The compilation of the Libro Rosso or register of the nobles, in $\mathbf{1 3 3 3}$, marked the beginning of class warfare, and of the subjection of the nobility to disabilities similar to those imposed by the Ordinances of Justice in Florence. From henceforth Perugia suffered from perpetual conflict; and it was her own internal weakness that caused her submission to the Church in I37I, and subsequently to the condottiere, Braccio. 
'Towards the end of the fifteenth century a despotism was established in Perugia through the predominance of one of her leading nobles, Gian Paolo Baglioni.

The rise of the despot.

In the vast majority of Italian cities the problem of government was solved, sooner or later, by the surrender of civic liberties into the hands of a despot. The Petrucci and the Baglioni came too late to save the situation in Siena and Perugia; but in the North Italian cities the despotism was established earlier, and with more permanent effect. It is not too much to say that every Italian despot based his authority primarily on popular consent. Supreme power was conferred on him by the citizens in order that he might perform certain definite functions. In many cases the despotism fell because it had forfeited popular favour, and had ceased to do the work for which it was created. On the other hand, the love of the citizens for their ruling family preserved the ascendancy of that family even when half the forces of Italy were bent upon its overthrow. Yet the element of force was not lacking. The despot was frequently a successful soldier, chosen because he could defend the city from her enemies or impose peace upon warring factions, while he sometimes won his election purely by conquest. The Signoria, or lordship of the city, was conferred by the citizens themselves, but the despot usually tried to render his position more secure by obtaining some external sanction for his authority in addition to popular election. He coveted the title of Imperial or Papal Vicar, and at a later stage he tried to obtain the investiture of his city, in order that he might hold it as a fief of the Papacy or the Empire. 
The political theories which lie behind the Italian Marsiglio despotism are nowhere more clearly expressed than in of Padua's Marsiglio of Padua's Defensor Pacis. This famous Pacis. treatise was written in the University of Paris in 1324, but it breathes the atmosphere of the Italian city-state. The people as the source of all authority is the root principle of the Defensor: "the sole human legislator is the whole body of citizens or the majority of them.' Next in importance is Marsiglio's insistence upon the concentration of executive power in the hands of a prince, who is the people's nominee and representative. He is the guardian of peace who gives the treatise its title. He alone has coercive jurisdiction in matters ecclesiastical and temporal. He is, in short, the modern state, efficient, all-absorbing, tyrannical. It has been said of Marsiglio that he put forward a theory of Church and State which was partly realized at the Reformation, partly in the revolutionary era, and of which part still awaits realization. Nevertheless the essentials of his theory could be seen in practical working in at least five North Italian cities within a few years of the publication of the Defensor Pacis.

Perhaps the most permanent effect of Henry VII's Can Italian expedition was the new importance which it della gave to two budding despots, Matteo Visconti and Can Scala, Grande della Scala. While Henry lived, he singled them despot of out for favour, and made them imperial vicars. At his death it fell to them to stem the tide of Ghibelline reaction, and in so doing to add to their own power and prestige. Can Grande is in many respects the most attractive of the Italian despots. A Trevisan poet 
described him at his death as 'the fount of human justice, the fount of courtesy, the flower of Lombard knighthood '. In him the man of ideas predominates over the mere politician, and his portrait is not marred by brutal or treacherous features. The permanent foundation of the Della Scala power in Verona dates from I277, when Can Grande's father Alberto was made Captain of the People for life. His three sons succeeded him in that office, and in I3II Can Grande became the supreme authority in Verona owing to the death of his elder brothers. The despotism did not replace the old municipal constitution, but was simply imposed upon it. Verona still had its councils, both executive and legislative, but all took an oath of fidelity to Can Grande, and he had power to alter and annul the statutes. Before his death his authority was extended over the neighbouring cities of Vicenza, Padua, Feltre, Belluno, and Treviso, under similar conditions. Thus Can Grande's state consisted in a federation of virtually self-governing municipalities, the sole link between them being the person of the despot. Can Grande owed much of his success to his qualities as a soldier. He had the power of inspiring devotion among his troops, and an instinct for discovering the weak spot in the enemy's position. Fatigue was unknown to him, and he was always the first to ford a stream or scale a wall. When he was not fighting, he worked off his energy in hunting and hawking. He was, moreover, a generous foe. He ruled his conquests well and wisely, and when a vanquished enemy fell into his hands he treated him with every courtesy. Above all, the despotism of Can Grande is distinguished by the splendours of his court. 


\section{Despots and Republics}

He encouraged great men of every kind to find a home in Verona, and laid himself out to be a model host. At one time, no less than twenty exiled Ghibelline princes took refuge with Can Grande. His court was thronged with scholars, musicians, sculptors, merchants, and the hospitality which he showed to Dante has given him a place in the seventeenth canto of the Paradiso. The highest point in the fortunes of the Della Scala was reached under his auspices. At his death in 1329 the glorious days of Verona were numbered, although it was not until 1387 that the Signoria fell before the rising power of Gian Galeazzo Visconti.

The supremacy of the Carrara in Padua dates from the Padua year 1318, when the city was hard pressed by Can Carrara. Grande, and the citizens agreed that the best means of self-preservation was to entrust the government to the care of a single man. Thereupon the Signoria was conferred on Jacopo da Carrara, one of the leading citizens, and successive members of his family were Lords of Padua until I405. They ruled over a small state, hemmed in between powerful neighbours, and dangerously near to the Venetian lagoons. Thus they were engaged in a perpetual struggle for existence, and long wars and heavy taxation did not increase their popularity in Padua. Meanwhile the watchful eye of the Venetian Republic was always upon them. Venice protected the Carrara against Della Scala and Visconti, but when Francesco Carrara showed signs of too great independence she determined to sweep a possible rival from her path. She allowed Gian Galeazzo Visconti to conquer Padua in 1389 , and although she helped to 
restore Francesco Novello in the following year, her motive for so doing was not love of the Carrara. In 1405 the Venetians entered the city, massacring every member of the ruling family whom they found, and the Paduans passed beneath the dominion of Venice with small signs of reluctance.

The Gonzaga in Mantua.

A more interesting and more durable example of a small despotism is that of the house of Gonzaga in Mantua. Lodovico Gonzaga wrested the supreme power from the hands of the rival family of Buonacolsi in 1328 ; and the dynasty which he established continued to flourish long after richer and more powerful Italian states had lost their independence. From very early days the Gonzaga were under the protection of the Empire. Lodovico held the title of Imperial Vicar, and in 1433 Gian Francesco II was made Marquis of Mantua by the Emperor Sigismund. This long-standing alliance was preserved in the sixteenth century. Charles $V$ counted the Gonzaga princes among his most devoted friends, and in 1529 he brought them to the highest point of their greatness by raising Mantua into a duchy. The Lords of Mantua eked out their small resources by serving as soldiers of fortune in the Italian wars, but in spite of their poverty they soon won a great reputation in the sphere of art and letters. When Gian Francesco II persuaded Vittorino da Feltre to settle in Mantua as tutor to his children in 1425 , the city became the most important educational centre in Italy. It was Vittorino's pupil, Lodovico Gonzaga, who decorated his capital under the guidance of Leo Battista Alberti, and through whom Mantegna came to Mantua, to live there for fifty years. 
Azzo d'Este, the first Lord of Ferrara, died in I21 2, and Ferrara in Dante's day the Ferrarese Court was already famous ${ }_{\text {House of }}^{\text {and the }}$ as the resort of the troubadours of Provence. Thus the Este.

Este were by far the oldest of the Italian despots. The permanency of their rule in Ferrara is remarkable owing to the fact that their supremacy was disputed both by the Pope and the Venetians. Ferrara lay nominally within the States of the Church, and Venice had a trading colony in the city. So both the Papacy and the Venetian Republic looked upon the Este as rivals to their own power; and it seemed more than once as if the ruling family would be overthrown by these formidable adversaries. But the loyalty of their subjects proved stronger than all the forces which could be brought against them. Early in the fourteenth century Ferrara was obliged to open her gates to the papal armies; after a few years there was a rising in the city and the Este were recalled. In 1482 the Pope and Venice made a joint attack on Ferrara. The Este must have fallen had it not been for the gallant defence of the citizens, which kept the enemy at bay until help arrived from outside. The story of the house of Este in Ferrara goes far to prove the truth of Machiavelli's saying that a prince's best fortress is the love of the citizens.

Of all the Italian despots, Gian Galeazzo Visconti The power alone came within measurable distance of uniting Italy of Gian under his rule. At the time of his death his possessions Visconti. extended over the whole of North Italy, from the frontiers of Piedmont to Padua and the March of Treviso. South of the Po he controlled the Via Emilia from Piacenza to Bologna, and established a protectorate over the Lords 1832.3 
of Romagna. He crossed the Apennines and all but succeeded in reducing Florence to submission. His possession of Lucca, Pisa, and Piombino cut her off from the sea, while his occupation of Siena and Perugia blocked the two main roads to Rome. At this time the power of the Papacy was almost non-existent in Italy. Naples was in the throes of a succession war, and Venice had not yet turned her attention seriously towards the mainland. Everything seemed to favour Visconti's domination; and when he died in 1402 he was said to have mantle, sceptre, and diadem already prepared for his coronation as King of Italy.

Character* The nature of Gian Galeazzo's rule was that of the istics of the typical Italian despot. It was an addition to, and not Visconti a substitute for, the forms of government already existing rule. in the cities which acknowledged his authority. This federal character of the despotism explains both its rapid growth and its sudden collapse when the controlling hand was withdrawn. While Gian Galeazzo lived he brought peace, good government, and material prosperity to the Milanese state. Like Can Grande before him, he was a patron of art and letters. The University of Pavia owed much to his favour, and he won undying fame as the founder of the cathedral of Milan and the Certosa of Pavia. It is impossible to deny the benefits of Visconti rule, yet the history of the means by which they established their power is one long tale of crime and treachery. Matteo Visconti wormed himself into Henry VII's favour, intrigued with Guido della Torre against him, and ended by convincing Henry that the conspiracy was the work of Della Torre alone. Gian 
Galeazzo became sole ruler of Milan by murdering his uncle Bernabò. He used the Carrara to overthrow the Della Scala, and then, turning on his allies, he drove them from Padua. As a family the Visconti were remarkable, both for their ability and their unscrupulousness, in an age which produced many able and unscrupulous men. They were not a race of soldiers, but Gian Galeazzo's wealth and influence enabled him to command the flower of the Italian mercenary forces.

Two other characteristics of the Visconti despotism are worthy of notice. Although they could not carry out Marsiglio of Padua's theory and deprive the Church of jurisdiction, the rulers of Milan contrived to unite spiritual and temporal authority in their own hands. The power of the Visconti began with Archbishop Otto in the thirteenth century, and Giovanni Visconti held both the Signoria and the archbishopric of Milan at the time of his death in 1354. Gian Galeazzo also endeavoured to increase his prestige by means of the marriage alliances which he formed with the chief European powers. His first wife was Isabella of France, the daughter of King John, who paid his ransom to the English with Visconti ducats. His sister became the bride of Lionel, Duke of Clarence, and his daughter, Valentina, married Louis, Duke of Orleans, thereby laying the foundations of the later French claims to Milan. In I395 Gian Galeazzo realized a long-standing ambition and obtained the investiture of the Duchy of Milan from the Emperor Wenzel. The city despot had become a prince of the Empire.

While the chief Italian republics fell into the hands of 
Venice- despots, or wasted themselves in internal feuds, Venice her con- alone attained to a form of government which was both
stitution. constitutional and efficient, free and strong. In 1297 the famous Serrata del Consiglio restricted the governing class to certain families, members of which had already sat in the Grand Council. Thus birth became the chief qualification for citizenship, but, in spite of this limitation, there was practically no disaffection among the disenfranchised classes. The plebeians were content to hold important and lucrative posts in the civil service, and to prosper as merchants, realizing that the cares and responsibilities of state were on the shoulders of the nobility, while the fruits of good government belonged to all. When the discovery of the Tiepolo conspiracy in r 3 ro showed the need for some extraordinary body which could give an element of strength and secrecy to the constitution, the Council of Ten was created, ' not a limb of the state but as it were a sword in her hand'. 'The art of discipline which had been denied to the Florentines was carried to perfection among the Venetians. Entire devotion to the service of the Republic was demanded of all who held office, and no mercy was shown to failures. In I355 the execution of the Doge, Marin Faliero, for conspiring to change the constitution, sent a thrill through Italy. 'Those who are for a time Doges,' wrote Petrarch, 'I would warn to study the mirror set before their eyes, that they may see in it that they are leaders not lords, nay not even leaders, but honoured servants of the state.'

Venice The efficiency of the Venetian government contrasted and Genoa. sharply with that of Genoa; and herein lies the clue to 
the success of Venice in her struggle with the rival maritime republic. At the beginning of the fourteenth century the power of Genoa in the East was at least equal to that of Venice. The Venetians formed the backbone of the Latin Empire while Genoa stood by the Greeks. Thus the restoration of the Greek Empire in I26I enabled the Genoese to take a leading position at Constantinople, and to establish their famous colony at Galata. The Venetians, on the other hand, were forced to occupy the second place in commerce, and to feel that they were out of favour at the Imperial Court. In the course of the naval wars of the fourteenth century Genoa struck some hard blows at her adversary, chief among them being the destruction of the Venetian fleet at Sapienza in 1354, and the taking of Chioggia in 137I. Yet domestic feuds prevented Genoa from reaping the fruits of her victories, and the year before Sapienza she was obliged to acknowledge the suzerainty of the Visconti. Internal weakness robbed her of her maritime supremacy, while internal strength saved Venice even in that darkest hour when the banner of St. George of Genoa fluttered over the lagoons at Chioggia.

Throughout the fourteenth century the prosperity Venetian and trading activities of Venice increased steadily. Her ${ }^{\text {commerce. }}$ merchants exported sugar to England and exchanged it for Boston wool, which was woven into cloth in Flanders, and so carried back in Venetian ships to Dalmatia and the Levant. In the course of the century the Fondaco de' Tedeschi in Venice was enlarged by the Republic, as the German merchants complained that it was impossible - to see across the courtyard for the 
piles of merchandise that lay there. About the same time it was decided to add a new hall to the Doge's palace for meetings of the Grand Council. This was the beginning of that triumph of Venetian Gothic, the Begin- Palazzo Ducale as we know it to-day. While Venice nings of mainland power.

was still primarily a maritime power, deriving her prosperity from Levantine trade, and recognized as the champion of Christianity against the growing power of the Turk, she was becoming increasingly occupied with mainland problems. The domination of the Della Scala taught her that a hostile power on the Italian mainland might deprive her of her food supply. It was a war with Mastino della Scala which laid the foundations of the Venetian Terra Firma by leaving her in possession of the March of Treviso. She fought with Hungary over Dalmatia, and alternately quarrelled with and protected her nearest neighbours, the Carrara of Padua. Her prosperity, her isolation, and her proud independence made her many enemies, and Italy must have appreciated the gibe of Nicholas, Bishop of Butrinto, who said that the Venetians looked upon themselves as a fifth element, belonging 'neither to the Church nor to the Emperor, neither to the land nor to the sea'. Yet the time was at hand when Venice could no longer stand aside from the main current of Italian politics. On the break-up of Gian Galeazzo Visconti's dominions she embarked in all seriousness on her career of conquest upon the mainland.

Growing national feelingPetrarch and

The rich and varied life of the city-states could not fail to engender a sense of patriotism among the Italians, which was increased by a consciousness of the superiority Rienzi. 
of their civilization over that of every other European country. A growing contempt for the foreigner is a characteristic of fourteenth-century Italy; and the abortive expeditions of Louis of Bavaria, John of Bohemia, and Charles IV helped to confirm the Italian point of view. Two men in particular gave expression to the national consciousness, and did their best to direct it towards the attainment of national unity. Both Petrarch and Rienzi found in the glories of ancient Rome their hope for the future of Italy. Petrarch's work for the revival of learning, and Rienzi's efforts to restore the Roman Republic were prompted by a common desire to make the great past live again. Both men were affected by the transference of the Papacy to Avignon. Rienzi spent his youth in Rome, and mourned over the city as a 'grey-haired widow on a rudderless ship'. His ambition was to restore to Rome that universal dominion which the departure of the popes had taken from her. Petrarch was the son of an exiled Florentine, who had made his home at Avignon, and his whole heart went out from 'Babylon' to his native land. To him Italy was not only his unknown home, but also the home of Vergil and Cicero, those companions of his life of whom he loved to speak as 'brother' and 'father'. 'My longing to see Rome, deserted and merely the shadow of ancient Rome though she is,' he wrote in 1334 , ' is scarcely to be believed.'

In Petrarch the ideals and characteristics of humanism Petrarch, first found expression. He was the first Italian to realize humanist, the importance of Greek, and both he and Boccaccio ${ }^{1304-74 .}$ laboured to learn a few words of the language that was 
all but lost to the western world. He had all the humanist's exaggerated love of Latin, priding himself on never having read Dante's Divina Commedia, and giving up writing in Italian on the ground that he did not like hearing his sonnets sung by common people in the street. In him, moreover, we see the first clear revival of the classical spirit. The works of the ancients, in Petrarch's eyes, contained 'all wisdom and rules of right conduct'. He could say without a qualm that he was wiser than any one of his time, because he was more deeply read in ancient literature. True humanist that he was, he found in the classics the key to a new interpretation of life. The world appeared to him no longer evil, but wonderful and beautiful and interesting. $\mathrm{He}$ was not ashamed to express his delight in fresh air and fine scenery, and he is said to have been the first person who climbed a mountain for pleasure. His ideal for man was the quest of glory, the conquest of the world by the attainment of imperishable renown. The laurel-wreath, more than any human Laura, was the object of his lifelong devotion. Such being his ideals and ambitions, his coronation in Rome as poet in I34I was undoubtedly the greatest moment of his life. This reception of the laurel-wreath on the Capitol, from the hands of the Roman Senators, was not only a revival of ancient practice, it was also the inauguration of a new Empire of Letters. Herein lies the importance of Petrarch's contribution to politics. He saw that Italy's greatness lay in the arts of peace and not in the arts of war. He besought her to lay aside her quarrels, so that she might be no longer a prey to foreign soldiery, but might cultivate the gifts with which Nature 
had endowed her, and establish a world-wide dominion over the human mind. It was Petrarch who first told modern Europe that Italy was 'the fairest country under heaven'. He spent his declining years at Arquà in the Euganean Hills, feasting his eyes upon the vast expanses of the Lombard plain. Petrarch's labours helped to make Italy the teacher of Europe; and he was found dead in his study one morning with his head resting on the manuscript which he had written in the watches of the night.

If the statues and inscriptions of ancient Rome stirred Rienzi Rienzi's imagination so that he longed to restore the ${ }_{\text {Roman }}^{\text {and }}$ glories of the past, Petrarch's coronation first imbued Republic. him with the hope that his dreams might be realized. His sudden rise to power as Tribune of the People, in May I 347, ushered in seven months of strenuous activity, ending in his no less sudden abdication in December of the same year. In the main his career resembles that of other victims of the republican tradition in Rome, where the fickleness of the populace and the turbulence of the nobility militated against any form of stable government. His distinction lies in the connexion which he established between the republican and the national idea. He conceived of Italy as a federation of communes and despots, deriving their authority from the Roman Republic, and independent of both Pope and Emperor. Edicts were issued restoring to the Roman people all their ancient rights and jurisdictions. The despots were invited to receive confirmation of their authority from the Roman Republic, and all the powers of Italy were summoned to a national Parliament in Rome. It was 
a great idea, embodying the highest aspirations of the age ; but neither Rienzi nor the Italian states were capable of putting it into practice. Only twenty-five cities sent deputies to Rome, and those who were represented cared much for preserving their own independence and little for furthering the cause of unity. The element of unreality in Rienzi himself prevented him from standing up against failure. On his flight from Rome the vision of the union of Italy faded like a beautiful dream.

Revival of From the time of Rienzi's failure the thoughts of Italy papal authority turned once more towards the Papacy. It has been said in Italy. that "from a commercial point of view the Pope was ,to Rome what Diana was to Ephesus'. The Romans longed for the return of the Papacy, while Italy saw in the ending of the Babylonish captivity the revival of her prestige and her best hope of unity. In I353 Cardinal Albornoz came to Italy as legate and Vicar-General of the States of the Church, and succeeded in establishing his authority throughout the papal dominions. With him came Rienzi, now a minion of the Pope. As Senator of Rome he resumed his old authority in the city, only to be executed, as a traitor to the cause of liberty, in October I354. In I367 Pope Urban V himself came to Rome, where he was met by the Emperor Charles IV. Yet both Pope and Emperor were foreign guests rather than monarchs returning to their capital, and after three years the Pope returned to Avignon. Meanwhile Italy grew more and more intolerant of a system which subjugated her to a crowd of greedy French officials. In I 375 a league of eighty cities was formed under the leadership of Florence, and Italy rallied round the banner of Liberty against 
the 'unrighteous pastors of the Church'. At no time in her previous history had Italy come so near to a general national rising, but the refusal of Rome to join the League robbed her of a great opportunity. The separatism which made Florence only a half-hearted supporter of Rienzi forbade Rome to take part in a movement emanating from ' Rome's most glorious daughter' Florence. Hence the permanent result of the Italian League was indirect. It led to the return of the Papacy to Rome in 1377 . Driven by the enthusiasm of St. Catherine of Siena, who saw a new Italy, peaceful and united, rising under the guiding hand of a restored and purified Papacy, Gregory XI emerged from the 'Captivity'. He received an enthusiastic welcome in Italy, but a year later Europe was plunged into the scandals of the Great Schism. Urban VI was Pope in Rome, while Clement VII was Pope in Avignon; and St. Catherine of Siena died of a broken heart, having seen in a vision the burden of the ship of the Church descending upon her shoulders.

The history of the Great Schism and of the restoration The Great of unity by means of the Conciliar Movement belong to the general history of Europe. Italy's share in the European crisis was largely determined by the fact that the existence of a rival rendered the position of the Roman Pope untenable, either in the States of the Church or in Rome itself. Twice over during the Schism, King Ladislas of Naples took possession of Rome. In 1408 he was acknowledged as lord of the city, while Gregory XII dallied at Lucca, obstinately refusing to negotiate with his rival Benedict XIII. Every lordling of the Romagna had an excuse for repudiating the papal suzerainty, and 
even Cardinal Baldassare Cossa, who had been sent as legate to Bologna, ruled the city as an independent tyrant. This ecclesiastical soldier of fortune was the driving force of the Council of Pisa, which met in 1409 and increased the number of popes from two to three by the election of Alexander V. In I4IO Cossa succeeded Alexander V as John XXIII, but he failed to break the power of Ladislas. The Neapolitans entered Rome once more in I4I3, and John XXIII was a fugitive. In despair of establishing his authority in Italy by other means, John consented to the demands of the Emperor Sigismund, and summoned a General Council to meet at Constance. The issue of this momentous Council was all that could be desired from the Italian point of view. The three rival popes were either deposed or induced to abdicate, and on November II, I4I 7, Oddo Colonna was unanimously elected Pope, taking the name of Martin V. All Europe recognized his authority, and, in spite of the efforts of the reforming party, he left the Council with undiminished powers. His return to Rome in 1420 ushers in a new period of Italian history. 


\section{The Age of the Renaissance}

\section{420-I 494}

By the beginning of the fifteenth century it was no Italy longer likely that Italy would be united under the in the suzerainty of any one ruler. In I4I2, Filippo Maria century. Visconti set himself to reconstruct the dominion which had once been his father's, but in so doing he came in contact with Venice. The Venetian Republic, as a mainland power, effectually prevented the Visconti or the Sforza from extending their rule over Eastern Lombardy, but it could not hope to absorb the duchy of Milan. Thus Venice and Milan resigned themselves to sharing the control of North Italy between them. To Florence the rise of the Medici brought fresh territory and the establishment of the Republic upon a firmer basis. She was less of a military power than Milan, but her wealth was almost as great, and her influence made itself more widely felt. Naples had fallen from the high position which she held at the beginning of the fourteenth century. Her Angevin rulers had become Italianized, and a rival French house of Anjou had already laid claim to their kingdom. When King Ladislas was succeeded by his sister Joanna II, in I4I4, it was clear that the Queen of Naples would have enough to do to preserve her own throne without aspiring to domination over her neighbours. To these four powers, widely 
divergent in character but practically equal in strength, the restored Papacy was added as a fifth. The history of Italy in the fifteenth century is the history of her five chief states. Until 1454 they were engaged in enlarging their borders, or in consolidating their power. In the forty years which followed they worked out a system of alliances by which the peace of Italy was preserved, and the five states vied with one another in literary and artistic production. Finally, in 1494, they yielded to the rivalries which sprang from deep-rooted separatism and opened the barriers of the Alps to let in the foreigner.

The Papal When Martin V became Pope an arduous task lay States. before him. Throughout the States of the Church there was hardly a city that acknowledged his authority. Bologna had declared her independence. Braccio, Count of Montone, was master of Perugia, Orvieto, and half a dozen other Umbrian towns. The papal vicars of Romagna were independent despots in all but name, chief among them being the powerful house of Malatesta, which seemed about to make Rimini and Pesaro the centre of a strong Romagnol state. At the time of Martin V's accession Sforza held Rome in the name of Joanna II, having driven out his rival Braccio a few months earlier Thus the Pope came to Italy as a prince without a terri tory. While he stayed in Florence, awaiting an opportunity to return to Rome, he could hear the Florentine children shouting in the streets :

Papa Martino

Non vale un' quattrino. Position Beyond the borders of Italy the position of the Papacy
of the Papacy in
Europe. was precarious. The Council of Constance had failed 
to reform the Church but it had succeeded in establishing the principle of the Conciliar Movement. By the decree Frequens the superiority of General Councils over the Papacy was asserted, and provision was made for the recurrence of such Councils at stated intervals. Thus the authority of the Papacy was no longer absolute or unquestioned. It had been shown that the government of the Church was ultimately democratic, and that supreme power belonged to the whole body of faithful Christians. In normal times the Pope was the mouthpiece and representative of the Church; but during the sessions of a General Council the whole body resumed the authority which it derived directly from Christ, and the power of the Papacy was overshadowed. Even more dangerous to papal authority was the growing tendency to look upon ecclesiastical questions from a national standpoint. Martin $\mathrm{V}$ considered that he had gained a victory over the Conciliar Movement when the Council of Constance failed to carry through a general scheme of reform, and he was left to deal with the problem by means of Concordats with the various nations. He was right in so far that the failure of the Council to reform the Church revealed the fundamental weakness of the Conciliar Movement, which was that Christendom no longer possessed a common mind on ecclesiastical questions. But national separatism was a dangerous ally for the Papacy, which depended, in as great a degree as the Councils, upon the essential unity of Christendom for its effective operation. The fifteenth century proved, in fact, that a revival of the papal power did not mean a restoration of the mediaeval Papacy. To the rising 
nations of Europe the Pope was less a source of undisputed authority than a foreign power, strong enough to be worth propitiating and able to exercise considerable influence as an arbiter. The bases of papal power lay in the States of the Church, and the re-establishment of temporal sovereignty in Italy was the primary aim of Martin $\mathrm{V}$ and his successors.

Martin V. The reign of Martin $V$ was in every respect a successful beginning of the new era. - By playing off his enemies one against another he succeeded in making his authority recognized through the greater part of the papal States. He made Braccio his Vicar in Perugia, and then used him to subdue Bologna. He married his niece to Guidantonio, Count of Urbino, and so gained a supporter in Romagna against the Malatesta. Throughout his reign he could depend upon his own family for trusty captains who would lead his armies and garrison his fortresses. In Rome he set himself to revive the prosperity of the city and to restore her half-ruined buildings. His contemporaries called him Temporum suorum felicitas-the good fortune of his time-and the title is expressive of the happier days which had dawned on Italy with the return of the Papacy.

Eugenius Eugenius IV experienced more of the vicissitudes of IV. fortune. His long struggle with the Council of Basel reacted on his position in Italy. On more than one occasion he saw his territories overrun by mercenaries calling themselves Generals of the Council, and in I434 a rising in Rome forced him to fly to Florence. Yet by the end of his reign he had won back all that was lost. The Papacy was firmly established in Rome and in the 
States of the Church. The obedience of Germany was restored to Eugenius on his death-bed, and the anti-Pope of the Council of Baselowas left without a friend in Europe.

The pontificate of Nicholas $V$ is remarkable as a triumph of humanism. The new Pope had little save learning Nicholas $\mathrm{V}$ and the to commend him for his high office, and he could not sance. even produce a coat-of-arms to quarter with St. Peter's keys. Hard work and a good education had placed him on the papal throne; and the supreme object of his reign was to bring the Papacy to the forefront of the Renaissance Movement. He was an insatiable collector of manuscripts and a patron of all men of genius. Rosellino and Leo Battista Alberti were among his architects, while he employed Fra Angelico and Benozzo Gozzoli as painters. If his ideals had been realized, the triumphs of paganism would have been made captive to the Church of Christ. Christian Rome would have become a glorious architectural whole, and would have entered on the heritage of ancient Rome as the fount of European civilization. In the last years of his reign the fall of Constantinople made a new demand upon the activities of the Papacy. If the popes, who had vanquished the Conciliar Movement, who had become the recognized rulers of an Italian state and the pioneers of the Renaissance, could also unite Europe in a Crusade against the Turk, the papal restoration would indeed be accomplished. The failure to achieve this crowning triumph is the tragedy of the reign of Pius II.

Pius II is certainly the greatest of the fifteenth-century Pius II popes, and his reign shows both the strength and weakness ${ }_{\text {Crusade. }}^{\text {and the }}$ of the restored Papacy. He is a far more representative 1832.3 
humanist than Nicholas V. Whereas the latter was a collector and a patron of artists, Pius was himself a literary artist. No one was more steeped in the spirit of humanism than he, and no one had a fuller opportunity of putting the ideals of humanism into practice. For the disciples of the new learning did not regard it as an end in itself. The complete humanist must always be a statesman, proving by his power to rule and to persuade that 'the model of all good living is to be found in the study of Letters'. Pius II's successful government of the Church seemed to justify the claims which were made on behalf of the new movement. His delight in natural beauty and his interest in archaeology made him an indefatigable sightseer; and his wanderings through Italy endeared him to numbers of his fellow countrymen to whom the Holy Father would otherwise have been only a name. He adopted a wise and patriotic policy with regard to Italian diplomacy. Outside Italy he obliterated the last traces of the Conciliar Movement, and enhanced the reputation of the Papacy throughout Europe. Yet he could not carry out his great crusading project; and although it may be argued that the conditions of the age were more than enough to account for his failure, it must be remembered that he was himself a child of the age. The ideals of the Renaissance were in essence both limited and individualistic. Their horizon was bounded by this world, which was looked upon as a field for man's conquest; and greater importance was attached to the success of the individual in making his mark in the world, than to the triumph of the cause which he had at heart. Thus the entire sacrifice of self, 
the readiness to accept personal defeat if by so doing some great ideal could be realized, was foreign to the Renaissance spirit. Pius was ready to go out against the Turk when there was reasonable hope that the States of the Church would not be torn from him during his absence. He was not prepared to stake his all upon a great venture. So he could not rekindle the vanished enthusiasms of Europe, and his death at Ancona, when he was about to set sail for the East, saved the would-be Crusade from certain disaster.

After the death of Pius II the Papacy entered upon The a downward path. From a worldly standpoint it was never more prosperous or more splendid, but the materialism and the selfishness of the Renaissance became increasingly apparent in papal policy. Sixtus IV carried the system of nepotism to lengths hitherto unknown. Former Popes had in the main used nepotism as a means of winning and maintaining their hold over the States of the Church. Sixtus IV treated the Papacy as the destined instrument for furthering the fortunes of Della Rovere and Riario nephews. His unwarrantable interference in the internal affairs of Florence, as a party to the Pazzi Conspiracy, showed how little the peace and stability of Italy weighed against his personal and family interests. The attack on Ferrara in conjunction with Venice is another example of his reckless self-seeking. In the sphere of art his name will live as the founder of the Sistine Chapel, and as one of the most generous patrons of his day. In politics, he is mainly associated with the recrudescence of a spirit of enmity among the chief Italian states which prepared the way for foreign 
domination. Innocent VIII was only less dangerous than Sixtus IV because he was less forcible. When in I 492 Rodrigo Borgia became Pope Alexander VI, selfishness and materialism sat incarnate on St. Peter's throne. What hope was there that a Borgia pope would show disinterested patriotism or high courage when Charles VIII crossed the Alps ? The suc- The kingdom of Naples should properly have been question the strongest of the five Italian states. It possessed an in Naples. ordered system of government and strong monarchical traditions at a time when the power of Florence and Milan was confined within their city walls. Until the death of King Robert, the grandson of Charles of Anjou, in 1343 , it had seemed more than possible that the union of Italy would come about under the suzerainty of Naples. In addition to the strength which came to him from the control of the military and financial resources of his dominion, Robert had behind him the power of France. He ruled Provence as well as Naples, and he was the obvious means by which the French kings could keep a controlling hand on Italy. Thus Robert's influence made itself felt throughout Italy; and it was not until the reign of his successor, Joanna I, that the inherent weaknesses of the kingdom began to appear. Joanna's possession of the throne being threatened by her cousin Charles of Durazzo, the grandson of Robert's younger brother, she adopted as her heir the French prince, Louis, who had just been invested with the duchy of Anjou by his father, King John of France. From the appearance of this second house of Anjou in Italy there were never less than two claimants to the throne of Naples, until 
the kingdom was merged in the Spanish dominions at the beginning of the sixteenth century. This everopen succession question was turned to their own advantage by the popes, who wished to enforce their claim to suzerainty, and by the baronage who desired to keep the monarchy weak. The Italian soldiers of fortune looked upon the struggle in Naples as their surest source of employment, and their influence was added to that of the Pope and the baronage in helping to perpetuate a state of unrest. So the natural resources of the kingdom were dissipated, and the appearance of a rival claimant to the throne was always the signal for civil war.

In I 382 Joanna I died a prisoner in the hands of Charles The kings of Durazzo, and he became King as Charles III. His $\underset{\text { House of }}{\text { of the }}$ son and daughter, Ladislas and Joanna II, in turn suc- Anjouceeded him on the throne, until, in 1435 , the latter died Durazzo. without heirs. The chief importance of these Durazzo rulers is that, although of foreign extraction, they were practically a native Italian dynasty. They had no French possessions to draw their attention away from Naples, for on the death of Joanna I Provence had been seized by Louis of Anjou. Moreover, such influence as France possessed in Italy was exerted on the side of Louis and his descendants. Thus the Durazzo princes were thrown back on their own resources. They stood for monarchical consolidation and the suppression of feudal independence, while the house of Anjou endeavoured to propitiate the baronage with promises of a milder rule. The rest of Italy had to choose between supporting a strong King of Naples, Italian in all but name, or an Angevin claimant, who would probably be at the mercy of his nobles, but 
who would also open the door to French influence. It is characteristic of Italian separatism that the latter alternative usually commended itself to the neighbouring states. Experience alone could teach them that greater advantages would arise from keeping the French out of Italy than they could hope to gain from a weak and divided Naples.

Alfonso of Joanna II was a lady of caprice. She quarrelled with Aragon, King of Sforza when he was at the head of her military forces, Naples. and threw him into the arms of the French candidate. Then she turned for protection to Alfonso, King of Aragon and Sicily, adopting him as her heir. Before long she grew tired of him and made a new will in favour of René of Anjou. Finally she died, leaving both claimants in the field. In the person of Alfonso of Aragon the cause of strong government found a worthy representative. 'A man of small stature but of boundless courage, scorning every form of danger. A master of intrigue and prone to break faith. A liberal-handed giver and a lover of great men.' So he was described by Aeneas Silvius, who had many opportunities of studying his character. $\mathrm{He}$ established himself on the throne of Naples after a seven years' contest with René of Anjou, and proceeded to turn his new kingdom into one of the chief centres of the Renaissance. The Neapolitan Court had been the resort of distinguished men under Robert and Joanna I, but now it was thronged with artists and humanists who spread the fame of their patron far and wide. Even more remarkable were Alfonso's achievements in diplomacy. On his first appearance in Naples all the chief states of Italy were against him. At his death they were all his 
allies. Filippo Maria Visconti was the first great convert to the Aragonese cause. In the course of his war with René, Alfonso was captured by the Genoese fleet and brought as a prisoner to the Duke of Milan. He succeeded in persuading his jailer that a strong King of Naples was less dangerous to Milan than constant French intervention; and from that time forward Filippo Maria Visconti was his friend. After Francesco Sforza had made good his claim to succeed the Visconti in Milan, he came to regard the Neapolitan question in a similar light. The advantages of the Aragonese alliance were brought home to him by the fact that he, no less than Alfonso, had personal cause to fear the presence of the French in Italy. Louis, Duke of Orleans, had married Valentina Visconti, and the heirs of this marriage had a better hereditary claim to Milan than the Sforza. So, in 1455 , Alfonso became a party to the treaty of Lodi, by which the chief powers of Italy formed themselves into a League for the preservation of peace and for defence against foreign invasion. His grandson and namesake was betrothed to Ippolita Sforza, the daughter of Francesco, and the Aragonese King of Naples took his place among the princes of Italy under the special patronage of Milan.

In 1458 the great Alfonso died, and his son Ferrante Ferrante had an opportunity of testing the worth of his father's of Aragon allies. His illegitimate birth prevented him from support of succeeding to the thrones of Aragon and Sicily, but the chief Alfonso considered that Naples was his to leave as he powers. wished. The Neapolitan barons, however, were determined not to let Ferrante assume the kingship in peace, 
and the son of René of Anjou promptly appeared in Italy to champion the French claims. It was a crucial moment in Italian diplomacy. Would the chief powers adhere to the policy of the Peace of Lodi and support Ferrante, whom his friends hailed as an Italian king? Would they, when a rival claimant was actually in the field, find it impossible to resist the ancient tradition which drew them to the side of René ? The fact that the former policy prevailed marks a definite stage in the growth of Italian unity. Each state, no doubt, was moved primarily by selfish interests, but at least it was recognized that those interests were common to Italy as a whole. 'Can René drive out Piccinino from the States of the Church ?' asked Pius II, as he prepared to throw over the traditional policy of the Papacy and support Ferrante instead of Anjou. Yet on another occasion he gave more disinterested reasons for his action. ' It would not conduce to the freedom of Italy if the French obtained the kingdom,' he told Cosimo dei Medici; ' in protecting Ferrante, Italy is protecting herself.' So Ferrante won Naples and reigned there for thirty-five years. Throughout this period the policy of the Peace of Lodi in the main held the field. The Aragonese dynasty stood as a visible proof that the chief states had been able to sink their prejudices and curb their jealousies for the common good of Italy. In spite of occasional lapses, they contrived to live up to this higher standard of patriotism for a considerable time. Ferrante fought on the side of the Papacy against Florence in the Pazzi War; but in the end Lorenzo dei Medici secured peace by going to Naples and making a personal appeal to 
the good sense and friendship of the King. Sixtus IV and Venice tried to rob the house of Este of Ferrara, but the intervention of Milan, Naples, and Florence prevented them from accomplishing their purpose. Thus the peace of Italy was maintained, and it seemed as if the sense of common interest and mutual understanding might one day make it possible to solve the problem of unity by some form of loose federation between the states. Nevertheless, Ferrante was still at enmity with his barons, and the Angevin claims on Naples were still maintained. The treacherous cruelty with which Ferrante avenged himself on any of the baronial party who fell into his power did nothing to help his cause, and the body of malcontent nobles increased throughout his reign. In I494, a combination of unfortunate circumstances led to the fall of the Aragonese dynasty, and to the crushing of such frail hopes of Italian unity as had arisen during the past forty years. A serious quarrel between Naples and Milan occurred at a time when Charles VIII had inherited the French claims from René of Anjou, and was being urged by Ferrante's exiled barons to undertake an expedition to Italy. Ferrante's death in the same year was the climax of Italy's misfortunes.

If Italian diplomacy of the fifteenth century can best Florence. be understood in connexion with the history of Naples, the fruits of that diplomacy are seen in their perfection at Florence. For here lay the heart of the Renaissance. Florence was at once the pioneer of the new movement, and its most characteristic product. The men who made her great were not strangers, drawn thither by the 
magnet of court influence, but Florentine citizens, who painted and built and wrote, not for personal fame or gain, nor even for the love of art alone, but for the greater glory of the Republic. Thus the atmosphere of Florence counteracted, to a certain extent, the characteristic weaknesses of the Renaissance ideal. Here the Renaissance was more spiritual and less material, owing to the simplicity and absence of ostentation in private life, which were part and parcel of the republican tradition. Cosimo and Lorenzo dei Medici could not be the central figures of a sumptuous court when their whole position in Florence depended on maintaining the tradition that they were nothing more than private citizens. So the glorification of the individual was less prominent than that of the state. Florence possessed the civic spirit, and selfishness lost itself in patriotism.

Return of During the first period of Medicean supremacy, that Cosimo dei is from I434 to I494, the Renaissance was at its height,
Medici to Florence, and the direction of the great literary and artistic revival I 434 .

was in the hands of Cosimo and his successors. Cosimo, as we have seen, succeeded to the peculiar position and functions of the Albizzi. His raison d'être was the inability of the Florentine Signoria to perform the work of government. Politically, he was distinguished from the Albizzi chiefly by the combination of tact and ruthlessness with which he kept the machinery of government in his own hands. No names were allowed to slip into the election bags which were not favourable to the Medici, and it was made clear to every citizen that, while support of Cosimo brought with it both political and commercial prosperity, enmity to him involved political nothingness 
and financial ruin. He was also in close association with the new ideals of diplomacy which were expressed in the formation of the Italian League at Lodi. The first step towards the friendly alliance of all the chief states was, indeed, made by Cosimo when he helped to place Francesco Sforza on the throne of Milan. But for him Florence would have certainly supported René of Anjou in the Neapolitan succession wars. Yet far more important than his dexterous handling of internal affairs, or his wise foreign policy, was his identification with all that made life worth living in the Florence of his day. In education, in artistic taste, and in intellectual outlook, he was a representative Florentine; and to this both he, and Lorenzo after him, owed their unique influence over the most critical and most fickle citizens in the world.

In order to understand all that it meant to be a repre- Progress sentative Florentine of the fifteenth century, it is necessary ${ }_{\text {Renais. }}^{\text {of the }}$ to consider the progress which had already been made sance in in the Renaissance movement in 1434. In that year Fefore the the Chancellor of Florence was Leonardo Bruni (Aretino), Medicean the first modern Italian who really mastered the Greek language. He owed his proficiency to the efforts of the older generation of scholars, notably to Colluccio Salutati and Niccolò Niccoli, who brought Manuel Chrysoloras to Florence and induced him to teach Greek in the university. Colluccio and Niccolo were too old to make much progress, but the younger men obtained a thorough grounding in the language, and the realm of Greek culture lay open before them. Thus the advent of Chrysoloras marks a stage in the Renaissance only second 
in importance to the life of Petrarch. Bruni's translations of Plato's Republic and Aristotle's Politics were the means by which the political thought of Greece entered into the daily life of fifteenth-century Italy. Meanwhile, the first great painter of the Renaissance had already arisen in the person of Masaccio, whose frescoes in the Carmine Chapel were executed between the years 1422 and 1428. 'After Giotto', wrote Leonardo da Vinci, 'the art of painting declined again, because every one imitated the pictures that were already done; thus it went on . . . until Tommaso of Florence, nicknamed Masaccio, showed by his perfect works how those who take for their standard any one but Nature, the mistress of all masters, weary themselves in vain.' Escape from formalism, the study of Nature, and of the human form, herein lie the secrets of the artistic revival which reached its consummation in the work of Leonardo and Michelangelo. In the sphere of architecture and sculpture Brunelleschiand Ghiberti held the field. The competition between them for the gates of the Baptistery, in I4OI, marked an epoch in sculpture such as the Carmine frescoes created in painting. Ghiberti won the contest, and at the time of Cosimo's return he was engaged on his second set of bronze gates, those of which Michelangelo said, 'They are so beautiful that they would do well for the gates of Paradise'. Brunelleschi, meanwhile, devoted himself more exclusively to architecture, and the year 1434 saw the completion of the dome of the Cathedral, the glory of Florence and of its creator.

Influence To this city of genius Cosimo returned not as a stranger dei Medici but as a home comer. In the days before his exile he 
had been familiar with the Convent of St. Spirito, the on the favourite meeting-place of the humanists, and Niccolò sence. Niccoli was his close personal friend. He possessed a fine collection of manuscripts, coins, and jewels. During his exile in Venice he had shown his gratitude to his hosts by summoning Michelozzo Michelozzi from Florence to build a library at his expense. Thus he stepped naturally into his position in Florence, and his influence can be traced in every aspect of literary and artistic development. He had a passion for Plato, and to him is due the foundation of the Platonic Academy which played so prominent a part in the Florence of Lorenzo the Magnificent. Marsilio Ficino was his discovery, and Marsilio handed on the tradition of Platonism to Poliziano and Pico della Mirandola. At his death, in $\mathbf{1 4 3 7}$, Niccolò left his library to Cosimo. The latter, knowing that during Niccolò's life-time his books had been at the service of every student, placed the collection in the Convent of St. Marco, thus creating the first public library in Florence. Among the churches and convents built at Cosimo's order were St. Lorenzo, St. Marco, and the Badia at Fiesole. He employed Brunelleschi at the Badia and in St. Lorenzo which became the shrine and burial-place of the Medici family. The Convent of St. Marco was entrusted to Michelozzo, who also built the Medici palace in the Via Larga, and the Medici villa at Careggi. The mysticism which helped to make Cosimo a Platonist drew him to Fra Angelico, who was engaged on his wonderful series of frescoes at St. Marco. Classicism explains his sympathy with Donatello. He also knew how to appreciate the gay and mundane art of Fra 
Filippo Lippi ; and in his old age he employed Benozzo Gozzoli to paint on the walls of his private chapel that joyful company of Florentines, wending their way through a spring landscape, which is called the Procession of the Magi. A man who could share thus in the manysided activities of Florence was a true Pater Patriae. With his death in $\mathbf{1 4 6 4}$ Florence lost her greatest benefactor, and the early Renaissance one of its most characteristic figures.

The Age of If Cosimo dei Medici was the father of Florence, the Magni- Lorenzo was her child. He grew up in the atmosphere ficent. which Cosimo helped to create. To the artists and men of letters who enjoyed his friendship he was less a patron than one of themselves, a fellow poet whose work was among the best that Florence produced. Among the features of the Laurentian Age, as distinguished from that of Cosimo, was the revival of Italian. The scorn of the earlier humanists for their native language gave way to a new-born enthusiasm for the Tuscan tongue, and Lorenzo's personal influence on the reaction was by no means small. He wrote a defence of Italian which he sent to Federigo of Naples, with a collection of Italian lyrics compiled by himself. His own poems are all in Italian, and in them the conflicting emotions and aspirations of his day find their fullest expression. On the one hand are the ballads and carnival songs, steeped in the fragrance of the Tuscan country-side, and yet tainted by coarseness and sensuality. In sharp contrast to these are the lauds and spiritual poems, which are none the less typical of Lorenzo and his age. Over all alike broods the sense of transient joy and calamities to come. 
Ah quanto poco al mondo ogni ben dura!

Ma il rimembrar si tosto non si parte.

Short indeed was the springtime of the Renaissance, and the remembrance of the happy days before the French crossed the Alps haunted the memory of a generation of Italians, who saw their country trampled under the feet of invading armies.

It is impossible to do more than mention the out-Lorenzo's standing members of Lorenzo's circle. Marsilio Ficino, who had been Lorenzo's tutor, was the high priest of the Platonic Academy. Cristoforo Landino wrote the first Renaissance commentary on Dante. Poliziano, both as a classical scholar and as an Italian poet, represented the highest achievements of the literary revival. Pico della Mirandola, as beautiful as he was accomplished, and even more lovable, was the most interesting personality of the group. Chief among the artists were Domenico Ghirlandaio, who exhibited both the immense increase in technical skill and the growing materialism of his day, and Sandro Botticelli, the most typical painter of the Medicean Age. Botticelli's Primavera might almost be regarded as an epitome of the Renaissance. The classical forms of the Graces, the woods and flowers in the first flush of spring, the mystical sense of a deeper beauty than the artist could express, Giuliano dei Medici, young and handsome, marked down by Cupid's arrow as he gathers the fruit which he is about to offer to the fair Simonetta -these are the leading features of the picture. In the Primavera, as in the Renaissance as a whole, we see an attempt to harmonize the religion and the paganism, the worship of Nature and the worship of the classics, the 
sensuality and the spirituality, the youthful egoism and joy in living, and the underlying sense of unreality and dissatisfaction which struggled with one another in awakening man.

Growing Intellectually and spiritually, Lorenzo was even more tendency towards closely identified with Florence than his grandfather despotism. had been. Yet politically he was further removed from his fellow citizens. The growth of the tyranny was an unmistakable feature of his rule. The constitutional changes which he introduced all tended to concentrate power in his own hands and in those of his supporters. His marriage with Clarice Orsini and his friendship with the rulers of other Italian states made it impossible to regard him simply as a citizen among citizens. As time went on, some of the outward signs of a despotism began to appear, and Florence saw in Lorenzo something of that desire to be first which had been the bane of many of her sons. Immediately her passion for equality was roused. Under Lorenzo himself there was no real danger. He had served his country too well to lose her favour, and Florence agreed with Guicciardini that although the city was no longer free, it could not have a better or more delightful tyrant. But before Lorenzo's death there were already signs of the storm which broke over the head of his son Piero, that man of ' small brain ', who succeeded to Lorenzo's position in Florence in $\mathbf{I} 492$.

Expan- During the first half of the fifteenth century Venice sion of Venice. and Milan were fighting over the possession of North Italy, almost without intermission. On the death of Gian Galeazzo, Venice seized Padua, Vicenza, and Verona. This brought her western frontier to the Mincio, 


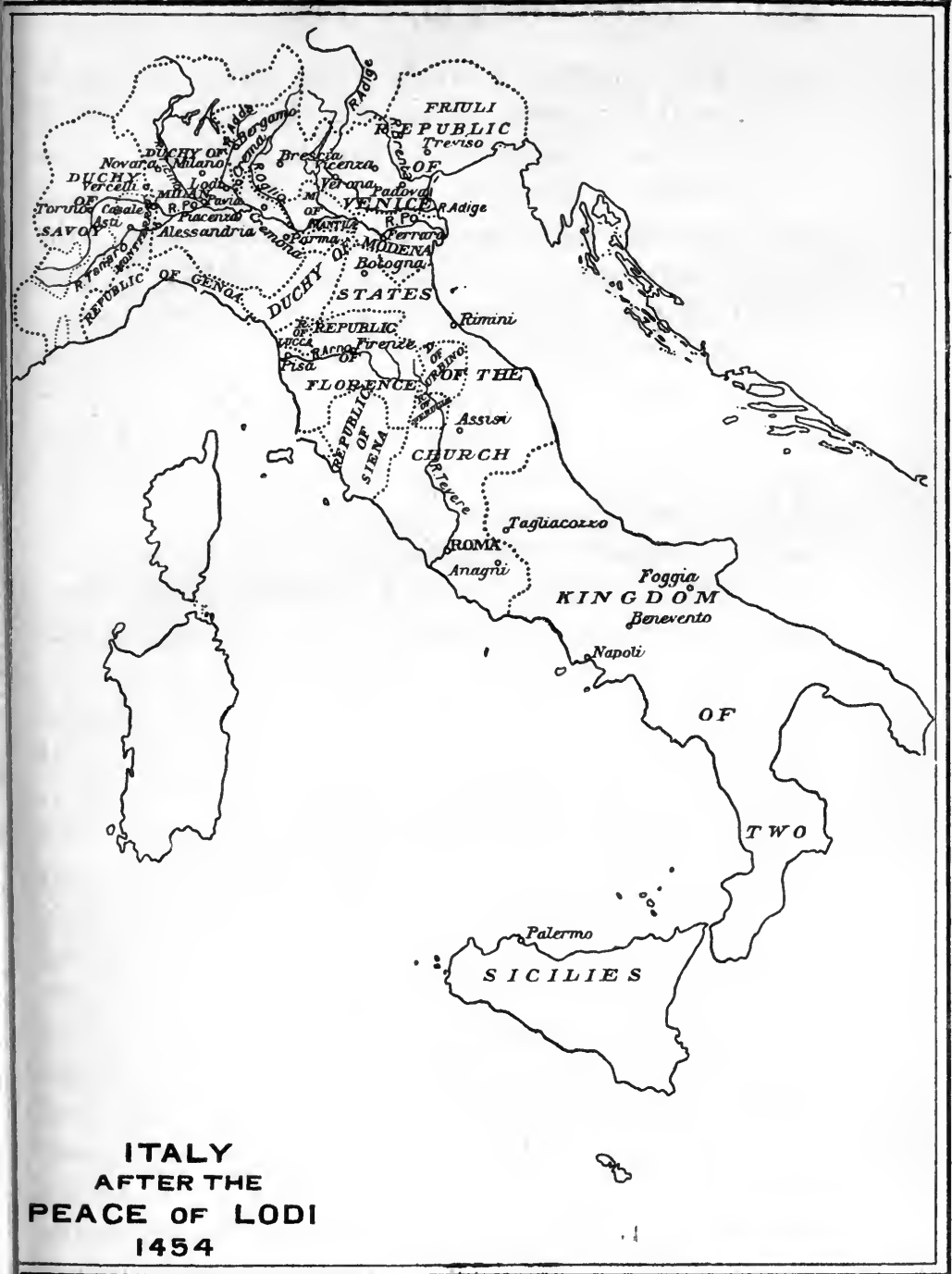

1832.3 
while the conquest of Friuli, a few years later, made the Isonzo her eastern boundary. Between $\mathbf{1} 425$ and I 447 she was engaged in no less than five wars with Filippo Maria Visconti, in which she conquered Brescia and Bergamo, but failed to take the much-coveted strip of territory between the Oglio and the Adda. Filippo Maria's death was followed by a three-cornered contest between Venice, the Milanese Republic, and Francesco Sforza. This ended in the Peace of Lodi, which established Sforza in the duchy of Milan and gave Venice the city of Crema, her sole gain after seven years' fighting. A frontier which reached to the Adda, and which included Cremona, with its strong position on the Po, still remained an unfulfilled ambition to the Venetian Republic. From I454 Venice enjoyed a period of peace, and the interest of her history lies in the use which she made of it.

The good The Renaissance came late to Venice, but by the end government of the fifteenth century there were many signs of its of the Venetian Republic. presence. Cardinal Bessarion's bequest of his library, and the editions of the Greek classics produced by Aldo Manuzio, are probably the two most important factors in the literary development of Venice. In the sphere of painting the Vivarini and the Bellini were preparing the way for Titian and Giorgione, Tintoretto and Veronese. The palaces which we know to-day were rising along the Grand Canal, and, in the little church of Santa Maria dei Miracoli, Venice produced at least one gem of early Renaissance architecture. Nevertheless, the most distinctive contribution of the Republic to Italian civilization, at this period, lay in the domain of government. Venice brought peace, prosperity, and freedom 
from civil strife to the mainland cities which acknowledged her authority, and all classes appreciated the benefits of her rule. The mainland nobles were the most restive among her subjects, as the presence of the Venetian governors deprived them of the position which they would naturally occupy in their native cities. But it only needed a short experience of French or German rule, at the time of the war of the League of Cambrai, to turn them into warm partisans of Venice. The lower classes were unanimous in their loyalty. 'Never on this earth were lords so well loved by their subjects as the Venetians have always been,' says Bayard, ' and this alone for the great justice wherewith they rule them.' Soldiers of fortune were a notoriously self-seeking and treacherous race, and, owing to the fact that the Venetian nobles all entered the navy, none of the mercenary captains of the Republic were Venetian born. Yet with a few exceptions Venice was well served. Carmagnola was suspected of treachery, and he died a traitor's death between the columns of the Piazzetta. But, when an attempt was made to lure Fortebraccio to the side of the League of Cambrai, his loyalty was proof against temptation. ' I have no wish to desert my duty to the Republic,' he replied. ' For sixty years I have been her servant, and if I had a hundred sons, I would give them all for her.' 'The well-known statue of Bartolommeo Colleone, seated on his horse outside the Church of SS. Giovanni e Paolo, is a memorial to another loyal servant of Venice. After a lifetime spent in fighting under Venetian banners, this old mercenary captain died in his castle at Bergamo in $\mathbf{1} 475$, leaving all his vast 
wealth to the Republic. The patriotism and public spirit of the Venetians were, however, strictly confined within their own territory. They cared nothing for the interests of Italy as a whole. When the peace of Italy was broken, as in the Ferrarese War of I482-4, the cause of the disturbance could usually be sought in Venice and her selfish desire for aggrandizement. Although she was loved by her subjects, she was hated by her neighbours; and, if at any moment she could add to her own power by bringing the foreigner into Italy, she would not hesitate to do so.

Milan- The Peace of Lodi gave Milan as well as Venice an rise of the opportunity for practising the arts of peace. Francesco
House of Sforza. Sforza, who became duke in $\mathbf{1 4 5 0}$, was a condottiere and the son of a condottiere. Both he and his father owed their fortune entirely to their genius for the profession of arms. The first Sforza had come from an obscure home in Romagna, and had made himself the head of one of the leading schools of Italian mercenaries. Now Francesco was the ruler of one of the five chief states of Italy. But the fact that he owed Milan to his sword was not one which Francesco Sforza wished to emphasize. He was married to Bianca Maria Visconti, the late duke's illegitimate daughter, and he preferred to be regarded as the rightful heir to the Visconti, and the chosen sovereign of the people of Milan. Thus the great aim of the Sforza dukes was to make their rule acceptable to their subjects. They are types of the beneficent despot; and even Galeazzo Maria, the villain of the family, did his best to increase the prosperity and renown of the duchy. 
Francesco Sforza and his two sons were indefatigable Archibuilders, and to them fell the task of finishing the two tecture great Visconti monuments, the Cathedral of Milan and ing under the Certosa of Pavia. Francesco's own foundation, the the Sforza. Castello of Milan, proved to be almost as vast an undertaking as either of the other two. Round these three buildings centres the history of Milanese architecture for the remainder of the century. They bear the mark of no single patron or architect but were in themselves schools of architecture, attracting disciples of each new style, and handing on traditions of their own to succeeding generations. The Cathedral and the Certosa, as the Visconti left them, were wholly Gothic in character, but now the Renaissance came to Milan with the Florentine architects introduced by Francesco Sforza. Filarete is responsible for the central tower of the Castello, and for the charming brick and terra-cotta Hospital which was Francesco's most permanent benefaction to Milan. Another Florentine was sent twice a month to supervise the building at the Certosa of Pavia, and the new influences which were thus brought to bear on the local schools are conspicuous in the work of the Milanese architect, Amadeo. In the reign of Lodovico Sforza, Lombard architecture was guided into fresh channels by Bramante of Urbino. This great innovator worked and experimented in Lodovico's service for some twenty years, before the fall of his patron forced him to take refuge in Rome. The influence of the Florentines and of Bramante in Milan are good examples of the way in which an enlightened despot could assist the artistic development of his dominions. The same process can 
be seen at work in painting. Francesco brought Foppa of Brescia to Milan, and Lodovico gave her Leonardo. Foppa was the principal master of the old Lombard School, influencing the work of such men as Borgognone and Zenale. The appearance of Leonardo created a revolution in Milanese art, and men like Ambrogio de Predis, Luini, and Gaudenzio Ferrari caught their peculiar grace, or sweetness, or animation from his inspiring presence.

Francesco Francesco Sforza had an uneducated man's veneration Sforza's zeal for for learning. He showed favour to the men of letters, education. especially to that most disagreeable of humanists, Filelfo; and he spared no pains over the education of his children. The young Sforza became perfect prodigies of learning. A Greek tutor was secured from Constantinople for Francesco's clever daughter Ippolita, and both she and her brothers were prepared with appropriate Latin speeches for every occasion. Yet their teachers were constantly reminded that their task was to train princes and not men of letters. The children wrote essays on such subjects as the framing and concluding of treaties. They were taught dancing, singing, riding, and fencing, while particular attention was paid to their manners. The practical character of humanist ideals of education may be gathered from the maxims which Francesco laid down for the guidance of his eldest son. Galeazzo was told to render to all their due, devotion to God and His Church, respect and obedience to his parents and teachers, politeness to all, according to their rank, "whether with cap or with head or with knee,' and especially to his parents' guests. He must learn to keep his temper and cultivate 


\section{The Age of the Renaissance}

justice and mercy, which are necessary in a ruler. $\mathrm{He}$ should speak pleasantly to every one, particularly to his own servants. He must not wish for everything that he sees, and he should avoid gossip and evil-speaking. $\mathrm{He}$ must eat and drink nicely and in moderation, and he should be able to distinguish a good horse from a bad. Great humanist educators, like Guarino or Vittorino da Feltre, would have little to add to the standard of good living set up by this soldier-duke.

Galeazzo Maria's rule in Milan did not do credit to Lodovico his education; and when, after a ten years' reign, he was Il Moro his education, and when, after a ten years' reign, he was and the murdered by some would-be republicans in 1476 , even Golden his wife acknowledged that he had received the due Age in reward of his crimes. His young son, Gian Galeazzo, succeeded him as duke, but the ablest man in Milan was Lodovico Il Moro, the late duke's brother, and in a few years' time the reins of power were firmly in his hands. Lodovico possessed the scientific spirit of the Renaissance. As an economist and a social reformer, an artist and a man of letters, he delighted in experiments of every kind. He carried out vast schemes of irrigation, and introduced new methods for the cultivation of the vine and the mulberry. He widened streets and improved the conditions of housing in his subject cities. He had the insight to recognize the unique genius of Leonardo, and to allow him to work in his own way and time. During his period of supremacy Milan showed what a Renaissance Court could be. Famous men came there as 'bees seeking honey', and all shared equally in the business and pleasure of the Court. Leonardo organized State pageants, and designed fortifications. Lodovico's young wife, Beatrice 
d'Este, supplied a distinctive touch of charm and gaiety. All took part in those eager discussions, on every kind of topic, which were dear to the children of the Renaissance. A design for the dome of the Cathedral, the respective merits of Dante and Petrarch, the identification of some classical monument, a new book, a new musical instrument, or a new method of warfare-each was discussed with equal enthusiasm and equal knowledge. Isabella d'Este called her brother-in-law 'the master of those who know', and to Baldassare Castiglione it seemed that the Castello of Milan was inhabited by the "flower of the human race'.

The

coming of the

Yet in Milan, as elsewhere, the sins of the Renaissance French. brought her golden age to an abrupt conclusion. It has been said of Lodovico that fear and ambition were the ruling motives of his life. He longed for power, and had seized it at the expense of his nephew, the rightful Duke of Milan. This nephew was married to Isabella of Naples, the granddaughter of King Ferrante, and Lodovico feared the vengeance that might fall on him as the author of Isabella's wrongs. He knew that the number of his enemies was increasing both within and without the duchy of Milan, and he also knew that Charles VIII was contemplating an expedition against Naples. Thus he saw a unique opportunity of silencing the threats of Ferrante and Alfonso, and at the same time earning the gratitude of the French King. Against this double advantage he had to set the sacred duty of Milan, which was to keep the gates of Italy closed against ultramontane invaders. But when fear and ambition urged, duty would certainly not restrain Lodovico Il Moro. 
Charles VIII crossed the Alps as Lodovico's ally, and passed through Milan on his victorious road to Naples. A few weeks later Duke Gian Galeazzo died. Lodovico was at once proclaimed as his successor, and so reached the summit of his ambitions. Never was Milan more prosperous or more glorious than in the years which followed the coming of Charles VIII. But at the time of Il Moro's greatest triumph another French army was already preparing to cross the Alps. The forces were in motion which drove Lodovico ultimately to a French prison, there to do penance for the ruin which he had brought upon Italy. 


\section{Italy and her Invaders}

$$
\text { I } 494^{-1} 5^{27}
$$

The

French invasions.

ThE years which followed the invasion of Charles VIII saw the political ruin of Italy. Charles made his way to Naples almost unhindered, and was crowned in the cathedral as King of Sicily and Jerusalem on May 12, I495. He then set out on his return journey; and, after an indecisive encounter with the forces of the Italian League at Fornovo, he was back again in France less than fourteen months after he had first crossed the Alps. In July I495, Ferrante's grandson, popularly known as Ferrantino, returned to Naples and the French Viceroy was compelled to withdraw. In the course of the next year the French forces were driven from every part of the kingdom. The Venetians, in the meantime, had seized a few Apulian ports, Florence had turned out the Medici, Lodovico Il Moro had consolidated his power. But for these indirect effects, Charles VIII's invasion had left Italy as she was before. Nevertheless irreparable harm had been done. The transitory nature of Charles's career in Italy had demoralized the Italians, so that they looked upon calling in the French as an easy method of furthering their own political ends. Moreover, the gates of Italy had been left open, and very soon other European monarchs followed in the footsteps of France. Ferrantino received help in men and money from his Spanish cousin, Ferdi- 
nand the Catholic. Maximilian, King of the Romans, grew jealous for the Imperial prestige, and himself appeared in Italy in 1496. In 1498, Louis, Duke of Orleans, succeeded Charles VIII on the French throne, and at once assumed the title of ' King of France, Jerusalem, and Sicily, and Duke of Milan'. This was the signal for a second and more formidable French invasion, having Milan as its chief objective. Lodovico Sforza fled on the approach of Louis XII; and his attempt to recover Milan in 1500 ended in his betrayal into the hands of the French by his Swiss mercenaries. From Milan Louis XII turned his attention to Naples. By the Treaty of Granada he and Ferdinand the Catholic arranged to conquer the Neapolitan kingdom and divide it between them. The conquest was effected, but the conquerors quarrelled over the spoils; and the battle of the Garigliano, in December 1503, left the Spaniards in undisputed possession of the whole kingdom. With a Spanish King of Naples, and a French Duke of Milan, Italy was no longer her own mistress.

The next stage in Italy's undoing began with the The War formation of the League of Cambrai in December 1508 . Maximilian, Louis XII, and Ferdinand bound them- Cambrai. selves to make a joint attack on Venice, and to strip her of all that she possessed on the mainland. Venice had helped Louis XII to win Milan, receiving as her reward Cremona and the Ghiarad'adda. Her dominionsstretched at last to the Adda; but now her sometime ally prepared, not only to take back what he had given, but to help himself to all her territory lying west of the Mincio. Ferdinand determined to regain the Apulian ports, and 
Maximilian claimed as his share Verona, Vicenza, and Padua, the March of Treviso and Friuli. These three foreign powers were joined by the Pope, the Duke of Ferrara, and the Marquis of Mantua, all of whom Venice had deprived of territory in the course of her expansion. Venice was left without a friend in Italy, and her crushing defeat at the Ghiarad'adda in May I 509 lost her the whole mainland dominion in a single day. To this she was brought by the calculated selfishness of her policy during the past hundred years.

Italy the In the course of the war Pope Julius II suddenly battle-field changed sides. He had used the French to recover his
between France own possessions; and now that Venice was sufficiently humbled, he resolved to use her against the French. The League of Cambrai fell to pieces, and the Holy League was formed in order to drive the French from Italy. Owing to the brilliant generalship of Gaston de Foix, France was more than a match for her enemies, but her successes ended with her victory at Ravenna in April I 512. Gaston de Foix was killed at the close of the battle, and the French were obliged to withdraw to Milan, which they found in possession of a fresh invader. Twenty thousand Swiss had descended on Italy in aid of the Holy League, and for the next three years the Duchy of Milan was practically a Swiss dependency. When Francis I became King of France, in all the vigour of his youth, his first act was to drive out the Swiss. The battle of Marignano in August I 5 I 5 restored Milan to the French, but it also made it possible for Italy to become the battle-field between France and Spain. From Charles V's election as Emperor in 15 19, his rivalry 
with Francis I was the central fact in European history, and Italy formed the stage on which the struggle was fought out. Foreign armies marched up and down the country, plundering and destroying. Horses were stabled in churches and palaces, and Leonardo's masterpiece in sculpture became a target for Gascon archers. The sack of Rome was only the most sensational episode in a long tale of desolation and destruction.

Foreign invaders destroyed the political independence Effects of Italy, but they could not destroy the Renaissance. of the of Italy, but they could not destroy the Renaissance. invasions During the respite from serious warfare afforded by the on the latter half of the fifteenth century, the new life had been $\begin{aligned} & \text { Renais. } \\ & \text { sance. }\end{aligned}$ able to grow and take root. Now the fruits of the Renaissance came to maturity in the midst of political degradation. The German and Spanish soldiers who ransacked palaces and destroyed manuscripts were too ignorant to know the harm that they were doing, but others, and among them the French in particular, were filled with wondering admiration at the sight of a civilization which far surpassed their own. Louis XII did his utmost to maintain the traditions of the court of Milan by the brilliancy and profusion of his entertainments. French governors-general and Spanish viceroys tried to take the place of native Italian princes as patrons of art and letters. In his attempt to play the prince-patron the foreigner was pitifully unsuccessful, but at least by this means Europe as a whole began to catch something of the Renaissance spirit. Meanwhile, the true life of the day flowed round centres which were momentarily free from political upheaval, or were farthest removed from foreign influence. 
The

Renaissance in Venice.

Until the outbreak of the war of the League of Cambrai, Venice felt nothing of the shock of foreign invasion. Consequently, the first decade of the sixteenth century was the supreme moment in Venetian art. Giovanni Bellini was painting until his death, at the age of eighty, in I516. Carpaccio stood at the height of his reputation and powers, while a brilliant set of artists was coming to maturity. Giorgione, Titian, Palma Vecchio, Lorenzo Lotto, and Sebastian del Piombo were all born within the last quarter of the fifteenth century. In their work the distinctive character of Venetian art gained expression. The oriental splendour of Venetian life, the serenity of the Venetian temperament, lulled by the calm of the lagoons, the materialistic outlook of a mercantile community with its sensuous delight in the beauty of the human form, all are reflected in the art of the day. It is in conformity with the Venetian character that these artists should rise to their greatest heights in the representation of Nature. The landscape backgrounds of Giorgione and Titian express the genius of a sea-faring people, who had learned to realize the sublime and the spiritual through their contact with sun and wind and rain and sea.

The

smaller

Italian courts.

Although the court of Milan ceased with the fall of Lodovico Il Moro, smaller courts, such as those of Mantua, Ferrara, and Urbino, carried on the great Ferrara. tradition. From the time when Niccolò d'Este summoned Guarino to Ferrara in I429, as the tutor of his son and heir Leonello, the Ferrarese court had maintained a high standard of cultivation. It had been famed for its poets even more than for its artists, and now it was the home 
of the king of court poets, Lodovico Ariosto, who published his Orlando Furioso in 1516 , when he was in the service of the reigning duke, Alfonso. The court of Ferrara also produced two of the most remarkable women of the Renaissance, Isabella and Beatrice d'Este, the daughters of Duke Ercole. Beatrice died in 1497, when she was twenty-two. During the six years of her reign in Milan she had been her husband's wisest political adviser, and the sharer of his intellectual pursuits as well as the joy and life of the Milanese court. Isabella, the elder sister, was married to Francesco Gonzaga of Mantua, and Niccolò da Correggio expressed the opinion of his age when he called her the first lady in the world. She came to Mantua as a bride in $\mathbf{1 4 9 0}$, and from that time Mantua. until her death in 1539 she was in close touch with all the men of genius in Italy. Leonardo and Titian painted her portrait, Mantegna decorated her rooms, Aldo Manuzio sent her his new editions of the classics as soon as they were printed, Ariosto read her the first draft of his Orlando Furioso. Meanwhile her soldier-husband was fighting, first as Captain-General of the Italian League against Charles VIII, and then on the side of the League of Cambrai against Venice. Isabella ruled Mantua in his absence, and fought the diplomatic battles of the little State through all the vicissitudes of the time. There is a certain hard brilliancy about Isabella d'Este which prevents her from being altogether attractive. A genuine love of art mingled in her with the collector's egoism and greed. She wanted to be distinguished from her fellows by the rarity and splendour of her possessions. She could dance at Louis XII's ball in the Castello of Milan with 
the Frenchmen who had usurped the place of her dead sister, if by so doing the fortunes of Mantua could be advanced. The greatest lady of the Renaissance, she suffered from the characteristic limitations of the Renaissance ideal.

Urbino. A more pleasing example of her type is presented by her sister-in-law, Elisabetta Gonzaga, the wife of Guidobaldo, Duke of Urbino. The mountain capital of Urbino, set high on the slopes of the Apennines, formed a refuge for the arts of peace throughout the early years of the French invasions. The founder of Urbino's greatness was Federigo da Montefeltro, the first duke. He had been educated with the Gonzaga princes in Vittorino da Feltre's school, and his career affords the most shining proof of the value of Vittorino's system. He was first of all a soldier, but he was also a scholar and a man of religion, who governed his household with the strictness of a monastery and collected one of the finest libraries in Italy. The ducal palace at Urbino, that perfect example of a fifteenth-century mansion, is his creation. Here it was that his son and daughter-in-law gathered round them the distinguished company which is immortalized in the pages of Castiglione's Courtier. Castiglione came to Urbino in 1504. He stepped at once into an atmosphere which combined the culture of a university with the intimacy of family life. Elisabetta was an ideal hostess, self-effacing and yet dominating, controlling her guests so skilfully that every one seemed free to say and do what he pleased. 'I came to Urbino with only forty ducats in my pocket, and I stayed there for six years,' wrote the future Cardinal Bembo. Besides this dis- 
tinguished scholar, the Urbino circle included Luigi da Porto, the soldier-historian of the War of Cambrai, Giuliano dei Medici, more attractive and less worldlywise than others of his family, Cristoforo Romano the sculptor, Emilia Pia, Bernardo da Bibbiena, and many others. Not least among them was Castiglione himself, of whom Vittoria Colonna said that if he wished to see the perfect courtier he had only to hold a mirror before his own face. It rests on the authority of Il Cortegiano that in no other place was the 'sweetness which flows from dear and cherished companionship' so fully tasted as it was at Urbino. "There sprang up in the hearts of all a supreme content each time we entered the presence of the duchess, and it seemed as if this were a chain which held us all bound together in love, so that there was never greater union of will, or more cordial love between brothers than that which reigned between us all.' But even the fastnesses of the Apennines could not save Urbino from political troubles. Guidobaldo and Elisabetta were forced to fly before Cesare Borgia in I 502, and only returned to their capital on Cesare's fall. In I516 Urbino became a prey to the ambitions of Pope Leo X. His nephew Lorenzo dei Medici was made duke, the rightful rulers went into exile, and the golden days of Urbino were over.

The early Renaissance in Florence, for all its greatness, Culmina. was essentially local in character; and but for the encour- tion of the Was esentis. agement given to strangers by court influence, the same sance in can be said of other cities before I494. Now, however, Rome. when dynasties were perpetually overthrown, and artists and men of letters wandered from one city to another in 1832.3 
search of peace and security, the movement took on a more cosmopolitan aspect. The habitués of the court of Urbino were drawn from all parts of Italy. When Urbino fell, there still remained Rome, which was in itself universal, and where the Renaissance was not Roman, but Italian and European. Thus it is in Rome of the early sixteenth century that the culmination of the artistic and literary revival must be soughi. The laying of the foundation-stone of the new St. Peter's in I 506 may be taken as the beginning of this last phase, while the death of Raphael in 1520 marks its close. The pontificates of Julius II and Leo X embrace the whole period. Rome during these years was a great intellectual centre, where poetry flourished, and where the finest scholars of the day were numbered among the papal secretaries. But it was far more productive in painting and architecture. The decoration of the Vatican Stanze, and of the Sistine Chapel, gave scope for the masterpieces of Raphael and Michelangelo, while the building of St. Peter's provided a training school in which classical form was perfected.

St. Peter's. Bramante furnished the original design for St. Peter's, but very soon Raphael and Giuliano da San Gallo were associated with him in the work. After Bramante's death, Peruzzi and Antonio da San Gallo assumed control, and in his old age Michelangelo crowned the unfinished structure with his famous dome. The aims of this generation of architects were determined by the magnitude of their undertaking. The exuberant decoration of the early Renaissance gave way to severity and simplicity in detail. All was subordinate to the ideal of 
proportion and harmony of design. Thus the buildings of the full Renaissance were more than individual expressions of delight in beauty. They were universal in character and appeal, because the personality of the artist was disciplined to an end greater than himself. The same universal quality distinguishes the work of the Leonardo. painters from that of their predecessors. They came to Raphael Rome from all parts of Italy, and represented every Michelvariety of local tradition. Michelangelo was trained in angelo. Ghirlandaio's studio at Florence. Raphael combined the influences of the Florentine school with those of Perugia and Urbino. Leonardo did his greatest work in Milan, and visited Rome in the course of the wanderings forced on him by the fall of Lodovico Il Moro. In the work of these three men the art of the Renaissance is consummated. Leonardo stands for the scientific spirit of the age. His aim was to understand everything and to do everything to perfection. His art is universal because it is the expression of a mind that could rest content with nothing short of universal experience. Raphael is the idealist who found in beauty the great reconciling force of the world. Uncritical and receptive, he painted what he saw, and all that he saw was beautiful. Michelangelo is more in touch with humanity as a whole than either of the other two. He knew that life means conflict, and he painted the unending struggle of man, battling with sorrow and evil by means of the life-force that is in him. He outlived the Renaissance in years, and he went beyond it in spirit. The assurance and complacency of those who had rediscovered man and the world were no longer his. Instead, he knew the dissatis- 
faction which springs from a sense of forces which man is powerless to control, and of horizons wider than those of the material universe.

Reaction Michelangelo is one representative of the reaction against the Renaissance ; Savonarola. against the Renaissance which was the inevitable effect of the disasters which had fallen on Italy. A generation, which had set out to conquer the world, found itself powerless to resist foreign invasion. So the ideals of humanism were discredited. It was seen that selfdevelopment, and the pursuit of renown did not solve all the problems of existence. The profound discontent with existing conditions, which can be seen in the art of Michelangelo, was expressed in political form by Savonarola. In the months which preceded Charles VIII's invasion, the Prior of St. Marco was preaching the coming of the French, as 'the sword of the Lord upon the earth', for the punishment of the sins of Florence. Italy was divided against herself, her military forces were unorganized, the whole country was politically and morally corrupt. To this she had been brought by following the ideals of the Renaissance to their logical conclusion. Therefore Savonarola called on the Florentines to renounce their paganism, and to realize once more the sin of the world and the need for repentance. As he preached, his prophecies were fulfilled. Charles VIII appeared on the Tuscan frontier, and Piero dei Medici, who had gone out to obstruct his passage, surrendered four of the principal Florentine fortresses into the hands of the enemy. The citizens had only just time to punish Piero for his weakness by driving the Medici from Florence before Charles VIII rode into the city. In the hour of 
humiliation, the whole population responded to Savonarola's appeal. He became the supreme arbiter, both in politics and religion, and for a little while he seemed to have established the reign of Christ in Florence. The story of his fall and martyrdom need not be retold. His interpretation of events failed to find acceptance in the rest of Italy, and after the first enthusiasm for purgation had died away, Florence also rejected his teaching. To the vast majority of Italians the foreign invasions did not come as a call to repentance but as an incentive to recklessness. The ills of the time were ascribed to Fortune, and man was urged to make the most of the opportunities afforded him by a prosperous turn of her wheel, because, sooner or later, he must inevitably be overtaken by calamity.

The career of Cesare Borgia is the most striking Cesare example of the way in which the misfortunes of Italy Borgia. could be made to serve the private ambitions of an adventurer. Cesare was destined for an ecclesiastical career, and was already a cardinal and Archbishop of Valencia when Alexander VI determined to turn him into a secular prince, by means of French aid. The Pope consented to the dissolution of Louis XII's marriage, and so left the king free to marry Anne of Brittany. In return, Louis created Cesare Duke of Valentinois, and promised to assist him in the conquest of Romagna. So, in I499, Cesare came to Milan in the train of Louis XII, and began the amazing series of campaigns which made him the master of Romagna and the terror of all Italy. The ruthlessness of his methods, combined with the knowledge that the power of France was behind him, 
rendered Cesare irresistible. One by one the cities of Romagna were taken, and their rulers slaughtered, until the native lords fled on the mere rumour of his approach. Having won his dominion by force, treachery, and murder, he proceeded to rule it better than it had ever been ruled before. Anarchy gave place to order and prosperity, and the name of Cesare Borgia was held in grateful remembrance by the inhabitants of the conquered cities long after his fall. So firmly had he established himself, that if it had not been for the accident of his own illness, his power would probably have survived the crisis occasioned by the death of Alexander VI. Such is the opinion of Machiavelli, and there is little reason for doubting his judgement. As it was, father and son passed out of Italian history together. Cesare achieved nothing permanent except in so far as he inspired Machiavelli to write his Prince.

The Il Principe-perhaps the most famous of all political Prince
of Machia- pamphlets-was written in the year 15I3. Its author velli. was deeply conscious of the moral degradation of the times, and he was also possessed by a great and patriotic love of Italy. Convinced that men were moved solely by self-interest, he hoped to play upon the selfish ambitions of an individual prince, so as to induce him to become the saviour of his country. His study of Cesare Borgia's methods had shown him what one man could do, if his whole force was bent on a single purpose. It seemed to him that the year $15 \mathrm{I} 3$ offered a unique opportunity for the regeneration of Italy, and that in Lorenzo dei. Medici he had found the man best fitted for the task. In 1512 the Medici had been restored to Florence. The 
most prominent member of the family was Cardinal Giovanni, the son of the great Lorenzo, who in February I 5 I 3 became Pope Leo X. Young Lorenzo was the son of his elder brother, Piero, and the natural heir to the Medicean supremacy. Thus he had greater advantages than Cesare at the outset of his career, as he could reckon upon the support of both Rome and Florence. In the same year the French were driven out of Italy by the Swiss, who set up Massimiliano Sforza in Milan as their puppet duke. If Lorenzo should prove capable of dominating Central Italy, neither Milan nor Venice would have the force to resist him, while the interference of the Spanish King of Naples was at least improbable.

Such were the circumstances under which Il Principe The pro. was written. It was concerned with a single problem-the blem of establishment of the state upon a firm basis. Machiavelli, like Dante two centuries earlier, realized Italy's immense capacity for greatness. He knew that individual Italian soldiers were superior, both in valour and military technique, to their foreign conquerors. He knew that the supremacy of the Italians in the arts of peace was such as to make Germans, French, and Spaniards who came in contact with them seem little better than barbarians. Yet all this energy and genius was wasting through lack of direction. It was Machiavelli's supreme object to turn the fruits of the Renaissance wholly to the service of the state. The condottiere system had cultivated war as a fine art, but it had been more profitable to the soldier of fortune than to his employer. Now the Prince must rely on a citizen army, in which the science of the mercenary companies would be accompanied by 
loyalty and obedience to the head of the state. The Prince must bend his whole intellect to the study of human nature, in order to confound his enemies and placate his subjects. He must sacrifice pleasure, friendship, and his soul itself to the one great purpose. "Where the salvation of country is at stake, no consideration of justice or injustice can find a place, nor of mercy and cruelty, honour and dishonour; every scruple must be set aside, and that course followed which will save her life and maintain her liberty.' Nowhere have the paramount claims of the state been more emphatically urged than in this passage from the Discorsi. And, if Machiavelli's theories had been carried to their logical conclusion, the state would have overruled more than morality. The whole realm of art and thought would have been subordinated to the same purpose. Princes would have acted as patrons of genius for political purposes only. Artists would have been essentially courtiers, and scholars primarily diplomatists. So the humanist doctrine, that the end of education is the training of the statesman, would have been perverted and distorted.

Italy rejects the Machiavelli's political ideals, however, were never paramount claims of the State. realized in Italy, and the causes of their failure lie deeper than in the personal weakness of Lorenzo dei Medici. Italy had been nurtured in the traditions of freedorn. This being so, as Machiavelli himself acknowledged, neither the passage of years, nor the material benefits which might accrue to her, would cause her to forget 'the name of liberty'. The cities who yielded themselves to despots did so on their own terms, and they were altogether lacking in a spirit of docility. A Cesare 
Borgia might seize supreme power for a few years, or even for a lifetime, but then would come a murder, and a revolution, and his power would vanish. Even the most dearly-loved of ruling families had to pay constant attention to public opinion in order to retain their popularity. Italy was too restive, too critical, and too intellectual to fall victim to the tyranny of the state. Herein lies her true greatness. The sack of Rome robbed Italy of some of the tangible results of the Renaissance; but civilization itself would have been the poorer if the genius of Italy had been subordinated to political ends.

The history of Italy during the remainder of Machia- The velli's life proved that his theories were fallacious. Medici Instead of the self-interest of an individual helping to lay the foundations of a state, it was seen that selfishness and materialism were really destructive forces. The failure of the two Medici popes to save Italy from disaster may be partly ascribed to the fact that they were too corrupt and self-indulgent to be able to attain their own selfish objects. Leo $\mathrm{X}$ began his reign with the determination to create a principality for his nephew Lorenzo. In 1516 , he succeeded in putting him in possession of Urbino, and he profited by his alliance with Francis I to obtain for him a French bride. But Lorenzo was not capable of rising to his opportunities. He did nothing to add to his reputation, and only alienated the Florentines by aping the manners of a tyrant. On his death in 1519 , the duchy of Urbino was united to the States of the Church, and Cardinal Giulio dei Medici took in hand the government of Florence. Meanwhile, Charles $\mathrm{V}$ was elected Emperor, and Leo $\mathrm{X}$ had to 
decide whether he would support Charles or Francis in the ensuing struggle. Everything pointed to the conclusion that his true interest lay in alliance with the Emperor. Charles, through the very magnitude of his possessions, was on the whole the weaker power, and the friendship of the Papacy would help to readjust the balance, so that neither sovereign could dominate Italy. Moreover, Leo $\mathrm{X}$ had set his heart on the conquest of Ferrara, and also on the recovery of Parma and Piacenza. The lastnamed places were in possession of Francis I, who was further bound to the house of Este by close ties of friendship. Thus it was clear that the papal ambitions could not be realized through the French alliance, and Leo $\mathrm{X}$ made a secret treaty with the Emperor in May 1521. Yet he could not make up his mind to break with France, and he continued to vacillate between the rival powers until death saved him from the consequences of his weakness.

Clement VII and the Sack of Rome.

Cardinal Giulio, who became Pope Clement VII in 1523, was looked upon as definitely Imperialist in sympathy. Yet he could not stand the test of the moment of panic before the battle of Pavia, when Francis I seemed on the eve of a crushing victory. Fear, the deadly sin of politics, impelled him to intrigue with Francis, and to lend him secret aid, even while he realized that his permanent interests were bound up with the Imperial cause. The battle of Pavia was fought on February 24, 1525, and its issue belied all expectations. Francis I was a prisoner, and Italy lay at the feet of the victorious Emperor. Clement VII had now every reason to be alarmed. Heknew that Charles was aware of his treachery, 
and that the victor of Pavia would have ample opportunity for vengeance. In despair, he continued to plot with Charles's enemies, aiding the Morone Conspiracy in Milan, and joining the League of Cognac, which aimed at the overthrow of the Imperial power in Italy. At this juncture Charles $\mathrm{V}$ found himself forced to take action. He sent fresh armies to Italy to reconquer Milan, and to take vengeance on 'that villain Pope'. The sack of Rome was not premeditated. It seems clear that all that Charles V intended was to bring Clement VII to reason by a rigorous assertion of power. But mutinous soldiers and Bourbon's recklessness brought on the senseless tragedy. On May 6, 1527, some twenty thousand German and Spanish troops poured into Rome, where they proceeded to sack and plunder without discrimination or mercy. On May 17 the Republic of Florence again drove out the Medici. Clement VII had reaped the full reward of his misdeeds.

The Sack of Rome marks the end of a period. During two centuries and more Italy had been striving to develop a political system which would preserve her independence, while retaining local diversities. The events of 1527 riveted the Spanish yoke upon her and so sealed her failure. Both the virtues and the vices of the Italians contributed to this result. It was no light task for a nation teeming with genius and vitality to learn to submit to political control. If Renaissance Italy had been less great she would have been easier to discipline. At the same time, the characteristic failings of the age were the chief cause of political corruption.. The Italian princes were too selfish to triumpl over separatist 
instincts, and too material to respond to an ideal of unity. Loss of independence followed as an inevitable consequence, and for over three hundred years Italy endured the chastisement of foreign rule. Yet in her darkest hour it was seen that she had really conquered Europe. Francis I carried the Renaissance back with him to France. Tudor England steeped itself in Italian literature, which it derived very largely from French sources. Italy was the one great standard of appeal in matters intellectual and artistic. Humanity is greater than humanism, and Italy's contribution to civilization as a whole is the measure of her value in the world's history. She did not conquer the world, in the sense that the humanists intended, but she established an ascendancy over the human mind which was made greater and more lasting by its independence of political domination. 


\section{ITALY, I $528-\mathbf{I} 789$}

\section{I}

\section{External Politics}

THE Sack of Rome has been called the death-blow of The HapsRenaissance Italy. It was certainly symbolical of the dominance disappearance of Renaissance life and culture before the in Italy. deadening spiritual atmosphere which the Hapsburg predominance diffused over the peninsula. The Hapsburg power had been gaining strength slowly but steadily; France was still contesting it, but France was losing as the Hapsburgs were gaining ground, and the fall of Rome marked another step in the process.

For the moment the sack seemed to have gained nothing for Charles but the horror of the orthodox world, yet so little advantage did his enemies take of their opportunity that only two years later he was strong enough to journey to Italy like a mediaeval Emperor. Meeting the Pope, princes, and ambassadors at Bologna, he settled their affairs and disputes, distributed honours and titles, and received from the Pope's hands the crowns of Lombardy and Rome as though he were indeed King of Italy.

Florence was the sop thrown to Clement to compensate his loss of dignity and power. For the last time the old independent party in the city had raised its head against the Mediceans and re-established a republic. 
Florence stood a year's siege, with Michael Angelo as director of fortifications, but the treachery of her own general brought her gallant struggle to an end. It is not to Clement's credit that a repetition of the Sack of Rome was only narrowly avoided. A degenerate Medici, Alessandro, bastard son of a Moorish slave, now ruled it with the new title of duke.

Charles could thus act as Italian overlord; but, content with excluding France from the peninsula, he did not attempt to convert his hegemony into more direct possession, a troublesome and dangerous business for which he had neither leisure nor strength. $\mathrm{He}$ meant to keep his hold by a system of alliances, consolidated by marriages; his natural daughter was married to Alessandro de' Medici, his niece to Francesco Sforza. Unluckily the death of Sforza without an heir reopened the difficult Milanese question, and led to another war with France. Its first result was the occupation, which lasted for nearly twenty years, of almost the whole of Savoy and Piedmont by French and Spanish armies; the next the investiture by Charles of his son, Philip, with the duchy of Milan.

The In 1540 the perpetual Imperial Vicariate of Italy was hegemony. bestowed upon Philip and his heirs, and thus all Imperial rights were definitely transferred to the Spanish monarchy. This was a step of immense importance for Italy's future, since those claims which the Empire alone had not for generations been strong enough to enforce became very real sources of power in the hands of Spain. The Peace of Cateau-Cambrésis (I559) confirmed Philip's authority. France renounced her rights on Milan and Naples, and 
for many years her private affairs effectually prevented her from taking an active part in Italian politics. Thus the Spanish hegemony consolidated itself firmly in Italy; throughout the sixteenth century it was not disputed, and throughout the seventeenth it was able to endure, only growing weaker by slow degrees, until the Hapsburg race itself failed from the throne of Spain.

Philip was no more desirous than Charles of converting his predominance into a monarchy; his ambition was to rule men's souls rather than their lands. While Italy was governed by Spanish methods, by the extinction of all liberty of thought and action, and made one of his instruments for extending this system over Europe, Philip was amply satisfied. The Papacy was to be controlled by its dread of Protestantism, the princes by a judicious mixture of fear and favour, the people by the Inquisition and kindred methods. Yet he was careful to overawe the country by bodies of soldiers stationed at Milan and Naples, and to control the princes and their armies by enrolling them in his service as condotti troops.

Philip could be certain of his power as long as France was kept out of Italy, and at the same time all tendencies to dangerous independence, such as an Italian league, were kept in check. The latter was easy enough, for the princes were far more concerned with their own petty jealousies and quarrels for ceremonial precedence and titles than with the preservation of any real independence. The old feudal states, such as Savoy and Ferrara, were especially jealous of the upstart Medici, and when Duke Cosimo I (de' Medici) obtained from the Pope the 
title of Grand Duke their fury knew no bounds. 'They never', said a contemporary, 'contended for dominion, liberty, and life, as they now contend for precedence with all their industry, skill, and diplomatic arts.' Any one of them preferred subjection to Spain to following the leadership of another Italian State. Indeed, when Savoy tried to head a movement towards national liberty, its failure was as much due to the jealousy of its neighbours as to Spanish repression. A better reason for their supine submission was the terrible need of peace to recover from the exhaustion of the late wars, and of protection from the inroads of the Mediterranean pirates. Lombardy, 'the garden of Italy,' had become a desert; 'the children cry in the streets for bread,' wrote a traveller; the country was depopulated, the land gone out of cultivation, industry and commerce at a standstill; Rome herself had not recovered from the sack. Pirates, sometimes as allies of the French, harried the coasts and plundered all they could reach. Spanish dominion certainly brought peace and the much-needed interval for recuperation, Italy again recovered a measure of her fertility and prosperity; but Spain was a broken reed for protection against the pirates. Philip was always too busy elsewhere to act vigorously against them, and his navy only kept up a desultory warfare about the coasts.

The relations of Spain to the Papacy are bound up Relations with the religious question, since the Papacy, in its life of Spain to and death struggle with Protestantism, was dependent Italian upon the Hapsburgs. Not all the popes were as subserPowers.

vient as Spain might have wished; some were too partial to the Medici, some showed a deplorable lack of 1832.3 
enthusiasm in supporting the Catholic League which was to deliver France bound into the hands of Spain. At the same time it was important for Philip to keep on good terms with the Papacy, partly because his attitude towards orthodoxy was part of his political programme, and partly because the Papacy could grant him the proceeds of the Crociata, an indulgence purchased by Spaniards for the furtherance of war against the Turks. Still the Popes seldom ventured to show much independence until Clement VIII had granted absolution to Henry of Navarre, and France could again be used as a counterpoise to Spain.

Venice alone of the Italian States maintained an attitude of cool detachment; she entertained Henry III and mediated between the Pope and Henry IV. She disliked her Hapsburg neighbours, both of whom had claims on part of her Terra Firma. Her commerce suffered from Spanish administration in Italy and from the constant predatory warfare between Spain and the pirates, and was endangered in the Adriatic by the Uscocchi, pirates from the Dalmatian coast, who were actually protected by Austria. It was indeed unfortunate that Venice and Spain could never co-operate sincerely against the common enemy, the Turk. Venice really preferred peace so as to safeguard her eastern possessions ; Spain rendered real peace impossible by guerrilla warfare; yet when Venice was involved in deadly struggle with the Turks for Cyprus, Spain, though co-operating in the Lepanto campaign, withheld the help which might have saved the island. Yet Venice dared not quarrel with Spain, while France was too weak to help her, and both 
she and Philip set too high a value on Italian peace to endanger it without extreme cause.

The Florentine dukes, though generally submissive, were not always as obedient as Philip could have desired. Alessandro, a dissolute tyrant, was assassinated by a private enemy (1537), and the duchy passed to a clever and vigorous cousin, Cosimo I. Siena, which had rebelled against Imperial misrule, was granted to him as a Spanish fief, but Spain retained five coast-towns, called the Presidi, as hostages for his good behaviour. Desirous of a title to correspond with his enlarged dominions, Cosimo persuaded Pius V to crown him at Rome as 'Grand Duke of 'Tuscany', thus infuriating his neighbours, and incurring for a time Philip's wrath at this disregard of the overlord's prerogatives. Cosimo cleverly maintained an influence over the Papacy, but his attempts at intrigue in France were a failure, and on the whole he and his son Francesco submitted to Spanish dominance. But Francesco's brother, Ferdinando, who succeeded him ( 1587 ), dared to assert his independence by marrying a French princess, helping to obtain absolution for Henry IV, and marrying his niece, Maria, to that monarch, thus reviving for a time the ancient friendship of the Lilies. Spain retaliated by occupying Piombino and Elba, and building a new fortress. Ferdinando was soon frightened into making a humble submission and the French marriages proved of no value to him.

The Dukes of Ferrara, whose policy was almost wholly inspired by jealousy of the Medici and their Grand-Ducal title, generally kept up friendly relations with the French court, but they were too weak to be dangerous to Spain. 
But the smaller princes, Parma, Mantua, and Urbino, and the great nobles of the Papal States were all in Spanish service, and helped to overawe the Papacy. Parma was the most notable example of successful Spanish policy. Pope Paul III had caused a war by granting that duchy and Piacenza, in defiance of Imperial rights, to his son, Pier Luigi Farnese (I 545), and Charles $V$ had been obliged to send Alva to Italy. But Farnese's descendants won Philip's favour and entered the Spanish Condotta, and Duke Alessandro served Spain faithfully for many years in the Netherlands.

Of the smaller republics, Lucca was allowed to remain independent, probably as a check upon the Medici. Genoa was very important to Spain, as the only port through which she could communicate with Lombardy. Genoa was kept faithful by Andrea Doria, who had been a commander in the Spanish service, and who gave her a new and more settled constitution. Genoese trade was encouraged; her merchants became the financiers of the Spanish government and soon grew enormously rich at the expense of that State and of its subjects.

Relations of Savoy to Spain and France.

It was in Savoy that the germ of Italian movements towards independence had its origin. In its young duke, Emanuele Filiberto (I 553), was revived that ancient strain of active, ambitious, efficient, and military princes by whom the mediaeval state had been gradually built up. Emanuele Filiberto had served Philip so well in Flanders that at the Peace of Cateau-Cambrésis he was allowed to recover the greater part of his duchy. Yet neither France nor Spain could easily endure to abandon it altogether, so important was its position to France as the 


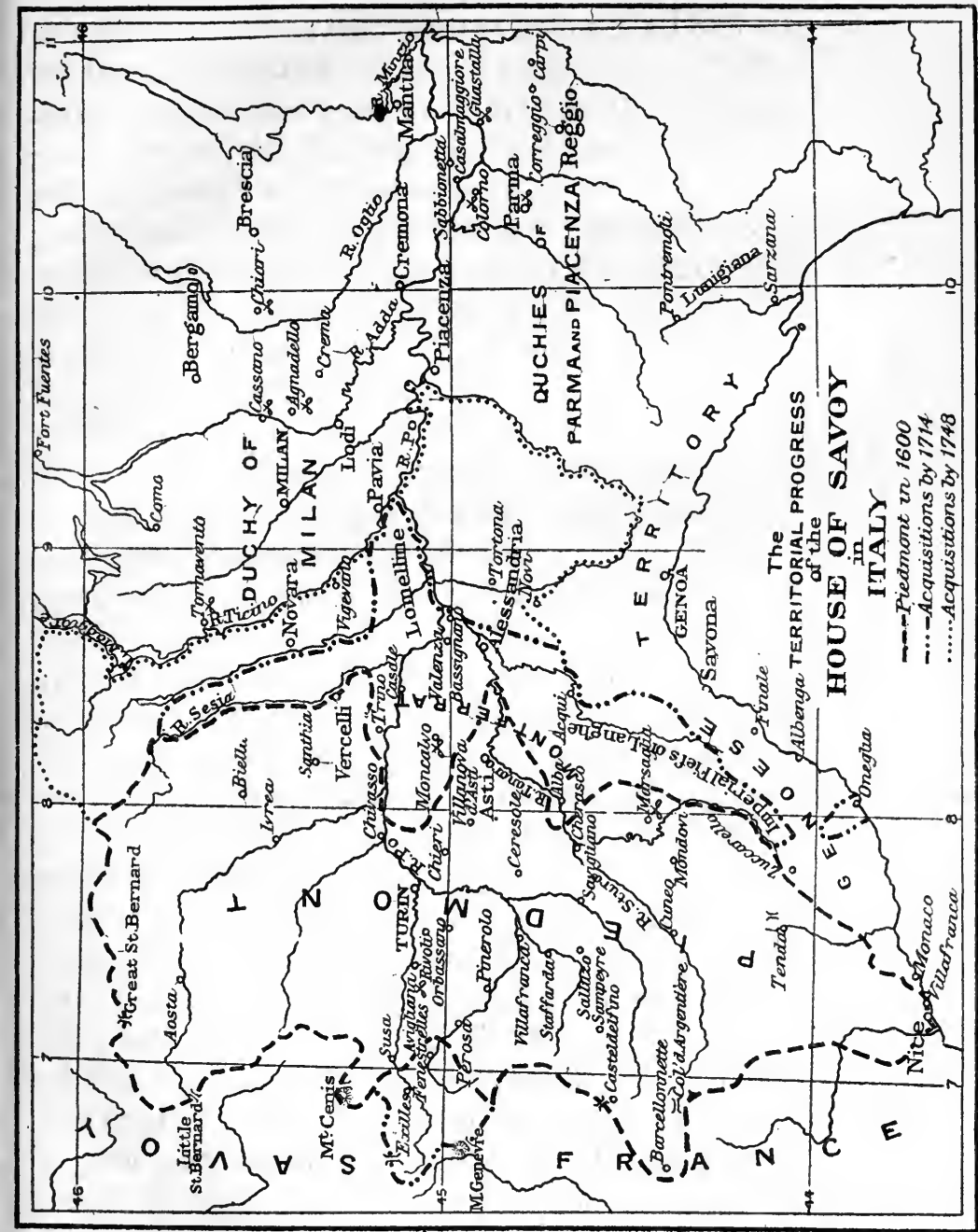


gate into Italy, and to Spain as the barrier against France, and as the main route between her northern and southern possessions. Hence France retained five fortresses which secured the passage of the Alps, and also the little Marquisate of Saluzzo, almost embedded in Piedmont; and to counterbalance this Spain garrisoned two other forts, so that Emanuele Filiberto was far from being master in his own states. Yet so skilful was his diplomacy that he recovered his fortresses by negotiation, conciliating France without alienating Spain; and he so reorganized his states and army that he commanded general respect and an independent position. 'He does not', wrote a Venetian, 'wish to be looked upon as a subject prince of Spain, but as a free though affectionate relation of His Majesty.' His son, Carlo Emanuele I, energetic, ambitious, and pugnacious, was not satisfied with his father's cautious policy. He wanted Saluzzo, Geneva and Montferrat, a possession of the Dukes of Mantua, and did not shrink from fighting for them. He seized Saluzzo, intrigued with the Catholic League, and invaded Provence, trusting that Spain would support his action; but Spain, cautious and jealous, never gave him adequate help; 'Spain aids him as a doctor feeds a sick man,' wrote a Venetian ambassador, ' enough to keep him alive, but not enough to make him lusty.' Carlo Emanuele could therefore make little resistance when Henry IV himself invaded Savoy, but what he could not keep by strength he gained by diplomacy. By the Treaty of Lyons (I60I) Henry surrendered Saluzzo to him in exchange for some of the western provinces of Savoy. Thus Carlo Emanuele gave up fertile plains and acquired 
rocky valleys; but the exchange was symbolical of the definite intention of the House of Savoy to become an Italian rather than a French power, and to obtain that mastery over the Alpine passes which should guarantee its independence.

This exchange also inaugurated the new policy of the Italian restored French monarchy, an endeavour to gain a footing policy of $_{\text {Henry IV }}$ in Italy by means of friendly alliances amongst the Italian States, thus gradually undermining the dominance of Spain, and replacing it by that of France. Henry IV was wise enough to make sacrifices in order to secure a friend upon his borders, and one who could open to him the gate of Italy. Another opportunity for his diplomacy immediately presented itself, a dangerous quarrel upon ecclesiastical questions between Venice and Pope Paul V. Spanish mediation had failed; Henry undertook the task and was successful. Carlo Emanuele was meanwhile growing exasperated with the selfish, tyrannical policy of Spain. ' Of all slaveries,' he wrote, 'there is none so bitter and unbearable.' By the 'Treaty of Brossolo (I6Io), Henry promised him help for the conquest of Milan on very easy terms. At the same time Henry was negotiating with the smaller Italian States, and there is no doubt that many of them had secret understandings with him. The attack on Milan was to begin on May 19, but on May I4 Henry was assassinated. Carlo Emanuele had to make a most humiliating submission to Spain. Once more the chains of Spanish domination were riveted upon Italy, and it was not until the time of Richelieu that France had strength sufficient to loosen them. 
Italy and However, with the death of Philip II, the Spanish Philip III. monarchy passed its zenith; the want of his centralizing control became apparent as Philip III and his ministers allowed the active direction of Italian politics to pass into the hands of successive governors of Milan and viceroys of Naples, independent, even defiant, of the central government. They abandoned the traditional policy of peace for Italy and government by judicious intermixture of favours with fear, and their intrigues, plots, and individual ambitions set all Italy by the ears. One governor of Milan tried to bully the Protestant Grisons into giving up their friendly relations with France and Venice. The Grisons controlled important valleys between Switzerland and Italy; the chief of these, the Valtelline, was inhabited by Catholics, and a later governor, using religion as a cloak for his aggression, stimulated them to rebel against their Protestant masters. Another governor promised to help Carlo Emanuele in an attack on Montferrat, but the Spanish government interfered and ordered both to refrain. Carlo Emanuele felt it more than he could bear to take orders ' as if he were a subject', and openly defied Spain (16I4). He and his little army fought with great courage, and, if they had received other support, might really have shaken off the Spanish yoke. 'This Power,' he wrote, 'appearing so terrible from a distance, will disappear like a shadow as we approach it.' But though he received a little help from France, no Italian State plucked up its courage to support him-most of them preferred peace under the aegis of Spain-and the opportunity was lost. Still, Carlo Emanuele had considerably increased 
his own reputation by his daring, and found that both Spain and France henceforth treated him with respect as an independent prince.

Even Venice, though goaded by piratical attacks upon her commerce, and actually at war with Austria for the possession of that eternal bone of contention, Gradisca, hesitated long to break the nominal peace with Spain. At last (1618), exasperated beyond endurance by the plots of the two governors with Bedmar, Spanish ambassador in Venice itself, she signed a league with Carlo Emanuele. But this alarmed the Spanish government, and the obnoxious conspirators were recalled. Thus matters stood in Italy when the outbreak of the Thirty Years' War and the advent of Richelieu to power opened a new chapter in European history.

Italy was too closely bound to the Hapsburgs to escape Early a share in the great struggle. Here, as elsewhere, religion was the pretext for their ambition, and accordingly they expected the Pope to act as their humble instrument. results of the Thirty Years' War. Hence the Valtelline, occupied by Spain under the pretence of freeing it from Protestantism, was ceded to the Papacy; but when Spain found it convenient she made peace with the Grisons and gave them back the Valtelline, thus demonstrating the insincerity of her religious pretences (1637). It is hardly surprising that the popes mistrusted Spanish zeal and were inclined to favour France. Urban VIII declined to join the Hapsburg League; he was certainly more afraid of strengthening the Hapsburgs in Italy than of weakening them in Germany. 'In Spain they consider me a heretic,' he said, yet he was none the less aggrieved at the idea of making 
concessions to the Protestants in Germany. The consequence of the narrow outlook and parochial policy of the Papacy was that in the final Peace of Westphalia it was totally ignored, and its objections to peace with the Protestants disregarded-a severe blow to its prestige.

As the Emperor grew strong in Germany he wished to re-vindicate the lapsed Imperial authority in Italy. An unfortunate succession question in Mantua gave him his opportunity and brought the horrors of the great war upon Italy. An Imperial army entered Lombardy and besieged Mantua, while France and Venice tried in vain to relieve it (1629). It was taken after a nine months' siege, and the three days' sack which followed forms one of the blackest pages in the annals of Teutonic barbarity. All Lombardy was treated with the utmost brutality, the subjects of Spain faring little better than those of the enemy; the requisitions of the army caused famine, and this was followed by the plague, spread over the country by the soldiers themselves. Manzoni's famous novel, I Promessi Sposi, gives an awful picture of the sufferings of the people. The successes of Gustavus Adolphus forced the Emperor to withdraw his army and leave Mantua to its French claimant, but not before Lombardy had been ruined for a generation.

Policy of Again Italy had to suffer vicariously for the enmity Richelieu. between France and Spain. Richelieu, slowly feeling his way to power, and constantly threatened by Protestant outbreaks at home, dared not attack Spain openly, nor was Spain any more anxious for direct war. But through Italy they could damage one another indirectly. Richelieu at first hoped much from an Italian system of alliances 
such as Henry IV had planned. He promised help to Venice to open the Valtelline Pass, and to Carlo Emanuele for an attack on Genoa, his old enemy and the close ally of Spain. But when it suited himself Richelieu made peace with Spain at Monzon (1626), completely disregarding the interests of his allies. Accordingly he had only himself to blame if his Italian friends were alienated. Carlo Emanuele never forgave him and threw himsel into the arms of Spain, not only refusing to help France to save Mantua, but also himself helping Spain to despoil the inheritance of the Gonzaga by seizing part of their territory of Montferrat, which he had so long coveted. Richelieu found himself shut out of Italy, with no road open by which he could relieve Mantua, or even Casale, the chief town of Montferrat, which the Spaniards were besieging. He decided that he must reverse the policy of Henry IV, and acquire an Alpine route at the expense of Savoy. Accordingly he seized Pinerolo, situated in an important position at the head of a pass, and then recovered Saluzzo, which Henry IV had once ceded to Carlo Emanuele. Just afterwards Carlo Emanuele died. It seemed as if his life-work were undone now that the French were once again astride the Alps, while Spain as usual withheld her promised aid. Indeed, it was many years before Savoy recovered the position which Carlo Emanuele's courage and energy had lately acquired. His restless ambition had led him into difficulties from which his less able son, Vittorio Amadeo I, had not sufficient skill to extricate himself. Accordingly, when the Emperor made peace with France (I630), Vittorio Amadeo allowed himself to be persuaded to acquiesce in the surrender of 
Pinerolo, thus giving up that independence which had been the aim of his father's policy.

With a French Duke of Mantua, a friendly Pope, and a road open into Italy, Richelieu felt strong enough to try again his scheme for an anti-Spanish league, and this time he was successful (League of Rivoli, 1635). Vittorio Amadeo was bribed by the promise of Milan with the title of King, Parma and Mantua joined, and the French invaded Italy, but with little result. The death of Vittorio Amadeo in 1637 delivered Savoy tied and bound into the hands of France, for Carlo Emanuele II was a child, and his mother Christine, sister of Louis XIII, was completely under French influence. Her position as regent was imperilled by her own folly and vanity, and by the efforts of the late duke's brothers, assisted by the Spanish Government and by the majority of the people, to oust her from the regency. Richelieu might have done what he pleased with her, but he bullied instead of humouring her, and drove her to desperate resistance by his demands for fortresses, even for the custody of her children. The military help he gave was not enough to protect her from her brothers-in-law. Piedmont was plunged in civil war, and ravaged by French and Spanish auxiliary armies. It was not until all parties were tired out and the country ruined that peace was made, the princes, disgusted with the niggardly treatment they had received from Spain, submitting to Richelieu's terms. Savoy, with her best fortresses garrisoned by France, was now little more than a French province.

Richelieu had certainly achieved the end for which 
he had striven. Though Spain still retained her Italian territories, the power of the Hapsburgs in Italy was shaken, and France had attained a great influence at small cost to herself. But France was feared rather than trusted, and her treatment of Savoy formed an objectlesson of what her friendship might involve. Hence, when Venice, Tuscany, and Modena formed a league to protect Parma from papal aggression (p. 300), they refused the suggestion of France that it should be converted into an anti-Spanish league, and declined French assistance.

The death of Richelieu and the accession of Mazarin Policy of to power might have created a more friendly feeling, for Mazarin was more conciliatory and courteous than his predecessor, and he gained credit by mediating successfully between the Pope and his enemies. But Mazarin still continued the policy of using Italy as a cat's-paw when at war with Spain, and neglecting to consult his Italian allies when negotiating for peace. No benefit accrued to Italy from the Peace of Westphalia (1648), since it did not end the Franco-Spanish war. Year after year hostilities dragged on in Piedmont, Montferrat, and Lombardy, the unlucky inhabitants suffering most in a quarrel which was none of theirs. Christine of Savoy had not the strength of will to extricate her son's states, while France still garrisoned several of her fortresses, and her brother-in-law, Prince Tommaso, was now in French service.

The Duke of Modena, who unwisely entered into the war on the French side, received little help, and was soon crushed into submission. Mazarin hoped to strike 
at Spain through Naples by encouraging the elements of revolt in that kingdom. With this object he sent Prince Tommaso to attack the Presidi (1646), dispatched a fleet in the hope of profiting by Masaniello's rebellion (p. 282), and later on sent Guise back with a fleet to try and stir up the revolt again (1655). But not any of these attempts were undertaken with much energy, and none had any success.

As at Westphalia, so in the Peace of the Pyrenees between France and Spain, the greater Powers negotiated without consulting their smaller allies, and procured for the latter just such terms as were advantageous to themselves and no more. No satisfactory settlement was made about Montferrat, which, with its valuable fortress, Casale, remained as a subject of contention to render any permanent peace impossible. Yet the North Italian States were thankful to welcome any respite after twentyfive years of war, and peace fortunately lasted for twenty years. Mazarin began to take advantage of it by encouraging more friendly relations. French troops were sent to help Venice in her war in Crete, Carlo Emanuele II and the Grand Duke of Tuscany were conciliated, and French wives were provided for the former and for the heir of the latter. The court of Savoy was now a small copy of Versailles. The young Duke of Modena had a French mother, and Mazarin took up the cause of Parma in its struggle with the Papacy.

Policy of Unluckily the death of Mazarin left French policy in Louis XIV the hands of Louis XIV, who demonstrated that ' France Louvois. was the premier Power in Christendom' in an arbitrary and provocative fashion which alienated all his neighbours, and his minister Louvois fell in with his evil policy. 
Louis was not content with reducing the smaller states to subservience, but wished them to feel and acknowledge their dependency. In consequence, when the next great wars began and France needed allies, she found in Italy only hatred and fear.

Louis began by deliberately provoking a quarrel with Pope Alexander VII on the question of ambassadorial immunities in Rome. By seizing Avignon and threatening invasion he succeeded in bullying the Pope into submission. He gained little by his triumph but the erection of a monument to keep alive the memory of the Pope's humiliation. After this the French Government exerted its influence in the Conclave to obtain the election of popes in its interest, but a more serious quarrel arose about the independence which the Gallican Church asserted against papal autocracy. Louis supported its claims and sent cavalry to overawe Rome; but the Pope, Innocent XI, resisted firmly, and has indeed been accused of subsidizing William of Orange against France. It certainly was the formation of the Grand Alliance which distracted Louis' attention, and so secured the Pope's safety.

Venice was strictly neutral, but she had no desire for an extension of French power. The smaller states Louis did not trouble to conciliate, but the Grand Duke, Cosimo III, was held in close, if uneasy, relation to France, on account of his troublesome wife, whom he could not control without the intervention of the French monarch. From the vicious and dissipated Duke of Mantua Louvois hoped to buy Casale. He was at the first attempt outwitted by a cunning minister, 
Mạttioli, who offered to sell it without the duke's authorization; but Louvois discovered the trick and contrived to seize Mattioli, who disappeared altogether. It has been conjectured that he was the famous 'Iron Mask'. However, Louvois soon afterwards succeeded in buying Casale from the duke himself, thus gaining that stronghold in the midst of Lombardy for which its neighbours had long contended. It seemed a great triumph, but none of his acts did more to embitter Italian feeling against him.

The selfishness and greed of his policy was most characteristically shown in his treatment of Messina and Genoa. The Messinese had revolted from Spain, and they made an offer of their city to France. They held out bravely, in spite of starvation, awaiting French help, but Louvois only looked upon the affair as a distraction to embarrass Spain, and when he needed the French fleet recalled it with ruthless disregard for the Messinese, whom he abandoned to the vengeance of Spain, not even making any terms for them in the ensuing peace. Genoa, weary of the bad faith and national bankruptcy of Spain, might willingly have lent her capital to France in exchange for protection. But Louis, jealous of her sea-power and commerce, attacked her shipping in the Franco-Spanish wars, and made her friendly attitude towards Spain an excuse for brutally bombarding the defenceless town (1683). Spain, far from interfering in her behalf, allowed her to be expressly excepted from the ensuing peace, so that the Doge himself had to ask pardon at the French court. But the moral victory was with Genoa, which had behaved throughout with dignity and courage. 
Savoy Louis intended to treat as a subject-province. Carlo Emanuele was peremptorily forbidden to touch France and Savoy. Geneva, was obliged to send some regiments to serve in France, and, when he attacked Genoa, was ordered to desist. In 1675 he died, leaving his little son, Vittorio Amadeo II, with his mother as regent, but virtually under French guardianship. Louvois bullied the duchess into submission to French dictation, and when France bought Casale she felt utterly helpless, 'imprisoned between it and Pinerolo'. Still, she would make almost any concession while France helped her to retain the regency and keep her son in subjection; but the lad was too clever for her and made a higher bid for Louis' favour. He married a French princess and seemed perfectly submissive; Louis believed him to be stupid and dissipated. Although, in the impending struggle between France and the Grand Alliance, the adhesion of Savoy was of immense importance for securing the road into Italy, Louis made no attempt to win the young duke's attachment, but continued to coerce, hector, and insult him, even forcing him to persecute his own subjects, the Protestant Vaudois. When the war began (I690), Catinat's army was sent to demand passage through Piedmont. But Vittorio Amadeo II, with an extraordinary secretive cleverness, had long been planning to free himself from French domination. While pretending compliance he was secretly negotiating with the League of Augsburg through his cousin, Prince Eugène, and preparing an army and fortifications. At the last moment he rejected Catinat's demands and definitely joined the League. Louvois now offered concessions, but they were 1832.3 
refused, and France was thus at the critical moment cut off from Lombardy.

War of The wars of I690-I7I4 brought two important Rise of the changes to Italy, the change from Spanish and French to power of Austrian domination, and the emergence of Savoy from
Savoy. its dependence on France to the position, not only of the first state in the peninsula, but of a European Power whose alliance was courted, and whose interests were considered in all peace negotiations. This was due to the skill and energy of the duke, and to his success in creating in his subjects a military spirit inspired by fervent patriotism and personal devotion. The Piedmontese, no longer the unhappy scapegoats of European quarrels, became a united nation, maintaining their independence and holding powerful invaders at bay. We cannot describe the details of the campaigns and diplomacy of these eventful years, but only briefly trace the stages of Vittorio Amadeo's career and his accessions of power.

In I690 Catinat seemed about to occupy the whole country as other French generals had done; the allies, who under-estimated the importance of Italy, delayed in sending help, and the Emperor, always jealous of Vittorio Amadeo, deliberately withheld it. But Piedmont resisted gallantly, and gave France so much trouble that Louis, who had been obliged to restore Casale to Gonzaga lest the Austrians should conquer it; was before long willing to come to terms. Louvois was now dead, and Louis consented to give up Pinerolo, though it was very bitter to him to cede territory to the adversary whom he had despised. By immediately joining forces with 
France, Vittorio Amadeo obliged the allies to allow. him to negotiate an Italian peace and obtain the withdrawal of the Austrian army from Italy (1696).

The Treaty of Ryswick (I697) confirmed Vittorio Amadeo's position. Free from the menace of the French at Pinerolo and Casale, he took his place henceforth as a European monarch, and both parties wished for his friendship and encouraged him to hope for a share in the Spanish inheritance, to which he had a remote claim through his great-grandmother. However, when Louis accepted the whole inheritance for his grandson, he offered no territory to Vittorio Amadeo, but only the hand of Philip V of Spain for his daughter. Vittorio Amadeo accepted unwillingly, for he always coveted territorial acquisitions; he disliked fighting against Prince Eugène and he quarrelled with his new son-in-law. $\mathrm{He}$ was soon again negotiating with the allies, who offered him Montferrat and a piece of Lombardy, but this time he was not quick enough in his change of alliance to delude the French, and Vendôme was able to invade Piedmont successfully (1704). Soon only Turin remained untaken; Eugène endeavoured to come to its relief, but was long kept back by the French armies in Lombardy. Turin held out gallantly; and when, after Ramillies, Vendôme was called home, Eugène burst through the French and arrived in time to save the city (1706). He and Vittorio Amadeo completely routed the French, and then turned back to conquer Lombardy. However, the Emperor refused, in spite of the entreaties of Marlborough himself, to give up all the Lombard towns which Vittorio Amadeo believed to be his share, 
so that after 1708 the duke, though he would not fight for the French against Eugène, would no longer help the allies.

England embraced his cause warmly, and he began to hope that she might obtain Milan for him, but to this the Emperor would never agree. The Congress at Utrecht even considered the possibility of making Vittorio Amadeo King of Spain; finally England, anxious that neither Spain nor Austria should command the Mediterranean, induced the Congress to give Sicily to Vittorio Amadeo with the title of king. As he had no fleet and the Sicilians very much objected to the transfer, the value of its acquisition seemed doubtful, but his ambition to be a king was satisfied. The Emperor was very angry, but could not prevent it. He refused to guarantee Vittorio Amadeo's new acquisitions by the Treaty of Utrecht, but the duke was nevertheless in effective possession of Sicily and of a considerable slice of Lombardy, was free from the threat of the French within his borders, and had the title of king. Far from being a French province, Savoy was now an independent nation, and the only state in Italy which possessed any vitality or promise for the future.

Revival of No less important a change for Italy was the revival Austrian and Imperial authority in Italy. of the Imperial power, consequent upon the efforts made by the emperors to acquire the Italian possessions of Spain. Spanish influence had become very weak; but in 1690 Spain still held Milan, Naples, and Sicily, and the Austrians were now the efficient, not the effete branch of the House, and might reassert the ancient Imperial claims to suzerainty over parts of Italy which 
had long been independent. An Imperial army soon descended upon Italy (1690), demanding feudal contributions everywhere, and meeting with little resistance. France laboured in vain to form an anti-imperial league; for, though the Emperor was feared, Louis was still more disliked and distrusted, and only the worthless Duke of Mantua clung to France for the sake of her bribes. The popes were timid; Venice, though not wishing for Austrians in Lombardy, was bound to Austria by their 'Holy League' against the Turks.

The Emperor had to agree to Italian neutrality in I 696 and withdraw his army, but he had already secured some of the wavering princes by Hapsburg marriages. Accordingly when, in I 701, Louis looked for allies to help him to secure the Italian part of the Spanish inheritance, the only prince who was really on his side was Gonzaga, who sold Mantua to him outright. The Grand Duke recognized Philip V in order to obtain the investiture of Siena, but would never fight for him. Most of the others declared themselves neutral; they would not risk anything for either claimant, but only dreaded war in their own territories. Venice, nominally neutral, was illtreated by both armies alike. Pope Innocent XII had indeed advised Charles II to leave his states to Philip, mainly because the Papacy had less to fear from Louis' grandson than from the Emperor; but, when the struggle began, Clement XI refused the investiture of Naples and Sicily to both claimants, with the result that both dispensed with it altogether, and ultimately ignored his claim to bestow it.

In I70r a new Imperial army was in Italy; but the 
French were the stronger until in I 706 Eugène relieved Turin, and rapidly conquered Milan and Mantua, thus finally ending the decadent and effete rule of the Spaniards and Gonzaga in Lombardy. The Milanese, at first terrified of the Austrians, had now experienced enough of the debauchery and domineering manners of the French to make them welcome new masters. The Neapolitans received the conquering Austrian army enthusiastically, and helped to drive the hated French from the peninsula. The Duke of Modena was rewarded for fidelity, the Duke of Parma punished for equivocation, the Grand Duke made his peace with some difficulty. It only remained to punish Clement XI for his refusal to recognize the archduke; an Imperial army threatened Rome and Clement retired hastily to St. Angelo. But the Emperor had no wish to outrage public opinion by another sack of Rome, and the Pope escaped easily at the price of recognizing the archduke, thus practically acknowledging two kings of Spain at once.

Austria seemed to dominate all Italy; and though the accession of the Archduke Charles to the Empire in I 7 I made the other Powers unwilling that he should be King of Spain, yet they were prepared to compensate him for its loss by allowing him to retain his Italian states. The Emperor's obstinate determination to be satisfied with nothing less than the whole Spanish inheritance caused his exclusion from the negotiations at Utrecht, but the terms he received in the final Peace of Rastatt were not unfavourable. Naples, the Presidi, Sardinia, Mantua, and all the Milanese, except the slice ceded to Savoy, were to be his. On Savoy he was determined to 
be revenged some day, but for the present he had to guarantee the neutrality of Italy. Certainly he had the lion's share of the peninsula as his property, and had every opportunity of pressing ancient feudal rights over Imperial fiefs, which might be held to include nearly the whole of Italy. He dreamed of a return to the days of the Hohenstaufen, and that without fear of papal rivalry. But his dreams were illusory, for in 1714 Austria had reached the limit of her power, and had no strength for further efforts. A renewed acquaintance with the hated Germans revived their unpopularity in Italy, and their rigid, meddlesome rule was contrasted unfavourably with the easy-going methods of the Spanish Government in its later years. Italy became rather a drag upon than a source of power to Austria. The Italian possessions of Austria made her more vulnerable to attacks from France and Spain, and she had also to reckon with the growing power of Savoy. Thus, even before the troubles of the Austrian succession began, the Emperor was losing ground in Italy. France was indeed for many years too weak to interfere there, but the new Spanish monarchy inherited the ideas if not the possessions of the old.

Spanish policy was now inspired by Philip's second wife, Schemes of Elizabeth Farnese, only child of the Duke of Parma, and Farnese. by her ambitious minister, Alberoni, also from Parma. As Philip's son by his first wife would inherit Spain, Elizabeth wished to carve out states for her own children in Italy, and Alberoni believed that this would be more advantageous for Spain than to possess them herself.

The succession to Tuscany and Parma was the question on which the struggle between Spain and Austria must 
soon turn. The direct male line of the Medici was dying out; the Duke of Parma was nearest in succession, but he had no male heirs. Siena was certainly an Imperial fief, but the Medici had always maintained Florence to be independent of the Empire. The Emperor, on the other hand, claimed Imperial rights over all Tuscany and over Parma also. Elizabeth wanted both for her sons, but she wanted still more than these. In I717 Alberoni seized Sardinia by a trick and then attacked Sicily. The Sicilians welcomed the Spaniards, but the other Powers interfered, and forced Philip to dismiss Alberoni and to relinquish his conquests, while Vittorio Amadeo had reluctantly to surrender Sicily to Austria and take Sardinia, a much less valuable property, instead (1720). Elizabeth was, however, by no means daunted: she boldly made advances to the Emperor himself; and he, anxious that Spain should guarantee the Pragmatic Sanction, promised her Tuscany and Parma for her eldest son, Charles. Finally, after fresh quarrels and negotiations, Charles was allowed to take possession of Parma, and was cheerfully received in Florence as heir of Tuscany (I732).

'War of But this was no stable settlement. Elizabeth wanted tiae Polish more of Italy, and many Italians wished to be rid of the sion' in Austrians; therefore as soon as France and the Emperor quarrelled about the Polish succession, the war spread to Italy (1733). Once more the alliance of the Duke of Savoy, now King of Sardinia, became important. Vittorio Amadeo had abdicated, but Carlo Emanuele III had equal abilities with, perhaps, more prudence. France hoped to unite Sardinia and Spain in league with 
herself, but their claims were irreconcilable, for Elizabeth coveted Lombardy, and Carlo Emanuele would never submit to have a Spaniard both there and in Tuscany. Fleury made a separate treaty with each; he promised Milan to Carlo Emanuele, a promise which he never meant to keep, and thus obtained valuable assistance in its conquest. For a time Carlo Emanuele felt as if the ambition of his House to rule Lombardy was to be realized; but he soon discovered the terms of Fleury's treaty with Spain, and though he was still victorious in the war, his success gave him no further satisfaction. He was sure that he could not now expect to keep Milan; and to conquer Italy for Bourbon-Farnese princes, who must certainly remain under the influence of France and Spain, would be more dangerous to Savoy than to leave part of the peninsula to Austria.

The collapse of the Austrian power in Italy seemed complete; Carlo Emanuele had taken Milan; next the Spaniards conquered Naples and Sicily with little difficulty. They were eagerly welcomed by the people, who, in spite of all its abuses, preferred the Spanish government to any other. Philip made over the two states to his son Charles as an independent kingdom; with a king of their own it seemed as if the people might have a chance of future good government and prosperity.

Neither Elizabeth nor Carlo Emanuele was satisfied with the peace which Fleury negotiated in 1735, Carlo Emanuele because he got only Novara and Tortona instead of all the Milanese, and Elizabeth because her son had to be contented with the Sicilies only. The Emperor kept the remainder of Lombardy, and his son-in-law, the 
Duke of Lorraine, was to have Tuscany and Parma,-not because he had any hereditary claim to them, but that he might give up his duchy of Lorraine to France. Only France was satisfied; but all knew that the peace would be nothing but a truce lasting until the death of the Emperor should open the question of the Austrian succession.

- War of Austrian Succession' in Italy.

Once again Fleury strove to make Sardinia and Spain co-operate, but Elizabeth had all the dread of the petty Italian prince for the successful House of Savoy, while Carlo Emanuele dreaded Bourbon ascendancy and resented the unreasonable greediness of Elizabeth. $\mathrm{He}$ now claimed Milan on the strength of a diploma which had been discovered, settling it in default of male heirs on the daughters of Philip II, one of whom was his greatgrandmother. Elizabeth wanted Tuscany and Milan for her second son, Philip. Meanwhile, England was offering subsidies to Carlo Emanuele if he would join her alliance with Maria Theresa, but the latter also was obstinate and disliked to cede territory to Sardinia. For a time Carlo Emanuele defended North Italy without any regular alliance, but in $\mathbf{1 7 4 3}$ Maria Theresa consented to the 'Treaty of Worms, by which Carlo Emanuele was to receive Lombardy up to Lake Maggiore and the Ticino, with parts of Pavia and Piacenza, and might take from Genoa the port of Finale, which he coveted in the hope of making a sea-power of Piedmont. France retaliated by promising to try and conquer Milan, Parma, and Piacenza for Don Philip.

Carlo Emanuele was attacked on both sides at once; Don Philip easily occupied Savoy, thus again proving its 
indefensibility, while Neapolitans and Spaniards advanced from the south. Genoa, frightened by the Treaty of Worms, joined the Bourbon League. Fortunately for Carlo Emanuele, England was able to draw off one of his enemies. An English squadron appeared off Naples, and gave Charles two hours to decide whether he would see Naples bombarded or recall his army. He chose the latter alternative.

The Austrians were of little value; their military power in Lombardy was small, and what they had was frittered away in a useless attempt to invade Naples. They fancied that the Neapolitans would rise in their favour, but were completely disappointed. Since England was now absorbed by home troubles, Carlo Emanuele found that he must rely on himself and his people; and the Piedmontese, pleased to fight against their old enemies, the French, responded nobly to his call. Once again Cuneo successfully defied a French besieging army. But in spite of gallant resistance, the French and Spaniards conquered a great part of Piedmont and Lombardy; in $\mathbf{I} 745$ they took Milan, where the people received Don Philip with pleasure. Carlo Emanuele's position seemed desperate, but a combination of diplomatic and military skill extricated him from it. While preparing to unite with Austria in a fresh military effort, he occupied France, with negotiations; the French minister, d'Argenson, thought that he could trick Carlo Emanuele and bully Elizabeth into acquiescence with his schemes, but he was beaten by the cleverness of the one and the obstinacy of the other.

Suddenly Carlo Emanuele and the Austrians relieved 
Alessandria, which had held out against a long siege, and immediately afterwards the Austrians recovered Milan.

At this juncture the death of Philip $\mathrm{V}$ ended the political career of Elizabeth Farnese. The new king was not anxious to conquer any more of Italy for his half-brothers; the Spanish army was withdrawn, the French soon followed, and a peace congress was opened.

Genoa was thus left at the mercy of her enemies. The Austrians, led by a Genoese exile, Botta Adorno, seized the city and ill-treated the people, while Carlo Emanuele occupied Finale. But the Genoese populace rose in arms, expelled the Austrians, and resisted all attempts at recapture until a joint French and Spanish army was able to relieve them.

Peace of Aix-laChapelle and its results.

As far as Italy was concerned the negotiations at Aix turned chiefly on the question of providing for Don Philip. France suggested that he should have Savoy and Nice, Carlo Emanuele taking Parma and Piacenza in exchange; but Carlo Emanuele, though he owned that he could not defend Savoy in war, would not give up the cradle of his race, nor the people who were attached to him. Austria would allow Philip to have Parma, but Carlo Emanuele claimed Piacenza. It was suggested that if, as was probable, Charles of Naples should succeed to the throne of Spain, his brother Philip might have Naples, but Charles wanted Naples for his own younger son. By the Treaty of Aix-la-Chapelle, Philip received Parma and Piacenza, and he retained them when Charles actually succeeded to Spain and left his son, Ferdinand, as King of Naples ; but the question of Carlo Emanuele's claims on Piacenza continued for many years to form the 
main concern of Italian diplomacy, until in 1763 Carlo Emanuele unwillingly accepted pecuniary compensation for them.

The Treaty of Aix left Carlo Emanuele in a very strong position; he had acquired a new piece of Lombardy, and had gained general respect by his late achievements. He was on good terms with the great Powers, especially with England, and his son was married to a Spanish infanta. It was unfortunate that he and the Italian Bourbons could not settle their differences and work together for Italian independence. It was a good opportunity, for foreign domination had reached its lowest point since 1494. But they always continued mutually jealous and hostile. Carlo Emanuele III had once said that he would devour Italy like an artichoke, leaf by leaf, and to judge by their attitude it seems as if the Bourbons always believed Sardinia capable of the feat.

The new arrangement of Europe in the Seven Years' War, while it saved Italy from active participation in the struggle, considerably detracted from Sardinia's importance. Far off from England and Prussia, it was shut in between the allies, Austria and France, who had no need of Carlo Emanuele. His position was still worse when Naples joined their party; the four Bourbon States mutually guaranteed one another's safety and possessions, and Naples surrendered the Presidi to Tuscany in return for Austria's protection of its boyking. Austrian influence throughout the peninsula was revived by the marriages of Hapsburg princesses to the King of Naples and the heir to Parma, and still more by the passing of Tuscany to Leopold of Austria as heir to 
the Duke of Lorraine, while Leopold's brother was married to the heiress of Modena. Thus Austria regained much of the power she had lost with her South Italian possessions, and though actually only holding Lombardy, she was still the chief Power in the peninsula at the beginning of the French revolution period.

Venice and the Turks.

Considering the former prominence of Venice, her part in Italian politics after 1527 appears very insignificant. The war of Cambray weakened her considerably, and warned her to avoid European politics as far as possible. In this she was generally successful, though in the seventeenth century she had a war with Austria and intervened in the Grisons affair, while her states, lying between Austria and Lombardy, often suffered when she was neutral. The waning strength of Venice was wholly absorbed in struggling to maintain her trade against pirates and rival commercial states, and her possessions against the Turks. Newly discovered trade routes and the dangers of the Eastern Mediterranean had diverted the world's commerce from the Adriatic; England, Holland, and Genoa were supplanting her in the carrying trade. Her own exaggeratedly protectionist policy hastened the process ; and though, in the seventeenth century, she slightly relaxed this, reform came too late. Again, her commerce suffered terribly from the marauders of the African and Dalmatian coasts. As they were not under the control of the Turkish Government, formal peace with the Porte was no protection, while the Dalmatian pirates were often encouraged by Austria. Yet open war with the Turks was still more ruinous to Venice; her forces and wealth were small 
compared with the inexhaustible resources of the enemy; and though her sailors were brave, in land fighting she had to rely mainly upon undisciplined natives and untrustworthy mercenaries. She had at first the advantage upon the sea, as the Turks were not a nautical people; but in the sixteenth century they created a vast navy, which, though constantly defeated, could never be destroyed. "You can stop wedding the sea now, it is our turn,' wrote the Sultan to the Doge.

If Venice could have secured the co-operation of Spain, Austria, and Italy in a joint crusade, the advance of the Turks might yet have been stopped, but mutual jealousies and the distractions of European war prevented this, and a state of war between Venice and the Turks was often an opportunity to English and Dutch merchants to supplant Venice in Eastern trade.

Unluckily, Venice had grown timid; her obvious dread of war emboldened the Turks to attack her, and her fear of meeting them single-handed often caused her to lose opportunities while waiting for European aid, which, if it ever came, was of little value. Hence, when the Turks attacked Cyprus in 1570, Nicosia was taken while the Venetian fleet awaited Spanish reinforcements. When they arrived the Spaniards refused to fight, so that Famagosta, which had bravely resisted for a year, fell also, and the whole island was lost. Two months later the Venetians and Spaniards gained an empty triumph over the Turks at Lepanto, but Venice had to make peace soon afterwards. 'Lepanto', it was said, 'might have been a Turkish victory.'

When in 1644 the Turks attacked Crete, Venice 
received little help from Europe, except a few irregular French troops which were soon destroyed by their own rashness; however, she was far more successful when she relied only upon herself. Candia, 'Troy's rival,' stood a siege of seventeen years, while the Venetians' ships, in their efforts to cut off the Turks from their army in Crete, won great battles, sailed the Aegean unopposed, even blockading the Dardanelles, and did deeds of individual daring which recall their earlier heroic days; yet at last Venice was exhausted by the superior forces of the Turks. Candia, reduced to ruins, surrendered in I669, but Venice gained an honourable peace, retaining a strip of Dalmatia which she had conquered during the war.

She was emboldened to join the Austrian 'Holy League' in its great war in I683, and, since the Turks had now other distractions, the Venetians, under Francesco Morosini, the hero of Candia, conquered the Morea and besieged Athens, the occasion on which the Parthenon was accidentally destroyed. Once more Venice commanded the sea and blockaded the Dardanelles, but the death of Morosini removed her best leader ; and in 1699 the Austrians, victorious on land, made peace without safeguarding Venetian interests. She was allowed to keep the Morea, but she found the Christian peoples, who had eagerly welcomed her, most troublesome to govern; they hated Latin Christianity and seemed to prefer Turkish anarchy to Venetian order. They would not help Venice when the Turks successfully invaded the Morea in I7I4; and though Austria seized the opportunity to attack the Hungarian Turks, she made peace as soon as she was herself satisfied. Venice had to cede 


\section{External Politics}

the Morea and nearly all her eastern possessions, except those on the Dalmatian and Albanian coast, where the descendants of her settlers still form a large proportion of the population. Her great struggle was over, and, as 'Trade follows the Flag', with it her commercial supremacy. Yet her gallantry as the outpost against barbarism had gained for her the respect and forbearance of Europe, and her neutrality was generally respected during those destructive wars which spared no other part of Italy. 


\section{Internal Politics and Administration}

Political life and Spanish influence in Italy.

Nothing in eighteenth-century history is perhaps more striking than the diplomatic cynicism which dealt out states, regardless of the feelings or interests of their inhabitants, as if they were counters in a game. Carlo Emanuele's attachment to Savoy when he might have advantageously bartered it away was considered sentimentality. Cosimo III de' Medici, when negotiating about the succession of his duchy, was stimulated by his dislike of Imperial overlordship, and perhaps by a prick of conscience, to declare that his ancestors had received the sovereignty from the people of Florence, and that it ought to revert to them. But such a theory was ignored by the scheming diplomatists at Utrecht. Hardly less remarkable is the apparent indifference of the people concerned to their many changes of master. Sometimes they welcomed a new one in hopes of better government, but they often learned by experience that no new government was likely to be better than the last. They had special prejudices-the Neapolitans against the French, the Milanese against their neighbours from Piedmont-but few preferences; though the nobles generally liked a distant master who did not interfere with their local tyrannies. The attachment of his subjects to the Duke of Savoy, and the loyalty of Venetian Lombardy-the best-governed state in Italy-for Venice, 
were the exceptions. How this state of things came about we can learn by a brief study of the administration of both native and foreign rulers during the period before us.

In comparison with the rest of Europe, Renaissance Italy had been particularly full in its political life, the nearest parallel in fact to classical Greece. But the very exuberance of its vitality gave it a deceptive appearance of strength ; it was in fact morally and physically decadent, and had no stamina to resist the blows of nations less civilized but more efficient in military organization. It was only the republics, Venice, Florence, and Siena, that made any effective resistance; and, far from uniting against the invader, they rejoiced to see one another in difficulties. Indeed, from the first it was with extraordinary indifference that one state watched the ruin of another, seemingly unconscious that its own turn must come. The whole foundations of civic society, its local princes, its city states, its merchant nobles and widespread commerce, upon which the fabric of Italy's great age had been built up, fell like a house of cards before a gust of wind. There only remained the institutions of which Spain approved, for example the Papacy and the feudalism of the centre and south; while Venice and Genoa were spared, the one as a bulwark against the Turks, the other as a state bank for Spain. With meek receptivity the Italians adopted Spanish standards of life and manners. The princes, infected with Spanish pride of place, contended for ceremonial precedence; their courts became little imitations of the Spanish in elaboration of etiquette. The merchant nobles, infected with Spanish contempt for trade, abandoned their careers, bought patents of 
nobility, which were freely disposed of by the impecunious Emperor, and lived at court, wasting the wealth of their fathers. The lower classes, ruined by the depredations of the soldiery and the loss of trade, were too weak to revolt. And the change of character which Spain initiated was stereotyped by the Counter-Reformation.

Influence of the Reforma. tion.

The

CounterReforma. tion.

The soil of Italy was not naturally favourable for the seeds of the Reformation. The Papacy and Curia firmly set themselves against a movement which must begin with reforming them nearly out of existence. Very cleverly the earlier popes evaded the Emperor's pressure for a council, and, when it could be eluded no longer, manœuvred it into a council, not for doctrinal reform, but for defining Roman orthodoxy and imposing it as an inflexible standard upon the churches of her communion. They were supported by nearly all the Italian clergy, who would lose much and gain nothing by a change; and by the bulk of the people, to whom the Church presented a lucrative career for intelligent but impecunious youths, while the convents sheltered unmarriageable daughters, and the papal funds were a safe and profitable investment in an age of financial insecurity. Widespread indifference to religion, the prevalence of crime and immorality, and the scepticism induced by humanism, made the Italians careless of the need for moral reform. Yet there were exceptions, and certain reform movements made their appearance even in Italy. First came a movement towards disciplinary reform, initiated by the better type of clergy, amongst whom was Reginald Pole. They would willingly have made some concessions to the Protestants, but their hopes of re-uniting Christendom 
were thwarted. Yet largely under their influence great changes took place in the character of the Roman Church and Papacy. Considerable disciplinary reforms, some of them recommended by the Council of Trent, were carried through by popes of strong will and severity, such as Paul IV and Pius IV. New preaching Orders undertook the reconversion of Italy. Most prominent amongst these were the Jesuits, who, by their system of education, imposed their type of unquestioning orthodoxy upon the growing generations. The old abuses and immorality of the papal court became impossible. Though Roman life was riddled with secret corruption and hypocrisy, it became necessary to conform, outwardly at least, to a standard of respectability.

Secondly, there were amongst the more thoughtful Italians cravings for doctrinal reform, generally the outcome of the freedom of thought inculcated by humanism. The earliest of these philosophical speculators did not come into conflict with the Church. Others were more strongly impregnated with Protestantism, and in Lucca and Siena there were definite Protestant movements; in Siena the leader was the Vicar-General of the Capuchins, Bernardino Ochino, a famous preacher. There was also a revival amongst the poorer classes of the mystical teaching of the Franciscans, and even of the Waldensians, which was particularly strong in the sub-Alpine valleys of Lombardy. The mass of the population was unaffected, but there was quite enough heresy to alarm Philip of Spain and the Church. In 1542 Paul III reconstituted the Inquisition, which had become almost obsolete in Italy; its first 
president, the ruthless Cardinal Caraffa, at once attacked the heretical leaders. Many, including Ochino, escaped from the country; others were taken and burned, their followers generally recanted. When Caraffa became Pope Paul IV the Inquisition grew stronger, and Pius V, who had also been Inquisitor, completed his work. To destroy the Waldensians, Philip II tried to establish the Spanish variety of the Holy Office in Lombardy; but the usually submissive populace showed such dangerous opposition that he abandoned the design. The task was undertaken by the nephew of Pius IV, Cardinal Borromeo, the most eminent figure of the Counter-Reformation. Of stern and lofty character, upright, learned and devout, he was most active in the disciplinary reform of the Church, while persecuting the Waldensians with relentless cruelty.

The last notable heretic was the pantheistic philosopher, Giordano Bruno, burned in 1600 , not as a Protestant, but as a freethinker. Protestantism in Italy had disappeared; Spanish influence and Jesuit education, the Inquisition and the Index, had killed all philosophical speculation, all freedom of thought and of speech, and with them all the political consciousness of the people and their desire for political activity.

Internal It will be well to review shortly the governments of politics and government of Venice. the different Italian States, touching on the more important points of their individual history. Venice, almost exempt from papal and Spanish influence, was undoubtedly the happiest. The government was stable, reserved and dignified ; the people steady, self-controlled, and devoted to the service of the State. This patriotism 
extended to the people of the subject provinces, who appreciated good government and dreaded foreign conquest. Commercial prosperity, personal security, and the protection of law existed both for town and provinces when the rest of Italy was ruined and distracted by war; the Renaissance accordingly endured much longer in Venice than elsewhere. In Venice alone freedom of thought continued; the Inquisition, controlled by a lay commission, had little power. The subjection of the clergy to lay jurisdiction led to a violent quarrel with Paul V (I606). ' I am Pope and demand obedience,' Paul exclaimed, and proclaimed an interdict. Not even the clergy took any notice of it. Venice might have become Protestant had not Paul thought it wiser to submit to French arbitration before she was driven too far. The leader of the opposition was a famous monk, Paolo Sarpi, learned, independent, patriotic, and idolized by the Venetians. He wrote works against ecclesiastical abuses and a history of the Council of Trent. In the eighteenth century Venice was involved in two or three quarrels with the popes by her high-handed use of her ecclesiastical rights, but her position in these matters was so well established by custom that the breaches did not become serious.

But decadence fell upon Venice at last. Corrupted by their own wealth the nobles became idle and dissipated. Though they could still fight on an emergency, they abandoned trade as derogatory to their dignity, and thus contributed to the ruin of Venetian commerce. Venice, with its security, comfort, and splendour, became the pleasure-resort of all the idle rich of Europe, and 
though order was preserved, manners and morals deteriorated. With idleness many of the nobles became poor, and then discontented with the government which repressed their disorderly conduct. In the Grand Council they formed an opposition to the Dieci, which was the actual governing body of the republic, and still more to the small inner committee of the Dieci, the Inquisitors of State. This committee had at first been appointed to deal with treason cases; by degrees it had become responsible for public order; its proceedings were secret, and it inspired great awe. By the eighteenth century the Inquisitors were more powerful than even the Dieci.

The discontented nobles were reinforced by pioneers of the new Liberal movement of that age, who wished to abolish secret tribunals and to establish open courts of justice as in other modern states. In 1746 the Grand Council refused to elect Dieci at all; but the people, who trusted to the Inquisitors to keep the nobles in order, wished for no change. After much agitation and debate, a moderate scheme of reform was adopted, and the Venetian government appeared as settled and safe as it had ever been. But beneath the surface there was corruption and discontent, and there was no real strength left to face the coming shocks of the Revolution.

The At the other end of the scale came the Spanish depenSpanish dencies. The chief objects of their government appeared
dependencies. to be to provide quarters for Spanish troops and posts for Spanish officials, who came ' in order to pay their debts', and seldom had to present accounts to the home government. The 'Council of Italy' at Madrid was supposed 
to control them, but they were generally almost independent. One of them, Osuna, might have made himself King of Naples, but that the people would not support him. They always thought that bad government was due to the officials, and believed that ' if they could only build a bridge to communicate with his Majesty', all would be well. The nobles, who could tyrannize over the people without interference, preferred a distant government- 'the King far off, the people weak,' was their motto. At the same time, the military spirit of the Neapolitan and the commercial instincts of the Lombard nobility were destroyed by the Spanish method of attracting them by titles and petty offices to a lazy and frivolous life in the towns, where they squandered their money and lost their former independence. Another way in which Spain strengthened her hold was by following the maxim, 'Divide et impera'; for she was skilful in keeping up class and local divisions in order to avoid any union against herself. So the nobles were suffered to oppress the poor; local jealousies, such as that between Messina and Palermo, and ancient feuds, such as that of Guelphs and Ghibellines, were fostered, and the towns favoured at the expense of the rural districts. The taxation, which was enormous, fell mainly upon the peasants, the nobles and clergy escaped, while prices were kept down to conciliate the city populace. The taxes were farmed out to Genoese money-lenders, who made more profit than the government. The revenue of Lombardy was said to be 'more than many princes get from great kingdoms', yet the rapacity of the government was never satisfied. Large districts went out of 
cultivation; the peasants flocked to the cities to beg, or became brigands. The country was in fact overrun with robber-bands, who were in league with their peasant friends, and whom the government quite failed to suppress. At the same time the coasts were harried by pirates. Famine was endemic, and naturally culminated in outbreaks of plague, which were made worse by the criminal folly of the government in refusing to recognize the danger until precautions were too late. The worst of these epidemics were at Naples in 1656 and in Lombardy in 1630; the latter was the result of the siege of Mantua and of a fearful famine (p. 250).

And in spite of special privileges the towns did not flourish, so perverse, even ridiculous, was the government's fiscal policy, with its customs and trades' regulations which ruined the commerce they were supposed to protect. The industrious merchants and artisans of Lombardy sometimes emigrated in despair to Venice or France. Nor did the towns escape famine when bad seasons made it impossible to keep down prices. In I62I there were bread riots in Naples which were ruthlessly suppressed; in 1643 a gabelle on fruit, the staple article of the Neapolitan's diet, led to a very dangerous rising, called after its leader Masaniello, a half-savage demagogue. Nobles were murdered, the Viceroy terrified into promising concessions. But these promises were broken, and a Spanish fleet bombarded the town. The mob proclaimed a republic, and, unfortunately for themselves, fixed upon that unstable adventurer, the Duke of Guise, as their leader. Mazarin, who distrusted both Guise and the rebels, would not give serious support; Guise 


\section{Internal Politics and Administration 283}

soon quarrelled with his followers, and a new viceroy tempted the mob to submission by lowering the hated gabelle. After this outbreak the Spanish government was more careful; better viceroys were appointed, and Naples recovered a certain measure of prosperity before the end of the century.

Sicily was better off than Naples; it had long been an Aragonese state, and retained its ancient constitution, customs, and local rights, with a certain independence of political life. The Spanish government behaved cautiously, lest too heavy an oppression should lead to a new 'Sicilian Vespers'. But the policy of fostering the jealousy of Messina against the seat of government, Palermo, led to the most dangerous revolt which the Spaniards had to face in Italy. Messina had shown some discontent and inclination to riot; a new viceroy tried to crush these tendencies with severity. The Messinese rebelled and asked help of France. When a French fleet arrived, they declared themselves French subjects. This was no disorderly mob revolt like that of Masaniello, but a well-organized rebellion, embracing all classes; and the Messinese showed much courage and endurance in the struggle. Louvois, however, played them false, and they had to submit, losing all the privileges of their city (p. 256). But as a rule the Sicilians were contented, and in the next century openly showed their preference for the Spanish monarchy.

It was said that Spain ' nibbled in Sicily, ate in Naples, and devoured in Milan'. Already devastated by war, Lombardy had little chance of recovery under its misgovernment. Both Naples and Sicily had remnants of 
their ancient constitutions to temper its worst abuses. Each had a parliament which voted taxes, the parliament of Sicily could also make laws; each had also strong municipal institutions, that of the city of Naples was independent, and often embarrassed the government. Lombardy had also a measure of municipal self-government, but not enough to give it any independence. The Lombards were easy to rule, patient, submissive, and industrious; but their industries were crushed by ruinous exactions and regulations, and their patience tried by religious persecution, famine, plague, and the tyranny of Spanish officials and native nobles, who kept disorderly troops of retainers, called 'bravi', little better than the brigands. Above all, Lombardy suffered from militarism. Strategically of great importance to the Hapsburgs, it was a place d'armes for a garrison of Spanish troops. The country had to pay for their maintenance as if it derived any benefit from them. On the contrary, their presence caused it to be continually plunged into the wars of the seventeenth century, sometimes at the caprice of ambitious governors against the wishes of the home government. The troops quartered on the people ate up what the tax-gatherer spared; French, Piedmontese, and Austrian armies fought for the miserable remnant. Yet the Milanese, cowed and enslaved, never rebelled, and showed hardly any political preferences but hatred for the Piedmontese.

Govern ment of the Medici.

In some respects the Medicean government resembled that of Spain. The Medici attracted the nobles to a stiff, ceremonial court on the Spanish model, thus detaching them from trade and extinguishing their independence. 
To occupy the energies of the younger and more active nobles they created a quasi-religious military order, that of St. Stefano, pledged to war against the Turks. It became in time little more than a band of Christian pirates. Taxation was very heavy; "the wealth of the private citizen is that of the prince,' said Cosimo I. But only under the weaker Medici, when the stock had become decadent, did the worst characteristics of Spanish rule, waste and disorder, vexatious fiscal policy and public distress, show themselves. Tuscany, in fact, suffered from too much rather than from too little rule, and had the advantages and disadvantages of the direct government of active, if not always efficient, sovereigns. Their first object was to equalize their subjects in order that none might be too powerful; Cosimo I allowed no parties, not even the old Medicean clique, no feuds, no class exemptions or privileges, no advantages for Florence over the subject towns, which accordingly found their circumstances much improved. Under his rule and that of his stronger successors good order was maintained, justice administered, nobles, magistrates, police, and clergy were all under strict control. The condition of the peasants was improved and a rural militia formed. Agriculture was encouraged and some of the marshes drained. A tolerable fleet protected the coast; good harbours were built at Porto Ferraio on Elba, and at Livorno. Ferdinando I made the latter a free port, and it was frequented by merchants of all nations, not to speak of Christian pirates who sold their spoil unquestioned. There was a lively trade with Holland and England. Unluckily the Tuscans themselves, largely 
under court influence, became so uncommercial that Livorno soon benefited few but its foreign frequenters.

The chief faults of the Medici, inherent in their position as a dynasty of despots, were arbitrary administration and espionage. Cosimo I, feeling uncertain of his position, and naturally of a morose and suspicious temper, was the most tyrannical; and terrible tales were told of cruelties and murders even in his own family, some of which were certainly true. Yet so quiet were the people under his strict government that there was only one important plot formed against him. His elder son, Francesco I, was a feeble character, and was ruled by his mistress, a beautiful Venetian woman, Bianca Capello. The younger, Cardinal Ferdinando, who gave up the cardinalate and married on succeeding to the duchy, was the best of the race and resembled the fifteenthcentury Medici in his pleasant manners and domestic tastes, and in real care for the welfare and social happiness of his subjects. The court was less formal, yet more moral; there was friendly intercourse between the people and the ducal family; and the state was never better ruled nor more prosperous. Ferdinando's one defect was that he allowed too much power to the ecclesiastics, and this fault became very serious in the government of his successors.

His son, Cosimo II, showed promise, but unfortunately died young, and the extreme clerical party was in power under the regency of his widow, Margaret of Austria. The decadence of the Medici and of the Tuscan state dates from this time. Cosimo's son, Ferdinando II, was both conscientious and popular; his interest in the new 
scientific discoveries of the age was remarkable (p. 326); but he was a weak ruler, and his son, Cosimo III, brought up by a superstitious mother, was naturally stupid and narrow-minded. Completely under clerical influence, and attempting to make his people moral by force, he was really the worst ruler amongst the Grand Dukes. He was terribly plagued by his troublesome French wife, Marguerite of Orleans, who hated her pompous husband and his dull court.' From this time family quarrels and matrimonial troubles dogged the steps of the Medici; hence the failure in the succession which caused so much anxiety in Cosimo's later years. He would have preferred to have it settled on his daughter, the Electress Palatine, but died with the question still undecided. His brother, Gian Gastone, the last of the Medici, reverted to the old family type in his humanity and friendly spirit; he lived at ease amongst his people and kept a lively court after the French fashion. He abandoned Cosimo's inquisitorial methods of government and became so popular that the people really regretted the failure of the Medici line. The Medici had suited the Tuscan spirit ; many of them were good rulers, according to their lights, and popular; the best were really sympathetic, kindly, and upright. They hated war, and by keeping out of European complications saved their country much misery.

The chief rival of the Medici for titles and honours was Lesser the ancient family of Este, Dukes of Ferrara, Modena, princi- $\begin{gathered}\text { palites. } \\ \text {. }\end{gathered}$ and Reggio. They were a highly cultivated race, were just, if strict, rulers, and had played a brilliant part in the Renaissance. Alfonso II and his sisters were the patrons 
of Tasso. The Estensi were fortunate in surviving the sixteenth-century wars, but unluckily the direct line died out in 1597, and the Pope seized Ferrara as a papal fief. From that date it altogether lost its former prosperity. Another branch of the family kept Modena and Reggio, and quarrelled with successive popes over Comacchio, which they declared not to be a papal fief. Francesco I (p. 253), ' a prince of high talents and no small ambition,' whose daughter married James II of England, took an adventurous part in foreign politics; and his state suffered, both under himself and his successors, from frequent occupations by foreign armies. The Dukes of Modena kept up a small but very extravagant court, and a petty army in gorgeous uniforms. The duchy, increased by Mirandola, passed through an heiress to the Archduke Ferdinand of Austria. The last Este, Francesco III, and Ferdinand himself, were successively governors of Milan, where their gay court made them popular.

The duchy of Urbino had also been prosperous, wellruled and contented under its Della Rovere dukes, who took a hardly less eminent part in the Renaissance. Unluckily this family also died out in 1631 , and the Pope asserted his right to incorporate Urbino as a papal fief into the states of the Church. The failing years of the last duke were saddened by his foreboding, only too surely justified, that his beloved and carefully tended state would soon be ruined under papal misrule.

The Farnesi of Parma were little distinguished from the time of Duke Alessandro, Philip's general, till the eighteenth century, when the question of the succession to their duchy was contended amongst the great Powers 
They made a fine collection of works of art, maintained a small court, an opera house, and a toy army like the Dukes of Modena, and also suffered from invading armies in the great wars. Between $1642-4$, Italian, if not European, politics were disturbed on account of their quarrel with the Papacy over Castro, their property in the Papal States, a contest that will be described in a subsequent account of the Papacy's Italian policy (p. 300).

The Gonzaga, who received from Charles $V$ the title of Dukes of Mantua, had been one of the most respectable princely families, and had played an important part in the Renaissance. They were weakened by their custom of granting appanages to younger sons, each of whom maintained an expensive court and quarrelled with the rest. The possession of the two important strategic posts of Mantua and Casale made them specially liable to the greed of more powerful neighbours, and involved them in many troubles. Decadence also set in after Guglielmo (died I 587) with Vincenzo I, who is said to have assassinated the 'Admirable Crichton', and with his three sons, all morally and physically degenerate. The failure of their line brought terrible sufferings upon their country (p. 250). The French branch of the family began well, but the same moral paralysis seemed soon to seize upon them. Carlo II, cowardly and debauched, was succeeded by the last and worst of the race, Ferdinando Carlo, who sold first Casale and then Mantua itself for a French pension. He generally lived at Venice, seeking diversion among actresses and buffoons. No country suffered more than his in the wars after 1690. His noble wife, Anna Isabella Gonzaga, tried in vain to 1832.3 
save the duchy, but it was annexed by Austria, and Ferdinando died in exile.

The

lesser

The Genoese constitution of Andrea Doria (p. 244) surrepublics. vived with slight modifications until the French Revolution. Yet internal factions quarrelled incessantly, and the discontented sometimes procured foreign assistance. Doria had admitted some newer noble families to share in the government, but there was great jealousy between them and the older families; they formed two groups, the Portico Vecchio and the Portico Nuovo. Civil war broke out in I57I; France and Tuscany helped the Portico Nuovo, Spain sent Don John to help the Portico Vecchio, and Genoa narrowly escaped Don John's plot to make himself her king. Certain reforms were effected, but there was still much faction, and twice the Dukes of Savoy (Vacchero plot, 1628, Della Torre plot, I671) made war to aid the conspirators. Foreign interference, however, united the Genoese, and their wars against Savoy and France (p. 256) created the spirit of patriotism which enabled them to make so gallant a resistance to Botta Adorno in 1746. The lower classes then took the lead, and it seemed as if they must be admitted to a share in the government, but no such change took place. For the rest Genoa was very prosperous; as Venice grew poor she grew rich; her merchants were the tax-farmers and bankers of the Spanish Government, and amassed large fortunes, which they invested safely in papal funds.

The possession of Corsica by Genoa was a misfortune for both. The Genoese Government, selfish and corrupt, could not bring order and civilization to the half-savage islanders, whose blood-feuds flourished unchecked. Taxa- 
tion and famine led to revolts from 1553 to 1567 , and again in 1729, when the Corsicans set up for a time a German king, Theodor of Neuhof, who tried to procure foreign assistance. But now the Corsicans were led by a patriotic Liberal party, which drew up quite a modern constitution, with a general assembly and executive council. They chose as their president Pasquale Paoli, one of the few enlightened patriots of the eighteenth century. For fourteen years he ruled well, healing feuds, keeping order, and with a band of devoted followers maintaining an incessant struggle against the Genoese and the French. The latter were trying to secure the island for themselves, and in 1768 bought it outright from Genoa. Paoli was at last defeated, and for many years lived in England, the pensioner of the English Government and the friend of Dr. Johnson.' Hoping that the French Revolution would mean freedom for Corsica, he returned to the island; but, though welcomed as the champion of liberty, he soon found that France did not intend liberty for Corsica, and returned to end his life in England.

Lucca remained independent, though always in fear of 'Tuscany, 'like a quail under a sparrowhawk'; but the Hapsburgs never allowed the Grand Duke to touch her. In the sixteenth century she showed some liberal spirit as the hotbed of Protestantism and the scene of a curious plot of the Gonfalonier, Burlamacchi, who dreamed of ridding Italy of foreign and ecclesiastical dominion, and uniting it in a confederation of free states. But in time the Lucchese abandoned trade and became otiose and stupid. Their last activity was a quarrel with 
Modena for the possession of the Garfagnana, which lasted many years until Spain intervened to make peace. Savoy and The history of Savoy is the history of the genius of Piedmont. a single family. When Emanuele Filiberto received back such parts of his own duchy as France and Spain did not particularly value, they consisted of tracts of country, largely mountainous, nowhere very fertile, and studded with innumerable castles of independent feudal nobles, many of whom openly preferred the French Government. They were inhabited by mixed races, poor, backward in civilization, with no common interests and a considerable leaven of disaffected Protestantism. The towns were few and small, and there was little industry or trade. Within fifty years this unpromising material had been welded into an almost homogeneous state, well-administered, fairly prosperous, and inspired with a loyalty which led the people, alone amongst all their neighbours, to share in the ambitions of their kings, and to fight for them with real enthusiasm, though their sudden changes of alliance must have been at times bewildering. The strong will and political talents of Emanuele Filiberto, 'Testa di Ferro' (Iron-head), began the work. Reserved, stern, prompt, self-sufficient, with a feeble person but immense energy, he was the 'strong man' who laid the foundations of the new state. He repressed feudalism, organized the administration, started new industries and trade. Taxation was heavy, but the taxes were well employed. A large and efficient native army was created; this greatly improved the morale of the people, and enabled Carlo Emanuele I to pursue his adventurous foreign policy with extraordinary 


\section{Internal Politics and Administration 293}

success. His daring and personal popularity enabled him to inspire the Piedmontese with a military spirit which astounded his contemporaries; and he could boast that he had 'as many soldiers as subjects'. Unfortunately his incessant wars used up the resources which his father had accumulated, and he left his country devastated, exhausted, and overrun with foreign troops. Vittorio Amadeo I had neither the time nor the strength of character to set matters right; and the disastrous civil war which followed his death destroyed the national unity which his immediate predecessors had created. After the war Savoy was ruled, under French direction, by the extravagant and foolish Duchess Christine. When Carlo Emanuele II came of age he found the administration disorganized, the treasury laden with debt, the nobles disorderly, the country impoverished. He worked hard at reform, and a long period of peace gave him the opportunity to effect much. The finances were restored, the army reorganized, roads, industries, and commercial relations improved. Unluckily his early death was again followed by a minority, and the selfish, proud, immoral regent, Giovanna Battista of Nemours, allowed the country to slip back into its former condition of internal disorder and of servitude to France, while she was scheming to prevent her son from taking his right place in the government. She wished to ship him off to Portugal to marry the heiress; but Vittorio Amadeo II, though a mere lad, frustrated her plan by shamming illness. Brought up under harsh restraint, the boy learned early how to hide his thoughts, and at last, cleverly outwitting her, he succeeded in forcing her to yield up the government. 
In his first few years Vittorio Amadeo so prepared his country and army that he was able to meet the shock of the great wars and to make them the opportunity for placing Savoy high among the nations. One of the most brilliant of his race, extraordinarily successful both in diplomacy and war, Vittorio Amadeo, like Emanuele Filiberto, was strong-willed and taciturn, with the same type of small but active frame and fiery moustache, always characteristic of the family. But if he inspired awe, he inspired affection also, and it was the enthusiastic devotion of his people which enabled him to secure the advantages which his talents had procured. His only serious mistake was his abdication in favour of his son, of which he soon repented. But Carlo Emanuele III would not afterwards allow him to interfere in the government, treated him with the most unfilial harshness, as if he were a dangerous lunatic, and allowed him to die neglected in captivity. Except for this blot on his character, Carlo Emanuele was worthy of the highest praise. Gibbon placed him second only to Frederick II amongst the sovereigns of Europe. Small in person but dignified, with a high standard of morality, uprightness and religion, a skilful politician and a cautious but successful commander, he was devoted to duty and to the welfare of his country. Both he and his father, though always supreme in their governments, chose excellent ministers, some famous for their diplomatic skill, others who helped their masters in the work of reforming the state. The most eminent was Ormea, whose ecclesiastical policy and that of the dukes will fall under the history of the Papacy. 


\section{Internal Politics and Administration 295}

In secular affairs Vittorio Amadeo's principal reform was the creation of a new executive in four distinct departments, all administered with business-like dispatch and economy. Taxation was reorganized, and ecclesiastical and feudal property which had hitherto escaped was made to share the burden. At the same time the revenue was raised, and a heavy blow struck at feudalism by a revocation of all grants of lands made to nobles for some generations; while a new official nobility was created which gradually leavened the old. Vittorio Amadeo also endeavoured to reform the chaotic condition of mediaeval law by publishing a complete legal code, which introduced some regularity and certainty, but showed no conception of personal liberty, equality, or humanity. The army was kept up to a high standard of efficiency, and military training improved the national physique, but militarism was a drag on agriculture and trade. Both were in a backward condition, and a multiplicity of state regulations did not benefit them. The kings in fact governed too much, leaving nothing to the initiative of the people; every detail of daily life was settled by law and enforced by the police, yet the people were on the whole contented. Those who had had most cause for complaint were the Vaudois, a Protestant sect, who had long lived in obscurity amongst the mountains till the Reformation led them to form unions with the Swiss Protestants. They were cruelly persecuted in the sixteenth and seventeenth centuries, and it was their sufferings which roused Milton to write his sonnet, 'Avenge, O Lord, Thy slaughtered Saints'. While under the influence of Louis XIV, Vittorio Amadeo II had been 
reluctantly obliged to co-operate with France in a fresb persecution. Thousands were driven into exile, but as soon as the duke was independent he encouraged them to return, and they gladly fought for him against the French.

Of the three states Piedmont was the most fertile, industrious, and prosperous; Savoy was less civilized, the nobles were often disorderly. Sardinia, the newest acquisition of the House, was very backward and illcultivated, the scanty population caring for little but their feuds. Some reforms were introduced, but the Piedmontese officials were unpopular, and the Sardinians discontented in spite of increased prosperity.

Vittorio Amadeo III, though well-intentioned and industrious, was not so clever or competent as his immediate predecessors. He was too much under the influence of his wife, a very formal Spanish princess, entirely under clerical domination. His army was his hobby, and he spent his time drilling it and devising new uniforms for it. As his reign proceeded, the shadows of the French Revolution began to fall across Savoy, showing themselves in agitation and even in riots. But the Savoyards and Piedmontese had certainly less cause for rebellion than most Italians.

The By the seventeenth century the Papacy was hardly Papacy. reckoned as a European Power, but its temporal possesPopes and
Cardinals. sions gave it a place among the Italian states and a share in Italian politics. Papal policy was of a hybrid character, partly determined by ecclesiastical, partly by Italian interests; and when these clashed, as in the time of Urban VIII (p. 249), the cause of the Church had some- 
times to take the second place. The government also was hybrid; it resembled that of other Italian states, but that the monarchy was elective and the officials all ecclesiastics. Hence, while the monarchy could never become absolute like that of Savoy, it could never be turned into an aristocracy like that of Venice, and the authority of each Pope depended upon his individual character. Being themselves old men, they generally ruled through a cardinal nephew or secretary, whose absolutism was tempered by a fear of reprisals in the succeeding reign. In the case of the Caraffa and Barbarini (families of Paul IV and Urban VIII) these actually took place. At the same time the cardinals were careful never to elect a pope from a family such as the reigning Italian or great Roman noble Houses, which might make him too powerful, or from those families which had recently produced a pope; and some popes were chosen from quite the poorer classes for personal qualities alone.

With the Counter-Reformation the character of the popes had changed. All were men of respectable, some of high character. Some were chosen for religious zeal, some for personal popularity, some for learning, some as good administrators, some under the temporary influence of a foreign state, some because the cardinals wanted a change from the strenuous activities or the politics of the last pope. Occasionally, when the Conclave could not agree, a harmless old man was elected, in order to ensure another vacancy speedily. The cardinals, who were only of real importance at the time of the Conclaves, naturally made the most of these opportunities; the elections were long and warmly contested, with inter- 
minable intrigues. Each pope left a party consisting of the cardinals of his creation headed by his cardinal secretary; in the seventeenth century there was also an independent party called the Squadrone Volante, which often decided elections. In the eighteenth another party called the Zelanti tried to secure the election of popes zealous for the ancient rights of the Church.

A certain number of cardinals represented the different Roman Catholic States; some were chosen as useful officials, others such as Filippo Neri for exceptional piety, and others such as Bellarmine for learning; but the majority were simply adherents of the ruling family. They were the heads of the Curia who transacted all papal business, whether spiritual or temporal. A clean sweep was generally made of all the principal offices at each election, which did not tend to increase the integrity or efficiency of the officials. There were also a great many sinecure offices, called Monti, for which the holders, or Montisti, had paid large sums. These offices were permanent, and were bought by persons who had saved money, and who wanted a safe investment with good interest. By creating fresh Monti, the Papacy always found it easy to raise loans, but the constantly increasing interest gradually absorbed nearly the whole revenue of the Papal States; and the popes had to raise fresh loans for the ordinary expenses of government, and for their extravagant expenditure on buildings and on the enrichment of their families.

The Papal Taxation was not so heavy as in some other states, but States. nowhere was prosperity at a lower ebb. The land was not half cultivated, malaria was rampant, disorderly 
barons and brigands flourished ; there were no industries, no professions except for ecclesiastics ; the administration was incompetent and corrupt. Ferrara and Urbino, which had been prosperous under their dukes, soon shared in the general ruin. 'God must will that the Papacy should keep its states,' wrote a Venetian; ' no other power that governed so badly could do it.' Within Rome, taxes and the price of food were kept low lest the always insubordinate population should rebel. The town was crowded with beggars supported by charity, with idle and unruly followers of native barons and of foreigners, especially of ambassadors, and with a cosmopolitan crowd of highly undesirable persons.

The chief developments in government, especially Popes of those in administrative nepotism and in Italian and the sixecclesiastical politics, must be briefly traced through seventhe reigns of the principal popes. The popes of centuries. the Counter-Reformation have already been mentioned, Adminisand Cardinal Borromeo, the best of cardinal nephews nepotism. (pp. 277-78). Gregory XIII (1572), famous for his reformation of the Calendar, ruled through a cardinal minister instead of a nephew. Sixtus V (1585) was chosen on account of his austere character to impose much needed order in the Papal States. In this he succeeded, but he impoverished them by storing in St. Angelo a vast hoard of unproductive gold, on which interest had to be paid. Sixtus governed by himself, Clement VIII (1592) through his able nephew, Cardinal Aldobrandini, whose skill absorbed Ferrara into the Papal States. Paul V (1605), who quarrelled so unfortunately with Venice (p. 279), conferred a huge fortune on 
his family; both he and Sixtus V built much, but Sixtus's buildings are known by his own name, Paul's by that of his Borghese nephews. Urban VIII (1623), ambitious and restless, wished to enrich his Barbarini nephews and to make the Papacy once more a leading Italian power; hence his indifference to Catholic interests (p. 249). For this purpose also he incorporated Urbino into the Papal States, and quarrelled with the Duke of Parma about a large property belonging to the Farnesi, called Castro, which was situated rather dangerously near Rome. The Barbarini picked a quarrel with the duke and occupied Castro; then they proceeded to attack Parma, but Venice, Tuscany, and Modena, alarmed at this aggressive policy, formed a league to repress the Barbarini (I642). The papal troops were easily defeated by Venetian and Tuscan levies, and Urban had to submit to French mediation and restore Castro to the Farnesi. But the Castro question was to agitate Italy for some time longer. Innocent X (1644) again annexed it; the League, not being afraid of him, would not interfere forcibly, but the duke was told that he might redeem it for a huge sum which he could never possibly pay. When Louis XIV quarrelled with Alexander VII (p. 255) he took up the Castro question, but by quiet persistency the Pope gained his own way, and Castro was finally incamerated into the Papal States.

Innocent $X$ 's reign showed the worst abuses of family influence; the Pope was ruled by his sister-in-law, Olympia Maidalchini; the government was full of corruption and intrigue; his own family, the Pamfili, also made a large fortune. Alexander VII (1655) meant 
to keep his relations from court, but broke his good resolutions, and flooded Rome with ' an inundation of Chigi'. But a reaction against nepotism had really taken place, and no more princely families were created, though some later families amassed great wealth. The masterful and unscrupulous nephew of Clement XI, Cardinal Albani, was able by sheer force of character to retain power even after his uncle's death; but the eighteenthcentury popes generally ruled through cardinal secretaries, most of whom were competent, but not too powerful.

A new chapter of papal history opens with the move- Liberal ments towards ecclesiastical reform of the Liberal anti-papal politicians of the eighteenth century. Except in France, ments of where Parliament asserted the rights of the Gallican the eighChurch against the Papacy, they were in no sense popular century. movements; the people remained as religious, and also as superstitious as- ever; attempts to interfere with popular devotions and religious confraternities were bitterly resented. They were largely due to the influence of Jansenism and of French atheistical philosophy, especially that of the Encyclopaedia, combining in the rulers of Italy with a natural jealousy of the power and wealth of the Church, which possessed vast property in every state, yet claimed freedom from the State's jurisdiction and taxation.

Vittorio Amadeo II initiated these movements by a series of laws against ecclesiastical abuses; he also refused to request papal investiture for Sicily and Sardinia. At first the popes were implacably hostile to him, but from the more conciliatory Benedict XIII, Ormea, after three years' difficult negotiations at Rome, obtained a satis- 
factory Concordat (1727). Then the cardinals, deeply indignant, elected Clement XII purposely to denounce the Concordat, and there was an open breach between him and Carlo Emanuele III. Relations, however, improved when Ormea, having invited to Piedmont the Neapolitan lawyer, Giannone, treacherously arrested him and kept him in prison till his death. Giannone had been driven into exile on account of the anti-papal tendencies of his History of Naples. The movement which Giannone represented was strong at Naples, especially amongst the lawyers, who had long been absorbed in the old Neapolitan controversy between Church and State. However, the Austrian Government refused to sanction anti-papal legislation, and Charles III, though strongly urged by his advisers, refrained from attacking the Church until he had received papal investiture for the Sicilies.

The accession of Benedict XIV (I740) seemed to offer a solution of all controversies. Benedict was a man of culture, tolerance, common sense, and real statesmanship. $\mathrm{He}$ understood that a non possumus attitude about ecclesiastical privileges was suicidal and that some concessions must be made to national Churches and governments if they were not to be hopelessly alienated, and if Christianity itself was to be saved from the growing atheism of the educated classes. He hastened to make Concordats with Naples and Savoy ; the latter in particular contained some valuable reforms.

Attack

Benedict's conciliatory policy served to divert the on the Jesuits. general attack from the Papacy itself to the Jesuits, who were specially hated and feared for their intrigue and ambition in Spain, Portugal, and France. All three 


\section{Internal Politics and Administration 303}

States declared the Order suppressed; and Clement XIII (I 758) found that he had to support a number of Jesuits forcibly deported from their homes to the Papal States. The Jesuits were not very unpopular in Italy, but the Bourbon princes of Naples and Parma followed the example of Spain. Clement, thinking that he could coerce a petty prince, presumed to threaten Ferdinand of Parma, and found all the Bourbons up in arms against him. France occupied Avignon; Naples invaded the Papal States and threatened Castro. At this crisis Clement died (1769). He had been the Pope of the Zelanti and opposed to all concessions ; the fate of the Roman Church hung upon the election of his successor, for another pope of his type might soon have had to face a new Protestant Reformation. The Bourbons demanded a pope pledged to suppress the Jesuits; this the Zelanti refused, but chose Clement XIV, who was known to be humble, moderate, and learned. He had a difficult course to steer between the pressure of the Bourbons and the violence of the Jesuit party; but he refused to be coerced and tried to settle the question on its merits. Meanwhile he restored friendly relations with all the courts except that of Naples, where the ruling minister, Tanucci, was carrying out a violently anti-papal policy. In 1773 Clement declared the Order of Jesus dissolved; terrible, but untrue, stories were told by the angry Jesuits of a remorse which drove him to madness and death.

His successor, Pius VI (I 775), found that the suppression Pius VI did little to satisfy the Italian governments which had Church now grown eager for real Church reform. Pius was ill- reform in fitted for his difficult part ; without strength of character Italy. 
or political skill, he was both vain and timid; and his foolish self-confidence led him into dangerous situations, from which his timidity ignominiously drove him. For example he visited Vienna and Venice in person, hoping that he could so impress Joseph and the Venetians that they would moderate their policy. In each case he found himself politely ignored, and had to beat an undignified retreat. He had always to contend with the lay Powers, which demanded concessions, and took them if they were not freely given, while the Zelanti and Jesuits constantly urged him to maintain the rights of the Church. Savoy was now fairly satisfied ; but Venice, the Emperor Joseph, Duke Leopold of Tuscany, Tanucci at Naples, and the Viceroy Caraccioli in Sicily, seized upon one ecclesiastical right after another. The Venetians simply continued their immemorial policy; Tanucci and Caraccioli were prompted more by personal hatred to the Church than by honest desire for reform, for many of the worst abuses were untouched out of deference to popular prejudices. The defiance of Naples culminated

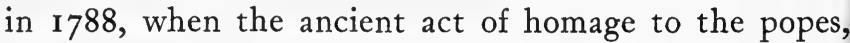
with the presentation of a palfrey, was refused. The breach continued until the Revolution.

The ecclesiastical policy of Joseph II and Leopold was more dangerous; for they based it on a modern theory of the relations of Church and State, which they tried to press to its logical conclusions. The suppression of superfluous convents and the subjection of the rest to diocesan instead of Roman control, the taxation of ecclesiastical property and the transference of patronage from the Church to the State were their principal demands. 


\section{Internal Politics and Administration 305}

Joseph in his own states-was master of the situation; he called himself 'supreme guardian of the Church and administrator of its temporalities'. Nor did he forget the older Imperial ideals, and on a visit to Rome he assumed the airs of an emperor in his capital. Leopold, aided by Ricci, the Jansenist Bishop of Prato, planned revolutionary reforms, of which the revival of the Synodical system and the creation of a national Church Council were the chief. But neither clergy nor people were sufficiently educated to appreciate his plans, many of which, such as burial in cemeteries, were excellent, but in advance of the age. An assembly of Tuscan bishops and the issue of educative pamphlets were useless. The submissive Lombards only grumbled, but the Tuscans obstinately resisted, and the people rioted against Ricci, whom they accused of heresy. In I 788 there was an open rupture between Tuscany and the Papacy. The Revolution, of course, ended all these movements ; it is impossible to say whether, without that check, they might have resulted in the creation of what Italy still lacks, a national Church.

The change to an Austrian government did not Austrian immediately benefit Milan and Mantua, which had been $\begin{gathered}\text { govern- } \\ \text { ment in }\end{gathered}$ abominably governed in the seventeenth century. LomCharles VI left their administration to the "Council of bardy. Spain', composed of Spaniards who had suffered exile for the Austrian cause, and who merely exploited Italy for their own profit. The conscientious Maria Theresa abolished the Council of Spain, and entrusted Lombardy to her able minister, Kaunitz. He initiated much-needed reforms and established a popular Milanese court under 1832.3 
Francesco III of Modena and his successor, the Archduke Ferdinand. Financial reconstruction was urgently needed; the abuses of the Spanish system still prevailed; but Prince Eugène, when governor of Lombardy, had improved matters by fusing all the intricate taxes into one, called the Diario. Still the apportionment of taxation, or Censimento, was as unfair as ever, and most of the burden fell on the peasantry. Kaunitz lowered the total taxation, abolished the distinction between city and provinces, and issued a much fairer Censimento; but the peasants were still too heavily burdened, while the clergy escaped. Pietro Verri's book on economic decadence in Lombardy (published in 1763) led to the appointment of a committee of public economy, a deputation from which went to Vienna. Verri gained over the young Emperor Joseph, who persuaded his mother to adopt part of Verri's schemes, including the establishment of a Chamber of Finance at Milan, and the abolition of the Appalto, or lease of the customs. 'Ever since the time of the Gospels the farmers of taxes have been odious to the people,' said Joseph. Peace, improved finance, and reformed trade regulations gave a great stimulus to Lombard industry. Verri formed a Società Patriotica, which propagated industrial and agricultural knowledge, and undoubtedly the foundations of the commercial success of modern Lombardy were laid at this time.

Unluckily, the Emperor, anxious to put into practice the ideas of the Encyclopaedists, and inspired with the most praiseworthy enthusiasm for the good of his subjects, imagined that he could regenerate his states by forcibly imposing a ready-made, Procrustean scheme of reform 


\section{Internal Politics and Administration 307}

upon them all, regardless of their habits and prejudices, of local institutions, and of divergencies of custom and character. Lombardy lost the last remains of its local government, for to Joseph liberty meant only personal security, not self-government. Many of the reforms, such as the abolition of feudal jurisdiction, were good in themselves, but were far too sweeping, hasty, and selfcontradictory. Joseph would allow of no delay, brook no advice ; ' he did good with a cudgel,' said the Lombards, and they begged his successor, Leopold, to restore the old ways. One of the most useful of Joseph's reforms was his attempt to humanize the barbarous criminal law of the Middle Ages upon the lines suggested in a book on crime and punishment by the Milanese lawyer, Beccaria.

The history of Tuscany in the eighteenth century Tuscany in resembled that of Lombardy. The Grand Duke, Francis the eighof Lorraine, husband of Maria Theresa, was obliged to century. govern by regents. The loss of a local court was bitterly felt, most of the revenue went to Austria to pay for Imperial wars, and the Lorrainer officials were exceedingly unpopular. The Tuscans, it was said, would have given all their property to get rid of them and have back the Medici. However, the last regent, de Richecourt, was an able administrator, who endeavoured to restore the finances, and to improve agriculture by permitting the export of surplus corn. He colonized the unhealthy Maremma, but unfortunately his colonists died of malaria. In 1765 the Florentines gladly welcomed the Emperor's younger brother, Leopold, who was to live among them as their own duke. Leopold's character and career are of great interest, and would repay a more detailed study 
than can be given here. He was a young man of good intelligence and high principles, with a great sense of duty and anxiety for the welfare of his people. His dream was to rule as a constitutional monarch with responsible ministers, and, though the want of political experience among the Tuscans made this impossible, he chose excellent ministers and followed their advice. Unluckily he was naturally gloomy and suspicious, and these defects grew upon him. He gave way to morbid suspicions about his people, was surrounded by spies and police-agents whom he entrusted with inquisitorial powers, and thus lost his early popularity. His religious reforms were not appreciated, and though he was more moderate and sensible than Joseph, yet his people found that there was ' too much government'. They hated to be torn from their old customs, and the clergy fomented their discontent. Hence Leopold's departure was not lamented when Joseph's death made him Emperor (I790).

Yet Leopold and his ministers, especially Neri, the chief, and Tavanti, the finance minister, were able to effect valuable reforms and to leave Tuscany in a more prosperous condition than it had been for generations. Neri entirely reformed the judicial system, suppressing the old feudal jurisdictions. He followed many of Beccaria's suggestions, abolishing torture and even the death-penalty. He reorganized municipal self-government, which had never entirely died out in Tuscany. The condition of agriculture was greatly improved by removing restrictions on the sale of corn and abolishing many oppressive customs which had rendered the peasants no better than serfs. Unluckily, Leopold 
allowed the owners of forests to cut them down, with disastrous results in the form of landslides, floods and exposure to bitter mountain winds. Immense industrial changes took place; the old guilds, whose regulations had become so injurious to trade, disappeared with many other vexatious hindrances, and Florentine trade wonderfully revived. Finally the financial system was reformed. Tuscany had been heavily overtaxed, and the money taken off by the Emperors for Imperial purposes, so that the government was deeply in debt; but strict economy, simplification of taxes, industrial prosperity, and the abolition of the tax-farming system caused an immense. improvement. Leopold paid off three-quarters of the debt, although he spent largely on public works.

The Austrian rule at Naples was even worse than the Austrian Spanish, because it was in the hands of the 'Council of $\begin{gathered}\text { rule at } \\ \text { Naples. }\end{gathered}$ Spain' at Vienna. It was, however, popular with and regretted by the nobles, who enjoyed even more independence than before, with the consequence that disorder and corruption were multiplied. Since no military preparations had been made, Naples easily fell to Spain (1734). The people were pleased to welcome back the Spaniards and to have a young king of their own.

Charles Bourbon was kindly and well-intentioned, but Spanish was too fond of his own pleasures, especially hunting and $\begin{aligned} & \text { Bourbons } \\ & \text { at Naples. }\end{aligned}$ building palaces, to govern well. He was ruled at first by his mother, and then by his strong-willed wife, Maria Amalia of Saxony. His reign was disturbed by disaffection amongst the nobles of the Austrian party, which was severely repressed by a committee, called the 'Committee of Distrust', with arbitrary powers of arrest and 
punishment. In 1759 Charles succeeded to Spain, leaving his young son, Ferdinand, under the charge of the minister, Tanucci. Tanucci was a Pisan lawyer, clever, ambitious, specious, but spiteful. In order to retain power he encouraged Ferdinand in lazy, self-indulgent habits. But Ferdinand also had a wife of talents and powerful character, Maria Carolina of Austria, who in I 77I ousted Tanucci from power, and henceforth virtually ruled the country. Anxious to make Naples independent of Spain, she commissioned a clever Irish adventurer, Acton, to reorganize the army and navy. Acton was very successful, but Charles of Spain disliked his influence with the Queen, and desired Ferdinand to dismiss him. However, Maria Carolina persuaded her husband to defy his father's wishes; there was a family quarrel with Spain, and Naples fell under Austrian influence.

Both Charles and Tanucci had endeavoured to reform the Neapolitan government, but without great success, so strong was the opposition of feudalism, clerical privilege, and ignorant conservatism. Attempts were made to check the power of the nobles, and Tanucci made considerable progress in limiting ecclesiastical privileges. In these matters the powerful lawyer class supported the government, but they changed their attitude to furious opposition when legal reform was contemplated. Some fiscal reforms were tried, but when a new magistracy for commerce issued new trade regulations, the Neapolitan local authorities petitioned for its abolition. The peasants were sunk in the direst poverty, the townsfolk were lazy, filthy, and vicious-' la plus abominable canaille, la plus dégoûtante vermine' that the traveller, 
des Brosses, had ever seen. But the government kept down the price of food, and they needed nothing else but entertainment, of which they got plenty. The country was not really discontented, and Ferdinand was popular in spite of his boyish frivolities-much more so than his grave, estimable brothers-in-law, Joseph and Leopold. 'When I travel,' he said, 'I can hardly tear myself from my people, yours are pleased when you are away. ... Do take a little rest, and let others do the same. Believe me, and govern them less; all your learning makes them dull.' Probably the Lombards and Tuscans, harassed by perpetual reforms, would have seconded this advice.

Sicily made distinct progress under its brilliant, cynical viceroy, Caraccioli, a friend of the Encyclopaedists, and one of the most interesting personages of the period. Feudalism was limited, the Inquisition abolished, and much ecclesiastical reform accomplished. But Caraccioli was too clever and caustic to please the Sicilians, and they were not sorry to see the last of him.

Parma, after the extinction of the Farnesi, was ruled Parma in by the youngest Bourbon dynasty. The Infant Philip the eigh( 1748$)$ and his son Ferdinand ( 1765$)$, during his minority, century. had an excellent minister, du Tillot, who brought about many reforms, especially in finance and ecclesiastical affairs. Unluckily Ferdinand was stupid and superstitious, and his wife, Maria Amalia of Austria, clever and strong-willed like all her family, hated du Tillot, and worked upon Ferdinand's religious prejudices until she secured his dismissal. 'The government and country fell into dire disorder, the Inquisition was restored, the Jesuits returned, and all du Tillot's work was lost. 


\section{Social and Intellectual History}

The end of the Renaissance.

OF the great changes which took place in the social and moral condition of Italy and of their causes something has already been said. The Renaissance, in its special manifestations of literature and art, was no doubt working itself out by the third decade of the sixteenth century, and signs of coming decadence are visible in the works of its greatest masters, Michael Angelo not excepted. Yet there was still considerable mental vitality amongst the Italians which might have taken other forms, and indeed, to a certain extent and at a rather later period, did so, especially in music and natural science. It was for the most part due to the political conditions of the age that general intellectual decadence set in so rapidly. War and suffering, misgovernment and disorder, poverty and distress, left the Italians neither time nor energy for their former pursuits. One after another the courts which had been the chief centres of Renaissance life, Florence, Milan, and, lastly, Rome, were overset and ruined. Ferrara and Mantua had better fortune, and for a time kept alive their type of culture, but they were not rich or strong enough to maintain it long. Venice remained untouched; and there, where the Renaissance had developed later than elsewhere, it continued to flourish till the latter half of the century.

Moral de- Other causes also contributed to the change. Besides cadence. the natural exhaustion following a period of intense 
mental development, the peculiar nature of the Italian Renaissance had contributed to a moral decadence which alone might ultimately have destroyed it. The Pagan ideal had been taken too literally; amongst the educated classes it had broken down the last props of a religion already weakened by the corruption of the Italian Church. The violence and treachery natural to the Italian character had no further restraint, and even the domestic virtues so characteristic of the middle classes had given way to the infection of Pagan immorality. It is true that religious observances were still followed; but they were merely formal, or were utilized as an excuse for a pageant. Much humanistic study had led to a frank atheism in philosophy; and while high ecclesiastics dispassionately discussed such subjects as the immortality of the soul, delicately reared ladies listened to the comedies of Machiavelli or told tales from the popular Novelle which are simply untranslatable. Even in the flowering times of the Renaissance ghastly crimes were committed by the debonair masters of gay and cultivated courts, patrons of all the arts, themselves often amateurs. No better idea of the manners and morals of the later Renaissance can be gained than from the memoirs of that delightful scoundrel, Benvenuto Cellini, to whom murder was but an incident in a variegated career.

Foreign influence did not mend matters; the foreign soldiery was brutal and half-savage; the French, always quickly intoxicated by the Italian atmosphere, became more depraved than the people they conquered; the Spaniards, with their artificial 'Code of Honour', introduced the formal duel, and the custom of wife- 
murder for real or imagined infidelity. A standard was thus set for the wife which the husband, both judge and executioner, would never have dreamed of requiring for. himself. Indeed, the easy social intercourse with women which marked the Renaissance was exchanged for the Spanish habit of seclusion; but seclusion only led to intrigue, and did not raise the moral standard. Such crimes as those of the sixteenth-century Medici and the still more famous Cenci case were characteristic of the age.

Amongst the lower classes religion was largely superstition, indeed the belief in witchcraft and magic was universal. Cardinal Borromeo conducted a campaign against witches as ferocious as his persecution of heretics; and numbers of unfortunate persons were murdered in times of plague because they were believed to spread the poison by magic.

Spanish

influence in morals and manners.

Moral regeneration followed, though but slowly, on the Counter-Reformation. The fact that a Cenci was now regarded with more reprobation than a Borgia had been indicates a change of standard. The Rome of Pius V, in which the Inquisition was the most active force, or of his successor when Filippo Neri founded the 'Oratory of Divine Love', was a very different town from the Rome of Leo X, when to the Protestants she seemed 'Babylon, the harlot of the nations'. Outward respectability and at least an appearance of religious devotion had become the rule. Pius $V$ would have burned the friends of Leo $\mathrm{X}$ for heterodoxy; yet under the veneer of decency and propriety there was still much vice, cruelty, and sensuality, only that hypocrisy had replaced shamelessness. The influence of the casuistic theology 
of the Jesuits tended in the same direction. This outward propriety was also in part due to the Spanish example which pervaded Italy, just as the stiff etiquette of manners and the black costume of the courtiers replaced the easy informality and the gay colourings of the Renaissance court. Its pleasant domesticanza, when talent and wit, beauty and wealth, were equally passports to society, had given way to a rigid observance of the rank and titles which now alone gave admittance to the princely circle. The artist and humanist could no longer be the friend and intimate of the prince, as Leonardo da Vinci was to Lodovico il Moro, or as Poliziano was to Lorenzo de' Medici; he must be the humble dependent, as Tasso was to Alfonzo II d'Este. Dedicatory prefaces, full of gross flattery of the patron, show the sycophancy to which literature was reduced.

Again, the influence of Spanish militarism, which made the army the only career for a gentleman, ousted the civic virtues, and created a society from which useful business was banished as only fit for the lower orders, and idleness, which led to immorality, ignorance, and poverty, was encouraged. The richer classes, already impoverished by the wars, and induced to spend their money on buying titles and maintaining them with empty display, had less to spare for books and pictures; no one now commissioned a great altar-piece, few but the Romans could afford to build. The old custom of open hospitality, which had been of so much advantage to those who lived by their talents, was abandoned.

Influence of the

Lastly, the Counter-Reformation, with the Inquisition Counterand the Index, swept away whatever was left of the Refo 
Renaissance type of culture. Its Paganism and Pantheism might be no loss to Italy; but with them were doomed its freedom of speculation and its untrammelled liberty of expression. The thinker was muzzled by the Inquisition which burned Giordano Bruno and intimidated Galileo. The effect of the Index was to transfer the centre of the publishing trade from Italy to Switzerland; while censors of the press might so transform an author's work that he could hardly recognize it. Boccaccio might only be published in a bowdlerized form, and Benedict XIII ordered that Raphael's frescoes in the Vatican should be whitewashed. Yet here again hypocrisy triumphed; for what was secretly bad could often be painted or published under devotional pretences. For example, Caravaggio's pictures of martyrdoms really ministered to a depraved taste for the horrible, and sensual tales could be made to pass muster as allegories of good and evil.

Learned and literary studies and general culture.
It must not, however, be supposed that the taste for art and study, and especially for the classics, died out altogether. The creative impulse was exhausted, but there were always some rich men who, either from a genuine love of beautiful and rare things, or wishing to gain reputation as connoisseurs, collected antiques, pictures or books. The Medici set an example in this respect. Cosimo I reassembled the older Medicean collections, founded an academy of design, and decorated the Pitti Palace. Francesco I fitted up for the collections the long gallery between the Uffizi and the Pitti. The famous Farnese collections are now at Naples, whither they were taken from Parma by Charles III. When in the eighteenth century Italy recovered comparative 
prosperity the fashion for collections spread, and was imitated by foreign travellers, who then purchased the Italian works now to be seen in European galleries.

Many great libraries came into existence at this time. Cosimo I bought complete book collections for his Bibliotheca Laurentiana, sending to the East for manuscripts. The Vatican Library was greatly increased, and Federigo Borromeo founded the Ambrosian Library at Milan. One Florentine library bears the name of the librarian, Magliabecchi, whose marvellous learning and feats of memory astonished his contemporaries.

The universities were busy and crowded, but it was long before they emancipated themselves from Aristotle and Galen. History was much studied, and even mediaeval history was no longer despised. Cosimo I recalled Varchi from exile to write his history of Florence. Cardinal Baronius wrote an erudite ecclesiastical history of the early centuries, based on Vatican documents. Paolo Sarpi and Cardinal Pallavicini wrote histories of the Council of Trent from opposite points of view. The Venetian ambassadors have given us contemporary history in their remarkable Relazioni, or reports of their embassies, full of political acumen and picturesque detail. Still more brilliant is the Storia arcana di Carlo VI by the Doge Foscarini, who analysed the weakness of Austria in 1733 with extraordinary insight and skill. But the chief Italian historian was Ludovico Muratori (I672I750), who collected great numbers of unpublished historical sources in his Rerum Italicarum Scriptores, though neither Piedmont nor the Republics would allow him to include their materials. He also wrote treatises 
on theology, archaeology, philosophy, and law, an accurate if uninteresting history, the Annali d'Italia, and a defence of the claims of Modena against the Papacy which brought him into trouble with the ecclesiastical authorities. However, the liberal-minded Benedict XIV gave him permission to publish what he pleased on ' matters neither disciplinary nor dogmatic'.

Little less absorbing than the study of antiquity was that of the Italian language itself. Some of the numerous literary academies, especially the famous Crusca of Florence, were founded expressly for this purpose. The Crusca drew up a vocabulary of words authorized for literature by the usage of great writers; but as they limited their list to Tuscans, even condemning Tasso's Gerusalemme, the learned of other towns refused to submit to their dictation, or to accept their idol Petrarch as the ultimate exponent of style, so that a lively battle was waged on the language question. Style had, however, unfortunately displaced originality, and covered poverty of ideas. Dozens of literary academies met constantly to hear and to praise the writings of their members; every one must write something, it did not much matter what, so long as the words sounded melodious. Indeed one academician gained applause for nonsense lines which simply sounded prettily.

One of the most famous of the academies was the 'Arcadia', whose members adopted the 'Arcadian' pose then popular, called themselves Strephon or Colin, and reckoned the years of the academy by Olympiads. It was founded by Queen Christina of Sweden, a curious and interesting personality, whose residence in Rome had 
some influence on seventeenth-century society. She had resigned her throne after embracing Roman Catholicism, and was jubilantly welcomed to Italy by Alexander VII, who entitled her Alessandria. Her desire to treat Rome as if she were its queen and her political activities and intrigues made her troublesome; but she ultimately accommodated herself to the social life of the place, patronized authors and scientific men, and created a literary circle of which the 'Arcadia' was the fruit. Christina was only the highest in rank of the numerous foreigners who now travelled to Italy in pursuit of culture. To us Milton is the most interesting, and the traces of Italian influence constantly show themselves in his writings. 'The Admirable Crichton,' Montaigne, Evelyn, and Bishop Burnet were others; the three latter were amongst the many who described their experiences.

A new era of philosophical thought was about to dawn Italian in Europe, and a free Italy might have had a considerable sophy. $_{\text {shilo- }}$ part in it, but the dominion of Spain and of the Inquisition crushed it out from the beginning. Giordano Bruno (1550-1600), a Calabrian, based his speculations on the power of human reason and on its logical freedom; he would not accept Aristotle and the Schoolmen as infallible, but insisted on working out his own conclusions. From the Copernican system he adduced a plurality of worlds, and he believed the whole creation to be animated by the indwelling presence of a Pantheistic God. He travelled much, and even tried to convince the conservative Oxford professors. His writings were obscure, disorderly, and eccentric, but foreshadowed much of later philosophy. He hoped to escape the wrath of the 
Church by outward conformity, but free speculation was no longer permitted. He was imprisoned for many years by the Inquisition, which easily proved the heterodoxy of his works, and would not accept a mere formal submission without a promise which Bruno would not give to renounce his right to freedom of thought. Bruno was condemned to death in 1600 , saying to his judges, 'You have perhaps more fear in pronouncing, than I have in receiving, this sentence'. At the stake he refused a crucifix; since he had lived without Christianity he would die without it.

Tommaso Campanella (I568-1639), also a Calabrian, was imprisoned for twenty-seven years for his share in a rebellion against the Spanish Government. Urban VIII, who was convinced of his orthodoxy, at last procured his release. He was rather a theologian than a philosopher, and his desire to be strictly orthodox hampered his speculations. His Città del Sole (City of the Sun) is an interesting Utopia, quite modern in its communism and state-regulated eugenics.

Natural Very different from the fate of metaphysics was that science in Italy. Before Galileo. of natural science, since fortunately it was not till the Inquisition discovered the pitfalls lurking in the Copernican system (16I6) that it occurred to the ecclesiastical mind how dangerous to orthodoxy the study of nature might be, and even after this discovery the enlightened patronage of the Grand Duke, Ferdinando II, gave safety and encouragement to the scientific student up till the middle of the seventeenth century. Some formidable difficulties had indeed to be overcome: the popular tendency to confound chemistry with magic, the natural 
prejudice against post-mortem dissections, and the rooted belief of learned authorities that Aristotle and Galen were as much inspired as Holy Writ, and that it was almost as sacrilegious to question them. But the higher Italian intellect, naturally more adapted to concrete than to abstract studies, keen, inquisitive, restless, logical, turned eagerly from the literary to the physical study of Nature and Man, with results of immense value in almost every branch of science.

Italian science falls definitely into two periods, before and after the era of Galileo's great discoveries. The earlier period was chiefly remarkable for progress in mathematics and medicine. The former was a popular university subject; the professors delighted in propounding problems to puzzle their rivals. An elementary form of algebra was studied; Tartaglia (1500-57) first discovered a method for solving cubic equations. This he revealed under an oath of secrecy to another mathematician, Cardano. Cardano most dishonourably published it with some improvements. Afterwards a method to solve equations in the fourth degree was discovered, but the algebraical symbols were not used until 1600 . Tartaglia translated Euclid into Italian, and wrote on various mathematical subjects, dedicating one of his books to Henry VIII.

Cardano was one of those early students who could not distinguish clearly between magic and science. As an. astrologer he cast a horoscope for Edward VI, and he believed and made others believe that he had a familiar spirit. Indeed, he lost his chair at Bologna because the Inquisition accused him of magic. His autobiography, 1832.3 
not dissimilar in style to that of Benvenuto Cellini, is a curious account of the fantastic speculations, the adventures and difficulties of an early seeker after knowledge, utterly confused between the real and the imaginary, and yet with some notions of a scientific law beyond his own comprehension.

Another mathematician, G. B. della Porta, who studied optics and discovered the principle of the camera obscura, was attacked by the Inquisition for magic, and his Neapolitan Accademia de' Secreti was dissolved. This academy, founded in 1560 , was the parent of all scientific societies; its title is very suggestive of the light in which science was regarded as a branch of occult study.

Medicine laboured under many disabilities, the authority of Galen, the difficulty of procuring bodies for dissection, and the general belief in fantastic and often disgusting remedies. The Belgian Vesalius, protected by the Venetian government, was indeed able to study anatomy by post-mortem examination at Padua (c. I 540); but the university professors, furious at his temerity in questioning Galen, drove him to abandon his work. His pupil, Fallopio, and Fallopio's pupil, Fabrizio (I539-16r9), both professors at Padua, made important discoveries; the former of the canals or tubes which still bear his name, the latter of the valves of the veins, whose use, however, he did not guess. Fabrizio was also the pioneer of comparative anatomy. He was a famous teacher; one of his pupils was Harvey, whose discovery of the circulation of the blood was dimly foreshadowed by Fabrizio himself.

Cesalpino (1519-1603) likewise was an anatomist who 
refused to accept Galen's authority; he was the first biologist to suggest the classification of plants somewhat on the lines of the family groups still recognized. The study of botany indeed received an impulse from the cult of gardens so popular in the sixteenth and seventeenth centuries, and the consequent compilation of beautifully illustrated botanical books. Francesco I de' Medici, whose only claim to distinction is his patronage of science, sent to far-off lands for specimens for the botanical gardens at Pisa. He had also a private laboratory where he made experiments, not only with drugs and poisons, but also in mineralogy and metallurgy. The old alchemy was, in fact, giving way to modern chemistry, just as astrology was preparing the great advance which was imminent in astronomy.

In 1587 , Galileo Galilei, son of a Florentine musician, Galileo. had been appointed to a professorship of mathematics at Pisa. He was then twenty-three years of age, but was already beginning to revolutionize scientific study. $\mathrm{He}$ refused to accept the authority of Aristotle, or indeed any premisses or arguments which had not been proved by experiment.

Galileo also extended to science the use of mathematical methods, and for this purpose studied all kinds of pure and applied mathematics. His irreverent attitude towards Aristotle scandalized the professors of Pisa, but he fortunately procured a chair at Padua (1592), the home of sixteenth-century science, where, under the aegis of the Venetian government, he worked safely, fruitfully, and happily for eighteen years. It was to Padua that he imported the earliest form of telescope 
from Flanders (I609); and, having improved it, he began to study the stars, and soon convinced himself that the Copernican system, which was already discussed and generally rejected in Italy, was undoubtedly correct. The mountainous character of the moon, the rotation of the sun, the nearness of the planets as compared with the stars, the phases of Venus, were discovered through the new telescope. Immense excitement was caused; people flocked from Venice to look through the telescope; Kepler himself wrote to congratulate Galileo. The discovery of the moons of Jupiter was a new sensation: Galileo called them the Medici stars in honour of Cosimo II, and the King of France sent to order some new stars to be dedicated to the Bourbons. But the acceptance of the Copernican system called down a storm of abuse from the obscurantist professors, and they supported their arguments by the authority of scripture. Galileo did not mend matters by suggesting that some passages of scripture were adapted to the times in which they were written, and controversy raged furiously. The Copernican system had not yet been condemned by the Church, and if Galileo had been able to adopt a milder tone, and perhaps to conciliate the Jesuits, he might have averted the coming storm. Or, if he had remained at Padua he might have defied it. But in I6ro he returned to Pisa at the Grand Duke's invitation; and Ferdinando, though he had the will, had not the courage to protect him. Soon afterwards Galileo visited Rome to explain his views; he was not unfavourably received, and some of his work was published by a Roman scientific society, the Accademia dei Lincei. But in 1616 the Inquisition formally con- 
demned the Copernican system, and when Galileo went to Rome to defend it, he was informed that he must mention it as an hypothesis, not as a fact. Galileo was the last man to trifle with what he believed to be truth, and, in his Dialogue on the Ptolemaic and Copernican Systems (1632), he made no secret of his convictions. Unluckily his enemies were able to arouse the personal enmity of Urban VIII against him, and the Inquisition was permitted to summon him to Rome on a charge of heresy. At first Galileo defended himself with candour and courage; but after many months the cross-examinations, with their threats, suggestions, and persuasions, were too much for the old man's spirit, and he signed the formal retractation which allowed him to escape from the hands of his tormentors to enforced residence at his own villa outside Florence. Here he was allowed to remain, visited by the Grand Duke and his brother Leopoldo, by his devoted disciples, and by many admiring foreigners, Milton amongst the number. Here, too, he finished his book on the laws of motion, which contained his last great discovery that 'every body remains in a state of rest or of uniform motion in a straight line, unless it is compelled to change that condition by impelled forces'. But his last years were burdened by the memory of his retractation, by the petty worrying of the Inquisition, and by the loss of his sight. He died in 1642 , the year in which Newton was born.

In spite of Galileo's misfortunes enormous strides had Science in been made in science since the beginning of the seven- Flore teenth century; the experimental method had taken Galileo. the place of the old a priori reasoning; the telescope and thermometer were in use, the barometer and microscope 
soon followed. The work begun by Galileo was carried on by a brilliant group of pupils, of whom Castelli (d. I644), Torricelli (d. I666), Borelli (d. I679), and Viviani (d. I 703) were the most distinguished. The centre of research had shifted from Padua to Florence, where the enlightened and generous Grand Duke, Ferdinando II, and his brother Leopoldo, loved to gather scientific workers and aid their study. A laboratory was established in the ducal palace under the direction of Leopoldo, who himself took part in the experiments. In 1657 the Accademia del Cimento (Experimental Society) was established; Leopoldo was its president, and its discoveries appeared in a beautifully illustrated book (Saggi di Naturali Esperienze fatte nell'Accademia del Cimento) compiled by its secretary, Magalotti. In it are accounts of Galileo's thermometer and Viviani's barometer, of the pendulum which Galileo had first used, and of the hygrometer which the Academy invented. There also are described the meteorological observations made in different countries at the Grand Duke's order, and various experiments in magnetism, electricity, the resistance of air and water, the velocity of sound and light, \&c.

Castelli, a friar, contrived not to offend the Jesuits, and was allowed to teach Galileo's theories in Rome itself. He studied and wrote on hydraulics, and superintended the experiments in draining marshlands which were undertaken by Urban VIII and Ferdinando II. In Tuscany artificial drainage was much needed, and on this subject Torricelli also worked. $\mathrm{He}$ was a student of pure and applied mathematics, and was also physician to the Grand Duke. Viviani worked on conic sections; he constructed 
a conjectural and, as it afterwards proved, a correct version of the last book of Apollonius. Both Torricelli and Viviani were devoted pupils of Galileo; Viviani behaved like a son to him, wrote his life, and is buried near him in the Church of Sta. Croce. Torricelli suggested, and Viviani constructed, the first barometer. Viviani was a member of the Paris Academy and of the English Royal Society. Borelli studied and wrote on animal motion from the point of view of the physicist; he worked on astronomy and had some idea of gravitation, and he investigated an eruption of Etna on the spot. While at Florence he worked with the most eminent biologist of the age, also a member of the Accademia del Cimento, Malpighi (d. I694). It was Malpighi who first made use of the microscope to study embryology, histology, and animal and vegetable morphology; he first enunciated clearly the principle that all animal and vegetable life have similar structures and laws of growth. Unfortunately Malpighi and Borelli quarrelled and both left Florence. The later work of Malpighi was mostly published by the English Royal Society, while Borelli profited by the patronage of Queen Christina of Sweden. This quarrel and the elevation of Leopoldo to the cardinalate, in 1666, put an end to the Accademia del Cimento and to scientific work in Florence. Before quitting the subject, however, mention should be made of a Dane, Stensen, who was physician to Ferdinando II and tutor to the sons of Cosimo III. He studied geology and crystallography, stated the nature of fossils, and declared that Tuscany had once been at the bottom of the sea. Unfortunately, having embraced Catholicism, and finding that geology would not agree 
with the teaching of the Church, he abandoned the former and retired to Denmark as a Romanist missionary.

Science in other parts of Italy.

Next to Florence, Bologna was most noted for scientific research; indeed, Malpighi was a Bolognese and did much work there. Cassini (d. I7 I 2), professor at Bologna, was an eminent astronomer, and wrote on the comets and on the rotation of the planets. Though not actually attacked by the Inquisition he may have thought it prudent to accept (1669) the post of Royal Astronomer of France, offered him by Colbert. Four of his relatives succeeded him in this position. Another professor at Bologna, Cavalieri (d. I647), founded the study of infinitesimal calculus. And it was a Bolognese, Grimaldi (d. I683), who foreshadowed the undulatory theory of light which, rejected by Newton, has since been established as one of the basic laws of physics.

The eighteenth century saw a great activity in the medical school at Padua. Morgagni (d. I77I) was the centre of a learned group there, and was much visited by foreigners of distinction. He wrote the first treatise on morbid anatomy, full of pathological knowledge, and based on numerous post-mortem examinations. Laura Bassi, the famous woman-teacher, professed science at Bologna. Amongst other workers was Spallanzani (d. I799); who was Laura Bassi's pupil. He was most eminent as a physiologist ; he discovered the uses of the gastric juices and disproved the existence of spontaneous generation. But he also studied other branches of science and travelled much, recording facts of scientific interest, and in particular making valuable observations on the crater of Stromboli. Amongst mathematicians the most eminent 
was Lagrange (1736-1813), who, though of a French family, lived and worked for many years in Turin. His criticism of Newton and Euler gave him eminence at an early age ; in astronomy he was studying planetary and lunar perturbations when he was offered and actepted the post of mathematical director in the Berlin Academy, since the 'greatest king in Europe' desired the presence of 'the greatest mathematician' at his court.

Perhaps the chief advances made in the eighteenth century were in electricity. Galvani ( $1737-98$ ) was a professor at Bologna, Volta (1745-1827) was a professor at Pavia. Galvani discovered that muscular contraction was produced in the limbs of a frog by contact with dissimilar metals, and Volta used this discovery in the invention of his electric battery. This new branch of electricity was called Galvanic or Voltaic after them, and the galvanometer and electric volt still preserve their names to us.

But in spite of these individual workers the promise shown by Galileo and his pupils was not maintained. The deadening influence of society and of the Church, the lack of encouragement, the risk of actual danger, the want of any contagious enthusiasm, all contributed to fetter the enterprising mind. One great genius might temporarily break through the chains, but not without much suffering, and they fatally trammelled the development of what had indeed become an intellectual movement of incalculable value to the world.

In one other direction, that of music, Italy for a time Music in took the lead. As court life became dull and formal, the Italy. Italians had turned more and more to the theatre for and recreation. Since the drama had become a monotonous music. 
réchauffé of Latin models, dramatists began to enliven it with interludes of singing and dancing. The musical part gradually became the most important, and thus emerged the opera. The development was slow, for it was difficult to achieve the art of fitting the music and words together and of illustrating the action by the music; but about the end of the sixteenth century, recitative, called musica parlante, was first used by Vincenzo Galilei, Galileo's father. In $\mathrm{I} 600$ an opera containing recitative was given at Florence to celebrate the marriage of Maria de' Medici, and a complete dramatic oratorio, also containing recitative, was performed in Rome. A little later the composer Monteverde tried to illustrate the characters and action by the music, associating particular melodies with each character. Before long every court had its opera-house, which became the centre of social life, its meeting-place and its chief topic of conversation.

The opera quickly stimulated the development of music, the one art which the Counter-Reformation had definitely encouraged. The Italians were naturally musical; there was a great deal of folk-music and considerable skill in its performance, but music as an art was in complete confusion; the laws of harmony, even the number of the tones, were unsettled. Church music had become very irreverent and unsuited to worship. The air being sung by the bass, the other voices often sang just what they pleased, so that an anthem in the bass might be accompanied in the treble by a profane drinking-song. The Council of Trent, therefore, seriously thought of permitting only plain-song. However, Cardinal Borromeo, himself fond of music, commissioned the Roman choir-master, Pales- 
trina (1524-92), to write a mass which would give the words a reverent setting. Palestrina's 'Mass of Pope Marcellus' satisfied the Council, and it was ordered that in future Church-music should conform to this model. Palestrina and his successors did much excellent work of this kind, and composed sacred cantatas for the Oratory of Divine Love from which the oratorio took its origin. The writing of music for the Church and for the opera systematized the art of music. Both caused a demand for prolific production, so that the seventeenth and eighteenth centuries are rich in Italian music, and show great progress both in composition and technique. Alessandro Scarlatti (1659-I725) wrote three hundred operas with immense fertility of ideas ; in the eighteenth century lived Porpora and Buononcini, who were both invited to London as rivals to Handel. Handel had, as yet, only written his operas, so that, though he eclipsed both rivals, his superiority was not so great but that Byrom could write :

'Strange all this difference should be 'Twixt Tweedledum and Tweedledee.'

Piccini (1718-1800) was brought to Paris by Madame du Barry's party as a rival to Gluck, whom the Dauphiness patronized. Gluck had suggested that the music of an opera should be written to fit the words; Piccini held to the older idea that the words should be made to fit the music. The Italian opera was, in fact, arranged simply as a display for the vocalists, the drama taking a very inferior position. But Pergolesi (1710-36), who first wrote opera on a domestic subject, broke through some of these early conventions. His music, both sacred and secular, is so beautiful in effect and pure in style, that his early death 
certainly robbed Italy of her greatest composer. Paisiello, who wrote the first 'Barber of Seville', effected further improvements by developing instrumentation. He was a very popular composer, and was patronized by Napoleon and by Catherine II.

Instrumental music. Instruments and performers.

The sonata, first used in the seventeenth century, was developed by Domenico Scarlatti (I683-1757), son of Alessandro, who employed two regular subjects with connecting sections. Concerted instrumental music had also made its appearance. Arcangelo Corelli (1653-1713) was one of its earliest composers; yet he knew so little of its possibilities that he believed that the violin could not be played above $\mathrm{D}$ on the first string, and was annoyed when Handel both wrote music for the high A and showed him how to play it. Later on much concerted music was composed for performance, often by amateurs, at the private concerts which were a great feature of eighteenth-century social life.

With the development of music followed the improvement of technique and of instruments. In the eighteenth century Amati was making violins at Cremona; Stradivarius was his pupil. Cristofori, a Florentine, made the first pianoforte about I7II. Domenico Scarlatti was pronounced the superior even of Handel in performance on the harpsichord.

Still more remarkable was the development of vocalization, the art of Bel Canto, whose home was Italy. There were two great conservatoires, at Venice and Naples, and they produced singers who were famous all over Europe, and for whose services princes contended. The Duke of Mantua is said to have spent the price of Casale on a 
prima donna. Castrati were much admired; the most famous was Farinelli, without whose nightly singing Philip V of Spain could not have retained his reason. Farinelli's voice had a compass of three and a half octaves, and a soprano, Lucrezia Ajugari, could sing an octave and a half above the treble clef.

In 1769 the boy Mozart visited Italy, and caused an immense sensation by conducting his own opera at the Scala Theatre. But the prophecy of Hasse- 'This boy will cause us all to be forgotten '-rapidly fulfilled itself, and before the century was over Germany had taken from Italy the primacy in music.

The classical influence which had so thoroughly per- Classical meated the literature and art of the Renaissance grew even influence stronger as the afflatus of original inspiration died away. Raphael himself had shown in the Farnesina frescoes how on six. teenthcentury it was gaining upon him; his pupils, even the best of literature. them, Giulio Romano, fell more and more under its spell. Classical themes, especially those which gave scope to the coarser tastes of the age, were very popular. Nowhere was classicalism more marked than in architecture, where imitation of the ancient models was easiest. Its chief exponent was Palladio, whose name has been given to the strictly classical type of architecture which became so fashionable all over Europe and determined the form of English building for two centuries. Palladio and his followers adhered to the rules of Vitruvius, and allowed little scope for ornament or for individuality of treatment. The greater part of the fabric of St. Peter's was built during the classical period; but since Michael Angelo was for many years its architect it escaped from the most 
deadening results of that frigid style, and was crowned with the dome which his genius designed. Rome, and indeed all Italy, abounds with the villas which are the happiest productions of the period; their gardens, of which the Boboli at Florence are a good example, were effectively laid out with terraces, statuary, and fountains in a partly natural landscape, and often still retain their subtle charm.

Nowhere was classicalism more out of place than in literature, where it became a mere slavish imitation of ancient models, sometimes of those least worthy of imitation, and resulted in a stilted, frigid emptiness. Characteristic of this style is the 'Cristiade' of a certain bishop, where the history of Christ is treated like that of a demigod. Innumerable comedies after Plautus and letters after Cicero appeared. The virtues of sincerity and simplicity are only discovered when writers like Benvenuto Cellini and Vasari threw off the chains of fashion and wrote in their native tongue with no effort after effect.

The But the natural activity of the Italian artistic mind 'Baroque' could not long be contented with a 'Rule of Thumb'
style. fashion and broke out with energy in a new direction, following the style which is called the 'Baroque'. In its earliest form it was created by Michael Angelo, whose vigorous genius rebelled against the stilted vapidity of the classical style. Even Michael Angelo was betrayed by his own energy into exaggeration of form and restlessness of action, and the artists who followed him, imitating his defects and not redeeming them by his genius, mistook violence for energy and monstrosity for nobility. They produced contorted forms, with bloated limbs and tor- 
tured muscles, swathed in billowy drapery, and they made a merit of the abnormal, of the bizarre, even of the horrible. The Counter-Reformation type of religious feeling, combining with this tendency, produced the sentimental saints, the sprawling, flabby angels, who not infrequently hide their defective anatomy under a wad of cotton-wool clouds, and the huge and ugly tombs of contemporary popes, with their pompous inscriptions, which disfigure the churches at this period, and particularly the interior of St. Peter's itself.

Nowhere does the Baroque displease a simpler taste more than in architecture, where, at its worst, every kind of sham or exaggeration was employed to give a novel effect. There were architraves without any supporting building, a jumble of 'Classical Orders', columns broken, falling, even upside down, crooked lines and angles, heavy and light parts interchanging their appearance. Everything was overburdened with decoration,--statues in every corner, gigantic inscriptions, bronze wreaths, patterns in coloured marble, even painted imitations of marbles. Polychromatic decoration was much used; a good example of this, the Mausoleum of the Medici in the Church of St. Lorenzo, has its interior encrusted with designs in marble and precious stones. Rome, where the popes indulged in orgies of building-palaces, churches, villas, and fountains-is full of the Baroque. It is perhaps at its worst in the Church of Il Gesù, at its best in the architecture of St. Peter's after the death of Michael Angelo. Fontana, architect under Clement VIII, raised the lantern; he was one of the better Baroque builders. Much of his work is in Naples, where the viceroys built new streets and 
palaces. Unfortunately, Maderna, architect to Paul V, substituted a Latin cross for Michael Angelo's design of a Greek cross for St. Peter's, and his ugly Baroque façade hides the dome from the Piazza. There is much of Maderna's work in Rome, and also that of Bernini, the best of the Baroque artists. Bernini had all the vigour of the school, with more sense of dignity; his buildings, especially the Colonnade of St. Peter's, are majestic as well as grandiose; his fountains are effective, and his statues, though wanting in repose, are often very interesting.

In Florence, the principal exponent of the Baroque was Amminato, who built the beautiful bridge of Sta. Trinità, but whose statues are petty and vulgar. The contemporary John of Boulogne, much favoured by the early Medici, escaped the Baroque influence, and showed that sense of beauty and form which characterize the Renaissance.

Venetian In Venice the Baroque harmonizes better with art. the general style than in the simpler surroundings of Florence. Its extravagance seems in keeping with the scenic splendour of the background. Indeed, it synchronizes in point of time with the zenith of Renaissance art in Venice, where the development had been much later than in other parts of Italy, and where comparative security and prosperity allowed the artists to continue their work uninterruptedly throughout the sixteenth century. To this period belong some of the finest buildings and greatest artists of Venice-Titian, Paul Veronese, and Tintoretto, whose brilliant and opulent style reflect the translucent richness of Venetian colouring and the splendour of Venetian life, its spectacular displays and gorgeous festivals. 
As the Baroque had been a reaction against classicalism, Eclectiso in its turn was eclecticism a reaction against the Baroque. cisminart.

Eclecticism was an attempt to follow the example of the best Renaissance artists, selecting from each the best qualities in his work; it was therefore imitative, not original, and though conscientious and often graceful and dignified, it was without inspiration or force. The three Caracci, Luigi, Annibale, and Agostino, initiated it at Bologna, and Bologna remained its centre under the Caracci's pupils. Much eclectic work can also be seen in Rome, and there a striking contrast can be instituted between Raphael, their principal model, and one of the best eclectics, Domenichino. In the Vatican, the latter's Communion of St. Jerome, a well-painted but conventional and uninteresting picture, stands opposite the work of Raphael's prime, the Transfiguration. The greatest of the eclectics was Guido Reni (1575-1642), who should not be judged by his most popular productions, his sentimental Ecce Homo, and his feebly pretty St. Michael of the Capuccini, but by the real grace and beautiful colouring of his Aurora of the Rospigliosi Palace. Guercino, Sassoferrato and Carlo Maratta were all diligent painters in this school.

The eclectics, who paid particular attention to the setting of their pictures, were the founders of the Italian school of landscape painting which grew up in the seventeenth century. Salvator Rosa (1615-73) painted landscape for its own sake, mostly of a gloomy, stormy type. The famous landscape artists, Poussin and Claude, though of French nationality, may be reckoned as Italians,' since they lived and worked principally in Italy.

1832.3 
Poetry in The Baroque style was not confined to art, for we find the sixteenth and its counterpart in the flamboyant mannerism of contemseventeenth centuries. porary literature. Tasso, the last poet of the Renaissance Tasso. (1544-95), represents the transition from the classical to the Baroque style. Tasso was peculiarly sensitive to outward influences: he needed encouragement, freedom, the stimulus of a cultivated atmosphere; but he was fettered by narrow fashions, the classical style and the Petrarchian dialect,- - by the Jesuit censorship of the press, by the need of conciliating a kindly but not very liberal-minded patron and his petty court; and he was fettered also by his education in submissiveness and sentimental devotion, and by his own pliant and weak character, his self-distrust and undue anxiety to please. At the court of Alfonso II of Ferrara he was sometimes caressed, sometimes neglected; the court poet was no longer the pampered favourite, but the humble servant whose business it was to provide adulatory dedications for his master. Tasso received real kindness from Alfonso's sisters, Lucrezia and Leonora d'Este, and there is no ground for the scandal which sometimes links his name with that of the latter; but he was constantly at variance with other members of the court, who were jealous of the favour shown him. These troubles, with his nervous dread of the Inquisition and his morbid melancholia, really unhinged an illbalanced mind. The duke, after long forbearance with Tasso's eccentricity, felt obliged to confine him in a lunatic asylum. After some years he was set free, and wandered about Italy, still suffering from harmless melancholia, but everywhere welcomed and kindly treated. The Romans intended to give him the crown of a poet laureate, but he 
died, just before the ceremony, at the Convent of St. Onofrio.

Tasso's first success was his pretty pastoral play, Aminta, admirably suited to please a court whose life it idealized and whose duke it flattered. It was followed by his lifework, the famous Gerusalemme Liberata, most popular with generations of Italians, full of grace and charm, showing a real religion and purity of thought outstanding in a corrupt age. Yet it shows Tasso's weaknesses to be those of his time, that wordy sentimental unreality, and that exaltation of manner over matter, of style over thought, which were gradually dominating literature. It suffered also from Tasso's anxiety to please a host of differing critics, and from his fear of infringing orthodoxy.

Another poet at the court of Alfonso II, Guarini (1 537I6I2), also seems to have suffered from the bitterness of eating another's bread and from the jealousy of rivals, and his troubles found expression in his pastoral drama, Pastor Fido, an attack on court life. It has musical interludes, and is an opera in embryonic form. Guarini showed much more strongly than Tasso the tendencies of the age. The Italians had now grown very weary of the monotony of the classical style and broke out into all kinds of literary exaggeration, flowery artificiality, fantastic metaphors and 'conceits', vapid sentimentality-anything, in fact, novel or startling. The style became popular all over Europe, and was called, after its professors, the Précieux in France, Euphuists in England, Marinisti in Italy.

The Marinisti were named after the most characteristic Marinism. exponent of the style, the Neapolitan Marino (1569-1625), 
very popular among his contemporaries, who considered him a classic. He visited France, where he had an immense success with the Précieux, and received every honour from the Italian Queen and court. Marino's most famous poem was an epic on Adonis, whose prurient sensuality is only too painful an illustration of contemporary taste. Shakespeare's poem is prudish in comparison. It masqueraded as an allegory of the warfare of the soul against evil, but thoroughly deserved its relegation to the Index. In literary style it is the climax of Euphuism; nowhere are the metaphors more extravagant, effects more exaggerated, melody of phrase more dominant over sense. 'The poet's object is to astonish,' said Marino, and he certainly attained his object.

The Academies, and particularly the Roman 'Arcadians ', took up the new style and reduced it to absurdity. The Jesuits adorned their religious manuals with 'conceits', the pulpit orator delighted his audience with farfetched and astonishing metaphors. The fashion spread even to learned treatises on history and science: for example, an astronomical work is entitled $T$ he Celestial Anatomy of the Comets.

French

As the seventeenth century advanced, the influence of

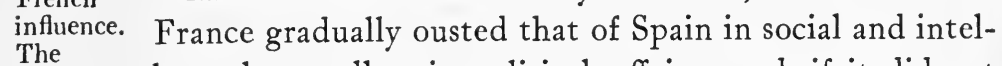

Rococo lectual, as well as in political, affairs; and, if it did not Period. bring with it higher ideals and morals, it at least brought a more liberal and intelligent outlook and an undoubtedly easier and pleasanter fashion of social life. The courts were no longer modelled on the gloomy Spanish pattern, they all endeavoured to imitate the amenities of Versailles. They could not attain to its brilliance, but they assimi- 
lated its frivolity, its artificiality and its looseness of moral tone. Yet there was something in the Rococo charm of the eighteenth century which was peculiarly suited to the Italian temperament, with its genius for what may be called the decorative side of life; for not even in France is that charm more gracefully expressed than in the Italian lesser arts of the period, and nowhere could the pseudoArcadian style, which had in itself the qualities of a miniature, have been more fittingly represented than in the miniature Italian courts.

Just as social life centred in the theatre or opera-house, so it endeavoured to imitate the conventions and artificiality of the stage. We can picture to ourselves the gentlemen in satin and velvet, with huge wigs and ruffles, the ladies with vast hoops, powdered head-dresses, patches, and fans, all bowing and curtseying in a kind of perpetual minuet. We can imagine them in a lofty ballroom, the walls adorned with gilt-framed mirrors and the ceilings with Arcadian frescoes, or in an artificial garden with fountains and statuettes decorating its stiff terraces. Or we can picture them in a boudoir, gay with painted and lacquered furniture, gilded clocks, and candelabra, marble, ivory, and crystal ornaments, or in the opera-house where every one in society had a loge for the season, and the gentlemen sauntered from loge to loge to gossip and flirt and take snuff, while the play itself was often but a secondary attraction.

The cicisbeo, or married lady's cavalier, seemed to dominate social life. He was her constant attendant, from her elaborate toilet-table to mass, to promenade, to the ball or opera. He waited on her, walked and danced 
with her in what seems to us an intolerable servitude; but the relationship was generally innocent, and indeed the cicisbeo apparently took the husband's place as the lady's guardian, and was often selected by the husband himself or by the lady's relations. Every rich family had also its abate or domestic chaplain, sometimes tutor and major-domo as well, who was expected to be always ready to sympathize with or entertain the ladies, and to make appropriate verses for every occasion, from the marriage of the daughter to the indisposition of the lap-dog.

The best trait of this society was its love of music and of verse; neither was perhaps of a very high type and improvisations were always most admired; yet the taste was perfectly genuine, and the chamber-concert was nearly as popular as the card-party.

The men met in the coffee-houses, but these were mere resorts for gossip and idling, not political and literary centres as elsewhere. The aim of society was amusement, and so long as the government provided a gay court with an opera-house and plenty of entertainments there was little political restlessness. The efforts of well-meaning reformers like Leopold of Tuscany were considered tiresome interferences with a best of all possible worlds, and the mutterings of the distant storm of revolution were unheeded. Indeed, in $\mathbf{1 7 8 7}$, an historian declared that few, and those peaceful, reforms were needed in an almost perfect society, and that 'Europe no longer fears a revolution'. Some few thoughtful minds there were, mainly amongst the lawyers, who were stirred by the writings of the Encyclopaedists, and some whom the classical revival of the latter half of the century awakened 
to a new standard in art, but to the majority the petty life of amusement and social intrigue was sufficient.

The conditions of middle- and lower-class life improved during the eighteenth century. War, plague, and famine were certainly less frequent, and though, in the southern states, misgovernment, with its resultant oppression and brigandage, was still rampant, in the northern there were distinct advances towards a better state of things. Thus, though the singing and dancing peasants of the Arcadian drama are certainly fictitious, we may believe that, except in outlying districts and backward states, the peasantry were tolerably contented.

The general level of morals was low; the Jesuits, who were not unduly strict, set the standard of religion. We do not hear of the great crimes and tragedies of former centuries, but this was because the Italians had become apathetic and conventional, and had no energy for strong passions any more than for heroic deeds and high aspirations. Men who could not conform to the ordinary standards of conduct were apt to become adventurers or social outlaws. Alfieri, the poet, wandered restlessly about, pouring out volumes of poetic fury against petty despots. Others turned to magic and made profit out of the foolish superstitions of society. Casanova was supposed to have learned from evil spirits the secrets of rejuvenation and immortality. Cagliostro pretended to perform miracles of healing and to make gold out of mercury. He lived luxuriously at the expense of his disciples, whom he formed into a lodge of mystic freemasons; at last, however, the Inquisition imprisoned him for life as a magician. The intellectual standard was low; Italy's lead in 
music and science was passing to other countries. Literature and art copied French models; indeed Italian authors borrowed shamelessly from the French. Polite society was all French; French fashions in dress were copied and French novels read, and we hear how 'ladies neglect the Tuscan language to gabble French'.

Eighteenthcentury verse and and pursue their vacuous love-affairs with flowery protestadrama. tions. Or else verse was degraded to become the medium of the most prosaic subjects, of works on medicine and agriculture, and even of the cookery-book. Innumerable academies multiplied versification; every one with the slightest pretension to culture could and did write verses on every occasion, from a contribution to a weddinganthology to an acrostic for a lady's album. The immense number of operas all required libretti; the best writer in this kind was Pietro Trapassi, generally known by his Arcadian pseudonym of Metastasio (1698-I782). He began life as a juvenile prodigy in improvisation; he attained immense popularity as a prolific writer of libretti, which he provided for all the Italian composers, and finally he became court-poet at Vienna. His elegant person and manners procured him constant admiration, especially from adoring ladies; his easy, flowing verse was admirably adapted to the florid music and bravura style of singing of the period. He possessed real charm and rhythmic beauty, but no dramatic qualities, no originality of character or plot, no genuine humour or passion. Like most of his contemporaries he employed the conventional characters and situations, manners, and sentiments. 
It is little wonder that the Italians, bored with this monotony, turned for variety to the Commedia dell' Arte, a form of drama, or rather of pantomime, of purely popular origin, which had, ever since the sixteenth century, taken a considerable part in public entertainment. A plot was sketched out, containing certain wellknown characters, in particular Pulcinello, a Neapolitan countryman, Pantaleone, a ridiculous Venetian nobleman, and his servant, Arlecchino. The dialogue, witty and topical, was improvised by the performers. Some of the Commedia dell' Arte companies attained great skill in this entertaining patter, and had a vogue abroad as well as in Italy. They visited France, Vienna, and Spain, and were in London just before Shakespeare's time. They influenced the characters and incidents of the French and Spanish dramatists, especially of Molière and Lopez de Vega, and also of the Elizabethans ; indeed, Holofernes and Parolles are regular Commedia dell' Arte types.

Their influence is also found in the work of the best Italian dramatist of the eighteenth century, Goldoni (1707-93). He might be called the Venetian Molière, inferior indeed in characterization and dramatic force, but with a real sense of humour, a happy turn of expression and instinct for dramatic situation without exaggeration or unpleasant coarseness. Breaking away from the Arcadian tradition he created a true comedy of manners, with characters drawn from real life in all classes. Goldoni was too vulgar and too much inclined to ridicule the frivolities of the rich to please the Venetian aristocracy, and they set up in opposition a very aristocratic dramatist, 
Gozzi (1722-1806), who invented, as an antidote to the dangerously socialistic tendencies of Goldoni's drama, a kind of pantomime, a mixture of fairy tales with the characters and incidents of the Commedia dell' Arte, which he used as a disguise for satire. For many years an acrimonious controversy raged between the two dramatists and their supporters, and it became a social, almost a political question; but Gozzi and his aristocratic backers finally succeeded in driving Goldoni from Venice. He retired to Paris, where his plays became very popular.

Arcadian The Arcadian fashion played as large a part in art as in and

Rococo styles in art. literature, but in Italy there was no Watteau to redeem it from the mediocre. Affectation and insincerity vitiated contemporary art; the churches were overloaded with ornament and crowded with preposterous monuments of vanity and bad taste; even sacred pictures were frivolous or gross. Ceilings, tapestries, and canvases were covered with sprawling, simpering deities, or with dressed-up shepherds in conventional landscapes. Tiepolo (I696I770), the one artist of the period who shows vigour and vivacity, with a feeling for colour and movement which link him to his Venetian predecessors, is rather of the Baroque than the Rococo school, betraying the violence and confusion of the former, and its straining after effect. Canaletto and Guardi painted innumerable Venetian scenes with considerable success; their style wants colour and warmth, but shows great care and mastery of detail.

The redeeming features of the Rococo style were the technical skill and dainty prettiness to be found in the minor forms of art, and these give the period a real value 
of its own. Italy had always been pre-eminent in decorative art, for example in ceramics, intarsia, and Venetian glass. The Medici particularly encouraged such industries, bringing tapestry makers from Flanders to teach, and setting up factories in coral and mosaic. Francesco I experimented in porcelain making in his private laboratory. In the eighteenth century these decorative arts reached a high state of perfection. Miniatures, jewels, porcelain, ivory, cameos, show exquisite care and finish, and such articles as snuff-boxes, clocks, fans, and musical instruments illustrate the elaborate charm of the Rococo style.

The influence of the new French philosophical ideas Serious on politics in the latter part of the eighteenth century study in has been described; they also influenced a few serious teenth writers on political science, economics, literary criticism, century. and law. The latter had always been studied in Italy, politics especially at Naples, where there was a powerful legal and ecocaste. Filangieri, a Neapolitan, wrote a treatise, $L a$ Scienza della Legislazione, on law, politics, and public morals. The Neapolitan government found him so useful an adviser that it allowed him to attack its many abuses with impunity. Still more important was Vico (1668-1743), who, after many years' study of the philosophy of history and law, produced his great work, Scienza nuova. He was the first thinker to point out distinctly the evolution through civilization of the human race, tracing it through myth and custom to religion and law, and always basing his theories on facts so far as he knew them. It is true that want of exact knowledge led him into mistakes such as a belief in 'cycles of development'; 
yet he was undoubtedly upon the right track, and his work, though disregarded by contemporary French writers, had much influence on Kant and later philosophy. On the practical side of law the work of the Milanese Beccaria on crime and punishment (p. 307) had the greatest importance, but his pleas for the humanizing of justice had little influence in Italy, though England, France, and Switzerland began to put his suggestions into practice.

In the seventeenth century two important authors had written on politics. The Piedmontese Botero based his theories on the political practice of Emanuele Filiberto and Cardinal Borromeo. He treated the state as the prince's private estate, suggesting improvements with a view to increasing its value to its owner. He showed some depth and penetration, but was too much influenced by the Counter-Reformation for independence of thought. Tassoni (I565-I635), a clever satirical poet, sincere, critical, and independent, despising the follies of the age and contemporary Marinism, had dared to attack the cult of Petrarch and to parody the popular heroic epic in a brilliant political satire, the Secchia rapita, a mock history of a bucket which became the object of warfare between two mediaeval towns. To win favour with Carlo Emanuele I he wrote some very outspoken philippics against Spain. 'Truly,' he said, 'those miserable creatures with such servility of soul that they like to be ruled by a foreign power are unworthy to be called Italians.' Unluckily Carlo Emanuele changed his party, and in order to conciliate Spain forced Tassoni to withdraw his philippics. 
In the eighteenth century Naples produced two eminent economists, Genovesi and Galiani. The former was attacked by the Church for his opinions, and a friend, in order to give him security, founded for him at Naples the first University Chair of Political Economy (I753). He was a physiocrat and protectionist, the more famous Galiani (1728-82) held opposite opinions. The latter was a brilliant writer and wit, but made a parade of his cynical cleverness. When twenty years old he wrote a work on money which became a classic of political economy. As secretary to the Neapolitan Legation he charmed all Paris with his social brilliance, although his dwarfish stature caused Marmontel to nickname him 'Harlequin with the head of Machiavelli'. But Grimm more politely called him. 'Plato with the vivacity of Harlequin'.

Of other Italian economists, the majority, including Beccaria, were physiocrats, and most of them, though advocating the abolition of gabelles, monopolies, and other hindrances to internal trade, were protectionists in external policy. Filangieri, however, though unacquainted with the teaching of Adam Smith, advocated free trade and complete freedom of industry. Verri, though a protectionist, opposed the physiocrats, and was perhaps the first writer to maintain that labour is the true producer of wealth. Verri, as a politician, had the good fortune to be able to put some of his theories into practice (p. 306) with successful results. He also attacked the literary, social, and economic abuses of the day in a journal called Caffè, to which Beccaria was a contributor. The government tolerated it in spite of 
its freedom of speech, but it could not contend against the prejudices of the Milanese, and was but short-lived. Some of its ideas were, however, adopted by the later Società Patriotica.

The value of journalism for social and literary satire was realized by other critics, and various new journals appeared. The most noted was Frusta Letteraria, founded by Baretti, who had travelled much, had been the friend of Johnson and Garrick and secretary to the English Royal Academy. He introduced Shakespeare to the notice of Italy. He attacked with independence and savage satire Marinist literature and contemporary life, but his views were so extreme that he abused Dante and Goldoni with almost equal ferocity.

The social follies of the day were satirized by the best of the eighteenth-century critics, Parini, who as domestic abate in grand families had ample opportunity to study them, and had sufficient literary talent to avoid the Marinist style and to write simple and forcible Italian. His best-known poem, 'Il Giorno,' is a satire on the daily life of a young Milanese nobleman, showing up sharply its vanity and idleness.

The Another direction in which French influence was Classical considerable was in the classical revival. Archaeology
Revival. had always been studied and collections made in Italy; the well-known Kircher Museum at Rome, for example, was founded in the seventeenth century. But now a new interest in the antique was awakened by the discoveries at Pompeii and Herculaneum, at the baths of Titus and the villa of Hadrian. Greek architecture was first shown to the West when Paestum was found in a forest. A new 
era of study and collection began, and Italian archaeologists were fortunately not all like the Neapolitan who, commissioned to describe Herculaneum, produced a monument of erudition on the Labours of. Hercules. -Among the best collections were those of Marco Borghese and of Pius VI, the latter housed in the Museo PioClementino in the Vatican. Finely illustrated books on classical remains and the engravings of Piranesi and Bartolozzi made the antiquities of Italy known to Europe. Bartolozzi's fine work is plentiful in England, where he lived for forty years.

The founder of modern archaeology was Winckelmann, who lived and worked for many years in Italy, and had the artistic soul of an Italian with the critical ability of a German. He first traced the development of ancient art to its different periods. The classical revival quickly spread to art, and Winckelmann's intimate friend, Raphael Mengs, was its apostle. Not himself a distinguished artist, he was undoubtedly a great teacher, and he directed the numerous artists of all countries who came to learn in Rome to the study of classical antiquity and the Renaissance with the most fruitful results.

Canova (1757-1822) the sculptor was undoubtedly the greatest artist of the classical school in Italy; he brought Italian sculpture out of the depths of mannerism and insincerity, and restored to it something of the dignity and grandeur of the ancient world. Canova and the pupils of Mengs were already causing the Rococo fashion to be superseded when the Revolution overthrew the follies and shams of the society which it represented.

One last link between the eighteenth century and the Alfieri. 
Revolution remains to be noticed, the poet Alfieri (1749I803), himself in part the product of the classical movement. A wealthy Piedmontese noble, of an adventurous, emotional, and vehement character, he led a roaming life, full of quarrels and love affairs, until he found happiness in the affection of the Pretender's unfortunate wife, the Countess of Albany. Plutarch's Lives created in him an enthusiasm for 'Liberty', the 'Liberty' of the French philosophers, and a hatred for tyrants, which he embodied in a series of plays. In each of them there is a typical tyrant and an heroic rebel, Saul and David, Philip II and Don Carlos, for example. The rebel declaims with earnest passion against the tyrant, but, as Alfieri strictly adhered to the rules of Greek tragedy, the plays contain little but declamation. Alfieri hoped to create through his plays an intellectual and moral renaissance, so that 'men might learn, through the stage, to be free, strong, generous, transported by true virtue, hating violence, loving their country, conscious of their rights, and be in all their passions ardent, upright, magnanimous'. He had little influence in his own age and country; there was no sentiment in the minds of his Italian contemporaries to respond to his passionate call for regeneration. The troubles of the Revolution age had to pass over Italy before the time came when her sense of nationality should awake, and Alfieri's words should inspire many patriots with their call to heroic self-sacrifice for her true liberty. 


\title{
THE EVOLUTION OF UNITY
}

\author{
I \\ France and Italy, I789-I8I5
}

ThE unification of Italy and Germany, and their Italian arrival among the Great Powers, are the most important ${ }_{\text {German }}^{\text {and }}$ facts in the political experience of nineteenth-century Unity. Europe. The two countries achieved unity simultaneously, but differed widely in the conditions out of which it emerged and in the means by which it was gained. Since Charles VIII descended upon the peninsula in I494, Italy had been subject to the foreigner. When the French Revolution burst upon her, the Hapsburgs dominated the north, and another branch of that Imperial House, the Spanish Bourbons, ruled the south. The settlement of I8I 5 intensified her bondage, obliterated the Republic of Venice, and planted Austria athwart continental Italy from the Alps to the Adriatic. Hence, unity involved not only the cohering of states hitherto apart, but the expulsion of a foreign power, whose resources undeveloped and divided Italy well might shrink from challenging.

A still more formidable obstacle to Italy's union was the fact that one of her princes was the sovereign pontiff of Roman Christendom. Since the Reichsdeputationsbauptschluss of 1803 , which completed the secularization of the Church in Germany, the Papal States were the sole survivor of its once universal Temporal Power. 
Their possession conferred upon the elected head of Roman Christendom a sovereign status which preserved to the institution he represented consideration as a member of the European commonwealth, a dignity which, with less spacious authority, it inherited from the days before the Reformation's assault. But the Pope's territorial sovereignty was incompatible with Italian unity, and its obliteration presented greater difficulties than did Austria's domination. Behind the Temporal Power was the veneration of half of Christendom. Even Cavour shrank from provoking it. His weaker successors did not venture to challenge it, and the plight of France, the principal champion of Clericalism, tardily created the conditions which made the adventure feasible in 1870. The fall of the Temporal Power was the last step in the difficult process of Italian unification, precisely because it was the most dangerous.

Other impediments to unity Germany and Italy shared in common-the political backwardness of their peoples, the particularist and parochial interests of their component states, the racial, temperamental, and constitutional idiosyncrasies which estranged North from South, Naples from Turin, Palermo from Florence or Milan, Bavaria or Baden from Berlin or Saxony. But German unity required neither the expulsion of the foreigner from her soil, nor the degradation of an international institution, as was the Papacy. By the rapid and calculated decision of war Bismarck made Germany one, and laid upon her the yoke of the Hohenzollern. Her failure to achieve a more equable and liberal unity, the obliteration of many of her finer qualities, the check to her constitutional 


\section{France and Italy, $1789-1815$}

development, and the deadening of her moral sense, Germany owes in large measure to Bismarck's impatient imposition of Prussia as dominator rerum.

German and Italian unity were achieved within a few months of each other, in the course of the Franco-German War of 1870-1. Differing materially in the circumstances out of which union emerged, the two events were accomplished by methods which also stand in contrast. The protracted rivalry of Austria and Prussia has no counterpart in the Italian movement. A plébiscite of the engrafted populations accompanied every step in Italy's progress from a heptarchy to a monarchy. On the other hand, German unity was imposed by the army of Prussia, and in the teeth of popular opposition. Italy fashioned a single and united state. Germany, in name an Empire, remained a Bund, a Confederation, of sovereign states under an Imperial flag. Italy achieved union by expelling the foreigner from her soil. Germany, under Bismarck's shrewd and unprincipled leading, expedited hers by wars which attached foreign territory-Schleswig, Alsace, Lorraine-to which she could lay no claim except upon the plea of convenience. Italian unity provoked no lingering resentment outside the Vatican. German unity constituted an indelible provocation to France; and threw Europe into two suspicious and, in the issue, belligerent camps.

Napoleon was the first to summon before Italy the Napoleon I vision of unity, and to excite ambitions which Cavour and Italy. satisfied more than half a century later. A conjunction of impulses permitted him to stimulate a spirit of nationalism there to which he was indifferent else- 
where. A strong and competent Italy was necessary as a strategic outpost against the Hapsburgs and to achieve his ambitions in the East. His Italian ancestry, his affectation of Imperial authority derived from Charles the Great, the fascination of classic Italy, and its alluring material for political experiment, all combined to make Napoleon tolerant to contingencies which his egotistical outlook elsewhere discouraged.

Before the French domination fastened upon Italy, her peninsula contained eleven states, suspicious, unfriendly, uneducated to recognize common interests, whose continental members were aloof from those of the peninsula, and among whom Sardinia-Piedmont, the maker of modern Italy, was so far from realizing her destiny that her people, half French, hardly understood that they were of the Italian stock. The eleven principalities in I789 exhibited a medley of monarchical, ecclesiastical, and republican constitutions. Piedmont (with Sardinia) and Naples (with Sicily) were states of royal rank, the former representing the territory of the ancient House of Savoy, the latter having been for just over fifty years, since I735, under Bourbon rule. The middle of the peninsula was ruled by the Pope, whose territory consisted of the Patrimony or Comarca, Umbria, Ancona, and Romagna (Legations of Ravenna, Ferrara, Bologna). To the north of Papal Italy lay ten of the Italian states. Four of them were duchies-Milan, Modena, Parma, Tuscany (a grand-duchy)-closely related dynastically to the Hapsburgs, and two of them, Milan and Tuscany, were appanages of that House. The remaining states were republics-Genoa, Lucca, San Marino, 
Venice-of which the last was incomparably the most powerful, and ruled the Dalmatian littoral of the Adriatic.

The French tricolour invaded Italy in 1796 and destroyed her political structure. Territorial changes followed with bewildering rapidity, until the Treaty of Vienna, or Schönbrunn, of October I809, so fatal to Austria, permitted Napoleon to complete his reconstruction of the peninsula. By 1810 the system of 1789 was compressed into a triarchy-omitting the small enclaves Piombino-Lucca (principality), Guastalla (duchy), Pontecorvo (principality), and Benevento (principality), which the Emperor bestowed upon his family or his officials : (I) Savoy, Piedmont, Parma, Genoa, Tuscany, Papal Italy on the near (west) side of the Pyrenees, and Venice's Dalmatian provinces were incorporated into France; (2) the continental portion of the Two Sicilies (excluding Sicily, where the Bourbons maintained themselves) was transferred without enlargement or diminution, first to Napoleon's brother Joseph, and, after his promotion to the throne of Spain (I808), to Joachim Murat, one of Napoleon's ablest generals, the husband of his sister Caroline; (3) Milan, Modena, continental Venice, the Papal Legations, and Ancona were fashioned into the 'Kingdom of Italy', whose crown Napoleon assumed, and whose government he entrusted to the Empress Josephine's son, Eugène de Beauharnais.

From I810-14 Italy was under Napoleon's domination. The tricolours of the French Empire and the Kingdom of Italy (the latter, green, white, and red) stood for the same social and political principles. The Code Napoléon 
was established. Lingering traces of feudalism were eradicated. The stifling police-ridden rule of the fallen dynasties was discarded. Law was uniform for all classes. Public life was open to the talented. Industry and commerce were encouraged. Education was promoted, and the Church was shorn of excessive wealth and privilege. Modern science and ability were applied to her backward society, and the life of Italy moved upon a larger platform. On the other hand, Napoleon's rule was blemished by inconsistencies. The plunder of her art treasures, annexation of her north-western provinces, and the indignities offered to the Pope, outraged Italy's traditions. Napoleon's financial exactions were onerous, and his drain upon Italy's active manhood to support unfamiliar and irrelevant causes in Russia and elsewhere was intolerable. Hence his fall in $\mathbf{1} 814$ was welcome even to a country he had set on the road towards a more promising future. Eugène abdicated (April I8I4). Murat, after Napoleon's escape from Elba (1815), challenged Austria ineffectually, and was shot by the Bourbons whose throne he occupied. The Kingdom of Italy was resolved into its original parts, and France again withdrew behind the Alps. The dethroned princes returned from exile, and the Pope was reinstalled in his own city. None the less, the old order and the ideas that supported it had gone for ever. A chapter, brief though it was, had been recorded in Italy's history, in which she exhibited the vitality of her old days, experienced the surging life of a great people, heard the trumpet call of independence, and began to understand the message of France's Revolution-Liberté, Égalité, 


\section{France and Italy, $1789-1815$}

Fraternité. Mazzini and Cavour, each in his way, built upon Italy's experience under Napoleon's brief, onerous, but stimulating rule.

The European Congress, whose deliberations produced Italy in the Treaty of Vienna in 1815 , approached Italy with ${ }^{1815 .}$ a purpose to restore the conditions which preceded the French cataclysm, though important modifications of the map of $\mathbf{1 7 8 9}$ were sanctioned. The most important effect of the treaty, as regarded Italy, was to restore and intensify the dominant position which Austria enjoyed before the Treaties of Campo Formio (I797) and Vienna (1809). The Duchy of Milan was obliterated. Together with the continental territory of the old Republic of Venice it was ceded to Austria, and with it constituted the 'Kingdom' of Lombardy-Venetia. Austria also recovered the Italian-speaking portion of Tyrol - the Trentino - as well as the Italian-speaking district on the Isonzo. Napoleon had incorporated both in the Kingdom of Italy, a fact which Italy did not permit herself to forget, and, after earlier disappointments, influenced her to declare war upon Austria in 1915. Gorizia, Trieste, and Dalmatia also passed to Austria, and gave her the eastern littoral of the Adriatic southward to Spizza. From I8I 5 to I 866 the establishment of Austria across Italy from the Alps to the Adriatic stifled the hopes of Italian union. Her rule in Lombardy-Venetia was not less enlightened than that of the other restored dynasties. But the composition of her 'ramshackle Empire' made her the determined foe of nationalism within and without her borders, and of the Liberal principles which the French Revolution 
had let loose upon Europe. Her military resources, the dynastic influence which she exerted upon the restored rulers of the peninsula, and the support which she could be counted on to offer to their reactionary policy, constituted a menace which the maturing spirit of Italy could not tolerate, and made her expulsion the first condition of union.

Elsewhere, with one important and one minor exception, the Treaty of Vienna restored the status quo ante bellum in Italy. The Kingdom of Piedmont-Sardinia (concisely and correctly, Sardinia) was restored. It recovered Savoy and Nice, which had been the French Republic's first spoil in Italy, and obtained the territory of the sometime Republic of Genoa, which now received the status of a duchy. Its enforced union with Sardinia was exceedingly repugnant to Genoa, whose citizens refused to recognize the administration of Turin, and at a later time united eagerness for Italian unity with a desire to break the connexion which the Vienna Congress had imposed. Tuscany, to which the island of Elba was attached (it had been conveyed to France in I802), was restored to the Grand Duke Ferdinand III, brother of the Emperor Francis II. Duke Francis IV, who, like his kinsman in Tuscany, was a member of the Hapsburg-Lorraine family, recovered the Duchy of Modena. The Duchy of Parma (with Piacenza and Guastalla) was assigned to Napoleon's wife, the exEmpress Maria Luisa, herself an Austrian, daughter of Francis II, cousin and niece respectively of the rulers of Modena and Tuscany. Lucca, which was not permitted to resume its republican status, was given as 


\section{France and Italy, 1780-1815 36I}

a duchy to Maria Luisa, daughter of Charles IV of Spain and wife of Louis, Duke of Parma (1802-3), who had been king briefly of the Kingdom of Etruria erected by Napoleon in 1801 . Central Italy once more obeyed the Pope, and the Bourbons returned to Naples, with which Sicily, racially and historically apart, was forcibly united.

Thus, omitting the insignificant Republic of San Marino, which alone of the original republics survives to the present day, the Treaty of Vienna constituted an octarchy, whose compression into a monarchy is the history of Italy in the first three-quarters of the nineteenth century. The Duchy of Milan and the Republics of Venice and Genoa disappeared from the map, the annexation of Genoa to Sardinia being the contribution of the Treaty of Vienna towards the unification of the peninsula. Until 1859, when the process of Italian unification began, Italy's political divisions remained as the Treaty of 1815 established them, with a single exception: on the death of the ex-Empress Maria Luisa in 1847 , the Duchy of Parma, in which she had only a life-interest, reverted to Charles II, son of Louis, Duke of Parma and sometime King of Etruria. In accordance with the settlement of 1815 he abandoned his mother's Duchy of Lucca to Tuscany on his succession elsewhere, and reduced the Italian octarchy to seven states.

The reactionary character of the Congress's settlement of Italy marked also the rule of her restored princes. Victims of the gospel of Liberalism preached by the French Revolution, they returned bigotedly opposed to 
constitutionalism, and set in motion once more the former illiberal régime, police, espionnage, clerical privilege and exclusiveness. Education was starved. The Press was muzzled. Opportunities for public service, open to the middle class under Napoleonic rule, were closed. Italy retired again into the eighteenth century, and Austria was looked to to support by example, and if need be by her arms, the reactionary system which was rampant throughout the peninsula. Dynastic ties bound almost the whole of it north of the Papal States to her. Maria Luisa entrusted the administration of her duchy to Austrians. The Dukes of Tuscany and Modena, relying on Austrian assistance, revoked the French Code, and restored the nobility and religious orders to their former privileges. The Pope abolished the civil administration and code which Napoleon had set up. The papal provinces reverted to the rule of the Vatican. In Naples a system of repression was instituted; and Ferdinand, whom England had induced to give Sicily a constitution in I8I2, bound himself by a formal agreement with Austria to veto innovations which were not in accord with her own illiberal standards. In Sardinia, Victor Emanuel I, after fifteen years' exile, restored the archaic constitution of 1770 , pursued a vendetta against all who had served France during the country's attachment to the Empire, restored the Church to its former privileges, and proposed to destroy even the material monuments of French enterprise.

Thus, Italy reverted to the old tyranny, absolutism, police law, and clerical rule. With no constitutional channels through which to express herself, unable to 


\section{France and Italy, I789-1815 363}

ventilate her grievances in a free Press, she was driven to obtain release by other means from the conditions to which the diplomacy of 1815 delivered her. In turn three parties worked for that end-the Carbonari, Mazzini's La Giovine Italia (Young Italy), and the Conservative Nationalists. Liberals, Republicans, and Moderates, alternating and in opposition, strove to refashion Italy, but without success, until Cavour took the helm.

\section{The Carbonari and the Revolutions of $1820-I$}

The Carbonari made their bid for Italy's regeneration in the abortive revolutions of $1820-1$ in Naples and Piedmont. Evolved from the Freemasons, a numerous body in Southern Italy, the society was founded by republican stalwarts early in the nineteenth century, when Joseph Bonaparte was on the throne of Naples, and in opposition to his foreign rule. It extended its opposition to Murat, and contributed to his fall. Its antiFrench bias commended it at first to the restored Ferdinand of Naples, and its influence helped to secure the Sicilian Constitution of 1812 , which lapsed upon his restoration and the union of Sicily with continental Naples. The society was neither exclusively monarchical nor republican in its aims. But its outlook was consistently Liberal, and though it was not clearly instructed as to the form which liberated Italy should assume, it contemplated procuring by leisurely and vague processes freedom from the foreigner and inter-state union. The 
unit of the society's organization was the venta, or band of twenty members, acting under the orders of a central venta or supreme lodge at Naples. Its ramifications and organized system of administration and justice constituted it a rival to the illiberal, corrupt, and incompetent Bourbon government; while the political vendita which Ferdinand conducted on his restoration swelled its membership and spurred it to activity.

From Naples the Carbonari spread to North Italy. Piedmont, Parma, Lombardy, possessed organizations which were in actual or indirect association with the Neapolitan lodge. By 1820 the Carbonari and allied societies probably numbered half a million members, differing in particulars, but at one in the ambition to expel Austria, to make Italy a nation, and to liberalize the absolutist governments which dragooned her. The malcontents were drawn chiefly from the middle class, which had cause to regret Napoleonic conditions, men whose activities were strangled in the parochial atmosphere that replaced the short-lived Kingdom of Italy, soldiers who had fought under the tricolour, civil servants whom the restored princes had dismissed. In the armies, especially those of Naples and Sardinia, the Carbonari were numerous and organized, and from within the army came the call for Italy's first national effort in I820. The corruption of Ferdinand's rule, and the indignity which an Austrian army of occupation offered to Neapolitan sentiment until i8r7, swelled the ranks of the Carbonari. They swarmed in the army, which was ill disciplined and unpaid. One of their number, Guglielmo Pepe, a Calabrian officer, once in Murat's service, now commander 
The Carbonari and Revolutions of $I 820-I 365$

of the provincial militia, a force of 50,000 men, was about to strike when the call to action came from another quarter.

The year 1820 broke cloudily upon the Holy Alliance The moveand the absolutist systems which its members, the $\underset{\mathrm{r} 820}{\text { ments }}$ of Emperors of Russia and Austria and the King of Prussia, regarded as a safeguard against the pernicious doctrines with which the French Revolution had infected Europe. In February the Duc de Berry, grandson of Louis XVIII of France, was assassinated, a crime denounced as the consequence of the government's laxity and truckling to Liberalism. A few weeks earlier a Spanish regiment, on the eve of embarking for South America, proclaimed the Constitution of I8I2, drafted while Ferdinand VII of Spain was a prisoner of Napoleon in France. It placed the sovereignty in the people, asserted the principles of legal equality and liberty, outlined a political system on the model of France's in I79I, vested the executive in the Crown and its ministers, and subordinated it to a single-chamber parliament elected by universal suffrage. The Spanish pronunciamiento and the ease with which it was accomplished excited imitators. Portugal succumbed to a Liberal movement which forced a Constitution upon the Crown. There, as in Spain, the revolution was accomplished without bloodshed. In Italy a repetition of the circumstances had another result.

On July 2, 1820, two young officers of a cavalry regiment quartered at Nola marched their troops to Avellino in the Principati and declared for the Spanish Constitution. So ripe was the country for revolt that within two days the Carbonari were out and ready for 
action throughout the greater part of the kingdom. Pepe and a considerable force joined the insurgents at Avellino, and thence, flying the Italian tricolour, marched upon Naples to intimidate the king. Ferdinand yielded, took an oath of fidelity to the Constitution, and invited the curse of Heaven to fall upon him should he prove false to it. Sicily also caught the blaze and rose, in name for the Sicilian Constitution of 1812 , in fact to break the union with Naples. Her effort was easily quelled. That of the Neapolitan Carbonari proved more serious.

Naples and In the autumn of 1820 the three members of the Holy the Powers. Alliance, with France and Great Britain, assembled at Troppau to discuss the European situation, and particularly recent events in Spain and Italy. Austria, closely interested, hoped to obtain a mandate to suppress the Neapolitan movement. But the Western Powers refused to admit the principle of intervention to the public law of Europe, maintaining that the wishes of the people and not the interests of foreign autocrats ought to decide a nation's internal policy. At Laibach, whither the Conference adjourned in 1821 , France and Great Britain maintained their attitude, though Ferdinand of Naples, who was present to unfold his case, represented himself as the victim of force and begged for aid. He had left Naples under a solemn promise to his Parliament not to act against the Constitution; the deputies permitting his departure, doubtful whether to seize the opportunity to depose him altogether, fling down the challenge to Austria, and, relying on the goodwill of the Western Powers, carry the revolution into the papal territories. 


\section{The Carbonari and Revolutions of I820-I 367}

Irresolution prevented them from adopting a definite course and delivered them to Ferdinand's cunning.

From Laibach Ferdinand represented himself to his Rieti, 182r. ministers as torn between loyalty to the Constitution and the need to conciliate Austria's determination to upset it. Both Russia and Prussia were willing to give Austria a mandate to act; and the Italian princes, except the Pope, were agreeable to the punishment of what appeared to them all a pernicious and dangerous example. Early in February I82I, therefore, an Austrian force crossed the Po and marched southward. The Neapolitan Parliament protested against the principle of intervention under which Austria affected to act, declared itself the ally of all constitutional states, and announced its resolution to make no peace with an enemy occupying its territory. In the army counsels were divided, many of the officers regarding it as hopeless to withstand the advancing Austrians. Pepe, however, scorning a defensive policy, boldly attacked them at Rieti on March 7, before the frontier had been violated. After a brave fight he was forced to retire. His army melted, and a fortnight later (March 23) the Austrians entered Naples. Ferdinand followed in their wake. The Constitution was withdrawn, the old absolutism was restored, the tricolour was proscribed, and to curb the Carbonari for the future, the king took into his pay four regiments of Swiss mercenaries. Ferdinand pursued his victory with vindictive energy. Political trials were general. About 800 persons were condemned to death. The prisons were crowded with prisoners. A list of over 100,000 suspected persons was drawn up by the 
police, and not until I827 was the Austrian army withdrawn.

The Pied- Three days after Rieti Piedmont flared to ineffectual mont Rising, revolt. Victor Emmanuel I, naturally disposed to I 820 . despotism, suspicious of Liberalism, and seconded by his Hapsburg wife, Maria Theresia, had set himself to destroy all traces of French occupation and to restore eighteenthcentury conditions. The old system of corruption, privilege, and police was revived. The Church received again its confiscated endowments and institutions. The Jesuits resumed control of the educational machinery of the kingdom. Officers and men who had fought the Austrians at Austerlitz, students, discharged civil servants, and others were drawn into the coils of conspiracy by the king's uncompromising attitude. The doctrinaire Spanish Constitution of 1812 was the aim of their effort, and its establishment was anticipated as the prelude to a war of independence against the Austrians. 'To the king's cousin, Charles Albert, Prince of Carignano, the malcontents looked for leadership.

Charles Al- Charles Albert was a member of the younger branch bert of
Carignano. of the House of Savoy, twenty-three years old, and, since Victor Emmanuel and his brother Charles Felix were childless, heir-presumptive to the Sardinian crown. He was manly, devoted to arms, not undeserving of his sobriquet 'The Sword of Italy'. But his character lacked decision, and his irresolute career caused him to be known as 'Rè Tentenna' (King Vacillator). Both he and his father affected towards the reigning branch of their House the attitude of the Orleans princes to their Bourbon relatives during and after the French Revolution. 


\section{The Carbonari and Revolutions of I820-I 369}

Charles Albert himself was educated at Paris, served in Napoleon's army, and was a Count of his Empire. Returning as a young man to his native country, he identified himself with Liberal opinion; and though his initiation as a Carbonaro is improbable, he did not discourage the society from looking for his support in a constitutional campaign and challenge to Austria. On March 6, I82 I, the leaders divulged to the prince a plot to secure a constitution from the King. Whether Charles Albert undertook to support the project is disputed, and is denied by himself. His youth, inexperience, and relation to the throne, counselled the wisdom of watching the event, of being guided by its issue. On that consideration eventually he acted.

Since the beginning of the year the relations between the government and the populace of Turin had been tense. In January affrays occurred between the students of the university and the troops, arising out of a demonstration, harmless in character, on the part of the former. Rioting followed and several students were killed. The circumstances spurred the malcontents to action, the visit of their leaders to the prince being inspired immediately by the belief that the government was in possession of their plans. Whatever encouragement Charles Albert gave at the interview on March 6, second thoughts, and perhaps fear of the consequences to the King, moved him to warn the conspirators that he could not be counted upon. In fact he cautioned the government. In the circumstances it was determined to postpone the rising, which had been arranged for March 8. But the decision was too late to influence the conspirators outside Turin, 1832.3 
On March Io the Alessandria garrison proclaimed the Spanish Constitution, raised the Italian tricolour, saluted Victor Emmanuel as 'King of Italy', and clamoured to be led against 'the Germans', whose unwilling agent they believed him to be. The revolt spread to the citadel of Turin, where, on the I2th, the Spanish Constitution was proclaimed and the garrison demanded to be led against the Austrians. Unwilling to quell the revolution by force, and unable to countenance the demand for war against Austria, Victor Emmanuel took a step which relieved himself of responsibility, but merely postponed the solution of the crisis. On the evening of March 12 he announced his abdication, and pending the arrival of the new sovereign, his brother, Charles Felix, then at Modena, conferred the regency on Charles Albert.

Novara, I82I.

After gaining the Spanish Constitution the conspirators planned to cross the Ticino into Lombardy, overpower the Austrian garrisons in Milan and elsewhere, and joining the local Carbonari, to cut off the retreat of the Austrian force from Naples, after which a Lombardy Convention was contemplated, to vote the union of Austrian Italy with Piedmont. Charles Albert, faced by the issue which his cousin had shirked, recognized the futility of challenging Austria. On the other hand, he met the demand for reform. The Spanish Constitution was proclaimed on March I3, the Regent excusing his action as taken under 'stress of circumstances', ' to preserve the kingdom to the new sovereign'. Two days later he took the oath of fealty to the constitution. While his action eased the situation, Charles Albert seems to have satisfied himself that it did not commit the new 
The Carbonari and Revolutions of $I 820-I$ 37I

sovereign, whose pro-Austrian and illiberal views were known. Charles Felix, in fact, refused to countenance his cousin's proceedings and ordered the prince to Novara, there to surrender his authority. After another crisis of indecision, Charles Albert fled to Milan, and thence into exile. Meanwhile, with Austrian help, the revolution was easily suppressed, and after an engagement between the insurgents and the royal army at Novara on April 8, the movement was at an end. A military commission was instituted ; more than five hundred insurgents were tried and condemned, ninety-one of them to death, fifty-three to perpetual imprisonment. The university was closed, and the regiments that had taken part in the revolt were disbanded.

The Carbonari had shot their bolt, and ineffectually. Austria's domination was riveted as firmly upon the peninsula as France's had been ten years earlier; and Italy's despots looked to her to support the political systems which the revolutions of 1820 and I82I had been powerless to dislodge. The movement had failed because the sentiment of unity was weak and the means to organize it inadequate. Italy awaited a leader who could stamp upon her consciousness a vivid impression of the oneness of her peoples, and an event whose magnitude, transcending the puny outbreaks of 1820 and 1821 , should fire her with the passion for unity and the resolve to attain it. The French Revolution of 1830 and Giuseppe Mazzini's La Giovine Italia provided her with both. With them the Italian Risorgimento begins. 


\section{3}

\section{Italy and the French Revolution of 1830}

Manzoni and Romanti. cism.

The political movements of 1830 in France, Belgium, Poland, Italy, and elsewhere closed the era of reaction which the settlement of I8I5 established and the Holy Alliance consecrated. France, whence the signal had come forty years earlier, and came again eighteen years later, led the van. The triumph of reaction achieved in Italy in I 820-I had not been disturbed, and the abortive efforts in Naples and Piedmont marked the last impulses derived from the first French Revolution. New forces came into play-Romanticism, of which Alessandro Manzoni (1785-1873) was the prophet, and a new school of history, which appealed to the present through the past. Behind Manzoni's I Promessi Sposi, published in I 827, a Milanese story of the seventeenth century, was the allegory of Italy baulked of her birthright by foreign domination. A few years earlier (1820) the periodical La Antologia had been founded in imitation of the Edinburgh Review, in close touch with the political and social unrest of the times, and with the proclaimed object ' to make Italy know itself and to set before Italians a national ideal'. Mazzini wrote for it, and eventually directed the spirit which animated it and Manzoni alike, but to conclusions patently radical and republican.

Romanticism did not become an active force until Mazzini gave it shape, a programme, and an organization. For the moment he was an unknown force among his countrymen, and the Carbonari, whose head-quarters 


\section{Italy and the French Revolution of I830 373}

had been transferred to Paris after the failure of $1820-1$, remained the only directive agency in the field. At the same time, the transference of head-quarters to France deprived the society of its distinctively Italian outlook, separated its management from the activities it affected to direct, and surrendered its control into the hands of doctrinaires.

The French Revolution of July I 830 and the stirring of Francis IV Liberalism in Western Europe invited the Carbonari to of Modena. rekindle the political agitation suppressed so easily ten years before. Neither Tuscany, Naples, Piedmont, nor Austrian Italy was affected by the movement of I83I, which expended its energy in localities that eluded the earlier effort-the Papal States and the small principalities, Parma and Modena. In the Papal States clerical misgovernment continued without mitigation, particularly in Romagna, where the Carbonari were recruited even from the officials and police in papal employ. A vain attempt was made to crush them in 1825 , when the situation almost resulted in open revolt. The July Revolution in Paris signalled a larger crisis. Parma, where the government was corrupt, the civil service inefficient, and the Church enjoyed its former licence, was readily inundated by the flood of revolution which flowed from elsewhere. In Modena, Duke Francis IV, grandson of Maria Theresia of Austria, had been restored to the duchy in 1815. Restless and intriguing, his marriage with the daughter of Victor Emmanuel encouraged him to hope that the Salic Law might be waived to give her the throne of Sardinia. His ambition even contemplated Northern Italy united under his rule, which 
should embrace the principalities and trans-Apennine territory of the Papal States. Francis fished indifferently in all waters that promised a harvest, now scheming with Austria against the Holy See, now with Rome against Vienna, and even with the Modenese Carbonari, whose leader, Ciro Menotti, was in close touch with the Carbonaro lodges in Paris, Rome, and Romagna.

Anticipating that the French Revolution would establish either a Republic or a Liberal Monarchy, Francis prepared to give effective assistance to the Carbonari. Louis-Philippe, whom the Revolution brought to the throne, had been in close touch with their head-quarters in Paris. But, once seated upon the throne, Louis-Philippe refused to permit France to become again the stormy petrel of revolt in Europe. Denouncing him as an 'abyss of roguery', Francis shrewdly resolved to suppress a movement which in other circumstances he meant to use. An abortive rising of the Carbonari at Rome, on December I0, I830, while the Conclave summoned on the death of Pius VIII was sitting, convinced Francis that the moment had arrived to act. On February 3, I83 I, he arrested Menotti and other Modenese Liberals, with whom he had been in close communication, and proposed to ingratiate himself with Vienna, and to obliterate evidence of his own collusion, by their summary execution. Menotti and another suffered death.

The Italian Francis, however, miscalculated the situation. Menotti's movements seizure stirred the Carbonari in Romagna to act. On
of $183 \mathrm{r}$. February 4 an insurrection broke out in Bologna, where secret societies had been more active than in any other part of Italy save Naples, and among whom Mazzini's 
influence was making itself felt for the first time in the peninsula. The papal pro-legate, deserted by the soldiery, nominated a provisional government and abandoned his post. The other Legations, Ravenna and Ferrara, followed Bologna's example, and within less than a month the whole of Romagna, the Marches of Ancona, and Umbria, to the Neapolitan frontier, had thrown off papal rule. Meanwhile, upon the news of the Bologna rising reaching Modena, Duke Francis fled. His neighbour, the Duchess of Parma, followed his example. The insurrection carried all before it with astonishing and encouraging ease. Nearly two and a half millions of Italians had made themselves 'free'.

On February 25, 1831, the provisional government at Bologna formally decreed the abolition of the Temporal Power in the province, drew up a provisional constitution, and ordered elections to take place for a National Assembly, which constituted itself the 'Assembly of the Free Provinces of Italy', and the provinces it represented, 'The United Italian Provinces'. Its army was put in motion towards Rome. Louis Napoleon Bonaparte, nephew of Napoleon I and afterwards Emperor of the French, who was serving with it, counselled the Pope to surrender the Temporal Power, with which his future career was to be so closely involved, and urged an assault upon the city. The Papacy, at the mercy of the revolution, was saved by the timely intervention of Austria, whose forces already were on the move.

The chief deterrent to Austria's intervention had been Austria removed by assurances from Paris. The July Revolution and reand the resuscitation of the tricolour as the national flag ${ }^{\mathrm{I}} 3^{\mathrm{I}-2 .}$ 
aroused the forebodings of Conservative Europe. But having reached the throne upon the tide of Liberal fervour, Louis-Philippe did not fail to see that its permanence required a more conservative anchorage. Austria already was proposing to reconstruct the anti-French league drawn round France's last revolutionary outbreak. To avoid that experience and discipline it was necessary to convince Europe that the consequences of the first Revolution were not likely to flow from the second. The choice of the constitutional royalist Casimir Périer for the Foreign Office calmed the European Chancelleries, whom the new minister hastened to assure that the Revolution would not menace France's neighbours. Upon his former friends the Carbonari, Louis-Philippe, like Louis Napoleon later, turned his back, and Austria was allowed to understand that, in spite of France's approval of 'the new principle of allowing the development of liberty wheresoever it may appear spontaneously', she was willing that Austria should take measures to regulate the Italian situation. Austria fulfilled the mandate, Parma and Modena were overrun, their sovereigns were restored. Bologna was occupied without resistance, and before the end of March the provisional government capitulated on the promise of an amnesty. As in Naples and Piedmont after their strokes for liberty, the old abuses were restored, and for the rest of its existence as a secular state the Papacy successfully resisted the growing demand, inside and outside Italy, for the reform of a government which continued nearly to the end of the nineteenth century the discredited principles of the eighteenth. As in I820-I, Austria showed no eagerness to evacuate territory she 
had preserved to despotism. In I832, therefore, Casimir Périer placed a French garrison at Ancona, in protest against Austria's continued occupation of the Legations. It was not withdrawn until 1837 , when both powers temporarily withdrew from papal territory, their latent antagonism and conflicting interest in the peninsula having then, as later, done much to confirm the Papacy in its obdurate refusal to set its constitutional house in order under the pressure of public opinion.

The Bologna Revolution exhibited neither the definiteness of purpose nor capacity in leadership which the cause of Italy demanded. Accompanying the design to destroy papal rule there went no clear idea of what should take its place. Some invoked the name of Napoleon and had in mind to form a new Kingdom of Italy, possibly under Jerome Bonaparte, Napoleon's only surviving brother, or Louis Napoleon Bonaparte, or perhaps under a son of Eugène de Beauharnais, Napoleon's former viceroy. But the difficulties which the abrogation of the Temporal Power and the settlement of Rome as the capital of the new state presented were beyond the ability of the lawyers and professors, ignorant of public affairs, into whose control the movement fell. The success of their effort also had been compromised by a short-sighted resolve of non-intervention, which forbade Bologna to accept the military help of the Modenese. On the other hand, the movement was no longer a military pronunciamiento of the 1820 type, but the convinced, though misdirected, expression of civilian middle-class opinion. The French Revolution of 1830 had prepared the soil. It remained for Mazzini to plant it. 


\section{4 \\ La Giovine Italia}

Giuseppe Mazzini.

Giuseppe Mazzini was born at Genoa on June 22, I805, the year and month in which the Code Napoléon was introduced into Italy. His father, Giacomo Mazzini, was a distinguished physician and professor of anatomy in the University of the city. His mother, Maria Drago, a woman of great beauty and depth of character, sustained him through long years of poverty and exile in England by her sympathy and support. Ill health intensified his studious application to books. In his father's library he found the philosophical and political writers of the French Revolution, and from them drew the inspiration and ideals of his active life. He displayed a remarkable facility in acquiring modern languages, spoke English fluently, and supplied a slender purse in later days by articles contributed to English magazines. At the University of Genoa, to which he was sent at the early age of thirteen, he was distinguished by his acuteness in philosophical studies, by an independent outlook which conflicted sometimes with authority, and by the ascendancy which his earnest nature exerted over his fellows. Besides the regular course of university study, he devoted himself to medicine and anatomy, with the idea of following his father's profession, and made sufficient progress to enable him to write his father's anatomical lectures. But experience of the dissecting-room caused him to abandon medicine for law, to the study of which he applied himself during the latter part of his university 
career. The natural tendency of his mind was towards literature, and with regret he abandoned the idea of making it his profession. So early as his first year at the university his writing attracted the attention of a literary association at Savona, which, ignorant of his age, elected him a member. It was not until half-way through his university curriculum that the problem of Italy's future came before him vividly, suggested by the execution at Genoa of two men who had taken part in the abortive insurrection of $182 \mathrm{I}$, and by a street collection in behalf of those banished for participation in the movement.

Having completed his five years' course at the university, Mazzini took his degree, and was admitted to practise as an advocate. As was the custom, he passed his noviciate in the Uffizio dei Poveri, whence the poor were able to obtain legal counsel without expense, and young lawyers gained experience in the courts. Mazzini's youthful appearance caused him to be known as ' l'Avvocatino', and he brought to his gratuitous task the equipment of a singularly gentle nature. At this time, too, he attached himself to the Carbonari, drawn to them by the Revolutions of 1820-I and study of the disease which they aimed at curing. But the opéra bouffe ceremony of affiliation excited his amusement and contempt, and he had difficulty in keeping his countenance during its performance. Of more importance, in his own words, he reflected 'with surprise and distrust, that the oath which had been administered to him was a mere formula of obedience, but contained nothing defining the aim to be reached '. It pledged him to ' war against the government', but neither declared the reason nor prêscribed 
the alternative. He had no liking for the society's secret organization, its methods of conspiracy, its mysterious control, and its employment of instruments which his rooted republicanism rejected. At the same time, though he found the Carbonari ' inferior to the idea they represented', he applauded them as men who were ' earnestly bent on reducing thought to action, belief into works', ready to 'defy excommunication and capital punishment, to persevere with persistent energy, and to weave a fresh web every time the old one was broken'.

The outbreak of the French Revolution in July 1830 rendered the autocratic governments of Italy alert for the activities of the Carbonari and other secret agencies. Mazzini was now twenty-five years old. The views which he expressed in 'Young Italy' were formed, and the authorities already regarded him as a suspicious character, ' a young man of talent, very fond of solitary walks by night, and habitually silent as to the object of his reflexions'. He was aware of the danger in which he stood, and while engaged upon a mission committed to him by his chiefs was arrested, upon the information of the spy who had affiliated him. "The government is not fond of young men of talent, the subject of whose musings is unknown to it,' the authorities explained to their prisoner's family. Mazzini was hurried to prison in the fortress of Savona, in the western Riviera, and remained there until February I83I, when he was permitted to exchange his cell for exile at Marseilles. He was precluded therefore from actively participating in the short-lived Revolution in Central Italy in the summer of that year.

His confinement at Savona afforded him leisure and 
detachment to examine the problem of Italy's future. He convinced himself that an effort to put life and purpose into the Carbonari would 'waste time and energy in the attempt to galvanize a corpse', and that Italy's regeneration needed ' a new revolutionary edifice on a new basis'. The Revolution of $183 \mathbf{I}$, when the popular instinct for unity broke down under stress of the crisis, confirmed his opinion. The provisional governments created by the Revolution refused either to give or receive assistance. 'None of our people', said the Bologna insurgents, 'shall take part in our neighbours' quarrels.' Consistently with that declaration, they actually disarmed a force sent from Modena to their support. In Mazzini's view, also, Italy's cause was handicapped by 'a fatal want of harmony between thought and action' on the part of those who affected to lead her cause. The error revealed by the movements of I820-I and I831, Mazzini declared later, 'lay in entrusting the government of the insurrection to those who had no share in making it. The preliminary conspiracy and the revolution have been represented always by two distinct classes of men. The first were thrust aside as soon as all obstacles were overthrown. The second entered the arena a day after, to direct the development of an idea not their own, a design they had not matured, the elements and difficulties of which they had never studied, and in the enthusiasm and sacrifices for which they had had no share.'

But, apart from errors of organization and leadership, there were two points of principle in which Mazzini differed fundamentally from the Carbonari and also from the Moderates who followed him. He was a son of Genoa, 
whose republican traditions survived its attachment to monarchical Piedmont. Foremost in his dogmatic creed was his affirmation that Free Italy must be a republic, and that the potential agents of her salvation were neither kings, statesmen, nor foreign or mercenary armies, but the people themselves, roused to achieve a great ideal. It seemed to him also that social reform, so urgently needed, was improbable of attainment under a monarchical constitution; and he regarded the experience of France as establishing his conclusion. The traditions of the past also linked Italy and republicanism, and unity under any other constitution seemed to him impossible. Sardinia and the Two Sicilies were monarchies and the principal secular states of the peninsula. That either would efface its dynasty in the cause of unity was beyond Mazzini's belief. The experiences of I 820-I and I83I strengthened his conviction. Louis-Philippe's desertion in the latter year, Mazzini wrote, was ' the third royal betrayal I had seen enacted under my own eyes in Italian matters. The first was the shameful flight of the Carbonaro conspiratorprince Charles Albert to the camp of the enemy. The second was that of the Duke of Modena, who, after encouraging and protecting the insurrection organized in his name by poor Ciro Menotti, attacked and seized him in the very moment of the rising and dragged him along with him in his flight to Mantua, to hang him as soon as Austria furnished him with the means of returning to his dukedom.' He held also that ' the whole tendency of the progressive movement taking place throughout Europe is providentially directed towards the gradual realization of the republican principle', and that the principle was 
essential if the recognition of human responsibility was to triumph over class privilege.

In February I83I, at Marseilles, Mazzini began the La Giovine long exile, spent for the most part in England; which with little intermission lasted for the whole of his life. At Marseilles he began the organization of La Giovine Italia, upon which he had reflected during and before his imprisonment at Savona. For two years, with scant help, he conducted a growing correspondence with all parts of Italy. Genoa and Leghorn were the first cities to establish lodges, and Genoa was the association's Italian head-quarters. It spread rapidly in the central and northern provinces, drawing its members chiefly from young men and students of the middle and professional classes, though the army, the Church, and the nobility were represented in its ranks. By 1833 'Young Italy's' ramifications extended throughout the peninsula, and Mazzini estimated its membership at from 50,000 to 60,000 .

The mottoes of the Association, Ora e sempre (Now and always), and Dioed il popolo (God and the people), expressed the spirit in which Mazzini launched his enterprise. Constancy was indispensable to the achievement of a great task, and Dio ed il popolo based the national cause on the groundwork of religion. In that fact is found another characteristic that differentiated Mazzini. His patriotism was the expansion of a sincere religious faith. The ' worship of Rome', he declared, was ' a part of his being'. 'Twice the Imperial City had given a religious system to the western world. In his exalted vision Rome, truly Catholic and purged of the contamination of 
secular responsibility, was destined to initiate " the third life of Europe', an existence springing from 'the heart, the action, the enthusiasm, and the sacrifices of our people', consecrated to inaugurate 'moral unity and fraternity in a faith common to all humanity'. Much of Mazzini's gospel was fantastic, inspired partly by his reflections upon the mediaeval Holy Roman Empire, partly by the Vision of Dante. But the association of morality and 'Young Italy' was intensely real to him; the political salvation of his people was to advance with their moral growth and social progress, until New Italy would lead the nations into the New Age, ' an angel of light among the nations that thought her dead'. The irrevocable conviction that Rome's traditions and pre-eminence singled her out to originate a new movement for Europe's regeneration inspired Mazzini to insist that the Temporal Power must fall and Rome become the capital of New Italy.

The oath of membership.

The oath taken by the members of 'Young Italy', generous, dignified, and impressive, drew the neophyte at once to Mazzini's exalted plane :

' I, A. B., believing in the mission entrusted by God to Italy, and the duty of every Italian to strive to attempt its fulfilment; convinced that where God has ordained that a nation shall be, $\mathrm{He}$ has given the requisite power to create it; that the people are the depositaries of that power, and that in its right direction by the people and for the people lies the secret of victory; convinced that virtue consists in action and sacrifice, and strength in union and constancy of purpose, give my name to Young Italy, an Association of men holding the same faith, and swear : 
'To dedicate myself wholly and for ever to the endeavour with them to constitute Italy one, free, independent, republican nation; to promote by every means in my power, whether by written or spoken word or by action, the education of my Italian brothers towards the aim of Young Italy; towards association, the sole means of its accomplishment, and to virtue, which alone can render the conquest lasting; to abstain from enrolling myself in any other Association from this time forth; to obey all the instructions, in conformity with the spirit of Young Italy, given to me by those who represent with me the union of my Italian brothers; to keep the secret of these instructions even at the cost of my life ; and to assist my brothers of the Association both by action and counsel Now and Always.'

'Young Italy' was a secret association, though Mazzini had objected to that characteristic in the Carbonari. But at the time when 'Young Italy' was launched there was no alternative. The Italian Governments were despotic, police and military systems were absolutely at their disposal, and open action could merely have the result of exposing the association to its most dangerous enemies, and of denying to it the period of incubation necessary for its ideas. The methods 'Young Italy' was instructed to employ were: education, 'by preaching exclusively that which it believes to be the truth'; and 'insurrection, by means of guerrilla bands, the true method of warfare for all nations desirous of emancipating themselves from a foreign yoke'. Mazzini's eye was upon the example of Spain and Greece, and of Switzerland at an earlier time. His movement was to be the impulse of peoples, and not the diplomacy of states. Italy offered admirable territory for popular and irregular fighting, 1832.3

c C 
and, in Mazzini's belief, Austria would be powerless to resist its assault.

Aims of 'Young Italy'.

'Young Italy' 'was designed to accomplish three dependent objects : to expel Austria from Italy; to make its kingdoms a united nation; and to establish its union upon a republican basis. In his insistence upon the second of these aims Mazzini's greatness consists; it contributed vital purpose to the cause which he had so passionately at heart. Until 'Young Italy' established it as the commonplace of patriotic effort, the idea of national unity had been wholly academic.

Its achievement seemed impossible, the spirit of local particularism too strong, the problem of the Temporal Power insurmountably difficult, the existing states too little confident of their place in an expanded one. Even Sardinia's horizon was bounded by the narrower ambition of a North Italian kingdom including Austrian Lombardy. Hence the conception of Italian unity, beautiful in contemplation, seemed impracticable in fact. The utmost approach to it seemed to be a federation of the existing states, such as Napoleon III advocated and Germany eventually achieved. But Mazzini never wavered in his determination that Italy must be and could be one. Difficulties, particularly that of the Temporal Power, he recognized. But he admitted no doubt that they could be overcome-as a schoolfellow said of him, his 'confidence in men was great and in himself unlimited'. Because he was able to convey his confidence to his people, to focus their thoughts and activities on what their fathers regarded as a hopeless task, Mazzini stands alongside Cavour as a maker of Italy. In most of his ideas he 
was impractical, and it was required of Cavour not only to reveal the one method by which Italian unity could be achieved, but to give united Italy the constitution most fitted to her state. In both his success convicted Mazzini of error and miscalculation. Yet Cavour's work would have been impossible had he not had behind him, not merely the resources of his own State, but the will of Italy's twenty-five millions to be one at every hazard. Cavour guided Italy to the plébiscites of 1860 . Mazzini made them almost unanimous upon the cause which he and Cavour had equally at heart.

From I83I to I843, when the publication of Vincenzo Charles AlGioberti's Del Primato morale e civile degli Italiani ('On bert and Gioberti's Del Pril 'Onato 'Young the moral and civil primacy of the Italians ') introduced Italy', the era of the Moderates, or Conservative Nationalists, 'Young Italy' directed the nationalist agitation and inspired two inadequate and fruitless insurrections. Driven from France upon the appeal of the Italian despots to Louis-Philippe, Mazzini betook himself to Switzerland to overlook the progress of his propaganda. The accession of Charles Albert to the throne of Sardinia in 1831 seemed of hopeful augury, and Mazzini addressed an open letter to the new sovereign: "Place yourself at the head of the nation. Write on your flag "Unity, Liberty, Independence". Free Italy from the barbarian. Build up the future, be the Napoleon of Italian freedom. Do this and we will gather round you, we will give our lives for you, we will bring the little states of Italy under your flag. Your salvation lies on the sword's point; draw it and throw away the scabbard. But remember, if you do not, others will do so against you and without you.' Mazzini 
neither expected nor, possibly, wished for a favourable reply. Charles Albert, who with difficulty had preserved his throne against his cousin and predecessor's effort at Verona (I 822) to bar him from the succession, was not disposed to encounter the suspicion of Metternich and the Holy Alliance. He maintained his predecessor's ministers in power, and Mazzini, from his observation post in Switzerland, convinced himself with characteristic impetuosity that the situation was ripened for action by the King's indifference and inactivity. In the spring of 1833 , he gave orders for an insurrection in Piedmont, anticipating that the army would rise and, after proclaiming a constitution, continue its victorious course against Austria. The plot was detected, and Charles Albert exacted a bloody revenge (April 1833). Courts martial were instituted, and 'Young Italy' had its baptism of blood. Undaunted, Mazzini organized the ill-judged 'Expedition of Savoy', an irruption of about seven hundred exiles into that province, while Giuseppe Garibaldi, a young sailor and one of the earliest members of 'Young Italy', received the task of undermining the loyalty of the Piedmontese fleet. The leader of the expedition, the Savoyard exile Ramorino, was incompetent and half-hearted, and after desultory fighting, the hapless army disbanded. With its dispersion (February 1834) 'Young Italy' abandoned militant activity entirely. From Geneva Mazzini betook himself in poverty to England. From there he continued to direct the association until the Risorgimento of 1848 called him to rule the shortlived Roman Republic, and to London he returned after that exhilarating experience. But at 1848 , it was 
said of him, his 'watch stopped'. To all but himself it was patent that Italian unity could not be won by enthusiasm and a programme alone.

\section{5}

\section{The Moderates of $1843^{-6}$}

One who took an active part in the awakening of Central Italy has recorded his reflections upon the situation in the early 'forties of the century, when Mazzini, from the seclusion of his English exile, was preaching insurrection and republicanism, and firing his countrymen with the vision of a united Italy. 'The idea of nationality', writes Marco Minghetti, 'had spread far and wide through many channels, open and secret, and the desire to become a great and free country had captured the greater number of the younger men. But the methods hitherto used to attain it had proved so inefficient that weariness and disgust followed. Experience had proved that conspiracies, secret societies, and partial insurrections were of no utility, that they made the governments more severe, retarded civil progress, arrested the increase of public prosperity, plunged many families into misery, and did not win the approbation of civilized nations. The rumours of wars and of European insurrections which were circulated every spring-time, the mystic declamations of Mazzini in the name of Dio ed il popolo, his inciting of others to insurrection and murder, while. he remained in security in London far from danger, all these things showed that the time had come to try another 
method, more serious, more practical, and surer.' The conviction gave birth to the Moderates, or Conservative Nationalists.

All who were fired by Mazzini's vision, but shrank from his methods and conclusions; who read the signs of the times, foresaw the upheaval which rent Europe in $\mathbf{1} 848$, and hoped to anticipate its destructive force; who turned their faces to Rome and looked to the Vatican as Italy's potential regenerator ; who bent their gaze with equal confidence towards Turin and Charles Albert, the Sword of Italy-all of these swelled the growing body of public opinion which, accepting in the main the gospel of 'Young Italy', was repelled by its methods and sought another platform on which to fight the cause of Italy. In this welter of opinion three groups are discernible: the social and economic reformers; the Neo-Guelfs, who, like their mediaeval forerunners, laid the cause of Italy on the throne of St. Peter; and the Piedmontese Nationalists, or Albertists, who looked to Turin to lead the way.

Social

Mazzini contemplated an era of social reform as the firstreform. fruits of regenerated Italy. The social reformers saw in that stage the preliminary to the regeneration which they and Mazzini alike desiderated. From I 839 to I 847 Scientific Congresses were held annually in the capitals of Northern Italy, and in 1845 at Naples. A period of eager railway development began at the same time, and the tunnelling of Mont Cenis was not long delayed. The prospect of economic union was discussed, and the annual gatherings acquired inevitably a political significance. As was said of the railways, they promised to 'stitch the boot' of 
Italy, though the advocates of economic reform advanced no theories regarding Italy's political future, nor conceived it opportune to formulate them.

The oracle of the Neo-Guelfs was Vincenzo Gioberti. Vincenzo $\mathrm{He}$ was born at Turin in I80I, and upon Charles Albert's Gioberti. accession in $\mathbf{1} 83 \mathrm{I}$ was appointed his chaplain. His liberal views, obnoxious to the clerical and reactionary party in power, condemned him to exile, and in 1833 he settled in Belgium as a private tutor. Thence he issued in 1843 his Del Primato morale e civile degli Italiani, an exposition of the Papacy as the divinely appointed agency for Italy's regeneration. Italy, ran his argument, contained all the conditions of political and moral revival within herself, and had no need to look outside for the force to achieve it. She demanded unity, independence, and liberty, of which the first two were attainable through a confederation of the Italian states under the Pope's presidency, and the last by means of internal reforms in each state effected by their respective Princes. ' I intend', Gioberti wrote, "to show that Italy alone has the qualities to become the chief of nations, and that though to-day she has almost completely lost that chiefship, it is in her power to recover it. ... Let the nations, then, turn their eyes to Italy, their ancient and loving mother, who holds the seeds of their regeneration. Italy is the organ of the supreme reason and the royal and ideal Word; the fountain, rule, and guardian of every other reason and eloquence; for there resides the Head that rules, the Arm that moves, the Tongue that commands, and the Heart that animates Christianity at large. . . As Rome is the seat of Christian wisdom, Piedmont is 
to-day the principal home of Italian military strength. Seated on the slopes of the Alps, as a wedge between Austria and France, and as a guard to the peninsula, of which it is the vestibule and the peristyle, it is destined to watch from its mountains, and crush in its ravines, every foreign aggressor, compelling its powerful neighbours to respect the common independence of Italy.' Gioberti's outlook was conservative and federalist. His message was to the princes more directly than to their subjects, but made a vivid impression on those who, in spite of their divisions, were responsive to appeals to Italy's past grandeur. It captured both Nationalists and Papalists, while the advent of Pio Nono in 1846 seemed to promise the Papacy's adoption of Gioberti's outlook, and that Rome, directing the fervour of her children, would gather Italy round her primacy.

Cesare Balbo.

The outlook of the Piedmontese group has expression in two works, of which the first, Cesare Balbo's Delle Speranze d'Italia ('The Hopes of Italy'), was published at Paris in 1843, and the second, Massimo d'Azeglio's Degli ultimi Casi di Romagna ('The recent Events in Romagna '), was published at Florence three years later (1846).

Like Gioberti and d'Azeglio, Balbo belonged to an older generation than the youths who had caught the infection of Mazzini's enthusiasm, whose hot-headed action, the Moderates supposed, was compromising Italy's future. Like Gioberti, Balbo was born at Turin (1789), the son of Victor Emmanuel's reforming minister. He shared Mazzini's and Gioberti's confidence in Italy's ability to raise herself to the place which of right was 
hers, and his remark, Italia farà da sè ('Italy will manage by herself '), has passed into a proverb. He accepted also the conclusions of Gioberti, of whom he was a profound admirer, in regarding federative union as the solution of Italy's political future. A Kingdom of Italy, such as the Unitarians had in mind, was to him a fantastic impossibility. His book in effect was an appeal to Charles Albert to challenge Austria and secure the first essential to a New Italy by extruding the foreigner. 'That the Kingdom of Italy is a dream', he wrote, ' is proved by the fact that it never was made.' Some had dreamed of it as the concrete expression of unity. Others hadlonged for it because it promised liberty, independence, a new social order. But the conception was vague and confused, and out of the very effort to realize it had come 'lessons, not new but profitably retaught-that we must not confound undertakings for the sake of liberty with those for independence; that the latter must have precedence of the former, and above all, that the Kingdom of Italy is impossible, with this variety of opinions, of intentions, and of states.'

Balbo's conclusions were emphasized by his friend Massimo Massimo Tapparelli, Marchese d'Azeglio. Born in I798, d'Azeglio. son of a noble Piedmontese family, d'Azeglio has been described as 'the first Piedmontese who made himself an Italian'. Painter, publicist, statesman, romancewriter, he was as familiar with Rome, Milan, and Florence as with Turin. As he showed later in the Siccardi Laws, he felt none of the tenderness of Gioberti and Balbo for the Papacy, though his Liberalism marched with an essentially aristocratic outlook. Like Balbo he was 
a convinced Albertist, and in 1845 was invited by the Romagna Liberals to expound his views. The summons, perhaps, was inspired by the imminent death of Pope Gregory XVI, which took place in the following June, and was anticipated as the probable signal for political disturbance and a renewed Austrian occupation. D'Azeglio's mission was designed to counter the propaganda of the Mazzinist group by advocating trust in Charles Albert and the power of Piedmont. He was successful in winning a considerable number of adherents, and his departure was followed by a brief and unsuccessful rising at Rimini, to force on the Papacy the much-needed reform of its constitution.

The insurrection, easily crushed, formed the pretext for d'Azeglio's pamphlet The recent Events in Romagna, published at Florence in 1846 . It bitterly attacked the character of the Papacy as a secular state, and bade it peremptorily put its house in order. Pio Nono, who read it, was perhaps influenced by it to appoint a liberal-minded ministry, which included Minghetti among its members. The book, says Minghetti himself, 'was the first practical exposition of the programme then first adopted-the substitution of public, peaceful, serious, and courageous discussion of our affairs, for secret societies and plots... The effect was greater than we had anticipated; the book was printed in Tuscany, was everywhere circulated and read, and was the general subject of conversation. This was what we desired, and it showed the ground to be ready for sowing the seed. All the Italian Governments felt it, even the Tuscan, which, notwithstanding its usual liberality, resented its 
publication and expelled d'Azeglio-by the orders of Austria, it was said.'

Thus Italy approached the historic year 1846 between conflicting programmes. On the one hand, 'Young Italy' and its chief in London incited to violence and preached Republicanism: On the other, the more prudent and responsible thinkers, alarmed by 'Young Italy's' drastic methods, turned in dismay to the Moderates, Neo-Guelfs or Albertists. The 'party of action', as the Mazzinists styled themselves, found the patriotic movement slipping from their control, and the formation of Cavour's Great Ministry (November 1852) gave to the Albertists the fashioning of Italy's future. From the Moderates Cavour took over their insistence upon open and official methods. From Mazzini he accepted the conviction of Italian unity, rejected the compromise of federation, and achieved the more difficult task.

\section{6 \\ Pius $I X$}

Meanwhile, before Cavour was in the saddle and the Italy in turmoil of 1848 burst upon Europe, Italy, already fired ${ }^{1846 .}$ by the appeal of Gioberti, saw with hope and wonder the banner of reform floating above the Vatican.

Since the abortive movements of I83I little change had taken place in the political conditions of Italy. Lucca was not merged into Tuscany until 1847 , and Francis IV of Modena was the only Italian sovereign reigning in 1831 who did not survive to witness the 
surge of hope which followed the election of Pius IX throughout Italy. There was little to that point to indicate the imminence of a period so fraught with promise for Italy's future. Gregory XVI, an uncompromising Conservative, administered the Papal States with the old machinery of repression. Tuscany, Parma, Modena, Lucca, and the Two Sicilies remained under Austrian observation. In Piedmont alone a spirit of progress was at work, which sprang, however, less from Charles Albert's conversion to Liberalism, than from his desire to prepare for the challenge to Austria which the dynastic interests of the House of Savoy could not permit him to evade. Agriculture was encouraged, railway development was pushed forward, Customs agreements with neighbouring principalities were made. Genoa was permitted to celebrate (1846) the centenary of Austria's expulsion. But to the cry for political reform the King remained deaf, and the Constitution retained its absolutist character.

Character The death of Gregory XVI on June I, I846, was of Pius IX. followed, after a fortnight's interval, by the election of Cardinal Giovanni Mastai-Ferretti, Bishop of Imola, son of an old but impoverished noble family of Sinigaglia, then in his fifty-first year. An epileptic constitution had defeated his youthful hopes of following a military career. Entering the Church, he acquired fame as a revivalist preacher. Ten years after taking deacon's orders he was appointed to the See of Spoleto (I827), whence in 1832 he was transferred to Imola. A man of the world, he had shown himself conciliatory to all parties, was versed in the literature of the patriotic movement, alive to the blemishes of his predecessor's 


\section{Pius IX}

government, and well disposed towards Gioberti's programme for a reforming Papacy. But his character was not sufficiently stable to play a controlling part in the approaching crisis. There was, too, a world of difference between the sympathies of a liberal-minded cardinal and the responsibilities of the sovereign pontiff. The adulation which his first measures excited carried him for the moment off his feet, though with a gesture of self-depreciation he protested, 'They want to make me out to be a Napoleon, I who in fact am only a poor priest'. But he neither understood, nor at bottom was sympathetic to, the Liberal programme, and the flood of revolution which the year 1848 let loose upon Europe caused him to draw back in dismay from a position whose dangers he had not realized.

The first act of the new Pope was to proclaim disapproval of his predecessor's rule by granting an amnesty to all persons-about 700 in number-who were in prison for political offences. The event made an extraordinary stir throughout Europe. 'We were prepared for everything but a Liberal Pope,' said Metternich in consternation, ' and now that we have one, who can tell what may happen ?' The event, he anticipated fearfully, portended ' a new era'. The Pope continued to excite Metternich's alarm. Gregory's Swiss Guard, which had dragooned the populace, was dismissed. Rome was conceded municipal government, and to some extent the Press was unmuzzled. A commission was appointed to revise the civil and penal codes. A Liberal, Cardinal Gizzi, was appointed Secretary of State, and a Council (Consulta di Stato) was set up to advise the Sovereign, to which, by a 
breach with the old clerical monopoly, laymen were declared eligible. The downfall of the Gregorian system roused the populace to demonstrations of adulation of which Pius very soon became suspicious. Mazzini, indeed, watching with some dismay the popular cult of Pius and Charles Albert, correctly plumbed the Pope's character, and found him ' nothing but a well-disposed man wavering between the influence of Austria and his own tendencies, but without any of those Italian intentions which others have been determined to see in his first acts'. By the anniversary of his election Pius was shrinking from the consequences of his early actions, while Austria, thoroughly alarmed at the progress of Liberal ideas, introduced troops into Ferrara (August 1847).

Meanwhile the Pope's example found or forced imitation. In Tuscany, economic and political discontent was prevalent before the election of Pius. The news of that event strengthened the Liberals, among whom was Bettino Ricasoli, the 'Iron Baron', whose influence a few years later brought Tuscany conclusively into united Italy. In 1847 the Grand Duke so far yielded as to publish a new Press law, allow the enrolment of National Guards, and promise a Council of State on the Roman pattern. In Piedmont, the Pope's appearance among the reformers heartened Charles Albert's timid coquetting with Liberalism, while the Austrian occupation of Ferrara stirred both court and people with indignation. The nation turned to Turin, invoking the 'Sword of Italy', and Charles Albert permitted himself for the first time to make public allusion to the eventuality of war and to 
promise his participation in it. 'If God permits a war for the freedom of Italy,' he wrote on the anniversary of Pius's amnesty, 'I will place myself at the head of the army.' Modena and Parma were too closely under the control of Austria to permit them to fall into line with their neighbours. In the south, Liberal movements in Sicily were easily repressed and the University of Naples was closed. But in Lombardy and Venetia, the States of the Church, Tuscany and Piedmont, the Pope's innovations awakened a new spirit which challenged Austrian domination. No Constitution had been conferred. But the Roman and Tuscan Governments no longer were rigidly autocratic; their Press was open for the ventilation of grievances, and their populations were permitted to enrol themselves in National Guards for the defence or conquest of their liberties. In an atmosphere of promise the annus mirabilis 1848 opened.

The French Revolution of February I 848 and the The Con. fall of the Orleans Monarchy loosened an avalanche of stitutions revolution such as Europe had not experienced since the Reformation. In Italy events did not await the impact of that shock. Austrian Italy was seething with discontent, and the self-denying ordinance of the Milanese to abstain from tobacco in order to deplete the Austrian revenue drew reprisals (January 3), in which many lives were lost. Sicily rose a few days later (January I2) for administrative autonomy and the Constitution of I8I2. The revolt spread to Naples, where Ferdinand was confronted with the demand for a Constitution. On February Io it was conceded. A week later Tuscany also obtained a Constitution, and Pius fired his country- 
men, waiting for a summons against Austria, with the message ' God bless Italy'. On March 5, Charles Albert, succumbing to public pressure and the insistence of Cavour's paper, Il Risorgimento, accorded a Statuto, which alone of the Constitutions of 1848 survived. His assent to it was gained by the desire to enlist popular sympathy in the war now imminent, and to secure the interest of the Liberal Powers. Pius also succumbed to a movement which so suddenly had captured the greater part of Italy. On March I 5 he accorded a Statuto of the character already conceded by his fellow sovereigns.

The 'Statutes' of I 848 were short-lived and tentative in character. But they secured a general recognition of constitutional principles, and also checkmated the more drastic programme of the Mazzinists or Democrats. They introduced the peninsula to conditions of political life which France had adopted in 1830 and was discarding at the moment when Italy was taking them to herself. They established generally the elementary safeguards of individual and political liberty: security of person and property, the right of petition, an open Press, along with ministerial responsibility, parliamentary control of taxation, and the establishment of a citizen or National Guard. But in every State, even in Piedmont, the Church maintained its privileges and exclusiveness, and the franchise excluded the working classes. For the moment, however, the country acquired rest from constitutional agitation and was free to concentrate upon a challenge to Austria which, it hoped, would satisfy the aspiration for independence.

Austrian Lombardy gave the signal for war. Smarting 
under the cruel repression which the Tobacco Riot had Milan: the invited, and stimulated by the progress of the constitu- Five Days, tional movement in Southern Italy, by the consummation of the French Revolution on February 24, by the rising of Vienna on March I3, and by the flight of the archreactionary Metternich, the province resolved to strike for liberty. 'Cross the Ticino,' Charles Albert was adjured, 'or we proclaim the Republic.' The news of Metternich's flight from Vienna to England, where he joined the French reactionary Guizot in exile, reached Milan on March 17. The rising was appointed for the following day, though official posters announced concessions which the crisis had drawn from the Emperorliberty of the Press, and convocation of the Estates. Scorning to wait until Charles Albert moved, the leaders launched their hazardous attack on the strong Austrian garrison. From March 18 to March 22 Milan's Cinque Giornate (Five Days) continued. Venice rose simultaneously, the old Republic was restored, and a Provisional Government was proclaimed. From end to end of Lombardy-Venetia the people rose against the tyrant who so long had held them in thrall. The garrisons were overpowered, and Marshal Radetzky, who had declared that three days of bloodshed would yield a generation of peace, evacuated Milan and took shelter, awaiting reinforcement, in the Mincio-Adige Quadrilateral, formed by the cities Peschiera, Mantua, Legnago, and Verona, which commanded the Brenner Pass and the military road from North Italy to Vienna.

From all Italy a chorus of invitation reached Charles The Albert, urging him to lead the country's stroke for 'Sword of 1832.3 D d Italy'. 
independence. 'The supreme moment', declared Cavour, ' has struck for the Sardinian monarchy.' Volunteers from all parts were flocking to the conflict. From the Papal States some 12,000 set out for Venetia. From Naples the Government, unable to resist the pressure of public opinion, prepared to send a large number of regulars under the veteran Pepe. At Florence the mob burnt the arms of the Austrian Embassy and dispatched nearly a thousand volunteers to the north. Parma and Modena were evacuated by their Austrian garrisons, the two sovereigns accompanied them, and their people joined the patriotic armies. Even Sicily sent a small contingent, though she was engrossed in her struggle for autonomy against the Bourbons. The enthusiasm was irresistible. But it was not without misgiving that Charles Albert donned the Italian tricolour, and on the day that Radetzky evacuated Milan (March 22) decided on war. Three days later his army crossed the Ticino into Lombardy, and the brief and luckless campaign began.

The first

War of Independence, 1848 .

The war upon which Italy entered with such splendid enthusiasm and noble ideals was in conduct and result ineffective and disappointing. Nor was it merely the obstinate tenacity with which Austria clung to her entrenched position in the Quadrilateral that laid Italy's high hopes in the dust. On the side of Italy the war was an orgy of emotionalism, of uncoordinated effort, of bad generalship and leading. By all the princes except Charles Albert it was viewed with indifference or hostility. Sardinia, and Italy herself, benefited eventually by the fact. But for the moment the abstention of the princes contributed to the failure of a cause to which the Pope's 
'God bless Italy' had given the dignity of a Crusade, and drove deep into the mind of Cavour the futility of Balbo's Italia farà da sè.

Charles Albert and the army of Piedmont forced the Defection Mincio at Goito on April 8, threatening Verona, guardian of Pius IX. of the highway to Tyrol. Repulsed on May 6, at Santa Lucia, an outpost of the fortress, the King had greater success at Peschiera, which fell to him on May 30, and defeated Radetzky's effort to pierce the extended Italian line at Goito. It was his last success. Contemplation of the consequences of victory alienated interests that suspected the ambitions of the Albertists. The Pope, no friend of Austria, encountered threats of schism from the German bishops, and feared the detachment of Romagna as the consequence of Piedmont's success. Naples and Tuscany also dreaded annexation. Charles Albert's declaration of war, therefore, was followed by reaction. A proposal for joint action by Tuscany, Naples, and the Papacy was rejected by Tuscany (April 18). But ten days later (April 29) Pius delivered an Encyclical, or Allocution, in which he severed himself conclusively from the nationalists. 'We assert clearly and openly', he declared, 'that war with Austria is far from our thoughts, seeing that we, however unworthy, are the Vicar of Him who is the Author of peace and the Essence of love.' Naples welcomed the Pope's example. The situation in that kingdom was exceedingly unstable. The constitutional administration had the confidence Reaction neither of king nor people, and Democrats and reactionat Naples. aries were at work. A sudden event placed the situation in the king's hands. The Assembly, promised by the D d 2 
Statuto, was summoned for May I5. It became known that the King proposed to exact from the deputies a preliminary oath to maintain the Constitution, a device to forestall democratic schemes of more drastic reform. Barricades were thrown up in Naples by the republicans, and the King seized the opportunity to control the situation. A force of twelve thousand mercenary troops was at his orders. Still, had the Deputies and National Guard boldly faced the position, victory probably would have rewarded them. As it was, they shirked an encounter and stood aside while the soldiery were let loose upon the barricades and their defenders. The Chamber was dissolved. The National Guard was disbanded. The Constitution vanished. Naples was lost to the patriotic cause, and Sicily was ruthlessly punished. The regular troops intended for Lombardy were held baçk, and the fleet was recalled from the Adriatic. Pepe and a small band of volunteers alone represented Naples's contribution to the fighting strength of Italy in the north.

Charles Albert.

After his success at Goito on May 30, Charles Albert remained inactive, torn with indecision. Strongly handled, the position was at his feet. The Bourbons had abdicated their claim to consideration in the future settlement of Italy. And elsewhere the prospect of union was becoming brighter. Released from their Austrophil dukes, the peoples of Parma and Modena declared for union with Piedmont. The Milanese, in the moment of their deliverance, came to the same decision. Venice, whose republican Constitution jeopardized the symmetry of a Pan-Italian Monarchy, followed Milan's example some- 


\section{Pius $I X$}

what later. But Charles Albert feared to put his fortune to the test. He was suspicious of the volunteer levies which comprised the greater part of the forces assailing Austria. He was fearful of the effects upon European opinion should the war be conducted by what might be regarded as popular and revolutionary agencies. He was as tender as Napoleon III, ten years later, to the Temporal Power. He feared the German Confederation, whose head he was fighting, and therefore did not venture to use his maritime resources, as he might have done in the Adriatic with considerable result. His aversion from revolutionary agencies forbade him to take advantage of Austria's internal commotions by stimulating the Hungarian opposition to German dominance. He refused the aid of Swiss volunteers, and generally his caution compressed the national movement into a narrow channel. Instead of utilizing the resources at his command to achieve the purpose which called Italy to his colours, he limited his range of vision to the old ambition of his House, an expanded Kingdom of North Italy.

The King's inactivity permitted the reinforcement Custozza, of Radetzky, whose superiority enabled him to change ${ }^{1848}$. the complexion of the war when the campaign was actively resumed in July. After a severe battle at Custozza (July 24-5), Charles Albert was thrown across the Mincio and fell back upon Milan, with Radetzky close on his rear. Unable to check Radetzky's advance, Charles Albert abandoned Milan to him on August 6, and thence retreated into Piedmont across the Ticino, which he had crossed with such high hope five months before. On August 9 the King concluded an armistice at Vigefano, 
known as the 'Salasco Armistice' after the General who negotiated it, which restored the status quo ante bellum. Lombardy passed again under the heel of Austria. Venice prolonged her resistance for another year.

Vigefano

The Vigefano armistice terminated a campaign armistice, 1848 . depressing in every particular except the courage, enthusiasm, and resolution with which it had been waged. Not only was Italy's deliverance unachieved, but Piedmont was only saved from Austrian occupation by the fear of French intervention. The Sardinian ministry accurately explained the disaster, so far as its causes were resident in Piedmont herself : 'The general opinion and judgement of the intelligent and experienced deplores greatly the fatality which had surrounded the throne with men known to be mutually antagonistic, courtiers, not soldiers, incapable of directing military affairs. . . . We are unwilling to suppose treason, actual or intended. But owing to evident indifference to the cause, declared aversion from all constitutional principles, absolute ignorance of the science of war, the results were very different from what the valour of the soldiers had a right to expect.' Throughout Italy the luckless campaign produced a sense of deep depression, but not of hopelessness. Everywhere, too, it caused a reaction against the Moderates, under whose auspices it had been conducted. At the beginning of the war Cavour announced the hour of the Sardinian Monarchy to have arrived. At the end of it d'Azeglio declared, 'The war of the princes is over, that of the people is beginning'. 'Whoever continues to cherish dynastic illusions', Mazzini gave warning, ' has neither intelligence nor heart, neither genuine love 
for Italy nor confidence in her future.' None of her political parties desired Italy's cause to be won by foreign arms, and though the French Republic seemed an obvious ally, the Moderates dreaded association with her dangerous politics. After Custozza, both Milan and Turin were fain to plead with France for assistance, but upon terms which permitted France to refuse, with the bitter comment, 'Italy must pay the penalty of her own follies'. Thrown back on herself, Italy turned from the larger vision which had filled her horizon to the unsatisfactory conditions of her political life, which the Constitutions had not yet had opportunity to alleviate. She looked to the Parliaments so recently conferred to sweep away the old régime and, as in France, to place the sovereignty in the people's hands.

Hence the Vigefano armistice opened a new chapter The Demoin Italy's progress towards unity and freedom. Her ' royal war' had failed, her Conservative Nationalists were discredited. The Democrats and Mazzinists found their opportunity. Italia liberata was still upon their banners. But unity was their immediate goal. That achieved, and Italy master of her actions, Austria might once more be challenged, and with happier result. Everywhere, in the latter half of 1848 , the Democrats assailed positions which the Moderates held. In Piedmont a struggle between them ranged the King, tortured with the memory of failure and alert to every means that promised to remedy it, reluctantly with the Democrats. In Tuscany a Democratic ministry was forced upon the Grand Duke.

At Rome the situation was more serious, and fired 
Rome: Italy to a blaze. In the crisis that followed the Pope's Assassination of Rossi, 1848 .

Encyclical of April 29, the Democrats forced their leader, Count Terenzio Mamiani della Rovere, upon Pius as his chief minister under the Constitution of March 15 . Though they were enthusiastic for the war, the Pope stubbornly refused to countenance it. The Austrian attack upon Bologna on August 8, a reprisal for the participation of papal volunteers in the recent campaign, not only failed to rouse him to action, but inspired him to release himself from Democratic control. $\mathrm{He}$ therefore prorogued the Chambers, sought an obsequious minister, and found one in Pellegrino Rossi, a native of Carrara, and sometime a professor in the University of France. His anti-democratic views won him the regard of Guizot, who sent him to Rome in 1845 to negotiate the suppression of the French Jesuits. A reformer and nationalist, Rossi shared Guizot's mistrust of democracy. Convinced that the Papacy was 'the one great thing left in Italy', and suspicious of Sardinia as a competitor, he commend ed himself to Pius as a man who would truckle neither to the Democrats nor to those who assailed the temporal power. Contemning the danger of his position, he aggravated it by the provocation of a biting tongue. On November I 5, when the Chambers were to re-open, he was assassinated. The event threw Pius completely into the arms of the reactionaries. On the I6th he was assailed with demands for a Democratic ministry, declaration of war upon Austria, and the summoning of a Constituent Assembly. He yielded apparently, summoned a ministry of popular complexion, and a few days later fled to Gaeta to claim the hospitality 
of Ferdinand of Naples. His commission of regency was disregarded at Rome. The Chambers appointed a supreme committee of the State, which forthwith summoned a Roman Constituent Assembly elected by universal suffrage to determine the constitution of the Papal States. On February 9, I849, it abolished the Temporal Power and proclaimed the Roman Republic. A few days later Leopold of Tuscany followed the Pope to Gaeta, and a Democratic Provisional Government was formed at Florence. Mazzini hastened from England, and the whole of Central Italy seemed won to the Republican cause.

Sardinia held aloof from the Republican enthusiasm Novara, which had carried Central Italy. Popular clamour ${ }^{1849 .}$ demanded resumption of the war against Austria, especially after renewed disturbances at Vienna in October 1848. The establishment of the Roman Republic, and the certainty of Austrian intervention, also pointed the desirability of instant action. But Charles Albert looked vainly for allies. Napoleon was willing to intervene, but his ministers were not disposed to place the resources of France at the disposal of the Holy See. Great Britain merely offered friendly mediation, though Palmerston warned Vienna that should a Napoleon again rise to power in France, he was likely to take a hand in the Italian question unless the Hapsburgs put their house in order. Thus Sardinia challenged Austria alone, a gallant venture which met with inevitable failure. On March I2, 1849, Charles Albert denounced the Vigefano armistice. A week later (March 20) he crossed the Ticino and advanced upon Milan. Brescia alone among the Lombard cities 
rose in sympathy, and Radetzky ended the war at a blow. Crossing the Ticino at Pavia, he placed himself between Charles Albert and Piedmont. At Novara (March 23) the single battle of the 'Three Days' War' was fought. Charles Albert was decisively beaten, and abdicated in favour of his son, Victor Emmanuel II, on the evening of his defeat. Five months later (August 27) the Austrian flag once more flew above Venice, defeated by famine and cholera. Italy was beaten. The first act of Sardinia's new sovereign was to sign an armistice which recalled his troops, and the fleet from the Adriatic ; which committed Alessandra provisionally to a mixed Austro-Sardinian garrison; and which mulcted the kingdom in the war expenses incurred by Austria (stated in the treaty of peace at $\{3,000,000$ sterling).

Yet, in spite of her humiliation, Italy emerged from the ordeal strengthened in fibre and purpose. Though Sardinia had failed, she was the one Italian State which had raised and kept aloft the banner of Italian independence. The Bourbons had proved themselves worthless. The Pope's Catholic interests had been found incompatible with the objects of Italian patriotism. As for the other princes, the war had demonstrated that, whenever the interests of Italy impinged upon those of Austria, they could be counted on to follow Vienna. But Piedmont remained staunch and firm, and during the ten years' truce, 1849-59, became the Mecca of those whose motto was d'Azeglio's, 'We shall try again'. Moreover, the apostasy of the Papacy had weakened its hold on Italy. The nationalist movement became in consequence to a large extent anti-Clerical. Sardinia 
in particular assumed an Erastian position in the Siccardi Laws; and her anti-Clerical demeanour for ever destroyed the hope which had filled the minds of some, of Turin and Rome jointly leading Italy towards her promised land. Yet another fact of import to the future was the intervention of France, notably her treatment of the short-lived Roman Republic. Palmerston's warning already was confirmed; and Cavour, on whom it fell to gather up the threads which the war had spun, took it to heart.

After Novara (March 23, I849) Italy lay at Austria's Florence, mercy. South Italy was lost to the national cause. I 849 . North Italy was saved from invasion only by Sardinia's humiliating peace. But at Florence and Rome the tricolour still flew, bearing hope that a portion of Italy might be saved to the cause for which all had sacrificed much. In Tuscany the Grand Duke's flight to Gaeta permitted the institution of a triumvirate, or provisional government, which the Democrats designed as a preliminary to the constitution of a republic, and the Moderates welcomed as deferring that dreaded step. Early in February 1849, Mazzini, on his way to Rome, urged the triumvirate to proclaim a republic and unite with Rome. But the Republican party was weak numerically, and the project of union roused much prejudice, chiefly through the threatened loss of Florence's metropolitan position and the sacrifice of her port, Leghorn, to Papal Civita Vecchia. The issue was undecided when the news of Novara arrived, and was subordinated at once to the greater problem presented by Austria's victory. To defy her further seemed madness. The municipal council, led 
by Bettino Ricasoli, rose to the crisis, ejected the recently elected Constituent Assembly from the Palazzo Vecchio, declared itself a Provisional Government in the name of the absent Grand Duke, and fended off the threatened republic and the unwelcome project of union with Rome (April).

The Meanwhile, taking advantage of the Pope's abdication-

Roman Republic I849.

so Mazzini interpreted his flight-the Roman Assembly on February 9 proclaimed a republic. Mazzini, having been declared a Roman citizen and elected to the Constituent Assembly, adjured his fellow members to prepare for war against Austria. Charles Albert's denunciation of the Vigefano armistice on March 12 increased his insistence upon that course, and even Austria's rapid and complete victory did not alter his conclusion. 'Even should Austria not attack us,' he explains, 'it was our duty to make ready to attack her. ... We could only win Italy to the Republic by emancipating her from the foreigner, by declaring by acts to the country, that what monarchy either could not or would not do, the Republic will.' Upon the news of Novara, the Roman Assembly, believing war to be imminent, created a triumvirate (March 30), of which Mazzini was the life and soul, which addressed itself with vigour to the task of reform, of ' raising the material condition of the less fortunate classes'. To the interests opposed to him Mazzini showed a generous leniency, and in his own deportment exhibited a simplicity and trust in the people which gained him their affection and confidence. He installed himself in the least pretentious quarters in the Quirinal, was accessible at all hours to the humblest citizens, mixed 
with the people freely, and took his meals in a cheap restaurant.

But the Roman Republic was a forlorn hope. After Napoleon the reaction in Florence (April) it was patent that Italian and Rome. union was as dead as the prospects of republicanism. Rome faced the certainty of intervention in the Pope's behalf ; for Austria, France, and Naples were all concerned to secure his restoration. France, in spite of sympathy towards a sister republic, could not efface the larger considerations which governed her policy. To permit Austria a free hand in the Pope's restoration would enable her to dominate the peninsula, a contingency which French interests could not permit. Louis Napoleon, recently elected President, already courting the French Clericals in order to free himself from the control of the Republican constitution, desired to intervene in the Pope's interests and his own, and after Novara was ready to declare war without delay. Public opinion in France also called for intervention in the Pope's behalf. Consequently, though the French Chamber merely authorized the government, as in 1832 , to occupy a point on the Italian peninsula as a warning to Austria, Napoleon had no scruples in using the force at his disposal in another manner.

On April 24, General Oudinot, in command of the RestoraFrench force, landed at Civita Vecchia, in the 'interests Pion of of Liberty and French influence'. The actual purpose of his coming was revealed at once. Rome was summoned to admit his troops, and the return of the Pope was demanded. In spite of odds, the Republic resolved to resist, and on April zo Oudinot was repulsed in an attempt 
to force the city. Having received reinforcements, he resumed hostilities in June, and after a vigorous and destructive bombardment, effected an entrance into the city. Mazzini, scorning to make terms, resigned his triumvirship, while Garibaldi and some three thousand who had fought under him preferred to run the gauntlet of other enemies rather than surrender to the hated French. On July I4, Oudinot proclaimed the restoration of the Temporal Power, and in the following April $185^{\circ}$ Pius returned to Rome. Venice, the single city over which the tricolour floated, fell in the interval. Republicanism had thrown its stake for Italy's future, and had lost.

\section{7}

\section{The Reaction, $1849-59$}

From the defeat of Charles Albert at Novara in I 849 until the outbreak of the War of Independence in 1859 , 'reaction and the hegemony of Austria' governed Italy outside the Kingdom of Sardinia. The collapse of the revolutionary movements in Milan and Venice, and Charles Albert's failure to support them, restored Austria to her old supremacy, while the crisis through which they had just passed disposed all the princes, except those of Sardinia and Naples, to accept her protection. Tuscany, Parma, and Modena were dependent on her. Romagna was under her military observation. Even Rome, out of antagonism to the unwelcome patronage of France, was in a submissive mood. Austria's policy proposed a league between herself and the Italian states for the common 
repression of Liberalism, pledging them all to maintain a federal army for that purpose, to refuse demands for a free Press, National Guards, the right of public meeting, and generally to make no constitutional concessions unacceptable to all the members. But Naples's suspicion of Austria defeated the proposal, which eventually resolved itself into a commercial and postal convention. To aid the process of reaction the position of the Church was strengthened. Tuscany, Modena, Naples, and Austria herself (1855) entered into Concordats with Rome, which conferred ecclesiastical independence, permitting their bishops to correspond freely with the Pope, recognized canon law, placed the control of education in the hands of the Church, and yielded criminous clerics to the jurisdiction of its courts. For the first time, the forces of reaction were organized, in a union more strict and effective than those nationalism so far had been able to employ.

The reaction varied in intensity. The Dukes of Parma and Parma and Modena were restored by Austrian arms, and their rule was maintained by the same sanction. In Parma particularly the reaction satisfied the standards of Austrian brutality. Within the first five months of Duke Charles III's rule three hundred persons were publicly flogged for trivial offences. The duke himself was in the habit of personally caning in the face passers-by who failed to raise their hats to him. In Modena the government reverted to its former absolutism. Leopold II of Tuscany, who came back at the head of an Austrian force, suspended the Statuto, and instituted a rule of severity to which Tuscany so far was a stranger. Pius IX at Rome Rome. 


\section{I 6 The Evolution of Unity}

reverted to the worst standards of the Gregorian system. The sanity, moderation, and ameliorative programme of the Republic were superseded by the old narrow and bigoted régime. Though an amnesty was granted, it was clogged with innumerable exceptions, and France's urgent advice to institute Liberal reforms was rejected.

Naples. In Naples and Austrian Italy reaction attained its greatest force. The Sicilian rebellion (1848) had been put down with a severity which gained Ferdinand his nickname, $R \dot{e}$ Bomba. In Naples the Constitution was shelved, and a vendetta of the most ruthless character was conducted against all whom the court suspected. Probably about 40,000 prisoners were brought to trial and, after a travesty of justice, were condemned to prison in circumstances which Mr. Gladstone, who saw them at first hand, denounced as ' a system of illegality, injustice, and cruelty which one would not have imagined possible nowadays in Europe', and flagellated as the Lombardy- 'negation of God'. Austrian Italy, Lombardy-Venetia, Venetia. submitted to repression whose rigour no European country except Poland had experienced. The provinces were placed under the discipline of Radetzky and martial law. Enormous fines were imposed. Floggings, even of women and girls, were frequent, and in two years nearly 4,000 persons were condemned for alleged political offences. Prisoners were bastinadoed, and a professor of Padua University died under the lash. Lombardy, in consequence, was a hotbed of sullen conspiracy, and in I 850 a committee was formed at Mantua by Enrico Tazzoli, a priest, to throw off the Austrian yoke and establish a republic. The government unravelled the 
plot and shocked the conscience of Europe by the 'Mantua 'Trials', which dragged on till 1855 . Tazzoli and eleven others, the twelve 'Martyrs of Belfiore' (so-called from the locality in Mantua where the executions were carried out), were hanged. A characteristically ill-planned Mazzinist effort to excite a rising at Milan in 1853 was followed by further severities and served to discredit Mazzini and the Democrats still more.

In Sardinia, alone of the Italian states, the reaction Sardinia. was denied an entrance. Not even Austria's offer to waive or reduce the war levy availed to induce the young sovereign, Victor Emmanuel II, to rescind his father's Statuto. 'I will hold the Tricolour high and firm,' he promised on the evening of his accession, and never wavered in that resolve. The circumstance carried important results. Sardinia, after 1849 , was the one free government in Italy, and consequently became the asylum of political refugees from the other states. They numbered tens of thousands, among them some of the finest intellects of Italy, under whose influence, exerted in the ten years 1849-59, Sardinia lost her provincialism and became cosmopolitan. 'Piedmont', said Cavour, at this juncture, 'must gather round herself every living force in Italy, and lead our nation to those high destinies to which it is called.' The period of reaction in Piedmont, therefore, was one of preparation, intellectual activity, and economic and industrial growth. Italy's future depended upon her, and good fortune gave her in Cavour a statesman of supreme ability who achieved it. 


\section{8 \\ Cavour}

Early Camillo Benso Conte di Cavour, younger son of an old career. Piedmontese family in the province of Pinerolo, was born at Turin in I8Io. Destined for a military career, for which he was temperamentally unfitted, Cavour entered the army as lieutenant in the corps of engineers, but resigned his commission after the accession of Charles Albert in $183 \mathrm{I}$, having adopted independent views which were out of harmony with the Conservative traditions of his family and outstripped Piedmont's narrow provincialism. ' $\mathrm{He}$ cares for nothing but politics,' said a relative at this period. English politics and the progress of the Reform agitation especially interested him. Indeed, his predilection for England gained him in later years the nickname 'Milord Risorgimento'. Upon resigning his commission he devoted himself for fifteen years to agriculture and cultivation of the family estates, an occupation which gave him leisure to study France and England at first hand and to acquaint himself closely with their characters. He contributed articles to French and Swiss magazines upon topics of political interest, his views being informed generally by remarkable insight. But he was still a comparatively unknown political force in Piedmont when, in 1847 , in conjunction with Cesare Balbo, author of The Hopes of Italy, he founded the paper Il Risorgimento and plunged into journalism. At the general elections which followed Charles Albert's gift of a Statuto in I848, Cavour was not elected. Four 
months later, however, he secured a seat as one of the members for Turin, and in spite of a squat figure and imperfect Italian accent, made an immediate impression upon the Chamber. On the dissolution of Parliament in January I 849 Cavour was not re-elected, and was therefore precluded from taking part in the angry debates upon the treaty with Austria to which the new sovereign had put his hand. He was elected upon a second dissolution later in the year (November 1849) and as a private member supported d'Azeglio, who as first minister declared it his mission 'to save the independence of this fort of Italy'. The debates upon the Siccardi Laws (1850) revealed Cavour's parliamentary gifts in their maturity and set him upon his ministerial career.

Cavour stands with Bismarck among the political His work. giants of the nineteenth century. He accomplished a similar work, and possessed some of Bismarck's characteristics-a contempt for inactive theorizers, a somewhat cynical tongue, a masterful character, rare ability to see into a diplomatic situation and to discern the appropriate means to the end in contemplation. But he lacked Bismarck's unscrupulousness and contempt for constitutionalism, and was inspired by a vision to which Bismarck was a stranger. Cavour before everything was a Piedmontese working for Italy. Bismarck was and remained a Prussian working for Prussia. Cavour was a fervent Nationalist, and the last victory of his career secured the principle Roma capitale (Rome the capital of Italy) from the Italian parliament 'which his policy had created. At the same time, the events of 1820,1831 , and I 848 convinced him that Italy's independence and unity 
were to be gained only by placing her in the current of European diplomacy. Austria was too powerful to be challenged unaided. His great object, therefore, was to secure the French alliance, and to take advantage of every situation which prejudiced Austria's international relations. Diplomatic caution and fear of estranging the other Italian states forbade him openly to avow himself a Unitarian. But he was none the less opposed to federalism, and the institution of the National Society in $\mathbf{1} 857$ aided him materially to resist it.

At home it was Cavour's policy to prepare Sardinia for the part in Italy's regeneration which circumstances imposed upon her. To secure for her the sympathy of the nationalists, who were Liberal by conviction, it was essential that she should develop the constitution which, alone of her contemporaries, she preserved in the reaction of 1849 . That course was also necessary to secure the sympathy of the western constitutional Powers, on whom Cavour relied against Austria. 'Italy', he said, 'must make herself by means of liberty, or we must give up trying to form her.' Hence, too, he aimed at developing the industrial resources of Piedmont, the nucleus of the future kingdom. Railway and economic development, which had been a marked feature of the past decade, was carried to farther lengths. Restrictions upon industry were removed. Moreover, in the Siccardi Laws, the State victoriously challenged and subordinated the Church to its interests.

The Sic- Even d'Azeglio's easy-going Conservatism found it cardi Laws, impossible to shirk the challenge which the Statuto of ז85. I 848 carried to the papal power. Outside the Church 
public opinion no longer cherished the sentiment of Gioberti and the Neo-Guelfs towards Rome. Pius IX had for ever shattered belief in a reforming and national Papacy. Its authority, after 1850, was supported by foreign bayonets. Its powerful organization was at the service of every illiberal government, and a noisy clerical press, which d'Azeglio treated with easy forbearance, openly and pertinaciously assailed the Liberal régime which Sardinia alone maintained among the Italian states. The clerical party were encouraged to fling themselves athwart the path which the Sardinian monarchy deliberately had chosen, and the Archbishop of Turin openly opposed the constitutional system.

The terms of the Statuto, which promised equal laws to all, were at variance with the privileged position of the Church and its courts of law (foro ecclesiastico). Not in Austria nor Spain did it enjoy greater licence and independence. Its annual revenue, including that of the religious orders, was nearly $£ 750,000$, though it was so unevenly distributed that the State needed to make an annual contribution to bring the income of the smaller parochial benefices to a living wage. Amid a relatively small population its monks, nuns, and priests numbered nearly 25,000. Through the Jesuits it controlled the educational system of the country, and also the charities. In the foro ecclesiastico it possessed its own tribunals, solely competent to try clerics on civil and criminal charges, and with general jurisdiction in all cases relating to heresy, marriage, sacrilege, blasphemy, tithe, and betrothal. The churches also enjoyed rights of sanctuary which thwarted the civil law and its officials. The 
situation was incompatible with the political system Victor Emmanuel II had accepted deliberately upon his accession, and in the last weeks of 1849 d'Azeglio invited Rome to agree to an amicable settlement.

D'Azeglio's agent, Giuseppe Siccardi, a lawyer and Moderate, was instructed to procure a readjustment of the existing Concordat with Rome, and to obtain the removal of the Archbishop of Turin and another prelate obnoxious to his diocese and to the government. Failing to realize the force of public opinion behind Siccardi's mission, the Papal Secretary of State declared the existing Concordat binding and irrevocable. The archbishop was patronized ostentatiously by the Pope, and Siccardi was informed flippantly that, " though the Holy Father is prepared to go to the antechamber of the Devil's house to please the King of Sardinia, he is not ready to accompany him inside'. Public opinion compelled d'Azeglio to proceed to strong measures. The tithes in the island of Sardinia, the only province of the kingdom in which they still existed, were confiscated, and in February 1850, Siccardi, who had been taken into the ministry upon his return from Rome, introduced the measures which bear his name.

Cavour and the Laws.

Cavour supported Siccardi in a speech which gained him applause and reputation. He hoped that, in the long run, the Clericals would realize that progress required the union and not the antagonism of the two great forces, religion and liberty. Their ideal relations he expressed in his famous aspiration, ' a free Church in a free State' (libera Cbiesa in libero Stato). But meanwhile, the outlook in Europe was threatening, and a fearless application 
of reform was necessary to save the ship of state. He therefore adjured the government to persevere in a policy which was needed to strengthen Sardinia's constitutional throne, to permit her to ' gather to herself all the living forces in Italy', and so enable the monarchy to accomplish its high destiny. Thus invited, the Chambers almost unanimously accepted Siccardi's measures. They abolished the foro ecclesiastico, swept away the Church's rights of sanctuary, established the equality of secular and clerical offenders before the law, and forbade the Church to acquire property under deed of gift or testament without the civil power's consent. Nowhere else since the Reformation had such reforms been carried without the Papacy's concurrence, and the breach between Rome and Turin widened irrevocably.

The Clerical party carried indignation to vindictive lengths. The Nuncio left Turin. The archbishop instructed his clergy to defy the new laws and to attend the civil courts only upon compulsion. He was cited for urging disobedience to the law, and upon refusing to appear, was condemned to a month's imprisonment. So great was the passion aroused by the sentence, that Pietro di Santa Rosa, Minister of Agriculture, was denied extreme unction upon his death-bed by his confessor, for his complicity in the Siccardi Laws. Public indignation was intense. The archbishop was again imprisoned, and the religious body to which Santa Rosa's confessor belonged was banished from Turin.

The crisis created by the Siccardi Laws needed stronger Cavour in handling than d'Azeglio's, and public opinion singled office, 1850 . out Cavour as the man whom the situation required. 
Though he sat with the Right, he had attached himself by strict ties to none of the political parties in the Chamber. In October $185^{\circ}$ he entered the ministry in Santa Rosa's room, added to his Department of Agriculture and Commerce charge of the Ministry of Finance a year later, and so completely overshadowed his col. leagues in ability, energy, and public estimation, that d'Azeglio soon complained that, like Louis-Philippe, he reigned but did not rule. Cavour, in fact, found himself increasingly out of touch with d'Azeglio's complacent Conservatism, and early in 1852 came to an understanding with Urbano Rattazzi and the Left Centre. The Extreme Right and Extreme Left were suspect in their The "Con-loyalty to the Statuto. But between them existed nubio', a compact body of opinion, formed by the Right and Left Centres, which could support a progressive ministry. Upon his own responsibility, therefore, and to d'Azeglio's grave annoyance, Cavour made a secret compact with Rattazzi for their co-operation in a programme concisely defined as 'Monarchy, the Constitution, independence (of Austria), civil and political progress'. Cavour was denounced by his colleagues as having divorced them in order to make a marriage (connubio) with the Left Centre, and as the Connubio the alliance is known. For the moment it brought Cavour's ministerial career to an end. In May I852, finding his position within the Cabinet intolerable, he resigned. D'Azeglio fell in the following autumn, upon the Senate's rejection of a bill to legalize civil marriages. Thereupon Victor Emmanuel invited Cavour to fill his place. In November 1852 , the Great Ministry (gran ministero), so closely 
identified with the achievement of Italian unity, began its course. A month later Napoleon became Emperor of the French. The boards were set for the drama of I859.

Cavour's success in bringing Sardinia iuto the council The board of Europe was the most striking feature of the Mran ${ }_{\text {Ministero, }}$ Great Ministry. But it was not its only achievement. 1852 . To consolidate the youthful parliamentary system, to develop the kingdom's material resources, and to force Europe to recognize it as the representative and champion of Italy's needs were cardinal purposes. Advantageous commercial treaties were made with Great Britain, France, and other foreign countries. The tariff was reformed in the direction of Free Trade. Agriculture, commerce, and industry were encouraged. The railway system was developed, Mont Cenis was pierced, and the irrigation canal which bears Cavour's name was dug. Equally energetic was the effort to strengthen the military resources upon which, one day, the cause of Italy would depend. The defences of Alessandria and Casale were taken in hand; and the Minister of War, La Marmora, reformed the army with such success that in the Crimea its organization and efficiency compared favourably with those of its more powerful allies.

The Connubio, and the inclusion of Rattazzi in the ministry, enabled Cavour to advance in two directions from which d'Azeglio's more timid policy shrank-the suppression of the monastic establishments, and the alliance with France and Great Britain in 1855 .

Cavour, left to himself, was not disposed to carry the Cavour policy that dictated the Siccardi Laws to further con- and the 1855 . 
clusions. But the fact that the State actually subsidized the Church established a general right to take its endowments into consideration, and since his preference for leaving the Church free to manage or mismanage its affairs, in the conviction that in the long run it would become patriotic, was not agreeable to Rattazzi, Cavour waived his personal view. The Siccardi Laws had vindicated the sovereignty of the State and its courts over ecclesiastical privilege. But the Church's income was still under its absolute control, and in relation to its obligations undoubtedly was excessive. The population of the kingdom numbered 5,000,000, of whom one in 2I4 was an ecclesiastic-three times the proportion that obtained in Austria. Over six hundred monastic houses existed, and the number of bishoprics was even more excessive. The relatively small resources which the State controlled made the Church's wealth the more disproportionate, and a dilemma was fairly stated, 'to submit to Austria or the priests'. As in the case of the Siccardi Laws, Rome met the suggestion of reform with an unyielding non possumus. In March 1855 Cavour's measure was carried in the Chamber by an overwhelming majority. It suppressed all religious foundations, excepting bishoprics and corporations devoted to education, preaching, and charitable work. It levied a pro rata tax upon the bishoprics and surviving corporations to replace the State subsidy. At the same time, a pension fund was provided for members of the disendowed houses, whose buildings were placed at their disposal for their lifetime. The Clericals, however, were successful in rousing the opposition of the King, and Cavour tendered 
his resignation. But the temper of the country would not permit the bill to be abandoned, and Cavour was soon recalled. Still, he deemed it advisable to counter opposition by accepting amendments which excluded from the operation of the measure nearly half the monastic houses (May 1855). They were not dealt with until I 866. Meanwhile, the compromise kept Cavour in office to carry out his foreign policy.

While the Dissolution Bill was stirring the country, The Cavour negotiated a bold stroke of policy elsewhere. Crimean In March 1854 France and Great Britain declared war 1854-6. upon Russia, an event which Cavour held a providential opportunity to place ' gallant little Piedmont' in the eye of Europe. To this point, probably, he had not thought out the process and ultimate form of unity. But he had no illusions upon Italy's inability to accomplish it unaided. It was a measure of obvious statesmanship to secure a powerful ally, and on the French Empire, with its professed homage to the cause of oppressed or incomplete nationalities, Cavour's hopes were centred. But in the early years of Napoleon's reign (1852-4) Piedmont was suspect as a radical enclave in conservative Italy, the asylum of dangerous political refugees. Nor was Piedmont unanimous upon the wisdom of the step to which Cavour eventually committed her. Some had the discernment to picture the Crimea as 'the near road to Lombardy'. But the majority were disposed to regard participation in an Eastern war of remote concern as a diversion of Sardinia's activities from the cause of Italy, and an undue drain upon her resources. Nor were the Western Allies entirely favourable to the ends Cavour had in view. Napoleon was 
not yet prepared to champion Italian nationalism. $\mathrm{He}$ was closely dependent upon the French Clericals, who had given him his throne and were its main support. To countenance a movement which threatened the Temporal Power of the Pope was impossible at a moment when Pius was supported by French arms. Certainly, at the close of 1852, the Emperor informed the Turin government that the time, he hoped, was not distant when the two countries would stand together 'in the noble cause of Italy'. But it required Orsini's bomb (1858) to bring him into action. Neither France nor England was disposed to buy Sardinia's help, nor did her military aid seem of sufficient value to commend the price she set upon it-their open countenance of her cause against Austria. The Allies, in fact, were drawn to approach her rather because Austria, whose alliance they preferred, could not be enlisted unless her Italian enemy was committed to peace or co-operation.

So convinced was Cavour that her intervention was of vital import to Sardinia, that he was prepared on almost any terms to associate the monarchy with the Allies in the Crimea. He replied to their first invitation to participate with an alacrity which threatened the withdrawal of Rattazzi and La Marmora from the Cabinet. But when, in December 1854, France and England formally proposed an alliance, Cavour was able to carry the Cabinet with him in the terms he demanded. Besides receiving a financial loan, he required that Sardinia should enter the Alliance as an equal and not as a stipendiary; that the Italian question should be brought up at the conclusion of the war; and that meanwhile Austria should be re- 
quired to withdraw the decree of sequestration passed in I 853 against the exiles from Lombardy-Venetia to whom Piedmont had given shelter. But on December 2, Austria, after a long period of doubt, formally entered into an agreement with the Allies. Her action threatened Sardinia with isolation, and Cavour hastened to intimate his willingness to join the Allies upon their own terms. On January 25, 1855, with some opposition from the Cabinet, he signed a one-sided Treaty, which bound Sardinia in the common enterprise against Russia, and merely secured a guarantee of her territory during her participation in the war.

In April I 855, seventeen thousand Piedmontese sailed Tchernaya, from Genoa and took their place in the lines round Sebas1855 . topol. La Marmora, who commanded them, asserted an equality with the allied commanders, while the equipment and organization of his force, and in particular its useful contribution to the victory at the Tchernaya in August I 855, placed the kingdom in excellent relations with the Allies. Though the treaty of alliance was carried in the chambers only against considerable opposition, and public opinion was puzzled at finding Sardinia in partnership with her traditional enemy and illiberal Turkey, the situation, as Cavour saw it, found expression in the mouth of a Piedmontese soldier toiling in the trenches before Sebastopol, 'Never mind, out of this mud Italy will be made'. To prepare the reward for their sacrifices, Cavour and his sovereign visited the capitals of the Western Allies in the autumn of 1855 , and were received with acclamation. Napoleon, in particular, gave encouragement, and his question to Cavour, "What 
can we do for Italy ?' drew an exhaustive memorandum on Italy's grievances and needs.

Cavour at To Cavour's disappointment, the war ended before he Paris,1856. was able to place his allies under heavy obligation. In February 1856, peace plenipotentiaries assembled at Paris, and Cavour, whom Austria had used all her diplomatic arts to exclude, took his place among them. A proposal that he should be admitted only to negotiations directly concerning Sardinia's interests was rejected by him indignantly. Apart from the intention to present Sardinia as the champion of Italian interests, he had three particular objects in view, though, probably, with little expectation of achieving them. He hoped to gain territorial compensation, possibly Parma or Massa-Carrara; to procure the recall of the Austrians from Romagna, which he hoped might become an independent State, or be attached to Tuscany or Modena; and to bring public opinion to bear upon Rome and Naples to compel reform of their scandalous governments. To carry the programme depended upon the support of France and England. England, however, was not willing to go beyond the last of Cavour's proposals, and the limit of Napoleon's co-operation was his readiness to rebuke Ferdinand's misrule.

In these circumstances Cavour was obliged to be content with an undertaking that, upon the conclusion of the chief business of the Congress, the Italian question should be raised for discussion. At that period the French plenipotentiary, with Napoleon's sanction, drew attention in moderate language to papal misgovernment, and warned Rome that foreign occupation could not cease until he 
bowed to the demands of Europe. He castigated more severely the excesses of the Neapolitan administration, and urged the Congress to admonish Bomba. The British plenipotentiary, Lord Clarendon, in rounder terms condemned the papal government, and warned Naples that the consequences would be serious if the advice of Europe was neglected. Austria, indignant at the introduction of the Italian question, refused to allow the discussion to be followed by a vote. Indeed, Cavour hardly can have looked for that conclusion. But he was repaid already for the sacrifices of a campaign which had cost Sardinia $£ 3,000,000$. Europe was henceforth committed to recognize the existence of an Italian question; Austria, for the moment, was without a friend in her attitude towards it; and Sardinia had advertised herself as the champion of Liberalism in the peninsula.

Still, Cavour was disappointed at the comparatively meagre results of his mission. As d'Azeglio scoffingly commented, he returned from Paris 'without even the tiniest duchy in his pocket'. In the vain belief that England would back him, he contemplated challenging Austria and unloosing against the Neapolitan Bourbons such a campaign as Garibaldi conducted four years later. In a memorandum to Paris and London he warned his late allies that, ' disturbed within by revolutionary activity, and from without by reactionary governments and foreign occupation, threatened also by an increase of Austrian influence in the peninsula ', Sardinia might be compelled to adopt measures 'of which it is impossible to foretell the consequences'. But cooler thoughts prevailed, and Cavour accurately measured the value of the Crimean 
adventure when he told the Chamber that the cause of Italy was now 'before the bar of public opinion' in Europe, and that Sardinia was recognized to be its advocate.

\section{9}

\section{Napoleon III and Cavour}

Convinced that the position was shaping, though slowly, towards an ultimate challenge to Austria, Cavour, after his return from Paris, continued to encourage the reforms -economic, financial, and military-on which success depended. Elsewhere the old régime continued with little modification. Neither Naples nor the Papal States corrected the abuses to which attention had been called at Paris. France and Great Britain made joint representation at Naples. But Bomba laughed at their counsel and denounced their action as an unwarrantable intrusion. Nor did a scheme, approved by Napoleon, to place Lucien Murat, son of Joachim, on the throne move him. Pius, also, turned a deaf ear to France's representations. Recent events had raised the prestige of the Papacy in Europe. A Roman Catholic hierarchy had been restored in England and Holland. The dogma of the Immaculate Conception had been proclaimed (I 854). Satisfactory Concordats had been arranged with Austria (1855) and the Italian States. The Pope, therefore, was in no mood for advice, and in default of reform the French and Austrian occupations continued. Austria, alarmed somewhat by the outcry at her severities in 1853 , showed a desire to conciliate her Italian subjects. Martial law was raised in May 1854, the 
obnoxious decree of sequestration was recalled (1856), and early in 1857 the Emperor Francis Joseph and his consort paid a visit to their Italian kingdom, and were received with marked coldness. 'We don't want Austria

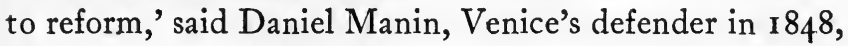
'we want her to go.'

Between the Congress of Paris in 1856 and his interview Mazzini, with Napoleon at Plombières in 1858 Cavour stands some- ${ }^{1853-7}$. what in the rear of the march towards unity. Master, as he was, of diplomatic fence and parliamentary tactics, he lacked Mazzini's art of stating a programme, invoking principles, inspiring a crusade. Mazzini himself, in the same period, was driving his countrymen to withdraw their confidence from him. Passionate and unpractical, condemned by the fears and hostility of the Turin government to eat out his heart in a foreign land, he was the more contemptuous of a policy whose methods challenged his own. His was the party of 'action'; and the ill-judged effort at Milan in 1853 was repeated by Carlo Pisacane at Naples in 1857, while demonstrations took place at Genoa and Leghorn. 'The question', said Mazzini in defence of these efforts, 'was not between the Republic and Royalty, but between action and inertness.' $\mathrm{He}$ complained that Sardinia, possessed of a well-organized army, navy, treasury, and arsenals, had won not an inch of foreign-held Italy. Her minister, rather, pursued inactivity under vague promises of 'vaster designs gradually being matured by the monarchy', and imposed upon 'a population of dupes, who persisted in committing the salvation of Italy to protocols which recognized the dominion of Austria in Lombardy; to the propositions of ministerial 1832.3 $\mathrm{Ff}$ 
Liberators [a name already being applied to Cavour], who teach their masters how to prevent the unity of Italy; to wars in the Crimea, seeking the co-operation of Austria ; to Anglo-French mediations which demand, but do not obtain, the liberation of a few prisoners; to the occult designs of the man [Napoleon III] who, having extinguished in blood the liberties of France and Rome, is doomed, by an inexorable fate, to live and die a tyrant.' 'Sleeping draughts, immobility, and opportunities,' was Mazzini's characterization of Turin's programme in relation to Italy's cause.

The

Cavour's position was candidly stated by himself to

National Society, I857. Giuseppe La Farina soon after his return from Paris. He expressed sincere belief in the ultimate union of Italy, and that Rome would one day become the capital of a united kingdom. But he avowed himself ignorant of opinion in the other Italian principalities, and declared his inability to act unless they were ripe for transformation. He was, after all, the servant of the King of Sardinia, bound to engage him in no enterprise which might imperil his monarchy. Cavour, in fact, was waiting for Napoleon. But he was ready to welcome any organization which should prepare the way for the action he desired. Such a force was the National Society, founded by Daniel Manin and Giorgio Pallavicini in the summer of 1857 . Pallavicini, a Lombard nobleman and convinced republican, had come to Piedmont as an exile during the rising of 1848 . Manin, after the fall of Venice, found a home in Paris. Like Pallavicini, he renounced his republicanism and reached the conclusion that Italy's salvation depended upon the co-operation of 'Italian public opinion and the Pied- 
montese army'. With the help of Giuseppe La Farina, the Sicilian historian, the two men launched the new society. It was the first organization of a non-revolutionary character to declare for union. 'Independence and unity' was its motto, with the corollary, 'Out with the Austrians and the Pope'. It killed republicanism, converted the autonomists, and removed their lingering attachment to a federated Italy. In Lombardy-Venetia and the duchies the society carried all before it. In Tuscany and Romagna, even in Naples, its influence was powerful. The adherence of the popular idol, Garibaldi, to the society did much to form the atmosphere Cavour required.

An unforeseen event brought Cavour's hopes of France Orsini, to sudden maturity. Since the events of 1849 , Napoleon ${ }^{1852 .}$ was regarded by the Mazzinists as the enemy of republicanism in France, the destroyer of Rome's liberties, and the bulwark of the Temporal Power. His crime, in their eyes, was blacker by reason of his early association with the Carbonari ; it vexed the soul of Felice Orsini, a member of the Roman Constituent of 1849 , Mazzini's agent in the Democratic outbreak at Genoa in 1853. Banished from Piedmont in consequence, Orsini, after many adventures, found his way to England in I856, where he supported himself as a lecturer, and stirred public opinion by his revelations of prison life in Mantua, whence he had made a dramatic escape to England. To rehabilitate himself with Mazzini, with whom he had broken, Orsini resolved to assassinate Napoleon, and in 1857 left England for the purpose. On January I4, I858, the sixth anniversary of the mock republican constitution of 1852 , Orsini and his 


\section{6

accomplices contrived to hurl three bombs at Napoleon and the Empress as they were being driven to the Opera. About one hundred and fifty persons were killed and wounded, and one of the carriage horses was killed. Napoleon escaped unhurt. The immediate effect of the outrage was the proclamation of martial law throughout France, an outcry against England, who had sheltered the criminal, and representations to Turin, which was regarded as the chief asylum of conspiracy. Orsini was executed, after writing a letter to the Emperor urging him 'to give Italy the independence of which France deprived her in 1849 , and to remember his vows as a Carbonaro'.

The Orsini outrage at first threatened to imperil Cavour's hopes of France. Napoleon peremptorily required that the press should be placed under restraint, demanded strong measures against political refugees, and wrote threateningly to Victor Emmanuel. But though the future was at stake, and Napoleon, who already had sacrificed Poland's deliverance to Russia's friendship, might be driven to desert Italy also, neither Cavour nor his master was willing to submit to the Emperor's demands. Their utmost concession was a moderate amendment of the Press Law. But reflection modified Napoleon's attitude. For 'liberty' in the abstract he had no enthusiasm; for the greater part of his reign he contemptuously disregarded it. But his very name conveyed a challenge to ' the iniquitous treaties of 1815 ', from which France herself had suffered, and his 'Napoleonic Ideas' had expounded the legend which grew up round the first Napoleon-that a French Empire was the providen- 
tially appointed friend of struggling nationalities. $\mathrm{He}$ was sincerely desirous of being Italy's deus ex machina, though, as was made clear at Plombières, not precisely in the manner that Italy preferred. Fear of the Carbonari also influenced him. Second thoughts therefore moved him to obey Orsini's adjuration to 'deliver Italy', and the assent of the Empress and the Clericals was given grudgingly to his proposal ' to do something' for her. At the same time, he had not the courage to act openly as the champion of the principles of which he constituted himself the guardian, and the first effects of their victory drew him back precipitately.

By indirect methods, characteristically, Cavour dis- Plombières, covered the re-orientation of Napoleon's policy. A private communication from Paris, containing a copy of Orsini's letter, reached him with a request to publish it in the Official Gazette. Suggestions of a marriage alliance between the Houses of Savoy and Bonaparte became current, and in the early summer of 1858 an agent of the Emperor, visiting Turin 'for his amusement', conveyed his master's invitation to Cavour to meet him 'by accident ' at Plombières, a village in the Vosges, conveniently isolated. In July Cavour travelled thither in such secrecy that, upon his arrival, he was nearly arrested, being without a passport. The motive of his journey was known only to the King and La Marmora. Napoleon's intentions were equally concealed from the French ministry.

In general terms Napoleon proposed that France and Sardinia should combine to free Italy 'from the Alps to the Adriatic'. A Kingdom of North Italy was to be formed under the House of Savoy, enlarged by the 
addition of Lombardy-Venetia, the duchies, Romagna (the Legations), and possibly the Papal Marches of Ancona. Tuscany, with the addition of Papal Umbria, would become the Kingdom of Central Italy. Thus, the Papacy would be restricted to the Patrimony, or Comarca. The Kingdom of Naples was not threatened in territory. But the expulsion of the Bourbons was contemplated, and Murat probably would replace them. To establish French dynasties in the peninsula was part of Napoleon's policy, if only to give France the protection which a strengthened Italy necessitated. $\mathrm{He}$ therefore proposed a marriage between Prince Napoleon (Plon-Plon) and Victor Emmanuel's daughter Clotilda, with the idea of their receiving the crown of Central Italy. With his eye upon a strengthened Alpine frontier, Napoleon demanded the 'reuniting ' of Savoy, and if possible Nice, to France. He insisted also that the war should be waged upon a pretext capable of diplomatic justification in France and England. As to the future of Italy, it was proposed that, after the elimination of Austria, Modena, and Parma, the four remaining states should be confederated under the hegemony of the new Kingdom of North Italy and the honorary presidency of the Pope. The spring of 1859 was appointed for the outbreak of war.

The Plombières pact exhibits in Cavour the boldness and clearness of vision that had thrust Sardinia into the Crimea four years before. He expressed to La Marmora his fear lest his 'usual self-reliance' might fail him at Plombières. In fact, much of the agreement was not to his taste. But 'in politics', he wrote, 'one thing is enough at a time. For the moment, the vital need is to get Austria 
out of Italy.' The following nine months, until the outbreak of war in 1859, were a period of great anxiety. On the whole, the European situation was favourable. Prussia was not averse from the prospect of a FrancoAustrian conflict; for her own quarrel with Vienna was nearing explosion. On the other hand, Germany had to be reckoned with. Austria held the Präsidium of the Confederation, and the Quadrilateral was regarded as the federal outpost of Germany in the south. The prospect of Prussian neutrality, therefore, was conditional on France's abstention from striking the first blow or giving Austria an opening to invoke the Bund in her quarrel. Franco-Russian relations assured the neutrality of the Tsar, who was prepared to hold any movement on the part of Germany in check. In England the prospect was less assured. In February 1858 Lord Derby's Tory ministry succeeded Palmerston, and continued in office until after the outbreak of war. Palmerston's fall was due to the anger roused by Napoleon's demands over the Orsini outrage, and by the ministry's submission to his dictation in framing preventive measures. The court and the government in the main were in sympathy with Austria, and Cavour knew that their interest was available to avert a conflict, should Vienna judge caution the safer policy.

A greater danger in Lombardy-Venetia was solved by Austrian Austria herself. It was of vital import to Sardinia that policy. war, when it came, should be capable of representation as one of deliverance, and not of conquest. Austria was alive to the danger, and for a few months, in $1857^{-8}$, seemed bent upon a policy of amelioration which, if persisted in, must have weakened the position of the 
annexationists. But the Emperor's brother, the young Archduke Maximilian, to whom, as governor, the effort was entrusted, was thwarted by the army clique which had learnt nothing from the past and was prepared, lightheartedly, to jeopardize the future. Lombardy-Venetia's hatred of her old oppressor was intensified by two unwise measures : the currency was depreciated, in order to make it uniform with the standard in other parts of Austria's financially misgoverned Empire; and not only was liability to conscription extended, but marriage was interdicted to all under the age of twenty-three who were liable to military service. Consequently, LombardyVenetia waited impatiently for war.

France Cavour's chief anxiety came from France. His agreement with the Emperor was verbal and secret, and Napoleon's shifting policy might at any moment lead him to repudiate it. French opinion was not captivated by the vision of a renovated Italy. The Clericals would certainly oppose war, if not entirely, at least from the moment that the Temporal Power seemed to be in jeopardy. Commercial interests were certain to protest against disturbance of business. Liberal opposition was growing, and was not likely to support a war which promised éclat to the Empire. As to Italy, Cavour had behind him all in Piedmont who knew what was in contemplation. ' To-day', d'Azeglio wrote magnanimously, ' it is no longer a question of discussing your policy, but of making it succecd.' Victor Emmanuel was eager for action. The National Society placed itself at Cavour's disposal and for the moment substituted 'Italian Independence' for 'Italian Unity 'as its motto. In spite of 


\section{Napoleon III and Cavour}

the army's objections, Cavour used the society to assemble a volunteer force of Cacciatori delle Alpi (Alpine Hunters), and conferred their command upon the eager Garibaldi. If the fresh enthusiasm of 1848 was lacking, there was everywhere expectancy and hope. But it was essential to manœuvre Austria into the position of assailant, in order to alienate from her the sympathies of Europe. It seemed almost impossible that Austria, with her great resources, and her power of wearing down her enemy by merely remaining passive, should allow herself to be placed in that position. But Cavour approached the task with confidence, and achieved it. To one who doubted his ability. he declared positively that Austria would open war ' about the first week in May'. She did so, in fact, on April 29.

As the period approached, Cavour's anxieties and the Napoleon complications of the European situation increased. $\begin{aligned} & \text { and Aus- } \\ & \text { tria, } 1859 .\end{aligned}$ The first warning to Europe, premature and unwise, Cavour thought, came from Napoleon. Having in mind the recent deposition of the Karageorgevich and substitution of the Obrenovich dynasty in Serbia, carried by the influence of France and Russia in opposition to Austria, Napoleon, at the New Year's diplomatic reception, I859, took occasion to express to the Austrian ambassador his regret that the relations of their governments were not as cordial as they had been. Whether or not the words were intended as a menace, Europe understood them to presage war. A few days later, the opening of the Sardinian Parliament deepened the impression. The Speech, as drafted originally by Cavour, contained a passage in which Sardinia was declared to be 'confidently resolved to fulfil the mission entrusted to her by Providence '. As 
his colleagues thought the phrase injudiciously menacing, Cavour communicated the text to Napoleon, who revised the Speech, added some high-sounding periods in which Sardinia was described as ' small in territory, but great in the ideas she represents and the sympathies she rouses in Europe', and inserted an arresting sentence: 'The situation is fraught with danger; for, faithful to treaties as we [Victor Emmanuel] are, we cannot shut our ears to the cries of woe that reach us from so many parts of Italy.' Victor Emmanuel substituted 'cry' for 'cries', and the Speech, particularly the phrase grido di dolore (cry of woe), rousing the Chamber to enthusiasm, one who heard it declared, ' fell like a rocket on the treaties of 1815 ,' from whose meshes Italy was seeking escape. Volunteers flocked to Turin from all parts of Italy. Even Tuscany, where autonomist feeling was strongest, was enthusiastic for war, and 'to go to Piedmont' became the test of patriotism. The 'Hymn to Garibaldi' was composed at this moment of national exaltation. On January 18 France and Sardinia united in an offensive alliance upon the Plombières terms, and made a military convention which bound France to provide 200,000 men. Before the end of the month the marriage of Prince Napoleon and Princess Clotilda, a girl of sixteen, cemented the alliance of the two countries.

Napolion et With a view to enlightening France and Europe upon
l'Italie, r859. his Italian outlook, Napoleon permitted the publication (February 1859) of a pamphlet, entitled Napoléon et l'Italie. Its author was La Guéronnière, one of the councillors of state ; but it received Napoleon's revision, and expressed his views. It reminded France of her rôle 
as the protector of nationalities, and sketched, on the lines of the Plombières agreement, a reconstructed Italy for her approval. Its purpose was to reassure the Clericals regarding the Pope. A united Italy, such as Manin's National Society aimed at, was not contemplated. A confederation of Italian states, an enlarged Sardinia among them, was outlined, under the presidency of the Pope, who was to be influenced to liberalize his government. The position of Austria was not defined, but the trend of the pamphlet was to accuse her as the chief bar to Italy's salvation.

The threatening outlook brought Lord Derby's Tory Lord Cowgovernment into action in the interests of peace. It ley's misviewed Napoleon with suspicion. His entente with Russia threatened trouble in the East, and a renovated Italy dependent upon France was not agreeable to British interests. Germany also, anticipating France's ulterior hopes, was beginning to think of 'defending the Rhine on the Po'. In February, therefore, Lord Cowley, British ambassador at Paris, was sent to Vienna to offer mediation, with Napoleon's qualified approval. Napoleon, in fact, influenced by the European situation and domestic ap: prehensions, was beginning to shrink from the prospect of war. At his suggestion, Russia proposed his favourite expedient, a congress of the Powers. Great Britain assented, and indicated the following topics : the FrancoAustrian occupation of the Papal States ; the Pope's misgovernment ; the relations of Vienna and Turin ; and the treaties of 1847 which made the duchies on the Po dependants of Austria. Neither the proposed reference nor the inclusion of Sardinia in the congress was agreeable to 
Austria, whose acceptance was conditioned, therefore, by the stipulation that Sardinia must disarm, dismiss her volunteers, and be excluded from the proposed conference. The demand was the first ray of light upon a situation which Cavour had begun to regard as hopeless, in view of Napoleon's obvious desire to escape from his obligations. Protesting that it was unreasonable to demand demobilization unless he was permitted other means of defence, Cavour refused to disarm. British diplomacy replied with a proposal that all the potential belligerents, France, Austria, and Sardinia should disband. France officially approved, and Cavour sought to attach unacceptable conditions to his enforced acquiescence. But at Vienna the military party triumphed, and at the moment when Cavour had brought himself almost to despair. On April 23 Austria delivered an ultimatum at Turin requiring disarmament within three days, an ill-judged move which defeated Derby's efforts for peace and compelled Napoleon to fulfil his engagements with Cavour. On April 26 Cavour rejected Austria's ultimatum, and on the same day Napoleon informed Vienna that he should regard her passage of the Ticino into Piedmont as a hostile act. Three days later (April 29) the Austrians crossed the river, and Napoleon declared war.

Mageuta, The war lasted little more than two months. The 1859 . Austrians anticipated a speedy conclusion before the French could come to their ally's assistance. But their initial advantage was lost by bad and hesitating generalship, and the situation was still intact when Napoleon established his head-quarters at Alessandria on May I4. Before leaving France, a manifesto to his people announced 
his intention to free Italy ' from the Alps to the Adriatic ... not to give Italy a change of masters, but to restore her to herself'. Such, probably, were his intentions when he found himself once more on the soil of Italy. But the effects of his intervention soon bade him pause. Moving along the new railway from Alessandria through Novara to Milan, the Allies defeated the Austrian commander, Marshal Gyulai, Radetzky's successor, at Magenta on June 4, at Melegnano four days later (June 8), and entered Milan amid enthusiasm.

Napoleon announced his arrival at the capital of The Milan Lombardy in a manifesto which seemed to tie him hand manif and foot to the cause of Italy. 'Unite', he bade the Italians, 'on one supreme object, the emancipation of your country. Fly to arms. Flock to the standard of King Victor Emmanuel. . . . Fight to-day, consumed by the fire of patriotism. To-morrow you shall be free citizens of a great country.' Italy answered the Emperor's call. As the Austrians fell back, the duchies and Romagna, responding to the National Society, demanded incorporation into Sardinia. Still more striking was the adherence of Tuscany. The Grand Duke fled from Florence (April 27) before a good-humoured but resolute rebellion, and eleven-twelfths of the Tuscan population expressed by petition their desire for annexation. The movement spread to Umbria and the Marches of Ancona, where, however, the Pope was able to suppress it. But elsewhere, excepting Naples, where Francis II-King 'Bombino' the last Bourbon sovereign, had just (I859) succeeded his father, Italy was unanimous for union and independence. In Parma, Modena, Florence, and Bologna (Romagna), 


\section{6}

\section{The Evolution of Unity}

Commissioners were nominated to represent the Turin government pending a formal act of union.

Solferino, After a brief halt at Milan the campaign was resumed, 1859 .

the Emperor Francis Joseph of Austria having assumed command after Magenta. On June 24, after a stubborn and sanguinary engagement, the Allies were again victorious at Solferino, and, as in 1848, Austria fell back upon the Quadrilateral. The end of the war seemed in sight. Venice was vulnerable to sea-power, though the Quadrilateral might hold out. Hungary could be stimulated to revolt, and Austria's downfall seemed probable. But Napoleon drew back in dismay from the avalanche he had loosened. A considerable inducement which had brought him into Italy was the hope of establishing his dynasty by a brilliant campaign which should recall the glories of the First Empire. But up to this point, though he had had no reverses, victory had not been easily gained; and he judged it wiser to retire on the laurels he had won rather than risk defeat in Venetia and consequent ruin in France. Perhaps, also, jealousy of Victor Emmanuel, whose soldierly qualities put his own into the shade, weighed with him. But more vital were the issues which the war raised in Italy and Germany. The unification of Italy was no part of his policy, and was contrary to France's interests. The defection of Tuscany to the Unitarians especially provoked him, since it barred a French dynasty at Florence. And though the Pope so far held the patriots at bay elsewhere than in Romagna, he might be overwhelmed. The Empress sent constant warnings of the consequences of such a disaster. Across the Alps, Prussia was becoming restive in face of France's success. If Austria fell, would 
not Napoleon's next assault be upon the Rhine ? Coveting Austria's position as President of the Bund, Berlin could not seem indifferent to the national cause when the smaller states were calling to be led to the Fatherland's defence. Hence, on the day of Solferino, Prussia called out her federal army corps and invited Great Britain and Russia to join her in offering mediation. Russia was equally, alarmed; an Hungarian rising was likely to spread to Poland. As to Great Britain, Derby's ministry fell in June, and Palmerston, once more in office, was anxious for that settlement of the Italian question which Napoleon most desired to avoid-a strong Italy, able to hold her own against Austria and France alike.

With barely a hint to Victor Emmanuel of what was Villain his mind, Napoleon suddenly proposed an armistice to $\underset{\text { rranca, }}{859 \text {. }}$ Francis Joseph, then at Verona. It was signed two days later, and on July 9 the two Emperors met at Villafranca, a village near the fortress. After a feebly pressed proposal to compromise on Venetia by constituting it an independent kingdom under Archduke Maximilian, Napoleon signed the Preliminaries of Villafranca on July I r. They provided that Austria should cede to France, for retrocession to Sardinia, the whole of Lombardy, except Mantua and Peschiera, the two western pillars of the Quadrilateral, which Austria retained for the defence of Venetia ; that Austrian Venetia should enter an Italian Confederation under the Pope's presidency; that the Grand Duke of Tuscany and his neighbour in Modena should be restored; that both Emperors should urge the Pope to institute 'some indispensable reforms' in his administration; and that a general amnesty should cover recent events. 
Implicitly, Parma was abandoned, with Lombardy, to Sardinia, whose exclusion from Tuscany, Modena, and Romagna, the Preliminaries were designed to secure.

Napoleon returned to France leaving consternation behind him. All Italy voiced the indignant outburst of Cavour, "the Emperor has dishonoured me before my King'. Hurrying to head-quarters, he implored Victor Emmanuel either to refuse Lombardy and abdicate, or to continue the war by himself. A bitter scene followed; the King rejected the alternatives, and Cavour resigned (July I3). Victor Emmanuel, after refusing to sign the Preliminaries, eventually did so, but added to his signature the qualification, 'so far as it [the document] concerns me,' implying his refusal to countenance the federation clauses.

The Union of Central Italy, I86o

Napoleon The interval between the ratification of the Prelimiand Union, naries of Villafranca in July I 859 and the return of Cavour
1860. to office in the middle of January 1860 was critical in the history of Italian unity. France and Austria were leagued to defeat the junction of Central Italy (Tuscany, Modena, Parma, and Romagna) with Sardinia; and the peace conference, which opened at Zurich in August and completed its labours on November 10, 1859, confirmed their veto. The Papacy was equally concerned to defeat the Romagna separatists. Its military power was not formidable; but 50,000 French were still in Lombardy, and their withdrawal would leave Central Italy to meet 
Austria and the Pope unaided. Great as was Italy's indignation at the Emperor's desertion, he ruled the situation; and his policy, though it veered to circumstances, remained constant until the Zurich Conference rose. His unflinching object to that point was to prevent the attachment of Central Italy to Sardinia, and to exert pressure at Florence and Turin to forbid it. When it became clear that Central Italy was not to be intimidated, Napoleon's policy veered to an alternative. He was prepared to acquiesce, but at a price-Savoy and Nicein the aggrandizement of Sardinia. His attitude created a situation of extreme difficulty for Cavour's successor, Rattazzi, who lacked the authority, and also the zeal for union, which marked his predecessor. Hence, in the interval between July I859 and January 1860, Central Italy was obliged to reckon with both Paris and Turin.

The Villafranca Preliminaries laid an obligation on Central Victor Emmanuel to recall his Commissioners from Italy, 1859 . Florence, Modena, Parma, and Bologna. But Central Italy refused to be coerced. Ricasoli at Florence, and Luigi Carlo Farini, a Romagnuol, in Parma and Modena, were forthwith elevated by popular acclamation to the interim dictatorship of the provinces. Both were animated by Ricasoli's determination 'to think neither of fusion nor annexation, but only of the union of Italy under the constitutional government of Victor Emmanuel'. The dictators at first hesitated to admit Romagna to their association, since her inclusion would involve them in the thorny Papal problem. But challenging their caution, Parma, Modena, and Romagna formed themselves into a single province, under Farini's dictatorship, bearing 1832.3 
the name Emilia (from the fact that the Via Emiliana traversed them all), and concluded a military convention with Tuscany for the maintenance of a common army to meet any action on the part of Austria. With hesitation Victor Emmanuel lent General Fanti, one of his ablest soldiers, to organize the League's army, while Garibaldi himself was appointed second in command. 'Italy has not signed the Treaty of Villafranca,' Farini protested, and Central Italy, heedless of European diplomacy, kept on her course. Resolutions passed by the four assemblies, conveying their determination to unite with Sardinia, were transmitted to Turin (September 3); and though the King dared not challenge Napoleon by accepting them, he let it be understood privately that he only awaited the opportunity to do so. His ministers, in fact, already had submitted the resolutions to Napoleon and had received his categoric injunction to reject them.

Napoleon was beginning to realize the difficulties to which his agreement with Austria tied him. Consequently the idea of a congress emerged, which, he hoped, would take from his shoulders the burden of the Central Italian question. But, consistent in his inclination to go round difficulties rather than surmount them, he clung to federation as a compromise between the annexationists and those who desired to keep Sardinia and Central Italy apart. In a long letter (October 1859) to Victor Emmanuel Napoleon insisted upon a confederation ' based on the real necessities and traditions of the peninsula, and on the exclusion of all foreign influence, to assure the work of Italian independence'. Venetia, though Austrian in allegiance, was to become a purely 
Italian province, and Peschiera and Mantua federal fortresses. Parma, as being 'strategically indispensable' to Piedmont, would be 're-united' to her, while a 'system of wise liberty ' was suggested for ' all the states of Italy'. The scheme contained provisions welcome neither to Vienna nor Rome, and had for its chief object the relegation of unity to limbo. Victor Emmanuel replied firmly, that he could not thwart the national will; that Central Italy was unanimous for annexation and against confederation; and that unless monarchical Sardinia guided the situation, more dangerous forces were likely to do so.

Events gave point to the King's warning. So strong Garibaldi was the feeling against Rattazzi's halting policy, that even moderate men called for action and desperate measures. Farini, the Emilian dictator, and Fanti, commander-inchief of the military league, were among them. By their orders the League's army, under Garibaldi, approached the papal frontier, with instructions to meet the Roman forces, should they invade, and alternatively to support any revolutionary movements in papal Umbria or Ancona. Garibaldi, as always, was eager to force the situation, particularly against Rome, and fanned the embers of unrest within the papal provinces in order to excuse intervention. Ricasoli at Florence, and eventually Fanti and Farini, saw the unwisdom of raising a European question round the Pope. But the King's intervention alone induced Garibaldi to desist. On November I6, I859, he resigned his command and retired into private life to await the call to Sicily a few months later.

Meanwhile, ten days before Garibaldi's resignation (November 7), the Central Provinces again showed their and Rome, 1859 . 
determination to unite with Piedmont. Against Ricasoli's wishes, Farini was attempting to 'Piedmontize' the Emilian province in preparation for fusion, and desired to expand the military league into a political association. Ricasoli opposed the latter project also, since it tended to encourage the idea of a Central Italian kingdom, whereas the imperative need was for Central Italy to join hands with Sardinia. After Victor Emmanuel's rejection of fusion in September, the annexationist leaders in the four provinces resolved that, if the King did not assume the actual sovereignty, the four assemblies would confer the regency upon his cousin, Eugenio, Prince of Carignano. Oaths of allegiance actually were taken to ' the elected king', the coinage bore his profile, and the flag of Sardinia floated over the Palazzo Vecchio at Florence. On November 7, with all but unanimity, the four assemblies elected the prince as regent. But again Rattazzi shrank from the proposal, and Carignano, refusing the regency for himself, delegated Carlo Buoncompagni, Turin's late commissioner in Florence, to undertake the government of Emilia and Tuscany. The government's continued truckling to Napoleon was bitterly resented. Buoncompagni found himself practically ignored as the prince's representative, and early in the new year (I860) resigned.

Peace of It was clear at length to Napoleon that Italy would not Zurich, 1859 . accept federation, nor Central Italy be held aloof indefinitely from Sardinia. There was danger, too, that if Italy were thwarted, the situation might become worse. Hence the idea of a congress presented itself, whose conclusions might free him from his obligations to Austria 
and his own people. The definitive Peace of Zurich was signed by the recent belligerents on November IO, I 859 . It provided that the frontiers of Austrian Italy should remain as they were settled at Villafranca; that Lombardy, without Mantua and Peschiera, should be abandoned to France for retrocession to Sardinia; that the Emperors should endeavour to form an Italian confederation, 'the object of which will be to uphold the independence and inviolability of the confederated states, to assure the development of their moral and material interests, and to guarantee the internal and external safety of Italy by the existence of a federal army'; and that Venetia should be included within the confederation. The fate of Central Italy-Tuscany, Parma, Modenawas reserved for consideration by a congress of 'the Powers who presided at the formation and recognized the existence of 'those states in I814-15. Romagna's restoration to the Papacy was implied.

The proposed European congress kept the Central Le Pape et Italian question open, as Napoleon desired. But now le Congress that his hands were free, and in order to achieve a showy diplomatic success, he began to press for the bribe suggested at Plombières, though the spoil had not in fact been earned. The idea of a French Tuscan monarchy, the interests of the Papacy in Romagna, might go by the board. With Savoy and Nice again in France's possession Napoleon could, he hoped, defy the Clericals. But the matter was one for private negotiation with Turin and not for public deliberation in a general congress. Hardly had the suggestion of a congress emerged, therefore, than he set himself to extinguish it. The desired result could be 
achieved most readily by stating a programme that should alarm Austria; and the return of Palmerston to power in June I 859 aided his plans. Palmerston was not concerned to support the Temporal Power, and was anxious to get both France and Austria out of Italy. He let it be understood, therefore, that he was ready to take part in the congress provided Rome was evacuated by the French, Austria and France accepted the principle of non-intervention in Italy, and Tuscany and Emilia were left in freedom to settle their future. Napoleon completed the dismay of Austria and the Clericals by permitting La Guéronnière to issue another inspired pamphlet, Le Pape et le Congrès, in December I 859. It counselled the Holy See to accept the loss of Romagna, perhaps even of Umbria and Ancona. It made clear, too, that France would not tolerate military action by Austria or Naples on the Pope's behalf. Denouncing the pamphlet as 'a worthless monument of hypocrisy and a disgraceful tissue of contradictions', Pius, in January $\mathbf{I} 860$, promulgated an Encyclical violently upbraiding the assailants of the Temporal Power and refusing to countenance the congress. Austria inquired whether the pamphlet outlined the programme to come before the congress, and learning that it did, also refused to participate in it. Deftly using Palmerston's pro-Italian bias, Napoleon had scotched the congress which stood between him and the spoils he looked for. But only one man in Italy dared yield them, and opportunely, in January I860, Cavour returned to power.

Cavour in General indignation at Rattazzi's inert policy and desire power, I860. for Cavour and a national programme had grown with 


\section{The Union of Central Italy: 1860}

the intrigues, in which the Extreme Left were implicated, to keep him out of office. Public opinion insisted upon his appointment to represent the nation in the proposed congress, and a month later (January I860) Rattazzi's fall brought him back to power. Little more than one year of life lay before him, but it was crowded with glorious events. His policy, he announced, would be 'Italian to the extreme bounds of possibility'. Recent events had cleared his vision, and he looked forward to removing the last impediments to Italy's independence and unity. His immediate object was to bring in Central Italy. Great Britain promised to recognize annexation provided the four provinces unmistakably expressed their desire by a public vote. Active support could not be looked for from London, and though with it Cavour might have defied Napoleon, he could not safely make France an enemy while the old quarrel with Austria remained open. Napoleon pressed that advantage to the full. He promised to recognize annexation after a plé. biscite, but secured his pay beforehand. On March 12 Nice and a secret, and on March 24 a public, treaty gave him $\begin{aligned} & \text { Savoy } \\ & \text { ceded, }\end{aligned}$ Nice and Savoy, subject to a confirming plébiscite. 1860 . Maintenant nous sommes complices, n'est-ce pas vrai? (Now we are fellow conspirators, eh ?), said Cavour to the French agent after signing the public Treaty of Turin. Meanwhile, on March I I-12, a plébiscite had been taken in Emilia and Tuscany. By an overwhelming majority (more than 750,000 against about 16,000 ) the two populations declared for union; and royal decrees forthwith proclaimed Emilia (Parma, Modena, Romagna) and Tuscany annexed to the Kingdom of Sardinia. On 
April 2, 1860, Victor Emmanuel opened a parliament at Turin whose members, drawn from Piedmont, Liguria (Genoa), Sardinia, Lombardy, Tuscany, Romagna, Parma, and Modena, approved the decrees of annexation by an almost unanimous vote. Meanwhile Nice and Savoy, under the influence of Clerical and government pressure, had decided for union with France. Their cession was confirmed by parliament, but not without opposition from Garibaldi, a Nizzard, who protested against an act which 'made him a foreigner'. But even with the loss of Savoy and Nice, the Kingdom of Sardinia had doubled her population, from $5,000,000$ to I I,000,000, half that of the whole peninsula. 'Italy of the Italians', Victor Emmanuel proclaimed, was born.

\section{Garibaldi and The Thousand, 1860}

The events of 1859 made Italian unity irrevocable, but left it incomplete. The hope of it gripped the hearts of all. Even the Mazzinists, for the most part, accepted the monarchy. 'In the name of the honour of Italy,' Mazzini wrote to the King, 'let us all make One.' But he was not prepared to accept what he called 'progressive unification'. 'I will not', he protested, 'fight to-day for the duchies, to-morrow for some other portion of Italy, then wait two or three years for war for Venice. ... The fact of the day is the revolution in the centre. There must be the fulcrum of the lever.' Rome was Mazzini's immediate objective. The outlying forts of autonomism would fall 
when the main citadel was taken. Once the King was master of 500,000 men and a marine, 'Piedmont and the Italian Revolution' would be strong enough for the culminating enterprise in Venetia.

Cavour surveyed the situation with different conclu- Cavour sions. That Venetia must wait, he held in common with $\underset{\text { Garibaldi. }}{\text { and }}$ Mazzini. The events of 1859 had created throughout Italy an intense repugnance to continued dependence on France. But without French help, or a revolution in Hungary, Austria was too strong to be challenged. Venetia therefore would have to await a favourable international conjunction, such as presented itself in I866. Rome was equally inaccessible while the French remained there. Its acquisition depended either on an arrangement with France, or on some change in France's circumstances which should permit the monarchy to go to Rome in spite of her. But the papal provinces of Umbria and Ancona were eager for annexation, and the Bourbon south was equally ready to rise. The three provinces (Ancona, Umbria, and the Two Sicilies), a population of $10,000,000$ eager for union with the monarchy, did not present the difficulties of the other enterprises, and were gathered in in the autumn of 1860 . But Cavour's diplomacy lacked candour. He dared not forfeit France's goodwill by openly countenancing revolution in Sicily and Naples. He was afraid to move officially lest Austria should descend upon him. He was forced, therefore, to work through underground channels, secretly aiding movements which officially he was called upon to deny. 'If we did for ourselves what we are doing for Italy,' he told d'Azeglio, 'we should be great knaves.' 
Not until Garibaldi's success threatened to create a situation in South Italy menacing the process of unity, did Cavour come into the open and secure for the monarchy the fruits of Garibaldi's daring.

The Papal Volunteers.

The Central Provinces having been gathered in successfully in March I860, Cavour turned to the most insistent problem, the relations of the enlarged monarchy with the Pope, who refused to recognize the loss of Romagna, excommunicated those concerned in the event as 'the new Sennacheribs', and broke off diplomatic relations with Turin. To render himself independent of the unwelcome and insincere friendship of Napoleon, Pius converted the Holy See into a minor military power by enrolling an army of 15,000 volunteers. Austria provided 6,000 seasoned troops, Ireland a few hundreds. Its most notable section was the French and Belgian volunteers, Papal Zouaves, of good family. They were Legitimists, for the most part, regarded Napoleon as a usurper, and shouted for the Bourbon Henry $\mathrm{V}$ under the windows of the French garrison at Rome. Their commander, General Lamoricière, had served Louis-Philippe with distinction in Algeria and notoriously was hostile to Napoleon. The formation of the Military League in Central Italy alone held back the papal army from invading Romagna, and its existence added to the difficulties of the monarchy. Victor Emmanuel vainly strove for a compromise with Rome, leaving Romagna to the monarchy, but with an admission of papal suzerainty, and Napoleon's annoyance grew with the Pope's obdurate refusal to adjust himself to circumstances. He was anxious to get out of Rome, and in April 1860 proposed the substitution of a Neapolitan 
army for the French there. When Bombino refused to take a step which would give Piedmont a casus belli, Napoleon proposed the enrolment of a native force subsidized by the Roman Catholic Powers, and on that basis signed, on May I2, a convention with the Vatican, eager to escape from French patronage, which provided for the evacuation of Rome on July I. Twenty-four hours earlier (May II) Garibaldi landed in Sicily and the situation was wholly changed.

Giuseppe Garibaldi, the third of the Triumvirs of Giuseppe Italian unity, was born at Nice in 1807 . He was, thereGaribaldi. fore, slightly older than Cavour and slightly younger than Mazzini. The son of a sailor, he went early to sea, joined Mazzini's 'Young Italy', and was condemned to death for participating in the foolhardy effort of 1833 . Escaping to South America he distinguished himself as a guerrilla leader in the civil war in Brazil, and later joined the Montevideans in their struggle against Buenos Aires, in whose service he organized the Italian Legion. Returning to Italy after the accession of Pius IX, he fought in the first War of Independence and confirmed among his countrymen a reputation established in Montevideo. After the fall of the Roman Republic, whose army he organized in 1849 , he again fell into the hands of the Sardinian government, by whom he was expelled from Italy. He betook himself to New York, worked there for more than a year as a candlemaker, and then became captain of a Pacific merchant vessel. In I854 he returned to Italy and settled down as a farmer on the little island of Caprera, off the Sardinian coast. Cavour called him thence to command the volunteers in the campaign 
of 1859 . His service in the army of the Military League followed, and terminated in November of the same year.

Garibaldi was the complement of the two men with whom events yoked him uneasily. He was incompletely educated, had 'the brains of an ox', said d'Azeglio, was obstinate, easily influenced by flattery, and hated the Pope and the papal system with all his heart. A splendid leader of irregulars, brave, reckless of danger, he is the single heroic military figure of Italy's battle for independence. His open, courteous nature, sincere faith, and adventurous career make him the paladin of Italy's crusade for freedom. Without the intellect of Mazzini, or the ability, patience, and practical sense of Cavour, Garibaldi was the popular figurehead of the movement they inspired or controlled, and yet so wayward, impulsive, and unreliable that he threatened not infrequently with disaster the cause he loved and served.

Sicily. Even before the termination of his Emilian command Garibaldi had been approached by the Mazzinists to foment rebellion in Sicily. 'To revolutionize the south', Mazzini wrote to Victor Emmanuel, ' is easy; I do not even ask Piedmont to initiate it ; we will do that.' But Garibaldi was doubtful of the chances of a popular rising against the 23,000 Neapolitan troops in Sicily, and at first held aloof. In his place, a young Sicilian nobleman, Rosalino Pilo, landed in Sicily in April 1860 and made an unsuccessful effort at Palermo. Pilo's ill-success convinced Garibaldi that it was his duty to go wherever 'Italians were fighting their oppressors'. On May 5, I 860, he set out on his adventurous expedition, still in doubt as to its wisdom, and leaving Cavour, who was 


\section{Garibaldi and The Thousand, $1860 \quad 46 \mathrm{r}$}

fully informed of what was intended, in yet greater doubt as to his official attitude towards it.

Garibaldi's heroic band, 'The Thousand,' the pick of The the Cacciatori, were drawn chiefly from North Italy. Lombardy, Emilia, and Venetia sent more than 800 of them. Milan, Genoa, and Bergamo accounted for nearly 400. Students and members of the legal and medical professions were particularly numerous in the ranks, and all wore the South American red-shirt uniform of their chief. Through treachery or mismanagement the expedition sailed without ammunition and with a portion only of the stock of Enfield rifles purchased for the National Society by Garibaldi's recently founded 'Million Rifles Fund'. With the connivance of the government the two vessels, the Piemonte and Lombardo, which carried the expedition, loaded at Quarto, near Genoa, and broke their voyage at Talamone, partly to land a detachment to threaten the Papal States, chiefly to obtain ammunition from the government store at Orbitello. On May I I the expedition arrived at Marsala, at the extreme west of Sicily, and Garibaldi at once assumed the title 'Dictator of Sicily', in the name of Victor Emmanuel.

Sicily was held by about 23,000 Neapolitan troops, Calatafimi, most of whom were stationed at Palermo. Garibaldi set ${ }^{1860 .}$ out thither forthwith, routed a superior force at Calatafimi (May 15), and a fortnight later (May 27) threw himself into Palermo and established himself in the heart of its friendly population. After three days' fierce street fighting with the garrison, the latter agreed to an armistice. The impossibility of dislodging Garibaldi was admitted, and on June 7 the royal troops evacuated the 
city. The victory roused Italy to enthusiasm. Volunteers poured into the island, and the forces under Garibaldi's orders soon numbered 20,000 , a match for the Neapolitan garrisons which still remained. Before the middle of August Garibaldi was completely master of Sicily (excepting the citadel of Messina) and Bourbon rule was at an end.

Napoleon and the crisis.

Meanwhile, Cavour watched with anxiety the European situation and Garibaldi's tardiness in annexing Sicily to the monarchy. After the fall of Palermo, Bombino sent an urgent petition to Napoleon to mediate between him and his enemy. Napoleon named his conditions: that Sicily received complete independence under a Bourbon prince, Naples obtained a constitution, and Piedmont was offered an alliance. The last proposal, grateful neither to Naples nor Turin, was devised by Napoleon to prevent the threatened aggrandizement of the monarchy at Naples's expense. While he urged Cavour to accept the alliance, he invited the British government to join him in imposing an armistice upon the belligerents and in a naval demonstration in the Straits of Messina to prevent Garibaldi from crossing to the mainland. Great Britain saved the situation. Palmerston's Foreign Secretary, Lord John Russell, reiterated his government's determination that Italy should be left free to work out her union, and at Cavour's urgent appeal, refused Napoleon's invitation to co-operate with the French fleet. The decision doomed the Bourbon kingdom to extinction.

Sicily and But though no European conjunction threatened the Dictator. to intervene between Garibaldi and the completion of 
his task, the situation in Sicily was critical. The Sicilians, whose hopes were centred on deliverance from the hated Bourbons, had little concern for the larger prospect of Italian unity. Nor was Garibaldi a successful ruler. The routine of administration was irksome to him, and he readily resigned it to Francesco Crispi, who fulfilled it with great enthusiasm and assiduity, but displayed little judgement. The island was soon in a condition of chaos, and annexation to Sardinia alone promised to correct it. But immediate union was the last thing that Crispi, and for different motives Garibaldi, desired. The Mazzinists who had planned the expedition desired to use it as a lever upon Turin. They were weary of Cavour's cautious diplomacy, of the French alliance to which he clung so tenaciously and, as they held, viewing Nice and Savoy, with such humiliating results. Garibaldi had created a situation which could be exploited to impede or defeat Turin, and Crispi, jealous because the Italian movement had escaped his party's control, was determined to use it for that purpose. Garibaldi, on the other hand, desired to postpone annexation only until the Bourbons had fallen. Otherwise, he was afraid, Cavour might forbid him to cross to the mainland and complete his task against Naples and Rome. He was ruffled also by Cavour's dispatch of La Farina to Sicily to procure instant annexation. La Farina was an enemy of Crispi, suspected by the Mazzinists as Cavour's confidant, and to Garibaldi unwelcome as one who had supported the surrender of Nice. Garibaldi summarily deported him (July 7).

On August 18, more than three months after his arrival Fall of the at Marsala, Garibaldi set out upon a still more daring ${ }_{1860 .}^{\text {Bourbons, }}$ 


\section{4}

\section{The Evolution of Unity}

exploit. Crossing the Straits from Giardini, near Taormina, he landed on the Calabrian coast. Reggio fell to him, and with swelling forces and growing enthusiasm he marched along the coast towards Naples, where his coming was looked for with unconcealed longing. Cavour was in dismay at the prospect. "If we are not at the Volturno before Garibaldi is at La Cattolica,' he said, 'the monarchy is lost.' Other possibilities vexed him. The Neapolitan army was intact; it might unite with Lamoricière and inflict such a defeat upon Garibaldi as should postpone indefinitely the hopes that were built upon the Dictator's adventure. The Mazzinists, already planning a concurrent assault upon Umbria, might even join with Garibaldi in a converging movement upon Rome. In that event Mazzini could dictate to the monarchy. Cavour therefore made a last effort to forestall Garibaldi. His agents at Naples were instructed to put themselves in touch with the conspirators and win over the army and the capital in behalf of Victor Emmanuel. Mazzini, however, who was in Naples, prevailed, and a Committee of Action was formed to delay the conclusion Cavour desired, until after the Dictator's arrival. On September 6 Bombino and his queen left Naples for ever and joined the army on the Volturno. On the following day Garibaldi entered Naples.

Castel- The failure of his secret efforts compelled Cavour to fidardo, 1860 . come into the open with a plan which, if successful, would place the king before the nation as 'the real Garibaldi' and gather Italy round the monarchy. Four days after Garibaldi's entrance into Naples, on September II, the 
royal army invaded Papal Umbria. A casus belli was found in Lamoricière's volunteers, whom an ultimatum to the Pope (September 7) described as 'suffocating every expression of the national sentiment'. The sudden assault drew down upon Cavour strong remonstrances from Russia and Prussia. That Austria would intervene seemed probable. Great Britain's friendship was passive. But Napoleon's wayward policy saved the situation. $\mathrm{He}$ had already secretly encouraged Cavour by the message fate presto (act quickly). He now used his good offices with Russia and let Austria understand that if she decided to fight, France would oppose her. Hence the critical campaign in Umbria and Ancona proceeded without hindıance. On September 18 Lamoricière was defeated at Castelfidardo. Ten days later (September 29) Ancona surrendered, and the two provinces were in the king's hands. On October I5 Victor Emmanuel crossed the Neapolitan frontier and received an enthusiastic welcome from the people of the Abruzzi. Garibaldi had aiready won the last of his victories against Bombino's army on the Volturno, and on October 26 the Dictator and the King met at Teano, near Capua. Garibaldi received the King with frank loyalty. Together they entered Naples on November 7, two months after Garibaldi's own triumphant entry. From the King Garibaldi received the utmost consideration. But he recognized that his work was done, and that the monarchy must reap the harvest he had sown. The King's arrival also made impracticable his hope to extend the campaign against Rome. Refusing reward, he returned to Caprera. Gaeta fell in February I86I, 1832.3 $\mathrm{H} \mathrm{h}$ 
466

\section{The Evolution of Unity}

and the citadel of Messina surrendered a month later. Bourbon rule was at an end.

The 'King It remained for Cavour to secure Garibaldi's harvest of Italy', for the monarchy. On October 4 he invited the chamber
r860. at Turin to approve the immediate annexation of those provinces of Central and Southern Italy which indicated their desire to be absorbed into the monarchy. Three weeks later (October 21-2) a plébiscite was taken throughout the Two Sicilies upon the reference, 'The people wishes Italy to be one and indivisible under Victor Emmanuel as Constitutional King and his legitimate descendants after him'. On November 4-5 a similar plébiscite was held in Umbria and the Marches. Everywhere annexation was voted by overwhelming majorities. Once more, in February I 86I, an enlarged parliament including representatives of the new provinces met at Turin. It spoke for all Italy except Rome and Venetia, and its first act was to confer upon the king the title, King of Italy. The circumstances justified the dignity. In April I 859 Victor Emmanuel had ruled less than five million subjects. He was now king of twenty-one millions.

\section{I2}

\section{Cavour and Rome, I86I}

National

Obstacles most formidable had been surmounted, and problems. united Italy took her place among the principal states of Europe. But, apart from the looming problem of Venetia, the new kingdom faced difficulties hardly less formidable than those Cavour had overcome. To co-ordinate and 


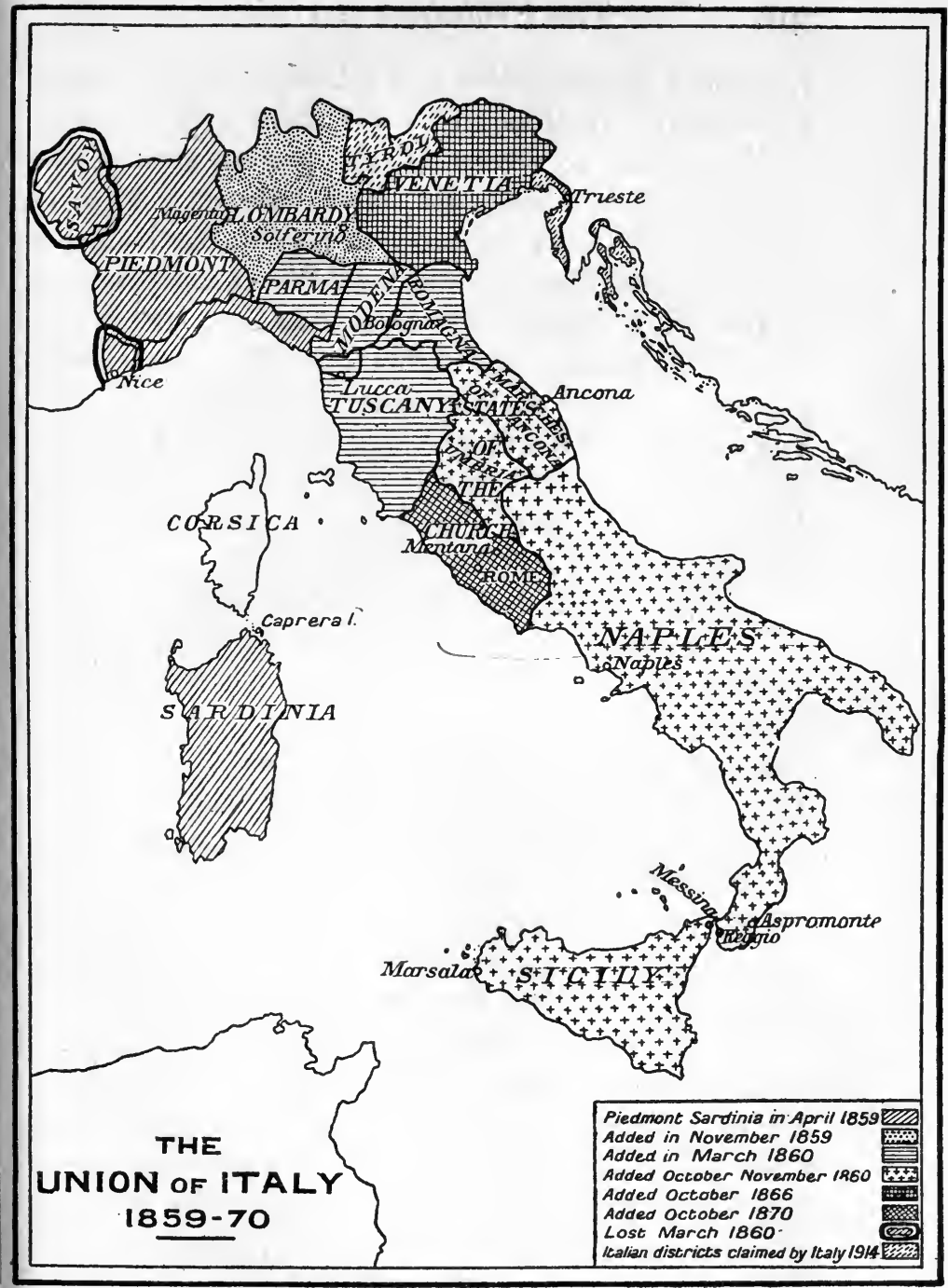

H h 2 
harmonize systems which had behind them generations of separatist tradition, to focus them upon common ambitions, and to accomplish the process without imposing Sardinia upon Italy, were tasks of immediate necessity. Between the proclamation of the Kingdom in $186 \mathrm{I}$ and the opening of the third War of Independence in 1866 they were, if not accomplished, at least wisely begun. A political and military system, an economic policy, a routine of local government, were devised. But to bring the South into line with the more progressive North, Cavour declared, was 'harder than fighting Austria or struggling with Rome'. The misgoverned kingdom of the Bourbons was riddled with poverty and corruption. Brigandage was endemic, the consequence of the economic conditions which prevailed. The dreaded Camorra, the secret society of the very poor, threw itself in every direction across the path of reform. Nor did the fall of the Bourbons remove these evils. To the fervid southerners the colder Piedmontese were antipathetic, and Farini, whom Cavour sent to Naples as Lieutenant, was not judicious in handling them. Bombino, an exile in Rome, and Pius also, encouraged the banditti and other agencies of disorder. Sicily was hardly in better plight. Elsewhere in the annexed regions local feeling was stirred by a shower of legislation, unifying the military, electoral, and economic systems of the kingdom. The old capitals, especially Milan, Florence, Naples, and Palermo, clung to their metropolitan dignity, and were averse from recognizing Turin, a city without historical traditions, as the capital of New Italy. Roma capitale was not only necessary for the completion of unity, 
but in Rome alone could every competing metropolis recognize its superior. Still, these and other difficulties were surmounted. The fabric was cemented by the inauguration of legal, administrative, military, and financial unity, and lingering autonomism was placated by a system of local government. Nor did Sardinia, like Prussia in Germany, impose herself upon Italy as dictator, but sank herself in the united kingdom which she had created.

The supreme problem that faced Italy in $186 \mathrm{I}$ was her The relations with the Church. Either to win or bend Rome Temporal was imperative for the national weal. By setting itself deliberately to thwart unity and independence the Papacy had made nationalism and anti-clericalism synonymous. In the provinces added to the Kingdom the Siccardi and monastic laws passed by Sardinia had been copied, even outdistanced, and clerical indignation increased in intensity as the Temporal Power was lopped to onequarter of its former size. ' Piedmont dares everything,' said Montalembert in France, 'France allows it, Italy accepts it, Europe submits to it.' The contention that the Temporal Power was necessary to enable the Pope to ' exercise his spiritual power throughout the universe in more liberty and security and peace ' carried little weight ; for more than ten years Pius had been tributary to Paris or Vienna. He denounced the Kingdom of Italy as the 'creation of revolution', stigmatized Victor Emmanuel as a man 'forgetful of every religious principle', guilty of 'sacrilegious usurpation', and insisted that the enemies of the Temporal Power had for their object the 'entire overthrow of our holy religion'. By his unyielding 
animosity, by his patronage of the Neapolitan banditti and every obstructionist force, Pius doomed the Temporal Power to destruction.

Roma capi- Cavour shared d'Azeglio's conviction, that ' without tale, 1860. Rome Italy is nothing'. In October 1860 , before the South was safely garnered, he told parliament without qualification: 'Rome must become the noble capital of regenerated Italy.' In March i 86I he moved it to vote Roma capitale in principle. It was necessary, in fact, to insist that Garibaldi and the Mazzinists had not the monopoly of that conviction. But, as Cavour warned parliament a few weeks later, 'the Roman question cannot be solved by the sword; only moral forces can overcome moral obstacles'. The very fact that Napoleon was at Rome against his will measured the strength of Catholic opinion protecting the Temporal Power.

Cavourand Cavour deliberately set himself-it was the last task of the Pope. his career-to convince the Papacy that its interests required it to walk with, and not in opposition to, the monarchy. His standpoint was expressed long since in the Siccardi debates-libera Chiesa in libero Stato (a free Church in a free State). He was ready to abandon the conditions which even loyal Catholic states had imposed upon the Holy See. He asked the Pope to surrender the Temporal Power and permit the completion of Italian unity. In return he was prepared to surrender to him almost unfettered control of the Church, subject to qualifications imperative in the interests of the State: the common subjection of churchman and layman to the civil law must not be challenged; the suppressed monasteries and foundations could not be restored; nor 
could the monarchy give back to the Church the control and direction of its educational institutions. But subject to these safeguards, the Church might remain an imperium within the State. The Pope would continue to reside in Rome, receive an adequate endowment from the State, and enjoy the status of sovereignty. He would be free to enforce canonic discipline. The bishops of the Church would be his vassals, its revenues would be under its own control, and the Conclave and Curia would be immune from civil interference. Napoleon, eager to escape from Rome, urged Pius to 'associate the Papacy with the triumph of Italian patriotism'. Even Pius was inclined to hold the loss of a nebulous Temporal Power compensated by freedom which, Cavour's opponents believed, would be used to attack rather than support the State. But the Pope drew back. The negotiations were abandoned, and the Emperor was reminded that 'the Pontifical territory is guaranteed by the oath of the Holy Father and the Cardinals. Therefore no diminution of it can be sanctioned by Pius IX or his successors'. Cavour's diplomacy had failed to solve the thorny problem. It awaited the Law of Guarantees (I 87 I) and an issue less satisfactory to both sides.

In June I86I Cavour died, prematurely spent in the Death of service of his country. ' Italy is made, all is safe,' were Cavour his last words. They are his epitaph. Indomitable courage, supreme ability and resource not only had triumphed over the external obstacles to Italy's unity, but had harnessed and reconciled the conflicting revolutionary and official systems which aimed to achieve it. 


\section{Sarnico and Aspromonte, I862}

Ricasoli, Italy still faced the stubborn problem created by the r $86 \mathrm{I}-2$.

existence of the petty state, the old Duchy of Rome, of which Pius, its Louis XVI, was sovereign. Ricasoli, who succeeded Cavour, was as eager as his predecessor to give Rome to the monarchy. He, too, saw clearly that only with the consent of France could that be done. He was prepared either to support Cavour's scheme of a 'Free Church' or to continue to discuss with Napoleon the eventual withdrawal of the French garrison. But the Pope's obduracy closed the former avenue, though Ricasoli was supported by a petition signed by 9,000 nationalist clergy, who urged the Vatican to reconcile itself to the monarchy and not to compel a choice between civil and clerical allegiance. Napoleon, weary of the situation, counting at one moment on the Pope's death to change it, and at another scheming to secure Sardinia for France in return for the capital that Italy so deeply desired, displayed his accustomed indecision, though the growing strength of the French Liberals compelled him to make tentative proposals for evacuation (January I 862).

Thus, though Ricasoli planned ' a perfectly quiet 1862 and something big in I863', his brief administration carried the kingdom no further on its road to unity. But he strengthened its fibre in two important particulars. The brigandage of the Neapolitan provinces, encouraged and organized, as it was, on papal territory, imposed on the government a task of tremendous difficulty. The 
banditti fought with the fervour of religion. But General Cialdini, who went to Naples as Lieutenant after Cavour's death, succeeded in eradicating the pest, and the most serious impediment to the peaceful absorption of the South into the monarchy was removed. The circumstances guided Ricasoli on another matter of urgency. As dictator of 'Tuscany he had shown marked tenderness to provincial or ' regional' sentiment, and had desired to preserve Home Rule in so far as it was compatible with the general interests of the united kingdom. But experience of office convinced him of the dangers of local autonomism. Instead he instituted a system of local government based upon the French prefectures. The lieutenancies of Naples and Sicily and the government of Tuscany were abolished. The administration of the whole kingdom was centralized in Turin, and the kingdom was divided into fifty-nine provinces, each under a prefect subordinate to the Minister of the Interior, a number which was increased to sixty-nine upon the addition of Venetia and Rome to the compartimenti territoriali, of which the prefectures were subdivisions.

Ricasoli's caution was disagreeable to Victor Emmanuel. Now that Cavour's influence was withdrawn, the king showed impatience at the slow operations of diplomacy and a disposition to encourage the party of action. Admitting that Rome for the moment was beyond his reach, he was eager to challenge Austria and hoped that Napoleon might be brought to support him. Ricasoli was an obstacle to the scheme, and Victor Emmanuel did not scruple to cabal for his removal. Rattazzi's jealous disposition brought him into the plot, and the prestige of 
Garibaldi was invoked to give it popular support. While Garibaldi still hoped to renew his frustrated attempt on Rome, the Democratic party of action was divided between Rome and Venetia. But a congress held at Genoa in December 186I opportunely healed Democratic divisions by creating an 'Association for the Emancipation of Italy', and immediately of Venetia. Thus Garibaldi, who accepted the presidency of the congress, was at liberty to support the King's policy, and Rattazzi let him infer the prospect of imminent action. Three months later (March I 862) the unworthy cabal triumphed over Ricasoli, and Rattazzi was called to office.

Rattazzi, The King deliberately had roused the very force I862. which Cavour found most dangerous and uncontrollable. Garibaldi was singled out for official patronage, and was forthwith made president of the Rifle-practice Clubs, formed at his suggestion to promote efficiency among the volunteers. For the alleged object of organizing them, he was sent into Lombardy, and was received with adulation. Everywhere the cry was raised for Venice and Rome, and concluding that he had behind him a sufficient force of opinion to coerce the government, Garibaldi determined to act. On the pretext of taking the baths, he betook himself to Trescorre, within striking distance of Italian Tyrol (Trentino), and began to organize an expedition. The government was aware of his preparations. But at the Sarnico, eleventh hour Rattazzi's courage failed him. On May I 5, $\mathrm{r} 862$. about $\mathrm{I}$ oo of the Garibaldini were arrested near Sarnico and were imprisoned at Brescia. Their comrades attempted a rescue, shots were fired, the projected expedition was abandoned, and Garibaldi retired sullenly to Caprera. 


\section{Sarnico and Aspromonte, 1862}

Hardly had public opinion digested the news of the Garibaldi Sarnico fracas than Garibaldi appeared in Sicily, upon in Sicily, the scene of his former triumphs. His excuse was an alleged plot to detach the island from the monarchy. But, though the circumstances remain obscure, there is little doubt that, the Tyrol attempt having failed, he hoped to achieve the designs upon Rome which Cavour had frustrated in I860. Landing in July I 862 at Palermo, where his friend Pallavicini was prefect, Garibaldi retraced the route of his famous march, and at Marsala led the people to the cathedral to swear 'Rome or Death' upon the altar. Once more the government took fright. On August 3 a royal proclamation condemned the expedition as ' an appeal to rebellion and civil war'. A fortnight later Garibaldi was declared a rebel, and Cialdini was commissioned to place Sicily under martial law. Heedless of Turin's denunciation, Garibaldi crossed to the mainland with a rabble following, 4,000 strong. He met with none of the enthusiasm of 1860 . Reggio was held against him, and, lacking food and equipment, he was compelled to retire to the heights of Aspromonte. On August 28 a royal force overtook him. A short engagement followed, and Garibaldi, wounded in the heel, surrendered at discretion.

Aspromonte brought the Roman question again to the Asproforeground. The nation was deeply stirred by the hero's monte, wound, and Rattazzi took advantage of the event to address a note to the Powers. 'The whole nation', it declared, 'demands possession of its capital. The existing situation has become intolerable, and can result only in consequences which are bound to affect adversely the 
peace of Europe and the religious interests of Catholic Christendom.' Great Britain, where a subscription of pennies produced $£ \mathrm{I}, 000$ in Garibaldi's behalf, alone received the note with sympathy. Napoleon, at the time of the Sarnico affair, had addressed an open letter to the Pope urging him to recognize the territorial status quo in Italy, to enter into diplomatic relations with the monarchy, accept a civil list from the Catholic Powers and their guarantee of the Comarca, and to reform his still mediaeval constitution. Pius rejected the proposals, and Aspromonte made Napoleon's position at Rome more difficult than ever. In view of his failure to induce the Pope to reform he could not represent his presence at Rome as a moderating influence. Garibaldi's adventure made it clear, also, that so long as the French garrison remained there was danger of armed conflict with the Italian people. And since Rome owed her protection at Aspromonte to the troops of the monarchy, it was difficult for the Emperor to defend the French occupation on the plea that otherwise the Holy See was defenceless. But the French elections were imminent, and Napoleon dared not alarm the Clericals, whom Garibaldi's dash had perturbed greatly. He therefore transferred the portfolio of foreign affairs to a minister agreeable to them, and abandoned the discussion of evacuation. Garibaldi's effort had merely established France more firmly at Rome, and Rattazzi was justly involved in the odium of the result. The government's treatment of the hero intensified the outcry against the ministry. Garibaldi was not released until October, and a few weeks later (December I, I862) Rattazzi resigned. 


\section{The September Convention and the Syllabus, 1864}

The rapid creation of the Kingdom of Italy affected The Conthe composition and transformed the balance of political sorteria. parties. The extreme parliamentary wings of the early days of the Statuto disappeared. The Extreme Left, purged of republicanism, had become a comparatively small body of Radical supporters of the Constitution. The Clerical Right had extinguished itself by obeying the Pope's command to associate with the Chamber neither as electors nor members. Consequently parliament was divided between the two constitutional bodies, the Moderates of the Right, of whom Ricasoli and Minghetti were typical leaders, and the Left Centre, which Rattazzi continued to lead, as in the days before the Connubio. Cavour's death in I86I opens a definite period in Italy's parliamentary government. For fifteen years the Right, or Moderates, were in power. Already they were beginning to be known as the Consorteria (Log-rollers), and though Rattazzi twice succeeded in dislodging themin 1862 and 1867 -they retained office from Ricasoli's accession to power in I86I until the ministry of Agostino Depretis in 1876 .

The Moderates for the most part were men of no National marked ability, swayed by the prejudices of the regional consolidagroups which they represented, and inspired generally by a narrow jealousy of Piedmont, which bore fruit in the transference of the capital to Florence in 1865 . Their 
domestic policy in the period of their power was focused chiefly on the kingdom's military and economic needs. Ricasoli founded a centralized system of local government, in which, following the French model, the mayors and prefects were appointed by the government; while the danger of encouraging an autonomist spirit was avoided by dividing the kingdom into provinces that did not correspond with old historic divisions. The problem of Neapolitan brigandage also was dealt with, but without eradicating the Camorra or its Sicilian counterpart, the Mafia, secret bodies of banditti which continued to prey on society. The fear of stimulating local sentiment also regulated the treatment of the military problem. The Piedmontese army remained the nucleus of the national force, recruits being drawn into it to acquire a national and patriotic sentiment. Not until 1875 was compulsory military service introduced and the army established on Prussian lines. The organization of the finances also was taken in hand. The necessity to maintain the army in a state of instant preparation, together with the creation of a navy that in the course of a few years set Italy among the naval powers, constituted a burden beyond her wealth. Half the annual revenue was absorbed by the interest on the debt. There was a recurring deficit in the annual budgets, which could be balanced only by new loans. By instituting new sources of taxation and the sale of secularized church lands, revenue and expenditure were more nearly equated. But the financial outlook continued to be serious.

The

In the circumstances it would have been better had the Church. foundation of the kingdom been followed by a period of 
quiet consolidation. Public opinion, however, refused to abandon the prospect of an immediate acquisition of the territories-Venetia, the Trentino, and the Roman Comarca-which were needed to complete the kingdom. The Roman question was the most difficult and the most pressing. The Consorteria, for the most part Liberal Catholics, were sincere in their attachment to Cavour's programme, which they carried eventually in the Law of Guarantees of $187 \mathrm{I}$. In the provinces annexed in 1860 they would have welcomed an understanding with the Vatican permitting an amicable adjustment of the claims of Church and State. But the Pope refused to recognize the Kingdom, and his attitude made an agreement impossible. The bishops refused to be installed by the government, and in $187 \mathrm{I}$ actually eighty-nine sees were vacant.

The incompetence of official statesmanship encouraged Victor the party of action, and even prompted the King to Emmanuel strike at Austria by fomenting revolutions. The out-baldi. break of the Polish revolution, in January 1863 , along with the threatening Schleswig-Holstein question, provided the situation he needed. Garibaldi paid a visit to England in the spring of 1863 , and the enthusiasm which greeted him there created the impression that Great Britain, who was closely interested in the Schleswig-Holstein question, would give assistance. Independently of each other, Victor Emmanuel and his Prime Minister, Marco Minghetti, endeavoured to use the situation to Italy's advantage. The King, entering into communication (I 863) with Mazzini, assured him of his anxiety to obtain Venetia and invited his co-operation. Mazzini would not bind 
himself by a formal compact, but indicated the methods to be pursued-the fomenting of insurrection in Venetia, the operations of an Italian army ' assisted by a popular initiative, and the volunteers under Garibaldi'. Above all, the King was urged to 'banish from his mind every idea of French aid for Italy, leave Garibaldi the free and independent chief of the volunteers, and understand that a national enterprise is ill conducted by a ministry discredited in the eyes of the country, and deliberately hostile' to the party of action. The King, who contemplated a reciprocal agreement with France under which Italian aid on the Rhine might be forthcoming in return for French assistance in Venetia, shrank from committing himself, and Mazzini broke off the negotiations. No better fortune attended the King's approach to Garibaldi (1863). His ambitious scheme contemplated organized revolts in Hungary and Galicia. Roumania promised co-operation, and on his return from England, Garibaldi went to Ischia to sail thither. Details of the ill-considered plot became public, Roumania drew back, Victor Emmanuel took alarm, and Garibaldi returned to Caprera in deep resentment.

Minghetti Minghetti at the same time was following another path and Napoleon. to the same goal. The European situation gave hope that Venetia might be gained without the dangerous weapons the King had in mind to use. The Polish question already divided Europe. Bismarck deliberately placed Prussia by the side of Russia, whose government had driven the Poles to rebel. France and Great Britain were moved to indignation by the treatment of Poland. In the event of war it seemed improbable that either Austria 


\section{The September Convention, $1864 \quad 48 \mathrm{I}$}

or Italy could preserve neutrality, and into whichever camp Austria placed herself Italy might profit by joining the other. But her sympathies were with the cause of freedom, and Minghetti turned to Napoleon. The Emperor was eager to play the Empire's asserted rôle as the friend of oppressed nationalities. But he counted Austria's alliance more valuable than Italy's. And though he gladly would have secured Venetia, and perhaps the Trentino, for Italy - possibly in return for concessions in South Italy, which might stand as a separate State under Fiench protection - he was unable to formulate a scheme which should give him Austria's army and at the same time discharge his obligations to Italy. A proposal for a congress (November 1863) met with little favour. It was clear that Venetia was still beyond the monarchy's reach, and Minghetti, impelled by public opinion to take action somewhere, turned to Rome.

Shortly before his death, Cavour had discussed with Napoleon the terms upon which his occupation of Rome might terminate. The Emperor was prepared to evacuate provided the monarchy guaranteed the Comarca from attack. If, after a decent interval, the Pope's subjects expressed themselves to that effect, Victor Emmanuel would be free to go to Rome. From the Emperor's standpoint the scheme had the merit of removing an invidious responsibility from his shoulders, and of permitting Italy to obtain her capital without involving him with the French Clericals. The negotiations proceeded so smoothly that evacuation was agreed upon, to take place at the end of June I86I. But, before that date was reached, Cavour died. Minghetti took up the 
negotiation where Cavour left it, and found Napoleon still eager to cut himself adrift from the Italian embroglio. The lowering war with Prussia and the prospect of a struggle on the Rhine made him anxious to retain Italy's friendship. Apart from its intimate relation to his own position he had no sentiment of attachment to the Temporal Power. He was humiliated, too, by the Papacy's use of his difficulties to its own advantage. It accepted his support and yet flouted his advice. In view of the future, his wiser course would have been frankly to draw the Liberals and Italy to him. Had he done so he would have faced Germany at Sedan (1870) in a stronger position. But it was ever his nature to compromise, and Minghetti's overture gave him the opportunity to secure a solution of that character.

The Sep- Negotiations with Paris began in June 1864 and protember Convenduced a definitive Convention on September I5. It tion, 1864. engaged France to withdraw from Rome so soon as the organization of the papal army permitted the Holy See to dispense with the French garrison, and in any case within two years. The Turin government undertook to guarantee the Comarca against external attack, and to tolerate the papal army so long as it was not employed to support an aggressive or reactionary policy outside the Papal Patrimony. Both at Paris and Turin it was desired to obscure the real meaning of the transaction. Minghetti had opened the negotiations with a reminder that Italy was not yet free 'from the Alps to the Adriatic', and that 'Turin consequently stood in a precarious and exposed position. Napoleon, on his part, was eager to convince the Clericals that Italy was pledged to respect the Tem- 


\section{The September Convention, I864. 483}

poral Power and to abandon all thought of Roma cupitale. 'We must find a solution', he suggested, 'which will allow me to make people think that you have given up Rome.' To that end a protocol, which was intended to be kept secret, but in fact was divulged, was introduced into the Convention. It bound the Italian government to move the capital from Turin to Florence or Naples within six months. The undertaking satisfied Napoleon's tortuous policy in its suggestion that Roma capitale was abandoned, and that he was therefore relieved of further duty as sentinel. But he fully understood what the convention portended. 'Of course you will go to Rome,' the French foreign minister admitted, 'but after a sufficient interval has elapsed to relieve us of responsibility.'

The September Convention was creditable neither to Napoleon nor Minghetti. In words, it bound Italy to respect the Temporal Power, in whose overthrow her future was involved irrevocably, and it made it impossible for her to go to Rome without breaking her bond. The intermediate capital was an inconvenient device, and the alleged military compulsion was a pretext. Turin was deeply wounded by the substitution of Florence, and the change was effected only after serious rioting and bloodshed in the old capital. Though the Convention was welcomed by interests which desired to humiliate Turin, and by others which affected to believe that it marked a real step towards the winning of Rome, it roused deep murmuring. The King signed the document only under the threat of ministerial resignations. Mazzini characterized it as 'Aspromonte in permanence', and excited public opinion by insisting that the Convention contained 
a secret clause ceding to Napoleon Western Piedmont between Savona on the Ligurian coast and the river Sesia, a concession which would have yielded to France all the passes from the Gulf of Genoa to the Little St. Bernard. The allegation almost certainly was without foundation, though the concession may have been mooted by Napoleon. But since the ministry dared not avow the real significance of the Convention, Mazzini's accusation found a universal echo: 'The Plebiscites, the Government, the Parliament, and the Country. have all pledged themselves to make Italy one nation, and Rome her capital. The Convention cancels that solemn, collective decree.' Public indignation, intensified by the Turin riots and massacres, made the continuation of Minghetti's ministry impossible. A week after the signature of the Convention he resigned. His place was taken by La Marmora, whose Piedmontese birth and military record somewhat allayed the suspicions of Turin and rendered easier the transference of the capital to Florence in 1865 .

'Quanta

The Pope's reply to the September Convention was the Cura,' I864. encyctical 'Quanta Cura' and the annexed Syllabus or Index of propositions condemned during his pontificate (December 1864). The Convention, temporarily at any rate, intervened between the Temporal Power and its chief assailant. But it carried consternation to the ranks of the Clericals throughout Christendom and seemed to call for an uncompromising statement of the Church's position in the face of its enemies. Since $185 \mathrm{I}$, with the tragic experiences of $1848-50$ behind him, the Pope had been preparing a sweeping condemnation of the errors of 


\section{The September Convention, I864 485}

modern thought. The dogma of the Immaculate Conception was defined in 1854 , but the larger programme halted. Its promulgation in 1864 . was due partly to the September Convention, which Pius discerned as the beginning of the end of the Temporal Power, partly to a cleavage among the Clericals at the recent Catholic Congress at Malines, where influential voices supported Cavour's project of a 'Free Church' against the theocratic ideal which Pius upheld as imperative in the relations of Church and State. The encyclical therefore was an answer to secularism and also to weak-kneed Clericals who were not prepared to uphold the strictest Ultramontane attitude towards the State's encroachments upon the theocratic imperium of Holy Church. It declared war upon the general trend of modern thought. It put outside the Church's pale all who assailed the Temporal Power or supported the compromise of a libera Chiesa. In the tones of Gregory VII and Innocent III it asserted the sovereignty of the spiritual over the civil, of the Sacerdotium over the Regnum. It demanded the free exercise of the foro ecclesiastico, claimed for the Church the monopoly of all systems of education, and for its laws supreme validity. The annexed Syllabus particularized these general pronouncements, utterances of uncompromising mediaevalism, which formally ranged the Papacy against the spirit of modern thought and progress. For Italy it was clearer than ever, that either the Temporal Power or herself must succumb. 


\section{The Third War of Independence, 1866}

The September Convention put Rome for the moment in the background and turned the nation's face again towards Venetia. Other reasons than patriotic sentiment demanded a settlement with Austria. So long as it was delayed, the moral and financial strain upon the country was considerable, economy was impossible, and the needed work of organization and consolidation could not be undertaken. War against the traditional enemy promised to brace the nation, as in I859. Piedmont, also, was not unwilling to escape, if only temporarily, from the depressing question of the capital, and Mazzini was busily intriguing for action. While the exile's sanguine nature continued to protest Balbo's conviction, Italia farà da s̀̀, La Marmora was under no delusion as to the impracticability of the adventure unless Italy could secure a powerful ally. Napoleon's conduct had created a deep prejudice against France. But a new situation opened in 1862 , when Bismarck was called to the helm in Prussia.

Italy and

'Italy', said one of her statesmen in $\mathbf{I} 862$, ' will always Prussia. side with the enemies of Austria.' For that reason she watched with close interest the growing antagonism of Prussia and Austria, and shortly before his death, Cavour had prophesied the day when 'Prussia will thank Piedmont for her example'. Since 1848 it was patent that there was not room for Prussia and Austria within the German system as then constituted. Bismarck took 


\section{The Third War of Independence, $1866 \quad 487$}

office determined to force the issue and to decide it by war. Immediately, and while he was still in the throes of parliamentary conflict over the credits for the enlarged army that he needed to assert Prussian interests, he made inquiries regarding Italy's attitude in case Prussia attacked Austria. The question was the more significant because the situation Bismarck contemplated was still remote. He stood alone, for the moment, in his determination to plunge Germany into civil war. But the SchleswigHolstein crisis in 1864 gave his unscrupulous policy the opening it needed, and though the Convention of Gastein in 1865 seemed to bring Prussia and Austria together, Bismarck intended it merely, in his own words, to ' paper the cracks'. In March I 866 he opened negotiations with Florence again.

Italy was not strongly inclined to a Prussian agreement. The demeanour of the Hohenzollern court towards Italian union had not been cordial. Prussia was an unknown force, and the issue of her late duel with Austria, in r 848-50, supported those who believed that Austria would hold her own in Germany. La Marmora stood almost alone in his confidence in the Prussian army. At the same time, he would have preferred not to be beholden to Bismarck, nor was it until the old project of buying Venetia from Austria had been broached in vain that La Marmora allowed himself to be drawn into Prussia's net. On March 9, 1866, in answer to Bismarck's invitation, General Govone visited Berlin, ostensibly to 'study the science of fortification', actually to negotiate a treaty, the foundation of which had been laid by a commercial agreement in the previous year. Simultaneously 
La Marmora proposed ' to link Italy with Germany' by the St. Gothard tunnel. The course of the diplomatic negotiations gave La Marmora ground to fear that Bismarck would use Italy for his own ends and that another Villafranca might be in store for her. Bismarck, on his part, feared that Austria might overbid him for

Prusso-

Italian

Treaty, I866. Italy's friendship. Hence, though an offensive and defensive treaty was signed on April 8, neither side regarded the other with confidence. The agreement bound the allies to make war jointly upon Austria and not to make peace separately. Italy was promised Venetia-La Marmora vainly endeavoured to include the Trentino alsoand Prussia proposed for herself equivalent territory. The treaty would become inoperative if Prussia failed to declare war within three months.

La Marmora's caution was not groundless. In the belief that Italy was on the point of attacking Venetia, Austria mobilized her army there on a war footing. Bismarck immediately warned La Marmora that he should regard the treaty as inoperative if Austria attacked before the allies jointly declared war upon her. In the circumstances, La Marmora behaved with particular magnanimity in rejecting Vienna's proposal to cede Venetia if Italy engaged to remain neutral. Napoleon also tested his probity. The Emperor was not averse from the prospect of war between the German powers. He was convinced that Austria would win, and in any case, that the exhaustion of the belligerents would permit him to intervene at his own time to realize the objects of his later policy-the expansion of the French frontier to the Rhine, and the fulfilment of his promise to free Italy. 
A bold course would have ranged him alongside Austria, a conjunction that might have postponed indefinitely the fruition of Bismarck's far-calculated policy. But, as invariably, Napoleon shrank from an open course and proposed his usual panacea, a congress (May), through which the four countries might obtain compensating spoils, France on the Rhine, Prussia in Schleswig-Holstein, Austria in Silesia, and Italy in Venetia. The congress was agreeable to no one; though Austria, fearing that France might join her enemies, secretly engaged to surrender Venetia whatever might be the issue of the war. On June I4 the German Federal Diet delivered an ultimatum in Austria's behalf. Prussia put her armies in motion, and on June 20 Italy declared war.

Italy entered her third War of Independence with Custozza considerable confidence. She could place in the field and Könignearly 250,000 men, more than twice the force available to Austria in Venetia and Tyrol. In addition to her regular forces, La Marmora permitted the volunteers to enrol, and gave the command of them to Garibaldi. The plan of campaign proposed co-ordinated movements of the Prussians and Italians on Vienna, while another Italian force masked the Quadrilateral. Napoleon, who did not wish Austria to suffer defeat, put pressure upon Victor Emmanuel to modify the plan. Jealousy between the Italian commanders, La Marmora and Cialdini, added another element of confusion, and bad leadership exposed La Marmora to a serious reverse at Custozza on June 24. For a fortnight the campaign was at a standstill. In the interval, on July 3, Prussia inflicted a crushing defeat on the Austrians at Königgrätz. Napoleon 
instantly intervened. Anxious to save Austria, he proposed an armistice to Italy on the basis of the cession of Venetia. But Italy, burning to avenge Custozza, was not in a mood to receive another province at the Emperor's hands. Fearing his intrigues with Prussia, she resumed the campaign with energy, and before the end of the month was in possession of all Venetia except the Quadrilateral, while Garibaldi was making progress in the Trentino. But Italy's humiliation was not yet complete. The fleet, on which her hopes were set, disregarded an order to attack Trieste, in support of an Hungarian rising against Lissa,1866. Austria. Instead, an assault was delivered upon Lissa, a naval station on the Istrian coast, an operation which had been successfully carried out when an inferior Austrian squadron joined action. A confused engagement followed, in which the Italian flagship and another ironclad were lost (July 20 ).

Lissa was followed by the depressing news that Bismarck, heedless of his Italian ally, had signed preliminaries of peace with Austria at Nikolsburg (July 26). Actuated immediately by fear of France's intervention, his calculating policy also looked forward to Austria's alliance in a joint war upon the traditional enemy of Germany. He therefore diverted Prussia from following a vindictive policy towards Austria, and on August 23 signed the Treaty of Prague with her. Italy, thus abandoned, vainly demanded Venetia and the Trentino, and her bitterness was increased by France's failure to give her support. She resented the prospect of receiving Venetia from Napoleon, and agreed to it only upon the stipulation that a plébiscite should enable the monarchy to acquire 


\section{The Third War of Independence, I866 49I}

the province by the will of the people. Peace was signed at Vienna on October 3, I866, and a plébiscite almost unanimously incorporated Venetia into the Kingdom. Excepting the Trentino and the Istrian peninsula Austria was expelled from Italy. With a population probably in excess of $25,000,000$, the monarchy stood fifth in population, and eighth in size, among the countries of Europe.

\section{I6}

\section{Mentana, 1867}

The French withdrew from Rome in December I866, in accordance with the September Convention, and Victor Enmanuel was able to boast that Italy was at length ' free of all foreign domination'. But her recent war with Austria stirred depressing reflections. She owed Venetia to Prussia, not to her own prowess. The memory of Custozza and Lissa sullied her military renown. A war which had been looked to to knit the nation left it suspicious of its leaders and divided. The Trentino was still in Austria's hands-another of France's ill offices. But the withdrawal of the Imperial troops made it opportune to arrive at a settlement with the Papacy and, as before, two policies struggled to achieve it, one of accommodation, the other of rash adventure.

Ricasoli, who had taken La Marmora's place in the Ricasoli cabinet upon the outbreak of war with Austria, was and the anxious to arrive at a settlement with the Vatican. Not 1867. merely did the situation threaten foreign intervention, but the religious and.moral life of Italy was deteriorating 
owing to the hostile relations of Church and monarchy. Ricasoli was prepared to concede much, even to retain the executive seat of government at Florence, treating Rome merely as Italy's 'capital of honour', where her kings should be crowned. Before the French left, he was searching at Rome for a modus vivendi. But even upon such sensible proposals as a customs union, postal agreement, common action against brigandage, Pius refused to treat. Ricasoli therefore fell back upon the Free Church Bill, and introduced it in January 1867 . It embodied the familiar principles of Cavour's scheme, released the Church from state control, and surrendered the State's power to nominate bishops, give its placet to their acts, and its exequatur to their temporalities. In return for its freedom the Church was required to sacrifice its state-paid or state-guaranteed subsidies, though about two-thirds of the income from its estates would be left at its disposal. It would be placed on a footing with other religious bodies, with complete liberty to manage its.affairs, enforce its discipline, and apply its canon law. But opposition to the measure was intense. The Church repudiated a proposal to reduce it to the status of a business concern, while advanced Liberals denounced a scheme which abandoned the State's control and conceded liberty which certainly would be used against itself. The more intolerant scouted the notion of compromise with ' the fatal sect of priests', and Garibaldi was called into the fray to denounce Ricasoli's surrender, as it was regarded. A general election revealed the strength of popular prejudice against the Bill, and in April $\mathbf{1} 867$ Ricasoli resigned. 
Rattazzi's call to succeed Ricasoli revived hopes and Rattazzi methods that had been dashed at Aspromonte. The and Rome Papacy was no longer under France's protection, and it was believed that the Emperor would endure much rather than return to a position of irritation and danger. Cavour's negotiations with him had suggested that Napoleon would not oppose annexation if the Pope's subjects declared in favour of that course, and the September Convention, which closed other avenues, left that one open. Moreover, it was known that France was breaking the spirit of the Convention, the Pope's Legion of Antibes being composed in large measure of French soldiers of the line, returned from the inglorious Mexican war, masquerading as papal volunteers. Garibaldi, chafing at inaction, yearned to erase the memory of Aspromonte, and protested his resolve to go to Rome, " in spite of priests and Bonaparte,' and to tear up the Convention on the Capitol. He was even ready to challenge France, a war with whom, he declared, would reinvigorate the country.

Rattazzi found himself, as in 1862 , in a situation of difficulty. He had to choose, as he put it himself, 'between disloyalty to engagements and stifling national sentiment,' but failed to associate himself conclusively with either course. In the middle of June 1867 , the news that the Romans were ready to rise encouraged a raid on papal territory near Terni. The effort was easily dispersed by royal troops before the papal frontier was reached. But it warned Napoleon, and 40,000 French troops were stationed at Toulon in readiness to sail to Italy, should their presence be required. Garibaldi, as ever, was deaf 
to counsels of caution. Since the Romans, divided in opinion, remained inactive, he determined to stimulate them by raiding the Comarca. His preparations were made openly and at the eleventh hour were arrested by the government (September 24). Garibaldi himself, incarcerated briefly in the fortress of Alessandria, was permitted to return to Caprera, upon terms which are disputed.

Mentana, Napoleon, fervently hoping that action might not be I867. required of him, let the Italian government understand that, if it failed to protect the papal territory in accordance with the Convention, he should send troops for the purpose. He insisted that the volunteers should be put down summarily, and threatened that otherwise France would compel Italy's observance of her public pledges. Rattazzi was prepared to accept the challenge. But the King refused to incur the risk, and Rattazzi resigned. In the confusion created by his fall Garibaldi saw his opportunity-perhaps Rattazzi encouraged him to act. Escaping from Caprera and eluding the vigilance of several ships of war blockading him there, he appeared in Florence. On the evening of the same day the Romans attempted a belated and ineffectual rising, and on October 23 rd Garibaldi crossed the frontier at Passo Corese. A firm manifesto (October 27) declared the new government's scrupulous regard for Italy's public obligations and desire to avoid a 'fratricidal war' with France. Garibaldi, however, continued his advance. Meanwhile, over 20,000 French troops landed at Civita Vecchia in the Pope's defence, and at Mentana, on November 3, Garibaldi fought his last battle for Italy. The volunteers held their own against the papal troops. But the French, 
armed for the first time in action with the new breechloading chassepots, easily routed the ill-armed force opposed to them. Garibaldi was made prisoner, and the rash adventure ended ingloriously.

Mentana proclaimed the French Empire obstinately fixed to maintain the Pope and thwart Italy's aspirations. Prussia's challenge was not three years distant, and friends were valuable. But Mentana cost Napoleon Italy, and Austria too, for Austria could remain indifferent so long as a Franco-Italian alliance did not threaten her. As' to the Roman question, Mentana took it back to the situation before the September Convention. The French were again in Italy, and remained at Civita Vecchia until I 870. Their presence was a constant irritant to Italy. But French Clericalism would not hear of their withdrawal. ' The French government', said its mouthpiece, 'cannot permit Italy to seize Rome. Never, never, will France tolerate such a violation of her honour and that of Catholic Christendom.' Hence the party of action looked with increasing interest to the situation beyond the Alps, where Prussia's impending challenge to France promised an opportunity to settle the Roman question in France's despite.

\section{I7}

\section{Roma Capitale, 1870}

European relations rapidly moved to the situation Italy Italy and required. In 1867 the Luxemburg dispute brought the inter France and Prussia to the brink of war. The treaties situation, between Prussia and the South German states, made 1867-70. 


\section{6? The Evolution of Unity}

public at the same time, carried a menace to France which could not be concealed. Both Austria and Italy were closely involved in her fortunes. Both had behind them experience of defeat which they desired to obliterate. Hence, in the summer of 1868 , the project of a triple alliance was mooted. But in Italy, though statesmen of all parties dared not break with France, public opinion would not permit an alliance with her. Victor Emmanuel, chivalrously mindful that France had given Italy Lombardy, and that desertion of her in her need savoured of ingratitude, was prepared to respond to her overture, and the military party, whom Königgrätz had not convinced of Prussia's military supremacy, were ready to support him. Vienna placed no difficulty in the way of Italy's demands for her friendship - the cession of Italian Tyrol (Trentino), and permission to form a naval station at Tunis, a significant demand in view of the future. Austria even was willing that Italy should occupy papal territory and that the three kingdoms should unite upon an agreeable candidate for the vacancy to be created by Pius's death. But Napoleon, still under bondage to Clerical prejudice, refused to abandon the Pope, and on no other condition would Italy take up arms for him.

The Span- A few months later the war signal came from an unish crisis, I868.

expected quarter. In September I 868 a military revolution drove Isabella II from the throne of Spain. A proposal to unite Spain and Portugal was entertained and abandoned, and in the spring of 1869 , at the instigation of Bismarck, anxious to embarrass France on her Pyrenean frontier, the Spanish crown was offered to Prince Leopold of Hohenzollern-Sigmaringen, a relative of the King of 
Prussia. In July 1870 the relations of France and Prussia reached a crisis, and on the 19th war was declared. Napoleon had resumed his conversations with Vienna and Florence, and now, as before, Victor Emmanuel was disposed to an alliance. But a powerful section of the ministry was unable to discern the advantage which the King anticipated from France's victory. The event, it. seemed, was likely to prolong the Temporal Power and accentuate its sinister consequences to Italian nationalism. Still, had Napoleon at the eleventh hour satisfied Italy's hopes of Rome, it is probable that her alliance might have been bought. As it was, he maintained his veto in the Pope's defence. Even so, the King continued to work for an Austro-Italian agreement, and had the French armies taken the field victoriously in South Germany, as Napoleon anticipated, Italy and Austria probably would have joined them. But Prussia struck with startling and effective suddenness. On August $3 \mathrm{MacMahon}$ was put out of action at Wörth. Gravelotte followed on the I8th. It was patent that France was outmatched and that the Empire could not survive its humiliation. Piteous appeals were flashed to Florence, and Prince Napoleon invited Italy to name her own terms for an alliance. But the Sedan, Emperor's cause was lost. Neither Italy nor Austria ${ }^{1870 .}$ would stir, and both already had proclaimed their neutrality. On August 19 the French garrison sailed from Civita Vecchia, and a fortnight later (September 2) Napoleon was a prisoner at Sedan. The Empire fell with him.

In the circumstances, even the cautious and Francophil ministry was driven to take advantage of France's 1832.3 $\mathrm{K} \mathbf{k}$ 
collapse. And the Pope, by a recent measure, alienated sympathy in every quarter. Mentana and the coincident suppression of the Roman revolt had stiffened his resolution and raised his prestige. The Oecumenical Council of 1870, the first since the Council of Trent, gave opportunity, as had been anticipated, to promulgate the dogma of Papal Infallibility. It was proclaimed at Rome within twenty-four hours of the declaration of war between France and Prussia, and its assertion of unyielding Ultramontanism left the Papacy isolated in Europe. For, interpreted in the Hildebrandine spirit of the Syllabus, the new dogma threatened uncompromising war with the spirit of modern civilization. The news of Sedan therefore removed the last scruple to action, and public opinion compelled the monarchy to act.

Roma On September 6 Italy denounced the Convention of Capitale, 1870.

I 864 and announced to the Powers her intention to go to Rome. Neither Great Britain, France, nor Prussia raised difficulties, and Austria, won by the guarantees which Italy proposed for the Pontiff's ecclesiastical liberty, consented to her action. On September 20 the Italian army, in strength out of all proportion to the forces it could expect to meet, appeared before the walls of Rome. After a few hours' cannonade a breach was effected, and the city was in the possession of the royal troops. Within Leonine Rome (St. Peter's and the Vatican) Pius for the moment maintained his authority. But on the following day, its inhabitants having expressed their unwillingness to be separated from the rest of Rome, Pius invited the Italian troops to protect him, stipulating that the plébiscite proposing annexation of the Patrimony to the monarchy 
should contain a clause confirming his spiritual authority. On October 2, the plébiscite was taken. By I33,000 against 1,500 votes annexation was voted, and with the vote the Temporal Power fell. In July $187 \mathrm{I}$ Italy transferred her capital to Rome, where the King established his court at the Quirinal Palace, once the summer residence of the popes. Four months later, on November 27, 1871, he opened the first complete Italian Parliament in his new capital.

It remained to define the relations of the Monarchy The Law and the Church, and to confirm to the Pope the spiritual of Guaranliberty for which he stipulated. Before transferring itself from Florence, Parliament, on March 2I, I87I, passed the Law of Guarantees, in effect the Free Church scheme which Cavour adumbrated and Ricasoli had failed to carry only three years before. But Liberal opinion was ready now to solve the controversy on the lines of the measure. Even those who believed that the freedom granted to the Church would be used to thwart the Kingdom, under whose protection henceforth it would live, admitted that the risk must be taken, and that a less generous policy would excite for the Papacy sympathy which it was essential to avoid. The Law assured to the Pontiff the status of a reigning sovereign, permitted him to receive and delegate diplomatic agents, declared his person inviolate, and placed attempts upon his life in the same category as those upon the King. It confirmed him in the possession and use of the Vatican and Lateran palaces, and forbade the state's officials to enter them without leave of the Pope or the Sacred College. An annual subsidy of $\oint_{0}$ 229,000 was placed at his $\mathrm{K} \mathrm{k} 2$ 
disposal, a revenue of which neither Pius nor his successors have availed themselves. To ensure him unrestricted communication with his subjects and agents throughout Christendom, separate postal and telegraphic systems were permitted him. The locus of general councils and conclaves was placed outside the sovereignty of the state, which abandoned the royal assent to acts of ecclesiastical authority, such as the appointment of bishops and the publication of Bulls, and generally except for admission to temporalities. On the other hand, the Church courts were denied the aid of the civil arm for the enforcement of their discipline, and the clergy remained subject to civil jurisdiction for offences involving public policy. In spite of large concessions, therefore, the State kept in its hands, and still keeps, considerable powers of control. Pius at first was disposed to accept the conditions which the Law created. But the pressure of Clerical and Ultramontane opinion made him change his mind. In May 187 I he refused to accept or to recognize the Law. The government shrank from expelling him from Rome, though he consistently ignored it. The claim to the Temporal Power was maintained, and the papal non expedit continued to exclude Catholics from association with the political life of the kingdom. Time has begun to heal the division, and fear of Socialism has broken down the Church's effort to hold itself aloof from politics. But the relations of the Vatican and Quirinal still constitute one of Italy's most serious problems. 


\section{The Triple Alliance, I882-1915}

The men who played their part in the winning of unity did not for long survive it. Mazzini died in 1872 , closing a life devoted, however mistaken in its methods, to what he himself called 'the sacred, inexorable, dominant, idea of duty'. Victor Emmanuel, Rè galantuomo and pater patriae, followed him in 1878 . The whole process of unity had been accomplished in a reign which found him at Turin at its opening and in Rome at its end. In 1878 , also, Pius IX ended a pontificate disastrous in the history of the Papacy. The coincident accession of Humbert I and Leo XIII at the Quirinal and Vatican at first promised to compose the feud between their causes. But the prospect vanished, and the antagonism of Church and State continued till 1905, when the papal non expedit closing parliamentary life to Catholics was withdrawn, and the organized Catholic laity were permitted to introduce a new force into national life, counteracting Socialism. Rattazzi and Ricasoli, last of the Cavourians, died, the first in 1873 , the second in 1880 . Garibaldi outlived them all, and survived till $\mathbf{r} 882$.

The struggle for union engendered a rooted antagonism France and to France which the fall of the Second Empire did not Italy. remove. Excepting the gift of Lombardy, paid for by Nice and Savoy, the French alliance had been of doubtful value, on a balance of loss and gain. On their side, the French Clericals and Monarchists could not forgive the Kingdom its treatment of the Holy See. Until 1874 
a French frigate was stationed at Civita Vecchia for the Pope's service, and until the Republic routed the Clerical and Monarchical reactionaries in 1877 , there was actual danger of a papal restoration. Even in $\mathbf{I} 882$ fear of that contingency contributed to draw Italy into the Triple Alliance with the German Powers. But the Consorteria ministries of the Right, between 1870 and 1876 , followed a cautious foreign policy, restricted themselves to the difficulties created by the intrusion of the Kingdom into the capital of the Papacy, and attempted to place the finances, army and navy, upon a satisfactory and adequate footing.

Transform. The Left, having used the twenty-fifth anniversary of ism. Victor Emmanuel's accession in 1874 to declare that 'so far as attachment to the king and the house of Savoy is concerned, the Left is not a hairbreadth behind the Right', came into power under Agostino Depretis in I 876. The party contained all the active elements of public life, though its history deteriorated later into a record of personal and parliamentary intrigue. With a short interruption, in 1878 , Depretis was in office from 1876 to 1887 . He passed an Act in 1877 , making elementary education compulsory for children between the ages of six and nine, and in $\mathrm{I} 88 \mathrm{I}$ a measure of electoral reform which almost quadrupled the electorate. But his domestic administration was remarkable chiefly for the disintegration and lowering of parliamentary life. The evil agent was 'transformism', a method first applied in $\mathbf{1 8 8 2}$, when Depretis invited members of the Right to join him against the Republican wing of his own party. The transformismo, as Depretis called the transaction, became a common practice thereafter, destroyed healthy party distinctions, 
encouraged opportunism, and was employed to maintain a parliamentary majority by calling to the ministry group politicians who commanded votes.

The activity of the French Clericals in $\mathbf{1 8 7 7}$, in Italia irrebehalf of the Temporal Power, coincided with the accession of the Left to power. By long tradition it was opposed to France and disposed to seek the alliance of Germany. But Austria's occupation of Bosnia and Herzegovina in 1878 stimulated the Republican party of action to protest that Italy's union was still incomplete. Nice and Corsica, in fact, were held by France, Malta by Great Britain, while Austria was in possession of Italian Tyrol (Trentino) and Istria. The agitation for the recovery of Italia irredenta (unredeemed), which coincided with the Francophil ministry of Cairoli (I878) and gave the Irredentist party its name, opposed the German alliance which Depretis preferred. But in 188I France drove Italy conclusively into the arms of the Central Powers by occupying Tunis. The event stirred Italy deeply. The situation of Tunis marked it as hers, should it pass from the possession or control of Constantinople, and in 1870 her gaze already was fixed upon it. Moreover, at the Berlin Congress in I 878 she had received encouragement to regard it as hers in reversion. As a Mediterranean Power she could not tolerate the further aggrandizement of France, who since I830 had been established in neighbouring Algeria, while the duplicity which accomplished the annexation increased her indignation.

The event dragged down Cairoli and brought back The Triple Depretis. Though Bismarck had encouraged France to Alliance, 1879. go to Tunis-intentionally to embroil her with Italy- 
it was to Germany that Depretis turned. The Dual Alliance of 1879 was the most solid international fact at the moment. It carried no menace to Great Britain, of whose platonic friendship Italy was not unmindful, offered the young kingdom the economic and political support it needed, and promised to make an end of intrigues between Vienna and the Vatican. But while it strengthened Italy to develop new interests in the Mediterranean and Red Sea, it compelled her to abandon Irredentism and tied her to partners whose interests, the future proved, thwarted her elsewhere. Throughout its history the master of the Italian peninsula has aimed at the command of the Adriatic. The infrequent and inconvenient harbours on the Italian, compared with those of the opposite Dalmatian littoral, forbid Italy to remain indifferent to that consideration. But Austria's occupation of Bosnia-Herzegovina in 1878 threatened to make her the dominant power in and across the Adriatic. Such a contingency was intolerable to Italy, and upon it the Triple Alliance eventually foundered. The treaty with the Central Powers was signed in May I 882 for a period of five years, and was renewed in $1887,1891,1902$, and 1912. The original agreement assured to the German Powers the defensive co-operation of Italy in case of their being involved with France or Russia. Italy secured the promise of help should her Mediterranean interests be threatened by France. Upon its renewal, in I887, the members united in a general defensive league, no one of the three being bound to aid an aggressive war undertaken by the others, a clause which enabled Italy to release herself from the Alliance in I9I 5 . 


\section{The Triple Alliance, I882-1915}

The decade following the achievement of union had Colonial been used by Italy to solve domestic problems. MemItaly. bership of the Triple Alliance encouraged her to enter a wider field, and Francesco Crispi, Garibaldi's associate in $\mathbf{1 8 6 0}$, the largest figure in Italian politics after the fall of Depretis in 1887 , established her as a colonial power. Only Africa offered scope for her ambition, and in it she acquired three coastal areas aggregating more than one million square miles-Eritrea, Somaliland, Tripoli. In I882 Great Britain invited her to occupy Egypt jointly with herself, a situation from which France had withdrawn. But popular sympathy with Arabi Pasha, for whose assistance Menotti Garibaldi organized an Italian Legion, forbade Italy to take advantage of the proposal. She turned her gaze instead towards Abyssinia, whose commercial opportunities had been realized in the time of Cavour. With the goodwill of Great Britain, who was anxious to counter Fiench activity, Massowah was occupied in $\mathrm{x} 885$, and the foundation of the future colony of Eritrea was laid. On the pretext of finding a healthy locality for Europeans, an advance into the interior began, which evoked the protests of the Negus of Abyssinia. He ordered the Italians to withdraw to the coast, and upon their refusal, took military measures against them. An assault upon their position was repulsed, but on January 26, I887, an Italian reinforcing column, five hundred strong, was cut to pieces. Opportunely the Negus was killed in battle by the Dervishes, and Menelik, King of Shoa, a rival claimant, became Negus under Italian protection (1889). Menelik at once (Treaty of Accialli, r 890) surrendered the hinterland of Massowah and recognized 


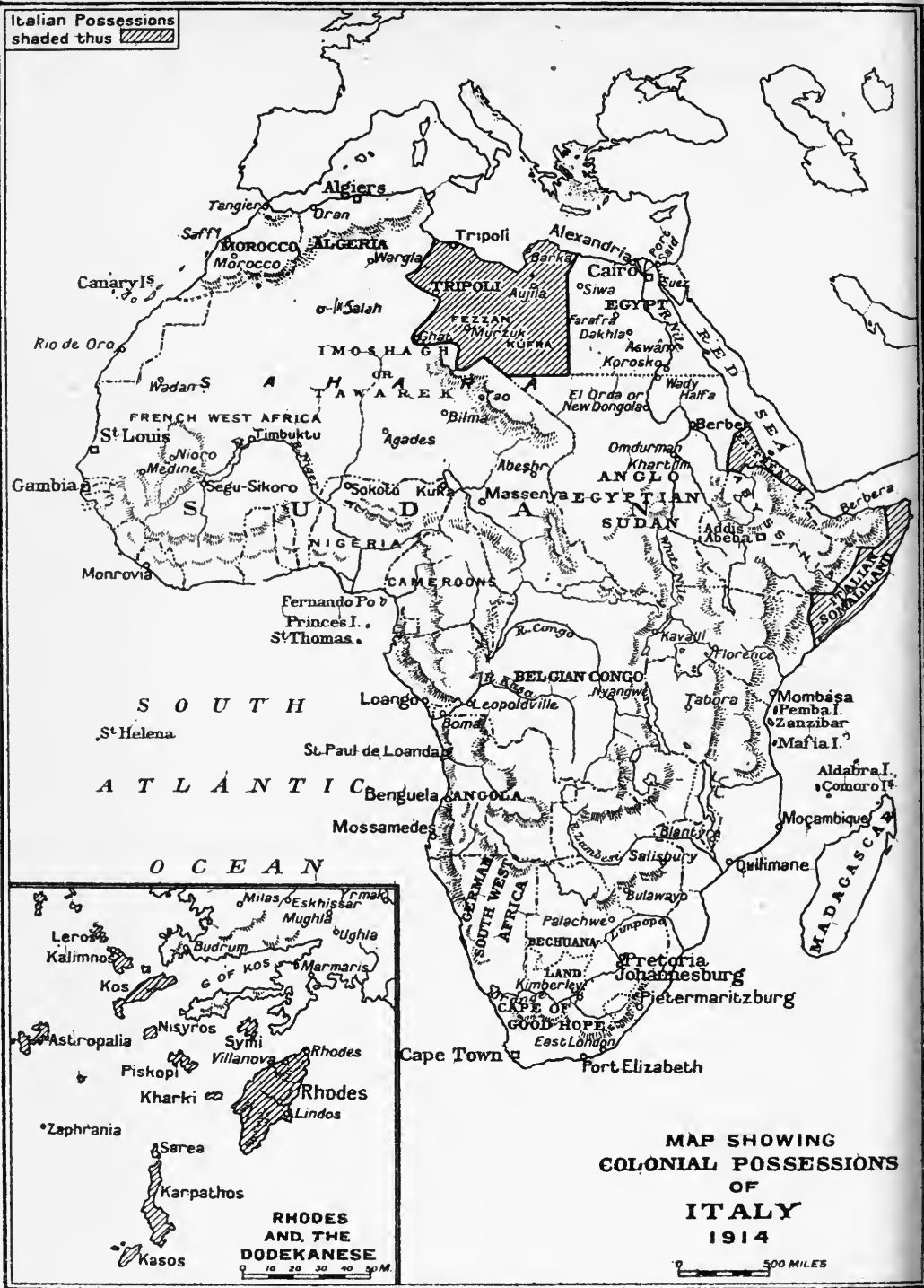




\section{The Triple Alliance, I882-1915}

Italy, so Crispi maintained, as suzerain of Abyssinia itself. The new possession forthwith (1890) was constituted the colonia Eritrea (Red Sea). But Menelik, perhaps instigated by France and Russia, repudiated the Protectorate. In answer, Crispi ordered the occupation of Adowah, within the northern frontier of Abyssinia. Goaded to action by the insistence of Crispi, General Baratieri attacked its garrison and suffered a humiliating defeat on March I, I896. In 1900 Italy accepted a treaty which reduced the colony to its present size, and abandoned her claim to the Protectorate. The experiment in aggressive colony building was not repeated. Meanwhile in I889, following Great Britain, Italy had established interests upon the Somali coast in the same neighbourhood. In r 905 she assumed direct administration of the Somaliland Protectorate.

In the chain of the Triple Alliance Austro-Italian Italy and relations were the weakest link. It snapped in 1915. Austria-Hungary's occupation of Bosnia and Herzegovina in 1878 roused an Irredentist outburst. For Austria not only retained the Trentino and Istrian peninsula, but her possession of Trieste, Fiume, and control of Cattaro, gave her a position on the Adriatic which Italy could but view with apprehension. In particular, it was imperative to keep Austria out of Albania, whose harbour Avlona lies only sixty miles from Brindisi. The marriage of Victor Emmanuel III to Princess Helena of Montenegro in I896 expressed Italy's concern to prevent the further expansion of Austrian influence upon the Adriatic littoral. From the same period, also, there developed between the two competitors a keen economic rivalry in Albania, 
which was terminated in 1907 by an agreement to support the creation of an autonomous principality, independent of Turkey.

Hardly had the compromise of 1907 been arrived at when Italy's alarm was excited in another quarter of the same field. In 1908 Austria announced a concession from the Turkish government to link up her Bosnian railway system with the Turkish main line to Salonika. A few weeks later the 'Young Turk' revolution gave Austria other opportunities to establish the economic and political control she aimed at. In the autumn (I908) she annexed Bosnia and Herzegovina, while Bulgaria, acting in collusion with her, proclaimed herself a kingdom independent of Constantinople. Russia's intervention in the interests of the Slav populations was forbidden by the Kaiser's intervention 'in shining armour'. In other circumstances it is probable that Italy would have protested actively against Austria's disregard of the Berlin Treaty. As it was, the Triple Alliance, renewed in December I9I2, established Italy's sanction as necessary to legalize Austria's future action in the Balkans, and, if necessary, her right to demand equivalent compensation.

FrancoItalian entente, 1896.

The strain upon Italy's relations with her nominal ally, and the growing intimacy of France and Great Britain, drew Italy within the orbit of the Entente to which her own Alliance was opposed. In I896 she recognized France's interests in 'Tunis, put an end to an exhausting tariff war with her (1898), and in 1903 and 1904 the rulers of the two countries exchanged visits. At the Conference of Algeçiras, summoned in 1906 at the instance of Germany to paralyse France's activity 
in Morocco, Italy did not scruple to dissociate herself from her partners. She was on the point of following Austria's example by annexing a portion of the Ottoman Empire convenient to herself. As early as 190I France had countenanced her designs on Tripoli, the last strip of the North African littoral remaining to Turkey. The reasons which moved her to go there in I9II are not known-probably fear of Germany's designs there and Great Britain's encouragement. A brief war with Turkey, War with concluded by the Treaty of Lausanne, or Ouchy, in Turkey, October I9I 2, conveyed to her the sovereignty of Tripoli, and placed her in occupation of the Dodekanese group, of which Rhodes is the most considerable island. The annexation restored the confidence which the Abyssinian venture had shaken. At the same time, it thwarted Germany's immediate designs, and complicated her calculated courtship of Turkey, whose economic and political vassalage formed an essential factor in her scheme to exploit the rich lands of Mesopotamia.

Turkey hastily concluded peace with Italy in 19I2, The Balupon the outbreak of a more alarming conflict. A week kan wars, before the Treaty of Ouchy was signed, Greece, Serbia, and Bulgaria delivered an Identic Note at Constantinople demanding the institution of radical reforms in Macedonia, the Balkan plague spot. Coincidently the Triple Alliance lapsed, and Austria and Italy reaffirmed the selfdenying Albanian agreement of 1907. But Italy faced a position of some difficulty: Russia was the ally of France and Great Britain, and the champion of the Serbs, whose ambitions Austria particularly suspected. Their outlook, like her own, was towards Albania. Italy's interests 
compelled her to resist both. Consequently, when Austria mobilized in December I9I2 to force Serbia to leave Albania alone, Italy, to whom Russian influence at Avlona was equally displeasing, supported Austria's proposal for an independent Albanian principality. The solution commended itself (Treaty of London, I9I3) to the Powers as the only condition which could keep themselves out of the contest. None the less, Serbia emerged from the war (Treaty of Bucharest, I9I3) with a great expansion of her territory, while Greece's establishment at Salonika dealt another heavy blow to the schemes of the Central Powers. The ruin of 'Turkey also confounded their policies. Hence, immediately after the conclusion of the Treaty of Bucharest, they concerted to correct the situation to their advantage by force of arms, and were withheld from doing so only by Italy's refusal to co-operate with them (August 19I3). For the moment the Central Powers forbore to take action, but prepared for the conflict which burst upon Europe a year later.

Italy and The Balkan wars of $1912-13$ changed the situation in the Triple the peninsula to Italy's advantage. Albania, created an
Alliance. autonomous principality, passed under the brief rule of a German prince. The general balance of power in the peninsula was to the disadvantage of the German Powers. Turkey, their dupe, appeared to be on the point of dissolution, and Bulgaria, their jackal, emerged from the war bitterly disappointed and enraged at her allies and more recent despoilers. Hence, upon the outbreak of the German War in August I9I4, Italy refused to admit a casus foederis binding her to enter a conflict which, she well knew, Germany had provoked. She was also concerned 


\section{The Triple Alliance, I882-19I5 5 II}

to prevent the Balkan situation being refashioned to her disadvantage. Austria's assault upon Serbia threatened to do so, while the appalling inhumanity with which the general war was conducted by the Alliance of which she was still a member, heightened her antipathy to her old friends. In December 1914, therefore, insisting that Austria's invasion of Serbia came under the operation of Article VII of the TripleAlliance, she demanded the Trentino to the frontiers of the Italian Kingdom of I8IO, the rectification of her eastern frontier to include Gorizia on the Isonzo, the establishment of Trieste and the Istrian region as an independent state, the cession of Lissa and other Dalmatian islands, Austria's renunciation of interest in Albania, and her recognition of Italy's sovereignty over Avlona. After laboured negotiations Austria rejected the conditions. On May 4, 1915, Italy denounced the Triple Alliance, and a few days later opened her fourth nounced war of independence against Austria, animated by the 1915 . frustrated ambitions of 1859 and 1866 , and in hope to terminate the more recent Adriatic antagonism of her traditional foe. 


\section{BIBLIOGRAPHY}

\section{ITALY BEFORE $125^{\circ}$}

IN a period so extensive and so controversial, with an historical literature so ample, it is impossible to do more than indicate a few of the more obvious and readily accessible sources, original and modern. Monographs and the vast periodical literature must of necessity be omitted in a brief bibliography.

Original autborities.-For contemporary chronicles, laws and other documents, reference may be made to the collections of Muratori (Rerum Italicarum Scriptores, Milan, 1723-5I, and a new edition, Città di Castello, in progress); Pertz (Monumenta Germaniae Historica, Scriptores and Leges, Hannover, I820-88); and to the publications of the numerous Italian, French, and German historical and archaeological societies. A useful guide to contemporary historians is furnished by Balzani (Ugo), Early Cbroniclers of Europe: Italy, London, I883. Papal and other ecclesiastical letters, lives, sermons and treatises will be found in Migne (Patrologia Latina, Paris, 184464); Theiner (Augustin), Codex diplomaticus Dominii Temporalis $S$. Sedis, Rome, 186r, contains the privileges for the Roman Church ; and Haller (Johannes), Die Quellen zur Gescbicbte der Entstebung des Kirchenstaates, Leipzig, 1907 , furnishes in a handy form the chief authorities for the foundation of the Papal State, 715-817, including the Constitutum Constantini. The Acta Sanctorum of the Bollandists, I 734 to the present time, may be consulted for the Lives of the Saints.

Modern Works.-General histories covering the whole period are not numerous. The two volumes of Villari (Pasquale), The Barbarian Invasions of Italy, English trans., London, 1902, and Mediaeval Italy from Charlemagne to Henry VII, English trans., London, I910, at once learned and interesting, form by far the best introduction to its study : fuller and more elaborate is the Storia politica d'Italia scritta da una Societa di Amici, edited by Villari, of which the volumes 
I Barbari, by Fr. Bertolini, Milan, 188I, and Storia dei Comuni Italiani dallo Origini al 1313, by Francesco Lanzani, Milan, c. I88I, cover the period: Gregorovius (Ferdinand), History of the City of Rome in the Middle Ages, vols. i-v, English trans., London, 1894, while dealing professedly with the history and monuments of Rome and the Papacy, includes much of the general history of Italy; Mann (Horace K.), Lives of the Popes in the Early Middle Ages, 590-1048, 5 vols., and Lives of the Popes in the Middle Ages, 1049-1216, 7 vols. (to be continued till-1305), London, 1902, in progress, is careful and detailed. Of the Cambridge Mediaeval History, with useful chapters on Italian history, the first two volumes only, dealing with the period from Constantine to Charles the Great, are at present published.

For special periods and subjects, the following may be recommended: Hodgkin (Thomas), Italy and ber Invaders, 8 volumes, London, 1880-99, second edition in progress, from the Visigothic Invasion to the death of Charles the Great, is a learned and accurate narrative, which reproduces much of the original authors; Hartmann (Ludo Moritz), Gescbichte Italiens im Mittelalter, of which vols. i-iv reaching to the end of the Ottonian Period are at present published, Gotha, 1897-1915, combines the most recent scholarship with real historical insight; Duchesne (Louis), Les Premiers Temps del'État Pontifical, 3 rd ed., Paris, 1911 , English trans., The Beginnings of the Temporal Sovereignty of the Popes, A. D. 754-1073, London, 1908 , is an illuminating sketch by an acknowledged master of ecclesiastical history; Pivano (Silvio), Stato e Cbiesa da Berengario $I^{\circ}$ ad Arduino, Turin, 1908, treats the period 888-1015 in North Italy from the constitutional and social standpoint; Gay (Jules), L'Italie méridionale et l'Empire byzantin, Paris, 1904 , is concerned with the south from 867 to 1071 ; Hampe (Karl), Deutsche Kaisergescbicbte in der Zeit der Salier und Staufer, 2nd ed., Leipzig, 1912, gives an able sketch of the period from 1024 to 1250 in Italy as well as in Germany ; Stephens (W. R. W.), Hildebrand and bis Times, London, 1888, and Balzani (Ugo), The Popes and the Hobenstaufen, London, 1889, are also useful for the same period; Luchaire (Achille), Innocent III (vols. Rome et l'Italie, and Papauté et Empire), Paris,1905-6, is a lucid exposition of the aims and achievements of the great pope ; Huillard1832.3

L 1 
Bréholles (J. L. Alphonse), Introduction to the monumental Historia diplomatica Friderici Secundi, 6 vols. in 11, Paris, 1852-61, and Oliphant (T. L. Kington), History of Frederick II, 2 vols., London, 1862, are valuable for his reign, while the lectures on Innocent IV by Mr. A. L. Smith in Cburch and State in the Middle Ages, Oxford, 1913, afford a penetrating commentary on the relations of the last Hohenstaufen Emperor with the Papacy.

For the history of the Italian Communes as a whole the work of Hegel (Carl) is indispensable, Gescbicbte der Städteverfassung von Italien, 2 vols., Leipzig, 1847, and translated into Italian as Storia della Costituzione dei Municipi Italiani, Milan and Turin, 1861; for individual cities the many special histories must be consulted. The best general account of the Normans is given by Chalandon (Ferdinand), Histoire de la domination normande en Italie et en Sicile, 2 vols., Paris, 1907, with a very full bibliography, while Haskins (Charles Homer) presents in a readable form the results of the most recent studies on the subject in two chapters, The Normans in the South and The Norman Kingdom of Sicily (with bibliographical notes), in his lectures on $T$ be Normans in European History, London, 1916.

Gebhard (Émile), L'Italie mystique, 6th ed., Paris, 1908, gives an attractive and sympathetic picture of Italian religious life, and Taylor (Henry Osborne), The Mediaeval Mind, 2 vols., London, I9I I, has interesting chapters on religion and learning; Tocco (Felice), L'Eresia nel medio evo, Florence, 1884, should also be consulted. Dudden (Frederick Holmes), Gregory the Great, bis Place in History, 2 vols., London, 1905 , is a judicious and elaborate study and contains a full account of St. Benedict and Cassiodorus; for the Rule of St. Benedict see the edition with English translation and notes by Dom O. H. Blair, 2nd ed., Fort Augustus, 1906; for Joachim of Fiore special reference may be made to Gardner (Edmund G.), Foacbim of Flora and the Everlasting Gospel in Franciscan Essays, Aberdeen, I912; of the vast Franciscan literature mention may be made of the Lives of St. Francis by Sabatier (Paul), Paris, 1894, also English trans.; by Joergensen (Johannes), French trans., Paris, I909, also English trans., London, \&c., I912 ; and by Father Cuthbert, O.S.F.C., London, I914, all with much bibliographical information; 
for the intellectual contribution of Italy in the Middle Ages, Rashdall (Hastings), Universities of Europe in the Middle Ages, vol. i, Oxford, 1895, and Vinogradoff (Paul), Roman Law in Mediaeval Europe, London and New York, 1909, are of great value.

The history of mediaeval Italian art may be studied in Venturi (Adolfo), Storia dell Arte Italiana, vols. i-v, Milan, 1901-1907; Bertaux (Émile), Rome, de l'Ère des Catacombes à l'Avènement de fules II, Paris, 1908, and L'Art dans l'Italie Méridionale de la fin de l'Empire Romain à la Conquête de Charles d'Anjou, Paris, I903; Brown (J. Wood), Italian Architecture, London, 1905, a clear and convenient introduction to the subject, which is treated with great detail in Cattaneo (Raffaele), Arcbitecture in Italy from the Sixth to the Eleventh Century, English trans., London, 1895 ; . Rivoira (G. T.), Lombardic Arcbitecture, 2 vols., English trans., London, 1910; Jackson (Thomas Graham), Byzantine and Romanesque Arcbitecture, 2 vols., Cambridge, 1913, and Gotbic Arcbitecture in France, England and Italy, 2 vols., Cambridge, 1915; for painting and mosaic see Crowe and Cavalcaselle, History of Painting in Italy, vol. i, London, 1903. All these works on art and architecture are fully illustrated.

\section{ITALY, 1250-1527}

A great deal of work has been done on this period, and new books are appearing every year. No attempt at a detailed bibliography has been made here, but an account of some of the most important and easily accessible books is given for the benefit of students.

The nearest approach to a general history of the period is to be found in the big Papal histories: Creighton, History of the Papacy from the Great Schism to the Sack of Rome; Gregorovius, Geschichte der Stadt Rom im Mittelalter (trans. Hamilton); Pastor, Geschicbte der Päpste (trans. Antrobus). Sismondi, Républiques italiennes, covers the whole period and is still useful, although in many respects out of date. Villari, L'Italia da Carlo Magno alla morte di Arrigo VII (trans. as Mediaeval Italy), stops at the year 1313, and Butler, Lombard Communes, does not go beyond the fourteenth century. The Cambridge Modern History, Vol.'I: The Renaissance, contains valuable chapters on the concluding years of the period.

$$
\text { L } 12
$$


There are a number of good modern histories of the different city states. Villari, The two first Centuries of Florentine History (trans.); Brown, Venice: An Historical Sketch of the Republic; Venetian Studies; Hodgson, Venice in the Fourteenth Century; Gardner, Dukes and Poets of Ferrara; Douglas, History of Siena, are all important books. The Italian States series, published by Methuen, contains the following volumes: Ady, $A$ History of Milan under the Sforza; Allen, $A$ History of Verona; Heywood, $A$ History of Perugia. Useful historical sketches of a slighter kind are to be found in the various volumes on Italy published in Dent's Mediaeval Towns series.

Among the vast Dante literature historical students will find especially useful : Paget Toynbee, Concise Dante Dictionary; Life of Dante; Church, Dante; Ferrers Howell, Dante; Armstrong, Dante's Political Ideal (Church Quarterly Review, 1890).

Of the many biographies and monographs belonging to the period the following are all based on independent research: Coulton, From St. Francis to Dante (on Salimbene's Chronicle); Heywood, Palio and Ponte; Ewart, Cosimo dei Medici; Armstrong, Lorenzo dei Medici; Horsburgh, Lorenzo dei Medici; Savonarola; Villari, Life and Times of Savonarola; Life and Times of Macbiavelli; Burd, Macbiavelli, Il Principe (critical edition with notes); Gardner, St. Catberine of Siena; Ferrers Howell, St. Bernardino of Siena; Ady, Pius II; Woodward, Cesare Borgia; Cartwright, Beatrice d'Este; Isabella d'Este; Baldassare Castiglione. For the Renaissance as a general movement,.Symonds, Renaissance in Italy, and Burckhardt, Die Cultur der Renaissance in Italien (trans.), are the most important. More specialized treatment of different aspects will be found in Anderson, The Arcbitecture of the Renaissance in Italy; Berenson, Florentine Painters; Venetian Painters; Central Italian Painters; Woodward, Education during the Renaissance; Vittorino da Feltre and other Humanist Educators.

The following translations from contemporary sources are easily accessible to English readers :

Dante, Inferno, Purgatorio, Paradiso, Latin Works; Dino Compagni, Cbronicle (all in Temple Classics edition); Machiavelli, History of Florence, The Prince (trans. N. Thomson); Castiglione, 
The Courtyer (trans. Hoby); Guicciardini, History of Italy (trans. Fenton); P. de Commines, Memoirs, Books VII and VIII (trans. Bohn); Villani, Cbronicles (selections by Selfe and Wicksteed).

\section{ITALY, 1528-1789}

Very little has been written in English on the subject of these three chapters. The best histories of the whole period are in Italian : C. Cantù, Storia degli Italiani; A. Cosci, Le Preponderanze straniere; D. Carutti, Storia della diplomazia della Corte di Savoia; E. Ricotti, Storia della Monarchia Piemontese; and S. Romanin, Storia documentata di Venezia. Ranke's History of the Popes is translated into English. K. D. Vernon, Italy: I494-I792 contains a more detailed account of the whole period. Very valuable are the Relazioni degli Ambasciadori Veneti (edited by E. Alberi, N. Berchet, and G. Barozzi), also the Recueil des instructions données aux Ambassadeurs et Ministres de France, the series on Savoy and Sardinia edited by H. de Beaucaire and that on Naples and Parma by J. Reinach. For more detailed study the Conferenze sulla Vita Italiana, in three volumes, for the sixteenth, seventeenth, and eighteenth centuries, edited by Fratelli Treves, are good; and the serious student should consult the excellent Italian historical periodicals, especially the Arcbivio Storico Italiano which contains many important articles. Older but valuable works are C. Botta, Storia d'Italia; L. Muratori, Annali d'Italia; P. Giannone, Istoria civile del regno di Napoli; and R. Galuzzi, Istoria del Granducato di Toscana sotto il governo della casa Medici.

For the sixteenth and seventeenth centuries the most important English works are J. A. Symonds's Renaissance in Italy, E. Armstrong's The Emperor Charles $V$, and H. F. Brown's Venice: an Historical Sketch of the Republic. The Memoits of Benvenuto Cellini are translated in 'Everyman's Library', and Manzoni's I Promessi Sposi is translated in 'Bohn's Standard Library'. The following are useful for special points: G. de Leva, Storia documentata di Carlo $V$ in correlazione all Italia; G. Claretta, Storia della Reggenza di Cristina di Francia, Ducbessa di Savoia; and Storia del Regno e dei tempi di Carlo Emanuele II, Duca di Savoia; G. Grill, Fattori 
dei movimenti riformatorii italiani nel XVI secolo (for Protestantism in Italy); and G. Brusoni, Istoria dell' ultima guerra tra' Veneziani $e$ Turcbi, dall anno 1644 fino al 1671 . For seventeenth-century diplomacy there are excellent French books : P. A. Chéruel, Histoire de France pendant la minorité de Louis $X I V$, and Histoire de France sous le ministère de Mazarin, I65I-61; M. Hanotaux, Recueil des instructions données aux ambassadeurs de France; E. Rott, Henri IV, les Suisses et la baute Italie: la lutte pour les Alpes (1598-1610); C. Rousset, Histoire de Louvois et de son administration politique et militaire jusqu'à la paix de Nimègue; B. Zeller, two books on the minority of Louis XIII and two on the early years of his reign.

For the eighteenth century, E. Armstrong, Elizabeth Farnese, and Foscarini, Storia arcana di Carlo VI, are of great importance, and the early part of C. Cantù, Storia di cento anni (I750-1850), is useful. For Tuscany, F. Scaduto, Stato e Cbiesa sotto Leopoldo I, is very valuable, and A. Zobi, Storia civile della Toscana dal 1737 al 1848, is lengthy but interesting. For Venice there is G. Dandolo, $\mathrm{La}$ Caduta della repubblica di Venezia e i suoi ultimi anni. For Naples there are M. Schipa, Il Regno di Napoli al tempo di Carlo di Borbone (an excellent modern work); P. Calà Ulloa, Di Bernardo Tanucci $e$ de' suoi tempi; F. Scaduto, Stato e Chiesa nelle due Sicilie; and a new edition by C. Manfroni of P. Colletta, Storia del Reame di Napoli dal 1734 al 1825 . There are a number of works on papal history, of which the best are perhaps P. de Ravignan, Clément XIII et Clément XIV; and Baron J. F. Bourgoing, Mémoires bistoriques et philosopbiques sur Pius VI et son Pontificat. For social and intellectual history, C. de Brosses, Lettres bistoriques et critiques sur I Italie; C. Cantù, L'Abate Parini e la Lombardia nel secolo passato; and E. Bouvy, Le Comte Pietro Verri (1728-97), ses idées et son temps, are all of interest.

\section{THE EVOLUTION OF UNITY}

The following are a few accessible works dealing with the period treated in Part IV :

The Cambridge Modern History, vols. x-xii.

Lavisse et Rambaud, Histoire générale $d u$ iv siècle à nos jours, vols. $\mathrm{x}$-xii. 
A. Debidour, Histoire diplomatique de l'Europe. 2 vols. Paris, 1891. C. Seignobos, A Political History of Contemporary Europe since I8I4. 2 vols. London, 1901. Popular edition in one volume (1915).

J. Holland Rose, The Development of the European Nations, $1870^{\circ}-$ rgoo. Third edition. London, 1912.

F. A. Kirkpatrick (ed.), Lectures on the History of the Nineteenth Century. Cambridge, 1904.

Bolton King, A History of Italian Unity. Being the political history of Italy from 1814 to 1871 . 2 vols. Second impression. London, I9I2.

W. J. Stillman, The Union of Italy, I815-1895. New edition, revised. Cambridge, 1909.

F. Bourgeois and E. Clermont, Napoléon III et Rome. Paris, 1907.

P. de la Gorce, Histoire du Second Empire. Paris, 1894-1905.

Johnston, R. M., The Roman Tbeocracy and Republic, 1846-1849. London, I901.

Bolton King and Thomas Okey, Italy to-day. London, I90I.

G. M. Trevelyan, Garibaldi and the Making of Italy. Fourth impression. London, 1912.

G. M. Trevelyan, Garibaldi's Defence of the Roman Republic. New impression.' London, I9I2.

G. M. Trevelyan, Garibaldi and $\mathcal{T}$ be $\mathcal{T}$ bousand. Fifth impression. London, 1912.

Cesaresco, Countess Evelyn, The Liberation of Italy, 1815-1870. London, 1910.

Pietro Orsi, Cavour and the Making of Modern Italy, I810-I86I. New York, I914.

Cesaresco, Countess Evelyn, Cavour. New edition. London, 1904. Bolton King, Mazzini. London, 1902.

Foseph Mazzini. A Memoir by E. A. V. With two essays by Mazzini : Thoughts on Democracy and The Duties of Man. London, 1875 . 
520

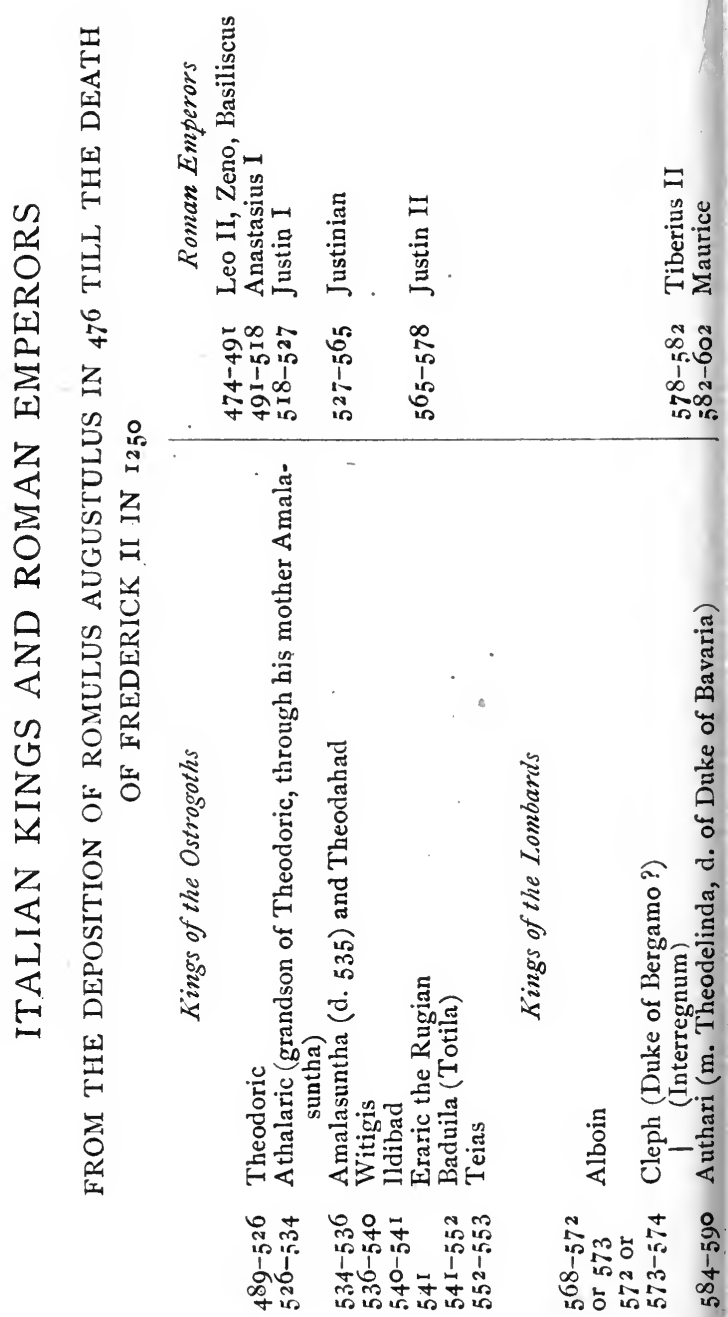



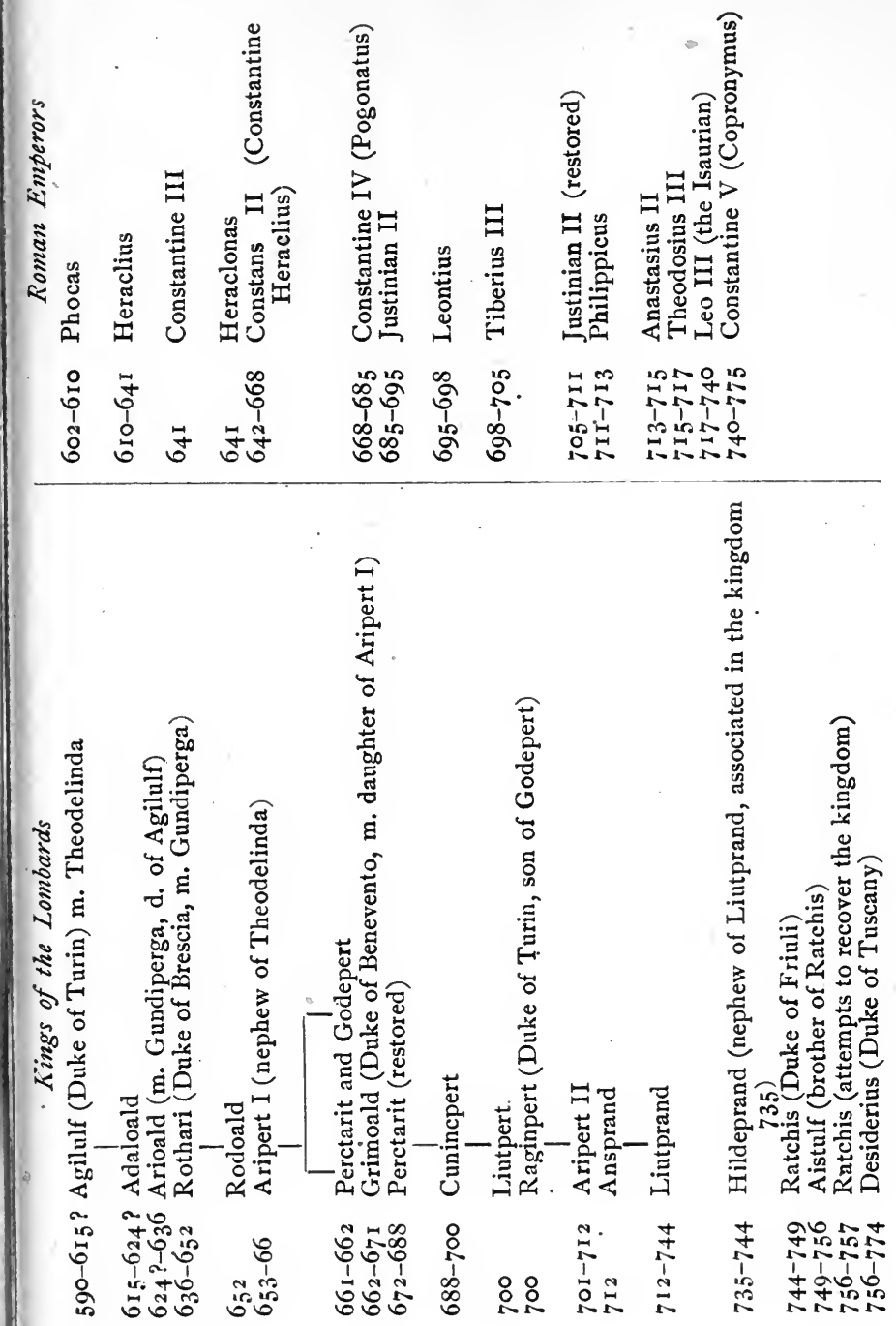

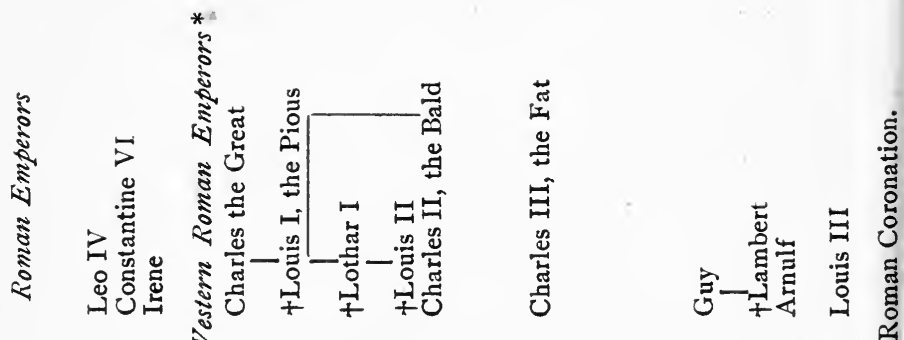

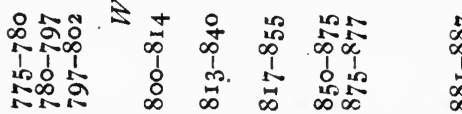
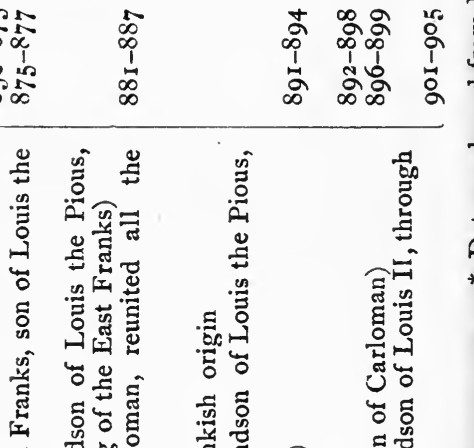

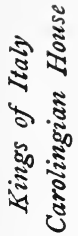

O)

‡ 政 岳 至 品

范

曰

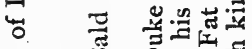

ㅇำ คิ

$\stackrel{\Xi}{\check{I}}$

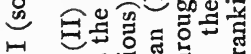

क्ष.

는

है 응루

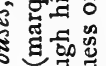

豞额总

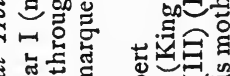

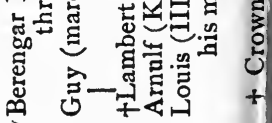

坖领

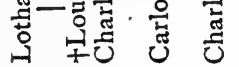

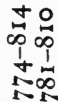

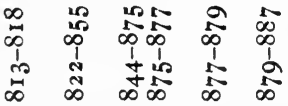

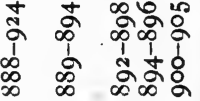


ปे

晃

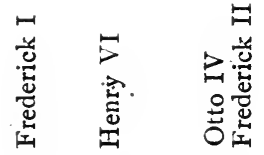

要
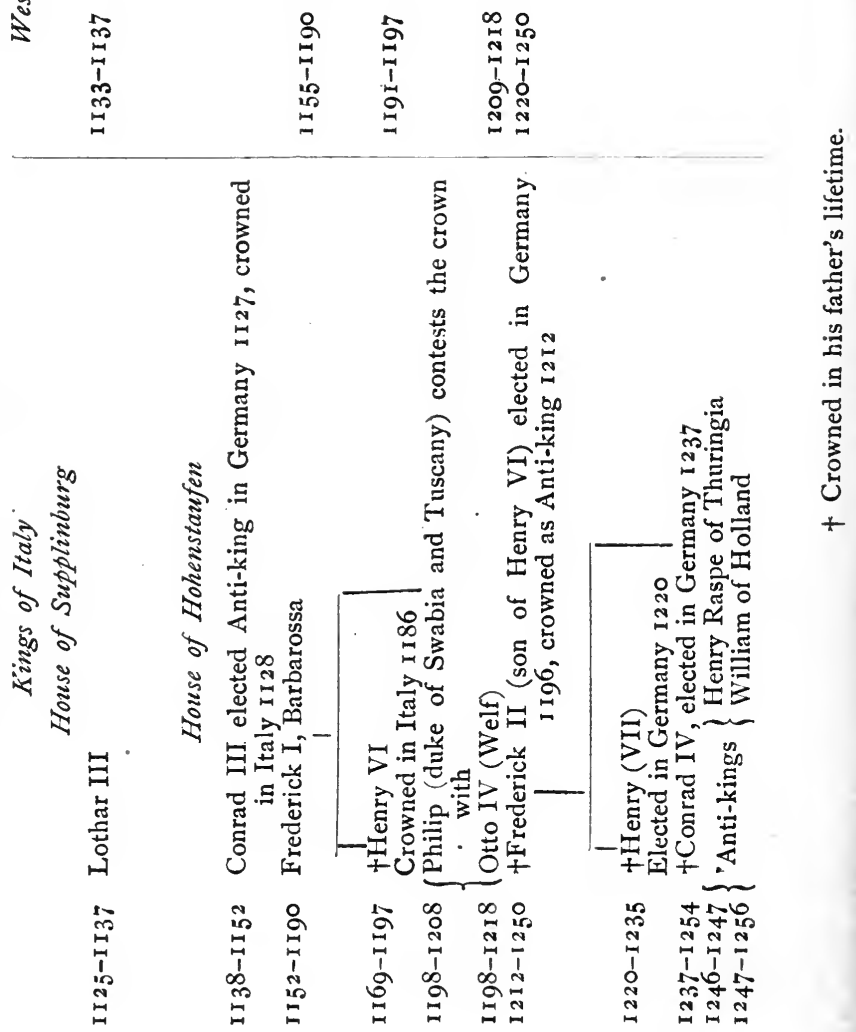
525

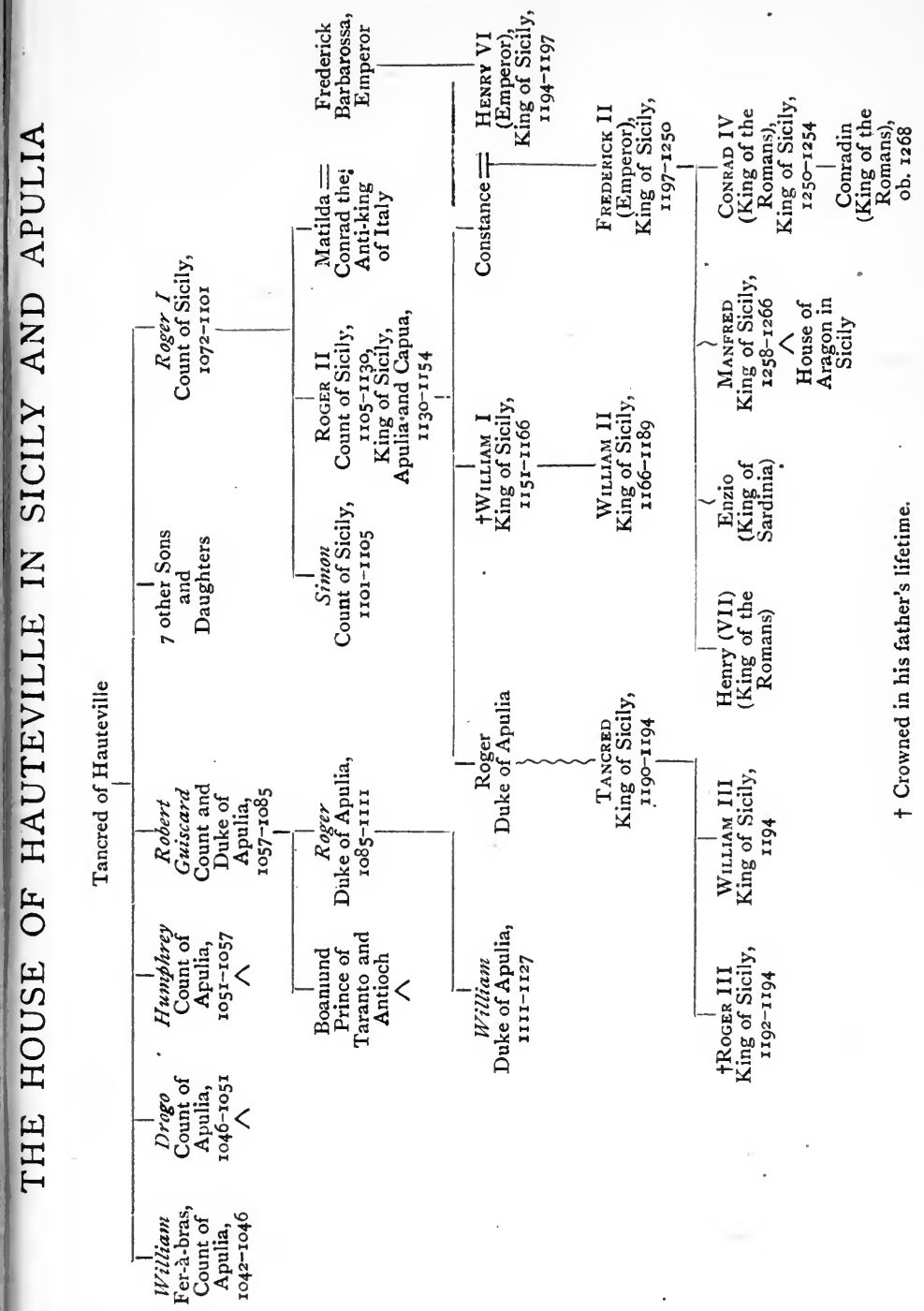




\section{URBINO. HOUSES OF MONTEFELTRO AND DELLA ROVERE}

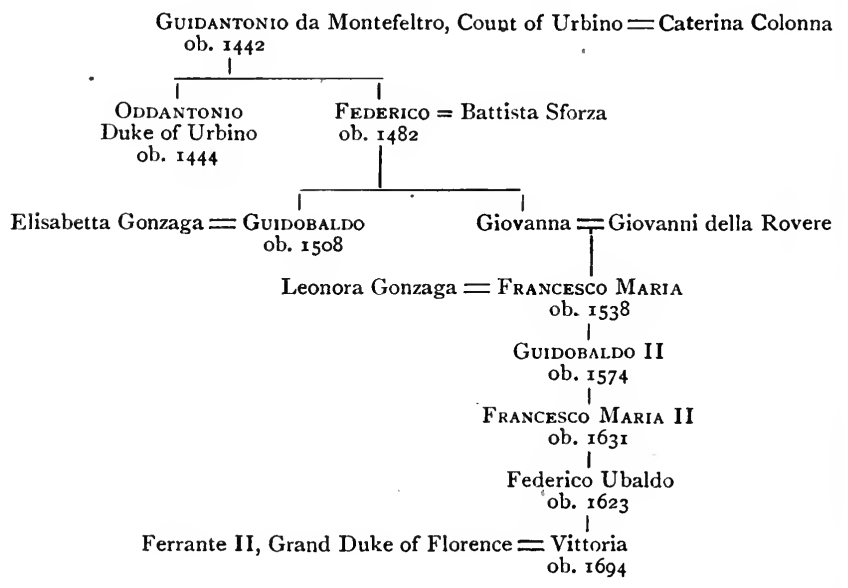




\section{MANTUA. HOUSE OF GONZAGA}

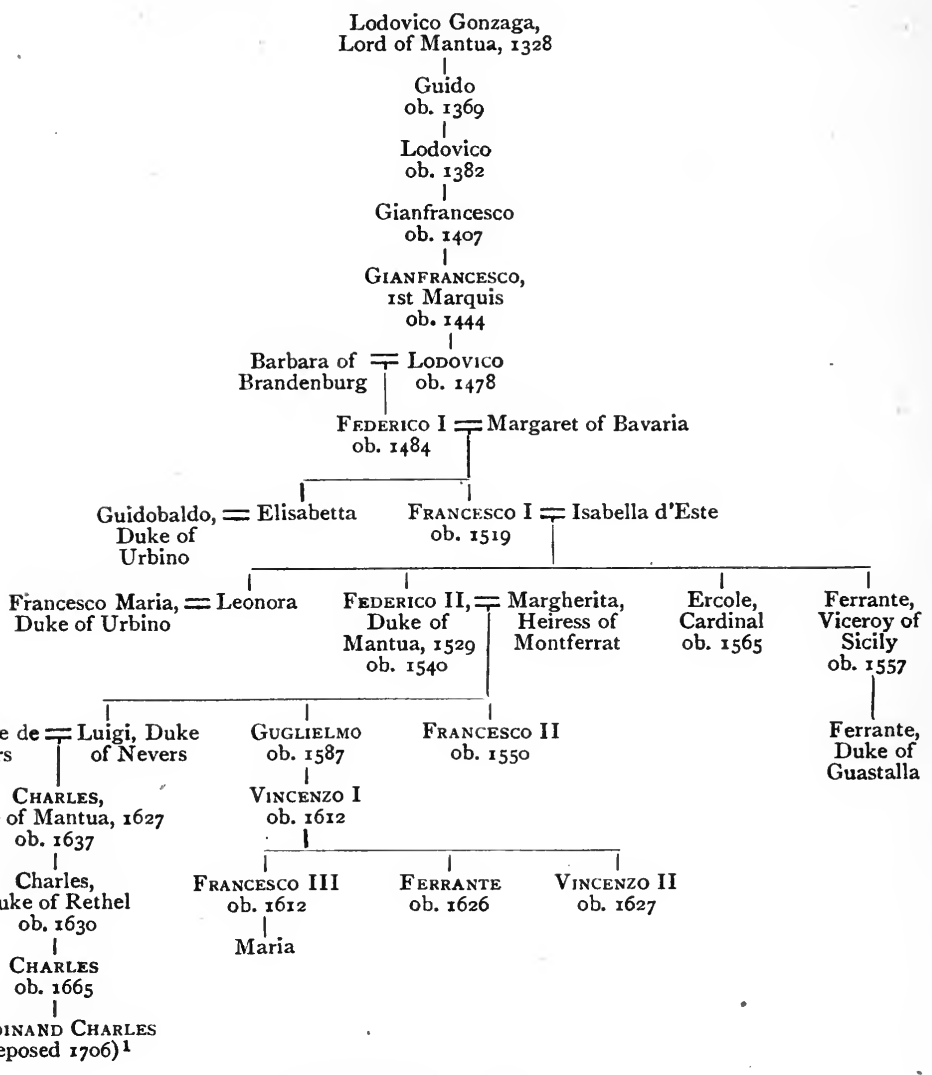

1 Mantua annexed by Austria. 


\section{FLORENCE. HOUSE OF MEDICI}

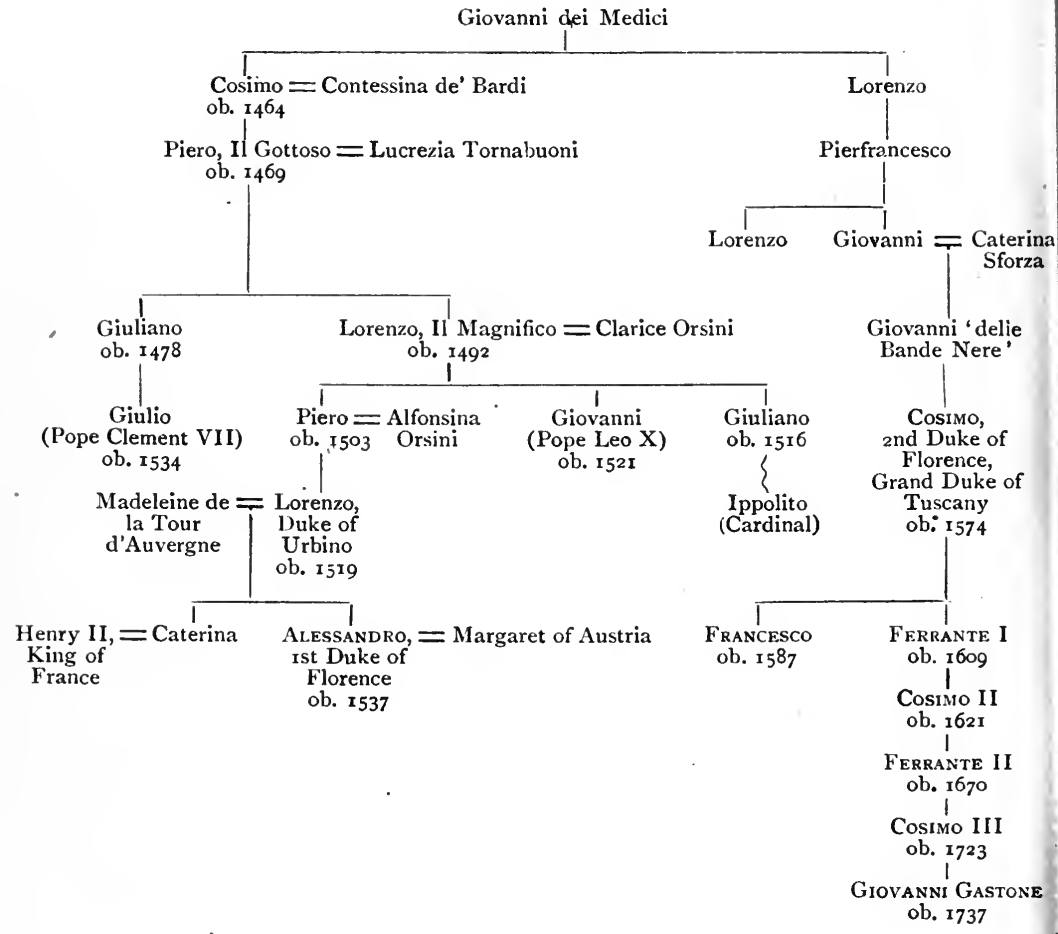




\section{FERRARA. HOUSE OF ESTE}

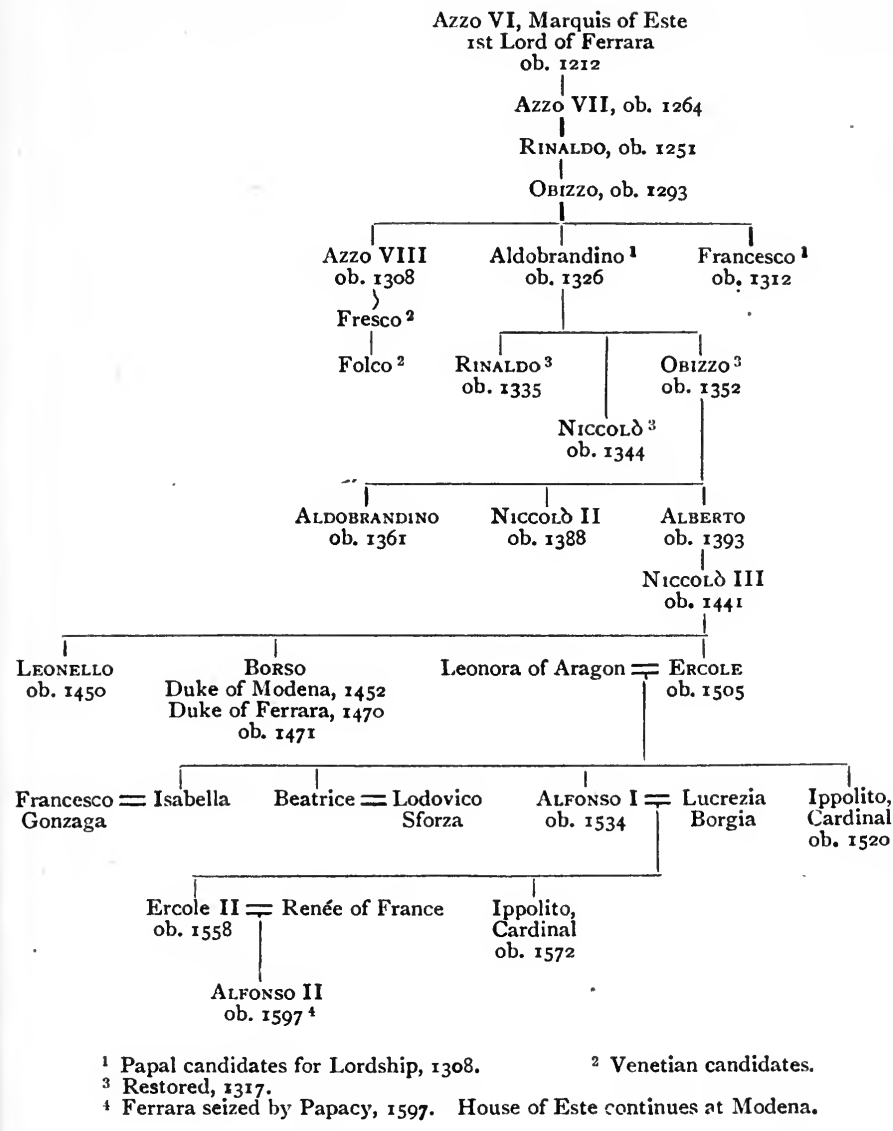




\section{SICILY AND NAPLES. HOUSE OF ARAGON}

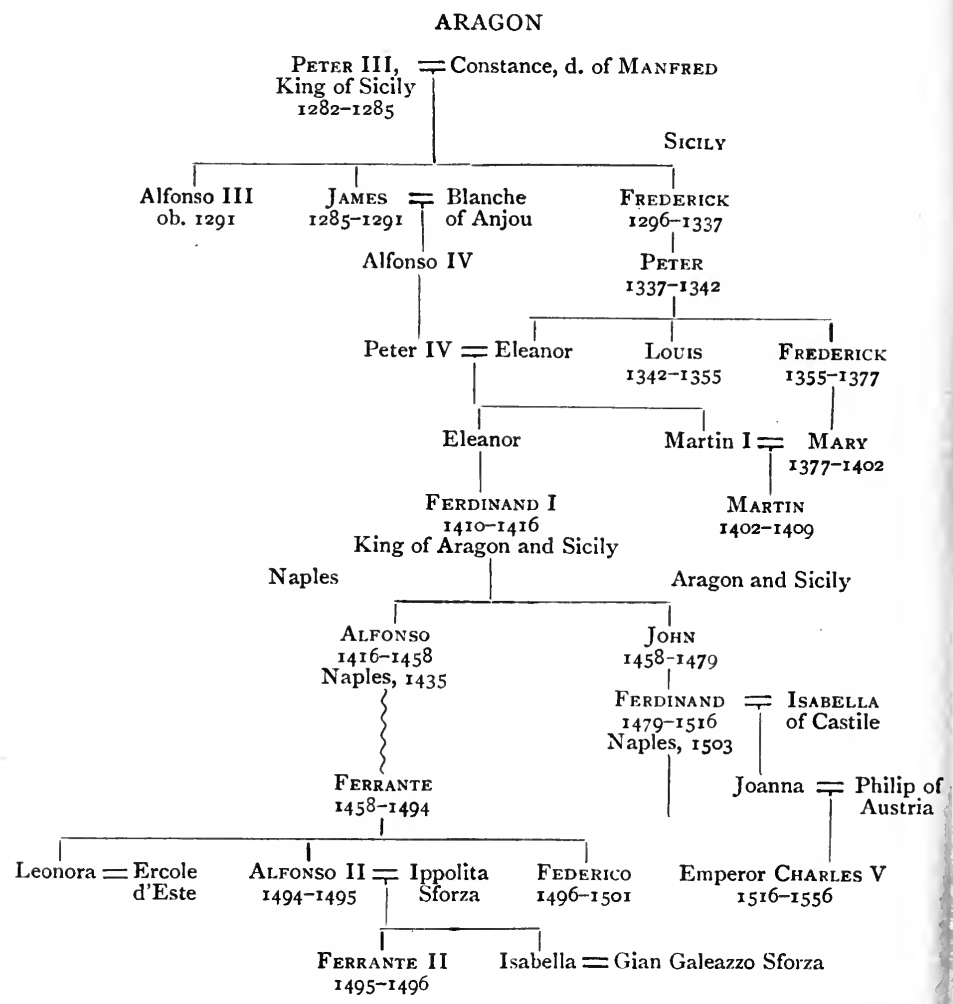




\section{SICILY AND NAPLES. HOUSE OF ANJOU}

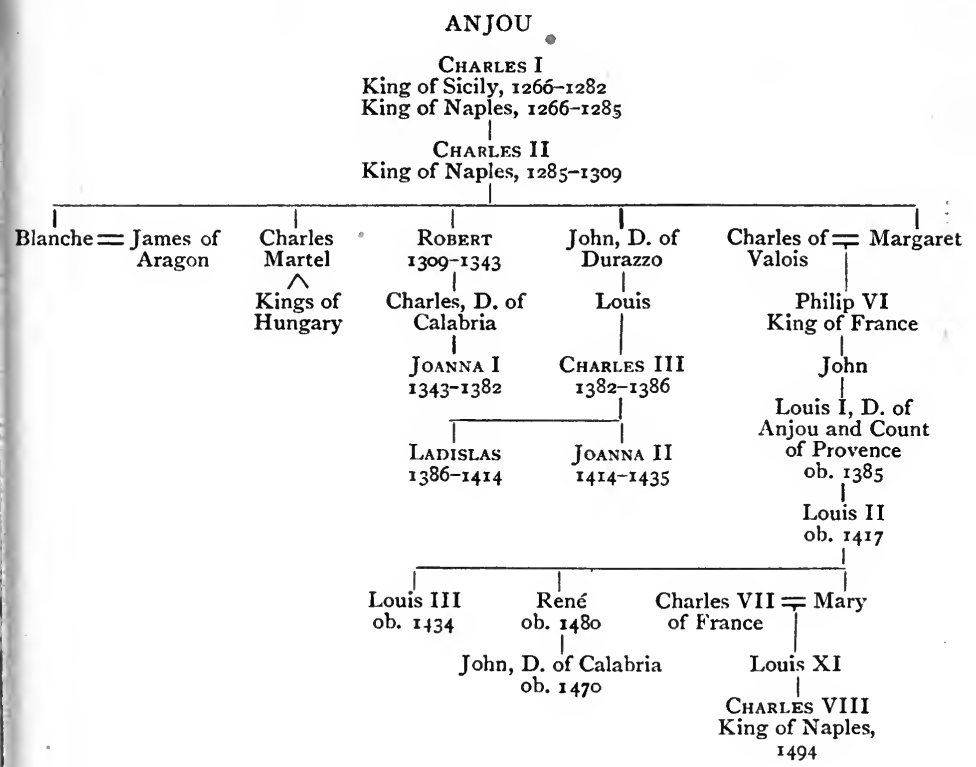


532

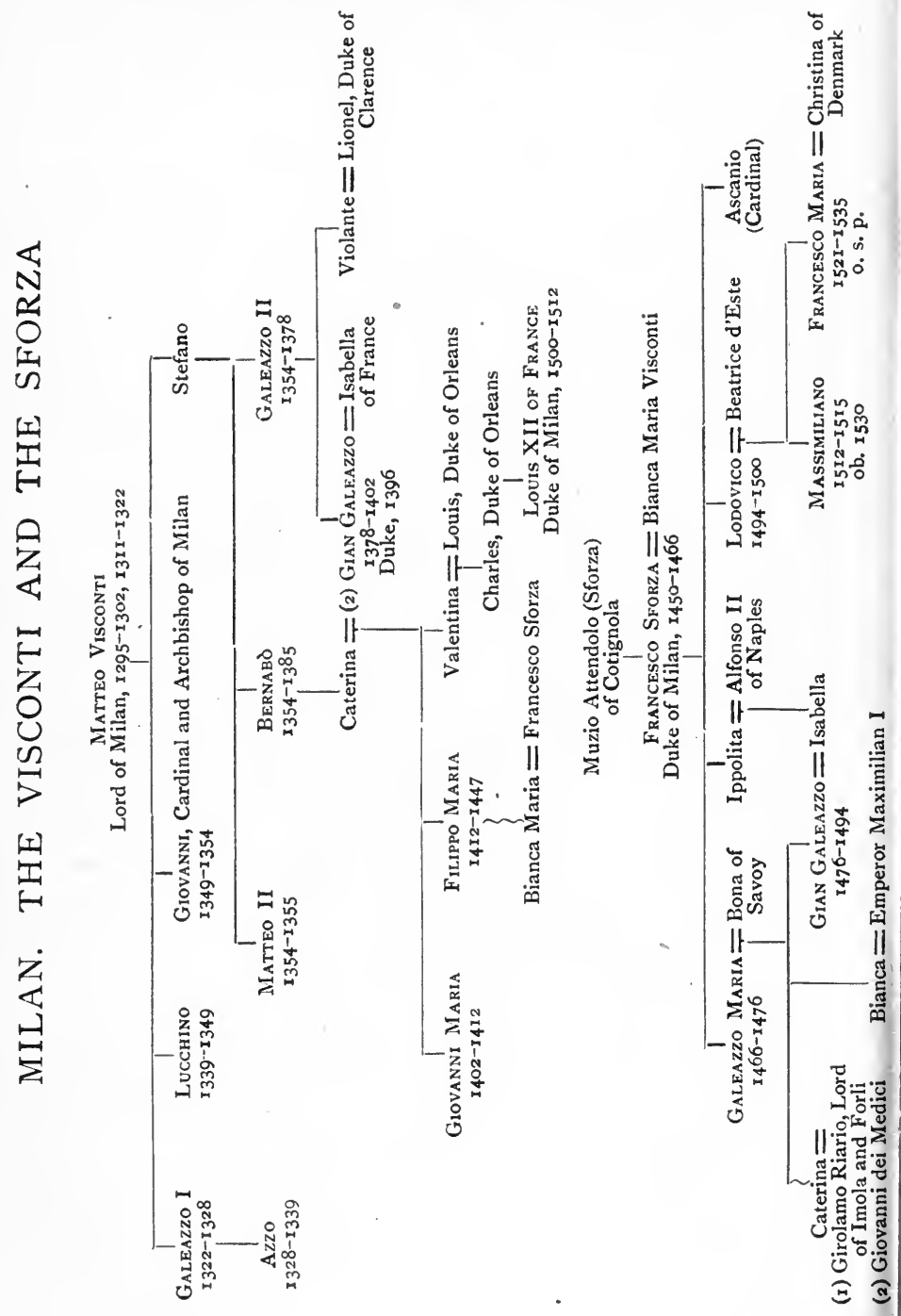




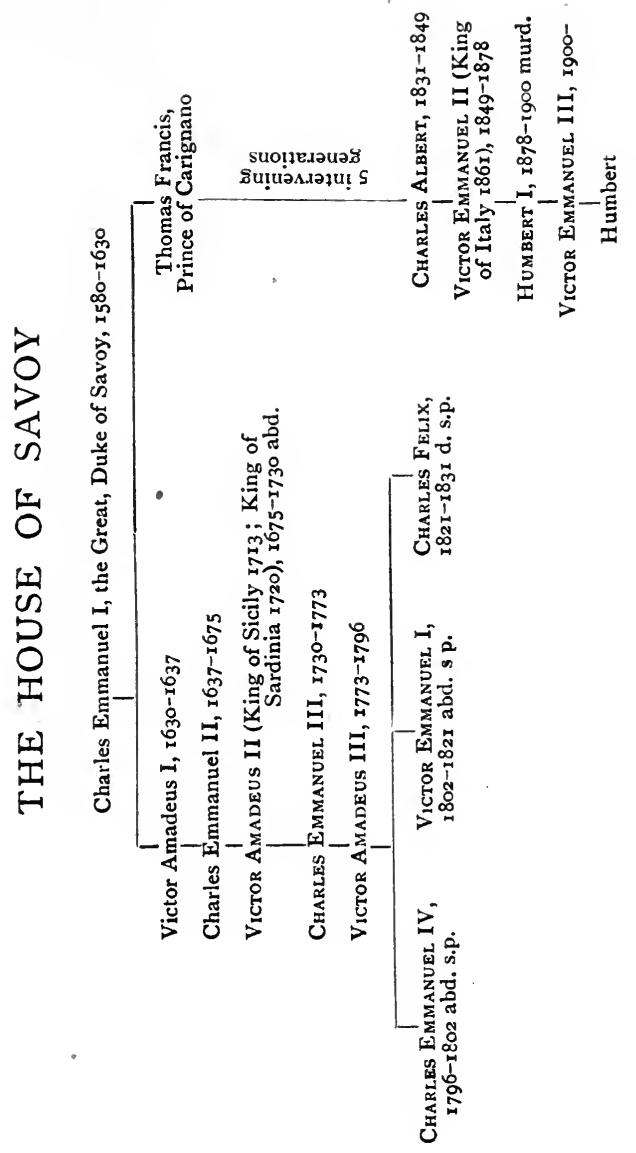




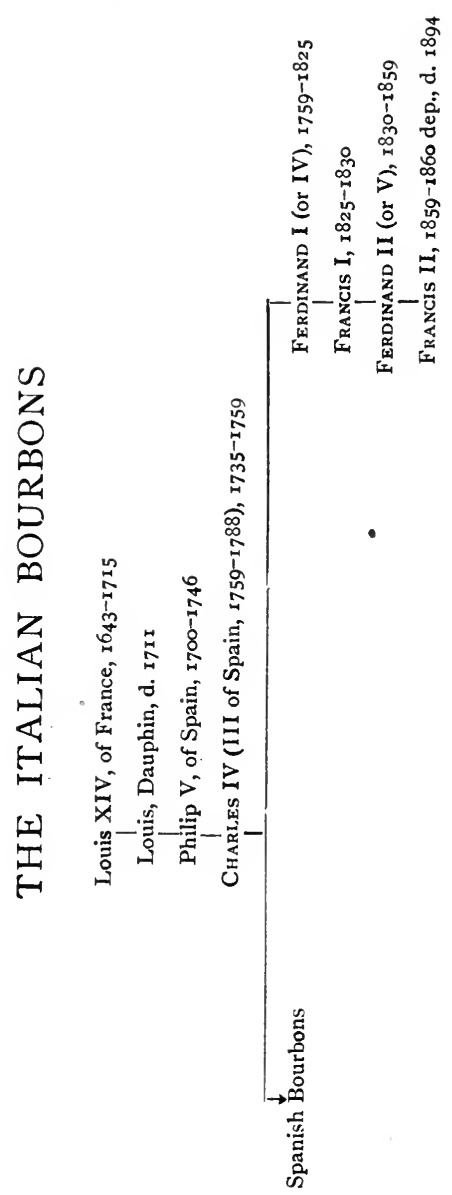




\section{LIST OF THE POPES, 590-I9I $7^{1}$}

*** Much uncertainty hangs over the dates of some of the early Popes. In all cases where the date of succession, or of death, is disputed, a note of interrogation is appended.

Gregory I, the Great, Sept. 590-March 604.

SabinianUS, Sept. 604-Feb. 606?

BONIFACE III, Feb.-Nov. 607?

BONIFACE IV, Aug. 608-May 615?

DeUSDEDIT, Nov. 615-Dec. 618?

Boniface V, Dec. 619-Oct. 625 ?

HoNorius I, Nov. 625 -Oct. 638 .

SeVERINUS, May-Aug. 640.

JoHN IV, Dec. 640-Oct. 642.

THEODORE I, Nov. $642-$ May 649.

Martin I, July 649 -June 653 , dep. ; ob. Sept. 655 .

Eugenius I, Ang. 654-June 657 .

VitalianUs, July 657 -Jan. 672.

Adeodatus, April $672-J u n e 676$.

Donus I, Nov. 676 -April 678 .

AgATHO, June 678-Jan. 682?

LEO II, Aug. 682-July 683 ?

BENEDICT II, June 684-May 685.

JoHn V, July 685--Aug. 686?

CoNo, Oct. 686-Sept. 687.

ThEODORUS, Sept.-Dec. 687 .

Sergius I, Dec. 687-Sept. 7or.

JoHN VI, Oct. 7or-Jan. 705.

JoHN VII, March 705-Oct. 707 .

Sisinnius, Jan.-Feb. 708.

Constantine, March 708-April 715.

GrEgORY II, May 715-Feb. 73I.

GREGORY III, March 73I-Nov. 74I.

ZACHARIAS, Dec. 74I-March $75^{2}$.

Stephen, March $75^{2}$, died before consecration.

STePHeN II, March 752-April 757.

PAUL I, May 757-June 767.

Constantine, usurper, June $767-$ Aug. 768 .

1 Reproduced, by permission, from Genealogical Tables by H. B. George (Clarendon Press, fifth edition, revised and enlarged by J. R. H. Weaver, I9I6). 
Stephen III, Aug. 768-Feb. 772.

HADRIAN I, Feb. $772-$-Dec. 795.

LEO III, Dec. 795-June 816.

STEPHEN IV, June 816-Jan. 81 7 .

PASCAL I, Jan. 817-May 824.

EUgenius II, June 824-Aug. 827.

Valentine, Aug.-Dec. 827 ?

GREGORY IV, Dec. 827-Jan. 844 ?

Sergius II, Jan. 844-Jan. 847.

LeO IV, April 847 -July 855 .

BENEDICT III, Sept. 855 -A pril 858 .

Nicholas I, April 858-Nov. 867.

HADRIAN II, Dec. 867 -Nov. 872 ?

JoHN VIII, Dec. 872-Dec. 882 .

MARINUS, Dec. 882-May 884 .

HADRIAN III (Agapetus), May 884-Sept. 885 .

STEPHEN V, Sept. 885-Aug. 89r.

FORMOSUS, Sept. 89I-April 896.

BONIFACE VI, 896 , died in fifteen days.

STEPHEN VI, $896-897$, dates unknown.

Romanus, Aug.-Nov. 897 ?

THEODORE II, 898 , dates unknown.

JoHN IX, July 898-July 900.

BENEDICT IV, July 900-Aug. 903.

I.eo V, Oct. - Nov. 903, dep.

Christopher, Nov. 903-Jan. 904, dep.

Sergius III, Jan. 904-Sept. 911.

ANastasius III, Sept. 91 I-Nov. 913.

Lando, Nov.9r3-May 9I4.

JoHn X, May 9I4-May 928.

Leo VI, June 928-Feb. 929.

STEPhen VII, Feb. 929-March 931.

JoHN XI, March 93 I-Jan. 936.

LEO VII, Jan. 936 - July 939.

STEPHEN VIII, July $939-$ Nov. $94^{2}$.

Martin III, Nov. 942-Jan. 946 .

AGAPETUS II, March 946-end of 955 .

JoHn XII (Octavianus), Jan. 956-Dec. 963, dep.

LEO VIII, Dec. 963-March 965.

BENEDICT V, $964-965$.

JоHN XIII, Oct. 965-Sept. 972.

BENEDICT VI, $972-974$.

BONIFACE VII, 974, driven into exile.

DoNUs II, 974, dates unknown.

BENEDICT VII, March 975-July 983 ?

JoHN XIV, Nov. 983-Aug. 984.

BONIFACE VII again-ob. March 985 .

John XV, never lawfully consecrated, ob. 985 .

JoHN XVI, July 985-996. 
Gregory V (Bruno), May 996Feb. 999 .

Silvester II (Gerbert, Abp. of Ravenna), April 999-May roo3. JоHN XVII (Secco), June-Oct. 1003.

JoHN XVIII (Phasian), Dec. I003 - May roog, res.

Sergius IV (Peter Boccaporco), 1009-May ror 2?

BeNEDICT VIII (John, Bp. of Porto), July 101 2-July ro24.

JoHN XIX (Romanus, brother of Benedict VIII), Aug. I024-May ro33.

BENEDICT IX (Theophylact, nephew of John XIX), I033-July I048, res.; deposed 1044, and restored on death of Silvester III ; sold the papacy to Gregory VI; restored again on death of Clement II.

Damasus II (Poppo, Bp. of Brixen), July-Aug. 1048.

LEo IX (Bruno, Bp. of Toul), Dec. 1048-April 1054.

VICTOR II (Gebhard, Bp. of Eichstadt), March 1055-July I057.

STEPHEN IX (Frederick of Lorraine), Ang. 1057-March 1058.

Nicholas II (Gerard, Bp. of Florence), Dec. 1058-July 1061.

Alexander II (Anselm, Bp. of Lucca), Sept. I061-April ro73.

GREGORY VII (Hildebrand), April 1073-May 1085.

VICTOR III (Desiderias, Abbot of Monte Casino), May 1086-Sept. 1087 .

UrbaN II (Otto, Bp. of Ostia), March I088-July I099.

PASCAL II (Rainer, Abbot of S. Lorenzo), Aug. ro99-Jan. III8.

Gelasius II (John of Gaeta), Jan. II I8-Jan. I II9.

Calixtus II (Guy, Abp. of Vienne), Feb. III9-Dec. II 24.

HoNoRiUs II (Lambert, Bp. of Ostia), Dec. II24-Feb. I130.
ANTIPOPES.

John XVII (Philagathus), May 997 -Feb. 998.

Silvester III (John, Bp. of Sabina), 1044.

GREGORY VI (John Gratian), May ro45-Dec. 1046, dep.

Clement II (Suidger, Bp. of Bamberg), Dec. 1046-Oct. 1047.

Benedict X (John, Bp. of Velletri), March 1058-Jan. 1059, dep.

Clement III (Guibert, Abp. of Ravenna), June 1080-Sept. I 100.

Albert, I102.

Silvester IV (Maginulf), Iro5IIII.

Gregory VIII (Burdinus), March III8-April II2I. 
InNocent II (Card. Gregory dei Papi), Feb. II 30 -Sept. I I 43.

Celestine II (Guy de Castro), Sept. II 43-March II 44.

Lucius II (Gerard, Card. of S. Croce), March II 44-Feb. 1145.

Eugenius III (Bernard, Abbot of S. Anastasius), Feb. $1145-J u l y$ I I 53 .

Anastasius IV (Conrad, Card. Bp. of Sabina), July I 153 -Dec. I I 54 .

HADRIAN IV (Nicholas Breakspeare), Dec. I I 54-Sept. II 59.

ALEXaNDER III (Roland Bandinelli Card. of S. Mark), Sept. II59Ang. II 8I.

Lucius III (Ubaldo, Bp. of Ostia), Sept. I I 8 I-Nov. I 85 .
ANTIPOPES.

Anacletus II (Card. Peter Leoni), Feb. II 30 -Jan. I 138 .

Gregorius, I 138 .
Victor IV (Card. Octavian), Sept. II59-April II64.

Pascal III (Guy of Crema), April I 164 -Sept. I 68.

Calixtus III (John of Struma), Sept. I 68 -Aug. I 178 , res.

Innocent III, I I $78-1180$.

URBAN III (Uberto Crivelli, Abp. of Milan), Nov, I185-Oct. I187.

GRF.GORY VIII (Card. Albert di Morra), Oct.-Dec. I 187 .

Clement III (Panl Scolaro, Card. Bp. of Palestrina), Dec. II 87-March II9I.

Celestine III (Card. Hyacinth), March II9I-Jan. $119^{8 .}$

INNOCENT III (Card. Lothario dei Conti di Segni), Jan. I I98-July I 216. Honorius III (Cencio Savelli), July I $216-$ March $122 \%$.

GREGORY IX (Card. Ugolino), March I 227 -Aug. I24I.

Celestine IV (Geoffrey Castiglione), I 24 I, died before consecration.

INNOCENT IV (Sinibaldo Fieschi), June I 243-Dec. I 254.

Alexander IV (Rinaldo, Bp. of Ostia), Dec. I254-May I 26 I.

URban IV (James Pantaleon, Patriarch of Jerusalem), Aug. I 26I-Oct. I 264 .

Clement IV (Guy Foulquois, Abp. of Narbonne), Feb. 1265-Nov. I 268. Vacancy till election of Gregory X, Sept. I $27 \mathrm{I}$.

GREGory X (Tebaldo, Archdeacon of Liege), Sept. 127 I-Jan. 1276.

INNOCENT V (Peter of Tarentaise), Feb.-June I 276.

Hadrian V (Card. Ottobuoni), July I 276 ; died before consecration.

John XXI (Peter, a Portuguese), Sept. I 276-May 1277.

Nicholas III (John Gaetano Orsini), Nov. I 277 -Ang. 1280.

Martin IV (Simon de Brion), Feb. I 28I-March I 285.

HoNORIUS IV (James Savelli), April I 285-April 1287 .

Nicholas IV (Jerome, Bp. of Palestrina), Feb. I 288-A pril 1292.

Coelestine V (Peter Morrone), July-Dec. I 294, res.; ob. May i 296.

BONIFACE VIII (Benedict Gaetani), Dec. I 294-Oct. I 303 .

BENEDICT XI (Nicholas Bocasi), Oct. I303-July I 304 . 
Clement V (Bertrand de Goth, Abp. of Bordeaux), June $1305-A$ pril I3I4.

JoHn XXII (James d'Euse), Aug. I316-Dec. I334.

BeNEDICT XII (James Fournier), Dec. I334-April I342.

Clement VI (Peter Roger, Abp. of Rouen), May I342- In Avignon.

Dec. $135^{2}$.

InNocent VI (Stephen Aubert), Dec. I352-Sept. I362.

URBAN V (William Grimoard), Oct. I362-Dec. I370.

GREgory XI (Peter Roger, néphew of Clement VI), Dec.)

I370-March 1378.

\section{THE GREAT SCHISM}

ROME.

URbAN VI (Bartholomew Pregnano, Abp. of Bari), April I 378 -Oct. I 389 .

Boniface IX (Peter Tomacelli), Nov. I389-Oct. I404.

InNocent VII (Cosmo Meliorati), Oct. I 404-Nov. I 406.

Gregory XII(Angelo Corrario), Dec. I406-July I415, res.; ob. Oct. I419.

\section{Avignon.}

Clement VII (Robert, Bp. of Cambray), Sept. I378-Sept. I394.

Benedict XIII (Peter de Luna), Sept. I 394-I 423 .

Clement VIII, I424-I 429, res. Felix V (Amadeus VIII, D. of Savoy), elected Nov. 1439. by Council of Basle, res. April I 449.

In June I 409, the Council of PIsA deposed both Gregory XII and Benedict XIII (though both refused to acknowledge its authority), and elected

Alexander V (Peter, Abp. of Milan), June I 409-May 1410.

JoHN XXIII (Balthasar Cossa), May I4IO-May I4I5, dep.; ob. 14 I9.

In I $_{4}$ I 5 the Council of Constance deposed John XXIII, induced Gregory $\mathrm{XII}$ to resign, and elected

Martin V (Otto Colonna), Nov. I417 -Feb. I43I.

Eugenius IV (Gabriel Condulmier), March I43I-Feb. I447.

Nicholas V (Thomas de Sarzana), March I 447-March I 455.

Calixtus III (Alfonso Borgia), April 1455-Aug. I 458.

Prus II (Eneas Silvius Piccolomini), Ang. I458-Aug. 1464.

Paul II (Peter Barbo), Aug. I464-July I 47 I.

Sixtus IV (Francis della Rovere), Aug. I 47 I-Aug. I 484 .

InNocent VIII (John Baptist Cibo), Aug. I484-July 1492.

Alexander VI (Rodrigo Borgia, Abp. of Valencia), Aug. I492-Aug. :503.

PIUs III (Francis Piccolomini), Sept.-Oct. 1503.

Julius II (Julian della Rovere), Nov. I 503-Feb. 1513. 


\section{0 - List of the Popes}

LEO X (Giovanni de' Medici), March I5I3-Dec. I52I.

ADRIAN VI (tutor of Charles V), Jan. I 522 -Sept. I 523.

Clement VII (Giulio de' Medici), Nov. I 523 -Sept. I534.

PAUL III (Alexander Farnese), Oct. I 534-Nov. I 549.

Julius III (John Maria del Monte), Feb. I 550-March I 555 .

Marcellus II (Marcello Cervini), April 1555.

PAUl IV (John Peter Caraffa), May I555-August I559.

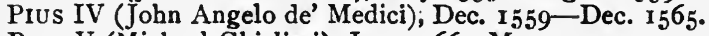

PIUS V (Michael Ghislieri), Jan. I 566-May I 572.

Gregory XIII (Hugh Buoncompagno), May I 572 -April ${ }_{585}$.

Sixtus V (Felix Peretti, Card. of Montalto), April I $5^{8} 5$-Aug. I 590.

URBAN VII (John Baptist Castogna), Sept. I590.

Gregory XIV (Nicholas Sfondrati), Dec. I590-Oct. I 59 I.

INNOCENT IX (John Antony Facchinetti), Oct.-Dec. I59I.

Clement VIII (Ippolito Aldobrandini), Jan. I592-March 1605.

Leo XI (Alexander Octavian de' Medici), April 1605.

PAul V (Camillo Borghese), May I605-Jan. I62I.

Gregory XV (Alexander Ludovisio), Feb. 1621-July I623.

URBAN VIII (Maffeo Barberini), Aug. I623-July 1644 .

InNucent X (John Baptist Pamphilo), Sept. I644-Jan. 16:5.

Alexander VII (Fabio Chigi), April 1655-May I667.

Clement IX (Julius Rospigliosi), June 1667 -Dec. I669.

Clement X (John Baptist Altieri), April 1670-July 1676.

INNOCENT XI (Benedict Odescalchi), Sept. 1676-Aug. I689.

Alexander VIII (Peter Ottobuoni), Oct. 1689-Feb. r69I.

INNOCENT XII (Antonio Pignatelli), July I69I-Sept. I 700.

Clement XI (John Francis Albano), Nov. $1700-$ March I721.

InNocent XIII (Michael Angelo Conti), May I721-March I724.

Benedict XIII (Peter Francis Orsini), May 1724-Feb. 1730.

Clement XII (Lorenzo Corsini), July I730-Feb. 1740.

BenEDICT XIV (Prosper Lambertini), Aug. I 740-May I $75^{8}$.

Clemen'T XIII (Charles Rezzonico), July I 758 -Feb. I 769.

Clement XIV (John Vincent Ganganelli), May I769-Sept. I 774.

Pius VI (John Angelo Braschi), Feb. I775-Aug. I799.

PIUS VII (Gregory Barmabas Chiaramonte), March 1800-Aug. I823.

LEO XII (Hannibal della Genga), Sept. I 823-Feb. I829.

PIUS VIII (Francis Xavier Castiglione), March $1829-N o v .1830$.

Gregory XVI (Maurus Capellari), Feb. I831-June 1846.

Pius IX (John Mastai-Ferretti), June $1846-F e b .1878$.

LEO XIII (Joachim Pecci), Feb. 1878 -July I 903.

Pius X (Joseph Sarto), Aug. 1903-Aug. 1914.

BENEDICT XV (James della Chiesa), elected Sept. I9 I4. 


\section{INDEX}

\section{A}

Abruzzi, 34, 101, 153-4.

Accialli, Treaty of (1890), 505 .

Accursius, jurist of Bologna, 137 . Acre, 52.

Acton, 3 ro.

Adda, River, 85, $210,219$.

Adelaide of Burgundy, wife of Otto I, 27.

Adelaide of Savona, wife of Roger I, Count of Sicily, ro5. Adelaide, Marchioness of Turin, 35 .

Adige, River, I 5, 20.

Adorno, Botta, 290.

Adowah, 507 .

Adriatic Sea, $115,242$.

Aegean Sea, 43, 272.

Aeneas Silvius: see Pius II, Pope.

Africa, 1, 7, 12, 25, 105.

African provinces of Empire, 17 .

Agilulf, King of the Lombards, I4.

Aimé of Monte Cassino (Amatus), chronicler, 96.

Aistulf, King of the Lombards, $19,65,66,77$.

Aix-la-Chapelle, Peace of, 268, 269.

Ajugari, Lucrezia, 333 .

Alaric I, King of the Visigoths, 8. Alaric II, King of the Visigoths, 135.

Albani, Cardinal, 301.
Albania, $5 \circ 7$.

Albany, Countess of, 352.

Alberic, Prince and Senator of the Romans, 77.

Alberic, Marquess of Spoleto, 77 .

Alberoni, Cardinal, 263, 264 .

Alberti, Leo Battista, architect, I 76,193 .

Albizzi, House of, 167, 169-70, 202.

Albizzi, Maso degli, I69.

Albizzi, Rinaldo degli, I69.

Alboin, King of the Lombards, 13.

Albornoz, Cardinal, 186.

Aldobrandini, Cardinal, 299.

Alessandria, 48, 268, 370, 410, $425,444,494$.

Alexander III, Pope, 47, 48, 86, $89,90$.

Alexander V, Pope, 188.

Alexander VI, Pope, 196, 229, 230.

Alexander VII, Pope, 255, 300, 319.

Alfieri, Vittorio, 343, 352 .

Alfonso of Aragon : see Aragon. Algeçiras, 508 .

Almohades, 107.

Alps, I I, I 2, I 5, 20, 25, 29, 35, 38, $51,65,66,71,190,196,217-$ I8, 246, 247, 25 I.

Alva, Duke of, 244 .

Amadeo, Giovanni Antonio, architect, 2I3. 
Amalfi, city of, 43,105 ; republic of, 25.

Amalric, King of the Visigoths, II.

Amati, Andrea, 332.

Amati, Supramonte, I6r.

Amminato, 336.

Anaclete II, Antipope, 45 .

Anagni, 157, 158, 163 .

Ancona, 46, 195, 377, 445, 457 ff.; march of, 52, 90, 91.

Angelico, Fra Giovanni, painter, 193, 205.

Aniene, valley of the, 120.

Anjou, Charles of, Duke of Calabria, 168.

Anjou, Charles I, Duke of, King of the Two Sicilies, 93, 98, 114 , I46-53, 155, 163, I96.

Anjou, Charles II, Duke of, King of Naples, 153, 162.

Anjou, Charles III of, King of Naples, 196, 197.

Anjou, Joanna I of, Queen of Naples, 196, 197, 198.

Anjou, Joanna II of, Queen of Naples, 189, 197, 198.

Anjou, John of, 162-3.

Anjou, Ladislas of, King of Naples, 187, 188, 189, 197.

Anjou, Louis, Duke of, 196, 197 . Anjou, René, Duke of, King of Provence, 198, 200, 201, 203.

Anjou, Robert, Duke of, King of

Naples, 162-3, 168, 196, 198.

Anne of Brittany, 229.

Apennines, 13, 15, $178,245$.

Apulia, 26, 30, 34, 51, 53, 96, 97,

98, 99, III, II3; Byzantine

cities of, 3I, 34; duchy of, 45,

99, 101, 103, 106, 109, I 10.

Aquapendente, 89 .

Aquileia, 8.

Aquino, 70.

Aquitaine, 7, 8, I35.
Arabs, 104, II4.

Aragon, Alfonso of, King of Aragon, and of the Two Sicilies, I 71, 198-9.

Aragon, Alfonso of, King of Naples, 2 I 6.

Aragon, Constance, Queen of, 153.

Aragon, Federigo of, King of Naples, 206.

Aragon, Ferdinand the Catholic, King of : see Spain.

Aragon, Ferrante of, King of Naples, 199, 200, 201, 216.

Aragon, Ferrantino of, King of Naples, 218.

Aragon, Frederick of, King of Sicily, 1 54, 156.

Aragon, Isabella of, Duchess of Milan, 520.

Aragon, Peter of, King of Aragon and Sicily, 153 .

Arbogast the Frank, magister militum, 7 .

Arce, 70.

Ardoin, Governor of Melfi, 98 .

Arduin, Marquess of Ivrea, King of Italy, 32, 35 .

Argenson, d', 267.

Aretino: see Bruni, Leonardo.

Arezzo, 167.

Arians, 7, I I, I4.

Arichis, Prince of Benevento, 22, 70.

Ariosto, Ludovico, poet, 223 .

Aristotle, I I3, I I4, 139.

Ariulf, Duke of Spoleto, 62.

Arnold of Brescia, 88, 125.

Arnulf, King of the Franks, Emperor of the West, 27.

Arpino, 70 .

Arqua Petrarca, 185.

Ascoli (Satriano), 98.

Asiatic provinces of Empire, 17.

Aspromonte, battle of (1862), 475 . 
Assisi, 128, I3 I.

Athaulf, King of the Visigoths, 8 . Attila, King of the Huns, 8.

Augsburg, League of, 257 .

Augsburg annalist, 4I.

Authari, King of the Lombards, I4.

Ave̊llino, 365 .

Aventine, 32 .

Averroes, I 14, 140.

Aversa, 34, 97 ; county of, 99 .

Avignon, 255, $3 \circ 3$; Papal 'captivity at, $157,160,163,171$, I83, 186.

Avlona, 5 II.

Azeglio, Massimo d', 393 ff., 410, 419, 420, 42I, 422, 424, 43I, 440, 457,470 .

\section{B}

Baduila (Totila), King of the Ostrogoths, 12.

Baglioni, Gian Paolo, 172.

Balbo, Cesare, $392 \mathrm{ff}$., 403, 418. Baldwin, Latin Emperor of the East, 146.

Bamberg, Bishopric of, 83 .

Baratieri, General, 507.

Barbarian Italy, 58.

Barbarini family, 297, 300.

Baretti, $35^{\circ}$.

Bari, 25, 30, 34, 97, 101, 105, I I I. Baronius, Cardinal, 317.

Barry, Madame du, 33I.

Bartolozzi, 35 I.

Basel, Council of, 192, I93.

Basil I, Emperor of the East, 26. Basileus, 96.

Bassi, Laura, 328.

Beatrice, Duchess of Tuscany, 37.

Beauharnais, Eugène de, 357, $35^{8}, 377$.
Beccaria, 307, 308, 348, 349 .

Bedmar, Count, 249 .

Belisarius, Roman general, I2.

Bellarmini, Cardinal, 298.

Bellini, Gentile, Giovanni, and Jacopo (painters), 2 I0, 222.

Belluno, I74.

Bembo, Cardinal, 224.

Benedict VIII, Pope, 36, 79 .

Benedict IX, Pope, 80.

Benedict XIII, Pope, 187, 30I, 3 I 6.

Benedict XIV, Pope, 302, 318.

Benedict, Prior of Chiusa, 134 .

Benevento, 13, 55, 83, 100; battle of (1266), I48-9; duchy of, $\mathrm{I}_{3}, \mathrm{I}_{5}, 22,25,34,69,70,84$; patrimonies in, 70 ; principality of, 103 .

Berengar I, King of Italy (Marquess of Friuli), Emperor of the West, 27.

Berengar II, King of Italy (Marquess of Ivrea), 27, 77 .

Bergamo, 48, 2 I0, 21 I.

Bernini, 336.

Bertinoro, County of, 91 .

Bessarion, Cardinal, 2 Io.

Bibbiena, Bernardo da, 225:

Bishops, Italian, 29; Lombard, 28.

Bismarck, Prince Otto von, 480 , $486 \mathrm{ff}$.

Black Sea, 7 .

Boamund, Prince of Taranto and Antioch, 4I, I03.

Boccaccio, Giovanni (poet), I65, I83, 3 I6.

Boethius, I I.

Bohemia, John, King of, 183 .

Bologna, 18, 48, 57, 140, 177, 188, 192, 237, 321, 328, 329, $337,374,375,376,408,445$; Archdeacon of, I38 ; Bishop of, I39; Law School of, 136, 
138; Medical School of, I39;

'Universities' of, 138 .

Bolognese doctors of the law, 137, 138, 139 .

Bolognese students, 138 .

Bonaparte, Jerome, 377 .

Bonaparte, Joseph, King of Naples, 357, 363.

Boniface, Marquess of Savona, 105.

Boniface VIII, Pope, 154-7, I63.

Bonifilius, jurist of Pavia, 136 .

Borelli, 327.

Borghese, family, 300 .

Borghese, Marco, 35I.

Borgia, Rodrigo: see Alexander VI.

Borgognone, Ambrogio Stefano da Fossano (painter), 214.

Borromeo, Cardinal Carlo, 278, 299, 314, 330, 348.

Borromeo, Federigo, 317.

Borugia, Cesare, 225, 229, 230, 231.

Botero, 348.

Botticelli, Sandro (painter), 207.

Bramante (architect), 213, 226.

Brancaleone, 144-5.

Brescia, 210, 409, 474.

Brienne, Walter de, Duke of Athens, 169.

Brienne : see John of Brienne; Yolande of Brienne.

Brindisi, 15, 52 .

Brosses, des, 3 II.

Brossolo, Treaty of, 247.

Brunelleschi, Filippo (architect), 204.

Bruni, Leonardo, 203, 204.

Bruno, Giordano, 278, 316, 3 I9.

Bruno, Bishop of Toul: see Leo IX.

Bruno of Carinthia : see Gregory V, Pope.

Bucharest, Treaty of (1913), 5 ro.
Bulgarus, jurist of Bologna, 137 . Buonacolsi, House of, 176 .

Buoncompagni, Carlo, 452.

Buonconvento, I60, I63.

Buonincini, 331.

Burgundians, 7, I I.

Burgundy, 35, 40, 135 .

Burlamacchi, 291 .

Busento, River, 8.

Butrinto, Nicholas, Bishop of, I 82.

Byrom, 331.

Byzantium, I7, 24, 31, 34, 43, $68,93,105,112$, II 3 .

\section{C}

Cagliostro, 343.

Cairoli, M., 503 .

Calabria, 15, 26, 30, 31, 96, 99, 101, 103, 105, 127; patrimonies in, 70 .

Calatafimi, battle of (1860), 46r.

Calixtus II, Pope, 40, I00.

Caltabellota, Peace of (1302), 156.

Camaldolesi, 124.

Camaldoli, r24.

Cambio, Arnolfo di (architect), 165.

Cambrai, League of, 211, 219, 220, 222, 223.

Campagna, 89 .

Campanella, 320.

Campania, I 5, III ; patrimonies in, $6 \mathrm{r}$.

Canaletto, 346.

Candia, 272.

Cannae, 97.

Canonists, 8r.

Canossa, 83 ; fortress of, 38,39 ; House of, 35, 37, 84 .

Canova, 35I.

Capella Palatina, I I 2.

Capitol (Rome), 46, 88.

Capua, 70 ; city of, 99 ; princi- 
pality of, $34,45,97,99, \mathbf{I} \circ \mathbf{I}$, Iо6, Iо9, 1 Iо.

Capuan cities, 84 .

Caracci family, 337.

Caraccioli, 304, 3 I I.

Caraffa family, 297.

Caravaggio, 3 I 6 .

Cardano, 321.

Carlo Emanuele I of Savoy, 246, 247, 248, 249, 25 1, 292, 348.

Carlo Emanuele II of Savoy, 252, 254, 257, 293.

Carlo Emanuele III of Savoy, 264-9, 274, 294.

Carmagnola, Francesco, Count of, 2 I I.

Carpaccio, Vittore (painter), 222.

Carrara, House of, I65, I75-6, I 79, 182 .

Carrara, Francesco da, 175.

Carrara, Francesco Novello da, 176.

Carrara, Jacopo da, 175 .

Casale, 25 I, 254-9, 289, 332, 425.

Casanova, 343 .

Casauria, monks of, 26.

Cassini, 328.

Cassiodorus, I I, I 2 I.

Castelfidardo, battle of (I860), 465.

Castelli, 326.

Castiglione, Baldassare, 2 I 6, 224.

Castracani, Castruccio, I67-8.

Castro, 289, 300, 303.

Catapans, 96.

Cateau Cambresis, Peace of, 238, 244.

Catenat, 257, 258.

Catepani, I 10.

Catharists, 127.

Cavalcabô, Guglielmo, I6I.

Cavalieri, 328.

Cavour, Camillo Benso Conte di, $386,3^{87}, 395,400,402,411$, 1832.3
417,418 ff., 455,456 ff., 466 ff., 481 .

Cefalù, cathedral of, 112.

Celestine V, Pope, I 54.

Cellini, Benvenuto, 313, 322.

Cenci family, 314 .

Central Italy, 27, 48, 49, 50, 51, $55,65,84,89,91,92,127,133$. Ceprano, 9r.

Cermenate, Giovanni da, I6r.

Cesalpino, 322.

Chamberlains, I 10.

Charles, Infant of Spain, King of Naples, 264, 267, 268, 302, 309, 310, 316.

Charles of Anjou : see Anjou.

Charles the Great, King of the

Franks and Lombards, Emperor of the West, 20, 22, 23, 24, 29, 30, 54, 69, 70, 71, 72, 84,92 ; grandsons of, 25 .

Charles, Duke of Valois, I 56.

Charles II, the Bald, Emperor the West, 27, 76.

Charles II of Spain, 261.

Charles II, Duke of Parma, 36I. Charles III, the Fat, Emperor of the West, 27, 76 .

Charles III, Duke of Parma, 4I5.

Charles IV, Emperor, I83, 186.

Charles V, Emperor, 176, 220, 235, 237, 238, 240, 244, 289.

Charles VI, Emperor, 262-6, 305, 317.

Charles VIII : see France.

Charles Albert, King of Sardinia, 368 ff., 382, 387, 388, 390, 39I, 398,400 ff., 407, 409, 410.

Charles Felix, King of Sardinia, 370, 37 I, 388.

Charles Martel, I8.

Chigi family, 301 .

Chioggia, taking of (137I), 18 r. Christina, Queen of Sweden, 318,

327. 
Christine of France, Duchess of Savoy, 252, 253, 293.

Christodulus, Admiral, 105.

Chrysoloras, Manuel, 203.

Church, States of the, I $54-5$, $177,186-7,190,192-3$, 195, 200, 233. See also Papal States.

Cialdini, General, 473, 476, 489 .

Cicero, I34.

Ciompi, Rising of the (1378), 169 .

Cistercians, I I8.

Civita Vecchia, 4I I, 4I3, 494, $495,497,502$.

Civitate, first battle of, 97 ; second battle of, 84,100 .

Clairvaux, Abbot of : see Saint Bernard.

Clarence, Lionel Duke of, 179.

Clarendon, Earl of, 43I.

Claude, 337 .

Clement II, Pope, 36.

Clement III, Pope, 88, 9 I.

Clement III, Antipope, 39 .

Clement IV, Pope, I48, I 50.

Clement V, Pope, I63.

Clement VII, Pope, 233-5, 237, 238.

Clement VII, Antipope, 187.

Clement VIII, Pope, 242, 299, 335 .

Clement XI, Pope, 261, 262, 301.

Clement XII, Pope, 302 .

Clement XIII, Pope, $3 \circ 3$.

Clement XIV, Pope, $3 \circ 3$.

Cleph, King of the Lombards, 13 .

Clotilda of Savoy, Princess Napoleon, 438,442 .

Cluniacs, 8I, i 18.

Cluny, Abbey of, 77, II I.

Cognac, League of (1526), 235 .

Colbert, 328.

Colleone, Bartolommeo, 2 I I.

Colonna, House of, $154,156$.

Colonna, Oddo: see Martin V, Pope.
Colonna, Sciarra, 157 .

Colonna, Vittoria, 225.

Comacchio, 288.

Commines, Philippe de, 170.

Como, 47.

Compagni, Dino, 154 .

Conrad II, Emperor of the West, $33,34,35,36,79,97$.

Conrad III, King of the Romans, 45,88 .

Conrad IV, King of the Romans and of Sicily and Jerusalem, 93, I43-4.

Conradin, King of the Romans, 98, 144-5, I49-50.

Constables, I Io.

Constance, Council of, 188,190 ; Peace of, 48 .

Constance of Aragon: see Aragon.

Constance, daughter of Roger II, Empress of the West, 49, 98 .

Constans II (Constantine), Roman Emperor, 17,63 .

Constantine I, Roman Emperor, $3,68,69,71,83,84,92$.

Constantinople, 3, 11, 18, 22, 61, $62,63,64,67,70$, 102, 106, 107, 108, 146, I5 I, I8I, 193.

Corelli, 332.

Corinth, 106.

Correggio, Niccold da (poet), 223. Corsica, I 5, 43, 69, 70, 84, 89, 290, 291.

Cortenuova, 53 .

Cortona, I67.

Cossa, Cardinal Baldassare : see John XXIII, Pope.

Cotentin, the, 97 .

Cotrone, battle of, 31,34 .

Cowley, Henry Lord, 443 .

Crema, 47, 2 10.

Cremona, 47, 53, 146, 161, 210, 219,332 .

Crescentii, 29, 79 .

Crete, 254, 271, 272. 
Crichton, the Admirable, 289,319.

Crimea, 63.

Crispi, Francesco, $463,5 \circ 5 \mathrm{ff}$.

Cristofori, 332.

Crusades, 4०, 43 .

Cuba, II2.

Cuneo, 267.

Curiales, 9.

Custozza, battle of (1848), 405 ; (I866) 489 .

Cyprus, 242, 27 I.

\section{D}

Dacia, 7.

Dalmatia, 24, I \&2, 242, 270, 272, 273, 359 .

Damasus II, Pope, 36 .

Dante, I I 5, I43, I 57-9, I75, I 84 , 216,350 .

Danube, River, $\mathrm{r}$.

Dardanelles, 272.

Depretis, Agostino, 477, $502 \mathrm{ff}$.

Derby, Edward, Earl of, 439, 443,447 .

Desiderius, Abbot of Monte Cassino, Pope Victor III, I0o.

Desiderius, King of the Lombards, 20, 66 ; Adelchis, son of, 22.

Diocletian, Roman Emperor, 2, 4 .

Domenichino, 337 .

Donatello, 205.

Donati, Corso, r68.

Doria, Andria, 244, 290.

Drogo of Hauteville, Count of Apulia, 34, 99.

Durazzo, 102.

Durazzo, Charles of : see Anjou, Charles III of.

Dux of Rome, 14, 19, 65, 67 .

E

East, Prefecture of the, 2. Eccelino da Romano, 53.
Edmund of England, King of Sicily, 93, 145 .

Edrisi, Arab geographer, I 13.

Egypt, 107.

Elba, island of, 243, 285, 360 .

Elbe, River, 95 .

Emanuele Filiberto of Savoy, $244,246,292,348$.

Emilia, 40, 85 ; province of, $45^{\circ}$, 452,455 .

Empire, Holy Roman, $5 \mathrm{I}$.

Empire, Western provinces of, II, 12.

England, 54, 95, I 8 I.

Enzio, son of Frederick II, King of Sardinia, 54, 57.

Eritrea, 507 .

Este, House of, I65, 201, 234.

Este, Alfonso d', 223, 287, 315, 338,339 .

Este, Azzo d', 177 .

Este, Beatrice d', 216, 223.

Este, Ercole d', 223.

Este, Francesco I d', 288.

Este, Francesco III d', 288, 306.

Este, Isabella d', 216, 223 .

Este, Leonello d', 222.

Este, Leonora d', 338 .

Este, Lucrezia d', $33^{8}$.

Este, Niccold d', 222.

Etna, Mount, 327.

Etruria, kingdom of, $36 \mathrm{r}$.

Etruscans, I.

Euclid, II3.

Eugene, Prince of Savoy, 257, $259,260,262,306$.

Eugénie, Empress of the French, 436,446 .

Eugenio, Prince, of Carignano, $45^{2}$.

Eugenius, Admiral, 105, I 13.

Eugenius II, Pope, 73, 74, I33.

Eugenius IV, Pope, I92, 193 . 
Exarch of Ravenna, I4, I8, I9, $61,63,64,68$. See Olympios, Ravenna.

\section{F}

Fabrizio, 322 .

Faenza, 66.

Faliero, Doge Marin, I80.

Fallopio, 322 .

Familiares, Iog.

Fanti, General, 450, $45^{1}$.

Farinelli, 333 .

Farini, Luigi Carlo, $449,45^{\circ}, 45^{\mathrm{I}}$, $45^{2}, 468$.

Farnese, Alessandro, 244, 288.

Farnese, Elizabeth, 263-8.

Farnese, Pier Luigi, 244.

Favara, I I2.

Federigo of Aragon : see Aragon. Felix V, Antipope, I93.

Feltre, Vittorino da, 174, 176, 215.

Ferdinand of Aragon : see Spain. Ferdinand, King of Naples and Sicily, 268, 269, 310, 31 I 362, $364,366,367,399,403,404$, 416,432 .

Ferdinand, Archduke of Austria, $288,306$.

Ferdinand of Spain, Duke of Parma, 3 II.

Ferdinand III, Grand Duke of Tuscany, 360.

Ferrante of Aragon : see Aragon.

Ferrantino of Aragon: see Aragon.

Ferrara, 66, 85, 89, I65, I77, I95, $201,212,220,222,223,234$, 375 .

Ferrara, Dukes and Duchy of, 240, 243, 287, 288, 299, 312, 338 .

Ferrara, Lords of : see Este, d'. Ferrari, Gaudenzio (painter), 2 I4.
Ficino, Marsilio, 205, 207.

Filangieri, 347, 349.

Filarete, Antonio (architect), 2 I 3.

Filelfo, Francesco, 214.

Finale, 266.

Fiore, Abbey of, 127 .

Fiorentino, 57 .

Fleury, Cardinal, 265, 266.

Florence, 126, 145, 148, 150,154 , $156,158,165-71,178$, 186, $187,189,190,192,195,200$, 20I-8, 2 I 9, 225, 228, 23I, 235, $237,238,264,274,275,285$, 312, 318, 326, 327, 328, 334, $336,402,445,45^{2}$.

Foggia, battle of (1254), I45.

Foix, Gaston de, 220.

Fontana, 335.

Fonte Avellana, 124.

Foppa, Vincenzo (artist), 214.

Fornovo, battle of (1495), 2 I 8.

Fortebraccio, 21 I.

Fortore, battle at the, 97 .

Foscarini, Doge, 317 .

France, 25, 51, 54, 95 .

France, Charles VIII, King of, 196, 201, 216-I9, 223, 224, 228.

France, Francis I, King of, 220, 22 I, 234, 236.

France, Isabella of, Duchess of Milan, 179.

France, Henry IV, King of, 242, $243,246,247$.

France, John, King of, 179, 196. France, Louis IX (St. Louis), King of, 57 .

France, Louis XII, King of, 219, 223, 229.

France, Louis XIV, King of, 254-9, 26I, 300.

France, Louis-Philippe, King of, $374,376,382$.

France, Philip IV, King of, 156. France, Philip VI, King of, 163 . Francis I : see France. 
lirancis, Duke of Lorraine, Duke of Tuscany, 266, 270, 307 .

Francis II, King of Naples and Sicily, $445,459 \mathrm{ff}$.

Francis IV, Duke of Modena, 360 , 373 ff., 382, 395 .

Francis Joseph, Emperor of Austria, 433, 446, 447 .

Franciscans, I28.

Franconia, 45 .

Frangipane, Giovanni, Lord of Astura, I49.

Frankish counts, 2 I ; emperors, 50.

Franks, 7, I1, 13, 19, 20.

Frederick of Aragon: see Aragon.

Frederick I, Barbarossa, Emperor of the West, 43, 47, 48, 49, $82,86,88,89,98$, I 37 .

Frederick II, Emperor of the West, King of Sicily and Jerusalem, 32, 49-57, 9I-3, 98, 104, 107, 108, І10, І1 3 , І1 4 , I I 5, I39, I4I-4, I48, 294, 329.

Friars, Minor, 55, I 18, I30, I3 I.

Friuli, Duchy of, 2 I, 28, 2 I0, 220.

\section{G}

Gabello, 66 .

Gaeta, 25, 99, 408, 409, 465.

Gaetani, the House of, I 55 .

Gaetani, Benedetto, Cardinal: see Boniface VIII.

Gaetani, Loffredo, Count of Caserta, 155 .

Gaiseric the Vandal, 8.

Galen, 139.

Galiani, 349 .

Galilei, Galileo, 3I6, 32 I, 323-7.

Galilei, Vincenzo, 330 .

Galla Placidia, 8.

Galvani, 329.

Garfagnana, 85, 292.

Garibaldi, Giuseppe, 388, 414, $435,437,44 \mathrm{I}, 442,450,45 \mathrm{I}$,
456 ff., 474 ff., 479, 489, 493 , 494.

Garibaldi, Menotti, 505 .

Garigliano, battle of (1 $5 \circ 3), 27$, 219 ; River, 35.

Garrick, 350 .

Gastein, 487 .

Gaul, 7, 8, I I ; Southern, 135 .

Gauls, Prefecture of the, 2.

Gelasius I, Pope, 4, I I 9 .

Geneva, 246, 257 .

Genoa, I 5, 43, I 15, I65, I8 I, I 99, $244,25 \mathrm{I}, 256,257,266,267$, $270,275,290,291,376,383$, $396,433,474$; duchy of, $36 \mathrm{I}$; republic of, $36 \mathrm{r}$.

Genovesi, 349 .

George of Antioch, Great Admiral, 108 .

Gepids, 7 .

Gerbert, Pope Silvester II, Archbishop of Ravenna, 31, 68, 78, 79 .

German electors, 45,49 .

German princes, $38,46,87$.

Germans, 3 I, 87 .

Germany, 29, 30, 33, 35, 36, 39, $40,45,49,50,5$ I , 54, 56, 57, $92,93,98$; King of, 54 ; kingdom of, $25,9 \mathrm{I}$.

Ghiara d'Adda, 2 19, 220.

Ghibellines, 45, 145-50, 153 , $156-$ $7,160-3,169$.

Ghiberti, Lorenzo (sculptor), 204. Ghirlandaio, Domenico (painter), 207, 227.

Giacoma of Settesoli, I3 I.

Giannone, 302 .

Gibbon, 294.

Gioberti, Vincenzo, 387, 391 ff., $397,420$.

Giorgione (painter), $210,222$.

Giotto, $155,158,204$.

Giovanna, Battista, Duchess of Savoy, 257, 293. 
Gizzi, Cardinal, 397.

Gluck, Christopher, $33 \mathrm{i}$.

Godfrey of Bouillon, King of Jerusalem, 4I.

Goito, 403 .

Goldoni, 345, 350 .

Gonzaga, 85 ; House of, 165 , 176.

Gonzaga, Anna Isabella, 289.

Gonzaga, Carlo II, 289.

Gonzaga, Elisabetta, Duchess of Urbino, 224.

Gonzaga, Ferdinando Carlo, 289, 290.

Gonzaga, Francesco, Marquess of Mantua, 223.

Gonzaga, Gian Francesco II, Marquess of Mantua, 176.

Gonzaga, Guglielmo, 289.

Gonzaga, Ludovico, Marquess of Mantua, 176.

Gonzaga, Vincenzo II, 289.

Gorizia, 359, 511 .

Goths, 5, 7 .

Govone, General, 487 .

Gozizi, 346.

Gozzoli, Benozzo (painter), 193, 206.

Gradisca, 249 .

Graeco-Romans, 104.

Granada, Treaty of (1500), 219.

Gratian, canonist, 124,138 .

Greccio, 130.

Greece, 92, 95.

Greek cities of Southern Italy, I.

Greeks, 31, 35, 87, 96, 97, 98, 99, I0I, 104 .

Gregory I, the Great, Pope, I4, 61, 62, 63, 69, II9.

Gregory II, Pope, I8, 64 .

Gregory V, Pope, 31 .

Gregory VI, Pope, 8I.

Gregory VII, Pope (Hildebrand), $37,38,39,40,75,81,82,83,84$, IOI, 124,136 .
Gregory IX, Pope, 5 I, 52, 53, 54, 55,92 .

Gregory X, Pope, I 5 I-2, I 57 .

Gregory XI, Pope, 187.

Gregory XII, Pope, 187.

Gregory XIII, Pope, 299.

Gregory XVI, Pope, 394, 396, 397.

Grimaldi, 328.

Grimm, 349 .

Grimoald, Duke of Benevento and King of the Lombards, 15 .

Grisons, the, 248, 249, 270.

Grottaferrata, Abbey of, 123.

Guaimar V, Prince of Salerno, $34,98,99$.

Guardi, 346 .

Guarini, 339 .

Guarino, Veronese, $215,222$.

Guelf and Ghibelline, 45 .

Guelf Italy, 57.

Guelfs, 45, 145, 147, 150, 156, $160-3,169,17$ r.

Guercino, 337 .

Guibert, Archbishop of Ravenna, Antipope Clement III, 39 .

Guicciardini, Francesco, 1 66, 208.

Guise, Duke of, 254, 282.

Gustavus II (Gustavus Adolphus), King of Sweden, 250.

Guy of Spoleto, Emperor of the West, 27.

Guy, Marquess of Tuscany, 77 . Gyulai, Marshal, 445 .

\section{$\mathrm{H}$}

Hadrian I, Pope, 20, 22, 69.

Hadrian IV, Pope, 46, 47, 82, 86, $89,103$.

Hadrianople, battle of, 7 .

Handel, George Frederick, 331, 332.

Hapsburgs, 237, 240，24I，249, 253, 26I, 284, 291. 
Harvey, William, 322.

Hasse, 333.

Hauteville, House of, 34, 97, 102. Henry II, Emperor of the West, $33,34,36,79,83$.

Henry III, Emperor of the West, $33,34,36,37,80,82,83,99$, I 00.

Henry III, King of England, 57. Henry IV, Emperor of the West, $37,38,39,82,83$, 101, 105, 136. Henry IV of France: see France. Henry V, Emperor of the West, $39,40,85$, I37.

Henry VI, Emperor of the West, King of Sicily, 32, 49, 50, 53, 90, 91, 98, 107 .

Henry (VII), King of the Romans, 51,53 .

Henry VII (of Luxemburg), Emperor, 141, 159-63, 167, I73.

Henry Aristippus, Archdeacon of Catania, I I3.

Henry the Lion, Duke of Saxony, 50.

Henry the Proud, Duke of Bavaria, 45,85 .

Herculaneum, $35 \circ, 35$.

Heribert, Archbishop of Milan, 35,36 .

Herlembald, leader of the Pataria, $4 \mathrm{I}$.

Hermann, Bishop of Metz, 83.

Hermann the German, I1 3 .

Heruli, 9.

Hildebrand: see Gregory VII, Pope.

Hippocrates, I 39 .

Hohenburg, Margrave Berthold of, 144 .

Hohenstaufen, $85,87,93,114$.

Holy League (1511), 220.

Holy Places, 4I, 95 .

Holy Roman Empire, 5 I.
Holy Sepulchre, Church of, $5^{2}$. Honorius, Roman Emperor, 8. Honorius III, Pope, 51, 52.

Horace, 134 .

Hugh, jurist of Bologna, 137 .

Hugh, King of Italy (Marquess of Provence), 27, 77 .

Humbert I, King of Italy, 501 .

Humiliati, 126, I31.

Humphrey, Duke of Apulia, 99 .

Hungarians, 25, 27, 28, 33 .

Huns, $7,8$.

I

Illyricum, Prefecture of, 2.

Innocent II, Pope, 45, 46, 80; 84, $85,86,88$, 106.

Innocent III, Pope, 32, 50, $5 \mathrm{I}$, $83,87,89,90,91,92,126$.

Innocent IV, Pope, 54, 56, 57, 86, 92, 93, I14, I43-4.

Innocent X, Pope, 300.

Innocent XI, Pope, 255.

Innocent XII, Pope, 261.

Insula Fulcherii, 85.

Irene, Roman Empress, 24.

Irnerius, jurist of Bologna, 137 .

Isabella of Aragon : see Aragon.

Isabella of France: see France.

Isonzo, River, 210.

Istria, 24, 69, 70.

Italy, Prefecture of, 2.

$\mathrm{J}$

James II, King of England, 288.

James, jurist of Bologna, 137 .

Jerusalem, 4I, 95; kingdom of, $52,54,108$.

Jewish scientists, 140.

Jews, I1 104 .

Joachim, Abbot of Fiore, 127, 128.

Joanna of Anjou : see Anjou. 
John VIII, Pope, 76 .

John XI, Pope, 77.

John XII, Pope, 28, 29, 77, 78, 80 .

John XIX, Pope; 36 .

John XXIII, Pope, I 88.

John, Don, of Austria, 289.

John of Anjou: see Anjou.

John of Boulogne, 336 .

John of Brienne, King of Jerusalem, 52.

John of France: see France.

John of Procida, I 53.

John Zimisces, Emperor of the East, 30.

Johnson, Dr., 291, 356.

Joseph II, Emperor, 304-8, 311 .

Julius II, Pope, 226.

Justiciars, I IO.

Justinian I, Roman Emperor, 6, I I, I 2, I3, 19, 46, 58, I35, 136 . Juvenal, I 34 .

\section{K}

Kaunitz, 305, 306.

Kepler, 324.

Kircher, $35^{\circ}$.

Königgrätz, battle of (I 866), 489 .

L

Ladislas of Anjou : see Anjou.

La Farina, Giuseppe, 434, 435, 463.

Lagrange, 329 .

La Guéronnière, 442, 454 .

Laibach, I3.

La Marmora, General, 425, 428, $429,438,484,486$ ff.

Lambert of Spoleto, Emperor of the West, 27.

Lamoricière, General, 458, 464, 465.

Lancaster, Edmund of : see Edmund of England.
Landino, Cristoforo, 207.

Lanfranc, Archbishop of Canterbury, jurist of Pavia, 136 .

Lateran palace, 68, 71.

Latin Empire at Constantinople, the, 146,151 .

Latin League, I.

Lausanne, Treaty of (1912), 509.

La Verna, I 20, 130.

Le Carceri, 120.

Lechfeld, battle of, 33 .

Leghorn, I67, 383, 41 1, 433. See also Livorno.

Legnano, battle of, 48 .

Leo I, Pope, 8.

Leo III, the Isaurian, Roman Emperor, 17, 18, 19, 64 .

Leo III, Pope, 22, 23, 70, 71, 72.

Leo IV, Pope, 25,75 .

Leo IX, Pope, 36, 74, 80, 8 I, 83, 100.

Leo X, Pope, 225, 226, 23I, 233, 234, 314.

Leo XIII, Pope, 50 I.

Leopold of Austria, Grand Duke of Tuscany, 269, 270, 304, 305, 307-9, 3 I I, 342.

Leopold II, Grand Duke of Tuscany, 398, 409, 4I5, 445, 447.

Lepanto, 242, 271 .

Liguria, I 3 , I 5 .

Lippi, Fra Filippo (painter), 206. Lissa, engagement at (1866), 490, 5 II.

Livorno, 285, 286.

Lodi, 42, 47, I6I ; Treaty of (1454), 199, 200, 203, 210, 212.

Lombard bishops, 33, 35, 134 ; cities, 42, 46, 47, 48, 137; dukes, I4, 2I ; Italy, I5, 24, 69 ; kingdom, 17, 19, 24, 58, 93 ; League, $48,49,53,89$; princes, 99; principalities of Southern Italy, 96 ; states, 30 . 
Lombards, 13 14, 15, 19, 26, 33, $35,62,64,97,98,100,135$; of Spoleto, 18 .

Lombardy, I 5, 27, 33, 35, 37, 39, $5 \circ, 52,53,54,56,71,85$, 134, 1 $36,145,189,237,241,250$, 253, 256, 258-60, 262, 265, 267, $270,277,278,28$ I-4, 305-7.

Lombardy-Venetia, kingdom of, $357,399,4$ I 6, 447 .

London, Treaty of (1913), 5 IO.

Lothar I, Emperor of the West, $72,73,74,133$.

Lothar II, King of Italy, 27.

Lothar II, King of Lotharingia, 75 .

Lothar III, Emperor of the West, $35,45,85,86$, 106 .

Lotto, Lorenzo (painter), 222.

Louis, Duke of Orleans, I79, I99, 219.

Louis of Anjou: see Anjou.

Louis, King of Etruria, 36r.

Louis I, the Pious, Emperor of the West, 70, 72, 73, 78, 91.

Louis II, King of Italy and Emperor of the West, 25, 26, 75, 76.

Louis III, King of Provence and Italy, Emperor of the West, 27.

Louis IV (of Bavaria), Emperor, I7I, I83.

Louis IX (St. Louis) : see France.

Louis XII : see France.

Louis XIV: see France.

Louis-Philippe : see France.

Louvois, 254-8, 283.

Lucca, 150, 167, 178, 187, 244, 277,291 ; duchy of, 360,361 .

Luini, Bernardino (painter), 2 I4.

Luitprand, King of the Lombards, 18, 19, 20, 64 .

Luna, 20, 69 .

Lyon, 126; Council of, 56 ; Treaty of, 246 .
M

Machiavelli, Niccolò, I68, I77, $230-3,313$.

Maderna, 336 .

Magalotti, 326 .

Magenta, battle of (1859), 445 .

Maggiore, L., 266.

Magliabecchi, 317 .

Maidalchini, Olympia, 300 .

Maio, Great Admiral, Iog.

Majorca, 43, 107.

Malatesta, House of, I90, 192.

Malpighi, 327.

Manfred, Prince of Taranto, King of Sicily, 93, I I3, I43-5 I, 153,163 .

Manin, Daniel, 433, 434.

Mantegna, Andrea (painter), 176, 223.

Mantua, 69, 85, 165, 176, 220, $222,223,250,251,282$, 289, 312, 4I6, 447, 45 I, 453; duchy and dukes of, 244,246 , 250-2, 255, 258, 261, 262, 289, 290, 305 .

Mantua, Marquesses of : see Gonzaga.

Manuel Commenus, Emperor of the East, 46.

Manuzio, Aldo, 210, 223.

Manzoni, Alessandro, 250, 372.

Maratta, Carlo, 337.

Marcellus, Pope, 33I.

Marches, 9I, I24.

Margaret of Austria, Grand Duchess of Tuscany, 286.

Marguerite of Orleans, Grand Duchess of Tuscany, 287.

Maria Amalia of Austria,Duchess of Parma, 3II.

Maria Amalia of Saxony, Queen of Naples, 309.

Maria Carolina of Austria, Queen of Naples, 3 Io. 
Maria Luisa, Duchess of Lucca, $36 \mathrm{I}$.

Maria Luisa, Duchess of Parma, $360,361,362,375$.

Marignano, battle of (1 $\left.5^{1} 5\right), 220$.

Marino, 339, 340.

Maritime republics, 30 .

Marlborough, Duke of, 259.

Marmontel, 349 .

Marozia, daughter of Theophylact, 77 .

Marquesses, 27, 28, 35, 47 .

Marsala, 461, 476 .

Marseilles, 383 .

Marsia, 78 .

Martin I, Pope, 17, 63.

Martin V, Pope, 188, 190, 191, 192.

Martin, jurist of Bologna, 137 .

Masaccio (painter), 204.

Masaniello, 282, 283.

Massa Fiscaglia, 89.

Massowah, 505 .

Matilda, Countess of Tuscany, 37, $38,40,85,89,136,137$.

Matilda, daughter of Roger Count of Sicily, and wife of Conrad, the anti-king, 105.

Matildine Lands, $85,86,89$, 9o, 9 I.

Mattioli, 256.

Maurice, Roman Emperor, 62.

Maximilian, Archduke, 440, 447.

Maximilian I, Emperor, 219, 220.

Mazarin, 253, 282.

Mazzini, Giuseppe, 371, 372, 374, 377,378 ff., $398,406,4$ I I ff., $433,456,460,464,479,483$, 501 .

Medeah, el-, 106.

Medici, House of, 142, 170, I89.

Medici, Alessandro dei, 238, 243.

Medici, Cosimo dei, 170, 200, 202-6.
Medici, Cosimo I dei, 240, 243, $285,286,316,317$.

Medici, Cosimo II dei, 286, 324 .

Medici, Cosimo III dei, 255, 274, $287,327$.

Medici, Ferdinando I dei, 243, $285,286$.

Medici, Ferdinando II dei, 286, 320, 324-7.

Medici, Francesco I dei, 243, 286, $316,323,347$.

Medici, Gian Gastoni dei, 287.

Medici, Giovanni dei : see Leo X, Pope.

Medici, Giuliano dei, 207, 225.

Medici, Giulio dei : see Clement VII, Pope.

Medici, Leopoldo dei, 325, 326, 327.

Medici, Lorenzo dei, 200, 202, 206-8, 230, 315 .

Medici, Lorenzo dei, Duke of Urbino, 225, 233.

Medici, Maria dei, 243, 330.

Medici, Piero dei, 208, 228, 23 I.

Mediterranean, 241, 270.

Melegnano, battle of (1859), 445 .

Meles of Bari, 34, 96 .

Melfi, 34, 98, 99, 100, 107 ; Constitutions of, 53 ; Synod of, 84 . Menelik, King of Shoa, 505 .

Mengs, Raphael, $35 \mathrm{I}$.

Menotti, Ciro, 374, 382 .

Mentana, engagement at (1867), 494.

Mercato, piazza del, Naples, 98 .

Messina, 97, 105, 110, 256, 281, $283,466$.

Metastasio, 344 .

Michael (Palaeologus), Eastern Emperor, 153 .

Michael the Scot, I13.

Michelangelo, Buonarrotti (painter), 204, 226-8, 238, 312, 333-6. 
Michelozzi, Michelozzo (architect), 205.

Milan, 8, 35, 37, 41, 42, 47, 48, 160, 162, 165, 178, 189, 201, 208, 210, 212-17, 219, 220, $221,227,229,235,240,262$, 284, 312, 31 7, 399 ff., 417, 445 ; duchy of, $238,247,248,252$, $259,260,262,265,266,359$, $36 \mathrm{r}$.

Milan, Isabella, Duchess of : see Aragon.

Milan, Dukes of: see Sforza, Visconti.

Mileto, 105.

Milton, John, 295, 319, 325.

Mincio, River, 208.

Minghetti, Marco, 389, 394, 477, 479,48 o ff.

Mirandola, Pico della, 205, 207, 288.

Missi Dominici, 21.

Missi, papal and imperial, 73,74 . Modena, 85 ; duchy and dukes of, $253,254,262,270,287,288$, $300,318,360,373,376,395$, 399, 402 ff., $415,445,447,449$, 453,455 .

Mohammedans, 64, 104 .

Mohammedan scientists, 140.

Molière, 345 .

Monçon, Peace of, $25 \mathrm{I}$.

Monreale, cathedral of, II 2.

Monselice, 69.

Montaigne, 319 .

Montaperto, battle of (1260), 145 .

Mont Cenis, 390, 425 .

Monte Cassino, abbey of, 34, II I, I20, 121 .

Montefeltro, Guidantonio da, Count of Urbino, 192.

Montefeltro, Guidobaldo da, Duke of Urbino, 224-5.

Montefeltro, Federigo da, Duk . of Urbino, 224-5.
Monte Gargano, 96.

Montepulciano, 167 .

Monteverde, 330 .

Montferrat, 246, 248, 25I, 253, 254, 259 .

Montone, Braccio, Count of, 171, I90, 192.

Montpellier, medical school of, 139.

Morea, 272, 273.

Morgagni, 328 .

Morone conspiracy (1 526), 235.

Morosini, Francesco, 272.

Moslem philosophers, 1 I4.

Mozart, John Chrysostom Wolfgang Theophilus, 333 .

Murat, Joachim, King of Naples, $357,35^{8}$.

Murat, Lucien, 432, 438.

Muratori, 317 .

Murrone, Pietro : see Celestine V, Pope.

\section{$\mathrm{N}$}

Naples, 12, I3, 62, 105, I53, 178, 189 , 196, 197, 198-201, 216, 21 8, 240, 267, 282-4, 310, 332, $335,347,349,399,403,433$, 464,473 ; duchy of, 25,97 , 101; kingdom of, 238, 248, $254,260-2,265,268,269$, 281-3, 302-4, 309, 310; kings of : see Anjou, Aragon; patrimonies in, 70 .

Naples (Two Sicilies), kingdom of : see Sicilies.

Napoleon I, Emperor of the French, $355 \mathrm{ff}$.

Napoleon III, Emperor of the French, 375, 377, 413, 425, $427,429,43 \circ, 435$ ff., 448 ff., $48 \circ$ ff., 486 ff., $493,496,497$.

Napoleon, Prince, $43^{8}, 44^{2}, 497$.

Narni, 9r. 
Narses, Roman general, I2.

Nepi, 62.

Neri, 308.

Neri, Cardinal Filippo, 298, 314.

Neuhof, Theodor of, 291.

Neuss, 91.

Newton, 325, 328, 329.

Niccoli, Niccolò, 203, 205 .

Nice, 268, 36o, 438, $453 \mathrm{ff}$.

Nicephorus Phocas, Emperor of the East, 30.

Nicholas I, Pope, 75, 76 .

Nicholas II, Pope, 37, 81, 84, 100, IOI.

Nicholas III, Pope, 15 I.

Nicholas V, Pope, 193.

Nicosia, 271.

Nikolsburg, Preliminaries of (I866), 490.

Nola, 365 .

Norcia, 78 .

Norman baronage, 102.

Normandy, III.

Normans, 24, 33, 34, 37, 40, 4I, $46,53,78,83,84,95^{-1} 15$.

Northern Europe, 95, 140.

Northern Italy, 27, 48, 5०, 89, 9०, $92,127,133,140$.

Northmen, 95 .

Novata, 265; engagement at, (1821) 371, (1849) 410.

O

Ochino, Bernardino, 277, 278.

Octavian, Cardinal, Antipope Victor IV , 47, 86.

Octavian, Prince and Senator of the Romans, Pope John XII, 28, 29, 77, 78, 80.

Oddo, Count of Savoy, 35 .

Oderzo, 15.

Odovacar, King of Heruli, Sciri, and Rugians, Patricius, 10.

Olympios, Exarch of Ravenna, 17,63 .
Orbitello, 46I.

Ordinances of Justice (1293), 166, 171 .

Orestes, Patricius, 9 .

Orlando of Chiusi, I 3 I.

Orleans, Louis Duke of, 179, I99, 219.

Ormea, 294, 301, 302.

Orsini, House of, 152.

Orsini, Clarice, 208.

Orsini, Felice, 435, 437 .

Orvieto, 190.

Ostia, 25.

Ostrogoths, 8, I०, 12.

Osuna, Governor of Naples, $28 \mathrm{I}$.

Otto I, the Great, King of Germany and Italy, Emperor of the West, 27-30, 32, 77, 78.

Otto II, Emperor of the West, 30, 31, 34, 79 .

Otto III, Emperor of the West, 31, 32, 78, 79 .

Otto IV, Emperor of the West, 50, 51, 91, 92 .

Otto, Bishop of Freising, chronicler, II 7 .

Ouchy, Treaty of (1912), 509.

Oudinot, General, 4I3, 4I4.

\section{$\mathrm{P}$}

Padua, 140, I 58, 165, 174-7, 177 , 208, 220, 322-4, 326, 328.

Padua, Lords of : see Carrara.

Padua, Marsiglio of, $165,173,179$.

Paestum, $35^{\circ}$.

Paisiello, 332.

Palatine judges, 32 .

Palermo, 25, 55, 101, 105, I10, I 12, I I3, 142, 145, I 53,28 I, $283,460,46 \mathrm{I}, 475$.

Palestine, 96 .

Palestrina, Giovanni Pierluigi da, 330, 331.

Palladio, 333 .

Pallavicini, Cardinal, 317 . 
Pallavicini, Giorgio, 434, 475 .

Palma, Vecchio (painter), 222.

Palmerston, Henry Viscount, 439, 447, 454.

Paoli, Pasquale, 29r.

Papal States, 56, 65, 70, 77, 83, $86,89,90,93,298-300,353$, $362,373,396$ ff., 466 ff., 498 . See also Church, States of the.

Parini, $35^{\circ}$.

Parma, 47, 69, 70, 234; dukes and duchy of, 244, 252-4, 2624, 266, 268, 269, 288, 289, 300, 3०3, 311, 316, 360, 373, 376, 399, 402 ff., $415,445,448,449$, 45I, 453, 455.

Partes Ravennates, 15.

Partes Romanae, 15.

Paschal I, Pope, 72.

Paschal II, Pope, 40, 100.

Passo Corese, 494.

Patriarch of Constantinople, 5, 63.

Patriarch of the West, 5 .

Patricius, 23, 32, 66, 70, 71, 73, 79, 82.

Patrimonium pauperum, 6r .

Patrimony of St. Peter, 40, 43, $46,5 \circ, 55,66,75,76,83,88$, 89-92.

Paul I, Pope, 68.

Paul III, Pope, 244, 277.

Paul IV, Pope, 277, 278, 297.

Paul V, Pope, 247, 279, 299, 300.

Pauperes Lombardi, I26.

Pavia, 8, 13, 19, 20, 22, 27, 69, 266 ; battle of $(1525), 234$, 235 ; Certosa of, 178,213 ; law-school of, 136 ; university of, $178,329$.

Pazzi conspiracy (1478), I 95, 200.

Pelagius, Pope, I3.

Pelavicino, Marquess Oberto, 145-6, 149 .
Pentapolis, the, $18,65,78,91$.

Pepe, Guglielmo, 364, 366, 367, 404.

Pepo, jurist of Bologna, 137 .

Pergolesi, 33r.

Périer, Casimir, 376, 377 .

Perugia, $13,65,165,170-2,178$, 190, $192,227$.

Peruzzi (architect), 226.

Pesaro, 190.

Peschiera, 403, 447, 45 I, 453 .

Peter of Aragon: see Aragon.

Peter of Bisignano, 100.

Peter Capocci, Cardinal, 93.

Peter Lombard, 120.

Peter Waldes, 126.

Petrarch (Francesco Petrarca), 165, 180, 183-5, 204, 216, 348.

Petrucci, Pandolfo, Lord of Siena, I 7 I.

Philip of Hohenstaufen, King of the Romans, 50, $5 \mathrm{I}$.

Philip II of Spain, 238, 240-4, 248, 266, 277, 278, 288, 352 .

Philip III of Spain, 248.

Philip IV : see France.

Philip V of Spain, 259, 261, 263, 268, 333.

Philip VI: see France.

Philip, Infant of Spain, Duke of Parma, 266, 268, 311 .

Pia, Emilia, 225.

Piacenza, 47, 177, 234; duchy of, 244, 266, 268.

Piccini, 331.

Piedmont, $15,103,150,177,252$, 253, 258, 259, 266, 267, 296.

Pilo, Rosalino, 460.

Pinerolo, 251, 252, 257, 258, 259.

Piombino, $178,243$.

Piombo, Sebastian del (painter), 222.

Pippin, King of the Franks, Patricius of the Romans, I9, $20,58,64,65,66,69,70,93$. 
Pippin (son of Charles the Great), King of Italy, 20, 22.

Piranesi, $35 \mathrm{I}$.

Pisa, 43, 145, 167, 170, 178, 323, 324 ; Council of, 188.

Pisacane, Carlo, 433 .

Pistoia, $150,167$.

Pius II, Pope, 193, 194, 200.

Pius IV, Pope, 277, 278.

Pius V, Pope, 243, 278, 314.

Pius VI, Pope, 303, 304, 35 I.

Pius VIII, Pope, 374.

Pius IX, Pope, 392, 394, 395 ff., $415,420,421,428,432,447$, $45^{8}, 466 \mathrm{ff} ., 484 \mathrm{ff} ., 49 \mathrm{Iff}$., $49^{8} \mathrm{ff}$.

Placentinus, jurist of Bologna, I37.

Plato, I 13.

Plombières, 437.

Po, River, I, I4, 33 ; valley of, I 3,97 .

Podestà, 48 .

Pola, 24.

Pole, Reginald, 276.

Poliziano, Angelo, 205, 207, 315.

Pompei, $35^{\circ}$.

Ponthion, I9, 69, 80.

Poor Clares, I3I.

Porpora, 33I.

Porta, G. B. da, 322.

Porto, Luigi da, 225.

Porto Ferraio, 285.

Poussin, 337.

Praefectus urbi, 3, 32, 79 .

Prágue, Treaty of (1866), 490.

Prato, $150,167$.

Predis, Ambrogio de (painter), 214.

Presidi, the, 243, 254, 262, 269.

Pretorian prefect, 3 .

Procida, John of, 153 .

Provence, 127, 196, 197.

Pseudo-Isidore, Decretals of, 75 .
Ptolemy, I I3.

Pyrenees, Peace of, 254.

$\mathrm{R}$

Radagaisus, 8.

Radetzky, Marshal, 40I ff.

Radicofano, 9I.

Ramillies, 259.

Ramorino, 388.

Raphael (Raffaello Sanzio), 226, 227, 316, 333, 337 .

Rastatt, Peace of, 262.

Rattazzi, Urbano, 424, 425, 428, $449,455,473,474,475,476$, 477,493 ff., 5 ㅇ․

Ravello, I I3, I 37 .

Ravenna, Archbishop of, 39, 68, 78 ; battle of (1 512$), 220$; city of, II-I4, I9; exarchate of, I 9, 20, 22, 65, 66, 68, 69, 78, 89, 91; law-school of, i 36 .

Reggio, 69, 70, 85, 287, 288, 464, 475 .

Regnum Italicum, 20.

René of Anjou: see Anjou.

Reni, Guido, 337 .

Rheims, 72.

Rhine, River, I.

Ricasoli, Bettino, 398, 412, 449, $45^{\mathrm{I}}, 45^{2}, 472,474,477,478$, 49 I ff., 5 ० .

Ricci, Bishop, 305.

Richard of Cornwall, King of the Romans, 93.

Richard I, Prince of Capua, 37, $84,100$.

Richecourt, de, 307.

Richelieu, Cardinal, 247, 249-53.

Ricimer the Sueve, Patricius, 9 .

Rienzi, I65, I83, I85-7.

Rieti, 78 ; battle of (1 821 ), 367 .

Rimini, I9o.

Rivoli, League of, $25^{2}$.

Robert of Anjou: see Anjou. 
Robert the Frisian, 95 .

Robert II, Prince of Capua, Io6. Robert II, Duke of Normandy, 4 I.

Robert Guiscard, Duke of Apulia, Count of Sicily and Calabria, $37,39,84,99^{-102}$, 106, 146.

Roger, Duke of Apulia, IOI, ro3.

Roger I, Count of Sicily, IOI-5; his daughters, 105.

Roger II, King of Sicily, Apulia and Capua, 45, 49, 84, 98, I05-8, I10-14.

Roland, Cardinal, Pope Alexander III, 47 .

Romagna, 42, 56, 90, 91, 136, $178,187,192,229,393,445$, $449,453,455$.

Romagna and the March, Dukes of, 49 .

Roman duchy, 62 ; Italy, ${ }_{15}, 18$, 19, 24, 58, 64, 71, 93, 136 ; nobles, $75,76,82,84$; people, 73 ; Republic (1849), 412; Republicanism, I44-6, I85 ; territory, 78 .

Romania, 20.

Romano, Cristoforo, 225.

Romano, Ezzelino da, I45.

Romano, Giulio, 333.

Romans, 22, 23, 26, 54, 62, 70, - $71,74,77,78,80,88,92$, I 19.

Rome, I-3, 5, 8, I I-1 3, I 7-20, 22 , $23,25,27,29,31,32,39,40$, $43,46,47,50,54,59,6 \mathrm{r}, 64$, $67,68,69,7 \mathrm{r}, 72,73,76,78$, $79,82,83,87-90,95,96$, I01, I I I I 144, I47, I 55-7, I60, I62, $178,183,184,185,186,187$, 188, 190, 192, 193, 221, 225-30, 23I, 233, 235, 237, 255, 262, 299-301, 312, 325, 330, 334-6, $350,35 \mathrm{I}, 4 \mathrm{I} 3$, 414 ; commune of, 88, 91, 125; duchy of, 14, $22,64,65,67,68,69,72$; law- school of, 136 ; see of, $4,5^{8}$, 59; Synod of, 82 .

Romulus Augustulus, Roman Emperor, 9, 10.

Roncaglia, 48, 49, 137 .

Rosa, Salvator, 337 .

Rosellino (architect), I93.

Rossi, Pellegrino, 408.

Rothari, King of the Lombards, I 5, 20.

Rovere, Count Terenzio della, 408.

Rudolf, Duke of Swabia, Antiking, 39 .

Rudolf, King of Burgundy and Italy, 27.

Rudolf (of Habsburg), Emperor, $15^{1-2 .}$

Rugians, 9.

Russell, Lord John, 462.

Ryswick, Peace of, 259.

\section{S}

Sabina, territory of, 70 .

Sagro Speco, I 20.

St.Andrew's, monastery at Rome, 61.

St. Anselm of Aosta, Archbishop of Canterbury, 120.

St. Augustine of Hippo, I 19 .

St. Basil, order of, $\mathbf{I 2 2 .}$

St. Benedict of Nursia, I 20, I 2 I, I 23, 128.

St. Bernard, Abbot of Clairvaux, $45, \cdot 46,106,125$.

St. Bonaventura, 120.

St. Catharine of Siena, 187 .

St. Clare, 55, I3 $\mathrm{x}$.

St. Denis, abbey of, 19.

St. Francis of Assisi, 55, I 8 , I23, 128, 129, I30, 132 .

St. Louis : see France.

St. Mary on the Aventine, Cluniac monastery, $8 \mathrm{I}$. 
St. Michael on Monte Gargano, shrine of, 96 .

St. Nicholas at Bari, church of, I I I.

St. Nilus of Rossano, I23.

St. Paul; basilica of, 25.

St. Peter, basilica of, 22, 23, 25, 77.

St. Peter, patrimony of: see Patrimony.

St. Peter Damiani, CardinalBishop of Ostia, 124, 125, 136.

St. Romuald of Ravenna, I23-5.

St. Sophia, basilica of, at Constantinople, I I.

St. Thomas Aquinas, 120.

Saladin, 107.

Salasco armistice, the (1848), 406, $4 \circ 9$.

Salerno, 39, 96, 101, 109, 110; medical school of, 114, I39; patrimonies in, 70 ; principality of, 34, 97, 103.

Salians, the, 79,82 .

Salimbene, Fra, 143.

Salonika, 107, 5 I0.

Salutati, Colluccio, 203.

Saluzzo, Marquisate of, 246, 25 I.

Salvani, Provenzano, 148.

Samnites, I.

San Damiano, Convent of, I3I.

San Gallo, Antonio da (architect), 226.

San Gallo, Giuliano da (architect), 226.

San Germano, Peace of, 53, 54 .

San Gimignano, 167.

San Marino, Republic of, 356, 361.

San Miniato, 167.

Santa Lucia, $4 \circ 3$.

Santa Rosa, Pietro di, 423.

Sapienza, battle of (1354), 18 r .

Saracens, 25-7, 3I，33，35，43, 96-8, 104, г23.
Sardinia, 15, 84, 89, 262, 264, 296, 360, 41 7, 428, 455, 456; kings of, 264, 266, 269, 301 .

Sarnico, 474 .

Sarpi, Paolo, 279, 317.

Sassoferrato (Giovanni Battista Salvi), 337 .

Savona, 379, 380 .

Savonarola, Fra Girolamo, 228, 229.

Savoy, 35, 240, 241, 244, 246, $252-4,257,260,262,263,266$, $274,292,293,296,360,438$, $453 \mathrm{ff}$.

Saxons, 7, 20.

Saxony, 45 .

Scala, House of, 165, 174, 179, 182.

Scala, Alberto della, 174 .

Scala, Bartolommeo della, $15^{8}$.

Scala, Can Grande della, $15^{8}$, I 73-5, 178.

Scala, Mastino della, I67, 182 .

Scandinavian peoples, 7 .

Scarlatti, Alessandro, 33 I.

Scarlatti, Domenico, 332.

Scholars, Greek, II3; Jewish,

I13; Mohammedan, II3.

Sciri, 9.

Sedan, battle of (1870), 497 .

Senator of the Romans, 79 .

Sergius III, Pope, 77 .

Sfax, I06.

Sforza, House of, 142, I89, 2 I 2.

Sforza (Muzio Attendolo), 190, 198 .

Sforza, Francesco, 199, 203, 210, 212-14.

Sforza, Francesco II, 238.

Sforza, Galeazzo Maria, 214, 215.

Sforza, Gian Galeazzo, 190, 208, $215,217$.

Sforza, Ippolita, I99, 214.

Sforza, Ludovico (Il Moro), 213 , 215-19, 222, 227, 315. 
Sforza, Massimiliano, 23I.

Shakespeare, 340,345 .

Siccardi, Guiseppe, $422 \mathrm{ff}$.

Sicilian Vespers, The (1282), 153.

Sicilies, The Two, kingdom of, 14 I-6, 1 50, $456 \mathrm{ff}$.; kings of, see Anjou, Charles I, Duke of ; Aragon, Alfonso, King of ; Aragon, Ferdinand, the Catholic, King of ; Manfred.

Sicily, 8, 12, 1 5, 17, 25, 31, 35, 54, $84,96,97,101,103$, I I I , I I 3 $15,127,260,261,264,283$, 284, 301, 311, 361, 366, 399, $402,404,416,460$ ff., 475 ; county of, 105, 106; patrimonies in, 61 ; kingdom of, $45-53,56,84,90-3,9^{6}$; kings of, see Conrad IV, Frederick II, Henry VI, Manfred, Roger II, Tancred,William I, William II, William III.

Sidon, 52.

Siena, 145, 148-50, 165, 170-2, $178,243,264,275,277$.

Sigismund, Emperor, 188.

Sila, forest of, 127.

Silvester I, Pope, 68, 6g.

Silvester II, Pope, 31, 78, 79 .

Simonetta, Vespucci, 207.

Sinibaldo Fieschi, Pope Innocent IV (q.v.), 56.

Sixtus IV, Pope, 195, 196, 201.

Sixtus V, Pope, 299, 300.

Smith, Adam, 349 .

Solferino, battle of (1859), 446.

Somaliland, $5 \circ 7$.

Sora, 70 .

South Italian dioceses, 64; towns, I06.

Southern Italy, 30, 32, 83, 84, 92, 96, 99, IOI, III I I I 4 , 135 .

Spain, 7, 8, is, 25, 95, 107, I 14.

pain, Ferdinand, the Catholic,
King of, and of the Two Sicilies, 219.

Spallanzani, 328.

Spires, 9I.

Spoleto, city of, 13 ; duchy of, I3, 15, 21, 22, 28, 55, 69, 70, $78,84,89,90,91$; dukes of, 49 .

Stensen, 327 .

Stephen II, Pope, I9, 64-6, 77, 93.

Stephen IV, Pope, 72.

Stilicho the Vandal, Magister Militum, 7,8 .

Stradivarius, Antonio, 332.

Strategoti, 1 Io.

Subiaco, 120.

Suburbicarian provinces, 59 .

Suidger, Bishop of Bamberg: see Clement II, Pope.

Sutri, Synod of, 36, 80 .

Syracuse, 97.

Syria, 52, 107.

Syrian cities, 43 .

\section{$\mathrm{T}$}

Taginae, battle of, $\mathbf{I} 2$.

Tagliacozzo, battle of (1268), I49-50, 153 .

Talamone, $46 \mathrm{I}$.

Tancred of Hauteville, 34, 97, 98 . Tancred, King of Sicily, 49, 98, 104.

Tanucci, 3०3, 304, 310.

Taranto, $15,25,26$.

Tartaglia, 32 I.

Tasso, Bernardo, 288, 315, 338, 339.

Tassoni, 348.

Tavanti, 308 .

Tazzoli, Enrico, 4I 6.

Tchernaya, battle of (1855), 429 .

Teano, 70, 465 .

Termoli, 96 . 
Terni, 493.

Tertiaries, I 3 I.

Teutonic peoples, 7 .

Thebes, 106.

Theodelinda, Queen of the Lombards, 14 ; descendants of, 15 .

Theodoric, King of the Ostrogoths, Patricius, IO-I2, I I I, I2 I, 133 .

Theodosius, House of, $4,7,8$.

Theophano, wife of Otto II, $3 \circ$, 31.

Theophylact, House of, 27,79 .

Theophylact, Lord of Rome, 76 .

Thrace, 7, Io.

Tiber, River, $\mathbf{I}$.

Tiepolo conspiracy (1310), 180.

Tiepolo, Giovanni Battista, 346.

Fillot, du, 3 I .

Tintoretto, Il (Jacopo Robusti), $210,336$.

Titian, Vecelli, 210, 222, 223, 336.

Tommaso, Prince of Savoy, 253 , 254.

Torre, della (plot), 290.

Torre, Guido della, 162, 178, 290.

Torricelli, 326, 327 .

Tortona, 265 .

Tours, 75 .

Trani, 97, I 13.

Trent, Council of, $277,279,317$, 330.

Trentino, the, 359, 488, 490, 491, 496,511 .

Trescorre, 474 .

Treviso, 174, 177, 182, 220.

Trieste, 359, 5 II.

Tripoli, 509.

Tripolitana, 106.

Troia, II 3 .

Troyes, battle of, 8 .

Tunis, $496,5 \circ 3$.

Turin, 259, 369, 370, 419; Treaty of (1860), 455 .
Turks, 95 .

Tuscan cities, $39,5 \circ$.

Tuscany, 13, 21, 40, 42, 45, 54, 69 , 124, 131, 136, 1 52 , 167 ; duchy of, $15,28,70,85,253$, 261-6, 269, 286, 287, 289, 291, $300,305,308,309,327,360$, 361, 398, 399, 403, 407, 4 I I ff., $445,446,447,453,455$; dukes of, 49 ; Lombard, 70 ; Roman, 70,89 .

Tusculans, 79 .

Tusculum, 88.

\section{$\mathrm{U}$}

Ugolino, Cardinal : see Gregory IX, Pope.

Ulfilas, Gothic bishop, 7 .

Umbria, I 3 I , 165, I7 I , 445, 457 ff. Urban II, Pope, 39, 40, 82, 95, $103,105$.

Urban IV, Pope, 147.

Urban V, Pope, I86.

Urban VI, Pope, 187.

Urban VIII, Pope, 249, 296, 297, $300,320,325,326$.

Urbino, 222, 224, 225, 226, 227, 244, 288, 299, 300 .

Urbino, Counts and Dukes of: see Montefeltro.

Uscocchi, 242.

Utrecht, Congress and Peace of, $260,262,274$.

Vacchero, 290.

Valens, Roman Emperor, 7 .

Valentinian III, Roman Emperor, 8.

Valois, Charles, Duke of, 156.

Valtelline, the, 248, 249, 251.

Valva, 78 .

Vandals, 7,8 . 
Varchi, $3 \mathbf{1 7}$.

Vega, Lopez de, 345 .

Vendôme, 259.

Venetia, 13, 69, 453, 488, 490, 491.

Venetian islands, 15 .

- Venice, 24, 43, 48, 70, 140, 146, 148, 165, 175-7, 178, 180, 18 1, 182, 189, 195, 205, 208-1 2, 219, 220, 222, 223, 242, 249, 25 I, $253,254,261,270,271,272$, $274,275,278,279,280,289$, 290, 300, 304, 312, 332, 336, 345,346 ; Peace of, 89,90 ; Republic of, 361, 404, 410 .

Venosa, 98.

Verdun, Treaty of, $\mathbf{2 5}$.

Verona, II, I 58, I65, I74-5, 208, 220,403 ; Lords of : see Scala ; March of, 136.

Veronese, Paolo (painter), 210, 336.

Verri, Pietro, 306, 349 .

Versiglia, 85 .

Vesalius, 322 .

Vesuvius, I13.

Vicenza, I 74, 208, 220.

Vico, 347.

Victor II, Pope, 36.

Victor III, Pope (Abbot of Monte Cassino), roo.

Victor IV, Antipope, 47, 86.

Victor Emmanuel I, King of Sardinia, 368-70.

Victor Emmanuel II, King of Italy, 35, 410, 417, 424, 437, $445,446,447,448$ ff., 456 ff., 469,473 ff., 479, 483, 49I, 494, 496 ff., 501 .

Victor Emmanuel III, King of Italy, 507 .

Vienna, Treaty of (1809), 357 ; (181 5), 359-61 ; (1866), 491.

Vigefano Armistice, 405 .

Vilgard of Ravenna, I34.
Villafranca, 447.

Vinci, Leonardo da, 204, 214, $215,221,223,227,315$.

Virgil, I 34 .

Visconti, House of, $151,165,179$, I 8I, 212.

Visconti, Bernabò, Lord of Milan, 179 .

Visconti, Bianca Maria, Duchess of Milan, 2 I 2.

Visconti, Filippo Maria, Duke of Milan, 189, 1 99, 2 10.

Visconti, Giovanni, Archbishop of Milan, $\mathbf{I} 79$.

Visconti, Gian Galeazzo, Duke of Milan, I68, I71, 175, 177-9, 182, 189 .

Visconti, Matteo, Lord of Milan, I62, I73, 178 .

Visconti, Otto, Archbishop of Milan, 179.

Visconti, Valentina, Duchess of Orleans, I79, 199 .

Visigoths, 7, 8, I I.

Viterbo, 91 .

Vittorio Amadeo I, Duke of Savoy, 91, 25I, 252, 293.

Vittorio Amadeo II, Duke of Savoy, 257-60, 293-5, 301.

Vittorio Amadeo III, 296.

Vivaria, abbey of, I2I.

Vivarini (painter), 210.

Viviani, 326, 327 .

Volta, 329 .

Volterra, 167.

Volturno, the, 465 .

W

Waldenses, 126.

Waldrada, 75 .

Walter de Brienne, 160.

Welf, House of, 35 .

Welf and Waiblingen, feud of, 45 .

Wenzel, (Emperor, 179 . 
Western Europe, 23, 95 .

Western provinces of the Empire, 59.

Westphalia, Peace of, 250, 253, 254 .

William I, King of England, 95. William I, King of Sicily, 46, 98 , 106, 109, I13.

William II, King of Sicily, 48,49 , 98, 104, 106, 107, 109, I 10, I I 2. William III, King of Sicily, 98 . William V, Duke of Aquitaine, 35 .

William of Apulia, chronicler, 96 . William, Duke of Apulia, OI, Io6.

William Fer-à-bras, Count of Apulia, 98, 99.
William of Orange, 255 .

Winckelmann, 351 .

Worms, Concordat of, 40 ; Synod of, 38 ; Treaty of, 266 .

$\mathrm{Y}$

Yolande of Brienne, wife of Emperor Frederick II, 52.

\section{Z}

Zacharias, Pope, I9, 66.

Zenale (painter), 2 I4.

Zeno, Roman Emperor, 10.

Ziyadet-Allah, emir of Kirwan, 25.

Ziza, II 2.

Zurich, Peace of, 453 . 


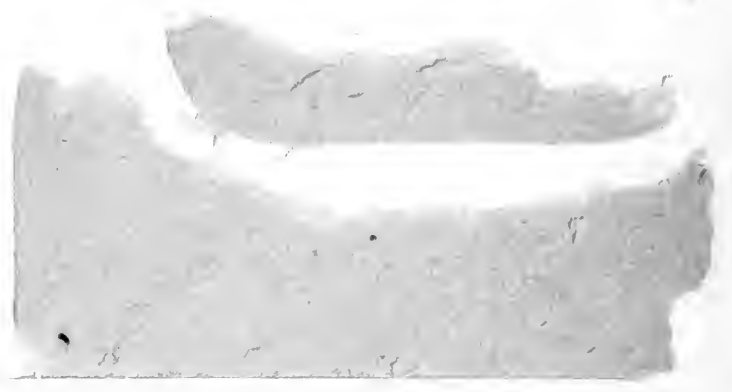

\section{PLEASE DO NOT REMOVE \\ CARDS OR SLIPS FROM THIS POCKET}

\section{UNIVERSITY OF TORONTO LIBRARY}

DG Jamison, Evelyn Mary

468 Italy, mediaeval and modern

J3 
